\title{
OS MEANDROS DA PRODUÇÃO PÚBLICA NA CONSTRUÇÃO DA PAISAGEM PERIFÉRICA PAULISTANA: O CASO DOS EQUIPAMENTOS EDUCACIONAIS.
}

ANA CAROLINA LOUBACK LOPES

São Paulo | 2011

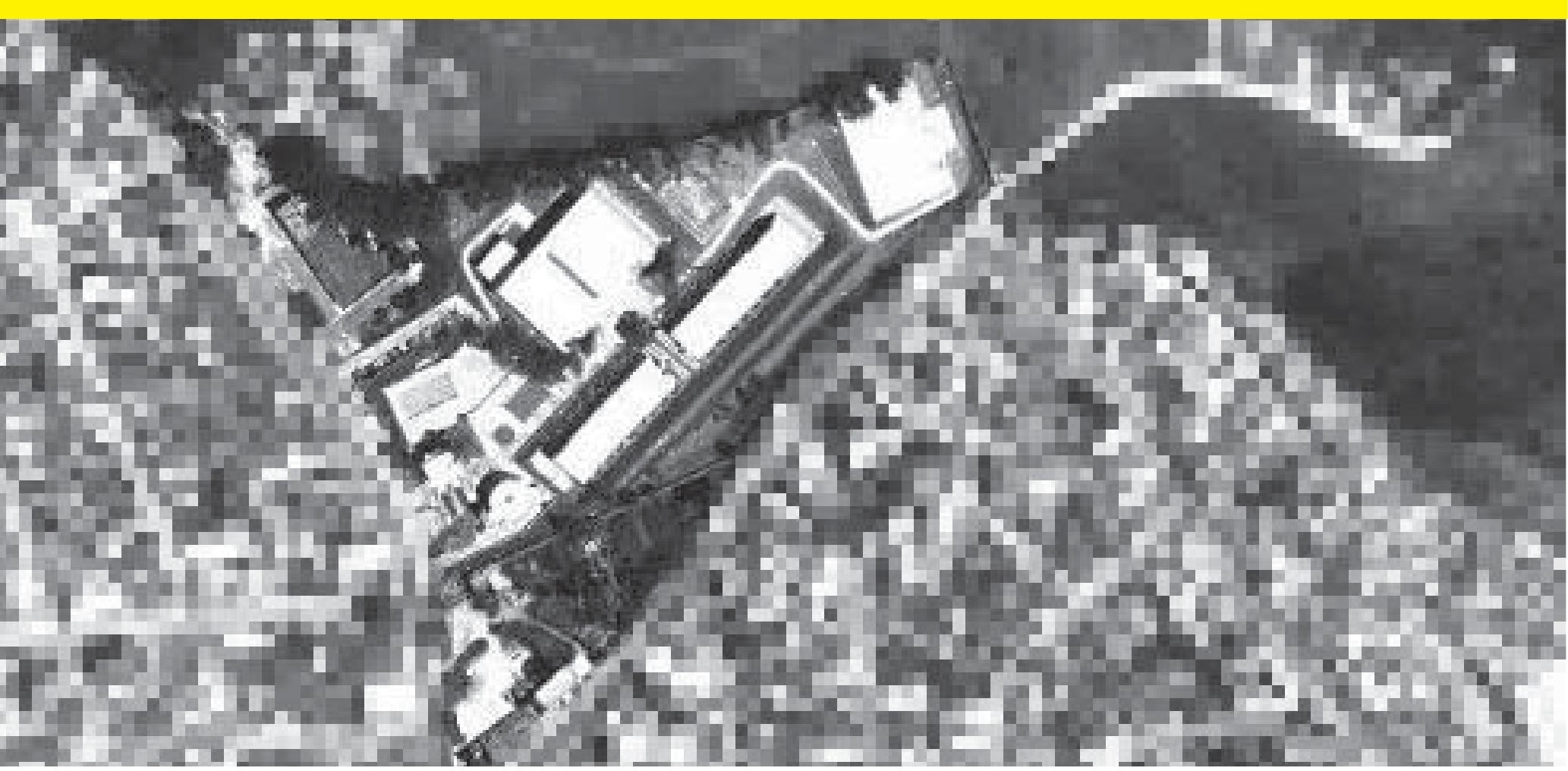




\section{OS MEANDROS DA PRODUÇÃO PÚBLICA NA CONSTRUÇÃO DA PAISAGEM PERIFÉRICA PAULISTANA: O CASO DOS EQUIPAMENTOS EDUCACIONAIS.}

ANA CAROLINA LOUBACK LOPES

Dissertação apresentada à Faculdade de Arquitetura e Urbanismo da Universidade de São Paulo - FAUUSP para obtenção do título de Mestre em Arquitetura e Urbanismo.

Área de Concentração: HABITAT

Orientador: Prof. Dr. Yvonne Mautner

São Paulo | 2011 
AUTORIZO A REPRODUÇÃO E DIVULGAÇÃO TOTAL OU PARCIAL DESTE TRABALHO, POR QUALQUER MEIO CONVENCIONAL OU ELETRÔNICO, PARA FINS DE ESTUDO E PESQUISA, DESDE QUE CITADA A FONTE.

E-MAIL: ANALLOPES@UOL.COM.BR

Lopes, Ana Carolina Louback

864m Os meandros da produção pública na construção da paisagem periférica paulistana: o caso dos equipamentos educacionais / Ana Carolina Louback Lopes -- São Paulo, 2011. 274 p. : il.

Dissertação (Mestrado - Área de Concentração: Habitat) FAUUSP.

Orientadora: Yvonne Mautner

1. Políticas públicas 2. Paisagem urbana 3. Escolas (Arquitetura; Equipamentos) I.Título 
A Francildo e Marcia, meus pais, que me ensinaram a fazer do estudo um prazer, uma necessidade. 

Àqueles que participaram desta minha busca, em especial...

. aos profissionais entrevistados, pelas valiosas contribuições: Prof. Júlio Roberto Katinsky, Prof. Ubyrajara Gilioli, Prof. Alexandre Delijaicov, Prof. Antônio Claudio da Fonseca, Arq. Mirela Geiger de Mello, Arq. Avanir Ferreira, Arq. João Canteiro e Arq. Paulo Pignanelli;

. à FDE, à EDIF e à CDHU, pelos materiais disponibilizados;

. à FAU, minha escola;

. à Maria Antônia e à Bia Goulart, por me apresentarem o desafio e o prazer de pensar o "espaço pedagógico", a Cidade Educadora, o Bairro-Escola;

. à Yvonne Mautner, orientadora presente, pela inspiração nos momentos de desânimo, pelos questionamentos nos momentos de euforia, pelas constantes provocações, sempre enriquecedoras;

. aos amigos, pelos conselhos, revisões e, sobretudo, por todo o estímulo;

- às queridas Sandra Salles, Camila Saraiva e Bel Xavier, com quem compartilhei lares, angústias, ansiedades, e, sobretudo, fortes amizades;

. a Anita Domenico, Virgínia Bessa e Juliana Galesi, companheiras de longa data, pelas noites de muita terapia coletiva;

. à Patrícia Guena, parceira de baile, pela constante disposição para ajudar;

. ao querido Raul Bueno, pelos sensatos conselhos "softwarianos";

. a Markus Vogl, amigo sempre presente, embora distante, por nossas muitas andanças pelas cidades, regadas às tantas discussões acerca delas;

- à Joana Gabos, amiga-irmã, pelas transcrições, pelas revisões, pelos almoços, pelos dias e dias formatando imagens..., por toda a força;

. a Marco Aurélio Queiroz, pela clareza nos momentos turvos;

. a Artur e Mariana, irmãos que me orgulham e inspiram;

. ao Máximo, pelos sonhos vividos e por aqueles ainda a sonhar. 



\section{RESUMO}

A pesquisa trata dos processos de produção pública de equipamentos coletivos em São Paulo e busca apontar os principais impactos urbanos derivados particularmente das diferentes políticas implementadas na cidade na última década. A relevância do tema parte da consideração da produção pública de arquitetura enquanto um processo de duas vias, que, se por um lado, conta com um potencial significativo de transformação urbana, por outro, constitui instrumento político-ideológico estratégico. Tido como prática exemplar da produção pública paulistana - em função da qualidade dos projetos, mas sobretudo por contar com um quadro conceitual e tecnológico evolutivo -, o processo de construção de equipamentos educacionais é aqui tomado como caso de estudo, visando compreender os contextos e distinguir as condicionantes que teriam viabilizado a construção de um histórico consistente no campo da produção pública de edifícios. Para tanto, foram priorizadas as práticas desenvolvidas na capital nos últimos 10 anos, referindo-se elas, em âmbito estadual, à atividade da Fundação para 0 Desenvolvimento da Educação - FDE e, em âmbito municipal, à experiência dos Centros Educacionais Unificados - CEUs. Dada a atualidade da discussão, a metodologia empregada tem forte cunho empírico, baseando-se em análise de projetos, estudos de campo e entrevistas com os agentes envolvidos.

palavras-chave: políticas públicas, paisagem urbana, equipamentos coletivos, escolas (arquitetura). 


\section{Abstract}

The research deals with the processes of public production of collective facilities in São Paulo and intends to identify the main impacts caused by different policies developed in the city during the last decade. The relevance of this topic applies to the consideration that public production of architecture is a two-way process, which has, on one hand, a significant potential for urban transformation and, in the other hand, works as a strategic political/ideological instrument. Known as an exemplary practice of São Paulo's public production - due to the quality of the projects, but most important, for its conceptual and technological evolution - the process of educational buildings construction is taken as case study, aiming to understand the contexts and to distinguish the conditions that enabled the consolidation of a consistent track record in the field of public production of architecture. Thus, the practices developed in São Paulo during the past 10 years will be detailed, what means, at State level, the activity of the Foundation for the Development of Education - FDE, and, at Municipal level, the experience of the Unified Educational Centers - CEUs. Focusing a contemporary situation, the methodology is strongly empirical, based on the analysis of projects, case studies and interviews with stakeholders.

keywords: public policies, urban landscape, collective facilities, schools (architecture). 


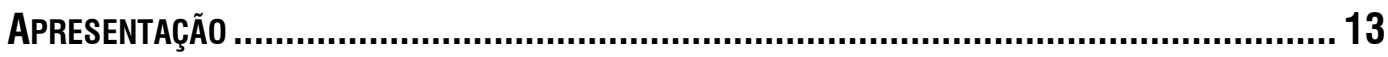

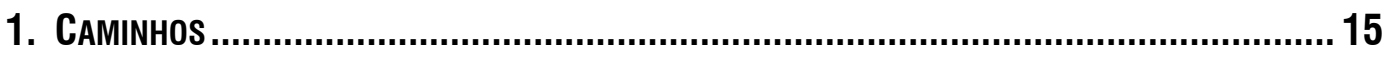

1.1. Por onde cheguei: Introdução .............................................................. 17

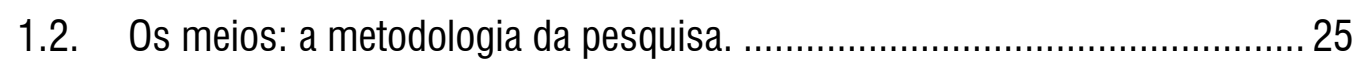

1.3. Para onde vou: os capítulos que seguem............................................... 26

2. Construindo escolas: a produção pública de edifícios educacionais em São Paulo 29

2.1. O Departamento de Obras Públicas - DOP .................................................. 32

2.2. A Comissão Permanente e os Parques Infantis ......................................... 35

2.3. As Escolas-Parque de Anísio Teixeira e o Convênio Escolar ....................... 40

2.4. O Fundo Estadual de Construções Escolares - FECE .................................. 46

2.5. A Companhia de Construções Escolares de São Paulo - CONESP .............. 51

2.6. A Fundação para o Desenvolvimento da Educação - FDE ........................... 55

2.7. A Cidade Educadora e as Praças de Equipamentos ....................................57

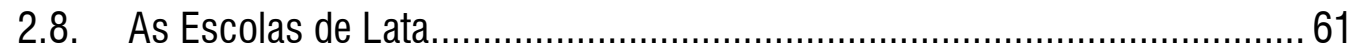

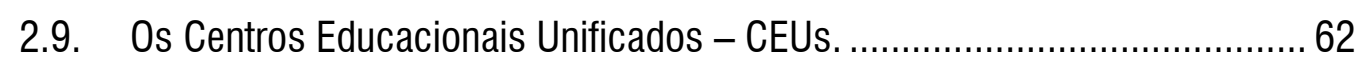

3. Desconstruindo as escolas: a produção atual da FDE E os CEUs ..........................79

3.1. As escolas: quadro geral da produção atual.......................................... 82

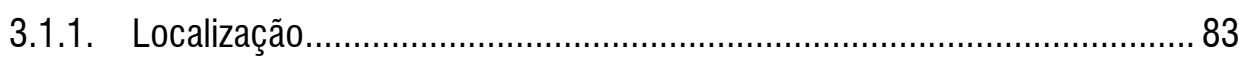

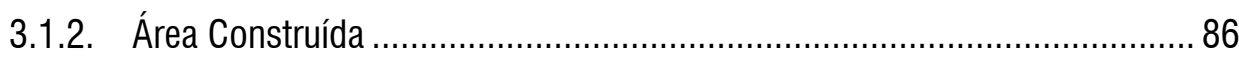

3.1.3. Data do Projeto/ Data da Obra .............................................................. 87

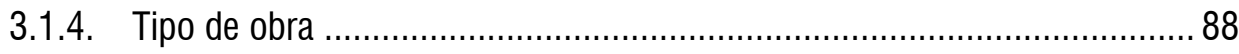

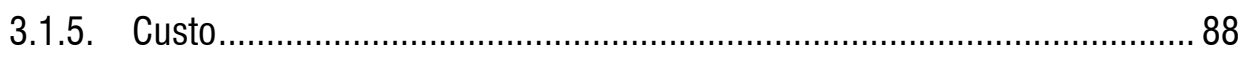

3.1.6. Projeto (Programa de Usos) ................................................................. 90

3.1.7. Partido arquitetônico …………………………………………….......... 91

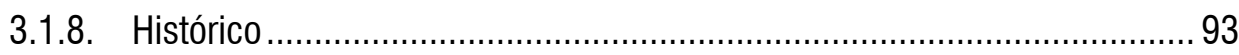

3.1.9. Proveniência da demanda .................................................................... 93

3.1.10. Equipe de projeto ……………………………………………….... 94

3.1.11. Coordenação do projeto …………………………………………….... 95 


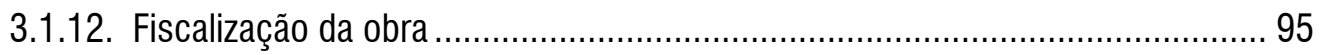

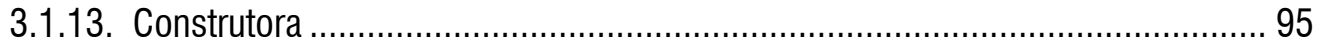

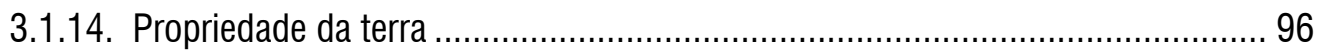

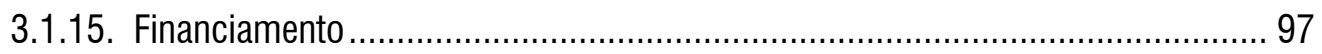

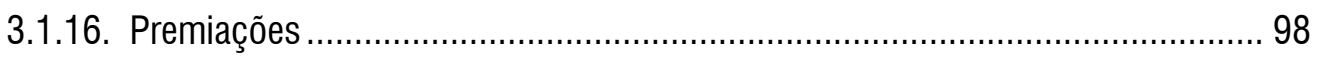

3.2. Duas escolas: FDE Ministro Oscar Dias Correia e CEU Pera Marmelo.................99

3.2.1. 0 Espaço: passeios, investigações e impressões. ......................................... 100

3.2.2. Os usuários: conversas. ......................................................................... 114

3.2.3. A Produção do Espaço: entrevistas com os diversos agentes....................... 117

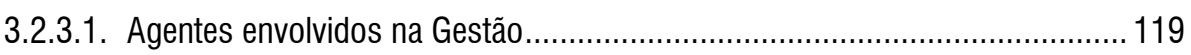

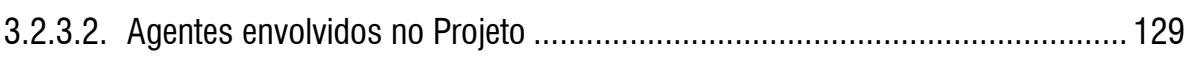

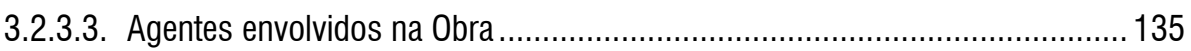

3.3. Os processos de produção pública de escolas. ...........................................136

4. A conStRUÇÃo PÚblica de ESCOLAS EM São PaUlO: PANORAMAS ................................141

4.1. Terceirização X Escritórios Públicos ............................................................143

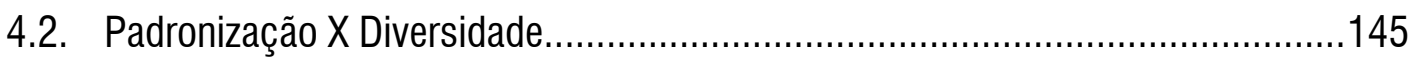

4.3. Programa de Usos Integrado X Programa de Usos Específico .........................149

4.4. Marco Urbano X Integração com o Entorno..............................................151

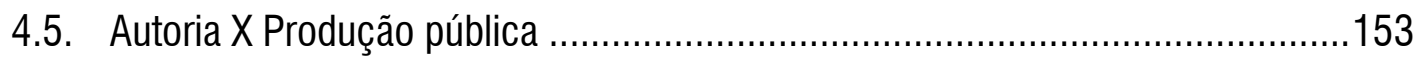

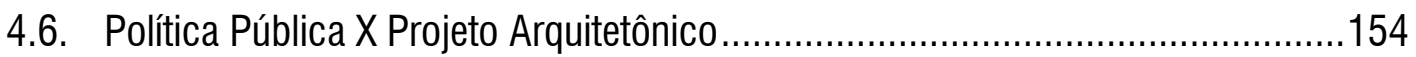

5. Construindo Periferias: a participaÇão do Poder Público na CONStruÇão da Paisagem PERIFÉRICA PAULISTANA. ...............................................................................161

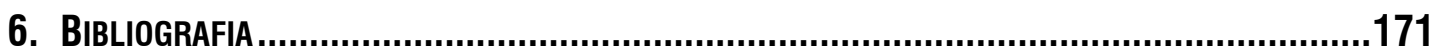

Anexo_Produção de Equipamentos Educacionais em São Paulo 2001 - 2010.................181

PrOduÇÃO dO GoveRnO dO ESTADO - FDE 2004 - 2009 ............................................... 185

Produção do Governo Municipal - CEUs 1a Gestão | 2001 - 2004 ................................227

Produção do Governo Municipal - CEUS 2a GeStÃo | 2005 - 2009...............................255 


$\begin{array}{ll}\text { CDHU } & \text { Companhia para o Desenvolvimento Habitacional e Urbano } \\ \text { CEDEC } & \text { Centro de Desenvolvimento de Equipamentos Coletivos } \\ \text { CENAFOR } & \text { Centro Nacional de Aperfeiçoamento Pessoal para a Formação Profissional } \\ \text { CEU } & \text { Centro de Educação Unificado } \\ \text { CIEP } & \text { Centro Integrado de Educação Pública } \\ \text { CONESP } & \text { Companhia de Construções Escolares de São Paulo } \\ \text { DOP } & \text { Departamento de Obras Públicas } \\ \text { EDIF } & \text { Departamento de Edificações } \\ \text { E.E. } & \text { Escola Estadual } \\ \text { EJA } & \text { Escola de Jovens e Adultos } \\ \text { EMEI } & \text { Escola Municipal de Educação Infantil } \\ \text { EMEF } & \text { Escola Municipal de Educação Fundamental } \\ \text { EMURB } & \text { Empresa Municipal de Urbanização } \\ \text { ETEC } & \text { Escola Técnica Estadual } \\ \text { FATEC } & \text { Faculdade de Tecnologia } \\ \text { FDE } & \text { Fundação para o Desenvolvimento da Educação } \\ \text { FECE } & \text { Fundo Estadual de Construções Escolares } \\ \text { FLE } & \text { Fundação para o Livro Escolar } \\ \text { IPESP } & \text { Instituto de Previdência do Estado de São Paulo } \\ \text { MANEQ } & \text { Manual de Equipamento } \\ \text { MEC } & \text { Ministério de Educação e Cultura } \\ \text { OP } & \text { Orçamento Participativo } \\ \text { PAGE } & \text { Plano de Ação do Governo do Estado } \\ \text { PREF.C.E. } & \text { Prefeitura - Construções Escolares } \\ \text { SEE } & \text { Secretaria da Educação do Estado } \\ \text { SME } & \text { Secretaria Municipal de Educação } \\ \text { SINDUSCON } & \text { Sindicato da Indústria da Construção Civil } \\ \end{array}$





\section{APRESENTAÇÃo}

É evidentemente uma tarefa da ciência tornar claro, pela análise, aquilo que é mistificado e turvo na vida diária.

David Harvey

Este trabalho dedica-se a estudar os processos de produção pública de equipamentos coletivos em São Paulo, analisando os principais impactos urbanos derivados das diferentes condutas de gestão implementadas no município. As prioridades assumidas por cada administração condicionam 0 direcionamento dos investimentos e a formulação das políticas públicas para a cidade, interferindo diretamente na forma com que se propõe o espaço. Apontar os principais reflexos dessas posturas, destacando continuidades e contradições, constitui o objetivo principal aqui almejado.

Tido como prática exemplar da produção pública em São Paulo - em função da qualidade dos projetos, mas sobretudo por contar com um quadro conceitual e tecnológico evolutivo, capaz de responder às demandas contemporâneas -, o processo de construção de equipamentos educacionais é aqui tomado como caso de estudo, visando compreender os contextos e apontar as condicionantes que teriam viabilizado a construção de um histórico consistente no campo da produção pública de edifícios.

Dado 0 anseio de realizar uma discussão atual acerca das políticas públicas desempenhadas na cidade, assume-se como campo de estudo as práticas desenvolvidas na capital nos últimos dez anos, período este que concentrou condutas bastante diversas, com impactos urbanos igualmente diferentes. Pretende-se, assim, avaliar a pertinência destas ações, na busca por uma crítica capaz de fundamentar os processos futuramente praticados. 
OS MEANDROS DA PRODUÇÃO PÚBLICA NA CONSTRUÇÃO DA PAISAGEM PERIFÉRICA PAULISTANA: 0 CASO DOS EQUIPAMENTOS EDUCACIONAIS 
1. Caminnos 
OS MEANDROS DA PRODUÇÃO PÚBLICA NA CONSTRUÇÃO DA PAISAGEM PERIFÉRICA PAULISTANA: 0 CASO DOS EQUIPAMENTOS EDUCACIONAIS

[16] 


\subsection{POR ONDE CHEGUEI: INTRODUÇÃo}

Durante seu desenvolvimento, esta pesquisa sofreu uma correção de rumo, fruto das consequentes indagações, que levaram à revisão do objeto de estudo, prezando, entretanto, o aprofundamento da temática proposta.

No início deste trajeto, o foco do trabalho estava na produção pública de habitação em São Paulo, tendo a pesquisa 0 objetivo de identificar os avanços construtivos e projetuais que os mutiões autogestionados ${ }^{1}$ imprimiram a tal processo, numa tentativa de daí extrair condutas e procedimentos que pudessem vir a somar às políticas habitacionais tradicionais. A prioridade estava em analisar os aspectos referentes à qualidade técnica e espacial, eficiência e novas formas de organização do canteiro, custos da construção e demais aspectos que pudessem ter assumido novas configurações dada a especificidade da mão de obra empregada. No entanto, iniciada a pesquisa e colocadas as reflexões teóricas que marcariam 0 curso de mestrado, uma importante questão despontou...

Por um lado, confirmou-se que, de fato, os mutirões autogestionados trouxeram importantes avanços arquitetônicos e construtivos, frutos de um processo de protagonismo social indiscutivelmente inovador, que impôs novos desafios ao sistema produtivo tradicional. Trabalhar com uma mão de obra não especializada e diversificada, com disponibilidade de tempo reduzida, demandava novas alternativas de organização do canteiro de obras. Ao contar com a participação dos próprios moradores na formulação do projeto arquitetônico, elevou-se o nível de exigências, remetendo a desenhos mais apurados, empenhados em responder à diversidade de demandas dos usuários, otimizar os recursos empregados e reduzir os gastos futuros com manutenção. Além de buscar desenhos inéditos, adequados às necessidades específicas das famílias moradoras, estes projetos se propunham, em geral, a incorporar novos materiais, disponíveis no mercado e a valores acessíveis, o que permitiu imprimir um novo padrão tipológico aos novos conjuntos.

Cabe aqui ressaltar que, em São Paulo, os mutirões realizados no governo Erundina, além de representarem uma vitória no processo de gestão democrática do município, estabeleceram um novo canal de participação
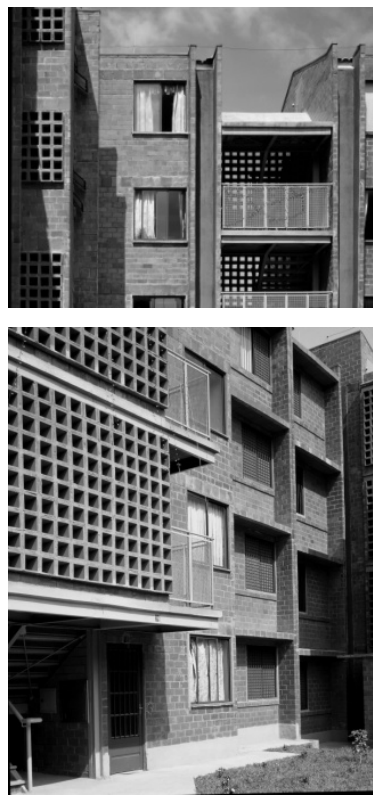

Conjunto Habitacional União da Juta (1991-1998), experiência de mutirão autogestionado, projeto da assessoria técnica USINA. Fotos: Nelson Kon/ USINA. 
social - por vias técnicas - e, sobretudo, impulsionaram o surgimento de uma nova geração de arquitetos, fruto da estruturação das assessorias técnicas, responsáveis pelo suporte a estes projetos. Esta nova geração de profissionais trocaria os escritórios pelos canteiros de obra, buscando "democratizar o desenho", nos moldes defendidos por Sérgio Ferro², encarando o projeto arquitetônico como, antes de tudo, um exercício de produção coletiva do espaço.

Entretanto, terminada a gestão de Erundina, os mutirões autogestionados começaram a minguar. Aos poucos, as políticas habitacionais reafirmaram a exclusividade das empreiteiras, sob a justificativa de redução de custos e tempo de obra. Os programas de mutirões mantidos pela Companhia de Desenvolvimento Habitacional e Urbano - CDHU passaram a empregar apenas a mão de obra gratuita, descartando, contudo, a autogestão. Com isso, os ganhos da proposta se perderam, dado que o caráter virtuoso da prática do mutirão deve-se, sobretudo, à participação dos usuários nos processos decisórios, e não só braçais, somada ao papel das assessorias técnicas no acompanhamento da obra.

0 mutirão apenas enquanto estratégia de barateamento da mão de obra é alvo de diversas críticas, dentre as quais talvez a mais contundente seja a de Oliveira (2003), que, seguindo a lógica capitalista, vincula o emprego da mão de obra não remunerada ao rebaixamento salarial, ou seja, à exacerbação da extração da mais valia.

Ora, a habitação, bem resultante dessa operação, se produz por trabalho não pago, isto é, supertrabalho. Embora aparentemente esse bem não seja desapropriado pelo setor privado na produção, ele contribui para aumentar a taxa de exploração da força de trabalho, pois seu resultado, a casa, reflete-se numa baixa aparente do custo de reprodução da força de trabalho de que os gastos com habitação são um componente importante - e para deprimir os salários reais pagos pelas empresas. (OLIVEIRA, 2003, p. 76)

Apesar de reconhecidos os ganhos construtivos inaugurados pelo processo dos mutirões autogestionados, nada disso viria a ser incorporado à produção habitacional posterior, que seguiu reproduzindo formas tradicionais, tanto de projeto, quanto de obra, com desenhos estandardizados - despreocupados com a caracterização dos usuários, com a introdução de novas técnicas e materiais, com a redução dos custos de manutenção ou sequer com a inserção urbana - e canteiros hierarquizados e arcaicos. Intrigava-me 
entender porque os avanços técnicos e de organização do canteiro experimentados nos mutirões não podiam ser absorvidos pela produção estatal, dadas as melhorias espaciais alcançadas, a viabilização de estruturas diferenciadas, o emprego de novos componentes, tecnologias e materiais.

Por outro lado, iniciado o estudo da produção pública na cidade, um importante paralelo viria a causar curiosidade: a constatação de que, dentro do próprio Poder Público, outras áreas de gestão apresentavam um histórico evolutivo de forte desenvolvimento conceitual e tecnológico, sobretudo no que se referia à implementação de equipamentos institucionais. Esse era 0 caso da produção de edifícios educacionais.

Além de um histórico consistente, marcado pelo casamento de políticas pedagógicas e propostas arquitetônicas, era nítido o desenvolvimento tecnológico alcançado, explícito na padronização e racionalização dos projetos, com constantes atualizações de técnicas e materiais construtivos, e na busca pela otimização da obra e pela maior eficiência do equipamento instalado. Basta uma breve retomada histórica, para que tais aspectos se evidenciem...

A implementação do regime republicano e 0 apelo político de educar a população enquanto reflexo do novo ideário nacional impulsionou, ainda em fins do século XIX, a construção dos primeiros edifícios escolares públicos em São Paulo, os quais, embora ainda dividindo o espaço por gênero e reproduzindo a grandeza dos edifícios neoclássicos, trouxeram um projeto de ensino inovador. Surgiram assim os Grupos Escolares, edifícios erguidos para abrigar não só alunos, mas sim um projeto de educação popular, fruto da instituição inédita de uma política pública de educação.

Dada a carga simbólica da intervenção, fez-se fundamental que os edifícios a comportar estes Grupos Escolares fossem imponentes, construídos exclusivamente para serem espaços de ensino, facilmente identificáveis na paisagem. Estas novas escolas viriam a refletir em sua arquitetura as mudanças de conduta da República em relação às escolas de primeiras letras do Império (BUFFA; PINTO, 2002).

Mais tarde, já nos anos 30, o modernismo veio a introduzir a preocupação com o lazer e com a disponibilização de espaços livres, o que se expressaria nos "Parques Infantis" de Mário de Andrade ${ }^{3}$, uma proposta que aliava

3. Mário de Andrade (1983 - 1945) foi o primeiro diretor do Departamento de Cultura e Recreação da Prefeitura Municipal de São Paulo, cargo que assumiu em 1935. Um dos principais projetos idealizados por sua gestão foi o Programa de Parques Infantis.

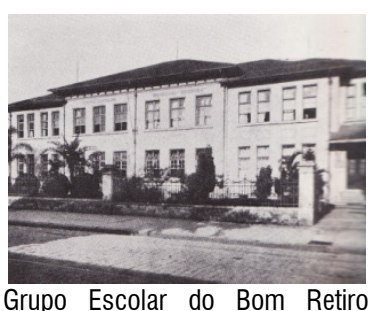

(1912). Fonte: CORREA, 1991

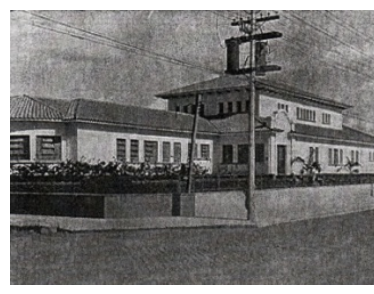

Parque Infantil da Barra Funda (1940). Fonte: NIEMEYER, 2002. 


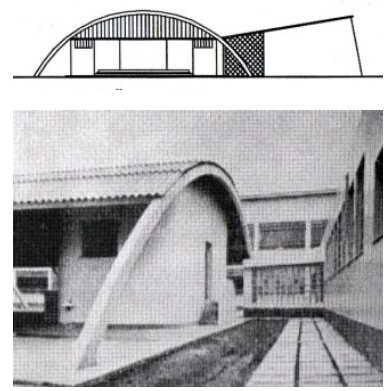

Acima, corte da E.E. Pedro Voss (1951), de Ernest Mange. Abaixo E.E.Visconde de Taunay (1949), de Hélio Duarte. Fonte: FERREIRA; MELLO, 2006a.

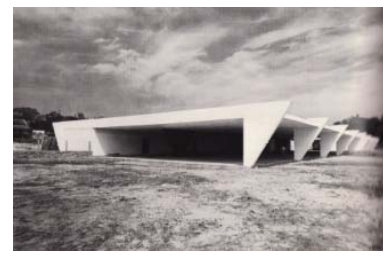

Ginásio de Itanhaém (1959), de Vilanova Artigas e Carlos Cascaldi. Fonte: FERRAZ, 1994.

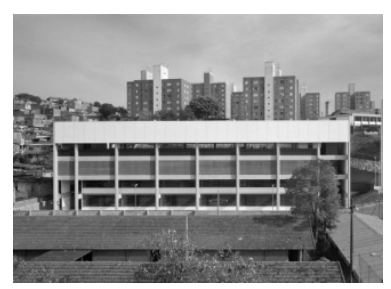

E.E. Jardim Umuarama (2003), Estúdio 6 Arquitetos. Fonte: FERREIRA; MELLO, 2006b. ensino, cultura e lazer, voltando-se à popularização dos equipamentos públicos. 0 programa consistia em intervir em grandes terrenos, criando alguns edifícios e, sobretudo, uma ampla área livre aberta à população local. Tratava-se mais de um projeto do "fora", do que do "dentro", priorizando 0 espaço externo ao construído. Até mesmo as escolas da rede vieram a incorporar tal diretriz, introduzindo os pátios abertos e as quadras esportivas: uma para as meninas e outra para os meninos.

Nos anos 50, a cidade veio a conhecer o "fenômeno chamado Anísio Teixeira" ${ }^{4}$ e, com ele, o conceito da "Escola-Parque", anteriormente testado em Salvador. Com 0 arquiteto modernista Hélio Duarte à frente dos projetos arquitetônicos, um novo padrão de edifícios passou a ser implementado. Edifícios calcados nos conceitos corbusianos, que refletiam na arquitetura a inovação que se pretendia no campo pedagógico. Ambientes integrados, amplos vãos livres e pátios internos buscavam estabelecer uma forte relação entre espaço interno e externo. Salas para atividades específicas explicitavam a reformulação do programa de ensino. A criança era o foco do projeto e, pela primeira vez, arquitetos e pedagogos passavam a trabalhar juntos.

0 trabalho de um arquiteto é sempre uma obra educacional ainda que não seja ele um professor. Entretanto, quando se juntam mestre e arquiteto, então uma obra poderá ser duplamente exaltada. (DUARTE apud BUFFA; PINTO, 2002, p. 93)

Com 0 aumento exponencial da demanda por vagas nas escolas, a solução encontrada foi, primeiro, a terceirização dos projetos e, segundo, a racionalização das técnicas construtivas. A terceirização teve início ainda nos anos 60, com a criação do Fundo Estadual de Construções Escolares FECE, permitindo agregar projetos de arquitetos como Vilanova Artigas, Paulo Mendes da Rocha, Ícaro de Castro Mello, entre outros. 0 concreto passou a ser a base das construções escolares, possibilitando alterações tipológicas importantes, como 0 aumento dos vãos e a ampliação das aberturas.

A contratação de escritórios privados tornou-se procedimento padrão, reproduzido pelas instituições sucessoras do FECE: a Companhia de Construções Escolares de São Paulo - CONESP e Fundação para 0 Desenvolvimento da Educação - FDE. Ambas viriam a fortalecer os critérios de padronização e otimização dos projetos, aprimorando catálogos e manuais a serem seguidos pelos prestadores de serviço. 0 pré-moldado assumiu espaço ao padronizar as técnicas construtivas, dada a rapidez da obra e a garantia de qualidade dos edifícios.

4. Termo utilizado pelo Arq. A. C. da Fonseca em entrevista à autora, em 19/01/2010. 
Na década de 90, a cidade se depararia com a "Cidade Educadora" de Paulo Freire, uma releitura da Escola-Parque de Anísio Teixeira, fortalecida pelos princípios freirianos da pedagogia da autonomia e da apropriação democrática do espaço urbano. Tais conceitos fundamentaram a formulação do projeto "Praças de Equipamentos" do Governo Erundina, que não chegou, contudo, a ser implementado. A proposta consistia em disponibilizar diversos equipamentos e serviços em torno de uma praça, formando polos institucionais locais em cada distrito, os quais estariam articulados em rede, de modo não só a fortalecer a presença do Poder Público nos bairros, como também alavancar um processo de estruturação urbana integrada.

Algumas gestões mais tarde, já nos anos 2000, as Praças de Equipamentos seriam revisitadas, dando origem aos Centros de Educação Unificados CEUs. Apoiado em um forte discurso pedagógico, a grande novidade dos CEUs está na tipologia multidisciplinar, que levou a bairros periféricos um "kit" completo de serviços públicos. Pedagogicamente, a proposta de um currículo variado, voltado à formação integral do aluno, parece não ter se consolidado, dado que a grade curricular destas unidades não sofreu grandes alterações. Por outro lado, a possibilidade do aluno se candidatar a atividades extracurriculares em sua própria escola representa um ganho indiscutível para os moradores das regiões contempladas pelo programa. Neste sentido, viabilizou-se a almejada formação integral, garantida pela oferta diversificada de equipamentos públicos.

Do ponto de vista arquitetônico, o projeto procurou exaltar a exclusividade do programa, optando pela implantação de edifícios padronizados, "carimbados" pela cidade. Apesar do traçado de forte cunho modernista, sem grandes apelos tecnológicos ou formais, os CEUs introduziram-se como referência marcante na paisagem das periferias paulistanas, sendo facilmente reconhecido pela população. Uma importante marca da cidade formal em regiões de ocupação predominantemente espontânea.

Essa retomada sintética da produção de edifícios escolares em São Paulo procura demonstrar a consistência apontada anteriormente. Ao contrário da produção habitacional, a política de construção de equipamentos educacionais contou com saltos conceituais qualitativos ao longo das décadas, refletidos na concepção espacial destes edifícios.

Além da demanda de custo e quantidade, o desafio de atender a novas perspectivas pedagógicas serviu de estímulo aos arquitetos, propiciando a realização de novas experiências e a consolidação de novos parâmetros tipológicos, coisa que raramente se vê em relação à habitação. Não à toa, diversos projetos de arquitetura escolar passaram a preencher as páginas

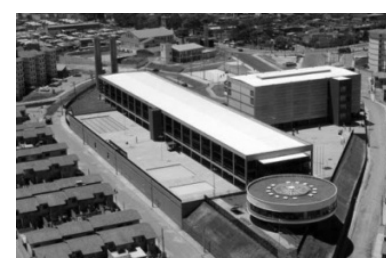

CEU Inácio Monteiro (2003). Fonte: DORIA; PEREZ, 2007. 
dos principais anais de arquitetura brasileira nas últimas décadas ${ }^{5}$ e os manuais e catálogos técnicos elaborados ao longo desta produção tornaramse referências de projeto inclusive para escritórios privados, consagrando a experiência pública na construção de edifícios educacionais.

Nessa procura de rumos, em cada fase da luta pela educação nacional, constroem-se escolas cuja arquitetura reflete talvez melhor do que qualquer outra categoria de edifícios, as passagens mais empolgantes de nossa cultura artística; os recursos técnicos que tivemos à disposição; as ideias culturais e estéticas dominantes; tudo condicionado a um projeto nacional de desenvolvimento. (ARTIGAS, 1970, p. 10)

Enquanto os edifícios educacionais evidenciam em sua arquitetura mudanças de diretrizes e políticas implementadas, assim como reflexos do contexto em que foram implementados, no caso da habitação os projetos seguem replicados, e em geral, descontextualizados. Desde o BNH 0 modelo "conjunto habitacional popular" continua se reproduzindo, seguindo basicamente os mesmos programas de usos e as mesmas diretrizes de inserção urbana anteriormente empregadas, norteado apenas pelas questões de custo, e nunca de benefício. As próprias limitações impostas pelas linhas de financiamento convergem para esta estagnação. Recordando o conceito de "aura" introduzido por Benjamin $(1994)^{6}$, diria que estes conjuntos perdem assim a sua aura, estando deslocados tanto em relação ao tempo, quanto ao espaço. São construções sem história.

Ao contrapor a edificação escolar à habitacional, emerge uma questão determinante, que consiste no fato de a primeira contar com terrenos dados e a segunda não. Apesar da grande parte dos terrenos destinados às escolas não contarem com condições físicas ideais, constituindo muitas vezes as sobras de novos loteamentos, são todos públicos. Em geral, a demanda pelo projeto já é recebida com a indicação do terreno a ser utilizado. No caso da habitação, a propriedade é privada. Para viabilizar a produção, investe-se na compra do terreno e repassa-se o imóvel. Com isso, o ônus da manutenção, excluindo-se possíveis problemas estruturais, será abarcado pelos futuros proprietários, o que reduz a prioridade do Poder Público à qualidade.

5. De 1950 a 1995, de acordo com os Índices de Arquitetura Brasileira, foram publicados 118 artigos referentes a projetos de arquitetura para edifícios escolares públicos em São Paulo. Destes, a revista Acrópole publicou 40, a Projeto 24, a Habitat 18, a Construção São Paulo 15 e os demais foram publicados por outros periódicos da área.

6. Em relação ao conceito de "aura", Benjamin assim o define: "As situações a que se pode levar 0 resultado da reprodução técnica da obra de arte, e que, alias, podem deixar a existência da obra de arte incólume, desvalorizam-lhe, de qualquer modo, o seu aqui e agora. [...] A autenticidade de uma coisa é a suma de tudo o que desde a origem nela é transmissível, desde a sua duração material ao seu testemunho histórico. [...] Pode resumir-se essa falta no conceito de aura [...]." (BENJAMIN, 1994, p. 79) 
Desse modo, as causas do descompasso podem ser várias, contudo parecem partir, sem dúvida, da questão da posse. 0 descaso com a qualidade da habitação, em favor da redução exacerbada dos custos, afasta o investimento em inovações tecnológicas eficientes e sustentáveis, uma vez que as construções serão repassadas, e a um valor mínimo. Tal economia, entretanto, gera custos enormes no médio e longo prazo, uma vez que a clientela alvo dos programas de habitação social, em geral, não dispõe de condições financeiras para arcar com os altos gastos de manutenção, fruto da péssima qualidade do imóvel. Com isso, segundo entrevista com Paulo Pignanelli, arquiteto da $\mathrm{CDHU}^{7}$, o Poder Público acaba sendo obrigado, muitas vezes, a assumir os reparos condominiais, uma demanda constante $\mathrm{e}$ infindável.

A construção de equipamentos públicos, por sua vez, conta com recursos ininterruptos, provenientes, sobretudo, dos cofres municipais e estaduais, $e$ sua gestão funciona, em certo sentido, nos moldes de uma empresa privada, dada a preocupação com 0 futuro patrimônio. Além disso, as políticas de implantação de equipamentos públicos - sejam eles educacionais, culturais, esportivos, de saúde, etc. - contam com uma demanda solúvel, ou seja, uma demanda numericamente quantificável, que embora crescente, pode ser mensurada. Já a política habitacional trabalha com uma demanda aberta, fruto das oscilações do cenário socioeconômico e dos interesses do mercado imobiliário.

Frente a esse quadro, entendeu-se que a questão da qualidade da produção habitacional vai muito além do conhecimento de alternativas técnicas, constituindo parte de uma teia político-econômica, que amarra 0 processo produtivo. Sendo assim, optou-se pelo caminho inverso de estudar um setor da produção pública que tivesse alcançado, em termos de política pública e não de ação isolada, um processo evolutivo de qualidade e modernização, buscando compreender as variáveis que viabilizaram este trajeto.

Tal pensamento levou a pesquisa a deslocar seu objeto de estudo, assumindo como foco a produção de edifícios educacionais em São Paulo, acreditando poder daí extrair importantes contribuições para a produção pública na cidade. A compreensão da estrutura produtiva, dos agentes envolvidos, dos quadros de recursos disponibilizados, entre outros fatores, compõe um cenário complexo, o qual encontrará seus reflexos nos edifícios implantados na cidade. Sendo assim, esta pesquisa se propõe a desconstruir 
este cenário, destrinchando cada um de seus componentes, de modo a identificar seus papéis e efeitos sobre o produto final, ou seja, o edifício.

A experiência profissional pessoal na construção de projetos educacionais, tanto no campo conceitual, ao participar da formulação do programa estratégico de governo da Prefeitura da Cidade de Nova Iguaçu - Programa Bairro-Escola -, como no campo prático, com a elaboração de projetos de escolas para as Prefeituras de Nova Iguaçu, Jundiaí e São Bernardo do Campo, levou-me a contrapor as diferentes modalidades de atuação pública.

A produção pública de edifícios escolares em São Paulo atualmente é compartilhada pelas diferentes esferas de governo, seguindo políticas específicas e, portanto, propostas e processos independentes, o que se reflete em diferentes partidos arquitetônicos e diferentes formas de inserção do equipamento na malha urbana. Com isso, não se trata de uma produção homogênea, contudo, ambos os procedimentos contam uma história. Mais do que a evolução das tecnologias construtivas e dos programas arquitetônicos, interessa analisar quais os contextos que viabilizaram tal desenvolvimento, seja do ponto de vista técnico-operacional, seja no tocante às estruturas institucionais e financeiras vigentes.

Em uma última estância, a pesquisa buscará apontar, a partir do estudo deste processo, as formas e as determinantes que delineiam a presença do Poder Público na paisagem periférica, 0 qual se constitui muitas vezes 0 único agente de produção formal destes espaços. Desse modo, os edifícios públicos passam a representar mais do que construções, carregando em si 0 peso simbólico da presença do Estado. Segundo João Canteiro, em depoimento à autora, esta seria a maior contribuição dos conjuntos habitacionais às cidades, por trazerem com sua implantação toda uma rede de infraestrutura associada, provendo as periferias de características urbanas, como vias pavimentadas, redes de serviços básicos instaladas e, sobretudo, equipamentos públicos.

[...] Isso acabou transformando-os, com todos os defeitos e críticas que têm os conjuntos habitacionais, numa ilha de excelência no que diz respeito a áreas institucionais. (informação verbal) $)^{8}$

As formas de atuação do Estado na construção da paisagem da cidade e os impactos ocasionados pelas diferentes condutas de gestão constituem a meta desta pesquisa, visando compreender as principais diretrizes de formulação do que seria um ideário urbano paulistano. 


\subsection{OS MEIOS: A METODOLOGIA DA PESQUISA.}

Por analisar um processo ainda em curso, a pesquisa contou com escassos dados estatísticos, algumas vezes não muito precisos. Desse modo, a metodologia empregada assumiu forte cunho empírico, apoiada em levantamentos de campo, entrevistas e análises subjetivas, embora sustentadas por estudos teóricos consagrados. 0 processo se concentrou em três momentos específicos, sendo eles: 1) levantamento bibliográfico, 2) estudo de caso e 3) discussão analítica.

Tendo por foco a produção de edifícios educacionais em São Paulo, a bibliografia consultada foi selecionada de modo não só a fundamentar a construção de um quadro histórico de projetos, mas, sobretudo, compreender os contextos em que estes se inseriram. Sendo assim, 0 estudo partiu das poucas publicações voltadas exclusivamente à interface entre arquitetura e educação, levantando autores como BUFFA e PINTO (2002), FERREIRA e MELLO (1998, 2006a, 2006b) e, sobretudo, as diversas dissertações e teses relativas ao tema.

Trabalhos especificamente dedicados aos diversos períodos da produção escolar foram essenciais ao aprofundamento da análise, trazendo uma riqueza de detalhes muitas vezes não necessária ao corpo escrito desta pesquisa, contudo fundamental para a compreensão dos processos históricos decorrentes. Este é 0 caso do trabalho de WOLFF (2002; 2010), acerca das primeiras décadas da produção escolar em São Paulo e do livro de NIEMEYER (2002), que analisa os Parques Infantis de Mário de Andrade. 0 livro de [Hélio] DUARTE (1973) e a consequente dissertação de ABREU (2007) foram contribuições imprescindíveis para a compreensão do consagrado Convênio Escolar. 0 doutorado de ALVES (2008) e os mestrados de FERRATA (2008) e VALENTIM (2006) disponibilizaram um completo panorama das atividades do IPESP, em particular do grupo liderado por Vilanova Artigas. A dissertação de BUITONI (2009) trouxe a obra da CONESP ao focar a figura de Mayumi de Souza Lima, o que seria retomado pelas publicações da Fundação para o Desenvolvimento da Educação - FDE, importantes relatos do histórico da empresa. Por fim, enquanto prática mais atual e, portanto, pouco publicada, a experiência dos Centros Educacionais Unificados - CEUs foi analisada a partir da obra de DÓRIA e PEREZ (2007) e da dissertação de MASCARENHAS (2006).

Visando complementar o estudo de uma área que é alheia aos limites da arquitetura, buscou-se ainda consultar autores da educação, como FARIA (1999a, 1999b, 2007), FREIRE (1987, 1995, 1996) e MARCILIO (2005), 
visando melhor compreender os projetos pedagógicos e suas interfaces com a arquitetura.

0 estudo de caso concentrou-se nos projetos realizados no município de São Paulo na última década, sendo esta a "prisão" da pesquisa, no termo cunhado por Eduardo Coutinho. 0 aprofundamento na análise destes casos se deu por três estratégias de aproximação do objeto, sendo elas, em ordem gradativa, 1) entrevistas com estudiosos e agentes envolvidos no processo, 2) levantamento dos projetos implementados no período e 3) estudo de campo específico.

Por fim, a discussão analítica a fechar esta pesquisa consiste numa articulação das etapas 1 e 2 aqui apresentadas, num exercício de avaliar 0 caso estudado sob o prisma do processo de construção da cidade. Neste sentido, um autor de grande influência foi PRETECEILLE (1977; 1986), que tece um importante olhar da sociologia frente à produção de equipamentos coletivos, colocada, segundo HARVEY (1982), como nó na rede do consumo. Ainda sobre equipamentos institucionais, foi considerada a discussão de cunho morfológico trazida por AYMONINO (1981), a qual exalta os impactos destes edifícios no meio urbano.

Ao tratar a questão das periferias, os diversos artigos publicados na Revista U.R. de 1992, intitulada "Projectar la Perifèria" - assinados por RAMONEDA, SOLÀ-MORALES, CHRISTIANSEN, entre outros -, trouxeram significativas contribuições para a reflexão a cerca do processo de produção e do papel dessas áreas no contexto das grandes cidades. Neste âmbito, vale citar ainda MAUTNER (1999), MARICATO (1979), LEFEBVRE (2001), entre outros.

\subsection{Para onde vou: os capítulos que Seguem.}

A estrutura da dissertação foi definida seguindo uma linha sequencial de análise, visando desconstruir processos já consagrados, para daí subtrair possíveis contribuições e levantar prováveis questionamentos. Desse modo, a pesquisa foi organizada em três capítulos analíticos e um quarto dedicado às conclusões.

0 capítulo 1, "Construindo escolas", traz uma contextualização histórica do objeto, pontuando os principais saltos da produção pública de edifícios educacionais em São Paulo. 0 verbo "construir" refere-se à ideia de 
reconstrução deste quadro evolutivo, por meio de um levantamento histórico apurado dos momentos mais relevantes e definidores da produção na cidade.

Realizado este mapeamento inicial, o capítulo 2, intitulado "Desconstruindo as escolas", procura destrinchar as experiências contemporâneas, de modo a identificar de modo detalhado os processos produtivos, os agentes envolvidos e os impactos proporcionados por cada conduta dada sua implementação no meio urbano. A ideia de "desconstrução" sugere ainda que falsos paradigmas sejam rompidos e lacunas sejam apontadas, visando direcionar a discussão rumo à busca por alternativas mais eficientes.

No capítulo 3, "A construção pública", são elencadas as principais características verificadas no capítulo anterior e, a partir delas, são delineados panoramas da produção pública na cidade, contraponto opções de gestão distintas e seus consequentes impactos. Neste capítulo pretendese discutir estruturas de projeto, exigências técnico-construtivas, possibilidades de inovação conceitual e as pressões do mercado da construção civil, que acabam por direcionar ações do Poder Público.

A dissertação se encerra com um capítulo conclusivo, cujo título indica as ambições propositivas almejadas pela pesquisa: "Construindo periferias". A partir das discussões realizadas, o trabalho se propõe a delinear possíveis contribuições para os processos de produção pública de edifícios em São Paulo, visando a formulação de políticas urbanas mais consistentes $\mathrm{e}$ intervenções conscientes de seu papel não só na construção da cidade, como também na consolidação de uma nova estrutura social. 
OS MEANDROS DA PRODUÇÃO PÚBLICA NA CONSTRUÇÃO DA PAISAGEM PERIFÉRICA PAULISTANA: 0 CASO DOS EQUIPAMENTOS EDUCACIONAIS 


\section{Construindo escolas: A PRODUÇÃO PÚBLICA DE EDIFÍCIOS EDUCACIONAIS em São Paulo}


OS MEANDROS DA PRODUÇÃO PÚBLICA NA CONSTRUÇÃO DA PAISAGEM PERIFÉRICA PAULISTANA: 0 CASO DOS EQUIPAMENTOS EDUCACIONAIS 
A Escola no Brasil é um fenômeno recente. A escola pública surgiu com 0 Movimento Republicano, configurando, mais do que uma proposta puramente pedagógica, uma estratégia de forte cunho político-ideológico: a Escola Republicana visava não apenas alfabetizar a população, mas, sobretudo, introduzir na sociedade o novo "espírito republicano".

A construção pública de edifícios escolares em São Paulo teve início, de fato, no início da segunda metade do século XIX, impulsionada pelo Ato Adicional de 1834, o qual remeteu aos Estados a responsabilidade pela promoção do ensino primário e profissional e à União as atribuições relativas aos ensinos secundário e superior. A partir da influência de republicanos como Oscar Thompson, Cesário Motta Júnior, Caetano de Campos, Rangel Pestana e Bernardino de Campos, nomes ocupados em difundir a escola primária, 0 Estado de São Paulo assumiu a necessidade de estruturar a rede de ensino com edifícios adequados às novas expectativas educacionais - e políticas. Políticos republicanos, intelectuais e educadores passaram a defender a necessidade de espaços especialmente construídos para abrigarem escolas.

Prédios grandes, arejados, bonitos, destinados a cumprir sua finalidade principal, a de ser escola, testemunham a valorização que 0 Estado dava ao ensino e serviam, ainda, para que a população os admirasse. Tais prédios passariam a compor a paisagem urbana da capital e de muitas cidades do interior. (BUFFA; PINTO, 2002, p. 32)

Edifícios construídos para serem escolas. Tais edifícios passariam a constituir novo marco na paisagem urbana, sendo facilmente reconhecidos pela população, simbolizando a presença do Estado na vida urbana. Bom exemplo disso é a Escola Normal de São Paulo, depois batizada Caetano de Campos, assim descrita por Artigas:

Magnífico edifício implantado em vasta área verde simboliza bem 0 ímpeto renovador [...] A Escola e o Relógio como que se transformaram em símbolos do ardoroso ideal republicano aparecendo nas praças mais novas em substituição da Igreja e do Cruzeiro. (ARTIGAS, 1970, p. 11)

Assim surgiram os Grupos Escolares, dando início à construção pública de edifícios educacionais em São Paulo. 


\subsection{O Departamento de Obras Públicas - DOP}

A construção pública de edifícios escolares teve início com 0 trabalho do Departamento de Obras Públicas (DOP), órgão atrelado ao governo estadual, que no final do século XIX e início do século XX implantou na capital e no interior diversos edifícios, acompanhando as áreas ocupadas pela economia do café. Apesar deste novo ideário de "edifício-escola", o vínculo entre arquitetura e concepções pedagógicas, segundo Buffa e Pinto (2002), é tardio. A grande inovação do período esteve na incorporação da educação enquanto política pública, o que, de acordo com Correa (1991), demandou uma reorganização da administração escolar, o uso de instrumentos de planejamento, os recenseamentos, a ampliação da rede e da clientela escolar. Criou-se um complexo sistema educacional, que incluía inúmeras formas de organização, classificação e níveis de instituições de ensino, sendo as principais categorias Escolas Isoladas, Escolas Reunidas, Escolas Ambulantes, Escolas Preliminares, Escolas Complementares, Escolas Modelo, Grupos Escolares, Escolas Normais e Escolas Profissionalizantes.

0 primeiro edifício na capital projetado para ser uma escola de ensino preliminar (ou primário) foi a Escola Modelo da Luz, mais tarde convertida em Grupo Escolar Prudente de Moraes, construída em 1893, com projeto de autoria de Ramos de Azevedo. Assim como Ramos de Azevedo, o DOP contou com outros arquitetos de renome, alguns estrangeiros, como Victor Dubugras, Giovanni Battista Bianchi e Carlos Rosencrantz, dando início a um histórico arquitetônico louvável, que se estenderia ao longo dos demais períodos da produção de escolas em São Paulo.

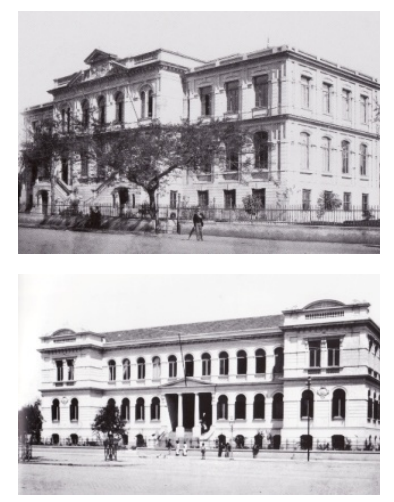

Acima, Escola Modelo da Luz e Escola Modelo do Brás. Ao lado, Escola Normal da Capital (posterior Caetano de Campos). Fonte: WOLFF, 2010.

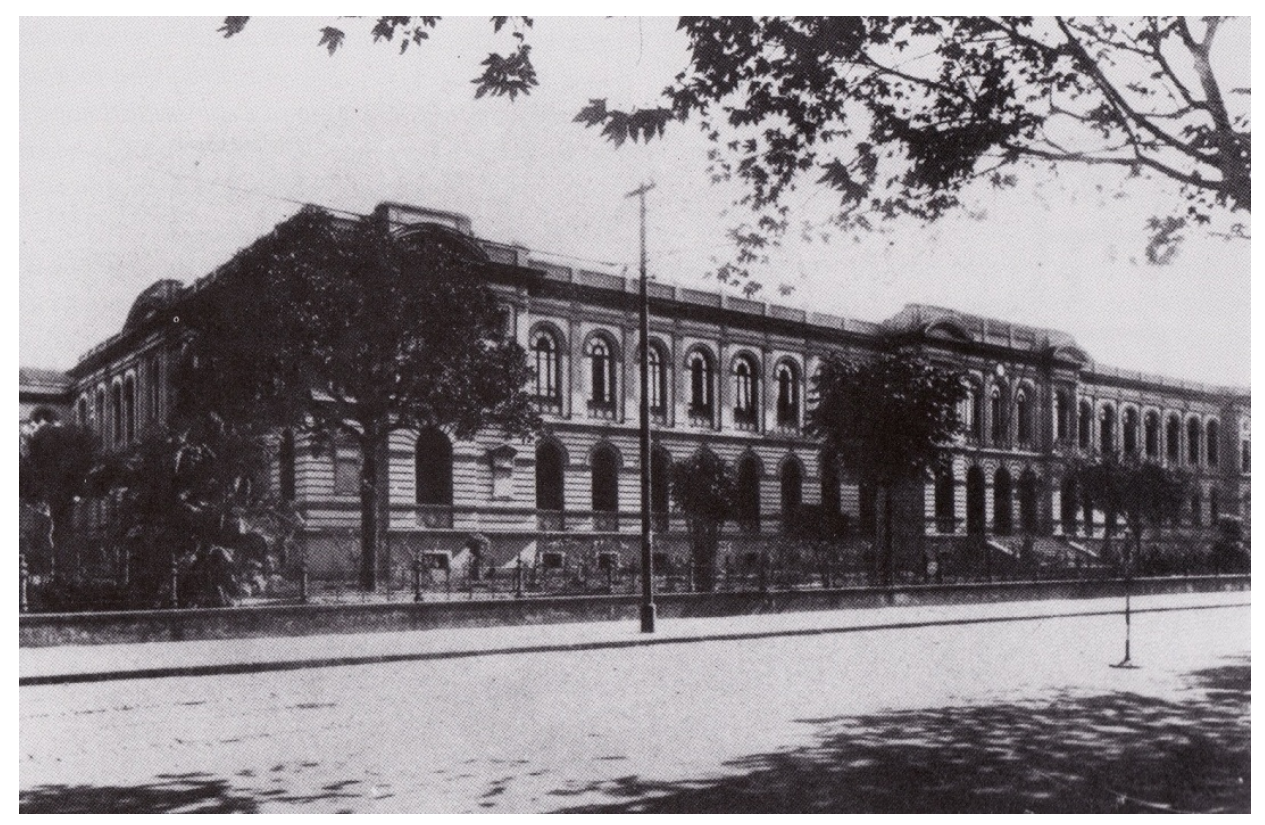




\section{CONSTRUINDO ESCOLAS}

A riqueza proveniente do sucesso da produção cafeeira neste período permitiu que estas escolas contassem com grande requinte construtivo, abusando dos materiais importados, assim como dos estilos importados, 0 que resultou na produção de uma rede de edifícios neoclássicos e ecléticos. Quanto à distribuição do programa, predominava a utilização de projetos-tipo, ou seja, projetos genéricos a serem carimbados tanto nos diversos bairros da capital quanto no interior (BUFFA; PINTO, 2002). Os edifícios eram quase sempre térreos e simétricos, com duas alas com acessos e recreios independentes, uma para cada sexo. As áreas administrativas eram bastante enxutas. 0 galpão para ginástica, festas e recreio coberto, assim como os sanitários eram construídos em blocos isolados.
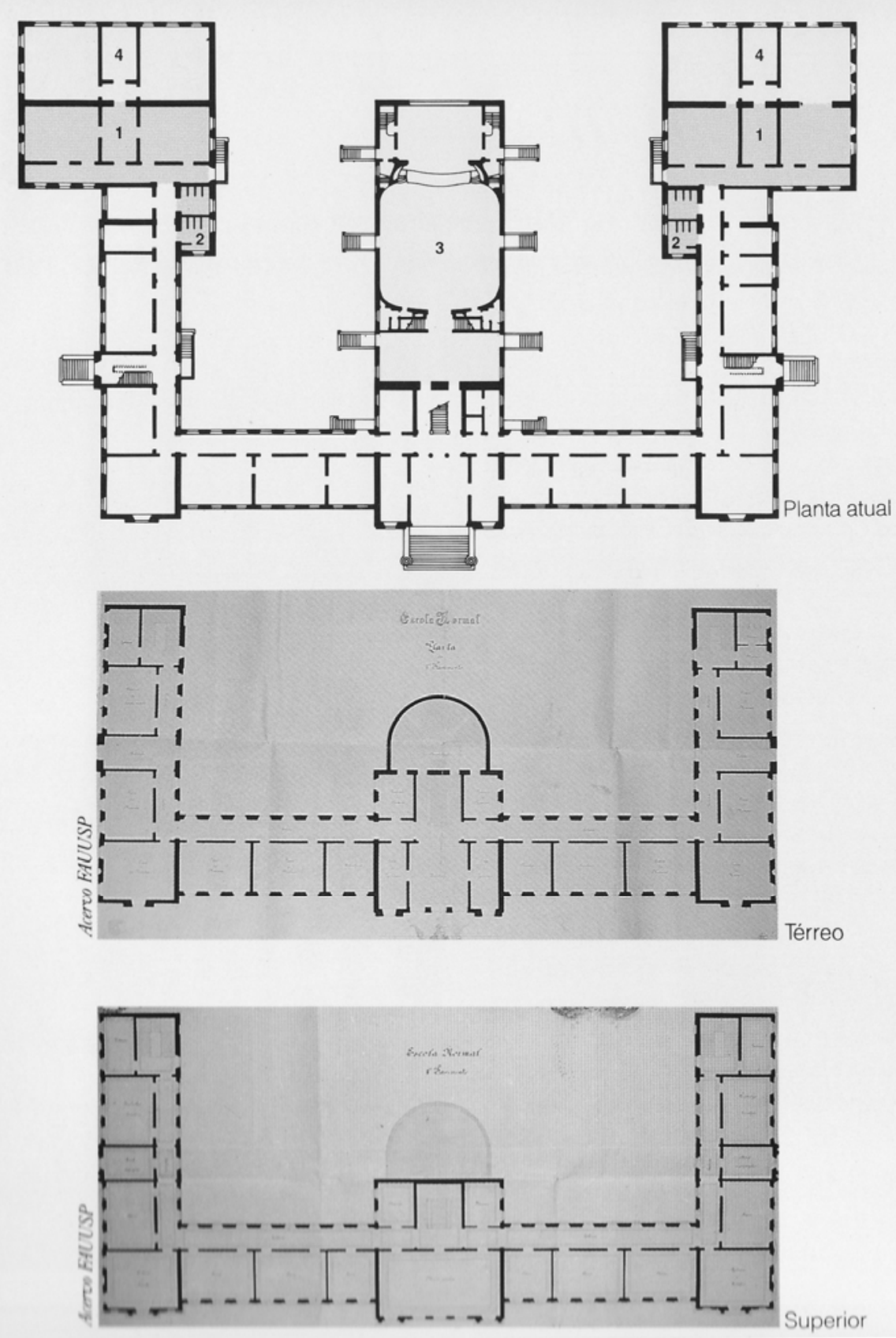

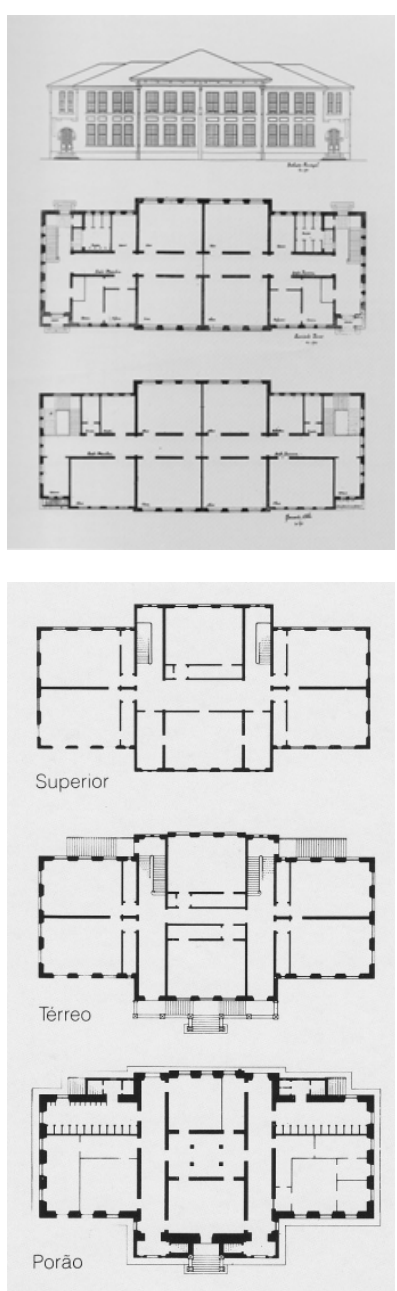

À esquerda, Escola Normal de São Paulo (Caetano de Campos); acima, Escola Modelo da Vila Mariana; abaixo, Escola Modelo da Luz, todas de Ramos de Azevedo: edifícios simétricos, com alas específicas para cada sexo, ausência de pátios internos. Fonte: CORREA, 1991. 
Tipologia Botucatu e alguns exemplares de sua utilização: Grupos Escolares de Araras, Espírito Santo do Pinhal, Araraquara e Campinas. Apesar da planta padronizada, nota-se a diversidade de possibilidades alcançada pelas fachadas. Fonte: CORREIA, 1991.

0 grande elemento diferenciador era a fachada. 0s projetos partiam sempre de uma das tipologias padrão: tipologia Brás, tipologia Vila Mariana, tipologia Botucatu, etc. A partir das plantas padronizadas, trabalhava-se a fachada, de modo a proporcionar um caráter particular a cada uma das construções. A opção pelo projeto-tipo constituía importante ferramenta para acelerar 0 processo de projeto, permitindo que os poucos arquitetos capacitados no assunto pudessem dar conta da imensa demanda por edifícios.
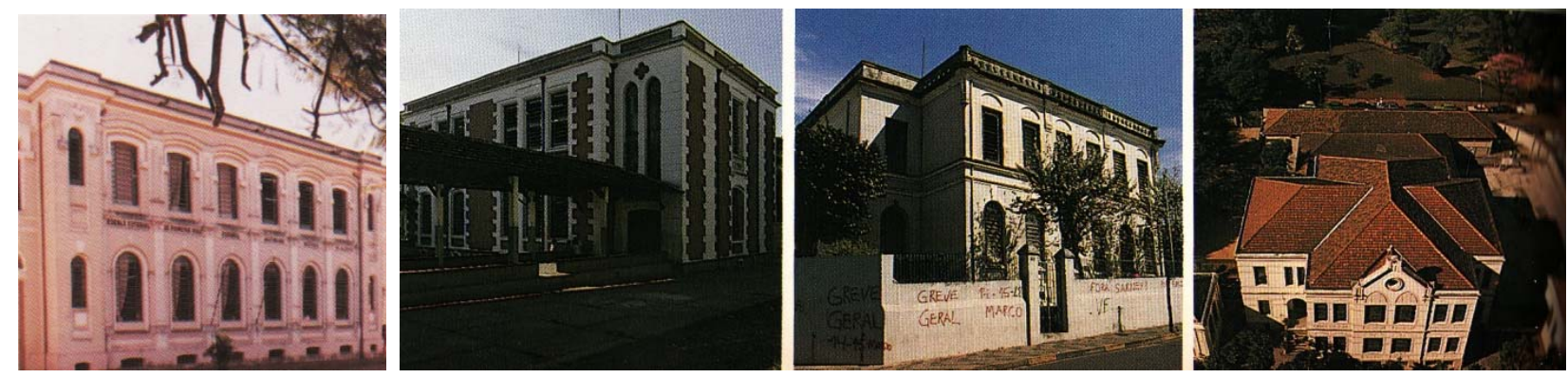

Os edifícios desse período, importantes mastros da bandeira republicana, eram, antes de tudo, monumentais, simbolizando a prosperidade e as expectativas que 0 momento político prometia. Da mesma forma, a localização destas escolas priorizava sempre terrenos centrais, onde 0 edifício escolar pudesse se destacar no espaço urbano, constituindo uma imponente referência na paisagem.

As escolas na Primeira República (1889-1930) caracterizaram-se urbanisticamente por ocuparem espaços estratégicos nos centros urbanos, ao pretenderem mostrar o papel redentor que se atribuía à educação no regime republicano recém implantado [...]. (ABREU, 2007, p. 83)

0 Grupo Escolar representava, enfim, o surgimento da escola pública e urbana. 0 ensino não só passava a contar com uma nova estrutura, como ele mesmo se reestruturara. Pedagogicamente, era a transição da escola de primeiras letras para a escola primária que conhecemos. Enquanto a primeira baseava-se na repetição e na memorização, em salas únicas que reuniam 


\section{CONSTRUINDO ESCOLAS}

toda a diversidade de alunos, a segunda, calcada no "método científico" e não mais no literário, prometia "instruir [...], moralizar, civilizar e consolidar a ordem social” (BUFFA; PINTO, 2002, p. 43), universalizando o ensino primário, fator considerado essencial à consolidação da República. Era a institucionalização do ensino. E os edifícios trataram de evidenciar isso.

Impossível não distinguir, com clareza, na paisagem da cidade, um edifício imponente onde funcionava um Grupo Escolar construído nas primeiras décadas do período republicano. [...] A localização privilegiada, ao lado de importantes edifícios públicos, no centro da cidade, garantia sempre que os alunos percorressem e reconhecessem a cidade e suas instituições antes mesmo de chegarem à escola. (BUFFA; PINT0, 2002, p. 43)

\subsection{A Comissão Permanente e os Parques Infantis}

Os anos 30, marcados pelo golpe de Estado de Getúlio Vargas e pela consequente instauração de um governo populista, trouxeram uma nova reforma no sistema educacional. Em 1933, com a elaboração do Código de Educação do Estado, organizado pelo educador Fernando de Azevedo, foi instituída a Comissão Permanente, visando não só suprir a forte demanda por vagas, mas também reformular pedagogicamente o ensino no país, de acordo com os novos conceitos da Escola Nova ${ }^{9}$. Formou-se então um grupo interdisciplinar preocupado em definir novas diretrizes para os projetos de edifícios escolares.

A Escola Nova, entre outras coisas, propunha a criança como centro do processo de ensino-aprendizagem, buscando não apenas formá-la

9. Escola Nova foi um movimento de renovação do ensino especialmente forte na Europa, na América e no Brasil, na primeira metade do século XX. Os primeiros grandes inspiradores da Escola Nova foram 0 escritor Jean-Jacques Rousseau (1712-1778) e os pedagogos Heinrich Pestalozzi (1746-1827) e Freidrich Fröebel (1782-1852). 0 grande nome do movimento na América foi 0 filósofo e pedagogo John Dewey (1859-1952). 0 psicólogo Edouard Claparède (1873-1940) e 0 educador Adolphe Ferrière (1879-1960), entre muitos outros, foram os expoentes na Europa. No Brasil, as ideias da Escola Nova foram introduzidas já em 1882 por Rui Barbosa (1849-1923). Entretanto, ganhariam força no século XX, especialmente após a divulgação do "Manifesto dos Pioneiros da Educação Nova", de 1932. Os principais nomes da vertente nacional foram Lourenço Filho (1897-1970) e Anísio Teixeira (19001971), aluno de Dewey.

Inspirados nas ideias político-filosóficas de igualdade entre os homens e do direito de todos à educação, esses intelectuais viam num sistema estatal de ensino público, livre e aberto, o único meio efetivo de combate às desigualdades sociais da nação. Para tanto, defendiam a universalização da escola pública, laica e gratuita. A educação deveria tomar como eixo norteador a vida-experiência e a aprendizagem, fazendo com que a função da escola fosse a de propiciar uma reconstrução permanente da experiência e da aprendizagem dentro de vida de seus alunos. 
intelectualmente, mas também estimular as dimensões física, emocional e social, fornecendo assim uma educação integral. Seguindo estes princípios, a Comissão Permanente foi formada de modo a agregar profissionais das mais diversas áreas, tais como pedagogos, professores, engenheiros, arquitetos, urbanistas, desenhistas, administradores, psicólogos, médicos e higienistas. Além da multidisciplinaridade, a Comissão contou com profissionais expressivos ${ }^{10}$, que ocupavam importantes cargos na administração pública, como, por exemplo, Prestes Maia, engenheiro responsável pela elaboração do famoso Plano de Avenidas. Tal fato faz evidente a relevância que 0 governo dera a este órgão.

Em resposta a todo esse prestígio, a Comissão veio a inaugurar a modernidade na arquitetura escolar paulistana, imprimindo um novo caráter aos edifícios escolares, atrelando o espaço ao ensino.

Como é possível perceber, na própria orientação para a escolha do terreno bem como nas propostas para a construção do prédio estão presentes preocupações típicas da Escola Nova: a criança é o centro da aprendizagem e a escola tem que ser alegre, acolhedora, bonita, espaçosa, higiênica, para possibilitar uma educação integral. (BUFFA; PINTO, 2002, p. 75)

Apesar de um consistente trabalho de definição dos novos conceitos a serem empregados nos edifícios escolares a serem construídos ${ }^{11}$, que iam de materiais construtivos ao próprio programa arquitetônico, a Comissão

10. A Comissão Permanente era composta pelos seguintes profissionais:

- Antônio de Almeida Junior - Médico e Diretor do Ensino. Ex-chefe do Serviço de Higiene Escolar;

- Oscar Machado de Almeida - Engenheiro. Diretor de Obras Públicas;

- Luiz Motta Mercier - Ex-Diretor do Ensino. Chefe dos Serviços de Prédios Escolares.

- Noemy Silveira Rudolfer - Psicóloga. Professora de Psicologia Educacional;

- Quintiliano José Sitrangulo - Delegado Regional de Ensino;

- Carolina Ribeiro -Pedagoga. Diretora do Curso Primário;

- Francisco Prestes Maia - Engenheiro. Engenheiro-chefe da Diretoria de Obras Públicas;

- José Maria da Silva Neves - Engenheiro-arquiteto. Membro da Secretaria de Viação e Obras Públicas. Professor adjunto da Escola Politécnica e da Escola de Belas Artes;

- Carlos Alberto Gomes Cardim Filho - Urbanista. Chefe da Divisão de Urbanismo da Prefeitura. Professor da Escola de Belas Artes;

- Geraldo de Paula Souza - Higienista. Diretor do Instituto de Higiene e professor;

- F. Figueira de Mello - Inspetor. Chefe da Inspetoria de Higiene Escolar e Educação Sanitária;

- Danton Malta - Oftalmologista. Inspetor médico escolar;

- Vicente de Sampaio Lara - Médico instrutor do Instituto de Higiene;

- Moacyr Álvaro Eyck - Oftalmologista;

- Milton da Silva Rodrigues - Engenheiro. Professor de Estatística do Instituto de Educação;

- Jorge Mancebo - Desenhista-arquiteto. Membro da Diretoria de Ensino.

11. As várias análises efetuadas pela Comissão, assim como a definição de novas orientações para a construção de escolas, foram agrupadas na publicação "Novos Prédios para Grupo Escolar”, de 1936. 


\section{CONSTRUINDO ESCOLAS}

Permanente construiu poucos edifícios. Embora haja controvérsia quanto ao número exato, acredita-se que não passaram de 15 prédios na capital e cerca de 40 no interior, erguidos no período entre 1936 e 1938 (BUFFA; PINT0, 2002). De qualquer forma, estes edifícios mostraram-se capazes de incorporar novos conceitos, bem como algumas ideias modernas de arquitetura, viabilizados pela evolução das técnicas construtivas vigentes. Apesar da participação reduzida no total da produção escolar do período cerca de 400 edifícios foram construídos no Estado entre 1920 e $1950^{12}$-, do ponto de vista arquitetônico, a contribuição da Comissão foi sem dúvida a mais significativa do período.

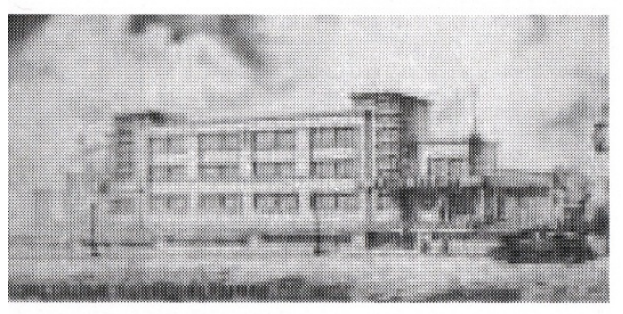

EEPG PROFO GODOFREDO FURTADO - JOSÉ MARIA DA SILVA NEVES

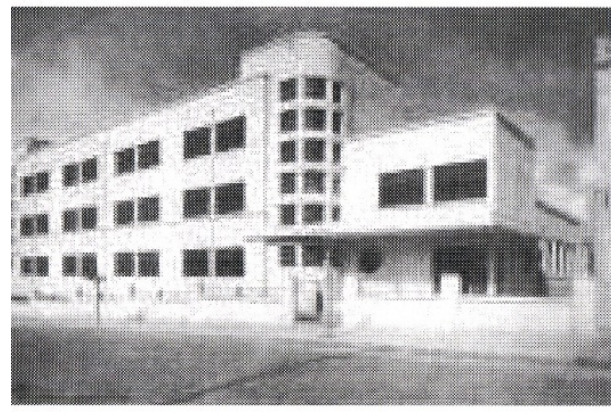

EEPG PROF GODOFREDO FURTADO - JOSÉ MARIA DA SIVIA NEVES

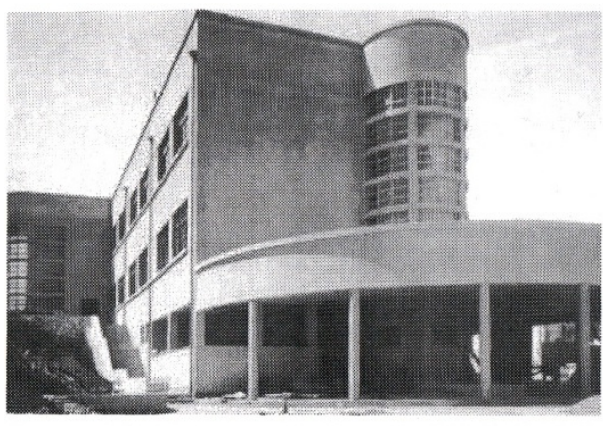

EEPG PADRE MANOEL DA NÓBREGA - HERNANI DO VAL PENTEADO

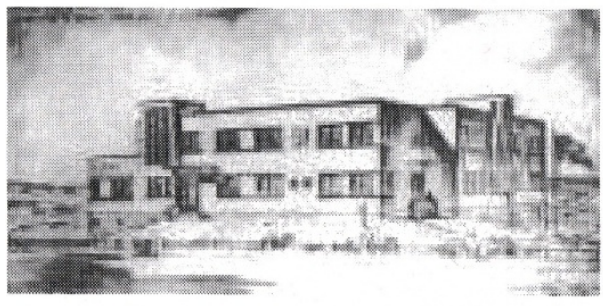

EEPG PROP PRINCESA ISABEL - JOSÉ MARIA DA SILVA NEVES

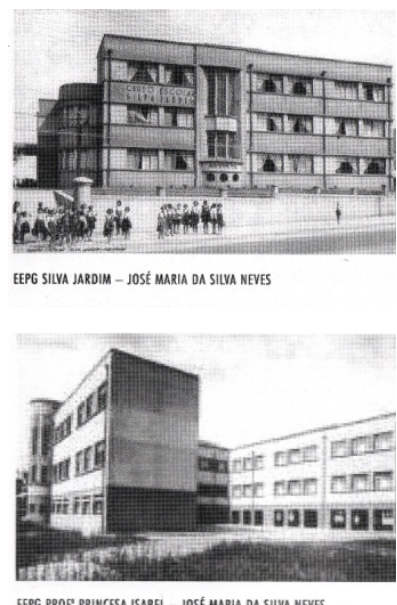

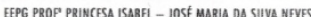

Alguns edifícios construídos pela Comissão Permanente. Traçado limpo, na busca por uma arquitetura moderna. Fonte: ABREU, 2007.

Liderada pelo arquiteto José Maria da Silva Neves, importante ativista do movimento moderno em São Paulo, a Comissão veio a descartar os projetos ecléticos até então produzidos, sugerindo edifícios escolares com feições pré-modernas, sem nenhuma referência a estilos históricos, compostos por formas geométricas simples, estrutura independe da vedação, pátios internos com pilotis e grandes aberturas envidraçadas. Os programas eram arrojados, incluindo ambientes para atividades variadas, tais como auditórios, salas de leitura, ginásios, etc. Tecnicamente, 0 emprego do concreto foi a grande inovação do período. Por possibilitar a execução de vãos mais generosos, permitiu integrar os pátios aos blocos principais e, ainda, ampliar as aberturas, aprimorando a qualidade interna das salas de aula. Outra 
Plantas do Grupo Escolar Visconde Congonhas do Campo, de José Maria da Silva Neves: estrutura independente, ambientes modulares, formas geométricas simples, pátio interno com pilotis. Fonte: BUFFA; PINTO, 2002. importante inovação foram as novas possibilidades de implantação do edifício no lote, privilegiando os aspectos de ventilação e insolação das salas de aula.

A elaboração dos projetos dos novos edifícios escolares revelou a preocupação com as questões higienistas, que pautaram 0 urbanismo moderno, através da correta implantação dos edifícios em relação à insolação e à ventilação dos ambientes. Assim, a rígida simetria do edifício eclético das escolas da Primeira República rompe-se e cede espaço para o edifício que busca o sol. Edifícios com plantas em forma de "L", "Z", "U", "E" são projetados, de preferência, com os corredores que dão acesso aos ambientes de um só lado, para garantir a iluminação das salas de aula na fachada mais propícia à incidência de luz solar. (ABREU, 2007, p. 47)

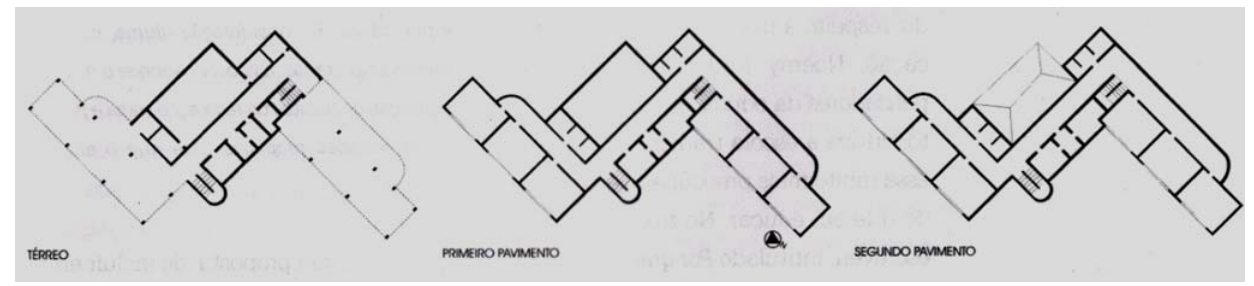

Paralelamente ao trabalho da Comissão na esfera estadual, no governo municipal a atuação de um outro órgão institucional, sob a coordenação do então secretário Fábio Prado, foi determinante no cenário das políticas educacionais do período: 0 Departamento de Cultura e Recreação, criado em 1935, que teve como primeiro diretor o poeta modernista Mário de Andrade.

A nova estrutura tinha por objetivo estimular um movimento cultural e artístico amplo em toda a cidade: "Uma educação para a cidadania, em sua concepção original, delineando com isso um projeto de nação com cores modernistas" (NIEMEYER, 2001, p. 106). Para tanto, o projeto do Departamento, organizado pelo jornalista Paulo Duarte, foi organizado de modo a englobar diferentes áreas ligadas à cultura, recreação e lazer, delineando-se diversos programas, entre os quais, os Parques Infantis.

Os parques infantis criados por Mário de Andrade em 1935 podem ser considerados como a origem da rede de educação infantil paulistana - a primeira experiência brasileira pública municipal de educação (embora não-escolar) para crianças de famílias operárias, que tiveram a oportunidade de brincar, de ser educadas e cuidadas, de conviver com a natureza, de movimentarem-se em grandes espaços (e não em salas de aula). Lá produziam cultura e conviviam com a diversidade da cultura nacional, quando 0 cuidado e a educação não estavam antagonizados, e a educação, a assistência e a cultura estavam macunaimicamente integradas, no tríplice objetivo parqueano: educar, assistir e recrear. (FARIA, 1999b, p. 61) 


\section{CONSTRUINDO ESCOLAS}

Os Parques Infantis eram equipamentos simples, compostos basicamente por um pátio coberto e ambientes auxiliares, contudo implantados em amplos terrenos em meio a bairros operários, de modo a preservar extensas áreas livres e gramadas, pela qual se espalhavam brinquedos e árvores. Sua construção fazia parte da política urbana da cidade, que, entre outras coisas, visava garantir o direito ao espaço público para as classes menos favorecidas economicamente, numa cidade que se deparava com um processo de urbanização fortemente acentuado (MASCARENHAS, 2006). Embora os Parques Infantis não constituíssem um equipamento com funções escolares, contavam com uma proposta integrada de educação infantil, levantando o histórico social dos alunos, acompanhando suas condições de saúde e estimulando o envolvimento das famílias em diversas atividades desenvolvidas pelas e para as crianças.

Importante salientar que, sob a direção de Mário de Andrade, os primeiros parques infantis não foram reduzidos a dar continuidade à ideia do lazer organizado das cidades industriais com a função de um papel moralizador, higienista e controlador do trabalhador urbano, particularmente das crianças, filhos desses trabalhadores. Mário de Andrade ampliou em muito as possibilidades deste equipamento urbano e vê nos parques infantis a possibilidade de investir na educação do trabalhador desde a sua mais tenra idade, incutindo-lhe os valores de nossa nacionalidade, na construção de um espírito de brasilidade, tão caro a todos os modernistas da Semana de 22, ou seja, o papel moralizador e organizativo, presente na gênese dos parques infantis, ganha contornos revolucionários em nossa cidade. (ABREU, 2007, p. 56)
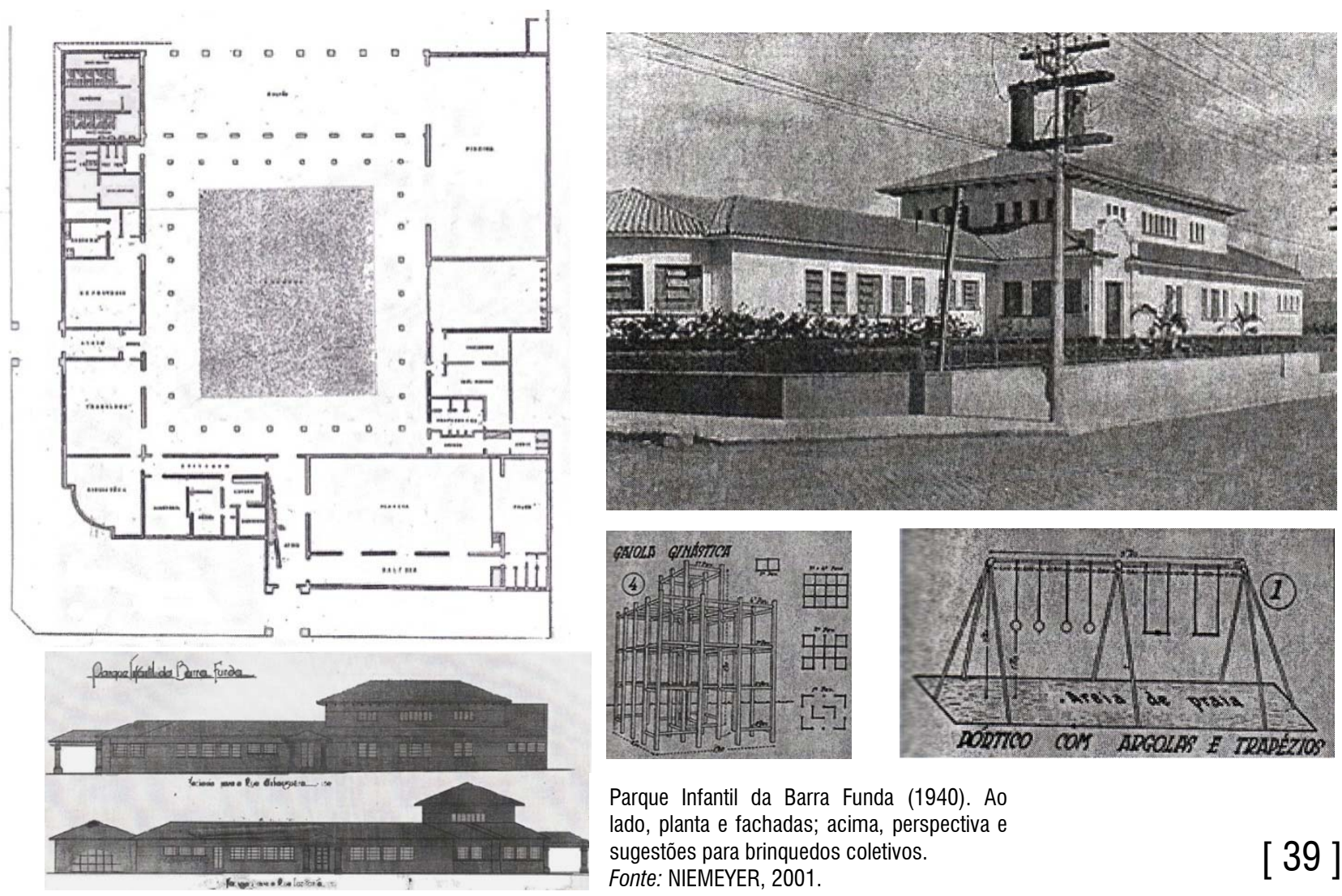

Parque Infantil da Barra Funda (1940). Ao

lado, planta e fachadas; acima, perspectiva e

sugestões para brinquedos coletivos. Fonte: NIEMEYER, 2001. 
Por ser a única iniciativa municipal voltada à educação naquele período, os Parques Infantis contaram com vultuosos recursos, dispondo de cerca de $10 \%$ do recolhimento de impostos do Município para sua implementação. 0 uso destes recursos pelo Departamento de Cultura gerou grandes discussões na Câmara Municipal, onde a proposta chegou a ser rebatida por um programa para construção de 1.000 escolas, considerado mais eficiente na complementação ao ensino oferecido pelo Estado, função esta a oficial finalidade da estrutura municipal.

Com a substituição de Fábio Prado por Prestes Maia (1938 - 1945), as prioridades para a cidade foram modificadas, exaltando-se as intervenções urbanas e deixando as dimensões culturais e educacionais restritas a ações pontuais (MASCARENHAS, 2006). Frente à nova política, em 1938, Mário de Andrade se demitiu do Departamento, 0 que afetou enormemente a implantação do programa de Parques Infantis. Se naquele momento a cidade contava com quatro Parques Infantis, estando outros três em obra, o quadro ao final da gestão de Prestes Maia não traria grandes alterações, contando com apenas nove Parques, ou seja, apenas dois deles projetados na última gestão. 0 projeto inicial considerava a implementação de cinquenta Parques.

Os parques infantis, além de criarem uma referência para o desenvolvimento de projetos educacionais, consideradas as questões do uso dos espaços livres urbanos, possibilitaram 0 início da discussão sobre a questão educacional de iniciativa municipal. (ABREU, 2007, p. 59)

\subsection{As Escolas-Parque de Anísio Teixeira e o ConvêNIo Escolar}

Não à escola-monumento, escola fortim que infunde respeito e que aparece às tenras fantasias das crianças como algo de tenebroso, de áulico e até de inimigo [...] As escolas do convênio escolar são amplas, horizontais, espaçosas no meio de jardins, são um convite amigável para as nossas crianças...

(DUARTE, 1951, p. 17)

Com 0 acentuado crescimento da cidade e a consequente escassez de vagas nas escolas, no final da década de 40, Prefeitura e Governo do Estado vieram a somar forças, firmando um acordo que ficaria conhecido como Convênio 


\section{CONSTRUINDO ESCOLAS}

Escolar $^{13}$. Atuando paralelamente ao DOP, o Convênio tomou por objetivo a construção em larga escala de edifícios escolares na capital paulista, visando sanar o déficit por vagas até 1954, ano da comemoração do $4^{\circ}$ Centenário de fundação da cidade. 0 acordo entre as diferentes esferas de governo entregou à Prefeitura a responsabilidade pela construção dos edifícios e ao Estado, a gestão do ensino.

Num primeiro momento, o Convênio produziu apenas três novos edifícios, sem grande qualidade arquitetônica e nenhuma inovação do ponto de vista pedagógico. 0 grande salto se deu com a assinatura do segundo acordo, em 1948. Só a partir deste momento o convênio de fato se concretizaria, com a criação da Comissão Executiva do Convênio Escolar, liderada pelo engenheiro José Amadei e pelo arquiteto Hélio Duarte ${ }^{14}$. Guiada por princípios essencialmente modernos e ideais revolucionários, esta comissão veio a introduzir um novo perfil aos edifícios escolares, tomando por base as propostas do educador Anísio Teixeira, pioneiro ao sugerir a escola em período integral e a disponibilização de tais edifícios para a comunidade. Conforme colocam Ferreira e Mello (2006), o intuito da Comissão seria então traduzir espacialmente este ideário educacional.

Após três meses de estudos e levantamentos, a Comissão veio a elaborar um plano quinquenal, onde previa a construção anual de 20 Grupos Escolares e 2 bibliotecas infantis, e ainda a manutenção de Parques Infantis e equipamentos de ensino auxiliares. Neste momento, Amadei, presidente da Comissão, destacou a precariedade da rede de ensino paulistana, atentando, sobretudo, para o fato de, entre os 111 Grupos Escolares existentes, 75 funcionarem em edifícios alugados, geralmente em péssimas condições. Fora isso, cálculos oficiais apontaram para um déficit de 40 mil vagas para crianças entre 7 e 14 anos.

No intuito de reverter este quadro, entre 1949 e 1959, o Convênio veio a produzir cerca de 70 escolas na capital, além de 500 galpões provisórios, 30 bibliotecas populares, 90 recantos infantis, 20 parques e outras tantas obras de restauração e manutenção de imóveis existentes. Apesar da demanda quantitativa, optou pela construção de edifícios de menor porte, a maioria

13. Foram firmados três convênios subsequentes entre Estado e Município de São Paulo: o primeiro vigorou de 1943 a 1948, o segundo, de 1949 a 1953 e o terceiro, de 1954 a 1959. Entretanto, coube ao segundo deles - período este liderado por Hélio Duarte - a maior contribuição no campo da produção de edifícios escolares, tanto quantitativa quanto qualitativa, sendo, portanto aqui retratado. Para mais informações, ver ABREU (2007).

14. Arquiteto carioca formado em 1930 pela Escola Nacional de Belas Artes, Hélio Duarte (1906-1989) foi um dos grandes nomes no modernismo do Brasil. Antes de vir para São Paulo, trabalhou em Recife, Rio de Janeiro e Salvador, adquirindo larga experiência com projetos de arquitetura escolar. 
com 12 salas de aula, contrariando o partido até então adotado. A ideia era formar, a partir dos edifícios escolares, pequenas comunidades de bairro com um raio de abrangência de cerca de $1.500 \mathrm{~m}$, as quais se distribuiriam por todo o município (ABREU, 2007). Pela primeira vez a construção de escolas era encarada como política urbana, visando à estruturação dos bairros periféricos e a consolidação de uma malha urbana mais homogênea.

Por que não considerar em cada bairro, a escola, o grupo escolar, como fonte de energia educacional, como ponto de reunião social, como sede das sociedades amigos de bairro, como ponto focal de convergência dos interesses que mais de perto dizem com a vida laboriosa de suas populações? (DUARTE, 1951, p. 5)

Tecnicamente, grandes avanços foram alcançados. 0 fato de ter como diretor técnico Hélio Duarte, arquiteto com ampla experiência em arquitetura escolar, fez com que a Comissão viesse a incorporar princípios racionalistas e funcionalistas, emblemas da arquitetura moderna de Mies, Gropius e Le Corbusier, nomes estes que naquele momento norteavam as discussões dos jovens arquitetos saídos da Escola Nacional de Belas Artes.

Desse modo, os edifícios produzidos no período vieram a valorizar os elementos construtivos, tais como amplos caixilhos em ferro, elementos vazados, marquises, pérgulas e pilares, e passaram a atentar para aspectos de conforto ambiental, tais como a promoção de ventilação cruzada, iluminação adequada, etc. No que diz respeito ao uso, tais edifícios empregavam, em geral, uma tipologia semelhante, que partia da distribuição do programa em blocos independentes para cada função, ligados por circulações cobertas. 0 pátio coberto ganhou destaque e se equipou de modo a possibilitar uma diversidade de atividades. A biblioteca e 0 museu foram incorporados ao programa (GILIOLI, 1994).

As obras arquitetônicas feitas pelo Convênio eram, do ponto de vista do sistema construtivo, muito simples e baratas, pois os edifícios tinham os seus componentes muito singelos, baratos e resistentes, sempre com um desenho moderno. As alvenarias e as estruturas eram revestidas, o que facilitava a construção e diluía os erros da obra. As esquadrias eram de ferro com vidro transparente, com um desenho elegante e específico para cada obra. Os pisos internos eram geralmente em cerâmica [...] e, nas salas de aula eram assoalho de madeira, também muito resistente e duradouro. Os forros eram, quando não sob lajes, de madeira compensada com um isolante térmico. Os telhados tinham a sua estrutura em madeira, com perfis de mercado (vigas, caibros e ripas), no galpão, a estrutura da abóbada era um arco abatido em concreto (pré-moldado no canteiro) e, as telhas eram as industrializadas (onduladas de fibrocimento). (TAKIYA, 2009, p. 45) 


\section{CONSTRUINDO ESCOLAS}
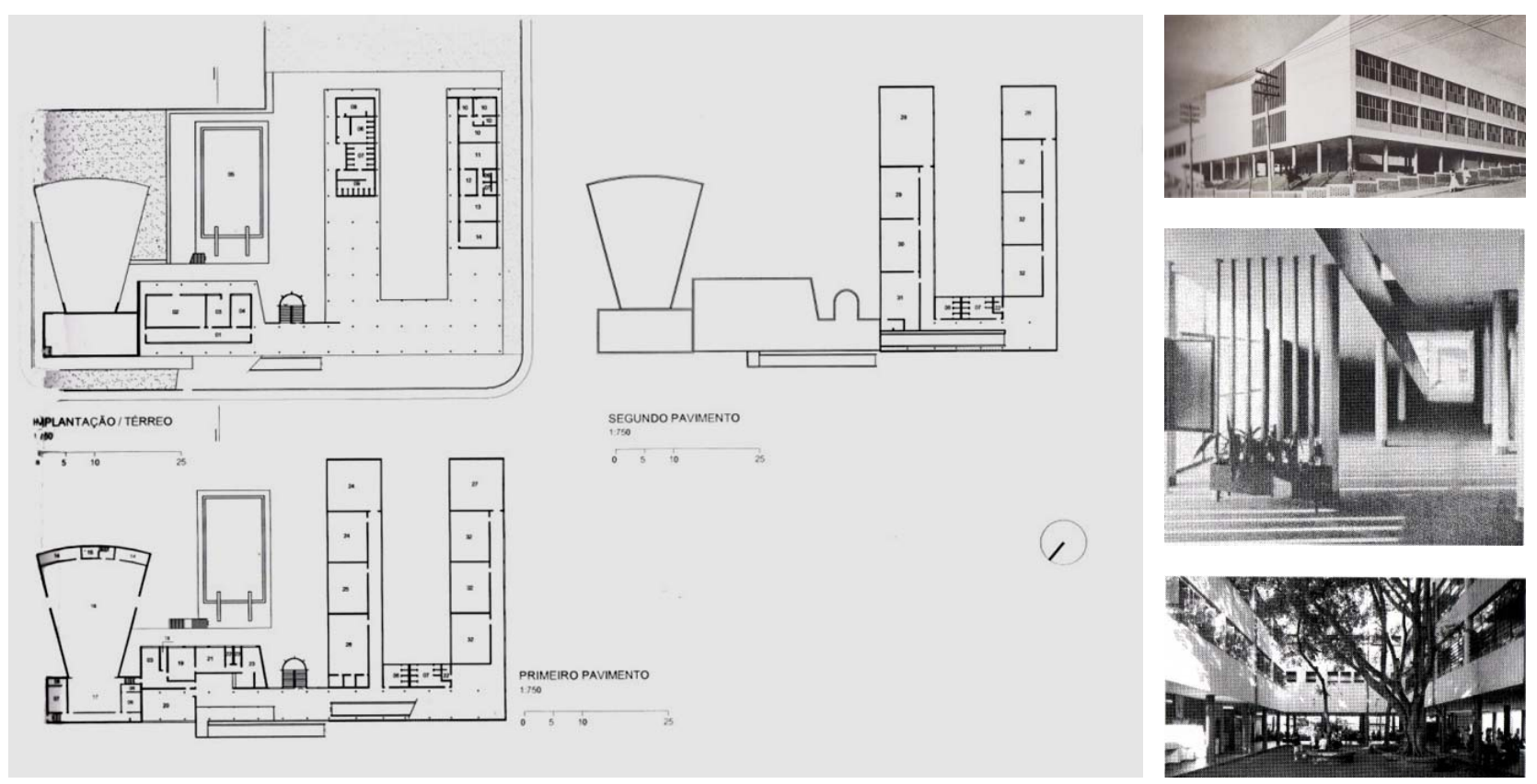

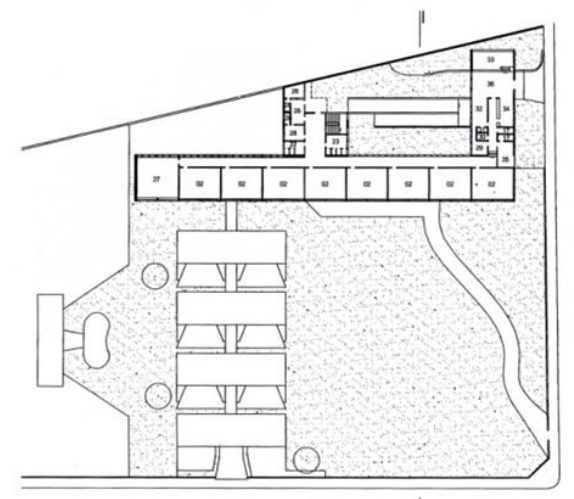

IMPLANTAÇAO / PRIMEIRO PAVMMENTO

${ }_{0}^{5}{ }^{\prime}$ io

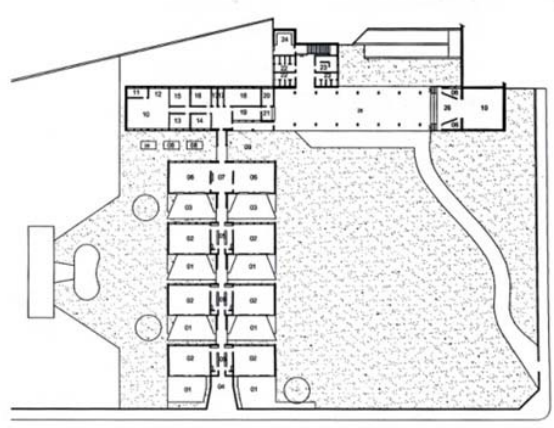

PAVIMENTO TERREO

0
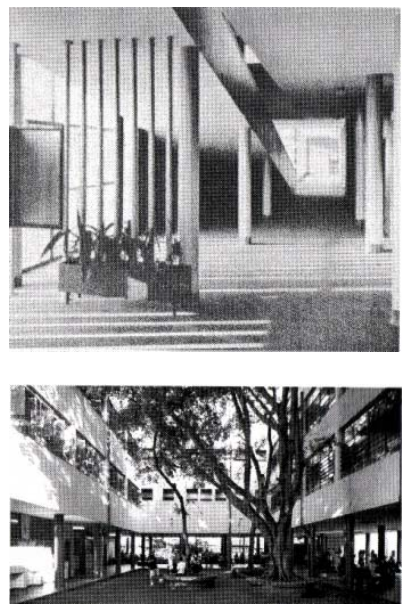

Acima, E.E. N. Senhora da Penha (1951), de Eduardo Corona. Ao lado E.E. Dr. Edmundo de Carvalho (1950), de Roberto Tibau. Abaixo, Visconde de Taunay (1949), de Hélio Duarte. Fonte: ABREU, 2007.

Traçado moderno, blocos funcionais independentes, pátio como elemento integrador, forte emprego de componentes construtivos, como brises, pilotis, marquises e grandes caixilhos.
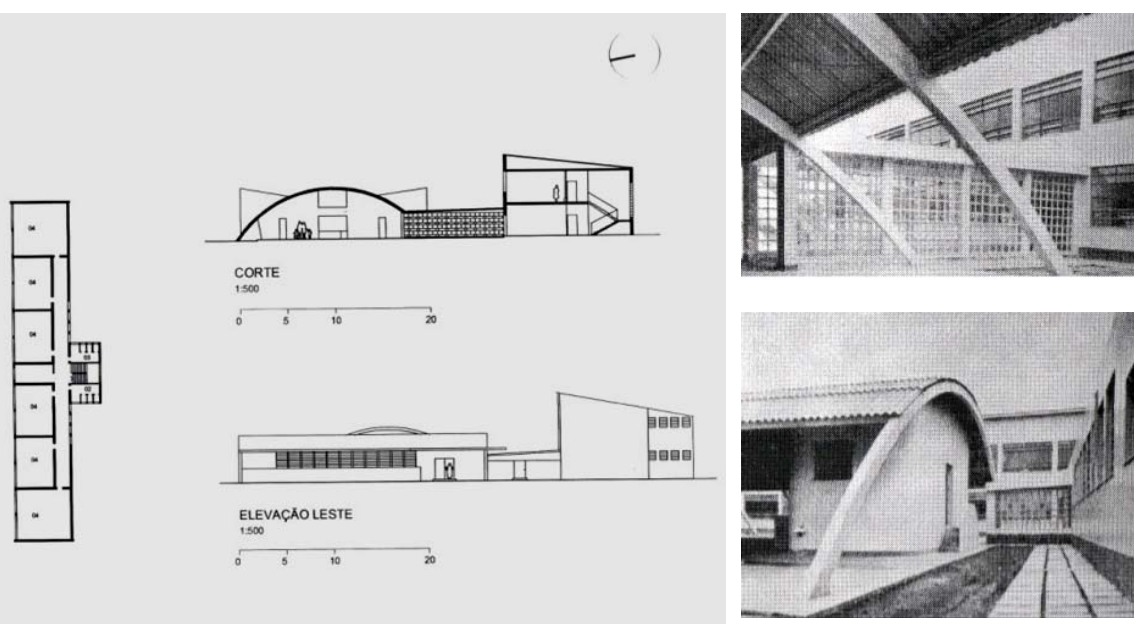

IMPLANTACAAO/ TERREO

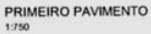

का iो

: क्ष 10 
Além de introduzir este ideário modernista às novas escolas, foi também Hélio Duarte o responsável por incorporar a estes projetos princípios e diretrizes sintonizadas com propostas educacionais vanguardistas. Vinha de uma temporada de trabalho em Salvador, onde tomara contato com novos conceitos pedagógicos, entre os quais o da Escola-Parque de Anísio Teixeira, que procurou trazer para as escolas do Convênio.

[...] 0 período do Convênio marca uma iniciativa pioneira de difusão e consolidação da arquitetura moderna em São Paulo através do poder público [...] Hélio Duarte foi o mensageiro e portador, em São Paulo, de importantes legados recentes no Brasil naquele momento: a arquitetura moderna carioca - de herança corbusiana e, àquela altura, já conhecida mundialmente sob a alcunha de brazilian style - e o projeto de Anísio Teixeira, pioneiro defensor de uma escola pública, laica e gratuita no Brasil, e figura de destaque na fundação do movimento Escola Nova, e na reforma de ensino do Distrito Federal, no início da década de 1930. (WISNIK In: FERREIRA; MELL0, 2006, p. 59)

Anísio Teixeira (1900-1971), integrante do grupo de intelectuais "Pioneiros da Escola Nova", pertenceu a uma geração que legitimou a educação enquanto campo de saber específico e importante instrumento político na formação de uma sociedade democrática. Depois de estudar o sistema educacional de diversos países europeus, Anísio se transferiu para os Estados Unidos, onde se dedicou ao estudo das ideias do filósofo e pedagogo John Dewey (1859-1952). A partir daí, passou a formular suas próprias teorias a cerca do sistema educacional, pregando, em síntese, a ideia da educação enquanto um processo de constante reorganização e reconstrução da experiência humana: não se aprende para depois viver, mas sim, aprende-se vivendo. E foi desta linha de pensamento que derivou 0 conceito de Escola-Parque, implantado durante sua gestão com Secretário de Educação da Bahia, no governo de Otávio Mangabeira (1947-1951).

A ideia de escolas-classe e escolas-parque consistia numa proposta de complementar o ensino tradicional, com atividades culturais, esportivas e de lazer diversas, de modo a proporcionar a formação integral do aluno. Para tanto, as crianças "estudariam" em horário integral, dedicando-se em cada um dos períodos a uma destas "escolas". À noite, parte destas estruturas seria aberta à comunidade, de modo a integrar toda a sociedade a esta rede de cultura e educação. É exatamente este conceito que o CEU veio a retomar, conforme será colocado adiante.

Se a escola-classe mantinha, em essência, a antiga escola convencional, as condições de trabalho da escola-parque iriam facilitar sobremodo a aplicação dos melhores princípios da educação moderna. (TEIXEIRA apud BUFFA; PINTO, 2002, 


\section{CONSTRUINDO ESCOLAS}

Foram então estes os princípios que nortearam a atividade do Convênio Escolar em São Paulo alguns anos depois. No entanto, se na Bahia Anísio Teixeira pode compartilhar suas ideias com uma equipe multidisciplinar que 0 apoiava, na capital paulista Hélio Duarte contava apenas com sua experiência em Salvador e uma equipe puramente composta por técnicos ${ }^{15}$, o que, para 0 arquiteto, teria comprometido a qualidade da produção:

[...] [as escolas] poderiam ser melhores, poderiam, outrossim, ser mais especializadas. 0 fator tempo impediu um estudo mais em profundidade na análise dos métodos de ensino e depois iríamos entrar em terras que as nossas águas não banham, a teoria da Educação - a teoria não, as teorias... (DUARTE, 1951, p. 4)

Apesar desta frustração, segundo afirmam Ferreira e Mello (2006) a produção do Convênio, além de representar a primeira manifestação da arquitetura moderna pública em São Paulo, inovou de forma magistral ao promover uma aproximação entre a escala da escola e da criança. E ainda, segundo Buffa e Pinto (2002), da mesma forma que discutia projeto arquitetônico, a Comissão revia a proposta pedagógica, colocando-a como principal elemento norteador para a construção dos edifícios:

Perguntam-se arquitetos e engenheiros da Comissão: 'Para que espécie de ensino deveriam ser feitos os grupos? Quais os rumos da educação? Qual o meio subjetivo adequado a uma melhor integração do psiquismo infantil? Qual 0 ambiente físico mais propício?' E respondem: 'Essas perguntas ficaram sem respostas. Procuramos, então, contornar o problema, imaginando um novo tipo de Grupo que mais se aproximasse da mentalidade infantil’. (DUARTE, 1951, p.4)

Destas indagações saíram edifícios escolares flexíveis, que "davam espaço" para a dinâmica de ensino se desenvolver, contrariando a compartimentação tradicionalmente empregada, com salas numeradas, laboratórios fechados e bibliotecas com acesso controlado. Hélio Duarte tinha clara visão de que a arquitetura não definiria a filosofia educacional. Contudo acreditava que ela deveria proporcionar espaços onde esta nova filosofia pudesse se desenvolver. Dessa forma, a Comissão criou sua própria rede pedagógica. Dos conceitos da Escola-Parque, apenas alguns foram incorporados, incluindo o principal deles: 0 conceito de educação integral. Além deste, 0 fato de referenciar 0 projeto à escala da criança, com a utilização de mobiliários leves nas salas de aulas, de modo a facilitar constantes 
rearranjos e a abertura da escola à comunidade, foram outras contribuições trazidas de sua experiência com Anísio Teixeira.

Embora o Convênio Escolar oficialmente tenha existido até 1959, sua contribuição significativa em termos de edifícios escolares se limitou ao período de 1949-1954, intervalo liderado por Hélio Duarte. Se inicialmente 0 Convênio contava com recursos vultuosos para realização de seus projetos, o que chegou inclusive a despertar críticas, com a aproximação do IV Centenário, parte da verba foi desviada para a construção do Parque do Ibirapuera, ficando as escolas em segundo plano. Frente às novas prioridades e às restrições orçamentárias, Hélio Duarte se demitiu do cargo.

Nos anos seguintes, foram construídos ainda 27 prédios, voltados à instalação de escolas de ensino primário municipal, mas, infelizmente, carentes do preciosismo de projeto dos primeiros anos. Paralelamente ao Convênio, em 1957, uma nova estrutura administrativa se encarregou da construção da rede educacional no Estado. Devido à disponibilidade de recursos, foi atribuída ao Instituto de Previdência do Estado de São Paulo (IPESP) a função de construir edifícios públicos. Para tanto, foi criado, em 1959, dentro do IPESP, o Fundo Estadual de Construções Escolares - FECE, com a missão de atender exclusivamente aos projetos relativos a escolas.

\subsection{O Fundo Estadual de Construçõós Escolares - fECE}

Ao assumir o governo de São Paulo em 1959, Carvalho Pinto encontrou um cenário escolar marcado pela insuficiência de escolas e vagas e pela degradação do ensino nas escolas existentes. Das 1.845 escolas públicas em 1960, 714 eram barracões de madeira ou edifícios improvisados (BUFFA; PINTO, 2002). Se em 1950, 52,6\% da população do Estado de São Paulo era urbana, em 1960 este percentual subiria para 62,8\%, falando-se de uma população absoluta de 12.974 .699 de habitantes ${ }^{16}$. Frente a este acentuado processo de urbanização, tornava-se cada vez mais distante a solução para 0 déficit educacional. Diante deste quadro, Carvalho Pinto elaborou o Plano de Ação do Governo do Estado - PAGE (lei 5444 de 17/11/1959), estabelecendo metas, prioridades e prazos para os diversos setores da administração pública. 


\section{CONSTRUINDO ESCOLAS}

Em termos de infraestrutura educacional, o Plano previa a construção de 3.000 salas de aula para possibilitar o funcionamento da rede existente em condições adequadas e outras 4.000 a fim de suprir o déficit e comportar 0 crescimento populacional dos quatro anos seguintes (FECE, 1963). 0 Plano autorizava ainda, por meio do Decreto 36.799 de 21/06/1960, a criação do Fundo Estadual de Construções Escolares - FECE ${ }^{17}$.

Neste ponto há de se fazer um parêntese: além de autorizar a criação do FECE, o decreto acima citado previa a possibilidade de contratar, por tempo determinado, pessoas alheias ao serviço público. Percebendo a dificuldade em se cumprir a demanda, o governo utilizou-se deste instrumento e estabeleceu um acordo com o Instituto de Arquitetos do Brasil - IAB para que os projetos fossem terceirizados para escritórios privados de arquitetura. Com isso, o poder público passou então a introduzir, de forma inédita, a terceirização dos projetos de edifícios escolares no Estado de São Paulo, conduta esta que se tornaria padrão nos anos posteriores. Entre 1959 e 1962, numa amostra de 130 projetos elaborados para o IPESP, cerca de 70 arquitetos foram contratados, muitos deles recém-formados (BUFFA; PINTO, 2002). Como colocam Buffa e Pinto, "pela primeira vez, os arquitetos paulistas foram convidados a projetar obras públicas" (BUFFA; PINTO, 2002, p. 131), o que se remete não apenas aos edifícios escolares, mas também postos de saúde, fóruns, etc.

A terceirização dos projetos trouxe ganhos em qualidade dos edifícios e a diversificação tipológica da rede, valorizando-se o projeto específico para cada obra. Neste momento as referências arquitetônicas eram outras. Com os preceitos modernos já consolidados na arquitetura brasileira, arquitetos como Lúcio Costa, Oscar Niemeyer e Afonso Reidy se detinham à busca de uma linguagem singular, inédita, que o mundo começava a conhecer e respeitar. Em 1960, Brasília foi inaugurada, causando grande repercussão.

\footnotetext{
17. Inicialmente a equipe da FECE foi dirigida por Carlos Pasquale e contou com os seguintes técnicos:

- Flávio Villaça - urbanista

- Celso Beisiegel - sociólogo

- Mário Viotti Guarnieri - arquiteto

- Clementina de Ambrósis - arquiteta

- Marlene Picarelli - arquiteta

- Mário Pereira Bicudo - professor

- Elza Rego Barros - professora

- Benegno Lagreca- professor

- Roberto Milton Moreto - desenhista

- Alice Oliveira Corrêa - desenhista
} 

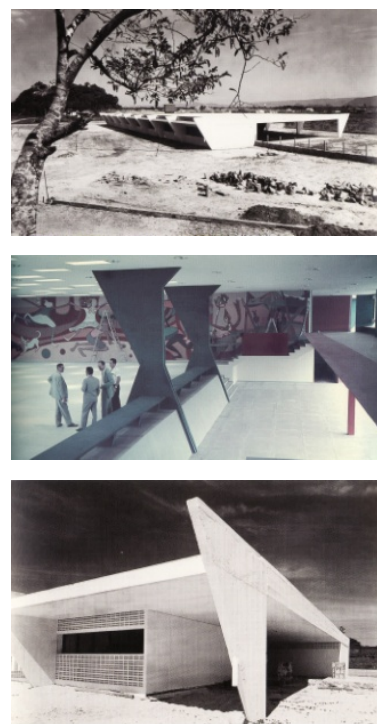

Ginásio de Guarulhos (1960), de Vilanova Artigas e Carlos Cascaldi. Destaque para 0 amplo pátio interno e para a "ousadia" formal no emprego do concreto armado. Fonte: FERRAZ, 1994.
Em São Paulo, os engenheiros-arquitetos saídos da Escola Politécnica também buscavam configurar sua própria linguagem, igualmente calcada nos princípios modernistas, contudo com percursos diferentes dos arquitetos cariocas. Nessa época, eram raras as construções de edifícios públicos por escritórios privados e 0 trabalho destes arquitetos limitava-se, em geral, à construção de residências; daí derivaria a "opção" pela linha de Frank Loyd Wright, intermediária entre a arquitetura tradicional e a radicalmente moderna de Gropius, Mies e Le Corbusier. Com o Plano de Ação de Carvalho Pinto, 0 mercado de trabalho destes profissionais foi consideravelmente ampliado.

Dentre os arquitetos contratados neste período, destacam-se, sobretudo, Vilanova Artigas, Paulo Mendes da Rocha, João de Gennaro, Ícaro de Castro Mello, João Clodomiro de Abreu e Roberto Machado de Almeida, responsáveis por edifícios que se tornaram verdadeiras referências arquitetônicas. Embora influenciados pelas ideias do Convênio Escolar, os projetos deste período trouxeram inovações técnicas importantes, sobretudo no que se refere à disposição dos espaços, onde fica clara a influência do pensamento moderno. 0 programa segue praticamente o mesmo: "Não havia um projeto pedagógico definido para amparar o desenho dos novos edifícios escolares" (VALENTIM, 2003, p. 166). Surgia, contudo, a preocupação em articular espaços internos e externos, princípio norteador das propostas e que reproduzia um pensamento nitidamente moderno: 0 de promover 0 diálogo entre edifício e cidade.
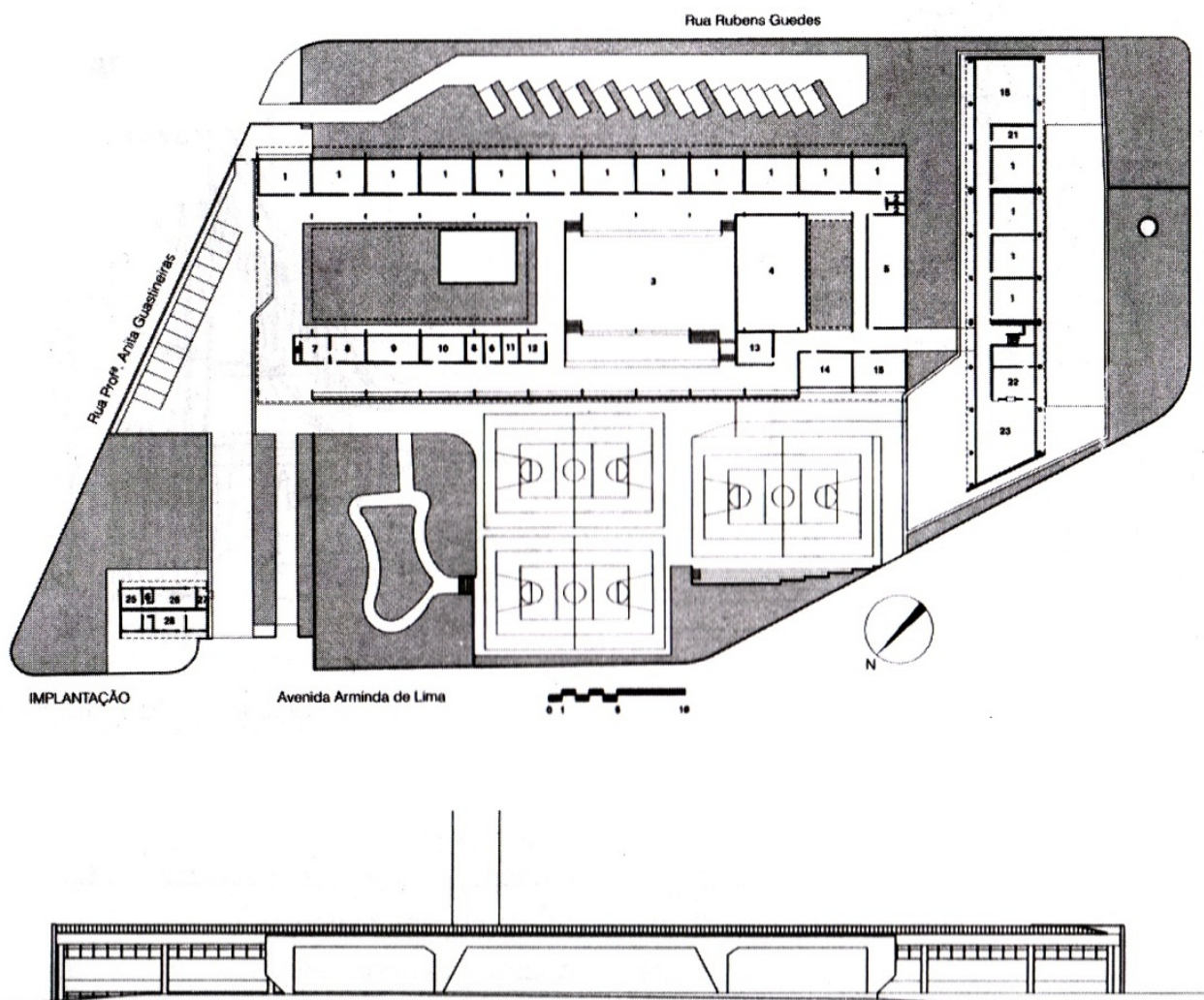

CORTE ESQUEMÁTICO 


\section{CONSTRUINDO ESCOLAS}

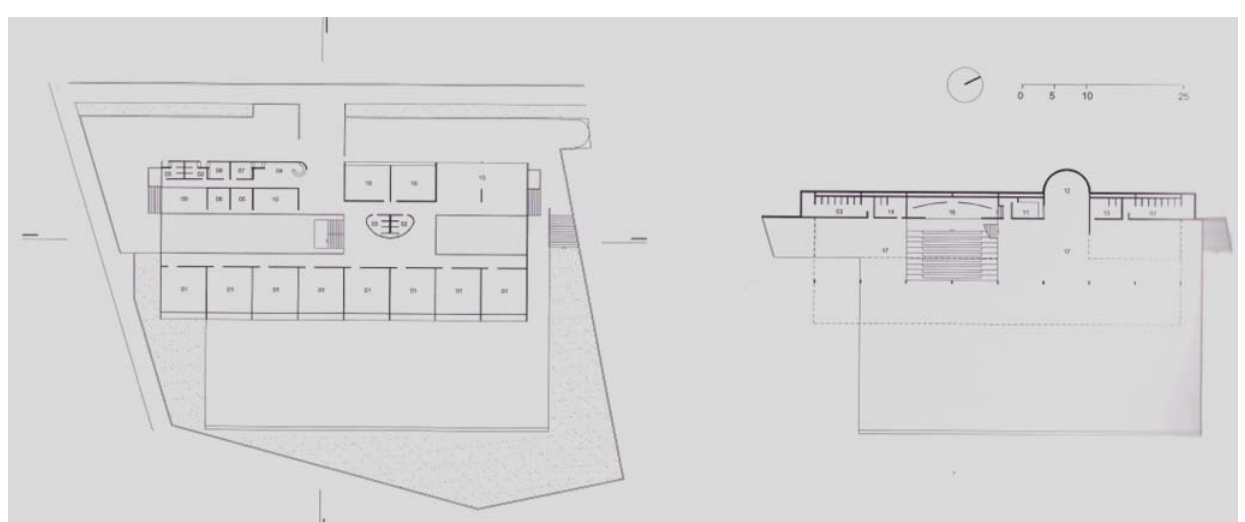

0 partido que tais arquitetos adotam é praticamente 0 mesmo do tempo do Convênio Escolar, isto é, projetam o bloco de salas de aula, 0 administrativo e 0 galpão para atividades recreativas e socializantes, só que, agora, a partir de um referencial nitidamente moderno: a cidade. (BUFFA; PINTO, 2002, p. 139)

Segundo Janice Silva (SILVA apud FERREIRA; MELLO, 2006), com o grupo de Artigas as escolas ganharam uma dimensão política e os edifícios passaram a ser pensados não apenas enquanto construção de salas de aula, mas sim enquanto elemento potencial de transformação social. Para Alves (2008), a privatização dos projetos do IPESP, a princípio encarada como um desvio de recursos previdenciários, ao contrário do que se poderia supor, levou a grandes avanços qualitativos, com desenhos arquitetônicos que desempenhavam "um papel muito mais amplo do que se poderia imaginar, realmente gozando de ampla liberdade de concepção e a ela fazendo jus, no que se refere ao alcance de suas proposições, em termos do conteúdo educacional dos prédios por eles projetados" (ALVES, 2008, p. 364).

\footnotetext{
0 elemento que diferencia as escolas projetadas por Vilanova Artigas daquelas do Convênio Escolar é a capacidade do projeto em revolucionar a própria ideia de escola, como um edifício com função estrita voltada para a educação. Artigas partiu de outra premissa buscando um outro conceito, no qual a escola é parte orgânica, elemento integrador e ativo da comunidade. Essa proposta não tem sua origem no ideário da Escola Nova, de raiz humanista, mas numa crítica de base marxista que diz respeito à conformação da sociedade brasileira, da qual a escola é parte. (SILVA apud FERREIRA; MELLO, 2006, p. 56)
}

Em geral, os edifícios passaram a contar com um único bloco, substituindo os corredores confinados, estreitos e pouco iluminados por "ruas", largas e ventiladas. 0 pátio assumiu a função de articulador de espaços, configurando-se como uma grande praça de encontro. A circulação tornouse fluida. 0 emprego de sistemas independentes de vedação garantiu a configuração dos novos arranjos. Se no período anterior o diálogo entre educadores e os arquitetos do Convênio Escolar já fora bastante escasso, nos anos 60 tornou-se praticamente inexistente. E embora os edifícios fossem inovadores, a proposta pedagógica seguia a mesma.

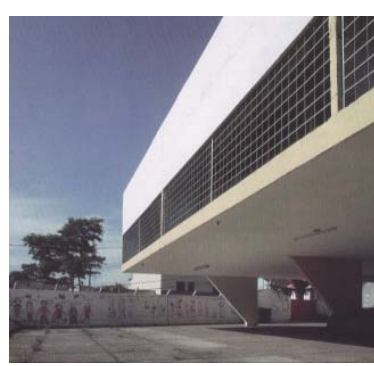

E.E. Prof. Suely Antunes de Mello (1961), de Paulo Mendes da Rocha e João de Gennaro. Fonte: FERREIRA; MELLO, 1998b. 
Tem sido praticamente nulo o diálogo entre arquitetos e educadores, ignorando esses últimos, quase que totalmente, a função dos primeiros no processo de concepção de um prédio escolar. Em tais circunstâncias, pouco pode ser feito pelo FECE no curto espaço de 2 anos e frente ao enorme déficit de salas a ser sanado. Esse pouco restringiu-se à fixação de diretrizes fundamentais em aspectos dos mais elementares, como a limitação dos tamanhos máximo e mínimo dos prédios escolares, a padronização dos programas a serem seguidos em seus projetos, e pesquisas gerais de índices referentes a diversas modalidades de áreas. Foi abolida a utilização de projetos padronizados e a maioria dos prédios escolares foi construída de acordo com projetos para cada caso. (FECE, 1963, p. 103-104)

0 distanciamento de profissionais ligados à área pedagógica deixou algumas lacunas nos projetos, sobretudo no que se refere aos fluxos e disposição dos usos, embora do ponto de vista arquitetônico tais obras tenham se destacado. Os Ginásios de Itanhaém (1959), de Guarulhos (1960) e de Utinga (1962), projetados por Artigas e Carlos Cascaldi, além de se tornarem marcos da arquitetura moderna paulistana, influenciaram fortemente os arquitetos posteriormente empenhados em projetar grupos escolares no Estado de São Paulo, que passaram a empregar a tipologia da grande "caixa", dentro da qual a escola se desenvolveria livremente.

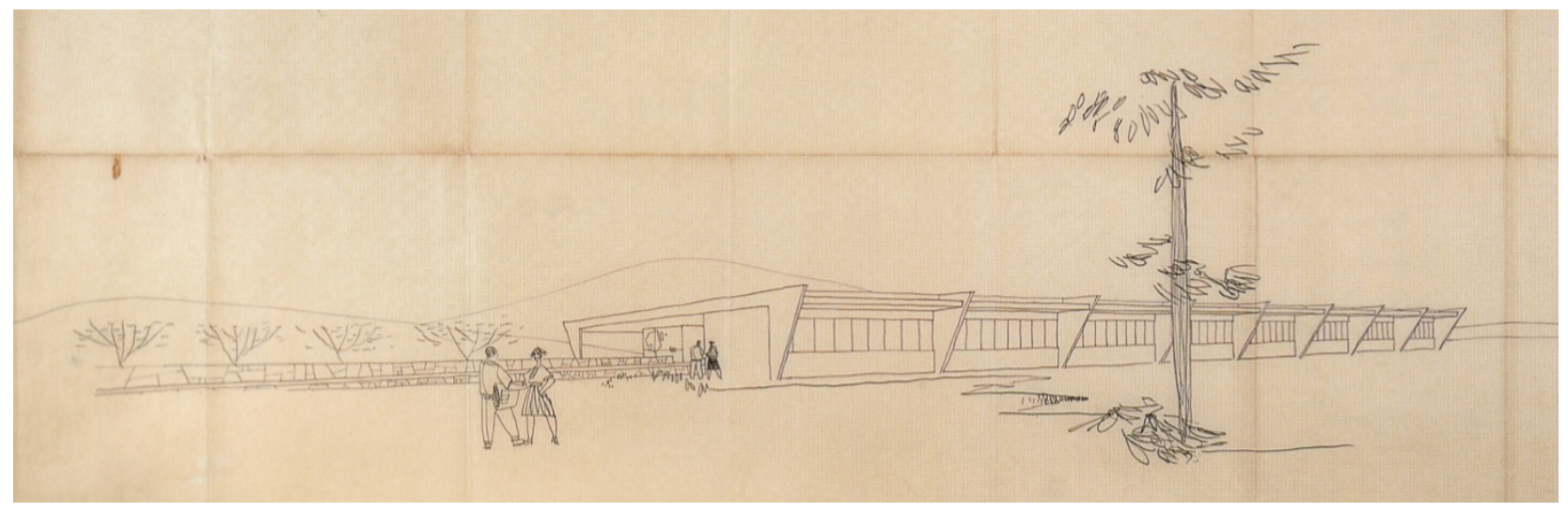

Ginásio de Itanhaém (1959), de Vilanova Artigas e Carlos Cascaldi Fonte: FERRAZ, 1994.
Para Gilioli (1994), ao elaborar tais projetos, Artigas introduzira uma nova concepção de espaço escolar: ao aproximar o pátio das atividades didáticas, abrigando ambos sob uma mesma cobertura, 0 arquiteto estaria "sugerindo um processo educacional onde seus múltiplos aspectos poderiam acontecer de forma simultânea ou sincrônica" (GILIOLI, 1994, p. 95).

Tratava-se de um período inovador da arquitetura moderna paulistana, que se expressou nos edifícios escolares, frutos de projetos ousados e eficientes. Infelizmente o mesmo não aconteceu do ponto de vista pedagógico. Segundo Alves (2008), o FECE estaria desde 0 início consciente desta perda de qualidade, considerando a diminuição do padrão arquitetônico e construtivo, 


\section{CONSTRUINDO ESCOLAS}

viabilização das metas de governo. Esta postura está expressa em documento da própria instituição, publicado em 1963:

As dificuldades encontradas pelo Convênio para realizar integralmente 0 seu programa, indicaram a necessidade de adequar os padrões dos prédios escolares à realidade - tendo em vista um mínimo de obras cuja construção era inadiável, e os recursos financeiros disponíveis para executá-los. Daí a padronização dos programas de necessidades, embora os projetos sejam elaborados individualmente e a inclusão apenas das dependências imprescindíveis às atividades didáticas. Entretanto, foram excluídas do programa inicial, e reservadas para uma $2^{\mathrm{a}}$ prioridade, todas as dependências que não eram imprescindíveis para 0 funcionamento da unidade escolar; tais como auditórios, piscina, quadras de esporte cobertas, casa do zelador, etc. (FECE, 1963, p. 16)

Até 1963, foram concluídas 2.782 salas de aula na capital e 3.332 no interior, totalizando 6.114 salas em todo o Estado (FECE, 1963). Em 1966, 0 FECE passou a concentrar todas as atividades relativas à construção escolar. De 1961 a 1971, a rede escolar no Estado cresceu 38,9\% com a construção de 860 edifícios, totalizando 9.390 salas de aula (FECE, 1963). Mais tarde, tal órgão seria sucedido pela CONESP e pela FDE, que viriam a consolidar os procedimentos aí implementados:

A terceirização dos projetos a diferentes escritórios de arquitetura feita pelo IPESP foi adotada pelos órgãos que viriam a se consolidar posteriormente como responsáveis pela construção escolar, isto é, o Fece, a CONESP e a FDE, pois é um fator que contribui à diversidade da produção arquitetônica e à economia de recursos humanos na entidade pública. (FERREIRA; MELL0, 2006, p. 19)

\subsection{A Companhia de Construções Escolares de São Paulo - CONESP}

[...] sobre o papel da escola na construção da moderna nação brasileira, deve-se registrar o discurso da CONESP, segundo a qual o planejamento educacional constitui parte do planejamento nacional.

(ALVES, 2008, p. 65)

A partir de 1964, com 0 Golpe Militar, o país viveria violentas transformações políticas e sociais e as diretrizes de governo sofreriam claros redirecionamentos. Neste cenário, em 1974, foi extinto o FECE e então criada, em 1976, a Companhia de Construções Escolares de São Paulo - 
CONESP, num plano de racionalização administrativa centralizada (GILIOLI, 1994). Na chefia da Companhia estavam os arquitetos Mayumi de Souza Lima e João Honório de Melo Filho.

Mayumi de Souza Lima (1934-1964), nome fundamental não só na história da CONESP, como também no desenvolvimento da arquitetura escolar em São Paulo, já fazia parte da equipe do FECE, tendo assumido sua Diretoria de Planejamento em 1965. Em sua passagem pelo FECE, deixara importantes contribuições, que mais tarde viriam a fundamentar as ações desenvolvidas pela CONESP. Entre outras coisas, Mayumi começara a discutir metodologias para o cadastro da rede física de escolas no estado de São Paulo, programas-modelo para os projetos de arquitetura e meios para incorporar sistemas construtivos regionais na produção pública (BUITONI, 2009). Tais estudos foram retomados durante sua atuação na CONESP.

Com a grande expansão urbana vivida por São Paulo na década de 70, a demanda por unidades educacionais acentuou-se significativamente. Com isso, a CONESP assumiu, naquele momento, o grande desafio de aumentar 0 ritmo produtivo, garantindo, contudo, qualidade à rede. As novas diretrizes políticas, entretanto, levaram ao parcelamento e separação do planejamento das escolas das atividades de projeto e obra propriamente ditas. Desse modo, a solução foi formular um sistema construtivo padronizado, que definisse não só dimensões, mas também materiais e processos.

A consequência desse parcelamento e do objetivo de produtividade/ eficiência se deu na padronização dos componentes no projeto [...] mediante redução qualitativa dos espaços escolares construídos [...]. Resultaram daí agrupamentos de prédios sem qualquer unidade, mera justaposição de salas sem expressão e sem conforto. É difícil imaginar o que poderiam oferecer de positivo esses espaços mal resolvidos que refletem a pouca consideração que as próprias autoridades educacionais têm pela criança. (LIMA, 1989, p. 67)

Para Mayumi, este novo sistema deveria associar técnicas construtivas tradicionais à pré-fabricação, de modo a incorporar a mão de obra disponível no mercado, o que possibilitaria gerar emprego, acelerar o processo construtivo em função da grande disponibilidade de operários capacitados para 0 trabalho e reduzir os custos.

Segundo a ideia de normatização, o caminho adotado [pela CONESP] foi 0 de abrir 0 leque de construtoras que poderiam se candidatar à execução das escolas. Com uma técnica tradicional e com os sistemas conhecidos, não só as grandes construtoras poderiam se habilitar; a disputa entre elas determinaria um preço final mais vantajoso. (PROJETO SÃO PAULO 450 ANOS, 2009) 


\section{CONSTRUINDO ESCOLAS}

Nos diversos órgãos públicos onde Mayumi trabalhou, esteve sempre interessada em buscar alternativas mais democráticas para o projeto e construção de espaços ${ }^{18}$. Para a arquiteta, a relação do espaço com 0 usuário era sempre o ponto primordial do projeto. Preocupada com tais questões, Mayumi realizou na CONESP suas primeiras experiências de projeto participativo, das quais a mais importante foi a reforma e ampliação da EEPG João Kopke (1976-1978). Tratava-se de uma escola situada em um casarão antigo no Bom Retiro. Durante os meses anteriores à demolição do casarão, Mayumi convocou uma equipe multidisciplinar para realizar atividades lúdicas com os alunos, visando conhecer os estudantes e suas famílias, para então desenvolver com eles o projeto de reforma do edifício.
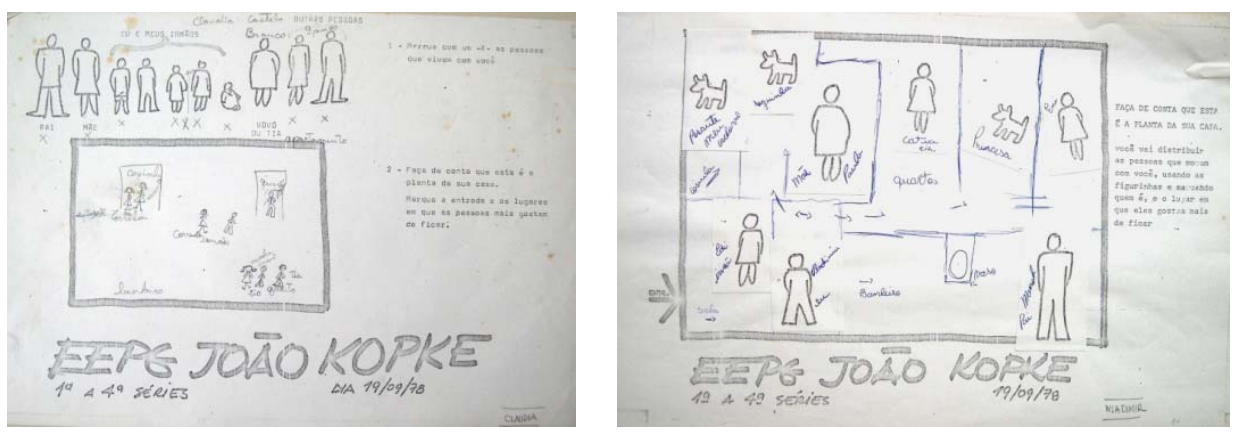

Desenhos elaborados pelos alunos da EEPG João Kopke durante 0 processo de projeto participativo, coordenado por Mayumi de Souza Lima. Fonte: BUITONI, 2009

Durante a gestão de Franco Montoro (1983-1986), Mayumi desenvolveu, também pela CONESP, outras experiências participativas de construção de escolas, empregando a autoconstrução, não em sistema de mutirão voluntário, mas sim por meio de uma gestão de obra a cargo da associação de moradores do bairro, com assessoria de técnicos da CONESP e contratação de mão de obra de acordo com os valores de mercado e a legislação trabalhista vigente (BUITONI, 2009). Deste período, destacam-se as escolas do Jardim Fortaleza e do Bairro da Varginha (1983-1984), ambas construídas com a participação da população na gestão da obra. Tais procedimentos inspiraram algumas experiências de autogestão retomadas mais tarde pelo governo Erundina.

Tanto 0 processo de projeto participativo implantado na EEPG João Kopke, quanto os sistemas de construção coletiva experimentados nas outras duas escolas, inspiraram Mayumi a publicar o livro Espaços educativos - uso e construção $(1986)^{19}$ e 0 célebre $A$ cidade e a criança $(1989)^{20}$, ambos

18. Mais tarde, em 1984, Mayumi viria a iniciar seu doutorado em História e Filosofia da Educação, na Faculdade de Educação da USP, sob o tema "Estado e Movimentos Populares na construção do prédio escolar: confronto ou colaboração?”. 0 curso não chegaria a ser concluído.

19. LIMA, Mayumi W. de S. Espaços educativos: uso e construção. Brasília: MEC/ CEDATE, 1988.

20. LIMA, Mayumi W. de S. A cidade e a criança. São Paulo: Nobel, 1989. 
Escola do Bairro de Varginha (1983). Canteiro experimental desenvolvido por processo participativo e autogerido. Fonte: BUITONI, 2009. empenhados em discutir a construção do espaço para educação. 0 primeiro livro, direcionado aos professores da rede pública, traz sugestões de atividades de percepção e transformação do espaço a serem desenvolvidas com os alunos. Já no segundo, com um caráter mais teórico e político, a autora coloca o espaço enquanto instrumento para formação de adultos criativos e inteligentes, ou seja, como um laboratório onde as crianças têm a oportunidade de experimentar novas experiências, apropriando-se do lugar e 0 transformando. A partir daí, discute a questão da tirania do desenho sobre o usuário, tema colocado internacionalmente pelo trabalho de Robert Sommer $(1979)^{21}$ e, no Brasil, muito discutido por Sérgio Ferro (1979) ${ }^{22}$, com quem Mayumi teve intenso contato, não só enquanto colegas da FAUUSP, mas ainda como companheiros do Partido Comunista e, sobretudo, no período de 1970-71, como docentes da FAU Santos. Durante o período em Santos, chegariam a desenvolver experiência inédita com os alunos do primeiro ano, levando-os a estudar, numa ação multidisciplinar, as favelas da região, o que envolveu desde o estudo das técnicas de autoconstrução até as propostas de intervenções no bairro e criação de linha de mobiliário popular.
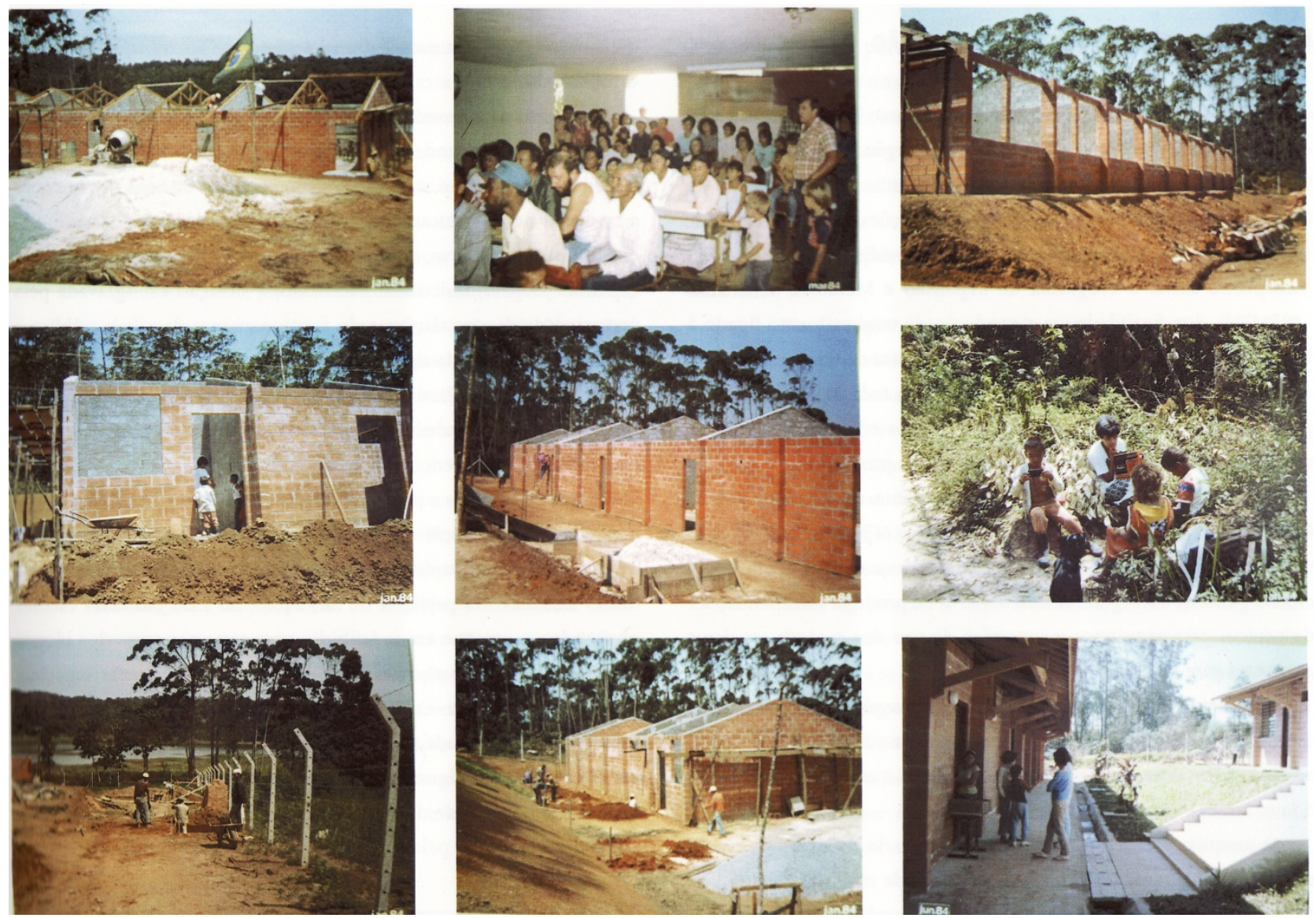

21. SOMMER, Robert. 0 papel do arquiteto - a conscientização do design. São Paulo: Ed. Brasiliense, 1979

22. FERRO, Sérgio. 0 canteiro e o desenho. São Paulo: Projeto Editores Associados, 1979. 


\subsection{A FundaÇão PARA 0 DesenVOLVIMENTO da EduCAÇão - FDE}

Em $1987^{23}$, foi criada a Fundação para 0 Desenvolvimento da Educação $\mathrm{FDE}$, que veio a suceder o FECE e incluir algumas atribuições da CONESP, que havia sido liquidada. Caberia à FDE não só suprir uma enorme demanda por vagas, mas também melhorar a qualidade do ensino, assumindo a responsabilidade pela execução das políticas educacionais definidas pela Secretaria de Educação do Estado, implantando e gerindo programas, projetos e ações destinadas ao bom funcionamento, ao crescimento e ao aprimoramento da rede pública estadual de ensino. Deveria atuar tanto na área pedagógica quanto de recursos físicos escolares, de modo a englobar a Fundação para o Livro Escolar - FLE, instituída em 1962, parte do Centro Nacional de Aperfeiçoamento Pessoal para a Formação Profissional Cenafor, criado em 1969 e a CONESP.

A partir de 1989, a FDE viria a assumir a execução de obras novas, até então a cargo da Companhia de Desenvolvimento Habitacional e Urbano do Estado de São Paulo - CDHU e da Companhia Paulista de Obras e Serviços, de 1987 a 1992. Entre suas principais atribuições estavam a construção, reforma e manutenção de escolas, a aquisição de materiais e equipamentos necessários à Educação, o gerenciamento dos sistemas de avaliação de rendimento escolar e a viabilização de meios para a capacitação de dirigentes, professores e demais agentes educacionais.

Apesar do histórico de projetos educacionais e a grande experiência acumulada ao longo dos anos, a FDE viria a se deparar com um novo problema, que veio a marcar o contexto urbano da capital: a ausência de

23. Vale mencionar que neste mesmo período o Estado do Rio de Janeiro vivenciava a marcante experiência dos Centros Integrados de Educação Pública - CIEPs, popularmente apelidados de Brizolões, por terem sido implantados pelo governo de Leonel Brizola. Com um projeto educacional de autoria do antropólogo Darcy Ribeiro, considerado pelo próprio como "uma revolução na educação pública do País", os CIEPs tinham como objetivo o ensino público de qualidade em período integral. Além do currículo regular, atividades culturais, estudos dirigidos e educação física, os CIEPs forneciam refeições completas a seus alunos, atendimento médico e odontológico. A capacidade média de cada unidade era de mil alunos.

Visando atender a uma forte demanda de qualidade, quantidade e velocidade, delegou-se o projeto arquitetônico dos edifícios a Oscar Niemeyer, que desenvolveu um sistema rígido de peças prémoldadas de concreto, visando baratear a sua construção. Daí resultaria uma volumetria facilmente reconhecível, que marca atualmente todo o território carioca. Os edifícios são sempre constituídos por três estruturas: 0 edifício principal, com três pavimentos, abrigando as salas de aula, centro médico, cozinha, refeitório, banheiros, áreas de apoio e recreação; 0 ginásio esportivo, que também pode receber atividades artísticas e culturais; e 0 edifício da biblioteca e dos dormitórios. 0 projeto inicial previa ainda tirar crianças carentes das ruas, oferecendo-Ihes os chamados "pais sociais", funcionários públicos que residiam nas unidades, cuidando de crianças também ali residentes.

Nos períodos de 1983-1986 e 1991-1994 foram erguidos mais de 500 CIEPS.
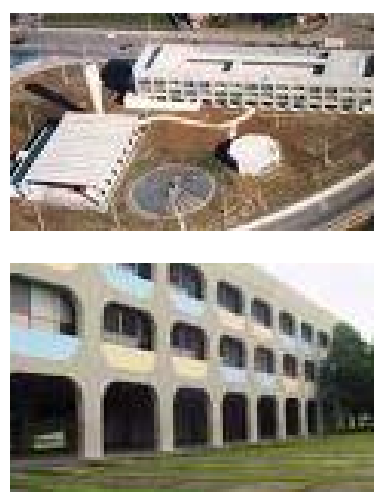

Acima, conjunto arquitetônico do CIEP; abaixo, detalhe da fachada. Fonte: domínio público. 
Algumas escolas construídas pela FDE nos últimos dez anos. Fonte: FERREIRA; MELLO, 2006.
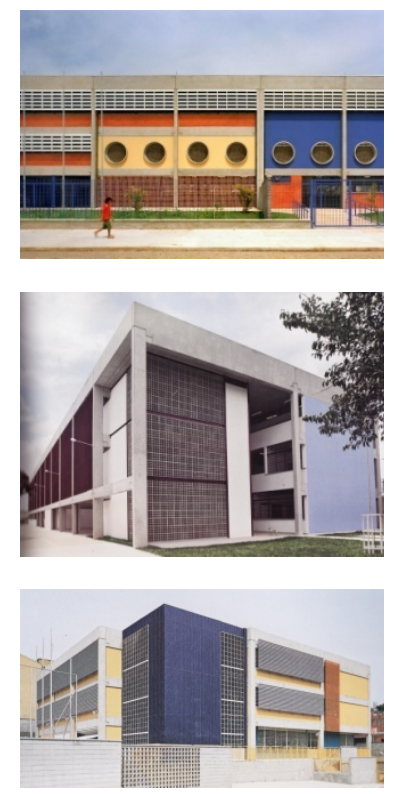

terrenos. Não contando com estoque de terras e dada a grande valorização pela qual passou a cidade nas últimas décadas, a FDE começou a lidar com uma grande dificuldade para a implantação de novos edifícios. Atualmente, a maior parte da produção se dá em terrenos institucionais de conjuntos habitacionais implementados pela CDHU, cujo parcelamento determina a reserva da área. Em geral, são reservadas as piores parcelas da gleba, áreas, em geral, inadequadas à implantação das unidades residenciais e, portanto, nada favoráveis à instalação de equipamentos. Outra solução recorrente é a utilização de terrenos de escolas já existentes, construindo-se nas faixas desocupadas ou, até mesmo, substituindo as edificações anteriores.

De qualquer forma, pode-se dizer que as experiências da CONESP e da FDE tornaram-se referências na construção, organização e funcionamento das escolas de hoje, dados os mecanismos de padronização de projetos e procedimentos instaurados, que vão desde os sistemas construtivos e dimensionamento dos ambientes, ao desenho de mobiliários e componentes. Atualmente, a FDE chega a disponibilizar para o setor privado uma série de catálogos técnicos e manuais detalhados, que orientam a elaboração de projetos escolares. Graças a esta padronização, a FDE alcançou um ritmo produtivo acelerado, destacando-se dos demais setores da produção pública: só no ano de 1998 a FDE administrou a construção de 3.690 novas salas de aula, ou seja, cerca de 370 edifícios escolares.

Nos últimos cinco anos, a FDE construiu 102 edifícios escolares em todo 0 Estado, dos quais $27^{24}$ estão localizados no município de São Paulo.

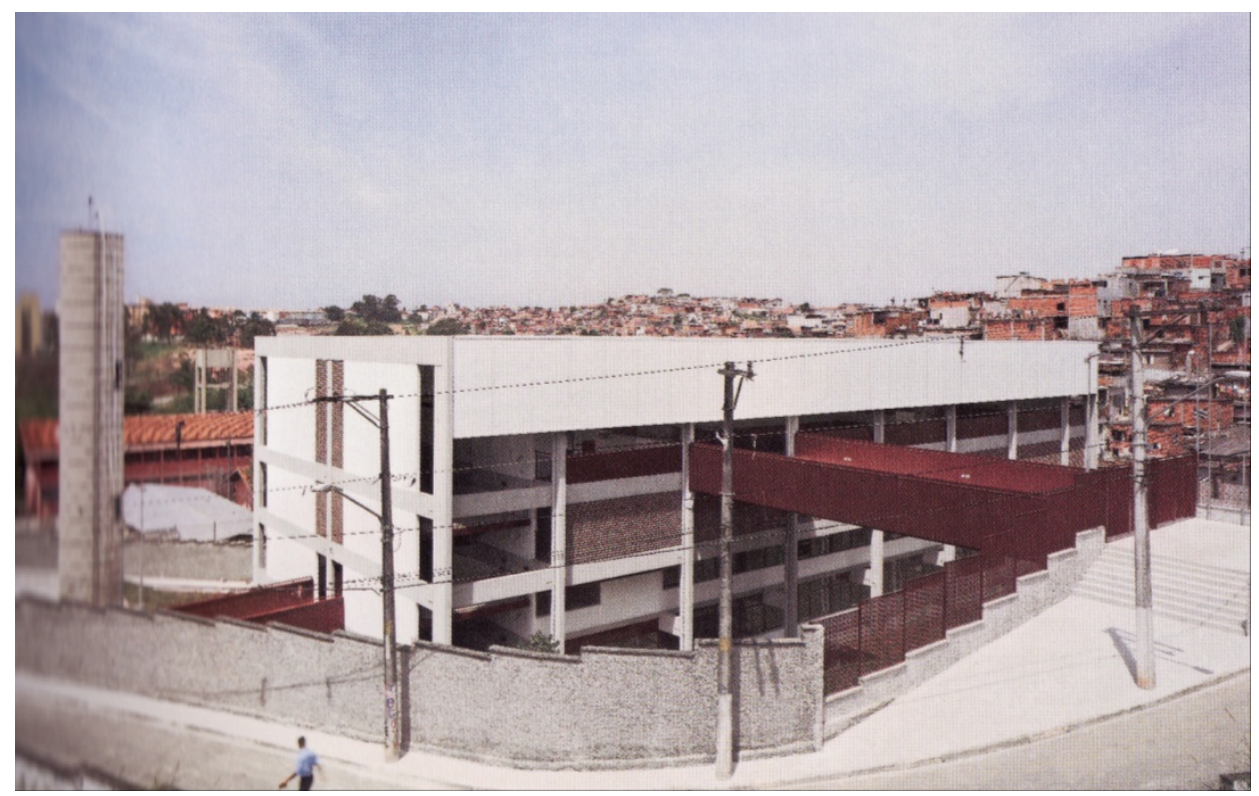

24. Estes 27 edifícios constituem objeto de análise desta pesquisa e serão analisados no capítulo 3. 


\subsection{A Cidade Educadora e as Praças de Equipamentos}

Sonhamos com uma escola pública capaz, que se vá constituindo aos poucos num espaço de criatividade. Uma escola democrática em que se pratique uma pedagogia da pergunta, em que se ensine e se aprenda com seriedade, mas em que a seriedade jamais vire sisudez. Uma escola em que, ao se ensinarem necessariamente os conteúdos, se ensine também a pensar certo.

(FREIRE, 1995, p. 24)

Quando Luiza Erundina assumiu a Prefeitura de São Paulo, em 1989, formou uma equipe de intelectuais e técnicos fortemente engajados em questões sociais, o que proporcionou um novo caráter às políticas públicas implementadas naquele momento. Paulo Freire assumiu a Secretaria de Educação, Marilena Chauí a Secretaria de Cultura, Paul Singer a Secretaria de Planejamento, Ermínia Maricato a Secretaria de Habitação, entre outros importantes nomes. Este mesmo governo convidou Mayumi de Souza Lima para assumir a direção do Departamento de Edificações - EDIF.

Criado em $1976^{25}$, através da Lei 8491/76, o Departamento consiste num escritório público de projetos, atrelado em sua origem à Secretaria de Serviços e Obras do Município ${ }^{26}$. Tem por função projetar, orçar e fiscalizar contratos relativos aos empreendimentos das diversas secretarias municipais, excetuando-se a Secretaria de Habitação. Como cabe às "Secretarias-Clientes" a definição da demanda, do plano de obras, o estabelecimento de prioridades e 0 repasse de recursos orçamentários, e à Secretaria de Finanças, a responsabilidade pelo pagamento, o Departamento se coloca como um órgão propositor da arquitetura e da engenharia do município, destinado à produção dos equipamentos sociais da cidade.

0 ateliê público do Convênio Escolar, como organização de escritório, pouco difere do atual Departamento de Edificações e a sua Divisão de Projetos [...]. As diferenças estão apenas na quantidade de projetos, entre pequenas reforma $\mathrm{e}$ obras novas e, os tipos de projetos, escolas, creches, pré-escolas, postos de

25. Segundo o Arq. Alexandre Delijaicov, membro de EDIF, o Departamento seria uma continuidade do Convênio Escolar, tendo sido fundado, de fato, em 1948, ano de criação da Comissão. Para ele, 0 Departamento assumiu as principais diretrizes dos órgãos anteriormente empenhados na construção escolar no município, tratando-se, portanto, do mesmo escritório, que teria assumido três diferentes nomes ao longo dos últimos 60 anos: de 48 a 56, Comissão Executiva do Convênio Escolar; depois, PREF.C.E., sigla originária do título Prefeitura - Construções Escolares; e, a partir da reforma administrativa de 1976, Departamento de Edificações - EDIF.

26. No Governo Marta Suplicy (2000-2004), EDIF foi transferida para a Secretaria de Infraestrutura Urbana, que passou então a se chamar Secretaria de Infraestrutura Urbana e Obras, facilitando a articulação entre os projetos de equipamentos sociais e infraestrutura. 
saúde, hospitais, postos de bombeiros e edifícios administrativos. (TAKIYA, 2009, p. 68)

Na direção de EDIF, Mayumi veio a elaborar um esboço de uma nova política de construção e manutenção de equipamentos públicos, visando, sobretudo, elevar o padrão construtivo dos equipamentos públicos.

Ela criticava a má qualidade dos equipamentos oferecidos à população periférica e propunha que fosse criado um setor de pesquisa dentro da EDIF, que pudesse testar e avaliar tecnologias e materiais destinados ao uso nos equipamentos públicos. Propunha ainda que se implantasse um processo mais organizado de planejamento das obras públicas e que houvesse programas arquitetônicos e normas de referência para a elaboração desses projetos, em função das pesquisas realizadas. (BUITONI, 2009, p. 41)

Norteado por tais críticas, o Departamento veio a desenvolver projetos interessantes, explorando tanto o caráter multidisciplinar quanto a introdução de métodos de projeto participativos. É deste período o projeto do Espaço Criança, na Favela Nova República, projeto desenvolvido por uma equipe multidisciplinar, que previa um centro de convivência para as crianças da favela, com espaços para diversas atividades lúdicas e de formação.

Entre 1990 e 1992, Mayumi assumiu a criação do Centro de Desenvolvimento de Equipamentos Coletivos - CEDEC, uma fábrica de elementos de argamassa pré-moldada da Prefeitura. Tratava-se de um setor de pesquisa e produção industrial de equipamentos situado dentro da estrutura da Empresa Municipal de Urbanização - EMURB, com ação complementar à EDIF. Suas atividades abrangiam pesquisa de materiais e de sistemas construtivos, treinamento de formação de pessoal, planejamento, projeto e execução de obras.

Para Mayumi, os objetivos maiores estavam em, por meio do CEDEC, 1) garantir a autonomia do poder público frente à ação das construtoras e 2) conscientizar a população sobre a importância do equipamento público de qualidade e da participação ativa dos usuários em sua preservação (BUITONI, 2009), ideais que refletiam não só os anseios da arquiteta, mas de um governo eleito pelos movimentos populares e por aqueles engajados nas lutas sociais. 


\section{CONSTRUINDO ESCOLAS}

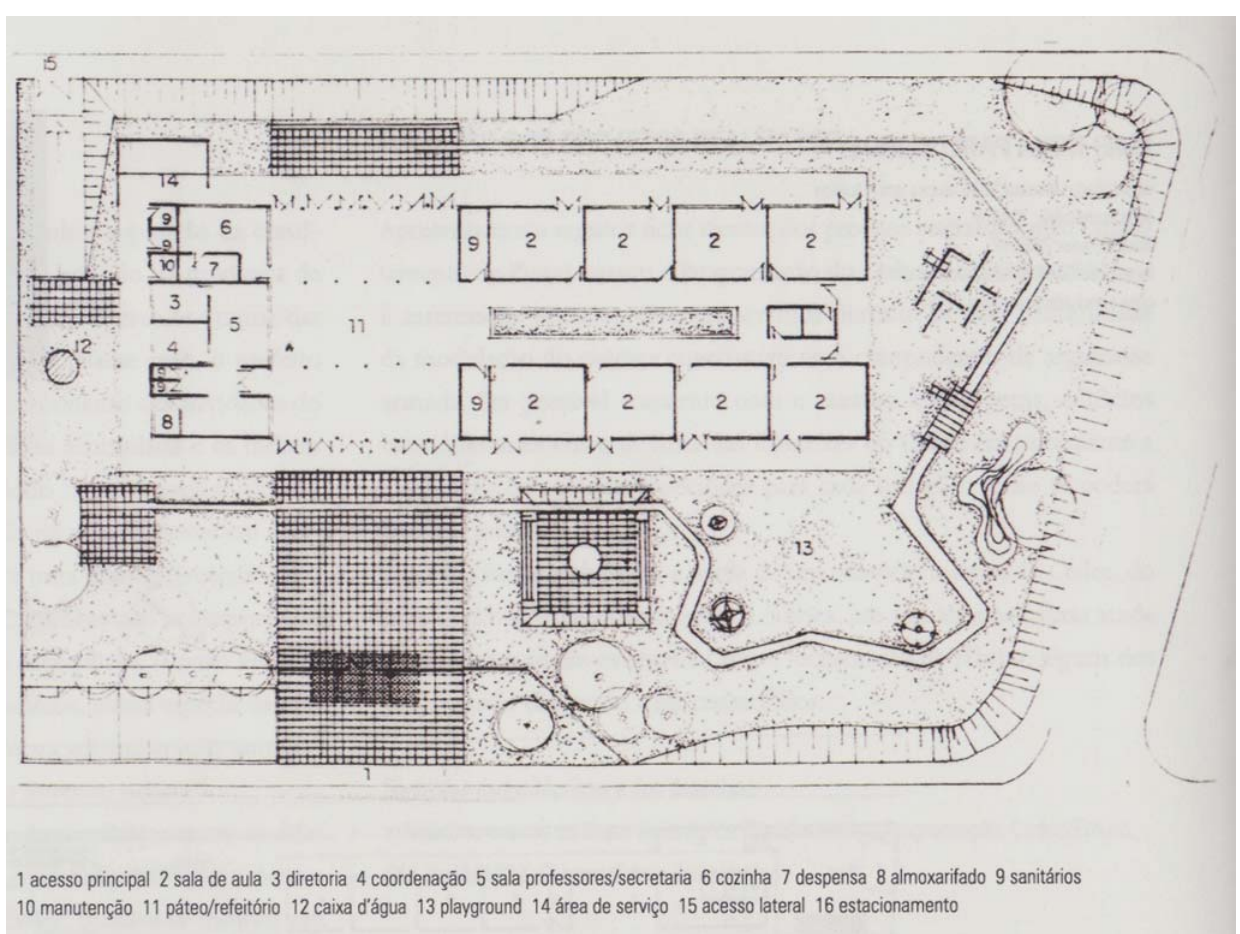

Além do importante papel assumido por Mayumi, a presença de Paulo Freire como Secretário de Educação foi determinante nos rumos do Departamento. Ao instituir um modelo político-pedagógico inspirado na noção de "escola pública popular" (GADOTTI; TORRES In: FREIRE, 1995), o novo secretário imprimiu novos rumos à política educacional. Num primeiro documento elaborado pela gestão Freire, publicado no Diário Oficial de São Paulo de 1 de fevereiro de 1989, com o título "Aos que fazem a Educação conosco em São Paulo", os princípios fundamentais da nova política foram oficialmente registrados:

A marca que queremos imprimir coletivamente às escolas privilegiará a associação da educação formal com a educação não-formal. A escola não é 0 único espaço de veiculação do conhecimento. Procuraremos identificar outros espaços que possam propiciar a interação de práticas pedagógicas diferenciadas de modo a possibilitar a interação de experiências. Consideramos também práticas educativas as diversas formas de articulação que visem contribuir para a formação do sujeito popular enquanto indivíduos críticos e conscientes de suas possibilidades de atuação no contexto social. (Diário Oficial do Município de São Paulo, 01/02/1989 In: FREIRE, 1995, pg. 16)

Com Paulo Freire à frente da Secretaria de Educação, os arquitetos de EDIF descortinaram novos horizontes: descobriram 0 conceito de Cidade
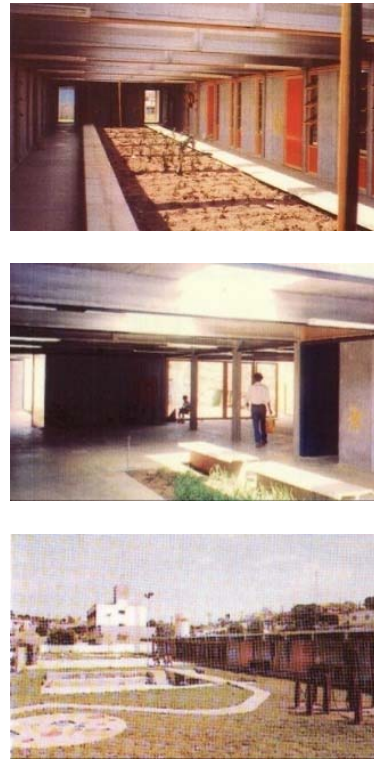

EMEI Jardim Robru (1991), CEDEC. Destaque para a préfabricação dos componentes. Fonte: BUITONI, 2009. 
Educadora $^{27}$ e, a partir daí, desenvolveram a ideia das "Praças de Equipamentos", que mais tarde seriam revisitadas, originando os CEUs.

As Praças de Equipamentos resgatavam conceitos das Escolas-Parque de Anísio Teixeira, principal referência para os arquitetos do Convênio Escolar, incorporando, entretanto, os conceitos freirianos da escola aberta e democrática, integrada com sua comunidade e com o território onde está inserida.

Acho que 48 está para Anísio Teixeira como 88 está para Paulo Freire. É, acho que se fosse colocar isso no Governo Erundina, seria assim. 0 que nós conceituamos naquela época, no início dos anos 90 , foi, na verdade, descobrir a origem deste escritório público de projetos. Nós não convivemos com nenhum deles, mas nas estantes da nossa biblioteca tinha um livro sobre sistematização de edifícios públicos, sistematização de elementos, componentes, ambientes e blocos, tudo dos anos 50. (informação verbal) ${ }^{28}$

Durante o governo Erundina, EDIF conheceu uma equipe de profissionais que, segundo o Arq. Alexandre Delijaicov, foi buscar nas gavetas o histórico do escritório público, o que os levou ao Convênio Escolar e a todo um processo de articulação entre arquitetura e educação, posteriormente abandonado pelos órgãos que o sucederam. 0 afã desta equipe em 89 passou a ser, então, a reconstrução de tais estruturas, promovendo uma reformulação no modo de se projetar equipamentos públicos, indo além da arquitetura do edifício, para chegar sim a um projeto de cidade. A "Cidade Educadora".

[...] foi neste momento que nós começamos a ir atrás do nosso histórico e buscar depoimentos. Convidamos o Tibau, o Corona... alguns estavam mais desanimados por conta do terrível problema público [referindo-se ao descaso frente ao trabalho anteriormente realizado pelo Convênio Escolar]. Outros deram entrevista mais animados. Mas nós recuperamos a história no sentido de reconhecer a importância da arquitetura do edifício público para o desenho da cidade. Porque nos anos 60 e 70, 70 principalmente, houve uma devastação da equipe de arquitetura, no sentido de fazer, nesta visão da época da ditadura, arquitetura para eles, e não para nós. (informação verbal) ${ }^{29}$

A proposta das Praças de Equipamentos consistia em agregar diversos equipamentos públicos em torno de uma praça, articulando as atividades desenvolvidas e criando uma espécie de centro de bairro, ou seja, um polo

27. 0 princípio de Cidade Educadora - conceito oficialmente instituído em 1990, com a realização do I Congresso Internacional de Cidades Educadoras, em Barcelona, e muito defendido pelo pedagogo Paulo Freire - parte da consideração da própria cidade, em seu uso e evolução, como principal instrumento de formação da sociedade, atribuindo ao espaço urbano funções educativas. 


\section{CONSTRUINDO ESCOLAS}

de desenvolvimento local, ao qual se articularia toda uma rede urbana e educacional. A ideia era resgatar as praças de bairro, a praça da igreja das pequenas cidades, ou seja, espaços públicos nada complexos, mas que poderiam assumir, entretanto, um papel de centralidade na dinâmica do lugar. De alguma forma, concretizava-se nesta proposta o que décadas antes o Convênio Escolar tentara instituir por meio do desenho de seus edifícios.

Com o Convênio, em São Paulo, unem-se o sentido modernizador na nova escola com as propostas da arquitetura moderna. Em relação com a cidade e atuando sobre ela, a escola do Convênio ainda, e pela primeira vez entre nós, é proposta como "centro de bairro", potencializando sua identidade enquanto espaço público operativo junto ao entorno urbano. (GILIOLI, 1994, p. 95).

Por falta de tempo, as Praças de Equipamento não foram implementadas. Toda a conceituação foi elaborada, áreas para instalação foram levantadas e algumas experiências piloto chegaram a ser testadas, no âmbito dos concursos nacionais para conjuntos habitacionais promovidos na época. Tentou-se atrelar as Praças de Equipamentos aos projetos habitacionais selecionados, como aconteceu com o projeto para Vila Pantanal, cujos vencedores foram Bruno Padovano e Hector Vigliecca. Nas gestões municipais que se sucederam - Paulo Maluf (1993 - 1996) e Celso Pitta (1997 - 2000) - a proposta foi reapresentada, contudo nunca encampada.

\subsection{As Escolas de Lata}

Em meio a um histórico de conquistas conceituais, apesar de alguns momentos de certa estagnação, na gestão de Celso Pitta (1997-2000) São Paulo veio a assistir um significativo retrocesso no que se refere à política escolar, denegrindo os avanços até então alcançados. Extrapolando os limites da relação quantidade, em detrimento de qualidade, foram erguidas as popularmente denominadas "escolas de lata": salas de aula construídas em contêineres de zinco ou folha-de-flandres, dotadas de péssimas condições espaciais, a começar pelos aspectos termo-acústicos ${ }^{30}$, onde 0 processo de ensino tornava-se inviável. Descortinava-se um cenário de literal sucateamento da educação pública.

30 Segundo matéria publicada na Folha de São Paulo de 18/10/2005, "Teto de "escola de lata" atinge $60^{\circ} \mathrm{C}$ ", um levantamento feito pela USP de São Carlos averiguou que a temperatura no telhado de zinco das "escolas de lata" chegava a $60^{\circ} \mathrm{C}$ em Ribeirão Preto ( $314 \mathrm{~km}$ a norte de SP). 
Apesar do "caráter emergencial" inicialmente atrelado a esta política, que visava desafogar a forte demanda por vagas, a gestão Pitta nunca substituiu as escolas de lata por edifícios dignos. Ao todo foram construídas em sua gestão 54 escolas nestas condições.

Não bastando o descaso da conduta do município, escolas similares, porém com 0 sofisticado nome de Escolas Padrão Nakamura, foram construídas pelo governo do Estado entre 1998 e 2002 ${ }^{31}$. A Secretaria Estadual de Educação justificou em seus discursos à imprensa que tais estruturas se diferenciariam das escolas de lata por contarem com uma estrutura metálica independente, com vedação de painéis de chapas de aço preenchidos com madeira, o que melhoria o desempenho.

A substituição destas estruturas só começou a ser realizada na gestão de Marta Suplicy, a partir de 2001. Nesse período, foram eliminadas 10 "escolas" e na gestão seguinte, inicialmente encabeçada por José Serra e depois assumida por Gilberto Kassab, foram substituídas as restantes. Mesmo assim, restaram ainda algumas salas improvisadas, cuja utilização foi proibida em 2002, pelo Ministério Público de São Paulo, que firmou um Termo de Ajustamento de Conduta com a SME para promover a substituição das 60 escolas nessas condições (MASCARENHAS, 2006).

A Prefeitura de São Paulo desativou ontem, há três dias das eleições, a última escola de lata - estrutura feita de chapas metálicas parecidas com contêineres. Mas ainda restam 56 salas na cidade feitas desse material. Espécie de "puxadinho escolar", as salas de lata foram construídas no mesmo terreno de escolas de alvenaria para abrigar turmas que não couberam no prédio principal. Hoje, alojam cerca de 7.000 alunos. (BALAZINA; TÓFOLI, 2006)

\subsection{Os Centros Educacionais Unificados - CEUS.}

Em 2003, com a eleição de Marta Suplicy à Prefeitura de São Paulo, a ideia das Praças de Equipamentos do governo Erundina foi retomada e convertida no programa estratégico da gestão sob um novo nome: Centros Educacionais Unificados, os polêmicos CEUs. 


\section{CONSTRUINDO ESCOLAS}

Segundo a Secretaria Municipal de Educação, os CEUs, mais do que a influência de Paulo Freire, incorporaram diversos outros conceitos, discutidos e aprimorados ao longo dos anos:

Os Centros Educacionais Integrados não surgiram por acaso ou por decreto, em 2003. As ideias, concepções e experiências, acumuladas em diferentes momentos históricos, contribuíram, sobremaneira, para enriquecer a sua proposta final. As ideias de educação para cidadania e de escola aberta de Paulo Freire, os projetos dos Parques Infantis, que Mário de Andrade criou em São Paulo nos anos 30, a Escola Parque, que o educador Anísio Teixeira criou na Bahia nos anos 50, onde as pessoas aprenderam a conviver com os espaços públicos integrados. (DÓRIA; PEREZ, 2007, p. 131)

Vale mencionar que a viabilização do programa contou com uma imensa vontade política, que colocou os CEUs como foco daquela gestão. Com a alteração da Lei Orgânica Municipal, em 2001, os gastos com educação foram elevados de 30 para $31 \%$ da receita gerada com impostos, autorizando-se deduzir desta fonte os gastos com transporte, alimentação e saúde, de modo a garantir a interdisciplinaridade de atendimento dos CEUs. Um item específico autorizou ainda a utilização destes recursos na criação e manutenção de "centros integrados de educação e cultura" (Lei 13.245/ 2001, art. $3^{\circ}$, inciso VII), viabilizando economicamente a construção dos edifícios.

Outro fator surpreendente foi a capacidade da Prefeitura em disponibilizar terrenos aptos à instalação dos equipamentos, cujo porte e padronização da volumetria demandava áreas extensas e com relevo não muito acentuado. Cada CEU ocupa uma área mínima de $11 \mathrm{mil} \mathrm{m}^{2}$, o que pareceria inviável ao recordar que as escolas até então construídas precisavam se acomodar em restos de terrenos de outras escolas ou em áreas institucionais dos conjuntos habitacionais, geralmente terrenos estes com perímetros recortados e relevo acentuado.

Por outro lado, vale mencionar, entretanto, que os CEUs, sob o discurso da inclusão das áreas mais periféricas da cidade, estão todos situados nos "limites do limite municipal", o que amplia a oferta de terra.

Outro fator a despertar curiosidade foi a forma como a Prefeitura conseguiu encontrar terrenos aptos à instalação de complexos dessa magnitude, uma vez que cada CEU possui terreno com área mínima de $11 \mathrm{mil} \mathrm{m}^{2}$. Sabe-se que a falta de terrenos ou a inadequação dos terrenos disponíveis são frequentemente usados como justificativa para a não-provisão de equipamentos públicos, devido ao comprometimento econômico-financeiro de projetos quando da necessidade de desapropriação de áreas. (MASCARENHAS, 2005, p. 15) 
A fase de localização dos terrenos para os 21 primeiros CEUs foi realizada em 40 dias, nos quais foram levantados 168 terrenos (MASCARENHAS, 2006). Dos 21 equipamentos instalados, 13 foram construídos em áreas desapropriadas $^{32}$, 0 que chegou a atrasar algumas obras, mas não comprometeu a implantação do programa.

Além da "facilidade" na obtenção dos terrenos, a experiência dos CEUs contou com uma eficiência administrativa surpreendente, tanto no que se refere às tramitações burocráticas, quanto aos processos licitatórios para execução das obras, permitindo que os equipamentos fossem concluídos num prazo médio de 1 ano, período extremamente exíguo para uma empreitada pública de tal envergadura. As obras tiveram início em setembro de 2002 e a entrega dos primeiros centros ocorreu a partir de agosto de 2003. A aceleração dos processos administrativos internos, entrave típico à implementação de ações públicas, foi viabilizada, em grande parte, pelo fato do projeto ter sido coordenado pela Secretaria de Governo, o que facilitou 0 trânsito pelas demais secretarias envolvidas (MASCARENHAS, 2006).

Tendo como ponto central da política de governo atingir as regiões mais carentes da cidade, demarcando a presença do Poder Público em áreas historicamente esquecidas, a localização dos CEUs foi definida a partir da análise dos Mapas da Exclusão/ Inclusão Social da Cidade de São Paulo, desenvolvidos em 1995 e 2000 sob a coordenação da socióloga Aldaíza Sposati, e do Mapa da Juventude de São Paulo, elaborado em 2003 pela Prefeitura, em parceria com o Centro de Estudos de Cultura Contemporânea. Não à toa, os dois mapas praticamente se sobrepunham, destacando as áreas mais pobres e violentas da cidade.

Seriam justamente estas regiões as contempladas pela instalação dos equipamentos, num intuito político integrado de urbanizar estas áreas, levar educação e cultura e consequentemente reverter as preocupantes condições sociais, marcadas, sobretudo, por altos índices de violência. Desse modo, a implantação dos CEUs trouxe consigo não apenas o equipamento, mas também toda a rede de infraestrutura básica necessária a um assentamento urbano: pavimentação, iluminação, saneamento e abastecimento de água. Só assim, "a cidade se constituiria", como coloca o Arq. Alexandre Delijaicov ${ }^{33}$, "a partir do tripé infraestrutura, equipamentos e habitação", o que considera a base para a configuração de uma malha urbana bem resolvida. Para os 


\section{CONSTRUINDO ESCOLAS}

arquitetos de EDIF, mais do que "centros educacionais", os CEUs constituem, fazendo alusão à própria sigla, "Centros de Estruturação Urbana" (DÓRIA; PEREZ, 2007), ou seja, polos irradiadores de qualidade urbana. Configurava assim um instrumento de planejamento urbano, atuando em áreas nunca "planejadas".

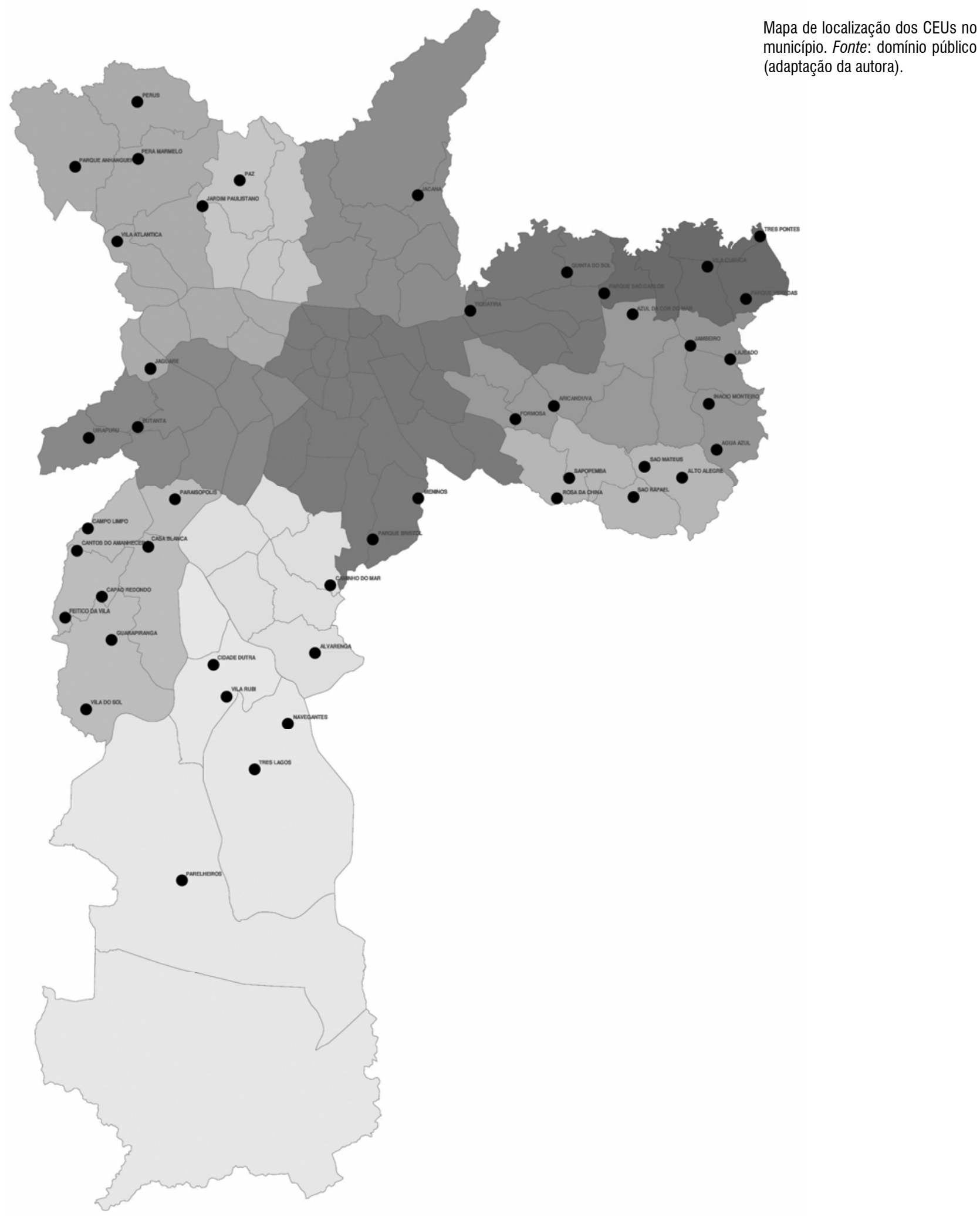


Segundo divulgação oficial da Prefeitura de São Paulo, os CEUs foram planejados com três objetivos principais: 1) promover 0 desenvolvimento integral das crianças e dos jovens; 2) constituir um polo de desenvolvimento urbano e sociocultural da comunidade; e 3) constituir um centro de inovações em experiências educacionais. Visando cumprir estas metas, 0 projeto dos CEUs agregou diversos equipamentos - culturais, esportivos e espaços públicos de convivência -, além de prover infraestrutura urbana básica ao entorno imediato dos edifícios, coisa que FDE, dado 0 engessamento dos recursos, nunca conseguiu promover.

0 programa dos CEUs segue um padrão, que conta com 14 equipamentos:

5 equipamentos de educação: 2 creches, 1 Escola Municipal de Educação Infantil - EMEI, 1 Escola Municipal de Educação Fundamental - EMEF e 1 Escola de Jovens e Adultos - EJA;

_ 3 equipamentos de cultura: 1 Biblioteca Pública, 1 Teatro Municipal com 1 sala com capacidade para 450 pessoas e outra para 150 e 1 Casa de Cultura, com ateliês, estúdios de rádio, TV e salas para música e dança;

_ 3 equipamentos de esporte e lazer: 1 ginásio, formado por quadra coberta e sala de ginástica, o Balneário Municipal, com piscinas e solário e 1 Parque Esportivo, constituído por uma pista de skate, quadras abertas, campos de futebol, playground e pequenos bosques, quando possível;

_ 1 telecentro;

_ 1 padaria-escola;

_ 1 Conselho Gestor.

Com este programa extenso, a ideia era que o novo equipamento suprisse toda a demanda básica por serviços públicos que um bairro pudesse solicitar. Cada unidade foi pensada para atrair não só os seus quase 2.400 alunos, mas toda a família e a comunidade, sobretudo nos finais de semana.

Cada CEU oferece - distribuídos por cerca de 13 mil $\mathrm{m}^{2}$ de área construída - uma biblioteca com 10 mil livros, além de jornais e revistas; telecentros com 20 computadores ligados à Internet, teatro, padaria comunitária, salas de música e dança, duas orquestras (uma de cordas e uma de Big Band), rádio comunitária, estúdios de produção e gravação de multimídia, escola de iniciação artística em teatro, artes plásticas e dança; pista de skate, três piscinas, ginásio de esportes e quadras de esportes descobertas. 0 CEU é acessível não só aos 2.400 alunos (de creche, educação infantil e ensino fundamental, aos alunos de EJA educação de jovens e adultos) que cada unidade pode atender, mas também aos funcionários, aos familiares de alunos e alunas, pais e parentes dos alunos, aos 


\section{CONSTRUINDO ESCOLAS}

alunos, irmãos e pais de alunos das escolas vizinhas, em fim, a toda a comunidade, que está sendo convidada a participar de suas atividades e, efetivamente, está participando de sua construção e de sua gestão, como se pode verificar pelos relatos que se seguem. Segundo dados da Secretaria, a cada mês, cerca de 30 mil pessoas participam das atividades e/ ou usufruem da estrutura e dos equipamentos de cada CEU. (DÓRIA; PEREZ, 2007, p. 112).

Apesar do programa ampliado, em geral, os CEUs seguiram as mesmas diretrizes do projeto Escola-Parque de Anísio Teixeira, buscando atender, portanto, a três objetivos principais: 1) desenvolvimento integral das crianças e dos jovens; 2) desenvolvimento da comunidade; e 3) implementação de experiências educacionais inovadoras. Talvez a diferença mais significativa do ponto de vista pedagógico, seja a utilização do Sistema de Ciclos, que é anterior a implantação destes equipamentos, tendo sido efetuada em 1992, na gestão de Paulo Freire. Tal estrutura educacional traz em sua essência 0 respeito ao tempo de aprendizagem de cada aluno, contrapondo-se ao sistema serial anteriormente empregado. Com isso, extingue-se a reprovação, procurando-se manter os alunos na escola e garantir a "qualidade social" da educação, dando espaço à individualidade e às dificuldades de cada um, evitando o sentimento de "fracasso-escolar".

Outra grande contribuição foi a introdução de mecanismos de gestão democrática nas escolas, como instituição do $\mathrm{OP}$ Criança ${ }^{34}$ e a constituição dos conselhos gestores dentro de cada unidade. Estes conselhos são encarados como o coração da proposta pedagógica, sendo inclusive incorporados ao programa de usos do equipamento. Apesar da intenção, a manutenção das unidades continua atrelada à SME, não havendo autonomia financeira dos equipamentos que, portanto, seguem dependentes das políticas implementadas pelas gestões municipais.

Do ponto de vista espacial, a concepção geral dos projetos arquitetônicos ficou a cargo de EDIF. 0 extenso programa foi espacializado em um conjunto de tipologias padrão, composto por três edifícios:

1) bloco didático, edifício com 150 por $20 \mathrm{~m}$, com três pavimentos, onde estão dispostos a biblioteca, o telecentro, a padaria comunitária e a EMEI, no térreo, com 8 salas de aula, e a EMEF, que ocupa os dois pavimentos superiores, contando com 14 salas;

34. 0 OP Criança é um mecanismo de gestão das escolas pelos próprios alunos, implantado em São Paulo em 2003, inspirado no Orçamento Participativo, processo de gestão realizado na cidade desde 2001. 0 OP Criança foi implantado, a princípio, em 4 dos 17 CEUs inaugurados naquele ano, estendendo-se posteriormente aos demais. 
2) bloco cultural, edifício com 20 por 45 metros, com cinco pavimentos, que abriga o teatro no térreo, três ateliês no primeiro pavimento, estúdios de música e fotografia no segundo, sala do Conselho Gestor, quadra e vestiários no terceiro e sala de dança no quarto;

3) prédio redondo, edifício de planta circular, com 11 metros de raio, ocupado pelo Centro de Educação Infantil - CEl, com 8 salas de berçário.

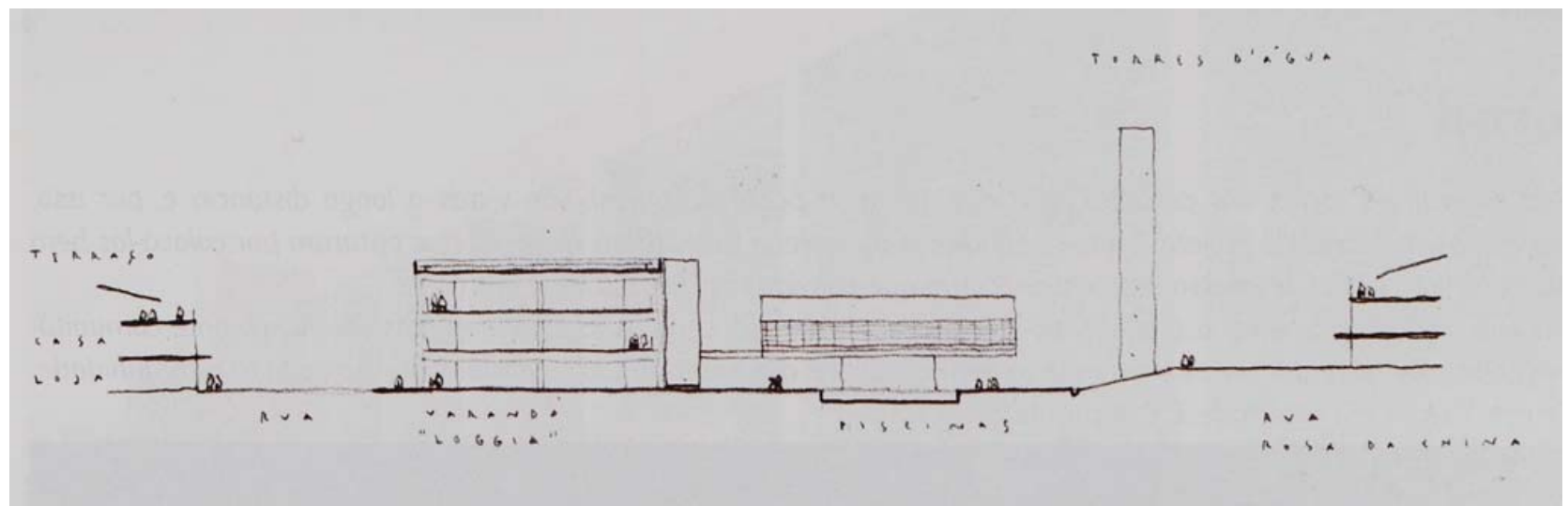

Corte esquemático dos CEUs. Fonte: DÓRIA; PEREZ, 2007.

Apesar da padronização inicial e do emprego de estruturas de concreto préfabricadas, o que visava reduzir o tempo de obra, os projetos puderam ser adaptados conforme 0 traçado de cada terreno. As cores também foram unificadas, com base numa linguagem cromática conceitual, que atrelava cada tom escolhido ao uso dado a cada edifício. Em função da tipologia marcante e do porte, os CEUs passaram a constituir marcos inconfundíveis na paisagem periférica paulistana. E mesmo em meio a muitas críticas, é inegável que tenham inserido uma nova referência arquitetônica para edifícios escolares e, sobretudo, marcado a presença do Poder Público nas regiões mais esquecidas da cidade, tanto do ponto de vista territorial-paisagístico, quanto no que se refere à oferta de serviços públicos.

A construção dos CEUs foi licitada em lotes e em duas etapas, uma em abril e outra em agosto de 2002, sendo o contrato assinado no mês seguinte. 0 processo licitatório foi bastante criticado, não só por considerar um valor acima da reserva orçamentária, mas também por restringir a participação de empresas de menor porte. 0 Sindicato da Indústria da Construção Civil SINDUSCON chegou a entrar com recurso jurídico, alegando que o edital vetara a livre-concorrência ao exigir um capital social mínimo alto e experiência anterior em construções simultâneas e de grande porte. 0 valor médio de cada unidade, que era de $R \$ 10$ milhões, subiu para $R \$ 13,7$ milhões, aumento justificado pela Secretaria de Serviços e Obras como fruto da ampliação do projeto, somado à atualização da tabela de valores da Prefeitura e à variação dos preços dos terrenos (MASCARENHAS, 2006). 
Relação das empresas responsáveis pela construção dos 21 primeiros CEUs.

\begin{tabular}{|l|l|}
\hline \multicolumn{1}{|c|}{ EMPRESA } & \multicolumn{1}{c|}{ EDIFÍCIOS A CONSTRUIR } \\
\hline Construtora OAS & LOTE 1: CEUs Paz, Pêra-Marmelo, Perus e Vila Atlântica \\
\hline Construbase Engenharia & LOTE 2: CEUs Jambeiro, Pq. São Carlos, Pq. Veredas e Vila Curuçá \\
\hline $\begin{array}{l}\text { Carioca Christiani Nielsen } \\
\text { Engenharia }\end{array}$ & LOTE 3: CEUs Alvarenga, Cidade Dutra, Navegantes e Três Lagos \\
\hline Construção & LOTE 4: CEUs Aricanduva, Meninos e Rosa da China \\
\hline Construtora Varca Scatena & LOTE 5: CEUs Inácio Monteiro, São Mateus e São Rafael \\
\hline Blokos Engenharia & LOTE 6: CEUs Butantã, Campo Limpo e Casa Blanca \\
\hline
\end{tabular}

Fonte: Revista de Engenharia, n. 561, 2004.

Apesar dos atrasos e aditamentos dos custos previstos (ARANTES et. al., 2003), entre 2003 e 2004 foram concluídos os 21 CEUs previstos para a primeira fase do programa ${ }^{35}$, a um custo médio de $\mathrm{R} \$ 17$ milhões. 0 custo mensal de manutenção de cada unidade foi calculado em $\mathrm{R} \$ 481.050,00$ (SME, 2003). Ao todo, os CEUs contribuíram com 50.400 novas vagas na rede municipal de ensino, o que representa $24 \%$ do total de novas vagas oferecidas no período 2001-2004 (MASCARENHAS, 2006). 0 incremento na rede de cultura e esporte figura ainda mais expressivo, dado o quadro anterior da oferta de equipamentos na cidade:

35. Os primeiros 21 CEUs de São Paulo são os seguintes:

- ALVARENGA - Cidade Ademar/ Pedreira

- ARICANDUVA - Itaquera/ Cidade Líder

- BUTANTÃ - Butantã/ Rio Pequeno

- CAMPO LIMPO - Campo Limpo

- CASA BLANCA - Jardim São Luís

- CIDADE DUTRA - Socorro/ Cidade Dutra

- INÁCIO MONTEIRO - Cidade Tiradentes

- JAMBEIRO - Guaianazes/ Lajeado

- MENINOS - Ipiranga

- NAVEGANTES - Socorro/ Grajaú

- PARQUE SÃO CARLOS - São Miguel/ Vila Jacuí

- PARQUE VEREDAS - Itaim Paulista

- PAZ - Freguesia do Ó/ Vila Brasilândia

- PÊRA-MARMELO - Pirituba/ Jaraguá

- PERUS - Perus

- ROSA DA CHINA - Vila Prudente/ Sapopemba

- SÃO MATEUS - São Mateus/ Iguatemi

- SÃO RAFAEL - São Mateus/ São Rafael

- TRÊS LAGOS - Socorro/ Grajaú

- VILA ATLÂNTICA - Pirituba/ Jaraguá

- VILA CURUÇÁ - Itaim/ Vila Curuçá 
Contribuição dos CEUs para as redes públicas de equipamentos de esportes e cultura.

\begin{tabular}{|l|c|c|c|}
\hline \multicolumn{1}{|c|}{ EQUIPAMENTOS } & $\begin{array}{c}\text { ANTES DOS } \\
\text { CEUS }\end{array}$ & $\begin{array}{c}\text { CONTRIBUIÇÃO } \\
\text { DOS CEUS }\end{array}$ & $\begin{array}{c}\text { DEPOIS DOS } \\
\text { CEUS }\end{array}$ \\
\hline Bibliotecas & 67 & 21 & 88 \\
\hline Teatros & 7 & 21 & 28 \\
\hline Piscinas & 65 & 63 & 128 \\
\hline Telecentros & 52 & 21 & 73 \\
\hline $\begin{array}{l}\text { Escolas Municipais de Educação } \\
\text { Artística - EMIA }\end{array}$ & 1 & 21 & 22 \\
\hline
\end{tabular}

Fonte: SME, 2004 In: MASCARENHAS, 2005, p. 113.

0 planejamento inicial da Prefeitura previa a conclusão da segunda fase ainda na mesma gestão, 0 que significaria a construção de outros 24 equipamentos. A superação dos gastos da primeira fase em relação à projeção inicial fez, entretanto, com que esta segunda fase não passasse do processo de escolha dos terrenos.

A construção dos CEUs talvez tenha sido a política pública mais polêmica dos últimos anos, gerando manifestações bastante divergentes. Para os opositores, críticas não faltam: além dos custos elevados, tanto de construção como manutenção, o que tornaria a proposta insustentável, ressaltam ainda: 1) o caráter marqueteiro e político-partidário da proposta; 2) a contraposição entre um projeto arquitetônico claro e uma proposta pedagógica genérica, o que faria do programa uma farsa conceitual; 3) a aplicação de verbas da educação em outras áreas, desviando-a de sua finalidade inicial; 4) a concentração de diversos equipamentos em uma área, quando poderiam beneficiar um perímetro mais amplo da cidade (MASCARENHAS, 2006).

Por outro lado, parece inegável a contribuição do programa para o contexto social da periferia paulistana. Em pesquisa de satisfação realizada pela Secretaria Municipal de Educação em 2004, 75\% dos entrevistados, entre usuários e não usuários, atribuíram notas 9 ou 10 de satisfação para 0 equipamento e $62 \%$ apontaram espontaneamente a construção os CEUs ao serem questionados quanto à atuação do Poder Público no bairro naquele ano.

Para Mascarenhas (2005), o CEU rompe com a lógica dos ciclos viciosos de pobreza, violência e exclusão das periferias paulistanas: 


\section{CONSTRUINDO ESCOLAS}

Mais do que a consciência sobre a diferença de oportunidades existente na cidade, os CEUs demonstram a consciência de que a pobreza e a exclusão da população representam uma ameaça à cidadania, e esta situação somente pode ser revertida por meio da intervenção direta do Poder Público, com 0 desenvolvimento de políticas públicas integradas. [...] A criação de espaços públicos, a presença qualificada do Poder Público nas regiões mais pobres da cidade, a integração das ações de educação, cultura, esportes e lazer como forma de aumentar sua efetividade são as formas pelas quais os CEUs alcançam uma inserção urbana positiva, contribuindo para reverter 0 processo de sobreposição de carências verificado nessas áreas. (MASCARENHAS, 2005, p. 128).

Na gestão seguinte, ao contrário das condutas de governo predominantes no país, o projeto de implantação dos CEUs seria mantido, tanto pela gestão de José Serra (2005-2006), quanto pela de seu sucessor Gilberto Kassab (2006-2010). Foram erguidos os outros 24 edifícios previstos no planejamento inicial ${ }^{36}$, havendo apenas alguns ajustes de localização nos casos de inviabilidade do terreno.

36. Os demais 24 CEUs, implantados posteriormente à gestão Marta Suplicy, foram os seguintes:

- ÁGUA AZUL - Cidade Tiradentes

- ALTO ALEGRE - Jardim Laranjeira/ Iguatemi

- AZUL DA COR DO MAR - Cidade A.E. Carvalho

- CAMINHO DO MAR - Jabaquara

- CANTOS DO AMANHECER - Jardim Eledy

- CAPÃO REDONDO - Campo Limpo/ Capão Redondo

- FEITIÇO DA VILA - Chácara Santa Maria

- FORMOSA - Vila Formosa

- GUARAPIRANGA - Jardim Kagohara

- JAÇANÃ - Jardim Guapira

- JAGUARÉ - Jaguaré

- JARDIM PAULISTANO - Jardim Paulistano

- LAJEADO - Guainases

- PARAISÓPOLIS - Jardim Parque Morumbi

- PARELHEIROS - Jardim Novo Parelheiros

- PARQUE ANHANGUERA - Jardim Anhanguera

- PARQUE BRISTOL - Pq. Bristol

- QUINTA DO SOL - Cangaíba

- SAPOPEMBA - Jardim Sapopemba

- TIQUATIRA - Penha

- TRÊS PONTES - Jardim Célia

- UIRAPURU - Jardim João XXIII

- VILA DO SOL - Jardim Capela

- VILA RUBI - Vila Rubi 
A grande discussão levantada pela nova gestão concentrou-se na redução do custo dos edifícios. Os CEUs produzidos pela gestão anterior proporcionaram gastos entre $\mathrm{R} \$ 17$ e $\mathrm{R} \$ 20$ milhões por unidade, fato que levou o novo governo a classificá-los como "obras faraônicas". Sendo assim, optou-se pela redução dos equipamentos, acompanhada de algumas reformulações do projeto arquitetônico, com vistas a baratear as construções.

Os novos CEUs passaram a contar com um Bloco Didático com 41 salas (9 para CEI, 9 para EMEI e 23 para EMEF), incluindo laboratório de ciências, sala de informática e espaço multiuso, um prédio administrativo, um prédio com 0 refeitório principal, biblioteca e telecentro (equipado com 20 computadores), três piscinas (semi-olímpica, recreativa e infantil), duas quadras poliesportivas (uma coberta e uma descoberta) e um teatro com, em geral, 200 lugares, variando para mais ou para menos de acordo com a demanda local. Da mesma forma, o número de vagas passou a acompanhar a demanda, planejando-se, em média, uma capacidade de 2.600 alunos.

A revisão do projeto arquitetônico concentrou-se em solucionar os problemas detectados nos primeiros edifícios e ainda reduzir os custos de manutenção e otimizar a obra, introduzindo técnicas de racionalização construtiva e a pré-fabricação dos componentes. Segundo o ex-prefeito José Serra, "Os novos CEUs serão horizontais e não terão elevadores. Decidimos substituir por rampas de acesso, pois a manutenção é muito cara e nunca encontrei todos os elevadores funcionando quando visitei os CEUs"37.

Alterações de desenho tentariam responder às questões de conforto e eficiência das construções. A planta do pavimento tipo de salas de aula, por exemplo, seria redesenhada, substituindo o modelo de corredores externos com salas geminadas no eixo central por uma configuração com salas nas fachadas, permitindo a ventilação cruzada e uma melhor iluminação. Parte da caixilharia seria também substituída, introduzindo modelos de menor manutenção. A volumetria assumiria um caráter um pouco diferenciado dos edifícios anteriores, prezando, entretanto, a implantação de projetos padronizados e racionalizados.

Você tinha uma tipologia padrão na concepção original. Depois você adequava a implantação, mas, a grosso modo, era uma tipologia específica. Depois houve a mudança para a nova tipologia, com ênfase principalmente na pré-fabricação, agilidade na execução de obra, foi um projeto novo para o mesmo programa, mas que também varia um pouco de acordo com o tipo de terreno. Tem terrenos que são muito pequenos, então houve uma verticalização maior dos blocos 


\section{CONSTRUINDO ESCOLAS}

educacionais. Eles foram feitos todos num bloco só. Em alguns lugares 0 déficit foi também reduzido. Então você precisou fazer também algumas adaptações. Outros ganharam alguns programas específicos, por exemplo: 0 CEU Paulistano $\mathrm{e}$ 0 CEU Parelheiros têm planetário. É um programa a mais que não tinha, por uma característica específica. (informação verbal) ${ }^{38}$

Apesar das promessas de redução dos custos de construção, os CEUs da segunda gestão mostraram-se superiormente mais custosos do que os anteriormente implantados. 0 custo médio das novas unidades foi de $\mathrm{R} \$ 26,8$ milhões, variando de $\mathrm{R} \$ 25$ a $\mathrm{R} \$ 37$ milhões, sendo que o mais caro, o CEU Feitiço da Vila, alcançou a cifra dos $\mathrm{R} \$ 36,9$ milhões.
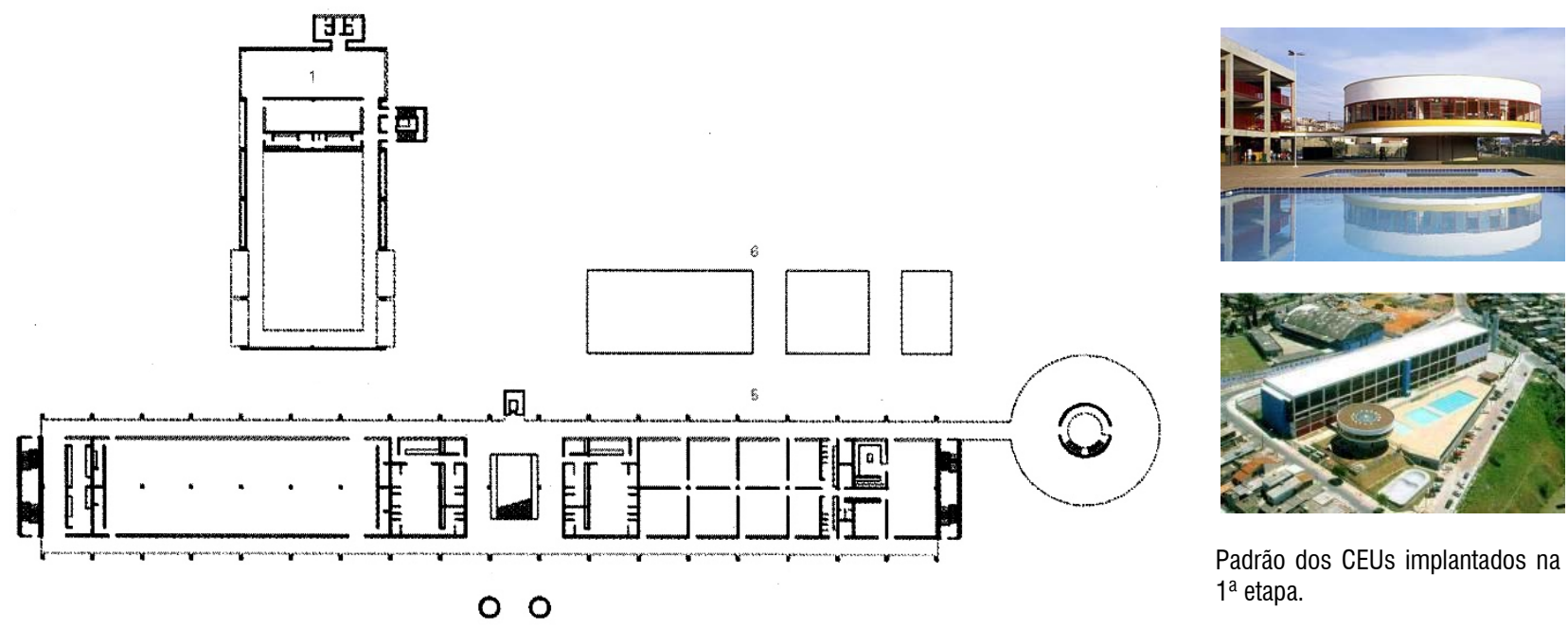

Padrão dos CEUs implantados na $1^{\mathrm{a}}$ etapa.
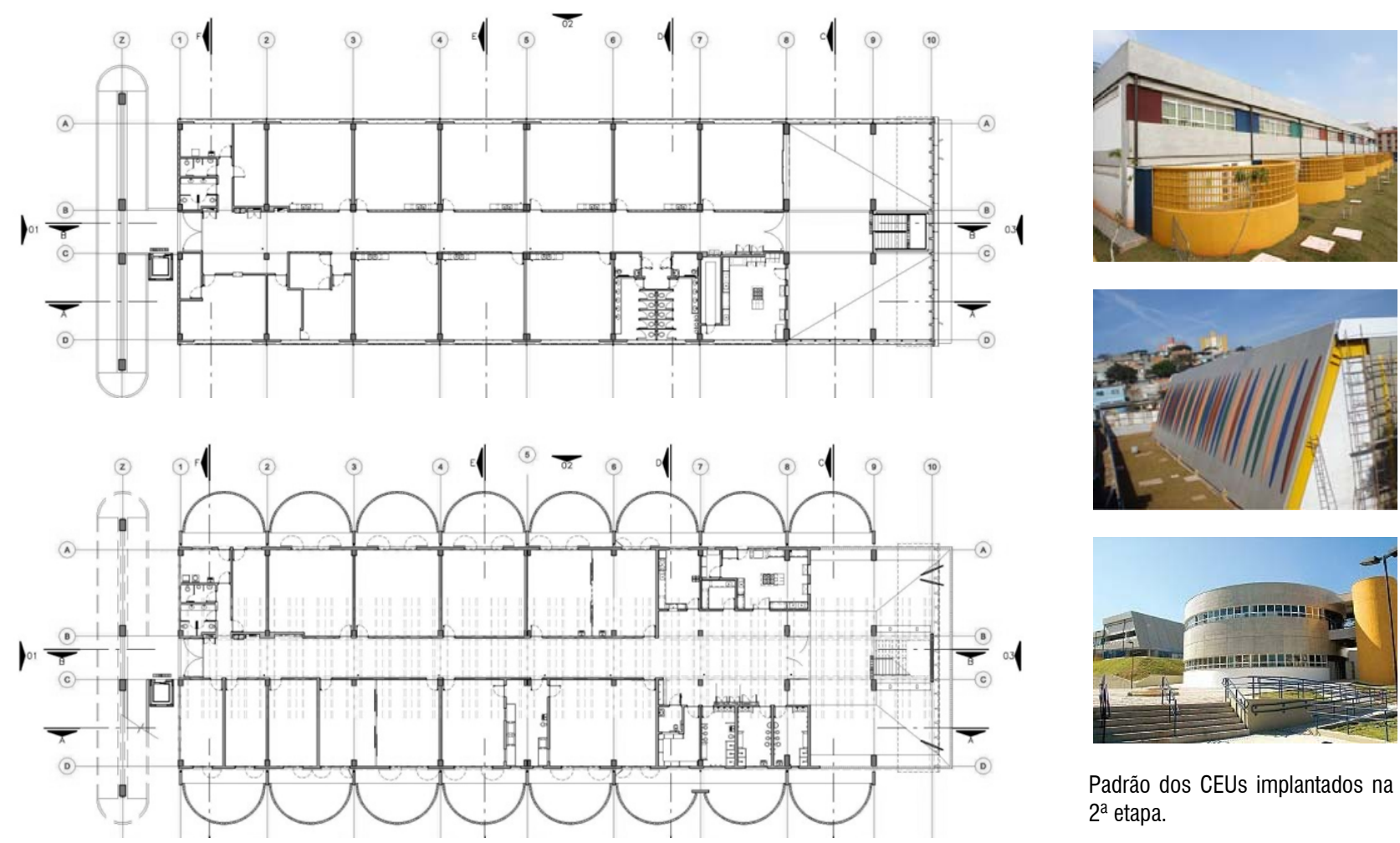

Padrão dos CEUs implantados na $2^{\mathrm{a}}$ etapa.

Fonte: DÓRIA; PEREZ, 2007/ EDIF.

38. Depoimento do Arq. João Canteiro à autora, em 03/02/2010. 
Em 2007, a Prefeitura começaria a implementar o Polo Educacional e Cultural de Heliópolis, adotando um partido bastante semelhante às Praças de Equipamentos freirianas. 0 projeto resume-se à integração de diversos equipamentos já existentes, por meio da construção de uma grande praça e um centro cultural. Uma área que já abrigava três creches municipais Centros de Educação Infantil (CEls) Heliopólis I, II e III, juntas com capacidade para 480 alunos - e a Escola Técnica Paula Souza, do Governo do Estado, foi articulada a uma praça contígua, onde já estavam instaladas duas escolas municipais -a EMEl Antônio Francisco Lisboa, com 462 estudantes e a EMEF Presidente Campos Salles, que atende 1.286 alunos. A cessão em regime de comodato de um velho galpão da Prefeitura para uma entidade local, a UNAS, permitiria a instalação do novo centro cultural, cujo projeto seria elaborado pelo arquiteto Ruy Othake, também responsável pela proposta urbanística de integração dos edifícios.

Assim, o polo, constituído por todas essas unidades educacionais e culturais e instalado nas duas áreas que se agruparam em uma única, terá um espaço de parque sem muro entre as edificações. Um jardim, portanto, que promove a convivência de estudantes de três a vinte anos com professores e funcionários. Essa convergência de crianças, adolescentes e adultos da comunidade vislumbra um futuro com fortalecimento da cidadania e da democracia. (ESCRITÓRIO RUY OTHAKE, 2010)

0 complexo todo conta com uma área total de $35.994 \mathrm{~m}^{2}$, onde não é permitido o tráfego de veículos, buscando promover circulação, encontros e permanência dos pedestres. Segundo a Prefeitura, o projeto foi desenvolvido desde 0 início de forma participativa, definindo coletivamente o programa do centro cultural e a grade de cursos técnicos a serem oferecidos pela Escola Paula Souza.
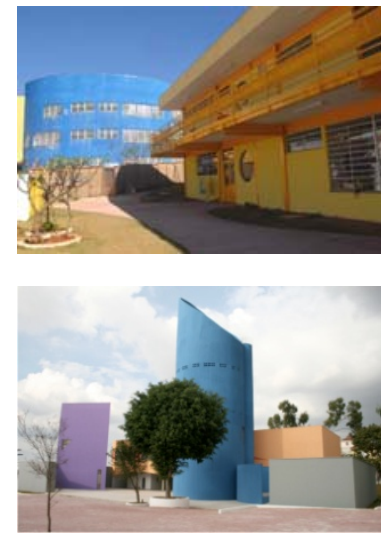

Polo Educacional e Cultural de Heliópolis (2007), projeto de Ruy Othake. Fonte: domínio público.

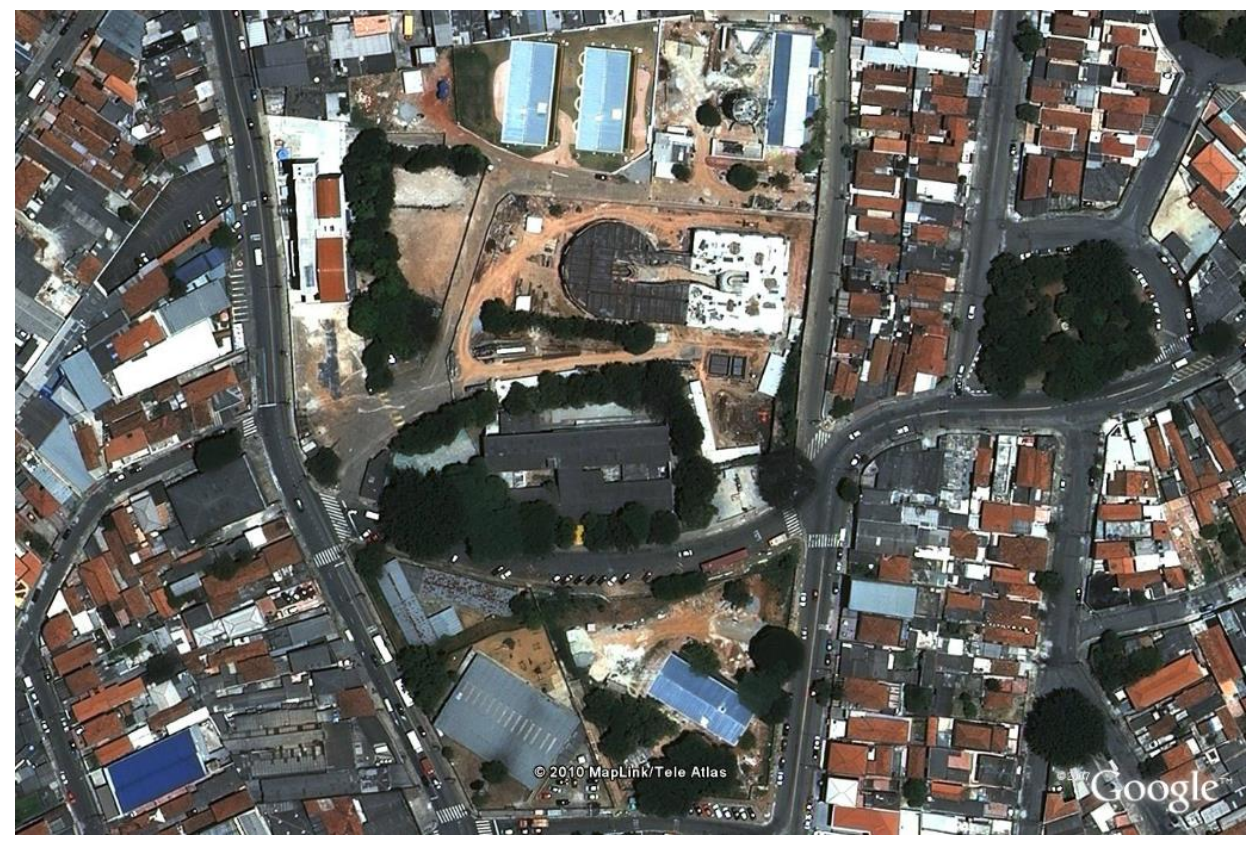


Desde 0 início da construção, a comunidade de Heliópolis participou ativamente das discussões sobre a obra. Entre outras coisas, os moradores pediram uma escola técnica e decidiram quais cursos deveriam ser oferecidos aos estudantes da região. Solicitaram também que 0 centro cultural tivesse um cinema. E mais: vão participar da gestão do complexo educacional. Decidirão, por exemplo, como o espaço vai funcionar nos fins de semana e em que horário ficará aberto. (SME, 2010)

Concretizava-se assim a Escola-Parque de Anísio Teixeira, a Praça de Equipamentos de Paulo Freire, o CEU de Marta Suplicy, agora sob a alcunha de Polo Educacional e Cultural, de Kassab. Equipamentos integrados, que buscavam constituir um grande complexo de ensino, onde a criança pudesse realizar toda a sua trajetória de formação. Atualmente, este projeto é uma importante bandeira do Governo Municipal, apresentada como algo completamente inovador. Inovador, nem tanto, mas uma iniciativa desejável para a cidade, sem dúvida. 
Quadro da produção educacional pública em São Paulo 1890-2000

Fonte: elaboração da autora a partir da bibliografia citada

1890

DOP

programa simples (salas, administrativo e recreio coberto)

paredes de tijolos auto-portantes

grandes pés-direitos

telhas de barro e platibandas, janelas estreitas, forro de madeira,

piso de madeira, ladrilho hidráulico

produz exclusivamente edifícios escolares

terceirização dos projetos para escritórios de arquitetura

1976

CONESP

sistemas construtivos padronizados

padronização de dimensões, maeriais e processos

preocupação em adequar projetos à mão-de-obra disponivel no

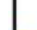

$$
\begin{aligned}
& 1987 \\
& \text { FDE }
\end{aligned}
$$

atuacão na área pedagógica e na provisão de recursos físicos uso de componentes pré-fabricados, inclusive na estrutura

padronização dos programas de uso seguindo modelo pedagógico

elaboração de catálogos técnicos próprios

preocupação com a inserção urbana

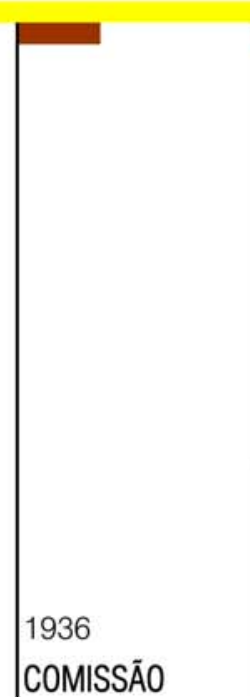

\begin{tabular}{ll}
\hline 1959 \\
1 IPESP
\end{tabular}

COMISSÃO

\section{CONVÊNIO}

base nas propostas de Anísio Teixeira

escola mais próxima da escala da crianca

espaços generosos e iluminados, jardins incorporados ao edifício, entrada destacada

grandes caixilhos de ferro, ventilação cruzada, recreio coberto em arco pré-moldado

no início, mesmos padrōes do DOP

projetos padronizados

parceria com o IAB: terceirização dos projetos

lajes de concreto sustentadas por pórticos

integracão urbana do edifício

\section{CDHU/ CPOS}

. execucãa das obras novas

setorização do programa em blocos funcionais

programa mais amplo

atenção para a orientação dos edifícios

estrutura em concreto armado (térreo livre), recreio integrado ao restante do edifício

uso da declividade dos terrenos

. janelas maiores 


\section{Quadro evolutivo das políticas educacionais em São Paulo 1890-2010.}

\section{Fonte: elaboração da autora a partir da bibliografia citada}

\section{0}

\section{Ideário Republicano}

Pela primeira vez no Brasil a educação é assumida como política pública, reflexo este de uma intenção políticoideológica de implementar um novo sistema de governo no país. A proposta de assumir 0 ensino como

responsabilidade governamental, demandou uma reorganização da administração escolar, 0 uso de instrumentos de planejamento, os recenseamentos, a ampliação da rede e da clientela escolar. Criou-se um complexo sistema educacional, que incluía inúmeras formas de organização, classificação e níveis de instituições de ensino, dentre os quais, os mais conhecidos são os Grupos Escolares.

\section{9}

\section{Escola-Parque}

Projeto pedagógico idealizado por Anísio Teixeira, sob a influência do pensamento de John Dewey. Para o educador, a escola precisava educar em vez de instruir, formar homens livres em vez de homens dóceis, preparar para um futuro incerto em vez de transmitir um passado claro, ensinar a viver com mais inteligência, mais tolerância e mais felicidade. 0 interesse do estudante devia orientar o seu aprendizado num ambiente de liberdade e confiança mútua. A ideia de escolasclasse e escolas-parque consistia numa proposta de complementar 0 ensino tradicional com atividades culturais, esportivas e de lazer diversas, de modo a proporcionar a formação integral do aluno. Para tanto, as crianças "estudariam" em horário integral, dedicando-se em cada um dos períodos a uma destas "escolas". A noite, parte destas estruturas seria aberta à comunidade, de modo a integrar toda a sociedade a esta rede de cultura e educação.
2001

\section{CEUs}

Programa de governo calcado no ensino integrado e no horário integral. Conforme o próprio título Centros Educacionais Unificados -

os CEUs trazem para a escola os demais equipamentos considerados importantes à formação do aluno -

cultura, esporte, lazer -, criando grandes complexos de equipamentos, disponíveis à população nos finais de semana.

Movimento de renovação do ensino inspirado, na América, por John Dewey (1859-1952). Os principais nomes da vertente nacional foram Lourenço Filho (1897-1970) e Anísio Teixeira (1900

1971), aluno de Dewey. No Brasil, o movimento ganharia força especialmente após a divulgação do

"Manifesto dos Pioneiros da Educação Nova", de

1932. Inspirado nas ideias de igualdade entre os homens e do direito de todos à educação, movimento acredita num sistema estatal de ensino público, livre e aberto, como único meio efetivo de combate às desigualdades sociais da nação. Para tanto, defendiam a universalização da escola pública, laica e gratuita. A educação deveria tomar como eixo norteador a vida-experiência e a aprendizagem.

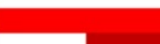

1935

Parques Infantis

Projeto idealizado por Mario de Andrade, que contava comequipamentos simples, compostos basicamente por um pátio coberto e ambientes auxiliares, contudo implantados em amplos terrenos em meio a bairros operários, de modo a preservar extensas áreas livres, pela qual se espalhavam brinquedos e árvores. Visava assim garantir o direito ao espaço público para as classes operárias, numa cidade que se deparava com um processo de urbanização fortemente acentuado.

1989

\section{Praças de Equipamentos Cidade Educadora}

Programa de governo inspirado no conceito de Cidade Educadora, que propunha Conceito muito defendido pelo pedagogo Paulo agregar diversos equipamentos públicos em torno de uma praça, articulando as Freire. Parte da consideração da própria cidade - em atividades e criando uma espécie de centro de bairro, ou seja, um pólo de seu uso e evolução - como principal instrumento de desenvolvimento local, ao qual se articularia toda uma rede urbana e educacional. formação da sociedade, atribuindo ao espaço Cada distrito contaria com uma Praça e cada Subprefeitura constituiria uma rede urbano funções pedagógicas.

urbana autônoma. Um dos distritos constituiria a sede - em geral, cada

subprefeitura agrega 2 a 3 distritos - e os demais abrigariam suas praças de equipamentos, contudo não teriam o subprefeito, mas sim um Conselho Gestor. 
OS MEANDROS DA PRODUÇÃO PÚBLICA NA CONSTRUÇÃO DA PAISAGEM PERIFÉRICA PAULISTANA: 0 CASO DOS EQUIPAMENTOS EDUCACIONAIS 


\section{Desconstruindo as escolas: A PRODUÇ̧̃̃̃ ATUAL DA FDE E OS CEUS}


OS MEANDROS DA PRODUÇÃO PÚBLICA NA CONSTRUÇÃO DA PAISAGEM PERIFÉRICA PAULISTANA: 0 CASO DOS EQUIPAMENTOS EDUCACIONAIS

[80] 


\section{DESCONSTRUINDO AS ESCOLAS}

Diferentes processos têm norteado a produção pública de escolas em São Paulo nos últimos anos. Na esfera estadual, conforme apresentado no capítulo anterior, a Fundação para o Desenvolvimento da Educação - FDE vem acumulando ampla experiência na racionalização dos projetos de arquitetura escolar, tendo consagrado processos produtivos baseados na terceirização e na padronização. No âmbito do Município, a responsabilidade pela construção de equipamentos educacionais vem sendo assumida pelo Departamento de Edificações - EDIF, órgão oriundo do antigo Convênio Escolar, que vem lutando pela preservação do escritório público de projetos.

Entendendo o desenho do edifício escolar como parte integrante de um desenho de cidade, os arquitetos de EDIF seguem concentrando as etapas de desenvolvimento dos projetos dentro da própria equipe, resistindo à tendência natural da administração pública de descentralização e redução dos quadros de funcionários. Além de projetos de escolas, EDIF é responsável pelo projeto das demais redes de edifícios públicos - excluindose apenas os projetos habitacionais -, o que permite que os investimentos sejam pensados de forma mais articulada, ampliando as possibilidades de integração entre as diversas categorias de equipamentos.

Condutas de projeto diferentes têm levado a resultados construídos próprios e cujas inserções no espaço urbano vêm a ocasionar impactos igualmente particulares. Buscando identificar estes contrapontos, foram levantados os principais exemplares da produção pública de edifícios educacionais no município de São Paulo nos últimos dez anos, de modo a produzir um apanhado preciso, que permita estabelecer alguns paralelos entre as diferentes experiências.

Visando garantir maior precisão às informações, o levantamento contou com duas etapas: 1) catalogação dos projetos e 2) estudo de campo.

No primeiro momento, foram mapeadas as principais experiências produzidas no período em análise, compondo, por meio de publicações e dados fornecidos pelos próprios envolvidos, um quadro detalhado dos projetos realizados. Além dos processos de projeto empregados, foram levantadas outras condicionantes consideradas determinantes no desempenho de tais equipamentos, como a origem dos recursos, os custos dos edifícios e o teor da demanda. 
No segundo momento, com o estudo do caso específico, realizou-se uma aproximação dos objetos, possibilitando apontar alguns impactos relativos à implantação dos edifícios, o grau de atendimento às demandas locais, a sustentabilidade das construções enquanto equipamentos públicos e os significados simbólicos dos mesmos na consolidação das paisagens locais.

Construído este quadro de caracterização dos processos, procurar-se-á então, fechando o capítulo, apontar os principais paralelos entre a produção de escolas desempenhada pelo Governo do Estado - FDE e pela Prefeitura Municipal - EDIF, fornecendo embasamento técnico para fundamentar a discussão a ser realizada nos capítulos subsequentes.

\subsection{As ESCOLAS: QUADRO GERAL DA PRODUÇÃO ATUAL.}

A catalogação dos projetos de escolas implantados no município de São Paulo nos últimos dez anos traz um quadro apurado das políticas desempenhadas no período e, sobretudo, da evolução em termos técnicoconstrutivos das propostas para estes equipamentos, destacados pela qualidade, se comparados ao universo da produção pública de edifícios na cidade.

Buscando fazer o mapeamento da produção de edifícios educacionais na cidade, o estudo tomou por objeto toda a produção da FDE no período e, dado o destaque da experiência, o caso específico dos Centros Educacionais Unificados - CEUs, programa prioritário das gestões municipais na última década. Em termos quantitativos, foram avaliadas 27 escolas produzidas pela FDE, os 21 CEUs implantados na primeira etapa do programa (gestão Marta Suplicy), os 24 edifícios construídos na segunda etapa (gestão José Serra/ Gilberto Kassab) e ainda o Centro de Convivência Cultural e Educativo de Heliópolis, por ser encarado como uma extensão do programa dos CEUs. Desta forma, o estudo contemplou 73 experiências de equipamentos educacionais implementadas na capital no período estudado.

A elaboração da ficha padrão procurou incorporar, além dos dados gerais de cada edifício (localização, área construída, data da obra e da construção e custo), informações descritivas do projeto arquitetônico (programa de usos, partido arquitetônico e histórico do projeto) e ainda um arcabouço geral da estrutura produtiva, de modo a apontar os diversos agentes envolvidos no processo de implementação do equipamento (equipes de arquitetura, 


\section{DESCONSTRUINDO AS ESCOLAS}

coordenação dos projetos, construtoras e fiscalização das obras). Foram incorporadas também informações relativas à propriedade da terra e origem dos financiamentos, dados considerados determinantes para a qualidade dos projetos, por implicarem diretamente nas condições dos terrenos disponibilizados e nas possibilidades de direcionamento do recurso.

Elaborada a ficha cadastral do projeto, desenhos técnicos e fotografias foram organizados, de modo a possibilitar a leitura do projeto arquitetônico. Sempre que possível, buscou-se retratar o entorno das edificações, permitindo apreender 0 contexto urbano nos quais os edifícios foram inseridos.

As informações foram obtidas junto aos órgãos gestores, publicações institucionais, periódicos de arquitetura e dados disponibilizados na internet. Embora nem todos os projetos ofereçam a mesma riqueza de dados, acredita-se que o estudo permita estabelecer paralelos concretos entre as diferentes condutas projetuais e apontar os principais ganhos e lacunas de cada processo. No caso dos CEUs, em função do programa contar com um projeto padronizado, alguns campos foram omitidos, dada a repetição das descrições.

A seguir, serão apresentadas as principais verificações oriundas deste levantamento.

\subsubsection{LOCALIZAÇÃo}

A localização dos equipamentos constitui ponto fundamental de uma política educacional. Um dos fatores de maior peso é, sem dúvida, a demanda. Nos casos estudados, a definição da demanda partiu, no entanto, de olhares específicos.

No caso da FDE, a demanda é definida por meio do cruzamento entre dados populacionais e 0 número de vagas oferecidas em cada um dos bairros, procurando sempre priorizar as regiões menos atendidas. Já os CEUs trabalharam com uma meta bastante particular e, por que não, mais ambiciosa: ao enxergar a educação como ferramenta de combate à violência e melhoria das condições sociais, o programa assumiu por demanda as áreas com os maiores índices de segregação urbana e vulnerabilidade social, tomando por base os dados do Mapa da Exclusão Social, de Aldaísa Sposati.

É claro que partindo de ambas as diretrizes, muitos dos resultados tendem a se cruzar. No entanto, alguns deles trazem diferenças, uma vez que 0 
Localização dos CEUs e das escolas da FDE no Município (2000 - 2010). Fonte: Google Earth 2010. Elaboração da autora. planejamento dos CEUs tende a excluir áreas com demanda por vaga mas cujos índices socioeconômicos não sejam tão preocupantes e a FDE, por sua vez, pode vir a desprezar áreas muito pobres cuja densidade populacional não seja tão alta.

A análise dos casos estudados pode ser resumida em duas conclusões: 1) nenhuma das escolas catalogadas encontra-se em bairros centrais da cidade e 2) há uma concentração das escolas catalogadas nas regiões Leste e Sul da cidade. Conforme mapeado abaixo, todas as escolas levantadas estão situadas no anel periférico do município, concentradas, sobretudo, nas regiões Leste e Sul da cidade, áreas com os índices socioeconômicos mais baixos e as taxas de crescimento populacional e expansão urbana mais expressivas da cidade (ver tabela abaixo).

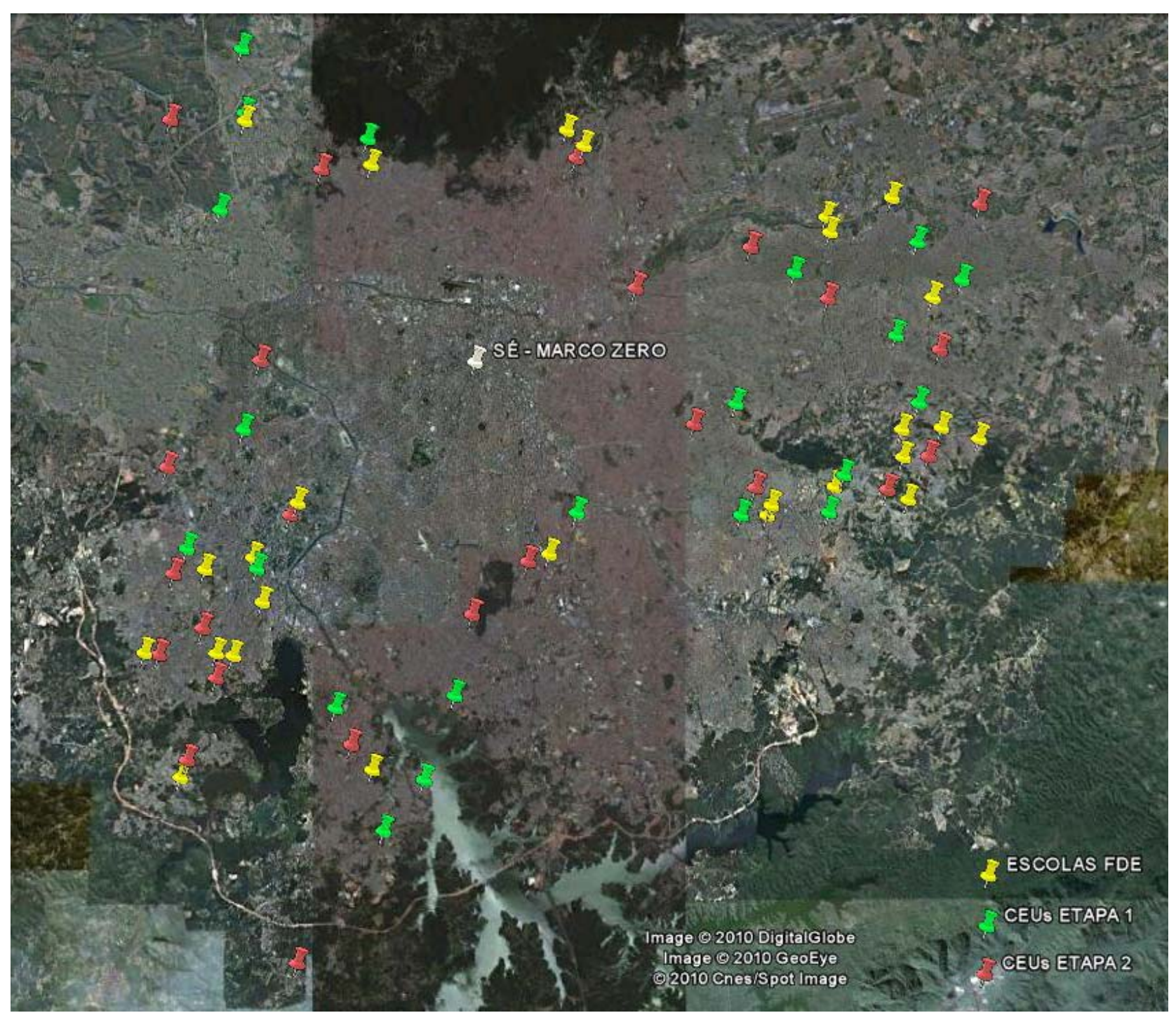




\section{DESCONSTRUINDO AS ESCOLAS}

Caracterização socioeconômica e urbana - Município de São Paulo, Regiões e Subprefeituras (2000, 2010).

\begin{tabular}{|c|c|c|c|c|c|c|c|c|c|c|}
\hline \multirow{2}{*}{$\begin{array}{c}\text { UNIDADES } \\
\text { TERRITORIAIS }\end{array}$} & \multicolumn{3}{|c|}{ OCUPAÇÃO TERRITORIAL (hab; ha) } & \multicolumn{5}{|c|}{ RENDA DOMICILIAR (dom.) } & \multicolumn{2}{|c|}{ EQUIPAMENTOS (un.) } \\
\hline & Área & $\begin{array}{l}\text { População } \\
2010\end{array}$ & $\begin{array}{l}\text { Crescimento } \\
2000 / 2010\end{array}$ & $\begin{array}{l}\text { até } \\
3 \text { S.M. }\end{array}$ & $\begin{array}{l}3 \text { a } 5 \\
\text { S.M. }\end{array}$ & $\begin{array}{l}5 \text { a } 10 \\
\text { S.M. }\end{array}$ & $\begin{array}{l}10 \text { a } 20 \\
\text { S.M. }\end{array}$ & $\begin{array}{l}>20 \\
\text { S.M. }\end{array}$ & $\begin{array}{l}\text { escolas } \\
\text { FDE }\end{array}$ & CEUs \\
\hline MSP & 150.900 & 11.057.629 & 0,58 & 656.517 & 472.989 & 778.395 & 555.038 & 532.319 & 27 & 46 \\
\hline REGIÃO NOROESTE & 14.340 & 1.006 .735 & 1,49 & 61.882 & 46.071 & 70.700 & 44.308 & 22.780 & 3 & 6 \\
\hline Freguesia/ Brasilândia & 3.150 & 418.170 & 0,64 & 28.954 & 20.499 & 30.402 & 18.458 & 9.270 & 2 & 2 \\
\hline Perus & 5.720 & 138.268 & 2,40 & 8.802 & 6.703 & 8.735 & 3.673 & 999 & & 2 \\
\hline Pirituba & 5.470 & 450.297 & 1,43 & 24.125 & 18.870 & 31.564 & 22.177 & 12.511 & 1 & 2 \\
\hline REGIÃO NORDESTE & 15.190 & 1.179 .900 & $-0,14$ & 61.602 & 50.012 & 92.326 & 75.359 & 61.642 & 3 & 1 \\
\hline C. Verde/ Cachoeirinha & 2.670 & 313.666 & 0,01 & 18.901 & 14.415 & 24.278 & 17.885 & 12.329 & & \\
\hline Santana/ Tucuruvi & 3.470 & 303.173 & $-0,76$ & 9.995 & 9.037 & 22.065 & 25.079 & 29.926 & 1 & \\
\hline Jaçanã/ Tremembé & 6.410 & 278.567 & 0,86 & 14.993 & 12.522 & 19.586 & 13.454 & 8.348 & 2 & 1 \\
\hline V. Maria/ V. Guilherme & 2.640 & 284.494 & $-0,67$ & 17.713 & 14.038 & 26.396 & 18.942 & 11.040 & & \\
\hline REGIÃO LESTE 1 & 15.800 & 1.647 .267 & 0,57 & 105.086 & 76.217 & 125.953 & 82.219 & 36.492 & 2 & 7 \\
\hline Ermelino Matarazzo & 1.510 & 210.263 & 0,26 & 13.738 & 9.902 & 16.961 & 11.014 & 5.305 & & \\
\hline Penha & 4.280 & 472.266 & $-0,08$ & 26.776 & 21.309 & 40.058 & 31.722 & 17.639 & & 2 \\
\hline Itaquera & 5.430 & 528.543 & 0,77 & 33.172 & 23.518 & 39.695 & 24.810 & 9.229 & 1 & 2 \\
\hline São Mateus & 4.580 & 436.195 & 1,34 & 31.401 & 21.488 & 29.239 & 14.673 & 4.319 & 1 & 3 \\
\hline REGIÃO LESTE 2 & 7.880 & 1.334 .675 & 1,25 & 109.951 & 69.417 & 86.360 & 35.235 & 9.852 & 9 & 8 \\
\hline Cidade Tiradentes & 1.500 & 219.868 & 1,44 & 16.954 & 11.642 & 15.573 & 4.891 & 773 & 2 & 2 \\
\hline Guaianases & 1.780 & 296.509 & 1,47 & 24.765 & 15.224 & 17.929 & 6.776 & 1.572 & 3 & 3 \\
\hline Itaim Paulista & 2.170 & 403.512 & 1,17 & 33.936 & 21.362 & 25.381 & 10.191 & 2.966 & 1 & 1 \\
\hline São Miguel & 2.430 & 414.786 & 0,92 & 34.296 & 21.188 & 27.476 & 13.377 & 4.541 & 3 & 2 \\
\hline REGIÃO SUDESTE & 12.750 & 1.504 .148 & $-0,22$ & 83.765 & 63.815 & 120.712 & 98.092 & 84.092 & 1 & 6 \\
\hline Aricand./Formosa/Carrão & 2.150 & 253.855 & $-0,50$ & 13.304 & 10.430 & 21.428 & 18.155 & 13.783 & & 1 \\
\hline Ipiranga & 3.750 & 425.451 & $-0,09$ & 22.446 & 17.766 & 33.399 & 28.412 & 25.312 & 1 & 3 \\
\hline Mooca & 3.520 & 296.184 & $-0,40$ & 12.502 & 9.777 & 22.707 & 23.231 & 29.413 & & \\
\hline V. Prudente/Sapopemba & 3.330 & 528.658 & 0,09 & 35.513 & 25.842 & 43.177 & 28.294 & 15.585 & & 2 \\
\hline REGIÃO OESTE & 12.790 & 906.320 & $-0,20$ & 30.495 & 24.032 & 51.981 & 59.083 & 127.347 & 0 & 3 \\
\hline Butantã & 5.610 & 383.061 & 0,14 & 17.341 & 13.466 & 22.992 & 21.126 & 31.874 & & 2 \\
\hline Lapa & 4.010 & 265.537 & $-0,19$ & 8.491 & 6.505 & 16.164 & 18.697 & 36.848 & & 1 \\
\hline Pinheiros & 3.170 & 257.722 & $-0,56$ & 4.663 & 4.061 & 12.825 & 19.261 & 58.624 & & \\
\hline REGIÃO SUL & 61.720 & 2.404 .190 & 1,89 & 166.272 & 111.336 & 154.315 & 75.949 & 39.655 & 9 & 14 \\
\hline Campo Limpo & 3.670 & 590.602 & 1,56 & 38.390 & 26.248 & 38.068 & 20.354 & 15.158 & 4 & 5 \\
\hline Capela do Socorro & 13.420 & 696.941 & 2,14 & 45.746 & 29.708 & 42.332 & 21.422 & 10.590 & 2 & 4 \\
\hline Cidade Ademar & 3.070 & 406.871 & 0,93 & 28.232 & 19.814 & 28.688 & 15.357 & 7.656 & & 1 \\
\hline M'Boi Mirim & 6.210 & 553.384 & 1,33 & 42.070 & 29.003 & 38.067 & 16.549 & 5.804 & 3 & 3 \\
\hline Parelheiros & 35.350 & 156.392 & 3,47 & 11.834 & 6.563 & 7.160 & 2.267 & 446 & & 1 \\
\hline REGIÃO CENTRO-SUL & 7.810 & 727.882 & $-0,20$ & 22.621 & 18.422 & 42.507 & 50.094 & 106.538 & 0 & 1 \\
\hline Jabaquara & 1.410 & 212.504 & $-0,07$ & 10.994 & 8.221 & 15.376 & 13.854 & 14.413 & & 1 \\
\hline Santo Amaro & 3.750 & 219.659 & 0,05 & 5.858 & 4.770 & 11.695 & 14.443 & 30.914 & & \\
\hline Vila Mariana & 2.650 & 295.719 & $-0,57$ & 5.769 & 5.432 & 15.436 & 21.798 & 61.211 & & \\
\hline REGIÃO CENTRO & 2.620 & 346.512 & $-0,76$ & 14.844 & 13.665 & 33.542 & 34.699 & 43.921 & 0 & 0 \\
\hline Sé & 2.620 & 346.512 & $-0,76$ & 14.844 & 13.665 & 33.542 & 34.699 & 43.921 & & \\
\hline
\end{tabular}

Fonte: IBGE - Censo 2000/ Sempla Dipro In: http://infocidade.prefeitura.sp.gov.br. Elaboração da autora.

$\left.{ }^{*}\right)$ Total de domicílios MSP: Base Amostra do Censo 2000, excluídos 41.422 domicilios sem resposta para este dado. 
A concentração dos novos equipamentos nas regiões Leste e Sul deve-se a uma conjuntura urbana que vai além da forte demanda populacional. Embora 0 crescimento destas áreas seja intenso e a necessidade de implantação de equipamentos constitua um fato evidente, é imprescindível apontar a questão da oferta de terrenos. Enquanto nas áreas centrais os terrenos são extremamente escassos e caros, nestas periferias ainda é possível encontrar grandes glebas desocupadas, capazes de hospedar edifícios novos, de dimensões apropriadas e programas de usos extensos. Os CEUs, em especial, dificilmente poderiam acontecer nas áreas centrais, dadas as dimensões do equipamento. Nas periferias, ao contrário, a implantação desses edifícios acaba funcionando como um elemento de estruturação urbana, que passa a se configurar com um marco simbólico, levando inclusive à valorização de seus entornos. Eis uma grande diferença entre ocupar uma área consolidada e consolidar uma área ocupada.

\subsection{2. Área Construída}

Por contar com um programa bastante extenso, que vai muito além do equipamento educacional tradicional, incorporando usos culturais e esportivos, os edifícios dos CEUs apresentam extensa área construída e demandam amplos terrenos para serem implantados. As escolas da FDE levantadas contam com área construída predominantemente em torno de 1.500 a $4.000 \mathrm{~m}^{2}$. Já os CEUs construídos na primeira gestão avançam para a faixa dos 12.000 a $14.000 \mathrm{~m}^{2}$. Os CEUs da segunda gestão são sensivelmente mais compactos, contudo mesmo o menor deles, 0 CEU Jardim Paulistano, conta com 9.301,45m², o que ainda representa uma área mais do que duas vezes superior ao maior edifício da FDE, a E.E. Prof. Paulo Kobayashi (União Vila Nova IV), que tem $4.359 \mathrm{~m}^{2}$.

A construção de equipamentos que demandem áreas extensas como as dos CEUs vem a interferir nos procedimentos para seleção dos terrenos: enquanto no caso da FDE os projetos foram elaborados a partir dos terrenos selecionados, no caso dos CEUs os terrenos tiveram que ser selecionados a partir dos projetos. De certa forma, o programa extenso e o desenho padronizado dos CEUs acabaram por determinar a localização dos equipamentos, sendo esta a do terreno com dimensões compatíveis e não necessariamente a daquele situado na área de maior demanda e mais fácil acesso. 


\section{DESCONSTRUINDO AS ESCOLAS}

0 porte imponente dos CEUs e 0 fato de congregarem usos diversos, algumas vezes abertos ao público, fazem com que extrapolem a dimensão simbólica do edifício educacional e passem a constituir uma importante referência urbana nos bairros onde se inserem. Construídos prioritariamente em bairros pobres e carentes de equipamentos públicos, os CEUs passam a suprir parte da demanda por serviços e a representar a presença do Poder Público nesses bairros, comumente marcados por grande informalidade na ocupação.

\subsubsection{Data do Projeto/ Data da Obra}

Nas escolas construídas pela FDE verificou-se, em geral, um prazo de dois a três anos entre projeto e finalização da obra, havendo poucas experiências que encurtaram esse processo e sendo elas, geralmente, obras de reforma de edifícios já existentes. No caso dos CEUs, este período reduziu-se a meses. Embora o desenho seja padrão, projetos específicos tiveram que ser elaborados a partir da seleção dos terrenos. Os prazos tanto para elaboração desses projetos, quanto para realização das contratações e execução das obras, foram impressionantemente reduzidos, algo raro e difícil de se alcançar em administrações públicas.

Além da chamada "vontade política", algumas estratégias permitiram acelerar os processos de projeto e obra dos CEUs. A centralização dos projetos e a padronização dos desenhos tornaram 0 processo de desenvolvimento das propostas mais ágil, cabendo aos contratados apenas a adequação do edifício ao terreno e a elaboração dos executivos. A contratação de construtoras grandes, com capacidade de disponibilizar diversas frentes de trabalho simultâneas, permitiu que as obras acontecessem de forma mais dinâmica. A incorporação de mão de obra local e até mesmo voluntária, garantiu as inaugurações dentro dos prazos.

Sendo assim, percebe-se que a experiência dos CEUs, embora tenha alcançado prazos ideais, constituiu procedimento de caráter excepcional, sendo pouco provável que a produção pública consiga garantir tal agilidade em programas de longo prazo. 


\subsubsection{TIPO DE OBRA}

Dada a dificuldade na aquisição de terrenos, a FDE vem trabalhando, nos casos mais complicados, com a adequação de edifícios existentes e até mesmo com a substituição dos mesmos por construções novas. Nos casos estudados, verificou-se que 5 das 27 escolas são frutos de reformas de equipamentos antigos. 0 procedimento está longe de se constituir em prática ideal, contudo parece ser a única possível. Parte dessa dificuldade está relacionada ao fato da FDE não realizar compra de terrenos, trabalhando exclusivamente com áreas de propriedade pública (ver item 3.1.14).

No caso dos CEUs, foram adotados sempre edifícios novos, podendo se relacionar com outros equipamentos já existentes. De qualquer forma, estes edifícios são sempre padronizados e contaram com terrenos limpos e que não demandaram grandes intervenções.

\subsubsection{Custo}

Apesar da diversidade dos projetos e técnicas empregadas, as escolas construídas pela FDE e os CEUs implantados na primeira etapa apresentam proporcionalmente custos bastante similares: enquanto o custo médio do $\mathrm{m}^{2}$ das escolas da FDE foi calculado em $\mathrm{R} \$ 1.223,11$, no caso dos CEUs foi de $\mathrm{R} \$ 1.295,37$, valor este alinhado com a média de mercado para construções do gênero. Considerando-se que alguns dos CEUs incorporaram custos de aquisição dos terrenos, 0 valor alcançado parece razoável, atestando a viabilidade da estratégia. A padronização dos projetos pode ocasionado 0 barateamento da obra, compensando gastos iniciais com a compra da terra.

No entanto, ao analisar os CEUs implementados na segunda etapa do programa, constata-se uma significativa discrepância. 0 custo médio do metro quadrado para estes casos foi calculado em $\mathrm{R} \$ 2.400,94$. A justificativa da atual gestão para valores tão elevados é a necessidade de aquisição de terrenos caros. De fato, na segunda etapa do programa um número maior de terrenos particulares precisou ser adquirido, conforme será apresentado no item 3.1.14. Por outro lado, se analisadas as fichas dos projetos, perceber-se-á que o valor dos edifícios construídos em terrenos públicos já é significativamente superior aos equipamentos construídos na primeira etapa: enquanto o valor médio dos CEUs da primeira etapa é de $\mathrm{R} \$ 17$ milhões, o edifício mais barato implantado pela segunda gestão ficou em $\mathrm{R} \$ 22,6$ milhões. 0 CEU Feitiço da Vila, o edifício mais caro do programa, 


\section{DESCONSTRUINDO AS ESCOLAS}

atingiu os $R \$ 36,9$ milhões, embora tenha capacidade para apenas 2.100 alunos, enquanto outros CEUs chegam a atender 2.800 estudantes.

\section{Custos dos CEUs implantados $-1^{\mathrm{a}}$ e $2^{\mathrm{a}}$ etapas do Programa.}

\begin{tabular}{|c|c|c|c|c|}
\hline ESCOLA & custo da obra* $(\mathrm{R} \$)$ & área construída $\left(\mathrm{m}^{2}\right)$ & custo do $\mathrm{m}^{2}\left(\mathrm{R} \$ / \mathrm{m}^{2}\right)$ & \\
\hline CEU Alvarenga & $17.000 .000,00$ & 14.077 & $1.207,64$ & \multirow{22}{*}{ 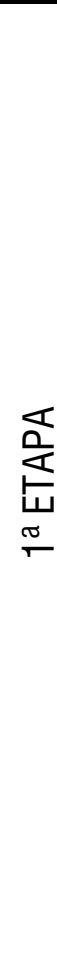 } \\
\hline CEU Aricanduva & $17.000 .000,00$ & 12.991 & $1.308,60$ & \\
\hline CEU Vila Atlântica & $17.000 .000,00$ & 12.548 & $1.354,80$ & \\
\hline CEU Butantã & $17.000 .000,00$ & 13.310 & $1.277,24$ & \\
\hline CEU Campo Limpo & $17.000 .000,00$ & 12.991 & $1.308,60$ & \\
\hline CEU Casa Blanca & $17.000 .000,00$ & 13.798 & $1.232,06$ & \\
\hline CEU Cidade Dutra & $17.000 .000,00$ & 13.121 & $1.295,63$ & \\
\hline CEU Inácio Monteiro & $17.000 .000,00$ & 13.121 & $1.295,63$ & \\
\hline CEU Jambeiro & $17.000 .000,00$ & 12.991 & $1.308,60$ & \\
\hline CEU Meninos & $17.000 .000,00$ & 12.991 & $1.308,60$ & \\
\hline CEU Navegantes & $17.000 .000,00$ & 12.981 & $1.309,61$ & \\
\hline CEU Parque São Carlos & $17.000 .000,00$ & 12.991 & $1.308,60$ & \\
\hline CEU Parque Veredas & $17.000 .000,00$ & 14.177 & $1.199,13$ & \\
\hline CEU da Paz & $17.000 .000,00$ & 12.992 & $1.308,50$ & \\
\hline CEU Pera MarMello & $17.000 .000,00$ & 13.783 & $1.233,40$ & \\
\hline CEU Perus & $17.000 .000,00$ & 13.091 & $1.298,60$ & \\
\hline CEU Rosa da China & $17.000 .000,00$ & 13.121 & $1.295,63$ & \\
\hline CEU São Mateus & $17.000 .000,00$ & 12.196 & $1.393,90$ & \\
\hline CEU São Rafael & $17.000 .000,00$ & 12.196 & $1.393,90$ & \\
\hline CEU Três Lagos & $17.000 .000,00$ & 13.401 & $1.268,56$ & \\
\hline CEU Vila Curuçá & $17.000 .000,00$ & 13.121 & $1.295,63$ & \\
\hline VALORES MÉDIOS & $17.000 .000,00$ & $13.142,33$ & $1.295,37$ & \\
\hline CEU Água Azul & $27.300 .000,00$ & 12.000 & $2.275,00$ & \multirow{25}{*}{ 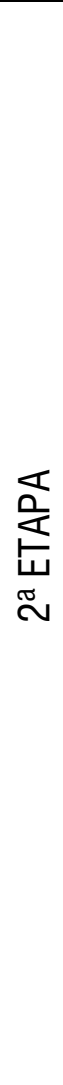 } \\
\hline CEU Alto Alegre & $25.500 .000,00$ & sem informação & & \\
\hline CEU Azul da Cor do Mar & $26.400 .000,00$ & 12.548 & $2.103,92$ & \\
\hline CEU Caminho do Mar & $26.700 .000,00$ & 10.957 & $2.436,80$ & \\
\hline CEU Cantos do Amanhecer & $28.800 .000,00$ & 11.205 & $2.570,28$ & \\
\hline CEU Capão Redondo & $24.100 .000,00$ & 10.716 & $2.248,97$ & \\
\hline CEU Feitiço da Vila & $36.900 .000,00$ & 10.878 & $3.392,17$ & \\
\hline CEU Formosa & $22.600 .000,00$ & 10.957 & $2.062,61$ & \\
\hline CEU Guarapiranga & $24.700 .000,00$ & 10.716 & $2.304,96$ & \\
\hline CEU Jaçanã & $28.300 .000,00$ & 14.517 & $1.949,44$ & \\
\hline CEU Jaguaré & $28.900 .000,00$ & 13.000 & $2.223,08$ & \\
\hline CEU Jardim Paulistano & $28.400 .000,00$ & 9.301 & $3.053,44$ & \\
\hline CEU Lajeado & $25.400 .000,00$ & 11.205 & $2.266,85$ & \\
\hline CEU Paraisópolis & $27.000 .000,00$ & 10.154 & $2.659,05$ & \\
\hline CEU Parelheiros & $27.500 .000,00$ & sem informação & & \\
\hline CEU Parque Anhanguera & $27.200 .000,00$ & 10.145 & $2.681,12$ & \\
\hline CEU Parque Bristol & $26.000 .000,00$ & 10.957 & $2.372,91$ & \\
\hline CEU Quinta do Sol & $25.200 .000,00$ & 11.205 & $2.249,00$ & \\
\hline CEU Sapopemba & $25.200 .000,00$ & 10.076 & $2.500,99$ & \\
\hline CEU Tiquatira & $26.900 .000,00$ & sem informação & & \\
\hline CEU Três Pontes & $28.400 .000,00$ & 11.205 & $2.534,58$ & \\
\hline CEU Uirapuru & $22.500 .000,00$ & 12.000 & $1.875,00$ & \\
\hline CEU Vila Rubi & $25.500 .000,00$ & 12.000 & $2.125,00$ & \\
\hline CEU Vila do Sol & $28.400 .000,00$ & 11.205 & $2.534,58$ & \\
\hline VALORES MÉDIOS & $26.825 .000,00$ & 11.283 & $2.400,94$ & \\
\hline
\end{tabular}

Fonte: MASCARENHAS, 2006/ DÓRIA; PEREZ, 2007. Elaboração da autora.

${ }^{*}$ ( ) dada a ausência de dados, utilizou-se o custo médio dos edifícios da primeira fase de implantação do programa 
Custos das escolas da FDE analisadas (2000 - 2010).

\begin{tabular}{|c|c|c|c|}
\hline ESCOLA & custo da obra $(\mathrm{R} \$)$ & área construída $\left(\mathrm{m}^{2}\right)$ & custo do $\mathrm{m}^{2}\left(\mathrm{R} \$ / \mathrm{m}^{2}\right)$ \\
\hline E.E. Prof. Marilza G. Francisco & $2.757 .482,32$ & 2.351 & $1.172,90$ \\
\hline E.E. Fernando Gasparian & $3.607 .284,63$ & 2.054 & $1.756,22$ \\
\hline E.E. Eudoro Villela & $3.205 .877,76$ & 3.091 & $1.037,17$ \\
\hline E.E. Jd. Dom Angélico II & $1.894 .775,60$ & 1.616 & $1.172,51$ \\
\hline E.E. Desemb. Luis Ambra & $3.438 .244,37$ & 3.399 & $1.011,55$ \\
\hline E.E. Belize & $2.971 .464,53$ & 3.549 & 837,27 \\
\hline E.E. Recanto Verde Sol & sem informação & 2.730 & \\
\hline E.E. Ministro Oscar Dias Correia & $3.589 .903,99$ & 3.953 & 908,15 \\
\hline E.E. H. Helene/ Prof. P.Kobayashi & $6.640 .259,35$ & 6.841 & 970,66 \\
\hline E.E. Fazenda da Juta IV & $2.313 .116,92$ & 1.926 & $1.201,00$ \\
\hline E.E. Dr. Pedro de Moraes Victor & $4.019 .427,09$ & 4.210 & 954,73 \\
\hline E.E. Prof. Maria Jannuzzi Mascari & $3.312 .689,17$ & 804 & $4.120,26$ \\
\hline E.E. República do Panamá & $3.151 .043,79$ & 2.285 & $1.379,01$ \\
\hline E.E. Jd. Capela IV & $1.123 .055,36$ & 1.701 & 660,23 \\
\hline E.E. José de San Martin & $2.950 .391,68$ & 2.817 & $1.047,35$ \\
\hline E.E. Roque Theophilo & $1.658 .303,82$ & 2.114 & 784,44 \\
\hline E.E. Prof. Maria H. G. de Arruda & $1.889 .601,86$ & 1.989 & 950,03 \\
\hline E.E. Prof. Nelson Gomes Caetano & $2.301 .036,87$ & 2.087 & $1.102,56$ \\
\hline E.E. Dom Agnelo Cardeal Rossi & $1.894 .380,00$ & 2.701 & 701,36 \\
\hline E.E. Governador Miguel Arraes & $3.424 .660,76$ & 2.825 & $1.212,27$ \\
\hline E.E. COHAB Carrãozinho III & $2.076 .902,23$ & sem informação & \\
\hline E.E. Parque Grajaú & $3.670 .598,30$ & sem informação & \\
\hline E.E. Fazenda Carmo IV & $4.620 .817,16$ & 3.819 & $1.209,95$ \\
\hline E.E. Jd. Santa Cruz & $5.377 .012,35$ & 3.735 & $1.439,63$ \\
\hline E.E. Jardim Pedra Branca & $5.290 .271,46$ & 4.136 & $1.279,08$ \\
\hline E.E. Vila Guarani & $4.703 .378,92$ & sem informação & \\
\hline E.E. Chácara Três Meninas II & $2.362 .197,55$ & sem informação & \\
\hline VALORES MÉDIOS & $3.240 .160,69$ & $2.782,74$ & $1.223,11$ \\
\hline
\end{tabular}

Fonte: Informações fornecidas pela FDE/ FERREIRA; MELLO, 2006b. Elaboração da autora.

Vale mencionar ainda que o projeto dos CEUs foi inteiramente reformulado para a segunda etapa de implementação, gerando novas contratações para 0 desenvolvimento dos anteprojetos e executivos das novas propostas, sob a alegação da otimização da construção e do barateamento da obra. A meta parece não ter sido atingida.

\subsubsection{Projeto (Programa de Usos)}

A FDE vem consolidando ao longo das décadas diversos catálogos de projeto, que vão do programa de usos e seus dimensionamentos ao desenho dos componentes construtivos e mobiliário. Essa foi a estratégia para garantir a qualidade dos projetos terceirizados e certa homogeneidade à rede. Dessa forma, quando um escritório se candidata a desenvolver um projeto para a FDE, ele recebe o programa de usos detalhado, indicando não apenas ambientes e dimensões, como também sugestões de modulação e 


\section{DESCONSTRUINDO AS ESCOLAS}

orientações básicas de projeto. Este programa é dimensionado de acordo com a demanda recebida da Secretaria de Estado de Educação, que determina 0 número de salas necessárias para cada locação. A partir daí, a FDE trabalha com jogos programáticos padronizados, que incluem a gama mínima de ambientes auxiliares, de acordo com as normas legais do setor.

Desse modo, o programa de usos das escolas construídas pela FDE é geralmente similar, variando sensivelmente de acordo com 0 porte do equipamento. Como os terrenos são cada vez mais reduzidos, e os recursos também, ambientes complementares são cada vez mais raros. Dada a extrema padronização, o desafio dos arquitetos contratados está em sugerir soluções que atendam às diversas exigências de forma mais econômica $e$ eficiente. Embora se possa pensar que os direcionamentos impostos pelo programa tendam a empobrecer os projetos, o que se tem percebido é uma riqueza significativa de soluções, com reduzida incidência de erros de projeto e grande eficiência no funcionamento.

Nos CEUs, não só o programa de usos é padronizado, como também os projetos trabalham com tipologias fixas. Os edifícios implementados na primeira etapa são praticamente idênticos, havendo pequenas variações nos casos em que os terrenos não permitiam a implantação integral do projeto original. Alguns edifícios demandaram uma maior verticalização ou a supressão de algum pavimento. 0 porte e a disposição do programa em três blocos foram, entretanto, mantidos.

A segunda etapa de implementação dos CEUs trouxe uma pequena reformulação dos programas de uso, que deixaram de ser idênticos e passaram a se adequar às demandas específicas de cada região. 0 porte dos equipamentos sofreu alterações e os CEUs construídos neste momento passaram a apresentar capacidades variáveis, indo de 1.600 a 2.800 alunos.

\subsubsection{Partido arquitetônico}

Por partirem de projetos específicos, cada escola da FDE lida com um partido arquitetônico próprio. Embora o programa seja padronizado, assim como a estrutura, os componentes e o mobiliário, cada experiência apresenta soluções particulares, de acordo com a locação e as condicionantes do projeto. Com a contratação de escritórios de arquitetura de primeira linha, minuciosamente selecionados sobretudo pela técnica, os resultados têm 
apresentado alta qualidade, prezando, sobretudo, a relação com os entornos e a humanização dos ambientes ${ }^{39}$.

No caso dos CEUs, a padronização, levada a seu ponto máximo, parece ter gerado dificuldades na implantação dos edifícios, implicando em resultados nem sempre satisfatórios. Com programas de usos padronizados e volumetrias previamente definidas, o projeto dos CEUs precisou ser moldado aos terrenos selecionados, sem respeitar as especificidades de suas configurações e as relações com seus limites. Independente das condições do lugar, todos os terrenos precisavam comportar o programa de usos em sua integralidade e disposto igualmente nas tipologias propostas.

Tamanha padronização pode ter trazido ganhos importantes, como a redução dos custos de construção, dada a repetição dos componentes, e, sobretudo, a consolidação de um marco simbólico, uma vez que a volumetria do CEU é facilmente reconhecida na paisagem. Perdas entretanto podem ser claramente identificadas, uma vez que os terrenos, na maioria das vezes, poderiam ser melhor aproveitados, com implantações que valorizassem as especificidades de relevo e a relação com 0 entorno. 0 projeto dos CEUs como foi implementado parece ter despido o edifício de sua "aura" ${ }^{40}$. A replicação volumétrica dos CEUs descartou, sem dúvida, a possibilidade dos edifícios nascerem de um contexto.

A padronização de equipamentos construtivos pode representar importante instrumento de garantia de qualidade da obra, contudo, quando a solução não é bem estudada, pode representar a instalação em larga escala de alternativas desastrosas. Segundo os técnicos envolvidos na segunda gestão de implantação dos CEUs, a reformulação dos projetos arquitetônicos teria se devido a problemas graves nos desenhos dos edifícios da primeira gestão. Segundo João Canteiro ${ }^{41}$, caixilhos mal especificados, disposição das salas de aula equivocada e revestimentos não adequados teriam levado a demandas enormes por manutenção nos primeiros edifícios. Em função destas constatações, o projeto teria sido reformulado, permitindo a ventilação cruzada das salas de aula, criando beirais para os caixilhos e substituindo alguns acabamentos. É claro que a própria volumetria tomou forma própria, explicitando a autoria das obras por uma gestão diferente daquela responsável pela primeira etapa do programa. 


\section{DESCONSTRUINDO AS ESCOLAS}

\subsubsection{HISTÓRICO}

Os contextos em que são implantados os edifícios são diversos. Muitas vezes, a demanda pelo equipamento é antiga, havendo grande expectativa da população. Fato recorrente é também a construção de escolas "de escape", ou seja, edifícios novos para distribuir a demanda intensa dos equipamentos já existentes.

Quanto aos terrenos utilizados, dada a dificuldade em encontrar terras vagas, muitas vezes a única solução são os campos de futebol de várzea, opção complicada, uma vez que os mesmos representam, em geral, as únicas opções de lazer das comunidades locais. Tais situações acabam por gerar novas demandas programáticas, na busca de garantir à população a manutenção das oportunidades já alcançadas e a disponibilização do novo equipamento.

\subsubsection{ProveniÊnCIA da demanda}

A demanda a ser trabalhada pela FDE é definida pela Secretaria de Estado de Educação, a partir de levantamentos constantes e das solicitações provenientes da população e de outros setores da administração pública. 0 primeiro fator na constituição da demanda é 0 crescimento natural do município. Não à toa, a maior parte da produção recente está concentrada nos bairros com as maiores taxas de crescimento populacional da cidade (ver item 3.1.1).

A própria política pública consiste num indutor de demanda: a construção de conjuntos habitacionais constitui atualmente uma das principais demandas por construção de escolas. Embora o projeto do conjunto habitacional já estime a população a ser atendida e inclusive reserve parte da gleba para a construção dos equipamentos públicos, não há integração entre as áreas de habitação e educação durante a elaboração da proposta. Em geral, a demanda chega à FDE quando o conjunto já está construído e ocupado. A área destinada aos equipamentos é, em geral, a sobra da gleba que não pode ser ocupada pelas unidades habitacionais.

No caso dos CEUs, como a diretriz principal foi atender os bairros indicados como os mais excluídos da cidade, não se trabalhou com uma demanda direta por vagas, mas sim com a demanda por serviços públicos, uma vez que 0 objetivo maior era a inclusão sócio-espacial dessas áreas. Sendo 
assim, os CEUs acabaram ocupando invariavelmente áreas com fortes demandas por vagas, sobretudo provenientes de ocupações irregulares e favelas.

\subsubsection{EQUIPE DE PROJETO}

Atualmente a FDE só trabalha com projetos terceirizados. Para garantir a contratação de escritórios de ponta, a instituição, atrelada à Lei 8.666/ 93 (Lei das Licitações), precisou encontrar um modelo de edital de seleção que fugisse da simples - e perigosa - tomada de preços. A solução foi a realização de concursos públicos, cuja premiação avalia a relação técnica e preço, com os respectivos pesos de 7,0 e 3,0. Com isso, invariavelmente 0 projeto selecionado é o que apresenta a melhor técnica, bastando que 0 orçamento demonstre a viabilidade financeira da solução proposta.

Desse modo, a FDE vem trabalhando nas últimas décadas com jovens arquitetos de vanguarda, preservando uma política implantada nos anos 60 pelo FECE, quando, para vencer a forte demanda por salas de aula, a instituição optou por firmar uma parceria com o IAB, dando início às diversas gerações de bons projetos arquitetônicos para as escolas do Estado de São Paulo.

Já o projeto dos CEUs foi todo concebido dentro do escritório de projetos de EDIF, coordenado pelos arquitetos Alexandre Delijaicov, André Takiya e Wanderley Ariza, terceirizando-se apenas os projetos básicos e executivos. A elaboração do anteprojeto pelos arquitetos da Prefeitura garantiu que a proposta arquitetônica estivesse casada com 0 projeto político-pedagógico da Secretaria Municipal de Educação, numa parceria interdisciplinar que trouxe muitos ganhos.

No entanto, apesar do diálogo constante e da interatividade entre as equipes, a solução arquitetônica sugerida peca em não transmitir 0 discurso modernizante e inovador sugerido pela proposta pedagógica. A estrutura cartesiana em concreto aparente, as plantas livres compartimentadas em salas de painéis leves, o térreo com pilotis e os grandes caixilhos na fachada imprimem um traçado essencialmente modernista aos edifícios, replicando a arquitetura dos anos 50 e não trazendo grandes surpresas do ponto de vista espacial, e sequer estético. Tampouco foram observadas inovações tecnológicas ou mesmo as tão corriqueiras soluções ecológicas, que poderiam, neste caso, assumir ainda um caráter pedagógico. 


\section{DESCONSTRUINDO AS ESCOLAS}

\subsubsection{Coordenação do Projeto}

Em ambas as experiências, a coordenação dos projetos foi realizada pelas equipes internas de cada instituição. Nos projetos da FDE, como o projeto é concebido pelo contratado, o acompanhamento pelos coordenadores é próximo e constante. Cabe à equipe de coordenação avaliar as propostas e aprovar cada solução, as quais precisam atender a uma série de quesitos, que vão de aspectos funcionais a questões financeiras. A experiência da equipe gestora da FDE evita que soluções frágeis sejam implementadas, exigindo que alternativas muito inovadoras sejam anteriormente testadas. Da mesma forma, auxiliam ainda na busca de soluções nas situações mais complicadas, dado 0 amplo repertório de experiências que a instituição tem acumulado ao longo dos anos.

Nos projetos dos CEUs, como a tipologia é dada, cabendo ao contratado apenas sua implantação e detalhamento, a necessidade de controle se reduz. De qualquer forma, os projetos foram todos gerenciados pela equipe de EDIF, buscando-se garantir 0 atendimento aos padrões exigidos. Na segunda etapa do programa, os executivos foram todos desenvolvidos por um mesmo escritório, garantindo a homogeneidade dos desenhos.

\subsubsection{FISCALIZAÇÃO DA OBRA}

A fiscalização é sempre realizada por funcionários das instituições gestoras dos programas, não havendo grandes peculiaridades neste processo.

\subsubsection{CONSTRUTORA}

A contratação das construtoras é sempre objeto de licitação específica. A grande dificuldade encontrada pelas instituições é como garantir a seleção de boas empresas e não das que oferecem apenas o menor preço. Buscando driblar o problema, duas interessantes alternativas foram encontradas pelos casos levantados.

Ao incorporar sistemas construtivos pré-fabricados, a FDE encontrou uma forma de selecionar as empresas construtoras pela técnica. Em geral, construtoras menos estruturadas não executam obras pré-fabricadas. Com isso, a instituição passou a garantir a contratação de empresas mais 
especializadas. Além de experiência comprovada no emprego da técnica, a FDE exige que o candidato exiba experiência na construção específica de edifícios educacionais, evitando a ocorrência de problemas recorrentes.

Já o processo de construção dos CEUs, contou com uma licitação por pacotes de projetos, conforme descrito no item 2.9. Para se candidatar, 0 edital exigia que a construtora comprovasse capacidade de executar três ou quatro edifícios simultaneamente, opção adotada dada a urgência dos prazos e 0 porte dos equipamentos. Desse modo, apenas as maiores empresas do ramo puderam se inscrever. É claro que, com isso, garantiu-se eficiência às obras, contudo fortaleceu-se a hegemonia das grandes construtoras do mercado.

\subsubsection{Propriedade da terra}

Ao contrário da Prefeitura, a FDE não realiza aquisição de terras. Sendo assim, os terrenos disponibilizados para a construção de escolas devem ser sempre áreas públicas. Segundo Geiger de $\mathrm{Mello}^{42}$, dada a restrição imposta, poucas opções mostram-se viáveis. A primeira, é a identificação de terrenos públicos, não destinados a áreas verdes, situados em áreas de demanda, que possam ser utilizados. Esta possibilidade tem sido cada vez mais escassa, dada a ausência de um estoque de terras públicas e a crescente ocupação de áreas públicas por moradias improvisadas e núcleos favelizados.

A segunda possibilidade consiste na utilização das áreas institucionais dos conjuntos habitacionais. Esta é uma conduta recorrente, mesmo porque os conjuntos habitacionais, ao serem construídos, já trazem consigo sua própria demanda. No entanto, segundo Geiger de Mello, as áreas institucionais destes conjuntos consistem, em geral, em terrenos complicados e de difícil acesso - "restos da gleba" -, uma vez que a prioridade nos projetos para os conjuntos é sempre a construção, em quantidade, das unidades habitacionais. Dessa forma, os projetos das escolas tornam-se complicados, implicando vez por outra no comprometimento da qualidade do edifício.

A terceira opção, que tem sido cada vez mais adotada, é a ampliação e até mesmo a substituição de escolas já existentes. Tal procedimento exige um planejamento minucioso, que envolve a realocação dos alunos e a definição precisa das etapas de obra, não sendo raro o funcionamento da escola 


\section{DESCONSTRUINDO AS ESCOLAS}

simultaneamente à execução da obra. Além desses transtornos, a opção pela adequação e/ou ampliação de edifícios traz, em geral, perdas na qualidade dos projetos.

Não se tratando, em geral, de terrenos muito amplos, as soluções costumam ser a concentração do programa em um único edifício e a supressão das áreas livres do terreno, que passam a ser ocupadas pela construção, dando fim aos pátios e demais áreas de lazer, sobretudo as quadras, que comumente têm sido realocadas nos últimos pavimentos dos edifícios. A esta conduta Antônio Cláudio da Fonseca se refere como um retrocesso no histórico projetual da FDE, lamentando que a construção de qualidade tenha que se render à escassez de terras:

[...] Esta mudança no Estado de São Paulo se dá a partir do fim dos anos 80, pelo início da escassez dos terrenos. Isto aqui é o primeiro grande recuo nesta tradição de lutar sempre pela qualidade. (informação verbal) $)^{43}$

No caso dos CEUs, embora a prioridade tenha sido a utilização de terrenos públicos, a compra de áreas particulares foi fundamental para que se cumprissem as metas de atendimento do programa. Dos 21 CEUs construídos na primeira etapa do programa, 13 envolveram a desapropriação de terrenos particulares. Na segunda etapa, dos 24 equipamentos, 18 contaram com a mesma estratégia. Mais uma vez, vale ressaltar o caráter excepcional da conduta. A compra de áreas privadas, além de constituir uma conduta onerosa aos cofres públicos, consiste num procedimento complicado e lento, sobretudo em áreas periféricas, quando, muitas vezes, a propriedade do terreno é desconhecida e/ ou a documentação não está regular. Neste contexto, o empenho político constituiu fator determinante para o sucesso do programa.

\subsubsection{Financiamento}

Em ambas as esferas de gestão analisadas - Governo do Estado, via FDE/ SEE e Prefeitura Municipal, via EDIF/ SME -, o financiamento dos equipamentos educacionais é originário inteiramente de recursos próprios. $A$ Educação, assim como a Saúde, são pastas que contam com o "privilégio" 
do "recurso carimbado", ou seja, uma porcentagem específica do orçamento que é destinada exclusivamente a estes setores.

No caso dos CEUs, a grande dificuldade a ser vencida foi a ampliação do programa. Embora os CEUs agreguem equipamentos de cultura e esportes, não há participação das relativas Secretarias na composição do orçamento. Além dos custos elevados, a SME deparou-se com a restrição legal de efetuar qualquer investimento em áreas que não a educacional, dificuldade frequentemente enfrentada pela FDE, que a impede, por exemplo, de intervir nas praças de acesso às escolas, considerando-se tal intervenção atribuição da área de Urbanismo.

Para viabilizar os altos custos dos edifícios e a multiplicidade de usos, a solução encontrada pela gestão de Marta Suplicy foi a alteração da Lei Orgânica Municipal, elevando a receita destinada à Educação e autorizando os investimentos nos demais itens do programa, assim como em serviços necessários ao funcionamento dos CEUs, conforme já mencionado no item 2.9 .

A composição de orçamentos com recursos provenientes de diferentes fontes, constitui experiência rara à política educacional, justamente pela área já contar com dotação específica. A concatenação dos investimentos e a multiplicidade de serviços num mesmo equipamento poderiam constituir, no entanto, uma estratégia interessante, inicialmente sugerida pelas Praças de Equipamentos, porém nunca ensaiada.

\subsubsection{Premiações}

A indicação dos projetos premiados visa apenas explicitar a qualidade dos edifícios que vêm sendo implementados pelas gestões públicas nos últimos anos. As escolas da FDE vêm frequentemente ocupando espaço em bienais e concursos de arquitetura nos últimos anos, funcionando como importante porta para jovens arquitetos.

Além dos prêmios de arquitetura, a FDE vem acumulando premiações em diversas áreas, seja desenho de mobiliário, elaboração de vídeos, material didático, publicações, etc., o que a consagra como uma instituição de ensino competente e preocupada com a atualização e a inovação de suas ações.

Da mesma forma, o projeto dos CEUs foi diversas vezes objeto de discussão em eventos de arquitetura, figurando em diversas mostras e exposições. 


\subsection{Duas escolas: fDe Ministro Oscar Dias Correia e CEU Pera MARMELO.}

A análise dos processos de produção das redes de equipamentos explicita as fragilidades e potencialidades de cada proposta. No entanto, os projetos não constituem arquitetura até que sejam implantados. A relação dos edifícios com seus entornos e o desempenho das construções diante de seu uso é que irão determinar o sucesso ou fracasso do programa implementado. Visando essa aproximação do objeto, a pesquisa assumiu o estudo de um caso específico, buscando contrapor os papéis dos diferentes equipamentos num mesmo meio urbano. Definiu-se assim a "área-estudo" ${ }^{4}$.

A área-estudo eleita foi 0 perímetro denominado Jardim Ipanema, bairro localizado no distrito do Jaraguá, zona norte do município de São Paulo. A opção por esta locação deve-se ao fato do bairro concentrar, em um raio inferior a 500 metros, diversos equipamentos educacionais públicos: a E.E. Ministro Oscar Dias Correia, o CEU Pera Marmelo, a EMEF Antônio Alves Veríssimo e a EMEl Prof. Dailce Monteiro da Silva Gomes. Tal proximidade permitiria contrapor a inserção de diferentes propostas em um mesmo lugar, numa mesma comunidade, com as mesmas demandas, obtendo desta contraposição algumas linhas de discussão.

A metodologia empregada foi a de um estudo presencial, no qual foram explorados três aspectos distintos: 1) o espaço, 2) os usuários e 3) os construtores. Nas diversas visitas ao local, caminhos diversos foram traçados, buscando absorver a dinâmica do lugar. Algumas pessoas foram entrevistadas e conversas frequentes com moradores, funcionários destes equipamentos e usuários em geral ajudaram a delinear o contexto local. Em paralelo, foram mapeados os agentes envolvidos nos processos de produção dos equipamentos e alguns foram entrevistados. Embora dotado de grande subjetividade, este momento trouxe impressões ricas para a avaliação das políticas e dos projetos, conforme será apresentado a seguir.

\footnotetext{
44. Termo cunhado por Aldo Rossi, a seguir descrito: "Introduzirei o conceito de área-estudo. Já que supomos existir uma inter-relação entre qualquer elemento urbano e um fato urbano de natureza mais complexa, até a cidade em que eles se manifestam, devemos esclarecer a que entorno urbano nos referimos. Esse entorno urbano mínimo é constituído pela área-estudo. Com esse termo pretendo designar uma porção da área urbana que pode ser definida ou descrita recorrendo-se a outros elementos da área urbana tomada em seu conjunto, por exemplo, ao sistema viário.(...) Mas a áreaestudo pode ser uma área definida por características históricas, ela coincide com um fato urbano preciso. Considerá-la em si significa reconhecer a essa parte de um conjunto urbano mais vasto características precisas, uma qualidade diferente. Essa qualidade dos fatos urbanos é de extrema importância; reconhecer diferentes qualidades aproxima-nos do conhecimento da estrutura dos fatos urbanos." (ROSSI, 2001, p. 62) - grifos do autor
} 


\subsubsection{O ESPAÇO: PASSEIOS, INVESTIGAÇÕES E IMPRESSÕES.}

0 estudo de campo do Jardim Ipanema contou com momentos distintos de análise, que partiram de diferentes graus de aproximação do objeto.

0 primeiro contato se deu por "passeios" pela área-estudo, ou seja, caminhadas pelo bairro, visando compreender a malha local, as articulações, os acessos e a dinâmica do lugar. Procurou-se que cada visita contasse com um trajeto específico, buscando evitar impressões distorcidas e tendenciosas.

Num segundo momento, partiu-se para as "investigações", mergulhando no estudo dos equipamentos em questão, por meio de visitas aos edifícios, conversas com funcionários, usuários e moradores do entorno, análise dos projetos, dados de funcionamento e demais características específicas. No caso do CEU, a visita ao edifício não foi autorizada, mesmo mediante diversos contatos, solicitações de agendamento, cartas oficiais e envio de fax à instituição.

A terceira estratégia de abordagem enquadra-se num campo de análise estritamente subjetivo, ao qual denomino "impressões". Cada visita ao local, sempre munida de um roteiro de atividades previamente elaborado, inevitavelmente levava a novos questionamentos, fosse em relação aos trajetos percorridos, aos dados coletados, ou, sobretudo, aos imprevistos presenciados.

Estes estudos de campo foram registrados na forma de um diário de bordo, cuja espontaneidade de linguagem e conteúdo procura abarcar ao máximo as impressões sobre o lugar. A partir deste instrumental pretende-se elaborar um quadro geral que descreva o espaço construído do Jardim Ipanema, atentando para as contribuições dos equipamentos educacionais para este processo. 


\section{DESCONSTRUINDO AS ESCOLAS}

visita jaRAguÁ 01: CEU Pera Marmelo, E.E. Ministro Oscar Dias Correia e Conjunto City Jaraguá C/ F.

DATA: 29/11/2009, 11:00HS.

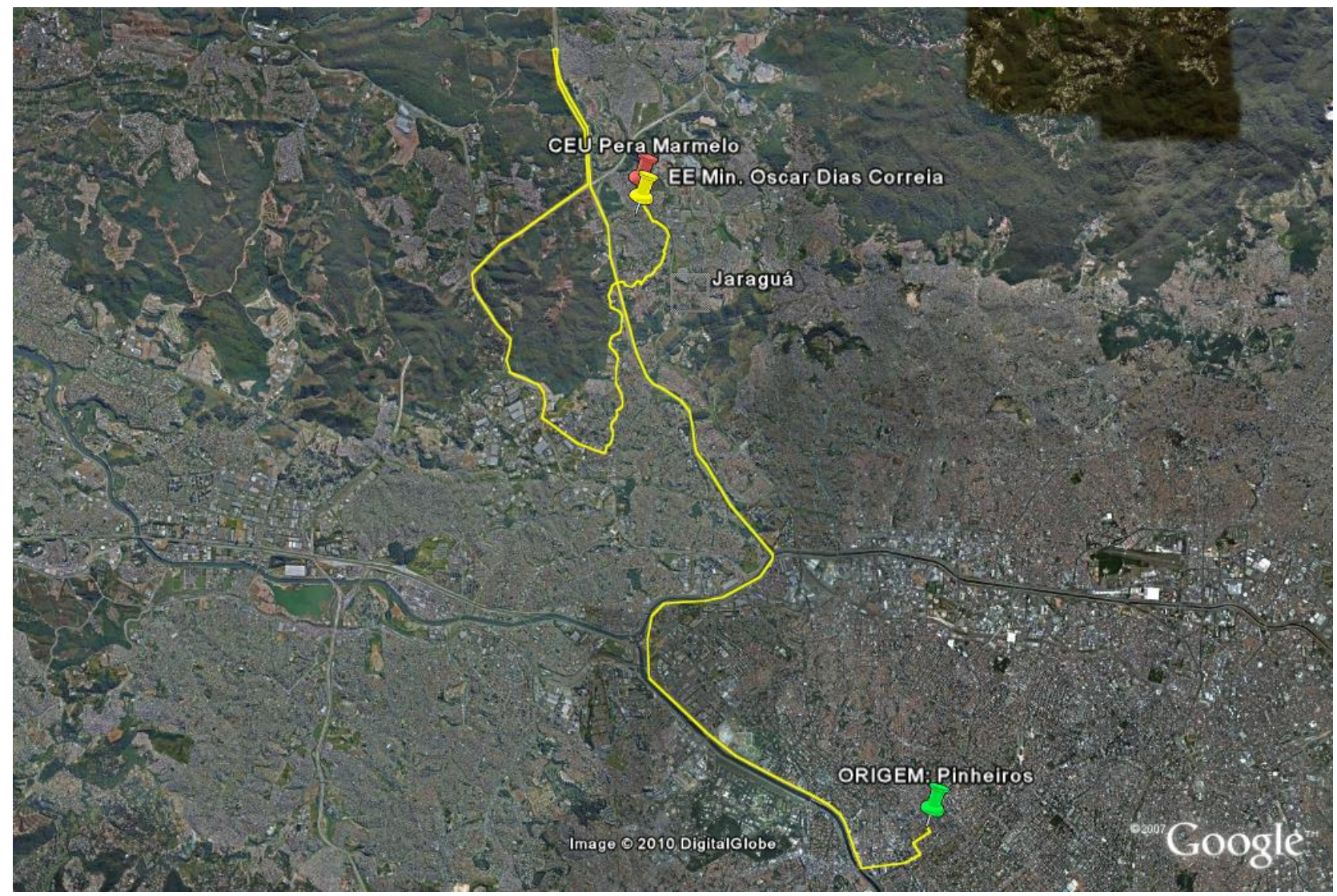

Esta primeira visita, preferi que fosse feita de carro, para que pudesse circular pelo entorno e melhor me situar na região. A ideia, no entanto, ofereceu seus contrapontos: quase duas horas perdida pela Zona Norte da cidade, circulando entre as Rodovias Anhanguera, Bandeirantes, com a única referência do Pico do Jaraguá. Daí já tiraria uma primeira impressão: a dificuldade do acesso àquela região, situada no limite norte da cidade, margeada por vias intermunicipais intransponíveis, delineada por trajetos mal sinalizados e contemplada por opções de transporte coletivo reduzidas.

Ainda na busca por meu destino, um fato me confirmaria uma das hipóteses iniciais: a 2 km de distância do Jardim Ipanema, ninguém conhecia a E.E. Ministro Oscar Dias Correia, mas todos sabiam me informar como chegar no CEU Pera Marmelo! "Escola Estadual Ministro Oscar Dias Correia? Não... Conjunto City Jaraguá? Não.... CEU Pera Marmelo? Ah! O CEU é fácil!" 0 CEU parecia constituir uma referência.

Depois de muitas voltas pela região, cerca de 20 minutos avistando o CEU sem conseguir atingi-lo, com a ajuda de um motoqueiro, finalmente cheguei a meu primeiro destino. 
0 CEU Pera Marmelo, embora tenha uma volumetria compacta em relação aos demais, em função da área limitada de seu terreno, constitui de fato um marco na paisagem: coroando o cocuruto do morro, o equipamento pode ser avistado à distância, com suas duas torres em forma de pórtico e o prédio redondo ao lado. Tratando-se de um bairro de ocupação espontânea, sem planejamento, com vias quase que aleatórias, a questão da referência urbana se torna bastante interessante, possibilitando uma rápida orientação do pedestre. Isto não significa, entretanto, que necessariamente facilite 0 acesso ao equipamento, uma vez que o trajeto nunca é tão óbvio, demandando percursos contrários ao destino e algumas voltas, até que se possa atingir 0 local almejado.

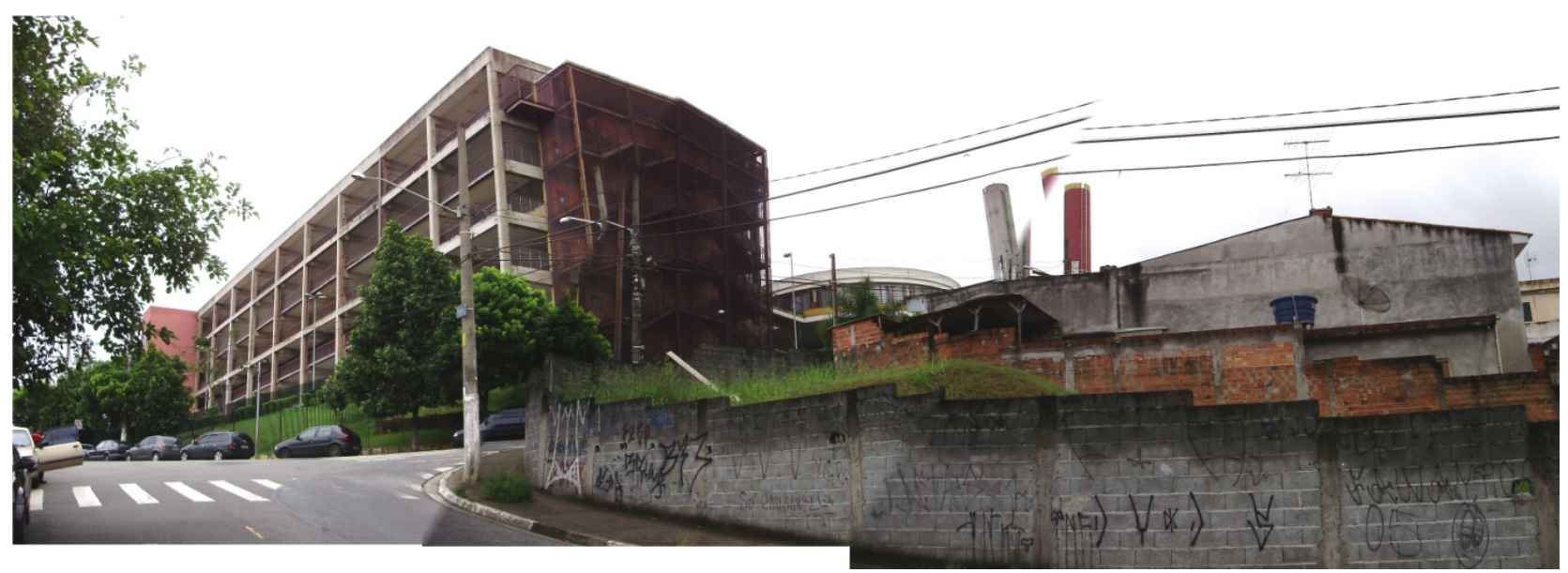

Vista na chegada ao CEU Pera Marmelo. Foto: Ana Lopes, 2009.
0 entorno, conforme imaginado, é marcado pela autoconstrução e pela ausência de padrões urbanísticos muito claros. As casas crescem verticalmente ao longo do tempo, de acordo com as possibilidades financeiras dos moradores. 0 bairro, entretanto, é bastante consolidado, dispondo de toda a infraestrutura urbana básica, ruas pavimentadas e a maior parte delas, sinalizada. No horizonte, a grandeza da Cantareira, colorindo a paisagem densa e árida. Apesar da proximidade com a área de preservação, a região é pouco arborizada. Os lotes, com dimensões enxutas, raramente apresentam quintais ou jardins e até mesmo os recuos são reduzidos. Não sei se por um processo recente ou não, 0 entorno imediato do CEU aparenta melhores condições urbanas que algumas quadras adiante.

Caminhando cerca de 200 metros dali, as residências ficam significativamente mais precárias. Ao me aproximar, jovens em grupos nas calçadas analisavam desconfiados a minha presença. As ruas se estreitam $e$ terminam em terrenos baldios. Resolvi voltar. Antes, entretanto, perguntei a algumas senhoras pelo CEU, cuja localização me apontaram rapidamente e se não me deixei levar por impressões pré-concebidas - com um certo 


\section{DESCONSTRUINDO AS ESCOLAS}

A chegada ao CEU foi recepcionada por um segurança incomodado com as minhas fotos - até então, do entorno. Era um domingo e o CEU oferecia apresentações de teatro para a comunidade. Famílias fotografavam seus filhos, poses no playground, em frente ao teatro, mas eu não fui autorizada a sacar a minha câmera. Cerca de um mês antes eu havia solicitado autorização para visitar 0 equipamento. Fax oficial para 0 setor de gestão, carta de apresentação da faculdade, cerca de três telefonemas por semana e minha entrada seguia vetada. Cada telefonema significava expor novamente toda a minha solicitação e 0 mesmo funcionário dizia desconhecê-la. Mas, enfim, como havia conseguido agendar uma visita à E.E. Ministro Oscar Dias Correia para aquele dia, por que não tentar conhecer o CEU também?!

Apesar de não obter muito sucesso, algumas impressões puderam ser absorvidas. Primeiro, surpreendeu-me a situação das piscinas. Um deserto de reservatórios de água vazios às vésperas do verão. Segundo o segurança, o complexo aquático estava fechado em função das chuvas. Mais tarde, escutaria de usuários que faltavam médicos e salva-vidas. Como ninguém da administração se dispôs a me explicar, ficaram as possíveis razões.

0 teatro estava lotado. Famílias inteiras chegavam e entravam. Consegui liberação para dar uma breve espiada... A qualidade do espaço, de fato, não perde para nenhum teatro da região central: palco de madeira, poltronas confortáveis, equipamentos de luz e som de primeira. Ao invés do foyer, uma pracinha com playground recebendo o público, com um pequeno ralf-pipe, onde as crianças não se continham em dar uma corridinha. Uma entrada independente facilitava 0 controle de acesso às demais dependências do equipamento. Aquele dia, só o teatro era utilizado. Nenhum outro uso disponibilizado.

Dado 0 acesso restrito, tirei algumas fotos mais do entorno, outras meio camufladas e segui para o meu segundo destino: a E.E. Ministro Oscar Dias Correia.

Bastante próxima do CEU, a escola se localiza às margens de uma importante avenida de tráfego local, a Av. Alexio Jafet, a qual concentra linhas de ônibus e constitui importante eixo de distribuição viária. Com isso, 0 acesso à escola torna-se mais fácil.

Construída em 2005, a E.E. Ministro Oscar Dias Correia foi implantada na área institucional dos Conjuntos City Jaraguá C e F, da CDHU. Tratando-se de um terreno de perímetro irregular e forte declividade, o projeto, de autoria do Arq. Ubyrajara Gilioli, optou pelo acesso em meio-nível, por meio de uma passarela metálica, que liga a avenida à recepção da escola. Os pavimentos
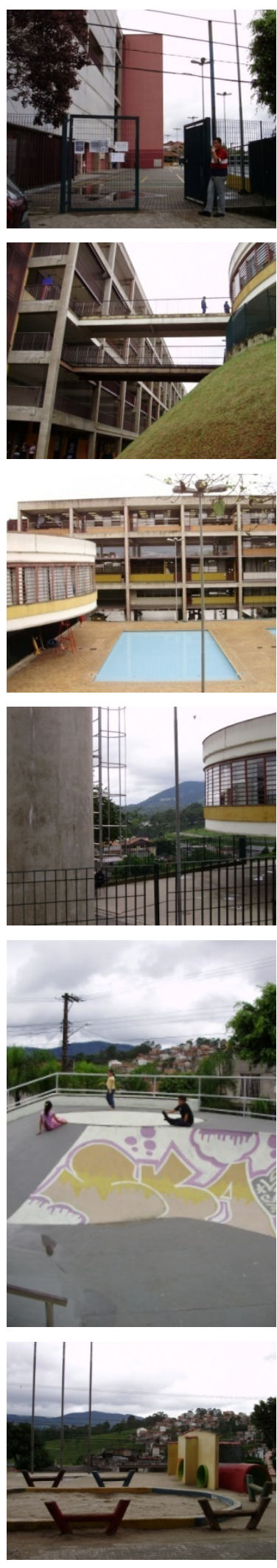

Entrada no CEU Pera Marmelo. Fotos: Ana Lopes, 2009. 


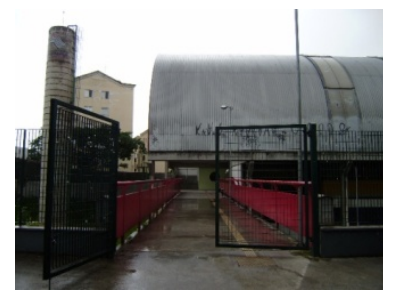

inferiores foram destinados aos usos mais restritos - aí estão as salas de aula, biblioteca e área administrativas - e os superiores passaram a abrigar os usos coletivos -quadra, sala de informática, etc. -, o que facilita o controle do acesso nos finais de semana.
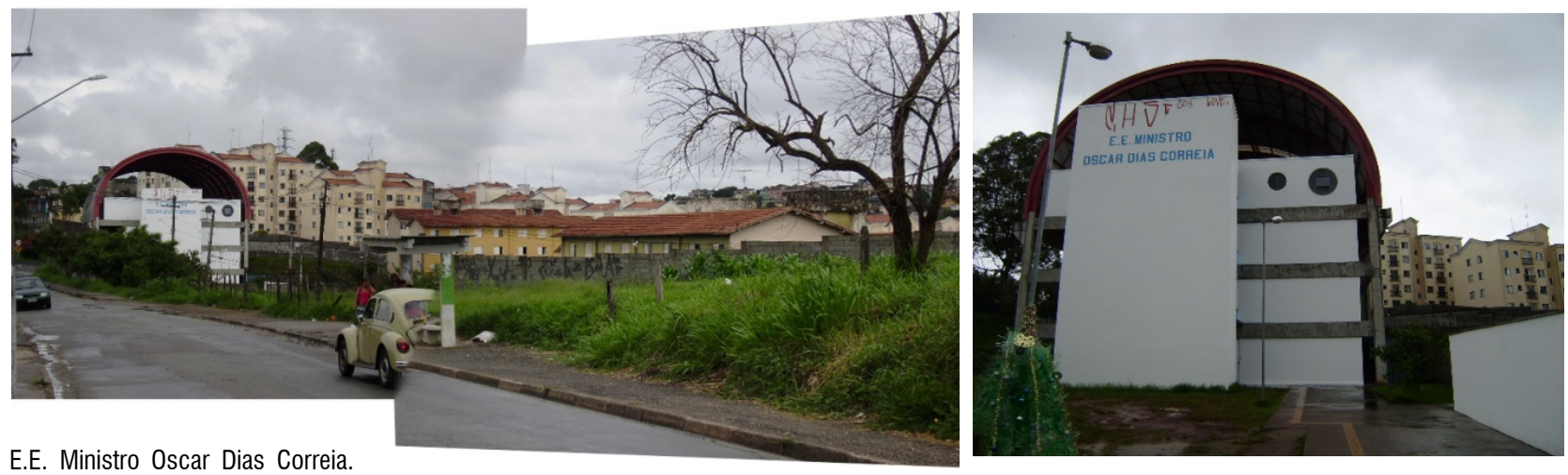

Foto: Ana Lopes, 2009.

Era dia do Programa Escola Aberta e a escola estava cheia. Atividades artesanais em algumas salas de aula, meninas dançando em outra, jogos na quadra, ping-pong no pátio, enfim, a escola pareceu, de fato, ser 0 equipamento de lazer do final de semana. Meninos brincavam nas aberturas circulares da caixa de escada; a arquitetura do edifício estimulava usos inesperados: buracos viravam telas de televisão ou mesmo palcos de teatro, enquanto os degraus se transformavam em plateias escalonadas.
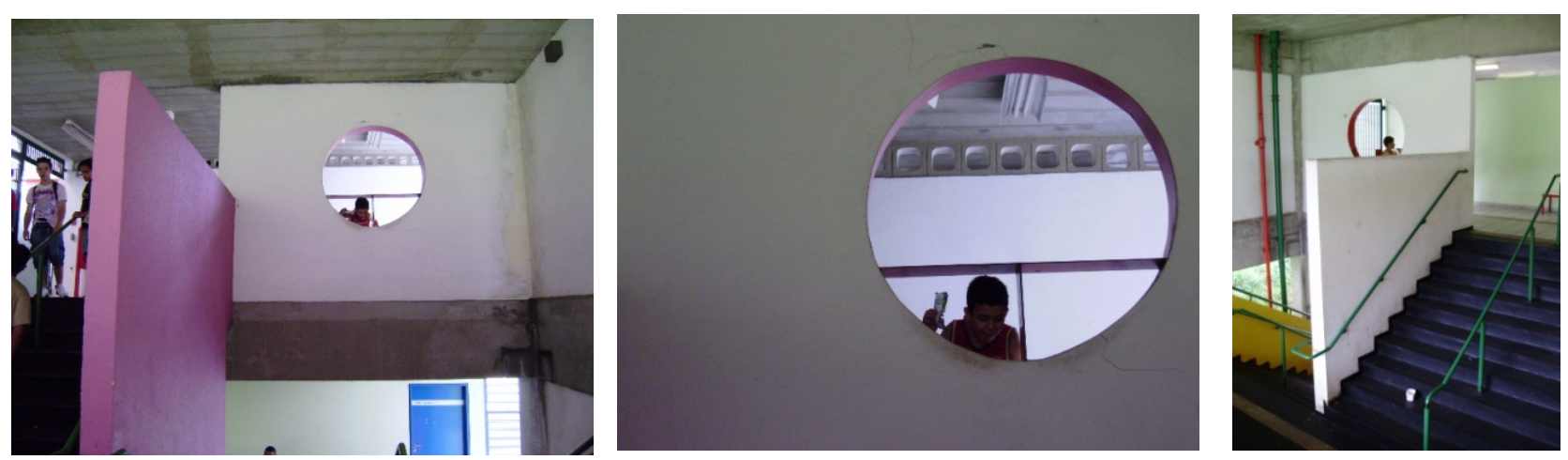

Aberturas nas paredes assumem caráter lúdico. Fotos: Ana Lopes, 2009.

Conversando com a professora coordenadora do Programa Escola Aberta, soube que a maior parte das crianças residia no entorno, sobretudo no conjunto da CDHU. Ao perguntar aos alunos, aleatoriamente, se gostavam da escola, a resposta foi, sem exceção, positiva, com ênfase para a quadra. 0 uso da quadra, entretanto, pareceu ser exclusivo dos meninos. Uma menina assistia entediada ao jogo e veio me perguntar o que fazia por lá. Quando perguntei se iria jogar também, disse que não. Que não gostava. Ao me perguntar sobre minha profissão, respondi e rebati a pergunta: o que ela gostaria de fazer. Seu sonho era casar. Tinha 12 anos. 


\section{DESCONSTRUINDO AS ESCOLAS}

Quanto ao edifício, sem dúvida, constitui uma outra referência na paisagem. Embora de porte menor que $0 \mathrm{CEU}$, a escola, com uma ampla cobertura em arco e a passarela metálica vermelha na frente, é facilmente diferenciada de seu entorno. Ao embicar na avenida, pode-se rapidamente identificar 0 edifício, com sua volumetria fortemente delineada, circundado por um mar de prédios de tipologia "H", da CDHU.

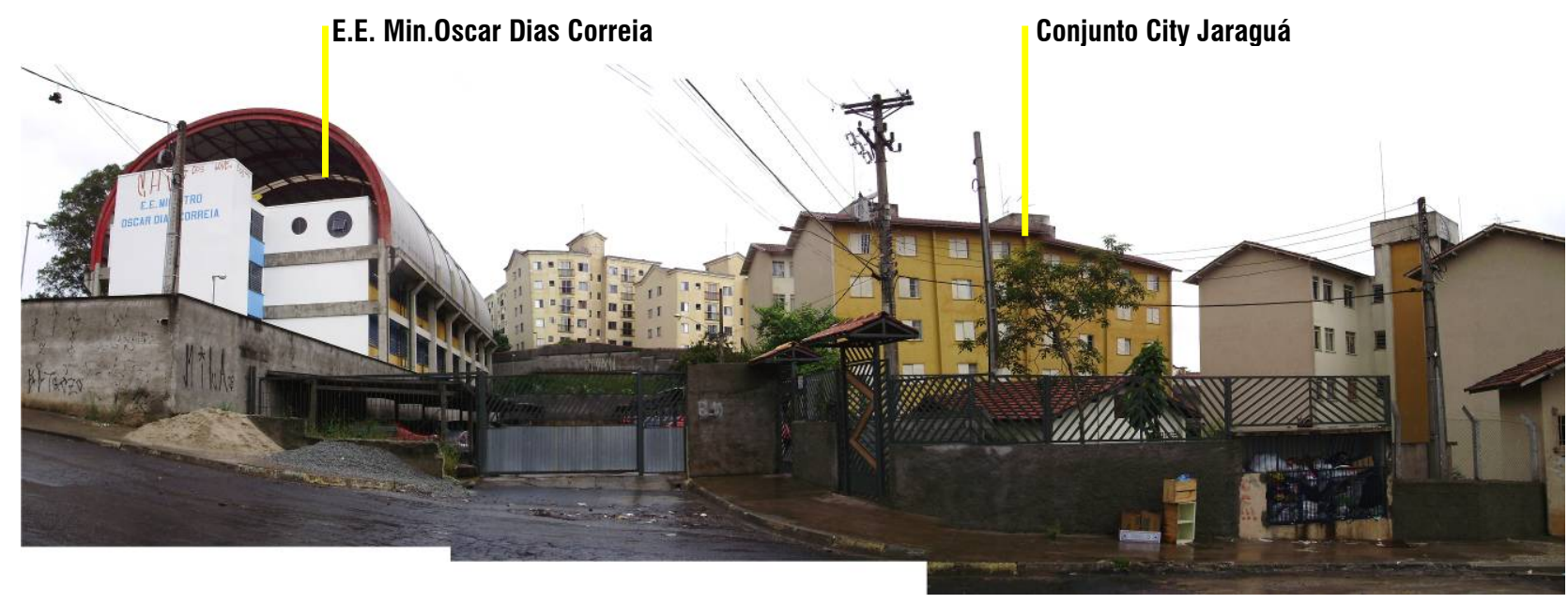

Após 6 anos da inauguração, o edifício apresenta boas condições de uso e está bem conservado. Pichações nas paredes externas marcam a presença

E.E. Ministro Oscar Dias Correia e Conjunto City Jaraguá. Foto: Ana Lopes, 2009. dos grupos jovens do bairro, mas o espaço está intacto e aparentemente apropriado pela comunidade. Os espaços internos parecem agradar aos usuários.

Saindo dali, dei uma circulada pelo conjunto City Jaraguá, que, naquele dia chuvoso, parecia um deserto de casas. Ninguém nas janelas, ninguém na calçada, ninguém chegando, nem saindo. Fui até 0 final da rua e ali percebi que era o fim. Não só o fim da rua, do conjunto, mas o fim da cidade.

Na volta, depois de cruzar o Rodoanel, ainda pude avistar ao longe o edifício do CEU.
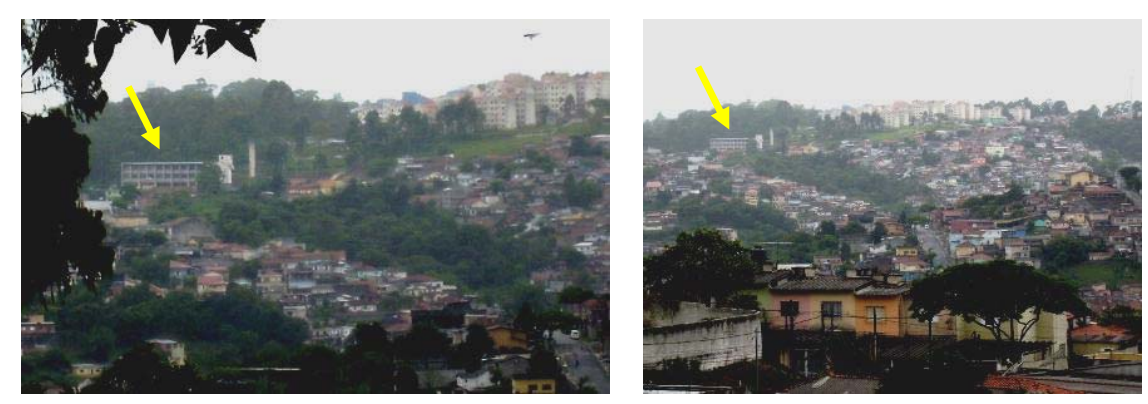

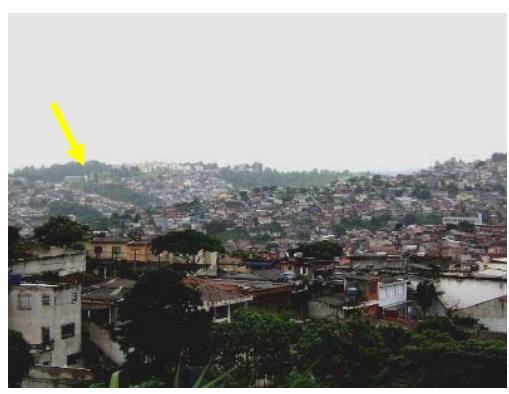

CEU Pera Marmelo avistado ao longe. Fotos: Ana Lopes, 2009. 


\section{Visita jaraguá 02: CeU Pera Marmelo, E.e. Ministro Oscar Dias Correia e Conjunto City Jaraguá C/ F.}

DATA: 30/01/2010, 14:00HS.

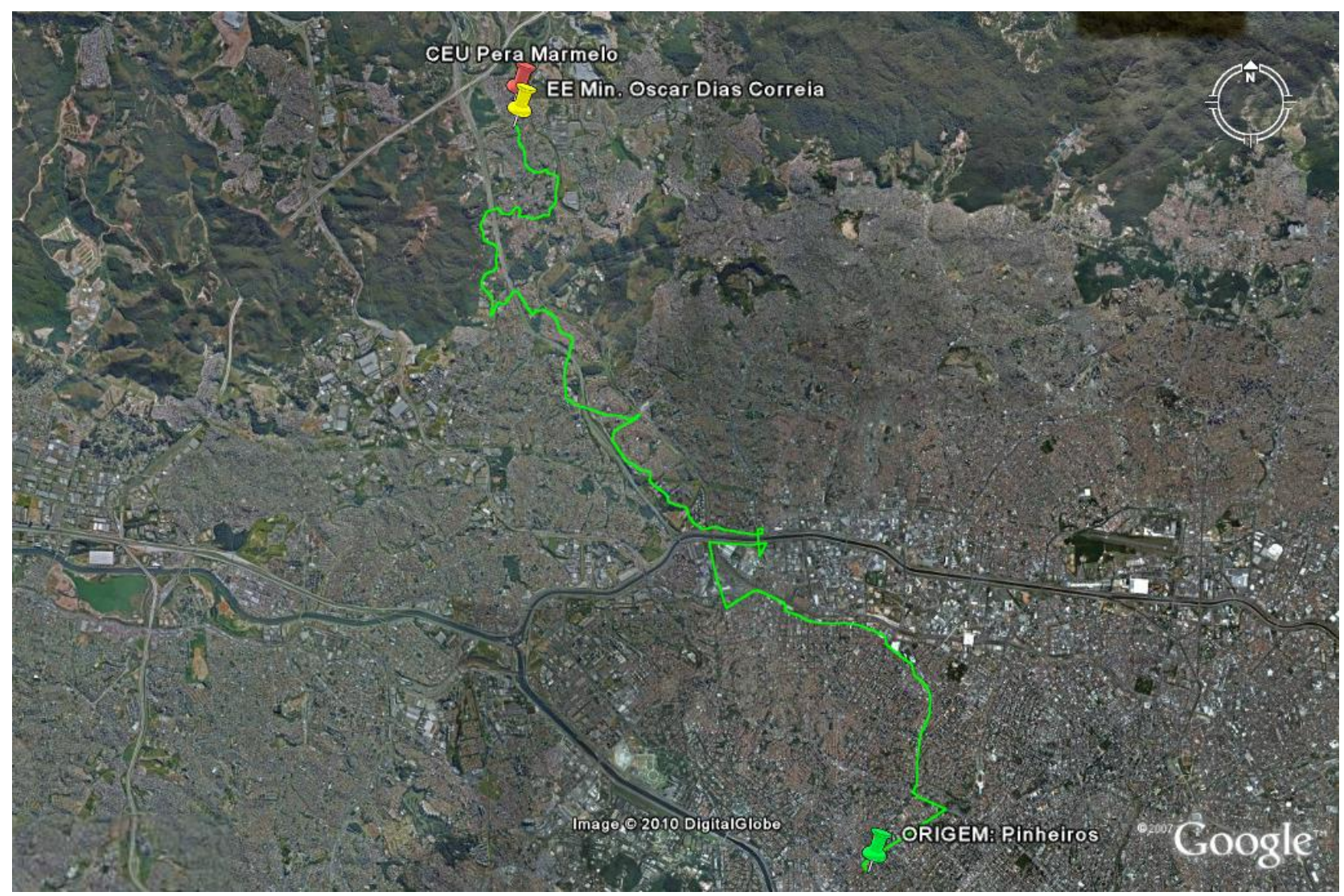

Sábado, hora do almoço, segui para o Terminal da Lapa para de lá tomar 0 8696-10 - Jaraguá, rumo ao Jd. Ipanema. Depois de alguns 40 minutos de espera, meu ônibus surgiu ao longe. Com o guia em punho, logo percebi que a viagem seria longa: o percurso atravessava cerca de cinco páginas do guia, quase sempre numa vertical rumo ao norte!

Com 0 trânsito favorecido pelo final de semana, o caminho até pareceu mais curto e, por volta das 14:00hs desembarquei no meu destino. Do outro lado da rua estava a E.E. Ministro Oscar Dias Correia, referência marcante, que pude facilmente identificar. Era período de férias e a escola estava fechada.

Panorama local a partir da parada de ônibus. Foto: Ana Lopes, 2010.
Procurei por algum morador do conjunto, mas ninguém nas ruas. Segui para o CEU, onde sabia que algo estaria acontecendo.

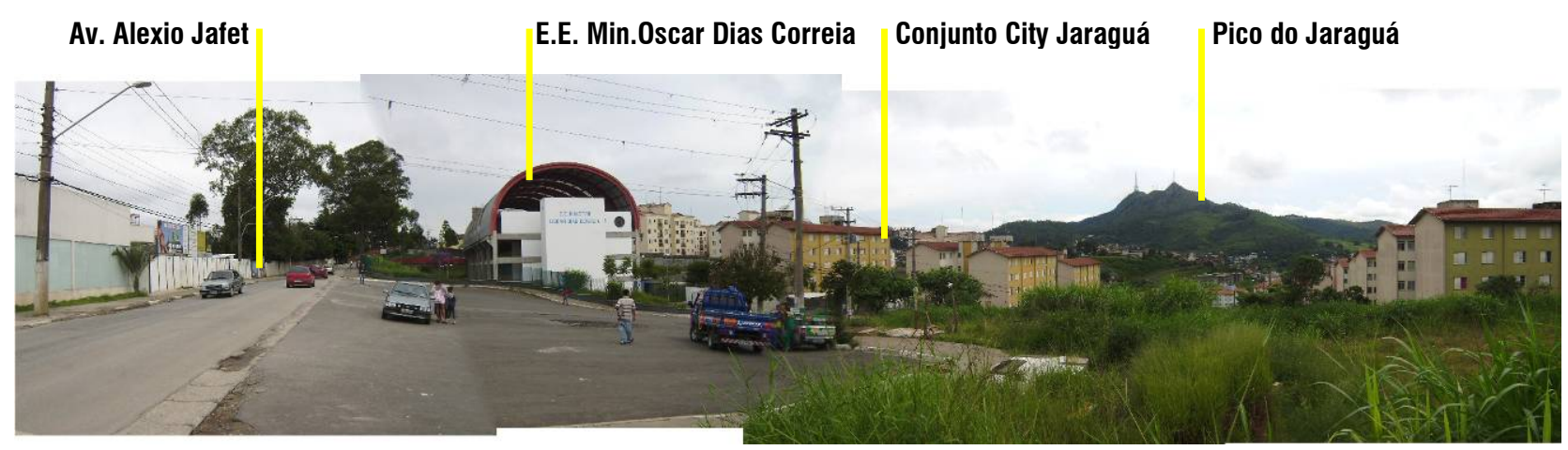




\section{DESCONSTRUINDO AS ESCOLAS}

Ao cruzar a Av. Alexio Jafet e adentrar na outra margem da avenida, logo percebi uma significativa mudança da paisagem. 0 conjunto infindável de predinhos "H" da CDHU, permeado por terrenos baldios e estabelecimentos comerciais improvisados, cedia lugar para sobrados geminados, cada um com sua garagem, caixilhos e revestimentos variados ao gosto dos moradores, enfim, aparentemente um bairro de classe média. As ruas todas pavimentadas, arborizadas e limpas. Influência do CEU? Talvez...

Chegando ao CEU, ao contrário do movimento da última vez, encontrei 0 prédio bastante vazio. Mais uma vez as piscinas estavam fechadas, em função do mau tempo, e na programação constava apenas um baile da terceira idade, às 16:00hs. Sendo assim, o que vi foram apenas alguns jovens no telecentro, uma dupla jogando tênis de mesa e outra, um vôlei improvisado. Cerca de uns cinco seguranças vigiavam o prédio e alguns funcionários da limpeza davam uma geral na área externa.

Desta vez, não me identifiquei como pesquisadora. Disse estar apenas querendo conhecer 0 CEU. Em todo caso, tirei algumas fotos meio camufladas e procurei não chamar muita atenção. Ao entrar no teatro, rapidamente fui surpreendida por uma das seguranças. Como se não entendesse, aproveitei para elogiar o teatro e pedir sua opinião. De pronto, acentuou 0 elogio à sala, que dispõe de "cadeiras novas e de boa qualidade, palco de madeira e toda a infraestrutura de luz e som instalada". A moça me disse não estar no emprego há muito tempo, mas que vinha gostando bastante, sobretudo por ser um lugar muito calmo.

Depois de mais uma volta pela área externa, decidi dar uma caminhada pelo bairro. Logo na saída, encontrei dois meninos, de cerca de 10 anos, brincando na calçada. Perguntei se estudavam no CEU. 0 mais desinibido, pendurado num poste, respondeu que não. Mas que o outro, "sim". Perguntei se gostava de estudar ali e recebi um sucinto "sim".

- 0 que gosta mais na escola? - prossegui.

- A lição de casa! - 0 amigo no poste respondeu.

- Aha! Prefere então a lição de casa à piscina?!!! - insisti para o mais calado.

Rendendo-se à provocação, disse que a piscina era sim a melhor parte. $E$ que, se pudesse, passava o dia todo lá. Concluiu lamentando o fato de naquele dia as piscinas estarem fechadas.

- Iria mesmo com chuva! - completou. 
Na sequencia, perguntei onde 0 outro menino estuda.

- Numa escolinha particular ali embaixo. Mas no ano que vem minha mãe vai me colocar aqui! - respondeu entusiasmado.

Para ter certeza, perguntei se gostava da ideia de se mudar para o CEU e me respondeu afirmativamente. Além da proximidade com sua casa, falou das várias atividades oferecidas pelo CEU além das aulas.

Além dos meninos, aproveitei para ouvir alguns moradores do entorno, tentando sentir um pouco da reação da comunidade ao equipamento. Algumas conversas foram gravadas e serão mencionadas no Item 3.2.2.
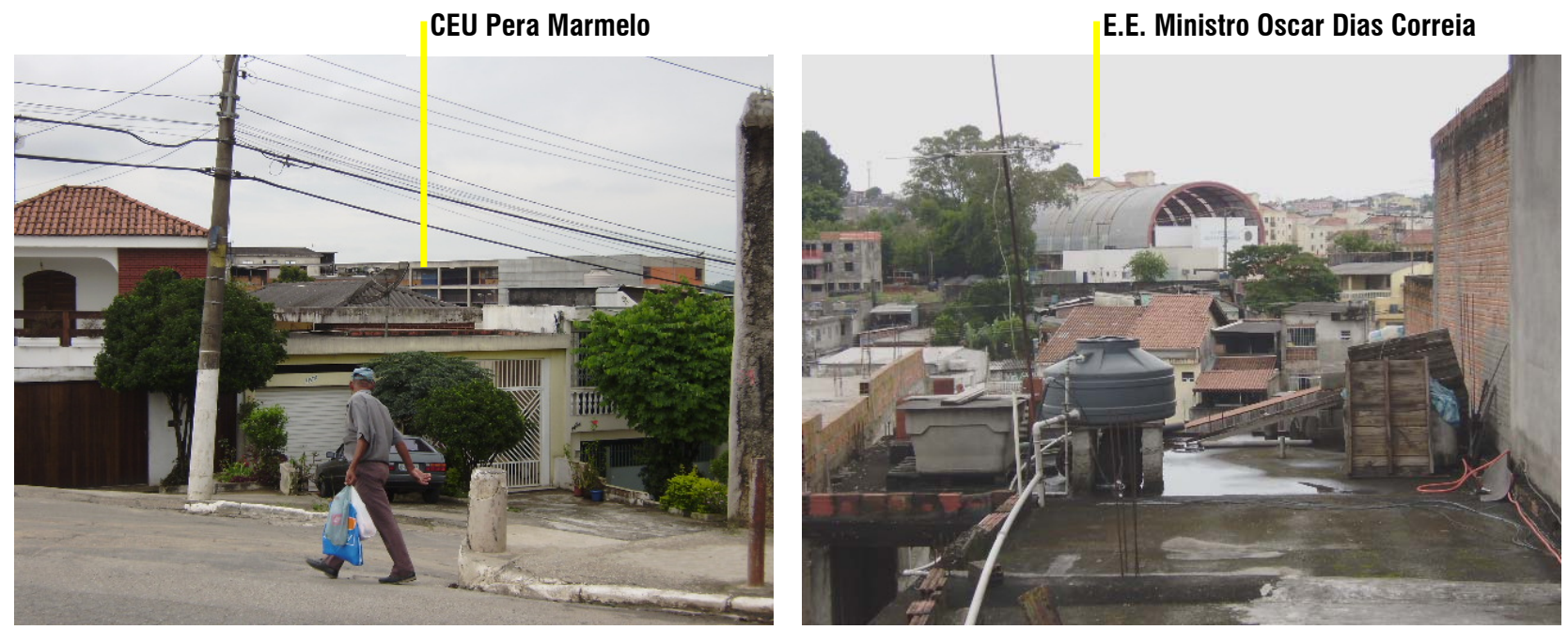

Presença marcante dos edifícios na paisagem. Fotos: Ana Lopes, 2010

Saindo do CEU, resolvi dar mais uma andada pelo Conjunto City Jaraguá, mas encontrei apenas uma moça chegando com a filha, moradora recente do bairro. Pensava em colocar sua filha na Ministro Oscar Dias Correia, em função dos elogios que ouvia da escola. Quanto ao CEU, embora ainda não conhecesse o Pera Marmelo, tinha sido vizinha do CEU Atlântica e gostava muito. Pretendia voltar a utilizar o equipamento.

Na volta para casa, resolvi experimentar a opção ônibus-trem-ônibus, 0 que reduziu bastante o tempo de viagem. Soube, entretanto, que durante a semana 0 trem pode ser bastante tumultuado; 0 ônibus, por sua vez, pode Estação Jaraguá da CPTM. Fotos: Ana Lopes, 2010. parar no trânsito. Dicas a orientarem minha próxima visita.
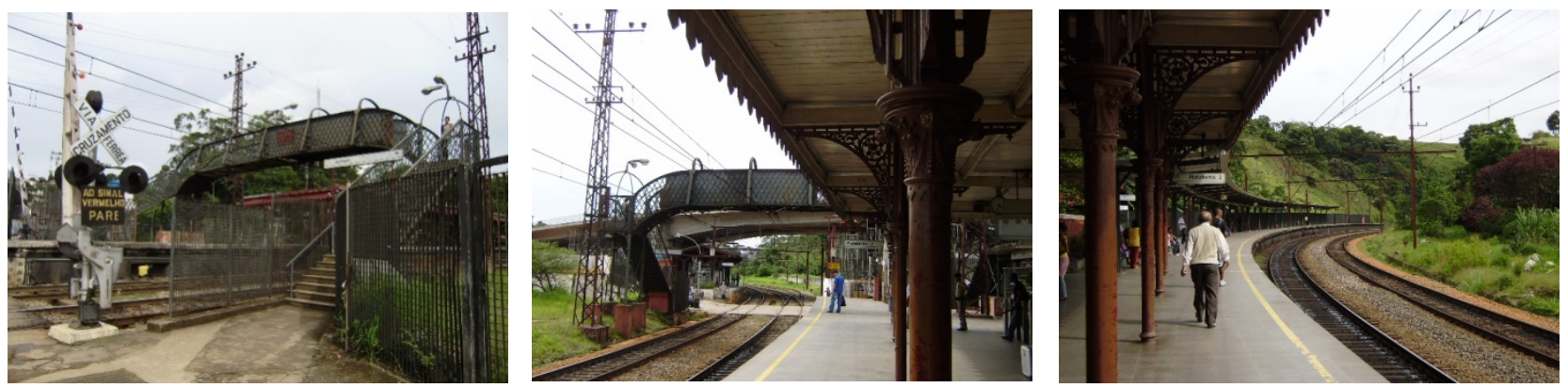


\section{DESCONSTRUINDO AS ESCOLAS}

Visita aO JaRaguÁ: CeU Pera Marmelo, E.E. Min. Oscar Dias Correia e emef antônio Alves Veríssimo.

DATA: 22/02/2010, 10:30HS.

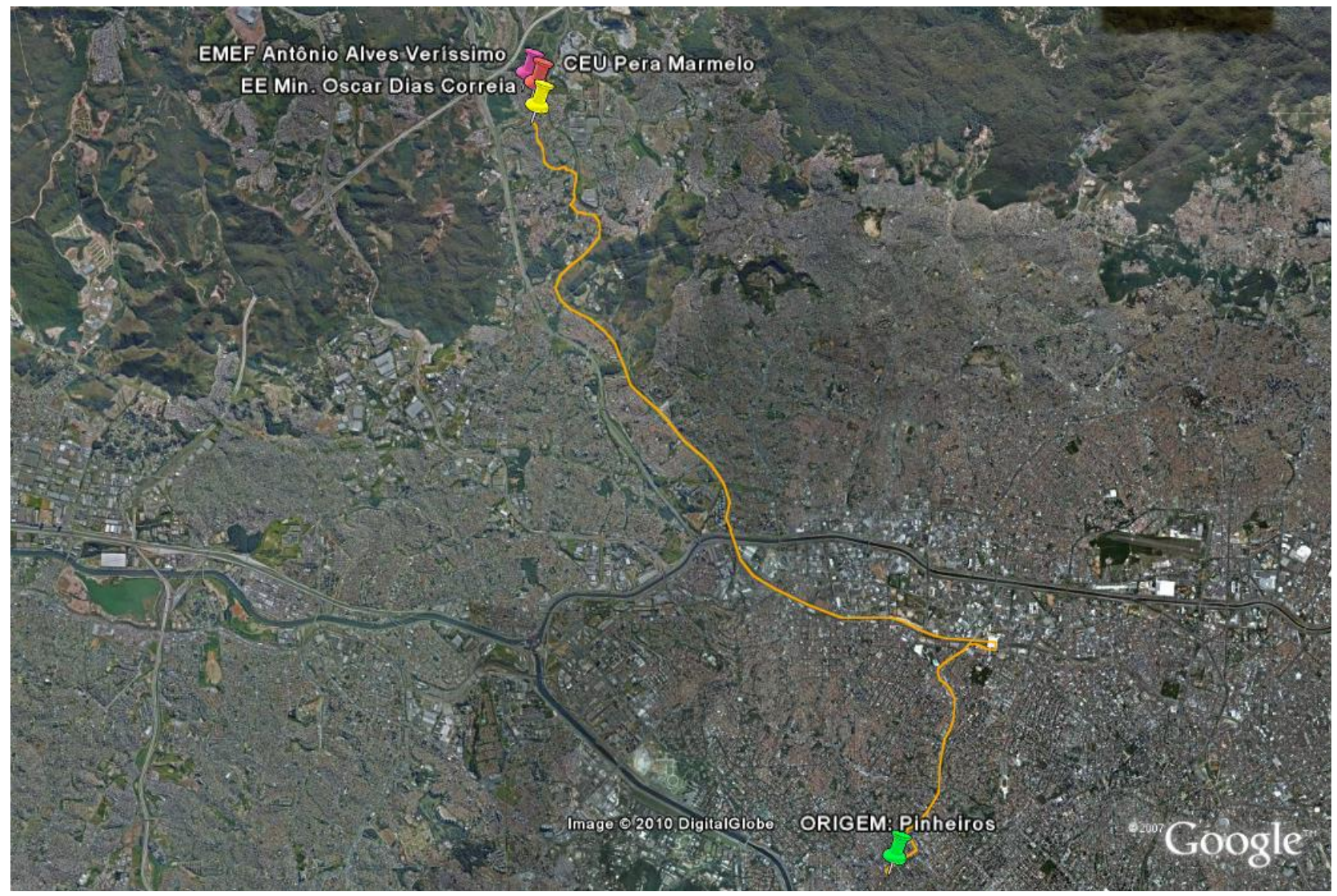

Desta vez, resolvi mudar a ordem dos fatores: ir de trem, mesmo porque pretendia chegar logo, e voltar de ônibus, para comparar os trajetos. A ida foi bem tranquila. Do terminal Barra Funda, tomei um trem da Linha 7 da CPTM, com destino à Francisco Morato, e desembarquei na bucólica Estação Jaraguá. Toda em ferro, com perfis delicadamente delineados e 0 entorno de um verde interiorano. Por alguns minutos, o desembarque naquela estação parece levar para algum lugar bem longe de São Paulo.

Dali, segui para a Estrada de Taipas, para tomar 0819 A-10 - Vila Aurora. 0 entorno parece tranquilo, com farto comércio local, igrejinha com cara de bem tombado e o pico grandioso no horizonte. Uns 20 minutos de espera e veio o micro-ônibus, que partiu abarrotado depois de comportar praticamente todas as pessoas do ponto.

0 trajeto foi rápido. Em poucos minutos reconheci a Avenida Alexio Jafet. Cheguei a dar informação a uma mãe quanto à parada da "escola Oscar" (!) e descemos juntas. A moça procurava desesperadamente por uma vaga para seu filho de 8 anos em alguma escola do bairro. 0 menino estava matriculado em uma escola particular, mas a mãe havia perdido o emprego 
há uma semana e não poderia mais pagar. Chegando à escola, obteve mais uma resposta negativa. Desolada, contava que o menino já estava na fila de espera das outras cinco escolas da região e não sabia mais o que fazer. Fato novo para mim, depois dos muitos depoimentos afirmando que a rede escolar na região era suficiente para a demanda.

Tentei uma conversa rápida com a funcionária da secretaria. Expus meu trabalho de mestrado e perguntei se poderíamos conversar por 5 minutos. A moça se negou e, com muito custo, forneceu o e-mail da escola para que eu pudesse enviar um questionário. Eram 10:30hs e o turno só terminaria às 11:30hs. 0 sol ardia e então decidi dar uma corrida ao CEU e tentar novamente estabelecer algum contato com a administração do conjunto.

Chegando ao portão da escola, mais uma vez fui anunciada com 0 costumeiro formalismo de seus seguranças:

- Bom dia. Se encontra aqui ao portão, uma senhora que se identifica Ana, que solicita falar com funcionário do setor de gestão, com vias a obter informação para seu trabalho de pós-graduação.

[ouço do outro lado do radio] - Ela precisa telefonar antes e agendar.

Pedi ao segurança que dissesse que havia enviado um fax, ligado diversas vezes, falado com um funcionário da gestão em visita anterior e não obtido resposta.

- Ah... mas hoje não tem ninguém aqui não. Só a coordenadora.

- A coordenadora? Está ótimo! - apressei-me em dizer.

Depois de muita negociação, consegui permissão para entrar na escola, subir ao setor de gestão e conversar com a coordenadora Vera. Minha chegada foi nitidamente mal recebida e a primeira resposta foi que eu deveria antes encaminhar solicitação oficial à Secretaria de Educação! Hein?!!! Para saber dos funcionários o que eles acham da escola e tirar algumas fotos?!!! Era esta a tão exaltada autonomia dos CEUs?!!! Numa tentativa derradeira, despejei sobre o balcão o recibo do fax enviado, a carta de solicitação de visita, a carta oficial da faculdade e comecei a declamar os nomes das pessoas a quem vinha solicitando informação ao longo dos meses. Complementei com uma pequena ameaça de que teria que mencionar a impossibilidade da visita em minha dissertação, indo contra 0 discurso participativo e democrático da instituição.

- Um momento. A coordenadora vai te atender.

Alguns minutos de conversa com a coordenadora Vera e sai de lá ao menos com o telefone da gestora - que nunca viria a me atender - e a informação 


\section{DESCONSTRUINDO AS ESCOLAS}

que se encontraria por lá em algum momento da tarde seguinte. Agradeci e perguntei se poderia tirar algumas fotos do entorno, a partir do corredor, verdadeiro mirante do bairro. Mais uma resposta negativa.

OK. Direito de imagem do bairro. Segui pelo corredor analisando aquela paisagem. A cidade parecia há pouco ter chegado ali. Casas autoconstruídas subiam o morro, de forma ainda pouco densa, marcando um nítido contraste com a paisagem natural. Este era 0 horizonte que se descortinava atrás do CEU. Chegando à caixa de escadas, não consegui me segurar e saquei umas poucas fotos, só para guardar aquela imagem.

Ainda era cedo para a saída das crianças. Resolvi caminhar até o Veríssimo. Perguntei pelo caminho e o segurança me apontou as caixas d'água ao longe. Segui naquela direção, pensando sobre a consagração das torres de água enquanto marcos na paisagem, pintadas em vermelho.
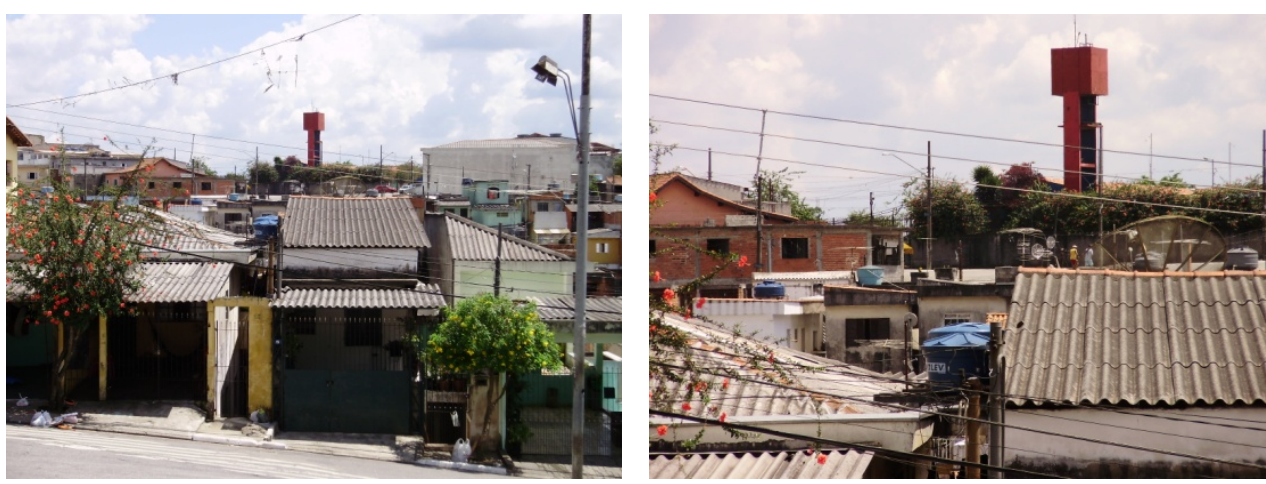

No meio do percurso, do alto do morro avistei o CEU, imponente na paisagem. Suas torres vermelhas formam realmente uma referência marcante, numa espécie de pórtico, avistado à distância. Lembro do comentário do Prof. Antônio C. Fonseca, quando dizia que o CEU não introduzira uma referência arquitetônica nova, uma vez que seguira uma linha modernista tradicional, já tão incorporada à paisagem da cidade. Yvonne Mautner, minha orientadora, complementaria dizendo que a periferia é arquitetonicamente moderna, dada a ausência de rebuscamento, mesmo que aí não resultante de uma opção estética, mas sim da escassez de recursos.

CEU Pera Marmelo

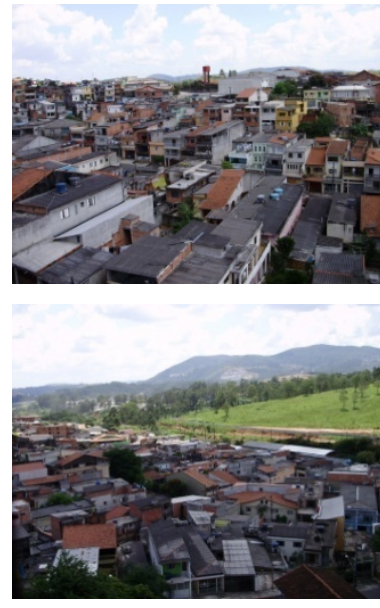

Paisagem vista dos corredores do último pavimento do CEU. Fotos: Ana Lopes, 2010.

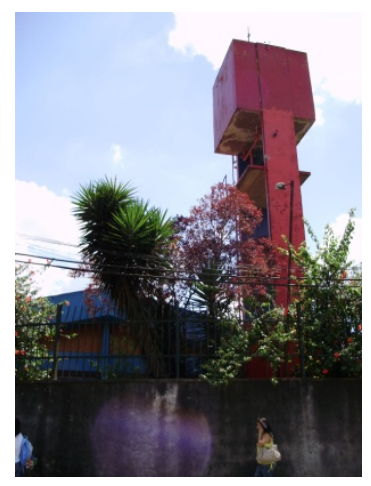

EMEF Antônio Alves Veríssimo avistada a partir do CEU e sucessivamente em alguns pontos do trajeto. Fotos: Ana Lopes, 2010.

CEU Pera Marmelo: referência visual em meio ao entorno. Foto: Ana Lopes, 2010.

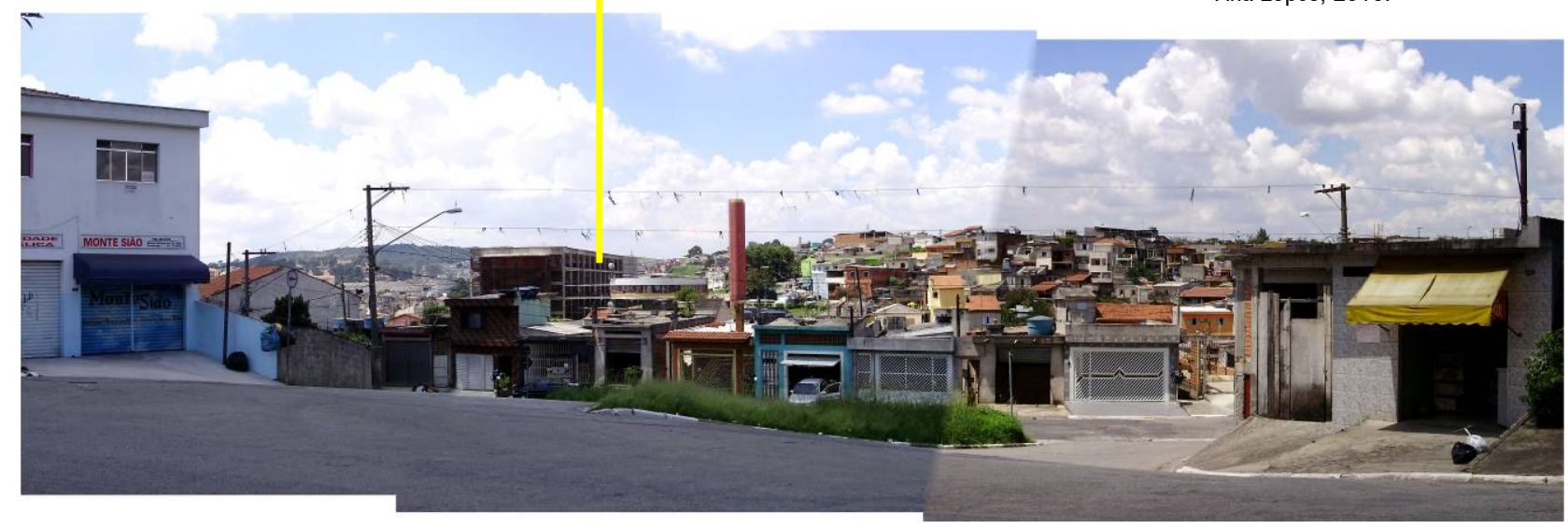



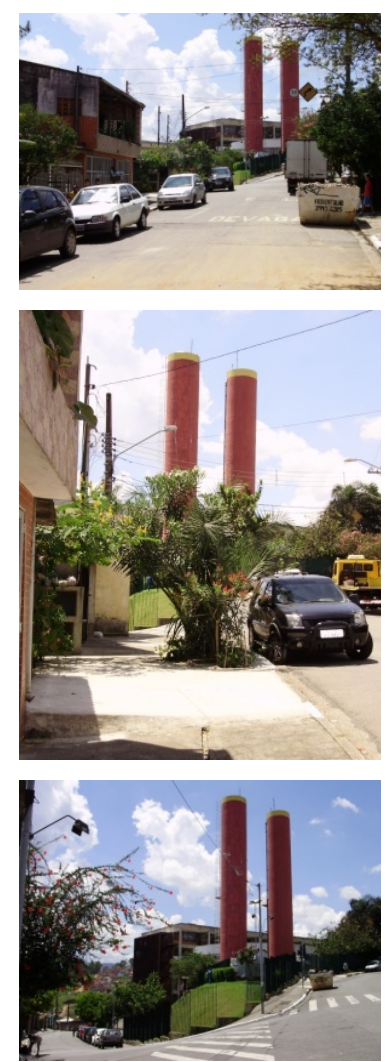

As torres de água do CEU implantadas como um portal de chegada, constituindo forte referência visual na paisagem. Fotos: Ana Lopes, 2010.

De fato, formalmente, o CEU não constitui um edifício tão peculiar àquela paisagem. Neste sentido, mais marcante seria 0 edifício da Ministro Oscar Dias Correia, com sua cobertura metálica em arco. Mas o seu porte causa impacto incontestável. A ausência de revestimento faz com que 0 volume se dilua de certa forma na paisagem. As passarelas e as estruturas metálicas de circulação, entretanto, parecem saltar daquele retrato. Assim como a volumetria curiosa do bloco redondo e as duas torres de água.

Cheguei ao Veríssimo na hora da saída dos alunos. Aproveitei para conversar com alguns deles. Senti uma sensação quase que patriota em relação à escola. Quando perguntei se gostavam, adoravam. Por quê? "Porque é a minha escola, onde estão os meus amigos." Quase como falar da família. Pode não ser tão boa, mas é a minha, onde me sinto confortável.

Quanto ao edifício, logo me assustei com a imponência dos muros. Ao contrário do CEU e da Oscar Dias Correia, cercados apenas por grades, 0 Veríssimo é completamente cercado por muros. Fica até difícil conseguir uma foto externa do edifício. A entrada é feita por uma pequena escadaria, encalacrada em meio aos muros. 0 prédio, de blocos cerâmicos aparentes, é marcado pela estrutura em concreto pintada de azul. Diferente das demais, a escola quase some na paisagem.

Ao lado da EMEF, seguindo um outro longo muro com desenhos pueris, está a EMEI Prof. Dailce Monteiro da Silva Gomes. Apenas dei uma olhada. 0 edifício, sem muito destaque, é agraciado por brises metálicos azuis, que conferem um pouco de modernidade ao volume. Fora isso, é um predinho sem grande apelo arquitetônico, com uma entrada quase marginal, que chega a confundir 0 visitante desavisado.
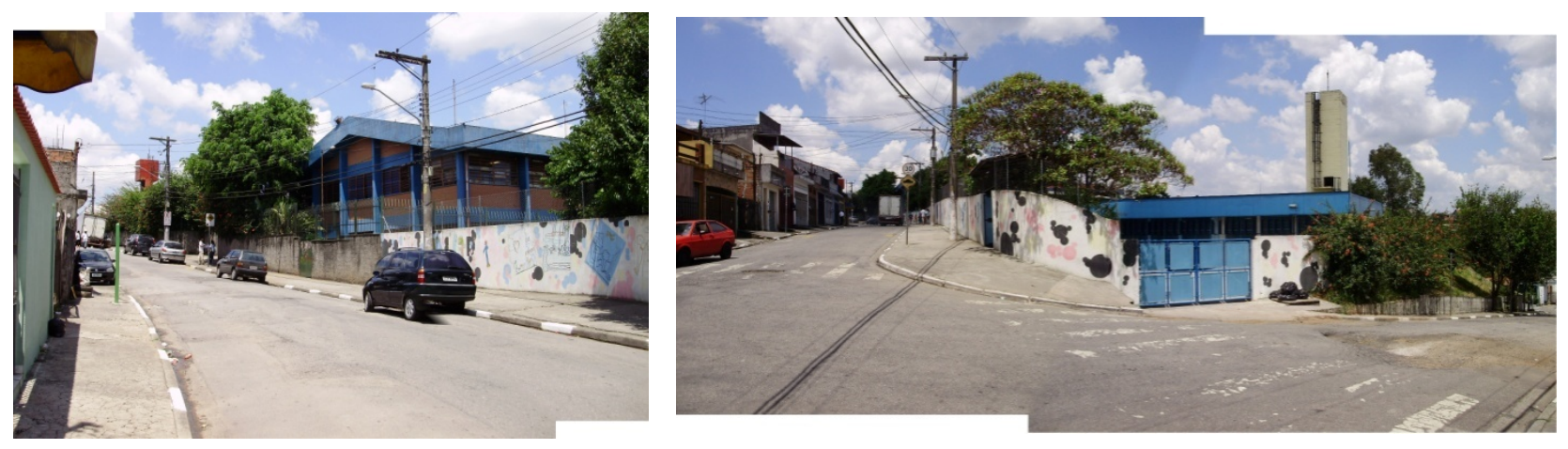

EMEF Antônio Alves Veríssimo e EMEI Prof. Dailce Monteiro da Silva Gomes. Fotos: Ana Lopes, 2010.
Retornei ao CEU para aguardar a saída do turno da manhã. Sentei numa lanchonete em frente ao portão principal e pedi uma água. Logo chegou um casal de pais, para esperar o filho. Aproveitei para conversar um pouco e passar 0 tempo. Os pais pareciam tranquilos e satisfeitos por terem os filhos ali. Reclamavam do período de aulas mais longo, 0 que viria a atrapalhar a 


\section{DESCONSTRUINDO AS ESCOLAS}

rotina. Contudo, elogiavam a diversidade de atividades, 0 que atraia 0 filho e o fazia gostar da escola.

Na saída dos alunos, conversei com mais uma mãe, que esperava a filha de 11 anos sair da aula de violino, do Projeto Guri. Embora a menina estudasse no Veríssimo, fazia aulas de música no CEU no contraturno, atividade com a qual a mãe se mostrava bastante satisfeita.

Na volta à Ministro Oscar Dias Correia, acompanhei duas meninas estudantes do CEU e moradoras do Conjunto City Jaraguá. Regiane e Gabriela estavam na sétima série. A primeira estava no CEU desde a primeira e a outra, há dois anos. Pareciam não muito satisfeitas com a escola. Diziam que apesar de toda a estrutura que o edifício oferece, pouco podiam usar. A piscina, por exemplo, era só para os inscritos na natação ou para uso no final de semana, quando ficaria cheia demais. A quadra estava em reforma há dois anos. Sendo assim, o que lhes restava era apenas uma escola como outra qualquer. Salientaram a preocupação com os próximos anos, pelo fato do CEU não oferecer o ensino médio. Na região, disseram não conhecer uma escola que disponibilize esta etapa. 0 Oscar teria apenas o supletivo e, com a mudança da lei, de seis meses para um ano, a oferta de vagas se reduzira bastante. Quanto ao bairro, disseram não perceber mudanças em função da construção do CEU.

Despedi das meninas e tentei mais um contato na escola estadual. Havia perdido a saída do turno da manhã, mas esperava conseguir conversar um pouco com os alunos que chegassem para o turno da tarde. Resolvi tirar mais algumas fotos, aproveitando o dia de luz intensa. Logo três crianças se aproximaram perguntando se eu era fotógrafa. Eram todos da quarta série, um com 11 anos e os outros dois com 10. Reclamavam da professora tê-los feito esperar no sol, do lado de fora do portão, sendo que ainda faltava meia hora para o início do turno e o calor estava de matar. Diziam um "somos criança" com uma revolta enorme.

Expliquei que era arquiteta e lhes contei que a escola onde estudavam recebera vários prêmios de arquitetura e saíra inclusive em alguns livros e revistas. A surpresa foi grande e logo veio um orgulho. Um deles logo quis me dizer o que achava mais bacana.

- Sabe o que eu acho mais legal? 0 que acha que tem ali? [apontou para a cobertura em arco]

- 0 que?

- Parece que são as salas de aula, mas não! É a quadra! Ninguém adivinha. É a parte que eu mais gosto. 

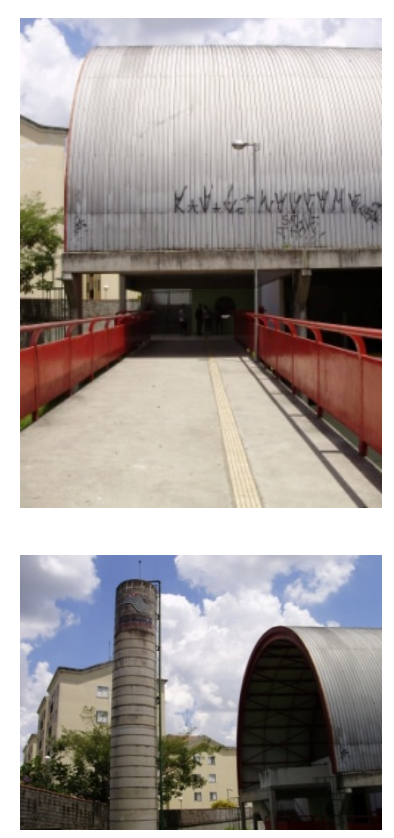

Cobertura metálica em arco da E.E. Ministro Oscar Dias Correia. Fotos: Ana Lopes, 2010.
Aquele comentário ficaria pipocando na minha cabeça. Além de já conhecer parte sem janelas. Mas por que o menino teria esta impressão? Porque a quadra, em geral, fica no térreo...? Porque as salas deveriam estar na parte mais imponente da volumetria...? Enfim, a resposta não encontrei. No entanto, era interessante perceber que aquela volumetria inseria novos padrões de ocupação àquela paisagem, causando, sim, certa curiosidade.

Depois de conversar com alguns outros alunos, inclusive moradores do Conjunto City Jaraguá, decidi regressar. Chegando ao ponto, avistei o letreiro Lapa e achei ser meu dia de sorte. Mal sabia que passaria uma hora e meia sacolejando dentro daquele ônibus, para então chegar à Lapa e pegar a minha segunda condução. Esta não era de fato a melhor opção de transporte para chegar à região.

\subsubsection{OS USUÁRIOS: CONVERSAS.}

0 conceito que você tem de um fato urbano sempre será diferente do tipo de conhecimento de quem vive esse mesmo fato. Essas considerações podem, em todo caso, limitar nossa tarefa; é possível que ela consista principalmente em definir esse fato urbano do ponto de vista do artefato. [...] Mas no próprio interior das ciências a que me referi [referindo-se à geografia urbana, topografia urbana, arquitetura e outras disciplinas], estamos assistindo a um tipo de análise mais vasta, mais concreta e mais completa dos fatos urbanos; ela considera a cidade como "a coisa humana por excelência", talvez também considere aquelas coisas que só se podem apreender vivendo concretamente um fato urbano determinado.

(ROSSI, 1993, p. 18)

Conforme defende Rossi (1993) no trecho acima, impossível a um estudioso definir um fato urbano com a mesma clareza e precisão que seu usuário. A cidade é "a coisa humana por excelência". Caminhando neste sentido, 0 contato com funcionários, usuários e moradores da área-estudo foi assumido como etapa essencial ao estudo de campo. Por meio dos depoimentos destas personagens, a pesquisa procurou complementar as impressões iniciais, frutos das andanças pela área, muitas vezes confirmando-as e, algumas outras, divergindo das conclusões previamente estabelecidas.

Para nortear estas "conversas", foram elaborados roteiros de perguntas específicos para cada entrevistado, sendo este professor, funcionário, 


\section{DESCONSTRUINDO AS ESCOLAS}

usuário ou morador. Apesar das diversas abordagens, apenas algumas delas foram utilizadas para este estudo, dada a inconsistência de alguns depoimentos e/ ou a escassez de informações de outros. Conforme mencionado anteriormente, houve dificuldade em acessar professores e/ ou funcionários em todas as escolas visitadas. Apenas no caso da EMEF Antônio Alves Veríssimo foi possível o preenchimento de um questionário encaminhado por e-mail, cujas respostas se fizeram extremamente enxutas, não trazendo grandes contribuições à pesquisa. Partindo destes depoimentos - embora sucintos -, alguns indicadores podem ser apontados.

Conforme imaginado, o CEU parece ter trazido impactos para o bairro, em geral, favoráveis, segundo depoimentos dos entrevistados. No entanto, este impacto teria se dado muito mais nas condições urbanas da região, do que na qualidade da formação educacional oferecida.

0 primeiro ganho significativo trazido pelo equipamento seria a possibilidade de acesso à cultura e ao lazer: com a implantação dos CEUs, o bairro passou a oferecer atividades culturais e esportivas, sobretudo nos finais de semana, possibilidade esta inédita para os moradores locais. Tânia, 32, moradora do entorno, diria o seguinte:

T. - É, de melhor mesmo, que teve com este CEU, é muita recreação. Tem "recreio nas férias", no final de semana tem o teatro, na terça-feira eles passam aqui entregando um folheto dizendo que tem teatro, tem apresentação à noite [...]. Então é uma aprendizagem muito boa, tanto para mim, quanto para os meus filhos. Muito bom. Tem muito recurso.

E, fora isso, tem outras coisas no bairro, de esporte, cultura, cinema ou coisas do tipo?

T. - Sem ser 0 CEU?

É. Sem ser o CEU.

T. - Que eu conheça, não.

Como a carência de equipamentos culturais e de lazer não é "privilégio" do Jardim Ipanema, mas sim comum à grande maioria dos bairros periféricos, a implantação do CEU Pera Marmelo ocasionou um intenso movimento pendular de usuários: moradores dos bairros adjacentes se dirigem ao Jardim Ipanema para usufruírem das atividades oferecidas pelo CEU.

Tem vindo mais gente para cá?

T. - Vem mais gente. Aqui é muito bom. Tem muita gente já vindo de outros lugares, vindo até morar aqui, por estar próximo do CEU. Tem muito curso que antigamente as pessoas não podiam pagar e hoje você faz praticamente de graça aí. Faz natação, teatro, esporte... 
Conforme mencionou a moradora, o CEU não trouxe apenas mais usuários para o bairro, como também pretendentes moradores. Com a construção do edifício, as ruas do entorno passaram por uma forte valorização imobiliária, dada a intensificação da procura por imóveis nas proximidades do equipamento. Mais do que a oferta de atividades de entretenimento, a implantação do CEU ocasionou intervenções urbanas diversas e trouxe uma significativa melhora nas condições locais de segurança . Além de promover maior fluxo de pessoas - sobretudo, à noite e nos finais de semana - os CEUs, por contarem com equipe de segurança reforçada, acabaram garantindo maior tranquilidade ao entorno.

T. - Ah, principalmente aqui nesta rua [referindo-se à Rua Pera Marmelo, onde está localizado o $\mathrm{CEU}$. Era muita baderna. Eu não morava aqui, mas já sabia que era muita baderna. Então, depois que foi construído o CEU aqui, muita coisa mudou. Tem mais segurança.

A contratação de serviços terceirizados, entretanto, é uma das críticas que se juntam à insatisfação de alguns moradores quanto aos gastos exorbitantes. Ao contrário das demais escolas do município, o CEU dispõe de equipe de segurança contratada, que, além de vigiar o edifício, controla o acesso ao equipamento, que só é feito mediante apresentação dos documentos do usuário.

Além de a contratação elevar os gastos da operação, diversos entrevistados mostraram-se insatisfeitos com a restrição ao uso do edifício. Onde antes tinha um campo de futebol de uso de todos, construiu-se um edifício restrito a poucos. Para alguns dos entrevistados, seria um uso quase privado de um equipamento público, conforme avalia o morador Dirceu, 52:

E nos finais de semana, vocês usam o CEU?

D. - Eu mesmo, não. Porque você vai entrar aí, é uma burocracia. 0 guarda pede o seu nome, o que é uma coisa errada. Eu acho que, se você vai entrar numa escola, e você é da comunidade, é daqui... 0 cara está sabendo que você é daqui.

Priscila de Almeida, 32, professora da EMEF Antônio Alves Veríssimo, também registrou insatisfação no que refere ao uso do equipamento, pelo fato dos cursos oferecidos serem restritos aos alunos da rede.

Enquanto educador, o que acha da proposta dos CEUs? Gostaria de trabalhar lá?

P. - Acho boa, mas me decepcionei, pois sua proposta inicial era de atender a comunidade, mas não está sendo assim. Estão priorizando os alunos da rede. 


\section{DESCONSTRUINDO AS ESCOLAS}

Quanto ao projeto arquitetônico em si, não foram manifestadas impressões. É fato que constitua uma referência na paisagem, funcionando como marco no horizonte. Comentários específicos, entretanto, não foram tecidos. Da mesma forma, não foram mencionadas inovações de caráter educacional frente às demais escolas da região. Tanto a E.E. Ministro Oscar Dias Correia, quanto a EMEF Antônio Alves Veríssimo, foram elogiadas pelos entrevistados e não foram manifestadas opiniões que relacionassem a qualidade do ensino à estrutura dos edifícios. A professora Priscila, enfatizou a qualidade dos professores como ponto forte da escola.

P. - Trabalho no Veríssimo há 4 anos, já trabalhei em várias escolas particulares. 0 diferencial dessa escola é 0 grupo docente antigo. (...) 0 que mais gosto é 0 conhecimento dos professores sobre a comunidade, pois já atenderam até 3 gerações de alunos do bairro (...).

Um fato curioso a ser mencionado é a relação da população com as distâncias. Para a maioria, embora se tratando se um bairro situado literalmente no limite do perímetro municipal, o Jardim Ipanema é considerado um bairro de fácil acesso e, para alguns, inclusive "próximo" ao Centro da cidade. A conclusão se deve, em parte, à proximidade da linha ferroviária, que interliga a região a todas as regiões do município, dada a integração com a rede de metrô.

\subsubsection{A ProduÇão do EspaÇo: ENTREVISTAS COM OS diverSOS AGENTES.}

Para entender a construção do espaço, é importante definir os contextos em que a mesma se delineia. Sendo assim, entrevistas foram realizadas de modo a alimentar dois momentos de desenvolvimento deste estudo: o primeiro, a definição dos contextos da produção; o segundo, a análise da produção propriamente dita.

0 primeiro momento baseou-se em discursos de estudiosos do assunto, enquanto 0 segundo buscou coletar depoimentos de profissionais diretamente envolvidos nos processos produtivos analisados. Ao levantar os depoimentos dos estudiosos, foi possível delinear um amplo panorama das políticas e processos implementados, o que serviu de importante referência para a reflexão a cerca da atuação dos profissionais envolvidos na produção dos edifícios. As conversas com estes profissionais, por sua vez, permitiram apontar características mais específicas, seja no que se refere ao papel de cada ator dentro desta cadeia, seja ao delimitar os interesses e prioridades 
estabelecidos por cada um. É justamente deste segundo momento que tratará o presente item.

Visando abarcar todas as etapas da cadeia produtiva - gestão, projeto e obra -, procurou-se abordar todos os agentes envolvidos no processo produtivo dos equipamentos: autores dos projetos arquitetônicos, equipes gestoras dos programas de governo (no caso dos CEUs há uma sobreposição deste segundo grupo com o primeiro) e as empresas construtoras destes edifícios. 0 fato de Estado - FDE - e Prefeitura - EDIF - trabalharem de formas distintas, torna esta pesquisa ainda mais pertinente, de modo a estabelecer os paralelos entre ambas as condutas.

Foram então elencados profissionais responsáveis pelas administrações públicas, ou seja, FDE e EDIF - Arq. Mirela Geiger Mello, Arq. Alexandre Delijaicov e Arq. João Canteiro-, os arquitetos terceirizados - no caso, o Arq. Ubyrajara Gilioli - e as construtoras envolvidas nestas obras - no caso, a Construtoras Paez de Lima, responsável pela obra da E.E. Ministro Oscar Dias Correia e a OAS, incumbida da construção do CEU Pera Marmelo e de outros três CEUs.

Duas lacunas, entretanto, não puderam ser preenchidas. A primeira refere-se à não realização das entrevistas com os construtores, em ambos os casos. As construtoras foram diversas vezes contatadas, por telefone e e-mail, contanto ambas alegaram não contarem com profissionais aptos a fornecer as informações requeridas, as quais não envolviam nenhum dado numérico, apenas impressões a cerca do andamento dos processos, dificuldades e formas de atuação.

A segunda lacuna está na tentativa frustrada de entrevistar a Makhohl Arquitetura, escritório envolvido nos projetos de alguns CEUs implantados na primeira gestão e que assina os executivos de todos os edifícios construídos na segunda etapa do programa. Uma conversa informal com um dos funcionários, pelo telefone, deixou alguns questionamentos, contudo nunca esclarecidos.

Por outro lado, enquanto agente indireto, foi entrevistada a Companhia para 0 Desenvolvimento Urbano e Habitacional - CDHU, principal "fornecedora" de terrenos para as escolas construídas pela FDE. Esta entrevista, embora ampliada para a política habitacional da empresa, possibilitou compreender melhor o diálogo entre as diferentes instituições.

A seguir serão comentadas as entrevistas realizadas e apontadas as principais considerações obtidas destes diálogos. 


\section{DESCONSTRUINDO AS ESCOLAS}

\subsubsection{Agentes envolvidos na Gestão}

a | Alexandre Delijaicov (conversa realizada em 29/09/2009)

0 arquiteto e professor Alexandre Delijaicov tem uma longa carreira junto ao Departamento de Edificações - EDIF e também leciona na Faculdade de Arquitetura e Urbanismo da USP. É um entusiasta dos escritórios públicos de projeto, o que fica explícito em seu discurso, ao lamentar a perda de espaço destas estruturas nas administrações públicas atuais. A conversa com 0 entrevistado girou em torno do histórico do departamento e visou delinear, sobretudo, o cenário de formulação e implementação dos CEUs, política esta que acompanhou de perto, assinando inclusive a autoria dos projetos implantados na primeira gestão.

Alexandre Delijaicov iniciou a conversa relatando seu ingresso em EDIF, aprovado em concurso público em 1990, e seguiu contextualizando 0 momento político que o departamento vivia. Embora não tenha chegado a trabalhar com Mayumi de Souza Lima, vivenciou o período de gestão de Paulo Freire na Secretaria Municipal de Educação. Em paralelo, presenciou também a implementação da descentralização administrativa, com a criação das administrações regionais, o que traria novas metas à gestão pública.

Ao expor o histórico do departamento, Delijaicov explicitou a experiência da instituição, que teria surgido há 60 anos, tendo, contudo, três nomes ao longo de sua história:

[...] de 48 a 56 chamava-se Comissão Executiva do Convênio Escolar; depois trocou de nome, chamou-se PREF.C.E., que era Prefeitura - Construções Escolares; e na reforma administrativa de 1976, EDIF passou a se chamar Departamento de Edificações. Mas é o mesmo escritório, o mesmo lugar, que foi fundado por uma equipe de jovens arquitetos cariocas. Deles, praticamente todos foram professores da FAU. (depoimento à autora)

Delijaicov mencionou a importância do papel de Hélio Duarte, que trouxera 0 espírito carioca do escritório público do Rio de Janeiro, que era dirigido por Carmen Portinho e Afonso Eduardo Reidy. A arquitetura que produziam contemplava 0 que Delijaicov considera 0 tripé básico da produção pública: habitação, equipamentos e infraestrutura urbana. Com Hélio Duarte à frente, o grupo de arquitetos formado por Roberto Tibau, Eduardo Corona, Ernest Mange, entre outros, construiria, a partir de 48, as bases da rede de edifícios escolares do Estado de São Paulo. 0 conceito norteador seria 0 das EscolasParque: 
Mas o programador, quem estava com a arquitetura do programa, para construir a EDIF em 1948, era 0 educador Anísio Teixeira. [...] Acho que 48 está para Anísio Teixeira como 88 está para Paulo Freire. É, acho que se fosse colocar isso no Governo Erundina, seria assim. (depoimento à autora)

Segundo 0 arquiteto, na década de 90 a equipe de EDIF viria a retomar as origens do departamento, por meio de manuais, desenhos, publicações e até mesmo conversas com os ex-profissionais que passaram por lá, como aconteceu com Roberto Tibau. Nesta época, o Diretor da Divisão de Projetos era Wanderlei Ariza, e abaixo dele, como Chefe de Projetos de Arquitetura, estava André Takiya. Acima de Wanderlei estava Mayumi, como Diretora do Departamento, constituído naquele momento por quatro divisões: três divisões básicas - projeto, orçamento e obra - e uma quarta, de planejamento, que receberia a demanda das secretarias-clientes. As principais seriam sempre Educação e Saúde, por terem verbas carimbadas.

Com Mayumi na direção do departamento, a equipe se empenharia num trabalho consistente de sistematização e racionalização da construção, buscando especificações geometrizadas, "numa coordenação modular entre elementos, componentes, ambientes e blocos". A ideia era formar, mais do que manuais, caderno de experiências. Para o arquiteto, "[...] isso não é uma coisa reducionista ou pasteurizante. Muito pelo contrário: é um exercício muito difícil da arte da construção coletiva do edifício público".

Delijaicov explicitou que naquele momento EDIF contava com uma ampla equipe multidisciplinar, que incluía até departamento jurídico, o que, para ele, constituía uma experiência exemplar. Nos 60 e, principalmente, nos 70, houve uma devastação da equipe de arquitetura e passou-se a fazer "arquitetura para eles" - ditadura - e não mais "para nós". Houve uma devastação do espaço público, por conta de uma demanda crônica.

0 papel da equipe técnica, de carreira, efetiva, é pensar numa política de Estado, num plano diretor arquitetônico que vá além de uma gestão, que passa muito rápido. Então, 0 que aconteceu nos anos 70, 80, foi 0 oposto: 0 arquiteto fica lá cumprindo uma tarefa, tendo que atender a uma demanda, que é crônica, e faz com que haja uma fragmentação, uma degradação do espaço público [...]. (depoimento à autora)

Segundo 0 arquiteto, nesse período teria se perdido a "sintaxe arquitetônica", ou seja, a coerência, o nexo, o elemento de coesão do conjunto. Para ele, tomaria espaço a antítese da Escola-Parque: a "Escola na Praça"45. Não 


\section{DESCONSTRUINDO AS ESCOLAS}

somente as escolas, mas os equipamentos públicos em geral, começariam a ocupar áreas verdes, rotatórias e canteiros, espaços vistos como alternativa para a ausência de terrenos públicos. Raramente se trabalhava com desapropriação de terras e a solução era ocupar as porcentagens não edificadas dos loteamentos, originalmente destinadas às áreas verdes. A este processo 0 arquiteto classifica de "barbárie", um grande equívoco enquanto política urbana, que acabou com diversas possibilidades de áreas verdes e de lazer.

Para o entrevistado este processo só começaria a ser revertido com 0 governo Erundina e, com ele, o conceito freiriano de fazer da cidade uma escola, ou seja, uma Cidade Educadora:

Então, nós imaginávamos que poderíamos recuperar esta dignidade, a qualidade da arquitetura do edifício público, pela fisionomia, pelo aspecto simbólico da visualidade do edifício público, mas principalmente pela reconquista do lugar. Porque a primeira arquitetura é a conquista do endereço, a apropriação do lugar. Então nós temos que reconquistar este lugar enquanto dignidade institucional do edifício público. (depoimento à autora)

A estratégia encontrada para promover esta conversão urbana seria a Praça de Equipamentos: a ideia era fazer de cada subprefeitura uma rede urbana autônoma, contudo articulada às demais, onde um dos distritos constituiria a sede, abrigando uma praça central, onde estaria o paço municipal (sede da subprefeitura), o teatro, a biblioteca, a creche, o restaurante popular, um espaço para plenárias, e também "a história do bairro" e os "projetos do lugar". Os outros distritos - em geral, cada subprefeitura agrega 2 a 3 distritos - abrigariam também suas praças de equipamentos, contudo não teriam 0 subprefeito, mas sim um Conselho Gestor. 0 conceito das Praças de Equipamentos dos anos 90 nada mais era do que uma releitura das Escolas-Parque de 48.

As Praças de Equipamentos tinham, na verdade, uma intenção físico-territorial, de realmente reconquistar um endereço nestes distritos, tinham uma intenção simbólica, "lá é um edifício público", mas também tinha um grande esforço no sentido de convocar, do ponto de vista da participação, da gestão participativa e inter-secretarial. (depoimento à autora)

Segundo Delijaicov, na época em que foi idealizada, no governo Erundina, a Praça de Equipamentos não foi implementada por uma questão de tempo. Toda a conceituação foi elaborada, contudo a mudança da gestão teria 
impedido a continuidade do projeto. Alguns ensaios teriam sido realizados em áreas objetos de um concurso público para habitação, como Jardim Pantanal e Jardim São Francisco.

Quanto à desarticulação entre as diversas estruturas de governo, Delijaicov ressalta o ganho administrativo que teria trazido o governo Marta, com a transferência de EDIF, então atrelada à Secretaria de Serviços e Obras, para a Secretaria de Infraestrutura Urbana e Obras. Assim, duas pernas do tripé habitação, equipamento e infraestrutura - se associaram, restando atrelar a esse projeto comum a política habitacional, o que jamais aconteceu.

Mas, a ideia da Praça de Equipamentos Culturais, tinha um pouco isso: você ter a habitação, que estaria, na verdade, gravitacionando em torno de uma modulação da cidade por parte de equipamentos sociais e, por sua vez, estas praças estariam com endereço ligado à infraestrutura urbana de transporte coletivo, de preferência, sobre trilhos. (depoimento à autora)

Segundo ele, este diálogo teria acontecido no passado, até o momento em que tomou espaço a terceirização. Embora EDIF tenha sempre resistido a este processo, o projeto da habitação teria saído das mãos do governo para as mãos das empreiteiras, processo que Delijaicov não se mostra nem um pouco favorável.

Uma das coisas mais importantes enquanto cultura de projeto, enquanto design público, cultura de projeto e edifício público, é que ao longo dos 60 anos, EDIF projeta. (depoimento à autora)

0 arquiteto defendeu ainda a importância do escritório público enquanto formação de um "saber fazer" construído ao longo da história, de forma coletiva, característica que um escritório privado, preso à autoria e ao peso do "gesto" arquitetônico, nunca teria. Falou também da possibilidade em interagir com outras áreas disciplinares, articulando as diversas políticas num mesmo eixo de intervenção. A possibilidade de se discutir a "arquitetura do programa", procedimento, segundo o arquiteto, típico do construtivismo russo, seria um ganho só possível para o escritório público, com sua estrutura multidisciplinar.

Ao retomar o Convênio Escolar e seu caráter reformador, 0 arquiteto mencionou o papel dos festejos do IV Centenário enquanto desarticuladores da política de implementação das Escolas-Parque. Para ele, as comemorações tiveram um papel político de transferir os recursos da política educacional para um projeto elitista, que beneficiava a área nobre da cidade e, ao mesmo tempo, paralisava um "perigoso" projeto de educação das massas populares. Da mesma forma, a terceirização, defendida enquanto 


\section{DESCONSTRUINDO AS ESCOLAS}

enxugamento da estrutura administrativa pública, não passava de uma estratégia para "desmantelar o escritório público de projeto".

Nós fazíamos, na verdade, 200 projetos por ano, e não é qualquer escritório que tem capacidade técnica, e cultura de projeto - cultura de projeto, orçamento e obra -, e a tendência é que os caras que ficam nervosos com isso vão minando por trás, a ponto, sabe, de desmantelar a equipe. (depoimento à autora)

Chegando aos CEUs, Delijaicov colocou que estes teriam partido da divulgação do caderno conceitual das Praças de Equipamentos, cujo projeto teria coincidido com uma postura política de entrar em áreas periféricas invadidas de grande vulnerabilidade, esquecidas pelo Poder Público. Por isso, a localização dos equipamentos em áreas de fronteira com índices sociais bastante preocupantes.

Então, um administrador público que investe em fronteiras, é confiar no outro. Realmente, vai tirar o déficit de São Caetano, Taboão da Serra, é só atravessar a rua. Mas isso é uma visão importante. (depoimento à autora)

0 entrevistado afirmou ainda que Paulo Freire teria constituído salto semelhante a Anísio Teixeira no contexto das políticas educacionais em São Paulo. A ideia da Cidade Educadora, de aproveitar o que já havia no bairro, apenas potencializando e hierarquizando a rede, seria tão reformadora quanto o princípio da Escola-Parque. Chega a considera que a sigla CEU melhor se enquadraria como "Centro de Estruturação Urbana" ou "Conjunto de Equipamentos Urbanos", traduzindo o potencial de estruturação do bairro, além do caráter educacional.

0 conceito dos CEUs teria sido construído de forma inter-secretarial e 0 projeto de arquitetura teria tentado traduzir todo este ideário, desde 0 novo programa, até as novas ambições, de uma formação integral e calcada na realidade específica de cada lugar:

Eles [os projetos] têm uma coordenação modular, a ideia da pré-fabricação. 0 conceito original era pré-fabricado, mas era totalmente desfamiliarizado, tivemos problemas várias vezes. Então, a ideia de incorporar a cultura construtiva local, também para empregar as pessoas. Só a estrutura era pré-fabricada, mais os vedos. $E$ os caixilhos podiam ser feitos por qualquer serralheiro. E o vedo, eu coloco elemento cerâmico. A piscina antes era coberta, lá na época da Mayumi. Nós mesmos reconhecemos, pela população que pediu a ideia das cidades fluviais, o conceito da praia urbana, e os diretores das escolas pediram para as piscinas ficarem descobertas, porque não era para formar para jogos olímpicos, mas é para formar um balneário municipal. (depoimento à autora)

Descreveu então o programa dos CEUs, que, em suas palavras, reúne 13 equipamentos, sendo 12 ambientes e $013^{\circ}$ equipamento, a alma do CEU, 
que é o Conselho Gestor. Quanto aos terrenos, dos 45 projetos, 30 teriam contado com desapropriação de áreas, tendo apenas 15 deles sido executados em áreas públicas.

Quanto à relação entre os projetos para habitação e para escolas, o arquiteto concordou que os edifícios educacionais tenham garantido qualidade superior, ao menos, do ponto de vista funcional dos ambientes internos. Atentou ainda para um fato interessante: a garantia de uma qualidade espacial mínima para os edifícios públicos, ao contrário das escolas particulares, muitas vezes improvisadas em casas reformadas, com ambientes inadequados para 0 ensino. Em relação à habitação, mencionou 0 absurdo da resignação aos empreiteiros: "Como você pode reduzir a unidade habitacional a 36/ $42 \mathrm{~m}^{2}$ ?". Concluiu com uma crítica à falta de vontade política em desapropriar terras para as políticas habitacionais, esforço concedido, por exemplo, à implantação do Metrô.

b | João Canteiro (conversa realizada em 03/02/2010)

João Canteiro é arquiteto e mestre pela FAU-USP e, na data da entrevista, respondia pela Assessoria Técnica de EDIF, órgão responsável, entre outras coisas, pela revisão do projeto dos CEUs. 0 objetivo da entrevista foi avaliar as principais alterações da proposta em relação à primeira etapa de implantação, tendo em vista se tratar do programa estratégico de governo da gestão anterior, que, surpreendentemente, foi encampado pela gestão seguinte.

0 primeiro ponto importante colocado pelo entrevistado foi o fato do CEU não constituir um equipamento exclusivamente educacional: "O CEU é um equipamento, na verdade, polivalente, vamos chamar assim. Então não dá para você comparar um CEU a uma escola, seja uma escola municipal, seja uma escola FDE. [...] 0 CEU é um programa muito mais ambicioso: não envolve apenas educação. Ele envolve cultura e envolve esporte".

0 segundo ponto interessante é que Canteiro, diferente de Delijaicov, remete a origem conceitual dos CEUs a Darcy Ribeiro, aos CIEPs, e a "outras experiências que aconteceram, que tiveram destaque nos anos de 70, 80 no Rio de Janeiro".

Ao descrever o programa dos equipamentos, ressaltou o deslocamento do Estado para o ensino técnico e superior - ETECs, FATECs e universidades -, deixando cada vez mais o ensino fundamental, as então EMEFs, sob responsabilidade do Município. Com isso, a segunda etapa de implantação 


\section{DESCONSTRUINDO AS ESCOLAS}

dos CEUs teria procurado articular os equipamentos às ETECs, de modo a ampliar a faixa etária atendida e dar maior continuidade ao ensino oferecido: "Então é a continuação: você vai da creche até a Escola Técnica no mesmo conjunto".

Outra diferença seria o fato da atual gestão trabalhar de forma bem mais setorizada: enquanto na gestão Marta a equipe de EDIF procurou se envolver no projeto pedagógico, buscando, segundo Delijaicov, uma arquitetura adequada aos bairros e aos novos conceitos, a EDIF da segunda gestão se concentrou nas questões técnico-construtivas dos edifícios, não se aprofundando nas questões conceituais que trazia a proposta:

Porque é assim: eu tenho uma instalação física, arquitetônica, projetada para você fazer a gestão. Se é um gestor indicado, nomeado, eleito ou se é um Conselho, a gente não entra neste mérito. Se você quer entrar nesta questão, você tem que conversar com a Secretaria de Educação. [...] A gente entrega 0 equipamento e sai do circuito. E depois só entra para dar a manutenção, se for 0 caso. Mas você tem as instalações pensadas e projetadas para dar este apoio, porque se não, você não teria em que equipamento instalar isso. (depoimento à autora)

Canteiro ressaltou o fato dos CEUs imprimirem às atividades culturais $\mathrm{e}$ esportivas um caráter educacional e, por isso, a gestão de todo 0 equipamento pela Secretaria de Educação, e não de Esportes ou Cultura. Desse modo, confirmou que os CEUs constituem sim mais do que escolas, disponibilizando equipamentos públicos nos finais de semana. Contudo, estes equipamentos servem, antes de tudo, ao ensino:

Você poderia passar isso para a Secretaria de Esportes. Mas optou-se por fazer disso uma atividade esportiva, mas de cunho educacional. Então têm professores de Educação Física orientando as atividades, professores de natação dando aulas, palestras... Então, é uma instalação esportiva, uma instalação esportiva que é aberta à comunidade durante 0 fim de semana, mas que acaba sendo um apoio à parte didática durante a semana. (depoimento à autora)

Nesta passagem, 0 arquiteto levanta uma questão interessante, afirmando ser - CEU sim uma escola, contanto uma escola com uma nova política pedagógica, caracterizada por agregar outras disciplinas à formação de seus alunos, atribuindo-Ihes, no entanto, cunho educacional, como sugeriam as Cidades Educadoras de Paulo Freire.

Em relação às inovações dos projetos, o programa teria sido reduzido em alguns pontos - por exemplo, a capacidade do teatro - e o sistema construtivo empregado seria substituído: "Este projeto novo é fantástico. Ele 
é todo em pré-moldado, ele tem iluminação zenital, é um negócio muito bonito".

Ao mencionar o impacto dos CEUs nas regiões em que foi implantado, sempre periféricas, 0 arquiteto mencionou 0 fato dos equipamentos públicos na periferia se destacarem muito por constituírem arquitetura formal e não necessariamente por contarem com um projeto arquitetônico diferenciado.

Tem áreas periféricas terríveis, onde você tem uma pobreza absurda, parece que desceu um disco voador. Você olha assim e vê aquele mar de casas em áreas invadidas, você só vê bloco, só tijolo baiano, aquela coisa marrom, homogênea. Aí, de repente, você vê aquele CEU, ele dá um impacto... (depoimento à autora)

Embora volumetricamente os novos projetos tenham sofrido alguns ajustes, o programa seguiu o planejamento inicial, preservando as áreas indicadas. Quanto ao processo de trabalho, também se seguiu contratando 0 desenvolvimento e o detalhamento dos projetos arquitetônicos, cabendo ao Departamento apenas os estudos iniciais e o gerenciamento do processo.

Em relação às demais escolas do município, Canteiro colocou a predominância de tipologias padrão, atualizadas ao longo dos anos: "Você pega um projeto padrão e, sempre que o terreno permite, você implanta, da melhor maneira possível, rebatido, mas você busca, para ganhar tempo, implantar um projeto padrão. Esse é o carro-chefe. Mas não é um projeto congelado".

Quanto à aquisição de terrenos, 0 entrevistado mencionou três possibilidades. A primeira seria a opção por áreas públicas, provenientes de parcelamentos, implantação de conjuntos ou urbanização de áreas, indo da esfera municipal, para a estadual e, por fim, a federal. A segunda possibilidade seria a ocupação de áreas verdes, uma vez que a legislação permite a ocupação de até $10 \%$ das áreas verdes com equipamentos. A terceira e última solução, seria a desapropriação. Contudo, segundo Canteiro, dado que o recurso para a desapropriação sai da verba da Educação reservada à construção do equipamento, este procedimento é evitado ao máximo, visando privilegiar as construções.

Quanto ao planejamento para os próximos anos, Canteiro afirmou que 0 programa dos CEUs será estabilizado e o foco será transferido para a construção de parques, visando preservar áreas frágeis, evitando que sejam invadidas. Outro projeto é ampliar significativamente a rede de escolas, dada a carência em diversas regiões da periferia, embora escolas em áreas centrais muitas vezes tenham sofrido tamanho esvaziamento a ponto de ter que receber novos usos. 


\section{DESCONSTRUINDO AS ESCOLAS}

Por fim, ao ser questionado quanto aos paralelos entre a produção pública de habitação e a de escolas, 0 arquiteto colocou como determinante a questão do financiamento: "A produção habitacional está ligada, além de outros fatores, a linhas de financiamento completamente diferentes. A produção institucional para educação ela é orçamentária do município". Sugeriu, entretanto, um outro caminho de análise desta relação, bastante interessante, que parte da hipótese que a implantação de habitação pública na periferia seria um importante estruturador - ou estimulador - da malha urbana:

[...] as áreas onde você tem conjuntos habitacionais implantados, elas são, em geral, muito mais bem servidas de equipamentos públicos do que 0 resto da cidade.[...] por ter uma ocupação mais ordenada, você tem hierarquia de ruas, de vias, você tem, bem ou mal, áreas institucionais, tem áreas verdes,... Isso acabou os transformando, com todos os defeitos e críticas que têm os conjuntos habitacionais, numa ilha de excelência no que diz respeito a áreas institucionais. (depoimento à autora)

c | Mirela Geiger de Mello (conversa realizada em 25/08/2009)

A Arq. Mirela Geiger de Mello trabalha na Fundação para o Desenvolvimento da Educação - FDE há 20 anos, ocupando atualmente o cargo de Chefe do Departamento de Projetos, departamento responsável por gerenciar todos os projetos de arquitetura da instituição. Geiger de Mello é mestranda da FAUUSP, onde desenvolve pesquisa a cerca da produção de edifícios escolares em São Paulo. Além disso, é coordenadora e organizadora das publicações lançadas pela FDE nos últimos anos, mencionadas na bibliografia desta pesquisa, as quais trazem importantes registros da produção de edifícios educacionais no Estado.

Mirela Geiger de Mello entrou na instituição logo em seu primeiro ano de gestão, assumindo a área de restauro. Na época, os projetos de obras novas foram transferidos à CHDU, embora fossem até então atribuição da CONESP, instituição considerada a antecessora da Fundação. 0 trabalho de restauro consistia basicamente em adequar os antigos Grupos Escolares às novas demandas curriculares, ditadas pelo programa da Escola Nova.

Segundo a entrevistada, a FDE trabalha hoje como uma grande setorização de funções. 0 Departamento de Arquitetura é responsável pelos projetos, obras e mobiliário, atendendo sempre a demandas vindas da Secretaria de Educação, via Departamento de Planejamento da própria FDE. Dessa forma, nada se discute do programa do edifício. A localização dos equipamentos, os terrenos e até mesmo as áreas dos ambientes já vêm pré-determinados, 
cabendo ao Departamento apenas dar forma ao conjunto de informações. Durante a conversa, Geiger de Mello, embora funcionária da instituição há 20 anos, alegou diversas vezes não estar apta a esclarecer determinados pontos, no que se refere, por exemplo, aos programas pedagógicos, ao diálogo com a CDHU para implantação de escolas em conjuntos novos e até mesmo ao histórico da instituição.

A arquiteta afirmou que a parceria com a CDHU em termos de projeto é rara, embora possa acontecer em alguns casos específicos, visando melhor adequar os projetos. Um grande empecilho para se atingir ganhos de qualidade urbanística nestes projetos seria o fato da verba da Educação não poder englobar nenhuma intervenção complementar ao edifício escolar, como uma praça de acesso, por exemplo.

Na verdade eles têm a verba deles e nós temos a nossa. Mas tanto eles não podem carimbar a escola no dinheiro deles, quanto nós não podemos carimbar a praça. Então o nosso desejo até talvez fosse maior quanto a esta intervenção urbana. Mas não é possível. Então a gente tenta fazer da melhor forma possível dentro do nosso lote, tá? (depoimento à autora)

Em relação à terceirização dos projetos, este seria um processo iniciado ainda nos anos 60 e jamais abandonado pela Fundação. Geiger de Mello justificou a conduta com 0 porte da demanda de projetos que com 0 Departamento trabalha, o que chega a uma média de 200, 300 projetos por mês, incluindo obra nova, reforma, ampliação, entre outros. Todos são elaborados por escritórios/ empresas contratados. A equipe interna faz a gestão destes projetos, incorporando 0 "saber fazer" adquirido pela instituição, tanto no que se refere à especificidade do programa educacional, quanto à questão da gestão pública:

A gente tem esta vivência, 'tá certo? 0 escritório que chega aqui não tem esta vivência. Então, a gente meio o leva a pensar nesta questão do prédio público. Prédio público que não tem manutenção, que não é como a casa. [...] Então uma coisa que a gente tenta é usar materiais, partidos de projeto, "n" questões que não envolvam muita manutenção a longo prazo. (depoimento à autora)

A terceirização de tantos projetos só foi possível graças a um sistema de padronização rígido, que, segundo a entrevistada, passa por constantes atualizações, tendo um departamento dentro da Fundação empenhado especificamente no assunto. Os erros e acertos em obras são constantemente adicionados ou suprimidos destes catálogos, visando garantir a melhor qualidade aos edifícios e reduzir os riscos. Desse modo, inovações são eventuais, tendo que passar por uma série de avaliações, técnicas e financeiras. 


\section{DESCONSTRUINDO AS ESCOLAS}

Geiger de Mello comentou ainda a experiência teste de emprego de estruturas pré-moldadas, na qual foram convidados quatro escritórios de arquitetura renomados, incumbidos de aplicar um sistema estrutural previamente estabelecido:

Na verdade é assim: a gente chamou uma consultoria de estruturas. Este consultoria de estruturas determinou tudo pra gente. A gente falou assim: "A gente quer fazer pré-fabricado, com peças idênticas, estrutura solidarizada" porque 0 pré-fabricado apresentava já algumas patologias quando ela não fosse solidarizada. A gente pediu para esta consultoria e esta consultoria definiu milhões de parâmetros. Foi definido pé-direito, as alturas, as vigas, os pilares, tudo é amarrado, tudo. 0 vão é $7,20 \times 7,20 \mathrm{~m}$, no outro sentido ele é $10,80 \mathrm{X}$ $10,80 \mathrm{~m}$ por causa da quadra, que normalmente está em cima. (depoimento à autora)

Um ponto interessante colocado pela arquiteta diz respeito ao processo de definição dos escritórios a serem contratados. Como o procedimento padrão é a licitação - e fora dela os valores oferecidos são extremamente reduzidos -, a FDE montou uma estrutura própria de edital, que atrela técnica e preço. Com isso, foi possível garantir a contratação de profissionais capacitados e não apenas aqueles que oferecessem o menor preço.

Então, hoje o que se faz? A gente faz como se fosse um mini-concurso. É uma licitação de projeto, em que a técnica vale 7 e 0 custo vale 3 . Então, quem ganha na técnica, ganhou. É muito difícil ele não ganhar. (depoimento à autora)

Por fim, ao ser questionada quanto aos paralelos entre as produções de habitação e escolas, a arquiteta preferiu não se manifestar, direcionando a questão à CDHU.

\subsubsection{Agentes envolvidos no Projeto}

Tendo por objetivo, antes de tudo, comparar os procedimentos de projeto de EDIF e FDE, assumiu-se o estudo de caso do Jardim Ipanema como ponto de partida, recorrendo-se aos envolvidos nos processos de produção das escolas situadas naquele perímetro. Desta forma, chegou-se ao nome de Ubyrajara Gilioli, arquiteto autor do projeto da E.E. Ministro Oscar Dias Correia (ou E.E. Jd. Ipanema, como é conhecida), edifício com volumetria bastante particular.

No que se refere aos CEUs, embora neste caso o projeto seja de autoria da própria EDIF, ao longo da pesquisa verificou-se que um escritório particular tivera presença marcante no processo de elaboração de tais propostas, 
sendo o responsável pelo detalhamento do projeto padrão implementado na primeira etapa e pelos executivos de todos os edifícios implantados na segunda gestão. Trata-se do escritório Makhohl Arquitetura, ao qual foram solicitados alguns esclarecimentos, contudo não atendidos.

Por fim, dadas as entrevistas anteriores, que colocam a implantação de novos conjuntos residenciais como uma das principais demandantes da construção pública de edifícios escolares, considerou-se fundamental incorporar a esta pesquisa o posicionamento da Companhia de Desenvolvimento Habitacional e Urbano - CDHU, de modo a complementar 0 quadro de agentes envolvidos no processo. Foi entrevistado o Arq. Paulo Pignanelli, funcionário da instituição há anos.

\section{a | Ubyrajara Gilioli (conversa realizada em 07/01/2010)}

0 Prof. Dr. Ubyrajara Gilioli é arquiteto, com escritório próprio desde 1961 e membro do corpo docente do Departamento de Projetos da FAU-USP. Além de autor do projeto da E.E. Ministro Oscar Dias Correia (ou E.E. Jd. Ipanema, como é conhecida), objeto de estudo da pesquisa, o arquiteto traz um interessante histórico no que se refere à arquitetura escolar, tendo sido contemplado pelo Instituto de Arquitetos do Brasil - IAB-SP com o prêmio "Rino Levi" pelo conjunto de obras realizadas, no qual constavam basicamente suas diversas escolas, entre as quais propostas executadas pela CONESP e FDE.

Durante a conversa, o entrevistado se mostrou um grande entusiasta da terceirização dos projetos e elogiou o esquema elaborado pela FDE. Para ele, o modelo de licitação empregado constitui uma grande vantagem, uma vez que valoriza a técnica - com peso 7 - em detrimento ao custo - peso 3 . Segundo 0 arquiteto, o cuidadoso processo de seleção se compõe em três etapas, a saber: 1) avaliação jurídica, que consiste na apresentação de uma série de documentos comprovando a experiência do escritório candidato, 0 que inclui a comprovação do chamado acervo técnico, ou seja, registros no CREA de realização de obras do mesmo perfil; 2) etapa técnica, que trata da avaliação qualitativa do projeto; 3) etapa comercial, onde são avaliados os custos do projeto. Para 0 arquiteto, a concorrência financeira seria a grande responsável pela má qualidade dos projetos públicos.

Segundo 0 arquiteto, o profundo detalhamento do programa registrado nos editais da empresa constitui já na seleção um importante instrumento de garantia de qualidade dos projetos. Além disso, o processo de licitação parte 


\section{DESCONSTRUINDO AS ESCOLAS}

de uma proposta 1:500, classificada como Estudo Preliminar, mas que, dada a exigência de detalhamento, delineia-se como um Anteprojeto. Esta proposta deve se basear nos catálogos elaborados pela instituição, que definem ambientes, componentes e materiais.

Além deste modelo de licitação apurado, para Gilioli, outra garantia de qualidade proporcionada pelas condutas da FDE viria da opção pelo emprego de componentes estruturais pré-moldados, o que acabaria por pré-selecionar as empresas a se candidatarem à execução das obras, dada a necessidade de uma maior capacitação. Além disso, a opção por tal sistema colocaria fim aos "puxadinhos", evitando a execução de ampliações improvisadas das escolas da rede.

Apesar das rígidas exigências de padronização da instituição, 0 arquiteto atestou a possibilidade de inovações projetuais, colocando como exemplo a própria E.E. Ministro Oscar Dias Correia, na qual conseguiu emplacar uma proposta de quadra na cobertura, coberta por uma estrutura metálica em arco, sistema construtivo não usual nos edifícios da rede.

Para 0 entrevistado, os catálogos viriam a facilitar o trabalho dos arquitetos, apresentando-Ihes um leque de experiências consagradas, o que pouparia um extenso trabalho de pesquisa. Mencionou, entretanto, 0 fato destes catálogos não estarem compatíveis à realidade atual, demandando uma atualização conceitual.

Quanto à interface com a CDHU, o arquiteto não só afirmou nunca ter presenciado nenhum diálogo entre os diferentes setores públicos, como criticou o fato de não haver uma preocupação com a implantação do equipamento ao se elaborar o projeto dos conjuntos habitacionais. Os terrenos institucionais provenientes destes parcelamentos tendem a ser sempre as piores parcelas da gleba, o que dificulta e encarece a implantação do equipamento.

Ao comentar o projeto específico para a escola do Jd. Ipanema, Gilioli mencionou a preocupação em viabilizar a utilização de parte do edifício aos finais de semana e a prioridade dada ao usuário, acreditando ser este 0 principal instrumento para a apropriação do equipamento pelos moradores.

Embora elogie a resistência de EDIF enquanto escritório público de projeto, 0 arquiteto expôs a terceirização dos projetos públicos como um processo inevitável e, possivelmente, favorável. Ao ser questionado quanto aos paralelos entre a produção pública de habitação e de escolas, Gilioli concordou, complementando que o grande problema da produção de 
habitação popular estaria já no início do processo, ao considerar-se que a habitação possa ser "popular". Com isso, já se definiriam as diferenças entre um projeto de habitação e um projeto de "habitação popular", ou seja, um bom e outro o mínimo: "Falar em habitação popular não faz sentido, porque parte do princípio que uma é pobre e outra não".

b | Paulo Pignanelli (conversa realizada em 06/01/2010)

Paulo Pignanelli é arquiteto e mestre pela FAU-USP. Funcionário da CDHU há 24 anos, o entrevistado ocupa atualmente o cargo de coordenador de projetos do setor de edificações. Dado o longo histórico na empresa, tem um conhecimento amplo dos processos e das mudanças de conduta e de foco ocorridas ao longo dos anos. 0 objetivo da conversa foi, antes de tudo, identificar as interfaces entre a CDHU e os agentes diretamente envolvidos na produção dos edifícios educacionais, muitas vezes implantados nas áreas institucionais de novos conjuntos habitacionais.

A estrutura da CDHU está fundamentada em dois departamentos: Departamento de Urbanismo e Departamento de Edificações, cada um deles formado por um gerente da área, um coordenador de projetos e os técnicos. Segundo 0 arquiteto a hierarquia teria se estruturado, a contragosto dos arquitetos, a partir do governo Quércia, com 0 aumento do recurso destinado à habitação e, consequentemente, 0 aumento da demanda por projetos.

A CDHU foi criada em 1944, no governo Ademar de Barros, contudo só começaria a operar, de fato, a partir dos anos 60, no governo de Carvalho Pinto, sob a gestão de Juvenal Juvência, que convidou Artigas para formar uma equipe de projeto para elaborar um projeto modelo. Daí resultou 0 conjunto CECAP Guarulhos, mais conhecido como Zezinho Magalhães.

A ideia era que esse conjunto fosse uma proposta modelar de cidade, originalmente. Essa ideia - era uma ideia do grupo do Artigas - era aproveitar essa oportunidade que 0 Governo do Estado estava abrindo e tentar modelar uma proposta desenvolvimentista de cidade e de urbanismo. Na verdade, quase que uma política industrial. (depoimento à autora)

Segundo Pignanelli, o Conjunto Zezinho Magalhães teria não só formado a equipe de projeto da CDHU, como também a maneira de trabalhar a ser adotada pela empresa e o modo de encarar a habitação social. Todos esses ideais seriam entretanto atropelados pela implementação do BNH, que introduziria uma política incisiva de priorização da economia em detrimento da qualidade. 


\section{DESCONSTRUINDO AS ESCOLAS}

E a grande madrasta dessa história toda foi 0 surgimento do BHN, nos anos 70 , que vem com uma proposta que ao invés de pensar no ponto de vista econômico da atuação, pensa no ponto de vista da economia: 0 mais barato é o melhor, a quantidade e 0 mais barato. (depoimento à autora)

Com o BNH, a maior parte das empresas de habitação desaparecia e a CDHU seria praticamente a única estatal a sobreviver, mantendo-se como a maior construtora em metros quadrados de habitação social do mundo. Tamanha demanda traria a necessidade de terceirização, à qual, segundo 0 entrevistado, a equipe procuraria resistir, mantendo o escritório de projetos.

As contratações de projetos externos acontecem sempre por processo licitatório de tomada de preço. Diferente da FDE, a CDHU não assume aspectos técnicos específicos como condicionante da contratação. Ao contrário, adota atualmente um sistema de contratação por lotes de projeto, 0 que significa fazer grandes licitações baseadas em valores, por regiões da cidade, em momento prévio à elaboração dos projetos, de modo que as contratadas passam a ser uma espécie de servidor externo, a serem acionadas de acordo com a necessidade da empresa. Os projetos a serem encaminhados para as contratadas podem ser um estudo preliminar, um básico ou um detalhe, dependendo da disponibilidade do escritório interno.

Em geral, as empresas contratadas seguem padrões tipológicos previamente desenvolvidos pela CDHU (há mais de 30 padrões), embora não sejam impedidas de desenvolver novas propostas, desde que adequadas às exigências técnicas mencionadas nos catálogos da empresa. Esses padrões tipológicos seriam atualizados de acordo com as alterações das normas de projeto, adequando-se às novas demandas legais. No momento atual, por exemplo, a principal causa de alterações nos catálogos viria das demandas relativas à universalização da acessibilidade, o que teria levado não só à atualização dos desenhos, mas à adoção de áreas mais generosas.

De qualquer forma, afirmou que atualmente o procedimento de projeto mais comum é a elaboração dos estudos iniciais pelo escritório interno e a terceirização das etapas de detalhamento. Com isso, a tendência é limitar-se aos padrões. Segundo Pignanelli, a dificuldade em relação à terceirização seria garantir a qualidade dos projetos, uma vez que as empresas privadas não têm experiência nesta categoria de projetos habitacionais. Desse modo, afirmou que a equipe interna chega a desenvolver projetos executivos, dada a incapacidade dos contratados.

[...] as empresas terceirizadas têm uma péssima qualificação técnica. [...] A história de projetos executivos é longa. Atualmente diminuiu bastante, mas alguma coisa a gente acaba fazendo, até porque eles não conseguem fazer 
direito. Enfim, chega um material qualquer nosso e a gente acaba tendo que refazer aqui. A gente tem um mínimo de gente qualificada, mas tem. (depoimento à autora)

0 programa de necessidades é sempre elaborado pela própria CDHU, visando minimamente assegurar 0 atendimento à demanda local. 0 partido arquitetônico é igualmente discutido e a implantação, definida em conjunto. A CDHU não trabalha com programa de locação (com exceção ao PAC, voltado exclusivamente a cortiços), contudo se torna a responsável por todas as demandas referentes à manutenção nos cinco primeiros anos do edifício, período de garantia assegurado pela construtora, e também às responsabilidades de formação e consolidação dos condomínios.

Quanto à disponibilidade de terrenos, o entrevistado mencionou que a empresa não conta com uma política de estoque de terras. Há uma busca por terrenos em áreas de demandas reprimidas, além de indicações da própria população quanto a lotes vazios, assim como áreas ocupadas pelos movimentos. A partir daí se dá a desapropriação dos terrenos. Uma outra situação seria a oferta pelos próprios municípios, que fazem a doação dos terrenos à CDHU em troca da construção dos conjuntos. Apenas no caso dos mutirões a situação se inverte: a CDHU repassa o recurso à Prefeitura, de modo a viabilizar a contratação de equipe técnica para formação da mão de obra. De qualquer forma, o projeto tem que passar por sua aprovação, visto que o morador será mutuário da CDHU.

Quanto à implantação dos equipamentos públicos nos conjuntos, a CDHU, em linhas gerais, engloba a construção de creches e centros comunitários em alguns de seus conjuntos. Embora isso tenha acontecido cada vez com menos frequência, em função da dificuldade de manutenção dos edifícios, a empresa conta com alguns projetos padrão que podem ser implementados. Quanto às escolas, os terrenos institucionais dos conjuntos são doados à FDE ou ao município, que se responsabiliza pela construção e manutenção do equipamento.

A implantação das escolas fica, entretanto, inteiramente a cargo do órgão executor. Feita a doação da área, é a Secretaria de Educação que define os programas e os órgãos de projetos, a implantação, não havendo diálogo algum com a CDHU.

Raramente, pode acontecer, porque não há nada que impeça. Mas institucionalmente não há nenhum diálogo, oficial, formalizado. Quando tem algum problema, a gente vai até falar com eles, eles vêm falar com a gente, mas 


\section{DESCONSTRUINDO AS ESCOLAS}

Por fim, diante da questão acerca dos paralelos entre as construções de edifícios habitacionais e educacionais, Pignanelli concordou que a segunda tenha alcançado nível qualitativo superior à primeira. Para ele, tal descompasso estaria vinculado às políticas implementadas, que no caso da habitação teriam prezado unicamente pela quantidade e pelo baixo custo, em detrimento da qualidade. Segundo o arquiteto, uma visão "política, quase que ideológica", contanto equivocada, "do que é habitação de interesse social".

0 que a FDE trilhou desde a época do FECE na construção de escolas e veio evoluindo numa curva ascendente [...], a CDHU fez ao contrário. A CDHU começou no ponto máximo, com o conjunto Zezinho Magalhães, em termos de qualidade em técnica construtiva, qualidade de material, áreas disponíveis, equipamentos, inovação tecnológica, do ponto construtivo mesmo, na utilização de materiais, na utilização de espaços novos, na qualificação dos espaços urbanísticos, [...], com toda a equipagem pronta do conjunto - escola, hospital, posto de saúde, centros comunitários -, tudo que é necessário para que uma cidade exista de fato. Ela veio decaindo e o ponto mais baixo desta curva foi realmente entre 70 e 90 , que é um espaço de tempo longo. (depoimento à autora)

\subsubsection{Agentes envolvidos na Obra}

Infelizmente a pesquisa não conseguiu coletar depoimentos dos agentes responsáveis pelas obras. A meta era entrevistar a Construtora OAS, responsável pela construção de quatro unidades de CEUs implantados na primeira etapa do programa, entre eles o CEU Pera Marmelo, e também a construtora Paez de Lima, a qual executou a obra da E.E. Ministro Oscar Dias Correia. As construtoras foram contatadas tanto por e-mail, quanto por telefone, diversas vezes, contudo alegaram não contar mais com os profissionais que acompanharam tais obras e que tampouco conseguiam identificá-los.

Apesar da ausência dos depoimentos, interessante notar 0 porte das empresas contratadas e o próprio processo de contratação utilizado em cada caso. Sem dúvida, o tamanho do equipamento e a urgência política de prazos para construção dos CEUs exigiram uma maior preocupação em selecionar empresas grandes, com maior capacidade de operação. Contudo, o fato da obra dos CEUs ter sido licitada em pacotes de três ou quatro unidades fez com que a candidatura se restringisse ainda mais às construtoras de maior porte, capazes de arcar com tamanho volume de trabalho e prazos tão exíguos. 
No caso da FDE, as restrições mais rígidas parecem se concentrar na etapa de projeto, cujo processo de seleção assume caráter tão criterioso que acaba por afunilar o leque de candidatos aptos a se inscreverem. Por outro lado, a etapa de obras admite construtoras menores, desde que capacitadas para executar sistemas pré-moldados e, em alguns casos, estruturas metálicas.

\subsection{OS PROCESSOS DE PRODUÇÃO PÚBLICA DE ESCOLAS.}

A partir do estudo da produção de edifícios educacionais em São Paulo e do aprofundamento em um caso específico, este item busca fazer um breve apanhado das características gerais que definem tais procedimentos. A seguir, serão frisados alguns pontos contundentes, que apontam importantes eixos de discussão, objeto do próximo capítulo.

1) Em ambos os casos não foram constatadas inovações espaciais que correspondam a novos conceitos pedagógicos. No caso da FDE, o projeto político-pedagógico segue o mesmo desde seus primórdios, seguindo os parâmetros da Escola Nova, que são apenas atualizados em função das demandas contemporâneas, tais como a introdução da informática ou das normas de acessibilidade universal. Não há, entretanto, inovações na conceituação do ensino. Da mesma forma, os projetos apenas respondem a estas necessidades, sem que haja a incorporação de novas possibilidades espaciais. No caso dos CEUs, embora o discurso corrente aponte para uma "reforma" pedagógica, introduzindo-se o conceito de Cidade Educadora e a democratização freiriana do ensino, os edifícios seguem reproduzindo um modelo padrão de equipamento educacional, com a particularidade da dimensão do programa. De qualquer forma, as salas de aula não fogem das salas de aula padrão, as quadras são quadras, bibliotecas, bibliotecas, e as piscinas, típicas piscinas públicas, fechadas à comunidade e incorporadas a um grande equipamento público cercado por grades e segurança eficiente. Não se constatou nenhuma nova referência espacial do ponto de vista do uso do espaço educacional.

2) Em ambos os casos os edifícios constituem novas referências espaciais no contexto urbano, contanto de pontos de vista diferentes. As escolas da FDE apresentam, em geral, estruturas e volumetria contemporâneas, tendo sido não à toa objetos de diversos prêmios de arquitetura. Quando implantadas em bairros periféricos, são facilmente 


\section{DESCONSTRUINDO AS ESCOLAS}

identificadas e passam inclusive a influenciar os padrões locais da autoconstrução, seja por meio das cores, dos materiais ou da própria tipologia. No caso dos CEUs, o equipamento é também facilmente identificável, contanto em função de seu porte. 0 desenho fortemente modernista poderia facilmente se mesclar ao entorno construído, não fosse pelas dimensões dos blocos, torres de caixas d'água e 0 marcante prédio redondo. De qualquer forma, ambos os casos tornam-se referências na paisagem não pelo requinte de suas arquiteturas, mas sim pela homogeneidade e precariedade dos entornos, tipicamente periféricos. Se estivessem situados em áreas centrais, provavelmente estes edifícios se diluiriam com facilidade em meio à massa de edifícios.

3) Tanto as equipes envolvidas na elaboração direta dos projetos da FDE, quanto dos CEUS, não contam com profissionais da educação e de áreas complementares, como psicologia, esportes, etc., tal como acontecia no Convênio Escolar. No caso dos CEUs, entretanto, em função do projeto ser elaborado pelo Escritório Público, o contato com a Secretaria de Educação é muito mais frequente, o que implica em soluções espaciais mais alinhadas à política pedagógica. De qualquer forma, a equipe de arquitetura em nenhum dos casos é chamada a discutir o projeto político-pedagógico, mostrando que o espaço ainda não é encarado como ferramenta pedagógica, como sugere a proposta de Cidade Educadora.

4) Nenhuma das políticas estudadas incorpora procedimentos participativos de projeto. Mesmo no caso dos CEUs, cuja proposta coloca a comunidade, por meio do Setor de Gestão, como figura central do equipamento, nenhum espaço de participação foi incorporado na elaboração dos projetos. Não por acaso, são frequentes as críticas por parte de usuários e moradores a cerca do programa dos equipamentos e dos procedimentos de gestão empregados.

5) Embora pedagogicamente os CEUs não apresentem inovação conceitual significativa, constata-se um importante salto no que se refere à política pública como um todo, que consiste na criação e viabilização de uma nova referência de equipamento público, o qual reúne programas diversos, como propunham as Praças de Equipamentos propostas na gestão Erundina. 0 programa de necessidades é expandido, permitindo ao equipamento educacional incorporar novos espaços ao currículo.

6) Em ambas as propostas, verifica-se uma busca por avanços técnicoconstrutivos, o que é evidenciado pelo emprego de sistemas estruturais 
padronizados e, no caso dos CEUs implantados na segunda etapa, por um sistema completo de componentes pré-fabricados. De qualquer forma, os custos da implementação de novos sistemas ainda apresentam-se, em geral, elevados, o que inibe a universalização destes avanços.

7) A terceirização dos projetos implementada pela FDE permite uma maior riqueza de soluções arquitetônicas, de modo a melhor adequar os edifícios aos terrenos e os programas de usos e partidos arquitetônicos às demandas locais. Já a solução "carimbo" implementada pelos CEUs permite, além da aceleração da etapa de projeto, a padronização integral dos componentes e a racionalização das obras, com a implementação de componentes pré-fabricados. Contanto, algumas adaptações comprometem a qualidade dos edifícios, que poderiam melhor aproveitar os terrenos. Dependendo da localização dos edifícios, os programas indicados mostramse inadequados.

8) No que se refere à implantação, as escolas da FDE, por terem maior liberdade de desenho, conseguem buscar soluções específicas para cada terreno, contando inclusive com algumas ousadas, como é o caso da própria E.E. Ministro Oscar Dias Correia, cujo acesso principal se faz por uma passarela metálica em meio nível. Da mesma forma, vale destacar que os terrenos utilizados para tais equipamentos, costumam apresentar condições, em geral, desfavoráveis, o que intensifica a demanda por soluções criativas. No caso dos CEUs, pelo fato dos projetos seguirem um mesmo desenho, as adaptações ficam mais restritas e, algumas vezes, comprometidas. Desse modo, pode-se afirmar que o programa só foi viabilizado graças a um esforço político atípico de aquisição de terrenos, os quais, além das elevadas dimensões, são, em geral, planos e com perímetros regulares, categoria raríssima no atual mercado de terras urbanas.

9) Dado o porte da política de implementação dos CEUs, associado ao fato do programa se dirigir às áreas mais excluídas da cidade, ações de estruturação urbana foram incorporadas aos projetos, tais como pavimentação de ruas, iluminação pública, melhoria da rede de infraestrutura básica e especial atenção às redes de transporte locais. No caso da FDE, mesmo nos casos em que as escolas são implantadas em conjuntos habitacionais, é muito difícil incorporar ações que ultrapassem o limite do lote. Segundo Mirela Geiger de Mello, em entrevista à autora, até mesmo a introdução de praças de acesso aos equipamentos devem ser solicitadas à CDHU, a qual, dada a escassez de recursos, raras vezes responde a essas demandas. 
10) Por fim, fica evidente a rigidez das estruturas administrativas de governo, que impossibilitam associar recursos de diferentes proveniências para implementação de projetos articulados. Além do caso citado anteriormente no que se refere à relação entre FDE e CDHU, órgãos da esfera estadual de gestão, no caso dos CEUs, é curioso que, mesmo constituindo um equipamento de programa misto (educação, esporte e cultura), todo 0 investimento tenha vindo da Secretaria Municipal de Educação, o que demandou uma revisão da legislação vigente ${ }^{46}$, elevando 0 valor da dotação para 0 setor, de modo a viabilizar sua implementação.

Quadro comparativo dos procedimentos de produção pública de edifícios escolares em São Paulo.

\begin{tabular}{|c|c|c|}
\hline CARACTERÍSTICAS DOS PROJETOS & $\begin{array}{c}\text { FDE } \\
\text { (Estado) }\end{array}$ & $\begin{array}{c}\text { CEU } \\
\text { (Município) }\end{array}$ \\
\hline Articulação inovação espacial $X$ atualização do projeto político-pedagógico & NÃO & NÃO \\
\hline Introdução de novas referências espaciais no meio urbano & SIM & SIM \\
\hline Interdisciplinaridade na formulação do projeto arquitetônico & NÃO & NÃO \\
\hline Participação dos profissionais da educação na elaboração do projeto arquitetônico & NÃO & SIM \\
\hline Participação dos profissionais da arquitetura na elaboração da política pedagógica & NÃO & NÃO \\
\hline Participação da comunidade na concepção do projeto arquitetônico & NÃO & NÃO \\
\hline Participação da comunidade na construção do edifício & NÃO & SIM \\
\hline Introdução de novo modelo de equipamento público & NÃO & SIM \\
\hline Inovação nos programas de necessidades & NÃO & SIM \\
\hline Inovação nas técnicas construtivas & SIM & SIM \\
\hline Inovação estética & SIM & NÃO \\
\hline Padronização dos critérios e componentes & SIM & SIM \\
\hline Padronização dos projetos arquitetônicos & NÃO & SIM \\
\hline Inovação nas soluções de implantação dos edifícios & SIM & NÃO \\
\hline Adequação dos terrenos aos programas/ projetos de escolas & NÃO & SIM \\
\hline Interface com ações de estruturação urbana & NÃO & SIM \\
\hline Participação de múltiplas fontes orçamentárias na composição dos recursos & NÃO & NÃO \\
\hline
\end{tabular}

Fonte: elaboração da autora.

46. Conforme já mencionado no item 2.9, a alteração da Lei Orgânica Municipal em 2001 determinou que os gastos com educação seriam elevados de 30 para $31 \%$ da receita gerada com impostos e seria autorizado deduzir desta fonte os gastos com transporte, alimentação e saúde, garantindo a interdisciplinaridade de atendimento dos CEUs (MASCARENHAS, 2006). 
OS MEANDROS DA PRODUÇÃO PÚBLICA NA CONSTRUÇÃO DA PAISAGEM PERIFÉRICA PAULISTANA: 0 CASO DOS EQUIPAMENTOS EDUCACIONAIS

[140] 


\section{A construção pública de ESCOLAS EM São Paulo: PANORAMAS}


OS MEANDROS DA PRODUÇÃO PÚBLICA NA CONSTRUÇÃO DA PAISAGEM PERIFÉRICA PAULISTANA: 0 CASO DOS EQUIPAMENTOS EDUCACIONAIS 
Os diferentes caminhos assumidos pela produção pública de edifícios educacionais nas diferentes esferas de governo retratam as posturas políticas adotadas e os processos produtivos que têm pautado a construção da cidade, cada um com suas justificativas e implicações. À parte das especificidades de cada obra, alguns panoramas contrários podem ser delineados, sendo instigante sua contraposição. Trata-se de opções polêmicas, que integram as discussões, seja a cerca da administração pública, seja no que se refere à indústria da construção civil.

A seguir, alguns destes panoramas serão contrapostos, visando avaliar, a partir do estudo realizado anteriormente, ganhos e perdas com que cada postura produtiva tem contribuído para a construção da cidade.

\subsection{TerceirizaÇão X Escritórios Públicos}

A figura do escritório público para a produção de equipamentos em São Paulo foi consolidada, de fato, na década de 30 , com a criação da Comissão Permanente. Incumbida de reformular pedagogicamente 0 ensino e suprir a demanda por vagas, a Comissão contou com a convocação de um grupo de profissionais multidisciplinar, empenhado exclusivamente na produção dos novos edifícios escolares. Formado por profissionais de vanguarda, entusiastas da Escola Nova, o grupo terminou por fixar-se na definição conceitual desta nova política, não conseguindo implementar muitos edifícios.

Com 0 Convênio Escolar, o escritório público foi fortalecido enquanto órgão executor de projetos. Contando com arquitetos de renome, o Convênio incorporou os princípios da arquitetura moderna à produção de equipamentos públicos, introduzindo padrões construtivos inovadores à paisagem da cidade. Além disso, dada a experiência do líder Hélio Duarte com 0 projeto de Anísio Teixeira, as escolas do Convênio passaram a introduzir programas novos e uma constante preocupação com a escala da criança.

A terceirização de projetos foi incorporada à produção pública na década de 60 , com a criação do FECE. A decisão partiu da elevada demanda por salas, o que ultrapassava em muito a capacidade de produção do escritório público, 
fazendo com que o déficit fosse continuamente se agravando. Com a contratação de escritórios privados - 0 que se deu inicialmente por meio de um convênio com $0 I A B$-, além de se ampliar a produção, garantiu-se a elaboração de projetos de alta qualidade, de autoria de arquitetos de destaque no mercado. Dessa forma, a conduta foi desde 0 início bem aceita, consagrando-se como procedimento padrão da produção pública na esfera estadual, hoje representada pela FDE.

Atualmente, todos os projetos de arquitetura da FDE são elaborados por escritórios externos, coordenados por fiscais internos e balizados por catálogos técnicos detalhados. No âmbito do Município, a equipe de EDIF insiste em manter 0 escritório público, que segue dando a linha das propostas arquitetônicas, assinando, no mínimo, os estudos preliminares, quando incapacitado de arcar com as demais etapas projetuais.

A terceirização é uma tendência comum vivenciada pelas diversas esferas de governo, sempre valorizada enquanto alternativa para redução dos custos com a equipe interna e como solução para driblar a tradicional ineficiência das estruturas públicas. Desse modo, a invés de uma estrutura de produção, criam-se equipes de fiscalização, o que transfere a esfera pública da posição de executor para a de gestor.

Atualmente a FDE está organizada em 4 diretorias: Administrativa Financeira; Obras e Serviços; Projetos Especiais e Tecnologia da Informação. A Diretoria de Obras e Serviços está dividida em 4 gerências - Planejamento, Projetos, Obras, Orçamentos e Especificações -, as quais são responsáveis pelo gerenciamento das diferentes etapas da produção dos edifícios escolares. A Gerência de Projetos tem por responsabilidade coordenar e fiscalizar a elaboração dos projetos contratados.

A influência da FDE sobre os projetos é forte, buscando-se dessa forma garantir qualidade aos edifícios, adequando-os de acordo com 0 amplo repertório de experiências acumulado pela instituição. Além da coordenação atenta, as exigências impostas pelos catálogos técnicos evitam que erros sejam cometidos. A seleção dos escritórios é realizada por meio de processo licitatório cuidadoso, composto por técnica e preço, atribuindo-se 7 pontos para técnica e 3 pontos para preço. Com isso, garante-se, no geral, a contratação das propostas de melhor nível técnico.

A inscrição nos processos seletivos da FDE se dá por meio da apresentação de estudo preliminar específico para a escola a ser construída, o qual já deve estar enquadrado nos critérios de padronização exigidos pela instituição e apresentados em seus catálogos técnicos. Apesar deste controle, os projetos 


\section{A CONSTRUÇÃO PÚBLICA DE ESCOLAS}

podem e devem apresentar propostas originais, sendo este inclusive um dos critérios de classificação.

Dessa forma, a diversidade de autoria dos projetos da FDE garante uma multiplicidade de soluções, produzindo uma rede de equipamentos variada, com edifícios únicos, que empregam, muitas vezes, soluções ousadas, além de se integrarem de forma particular a seus entornos. A visibilidade que têm ganhado os projetos das escolas da FDE tem atraído cada vez mais jovens arquitetos, apesar dos reduzidos honorários.

Além desta variedade de soluções de qualidade e da possibilidade de trabalhar com um número de projetos elevado, dada a simultaneidade da produção, a terceirização acarreta um novo quadro institucional, marcado pelo distanciamento do órgão gestor da rotina de produção, levando a uma especialização funcional. Ao desvincular os papéis, permite-se que a estrutura pública possa se dedicar exclusivamente às atividades de coordenação, fiscalização e, sobretudo, planejamento da produção, item fundamental no desenvolvimento de políticas públicas.

No caso do escritório público, dada a unicidade da autoria das propostas e 0 porte elevado da demanda, os projetos tendem à padronização e à simplificação das soluções. Embora na prática isso possa significar redução da qualidade do projeto, em teoria tais características - se de qualidade são interessantes à produção pública, dada a otimização do investimento.

A grande vantagem do escritório público está, no entanto, na possibilidade de diálogo com os demais órgãos da administração pública, o que tende a garantir projetos mais afinados com os conceitos praticados e com as políticas implementadas. No caso dos CEUs, conforme mencionado anteriormente, buscou-se esse diálogo desde o início, com reuniões constantes entre EDIF e Secretaria Municipal de Educação para 0 desenvolvimento da proposta arquitetônica.

\subsection{Padronização $X$ Diversidade}

A padronização tem por objetivo central a otimização dos processos produtivos, vindo como herança da industrialização e da racionalização da produção. No caso da construção, esta padronização pode acontecer em 
diversos níveis, indo desde programas de usos e partidos arquitetônicos, a sistemas estruturais, componentes construtivos, até o canteiro de obra.

No caso da FDE, as coleções de catálogos técnicos, constantemente atualizadas frente à aprovação de novos testes e propostas construtivas, dão as diretrizes dos projetos a serem elaborados pelos escritórios contratados, garantindo que se cumpram os principais requisitos de qualidade exigidos.

[...] o manual de projetação é uma necessidade técnica e profissional; a profissão torna-se cada vez mais difícil de dominar na extensão de sua matéria e as noções perdem sua unidade teórica para além de sua positiva eficiência técnica. (GREGOTTI, 1975, pg. 41)

A utilização de catálogos técnicos como instrumentos de controle da qualidade da produção pública de edifícios educacionais constitui estratégia antiga às instituições brasileiras. Em 1974, 0 Ministério de Educação e Cultura - MEC instituiu o MANEQ - Manual de Equipamento, que continha todas as diretrizes para a construção dos edifícios e mobiliários escolares, indo dos programas de usos e respectivos organogramas ao dimensionamento de todas as peças e componentes a serem utilizados. 0 MANEQ, que contou com diversos volumes, serviu de base para estruturar a produção de edifícios escolares no país. Depois dele, as diversas estruturas de produção pública de escolas viriam a criar seus próprios manuais, adequados a suas demandas específicas e embasados no repertório adquirido por cada instituição.

Em São Paulo, a racionalização da produção pública de escolas foi concretamente estruturada com a criação do FECE. Com a implementação da política de terceirização dos projetos, se por um lado ampliaram-se as possibilidades de produção, por outro se criou a demanda por instrumentos de controle de qualidade, dado o distanciamento dos órgãos gestores das etapas de projeto.

Torna-se assim sintomática a "reestruturação" empreendida pelo Fundo no início da década de 1970, com a "racionalização de métodos e a adoção de meios técnicos adequados", a qual pretendia constituir, no que se refere aos procedimentos adotados para o diagnóstico e planejamento, um "divisor de águas" em relação ao período anterior [...]. (ALVES, 2008, p. 70)

A produção atual da FDE conta com catálogos técnicos de ambientes, componentes, mobiliário, paisagismo e inclusive orientações para as implantações dos edifícios. 0 programa de uso é sempre padronizado, variando apenas em termos dimensionais de acordo com a demanda específica de cada local. 0 sistema construtivo é modular, havendo uma gama de possibilidades pré-determinadas. Embora os manuais balizem as 


\section{A CONSTRUÇÃO PÚBLICA DE ESCOLAS}

propostas, não tolhem a liberdade criadora dos autores, que podem solucionar das mais diversas formas a demanda recebida, desde que respeitadas as diretrizes pré-estabelecidas pela instituição.

Apesar da padronização cuidadosa, a FDE ainda não consegue trabalhar com sistemas inteiramente pré-fabricados, dado o custo elevado de aquisição de tais componentes, mesmo que, em geral, mostre-se compensatório se considerada a otimização da obra. Embora os catálogos definam sistemas compositivos completos, a incorporação de componentes pré-fabricados se restringiu aos componentes estruturais, contando com componentes de vedação, cobertura e caixilharia convencionais, disponíveis no mercado.

À primeira vista, parece contraditório não se estender a pré-fabricação a outros elementos da obra, pois representaria a redução do tempo de trabalho e a racionalização dos métodos construtivos. No entanto, são elementos cujo valor no mercado é ainda muito superior ao equivalente convencional. (FERREIRA; MELLO, 2006b, pg. 29)

Apesar do emprego de componentes e métodos convencionais, 0 desenho é industrializado. À parte da estrutura pré-fabricada, os demais elementos do projeto estão todos especificados nos catálogos com elevado nível de detalhamento, bastando serem selecionados e inseridos no projeto. Verificase, portanto, um descompasso entre projeto e execução: trata-se do desenho de um edifício industrializado, contudo, a produção não 0 é47.

Já no caso dos CEUs, optou-se por uma tipologia padrão, desenvolvida por EDIF e posteriormente implantada e detalhada por escritórios contratados. Dessa forma, o Poder Público visava não só garantir a inserção de uma forte marca no meio urbano, reconhecível pela população em função da volumetria, referência inconfundível na paisagem, mas também otimizar as obras, empregando um sistema construtivo racionalizado e,
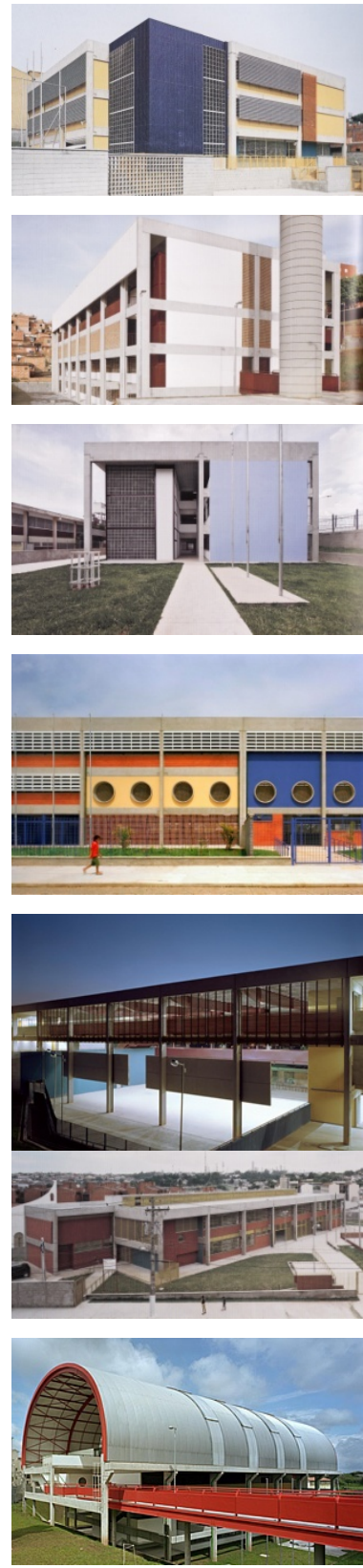

Algumas das diversas tipologias das escolas construídas pela FDE. Fonte: FERREIRA; MELLO, 2006b.

47. Esta mesma contradição levou ao embate entre Vilanova Artigas e o Grupo Arquitetura Nova ainda na década de 60. Enquanto Artigas acreditava que o desenho de uma arquitetura industrializada pudesse impulsionar a industrialização da construção, o grupo formado por Sérgio Ferro, Flávio Império e Rodrigo Lefèvre, defendia soluções construtivas que partissem de técnicas e materiais simples, visando empregar a mão de obra disponível e a cultura técnica local. Ao projetar o Conjunto Zezinho Magalhães, em 1967, Artigas se veria contrariado, ao fracassar com a construção do projeto, que foi executado com um número bastante inferior de edifícios e de forma tradicional, com uso intensivo de mão de obra e pouca mecanização. Segundo Sérgio Ferro, a industrialização do desenho e 0 afastamento do arquiteto em relação aos processos construtivos representavam 0 grande vácuo no qual esbarrava a industrialização da construção naquele momento: "Para ele [Sérgio Ferro], os arquitetos sofriam do mal que eles próprios produziram: o ocultamento e, consequentemente, 0 desconhecimento das relações de produção no canteiro de obras. Se o desenho foi capaz de alterar a forma de construir ao tornar-se uma mediação necessária entre o produtor e o produto na "revolução" descrita por Artigas, agora, o mesmo desenho parecia impotente para realizar sua segunda revolução: conduzir a produção em direção à industrialização." (ARANTES, 2002, pg. 104) 
consequentemente, capaz de garantir maior qualidade, velocidade e economicidade à obra.

A racionalidade construtiva era um modo com que se podia ler toda a história, ainda quando aquela racionalidade permitia a escolha de linguagens diversas $\mathrm{e}$ alternativas. [...] Por outra parte, esta ideia de racionalidade converteu-se num instrumento necessário ao se complicarem as técnicas de construção e ao crescer, sob a pressão dos fenômenos do urbanismo, a prepotente inserção de edifícios, serviços e terrenos como valor econômico na dialética capitalista. (GREGOTTI, 1975, pg. 130)

A eficiência da padronização enquanto conduta de racionalização da produção constitui fato comprovado. No entanto, olhando por outro prisma, apesar de pertinente, pode levar a simplificações de projeto, que refletem em redução da qualidade espacial. No caso dos CEUs, verificou-se uma estreita margem para adaptações locais e vinculações com aspectos culturais, além de uma nítida dificuldade com as adequações físicas do edifício ao próprio terreno, gerando deformações da volumetria, nem sempre bem resolvidas em termos funcionais. 0 CEU Atlântica, por exemplo, ao ser implantado em terreno de forte desnível, precisou contar com uma passarela e uma caixa de circulação específica para adaptar o acesso ao teatro, pensado inicialmente em nível com o bloco didático. No CEU Parque Veredas, o prédio da CEI precisou contar com pé-direito triplo, para que pudesse se conectar ao bloco didático.

Apesar da padronização, vale mencionar que a produção dos CEUs tampouco constitui processo inteiramente industrializado. A opção por um padrão garantiu a pré-fabricação apenas das peças de estrutura, nos edifícios da primeira fase, e, de alguns componentes de vedação e caixilharia, nos projetos implementados na segunda etapa.

Em termos políticos, a imponência dos edifícios padronizados dos CEUs é evidente e torna-se conveniente, sobretudo nos casos em que os equipamentos estão situados em regiões periféricas, de grande informalidade de ocupação. Além de se configurar como marco na paisagem e registro da presença do Poder Público na região, introduz um elemento de estruturação urbana em área de ocupação espontânea, assim como acarreta intervenções complementares - como pavimentação das ruas, implantação de redes de infraestrutura, etc. 0 edifício passa a centralizar as atividades do bairro, proporcionando, a concentração de serviços e comércios a seu redor.

Vale mencionar ainda, que, tanto a padronização dos projetos do CEUs, quanto os catálogos de projeto da FDE são estratégias que visam garantir a estas instituições a qualidade e o bom funcionamento dos edifícios. Embora 


\section{A CONSTRUÇÃO PÚBLICA DE ESCOLAS}

contando com maior liberdade, a produção da FDE talvez seja até mais exigente quanto aos aspectos particulares ao edifício escolar, chegando a definir mobiliário, revestimentos, sinalização, etc., detalhamento este fruto da especialização da instituição na área da educação.

\subsection{Programa de Usos Integrado X Programa de Usos Específico}

0 fato dos CEUs contarem com um programa de usos diversificado, multidisciplinar, constitui experiência nova à produção pública em São Paulo. A começar pelas limitações burocráticas, ambas as esferas de governo sempre encontraram grande dificuldade em articular políticas públicas de diferentes áreas. Muitas vezes, o recurso direcionado para uma Secretaria sequer pode ser empregado em usos complementares a sua atividade principal. É o caso, por exemplo, dos projetos para as escolas da FDE em conjuntos habitacionais, que, segundo Mirela Geiger de Mello, são obrigados a se restringir aos limites do edifício, dadas as imposições relativas à destinação da dotação orçamentária:

[sobre a existência de diálogo com a CDHU] Não... Talvez a gente converse alguma coisa sobre acessos. [...] Aqui o dinheiro é carimbado. É como se fosse carimbado. Ele tem que ser destinado à escola pública. Por exemplo: eu não posso falar que eu vou urbanizar uma praça inteira na frente da escola. Esta urbanização tem que ser da CDHU. Eu posso eventualmente fazer uma ponte com a CDHU... De repente, a minha escola está dando de frente para algum lugar que é muito mais legal para receber a escola e a CDHU fez de um jeito que a gente está voltando as costas para esta praça. Enfim, aí dá para conversar [...] $\mathrm{Na}$ verdade eles têm a verba deles e nós temos a nossa. Mas tanto eles não podem carimbar a escola no dinheiro deles, quanto nós não podemos carimbar a praça. Então 0 nosso desejo até talvez fosse maior quanto a esta intervenção urbana. Mas não é possível. Então a gente tenta fazer da melhor forma possível dentro do nosso lote. (informação verbal) ${ }^{48}$

Desse modo, o comum é que cada Secretaria se especialize na sua área e desenvolva políticas próprias, isoladas das demais. A FDE é, sem dúvida, instituição que detém a expertise da arquitetura escolar. Seus projetos primam pela funcionalidade e estão sempre em completa harmonia com a política pedagógica praticada. Seguem uma linha programática rígida, 
variando apenas em suas dimensões, a partir da demanda de cada local. Os usos nunca fogem à estrutura de salas de aula, sala de informática, reforço, leitura e uso múltiplo, áreas administrativas, serviços e quadra poliesportiva. Sobretudo por razões econômicas, dificilmente as escolas da FDE contam com ambientes complementares e/ ou até mesmo redefinições espaciais do programa padrão, que é sempre modulado de acordo com as normas técnicas da instituição.

Já os CEUs, ao integrar escola e creche a usos esportivos e culturais, constituiu-se em um equipamento híbrido, potencial palco para ensaio da articulação de ações multi-secretariais. Como defendia Paulo Freire, tornar a cidade "Educadora" consistia justamente em atribuir caráter pedagógico aos espaços e atividades da vida urbana e não somente àqueles compreendidos pelas escolas. E, sendo assim, a própria escola, espaço de formação da criança, ganhava novos referenciais.

Apesar do discurso da formação integral e da disposição política para execução do programa, verificou-se que na prática a integração entre as diversas áreas de governo não se concretizou. Os CEUs foram desenvolvidos como um programa da Secretaria Municipal de Educação, com edifício encomendado à EDIF. Embora as demais Secretarias possam ter prestado alguma assistência, seus papéis não foram significativos na concepção, nem na execução da política.

Em termos orçamentários, o recurso saiu integralmente da Educação, que, por meio de decreto específico, teve sua dotação elevada e suas possibilidades de atuação ampliadas (ver item 2.9), viabilizando assim a implementação do programa. Da mesma forma, a manutenção é de responsabilidade exclusiva da Secretaria, o que tem tornado a gestão dos CEUs bastante complicada.

Os projetos dos CEUs foram inteiramente desenvolvidos por EDIF, que, ao contrário da FDE, tem por atribuição o desenvolvimento de projetos de edifícios públicos para as diversas áreas - educação, saúde, cultura, esporte e lazer, etc. -, do que se excluem apenas os projetos habitacionais.

Apesar do programa de usos extenso, diria que o CEU não conta com um programa integrado, mas sim com diversos programas somados, ou seja, 0 CEU não lida com novas referências espaciais e programáticas, mas sim trata de reunir num mesmo terreno diversos dos equipamentos já disponibilizados na cidade. A ideia da formação integrada, do espaço livre, pedagógico por essência, não transparece na arquitetura do conjunto. 


\section{A CONSTRUÇÃO PÚBLICA DE ESCOLAS}

\subsection{Marco Urbano $X$ Integração com o Entorno}

Os CEUs figuram como um novo conceito de equipamento público, que ultrapassa as possibilidades de um equipamento educacional ou cultural, fundamentando-se no princípio da formação integral e do acesso democrático da população às diversas modalidades de serviços públicos. Inspirados nas Praças de Equipamentos de Paulo Freire, os CEUs carregavam entre suas expectativas 0 anseio de constituir mais do que um equipamento institucional, configurando-se como um elemento estruturador do bairro. Neste sentido, Delijaicov chega a sugerir outras leituras para a sigla "C-E-U", que em sua opinião poderia ser melhor traduzida como "Centro de Estruturação Urbana" ou ainda como "Conjunto de Equipamentos Urbanos".

A ideia das Praças de Equipamentos sugeria um espaço central local, que concentraria diversos serviços, marcando a presença do Poder Público em cada região da cidade. Estas Praças seriam hierarquizadas, de modo a formar uma rede urbana autônoma dentro de cada Subprefeitura. Cada Distrito teria sua própria Praça estruturadora, articulada às demais. As Praças seriam abertas ao trânsito e uso, não contariam com barreiras físicas, buscando constituir, assim, estruturas integradas ao entorno dos bairros.

Embora guiados pelo projeto das Praças de Equipamentos, os CEUs tomaram um caminho bastante próprio, desviando-se do projeto de Paulo Freire em seu principal conceito: o de ser uma Praça. Apesar de concentrarem equipamentos diversos num só conjunto, defendendo a ideia da Cidade Educadora, os CEUs não extrapolam os limites do equipamento institucional, voltando-se para dentro de seus muros, com controle de acesso e uso limitado a horários pré-determinados. 0 acesso às piscinas ou ao teatro, por exemplo, são geralmente restritos aos finais de semana ou apenas aos matriculados na instituição nos horários de aulas.

Em resumo, as Praças de Equipamentos prometiam-se mais democráticas: ao invés dos alunos emprestarem sua "escola" ao restante da comunidade, nos finais de semana, as escolas levariam seus alunos a utilizar os equipamentos oferecidos pelas Praças. Neste ponto a cidade se faria Educadora. Não foi o que construíram os CEUs.

Pior do que a restrição às atividades oferecidas é 0 impedimento físico ao acesso e à circulação. Mesmo ocupando áreas extensas, os CEUs são sempre fechados e isolados de seu entorno, constituindo-se numa edificação autônoma da malha urbana e um marco nítido na paisagem, dada a especificidade do conjunto volumétrico. A padronização dos projetos 
À esquerda, CEU Pera Marmelo; à direita, E.E. Ministro Oscar Dias Correia: inserção dos edifícios na paisagem local. Fotos: Ana Lopes, 2009.
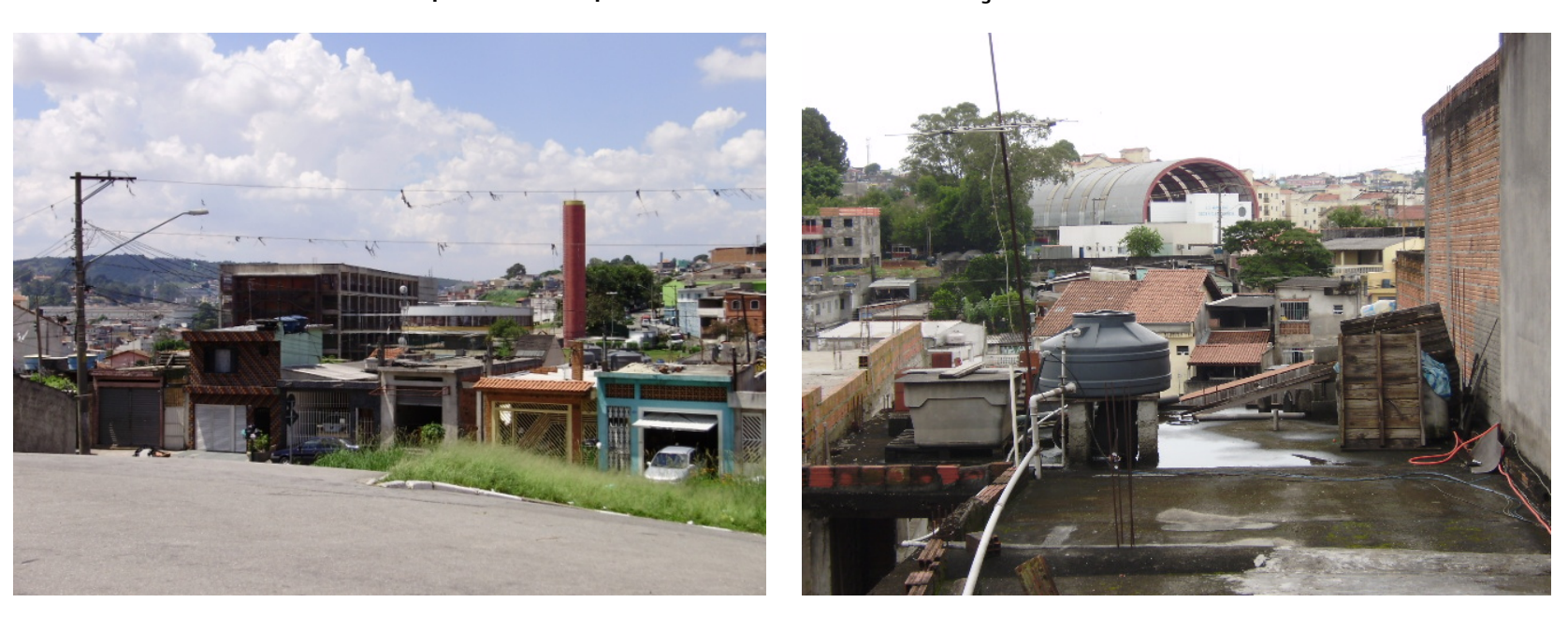
bairros, chegando a influenciar o perfil construtivo das casas do entorno e do repertório arquitetônico da autoconstrução. restringe as possibilidades de diálogo com 0 local, fazendo com que 0 projeto se volte para dentro e não para o bairro.

No caso das escolas da FDE, este diálogo com o entorno é superiormente mais presente. Apesar de constituírem equipamentos de uso específico e restrito, sem grandes ambições urbanas, os projetos desenvolvidos para as escolas da FDE têm sempre buscado integração com seu entorno, até por lidarem, muitas vezes, com terrenos complicados, de perímetro recortado, dimensões reduzidas ou declividade acentuada. No caso da E.E. Ministro Oscar Dias Correia, por exemplo, o desnível entre o terreno e a rua determinou a volumetria do edifício, cujo acesso se dá por uma passarela metálica que cruza o terreno. As dimensões reduzidas do terreno levaram à locação da quadra de esportes no último pavimento do edifício. Nos demais projetos estudados, pode-se verificar uma ampla variedade de soluções arquitetônicas para os contextos urbanos trabalhados, que vão desde dificuldades de acesso à priorização de visuais interessantes, o que leva a edifícios únicos e integrados a seu entorno.

Mesmo integradas a seu entorno, as escolas construídas pela FDE parecem, algumas vezes, representar referências visuais mais fortes que os edifícios dos CEUs. 0 caso do Jardim Ipanema é prova desta constatação, dada a ousadia volumétrica da E.E. Ministro Oscar Dias Correia. Com uma tipologia arquitetônica discreta e um desenho tipicamente modernista, os CEUs se diferenciam na paisagem não pela originalidade do traçado, mas sim pelo conjunto volumétrico: edifício retangular, bloco cultural, prédio redondo e as duas torres. Tratando-se de um projeto padrão e de grandes dimensões, 0 complexo torna-se facilmente identificável. As escolas da FDE, entretanto, destacam-se por introduzirem novas referências estéticas e espaciais aos 


\subsection{Autoria X ProduÇão PÚblica}

A produção pública de edifícios lida com um princípio que vai contra a raiz da atividade artística, que é a não autoria. Ao comparar os projetos estudados, tem-se um interessante exemplo deste embate: de um lado, os escritórios particulares de arquitetura, que por meio dessas escolas enriqueceram seus portfólios; de outro, a experiência do projeto público, que não carrega assinaturas, mas sim marcas de governos.

Embora se saiba da participação definidora de arquitetos como Alexandre Delijaicov, Wanderlei Ariza e André Takya na concepção dos edifícios dos CEUs, não são estes nomes a referência, mas sim os governos de Marta Suplicy, na etapa implementadora do programa, e Serra e Kassab, na etapa de continuidade. Já as escolas construídas pela FDE têm autoria específica, ficando nítido o traçado do autor.

A visibilidade da autoria faz com que os arquitetos busquem soluções inovadoras e procurem fazer desses projetos parte de seus porttólios. No caso do projeto público, a proposta arquitetônica ganha caráter político: ao almejar a consolidação de uma marca, a tendência é o emprego de desenhos padronizados, facilmente identificados na paisagem segundo um conceito de rede, 0 que, muitas vezes, acaba distanciando 0 edifício do contexto local. Por outro lado, a otimização da etapa de projeto por meio do desenvolvimento de uma proposta-tipo, pode permitir um desenho mais detalhado, evitando problemas futuros.

Experiências passadas mostram casos de produção pública "autoral". 0 período do Convênio Escolar proporcionou a elaboração de um verdadeiro catálogo de projetos arquitetônicos assinados por profissionais que encabeçavam a vertente modernista e, naquele momento, compunham a equipe do Escritório Público de projetos. Com o FECE escritórios privados começaram a ser contratados e 0 Escritório Público passou a se dedicar a projetos mais padronizados.

Além dos dois exemplos aqui estudados, talvez tenha se colocado nos últimos anos uma nova experiência, híbrida em autoria, com a criação das assessorias técnicas e 0 desenvolvimento de projetos participativos. Neste caso a autoria é compartilhada por uma estrutura tríplice, na qual, além do Poder Público e do escritório contratado - no caso, as assessorias técnicas -, a comunidade tem especial papel, estando, em geral, associada a movimentos de moradia. Desse modo, os moradores locais, futuros usuários, tornam-se também autores dos projetos de suas casas. 
Por um lado, a autoria pode ser uma ferramenta interessante enquanto garantia de qualidade e inovação projetual, dada a preocupação com a assinatura da obra. Por outro lado, o projeto público, não autoral, não tendo necessidade de marketing ou destaque na malha urbana, pode assumir 0 papel de constituir parte de um projeto maior de cidade, que inove pelo conjunto e não pelo específico, atendendo, sobretudo, às demandas do coletivo. Aí está o cerne de uma consistente política pública.

\subsection{Política Pública X Projeto Arquitetônico}

0 projeto arquitetônico para um equipamento institucional, por mais que vise cumprir uma função específica, constitui, antes de tudo, instrumento político, carregando, desde a sua localização a sua configuração espacial, as diretrizes de um programa de governo. Entre sociólogos, como Preteceille (1977), as dimensões ideológicas da implementação destes equipamentos vêm sendo amplamente estudadas e debatidas, visando aprimorar as estratégias de planejamento dessas redes.

[...] desenvolveu-se de alguns anos para cá um novo tipo de questionamento sobre os equipamentos coletivos, no sentido de uma crítica "radical" das instituições. Podem-se aí distinguir duas correntes teóricas, a primeira que analisa os equipamentos coletivos como aparelhos ideológicos de Estado, inspirando-se no trabalho de L. Althusser (1970) ${ }^{49}$, e colocando em destaque suas funções de repressão, de integração, de hegemonia política e ideológica; a segunda, de inspiração neofreudiana, na linhagem de Deleuze e Guattari, que considera os equipamentos coletivos como um meio de "territorialização", de "fixação dos fluxos libidinosos". (PRETECEILLE, 1977, p. 15)

Além das correntes acima citadas, Preteceille aponta ainda para a questão da homogeneização imposta pelos projetos de equipamentos coletivos, que acabam por definir um tipo de indivíduo ao qual direcionar aquele equipamento, ignorando a heterogeneidade do coletivo e definindo os parâmetros de "normalidade" a serem assumidos pela população: "(...) Só há pessoas normais. 0 conceito de normalidade surge no terreno dos equipamentos coletivos (da medicina e da educação particularmente)." (CERFI apud PRETECEILLE, 1977, p. 16) 


\section{A CONSTRUÇÃO PÚBLICA DE ESCOLAS}

Aymonino (1981) complementa a crítica, relacionando a importância da consideração das novas formas de trabalho e dos aspectos culturais para a definição dos equipamentos a serem implementados:

Por lo tanto, si pretendemos superar las limitaciones de los estándares y definir los equipamientos como un elemento urbano real (que contenga todas las componentes de la vida social) debemos relacionarlos también con los espacios de trabajo y con las posibilidades abiertas por una nueva interpretación del tiempo libre. (AYMONINO, 1981, p. 92)

A produção de escolas em São Paulo já teve início como uma estratégia de cunho político, prestando-se a fortalecer o ideário republicano, por meio da democratização da educação. Para tanto, as primeiras escolas da capital foram construídas em regiões privilegiadas da cidade, sobretudo em grandes praças da região central, com desenho rebuscado e acabamento de primeira qualidade, buscando constituir um marco forte na paisagem, simbolizando a presença do Poder Público e das novas diretrizes de governo implementadas.

As plantas reproduziam 0 modelo de sociedade que se pretendia formar: 0 desejo de ordem era nitidamente expresso no desenho dos edifícios. Edifícios simétricos, com desenho em "U", abrigando alas separadas por gênero, com acessos independentes, área administrativa no centro, controlando os acessos.

Com a criação da Comissão Permanente, em 1936, sob o contexto de modernização instituído pela Era Vargas, nota-se uma significativa mudança nos projetos de arquitetura escolar, empregando-se conceitos de racionalização construtiva e um programa de usos mais diversificado. 0 concreto armado passa a ser amplamente utilizado, permitindo a adoção de vãos mais generosos. 0 pátio é introduzido como ambiente chave, tornandose 0 espaço de integração dos diversos setores do edifício. Com a ampliação da rede, terrenos mais complexos passam a ser utilizados, fazendo com que os projetos se adequem aos desníveis e contornos irregulares.

Interessante notar que, se no final do século XIX as intervenções eram norteadas pelo ideário republicano e o edifício escolar refletia em seu projeto tais condicionantes, na década de 30 , da mesma forma, a política modernizante de Vargas ditaria as diretrizes de implantação destes edifícios. A política de estruturação viária implementada pelo Plano de Avenidas de Prestes Maia, de 1930, procurava priorizar os fluxos, imprimindo um caráter funcionalista à cidade, em detrimento das aspirações puramente monumentais das décadas anteriores. Reflexo disso é, por exemplo, a reformulação urbanística do entorno da Escola Normal da Capital (atual Caetano de Campos), que passou a ser circundada por vias.
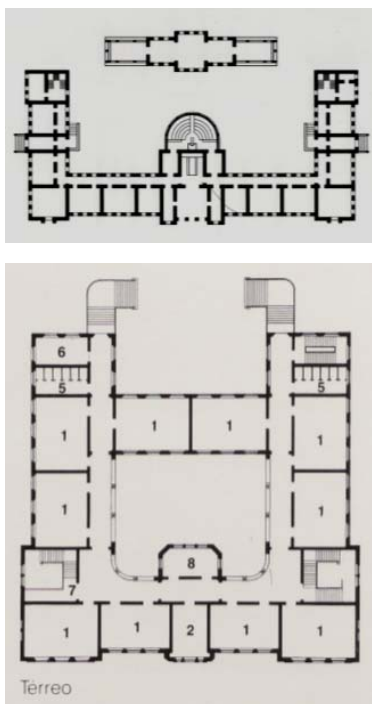

Algumas das tipologias padrão utilizadas nos grupos escolares: acima, tipologia Escola Normal da Capital; abaixo, tipologia Brás. Fonte: CORREA, 1991.

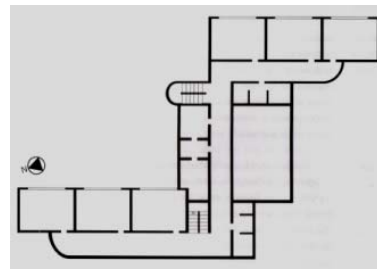

Grupo Escolar Visconde de Congonhas do Campo, projeto da Comissão Permanente. Fonte: BUFFA; PINTO, 2002. 

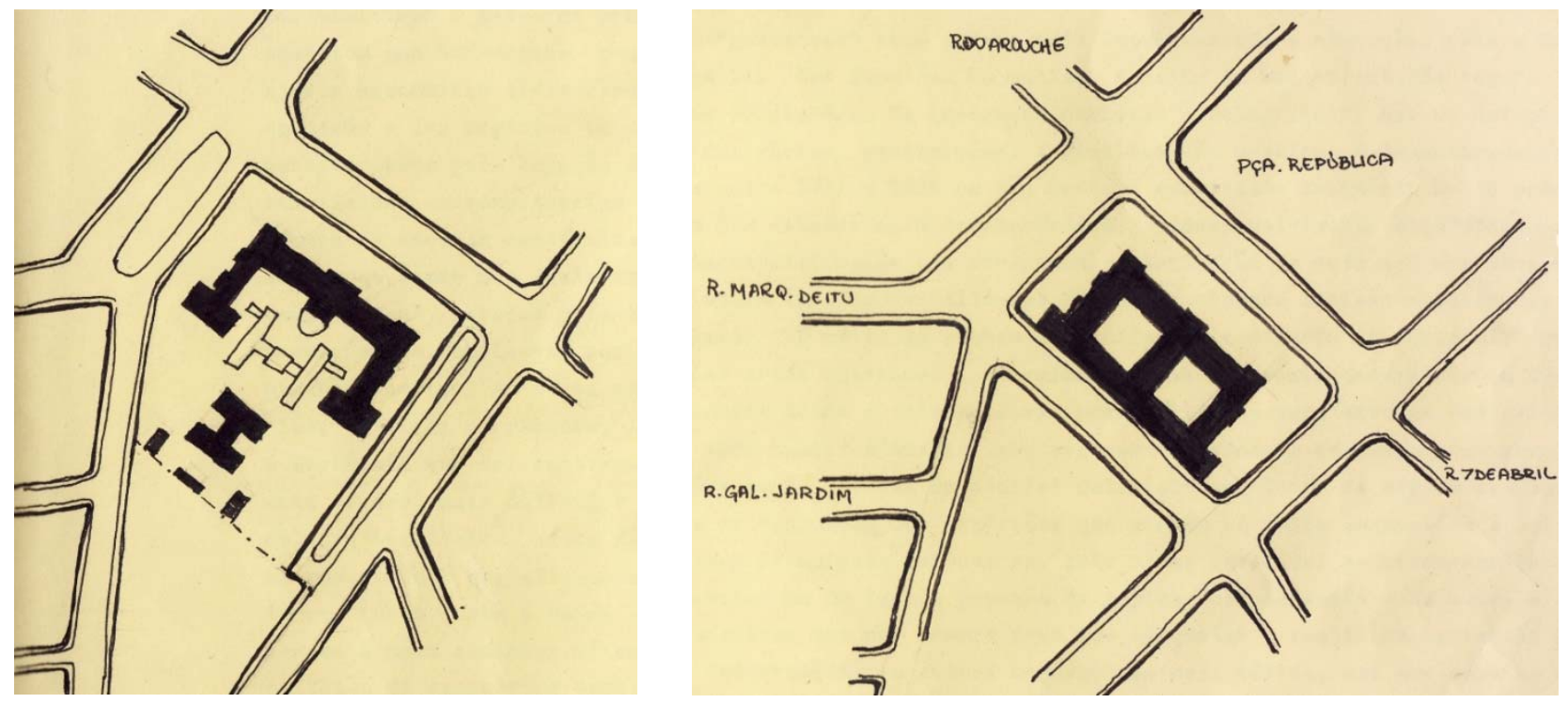

Implantação da Escola Normal da Capital: à esquerda, situação no momento de sua construção; à direita, após reformulação viária de 1940. Fonte: SANTOS, 1973.
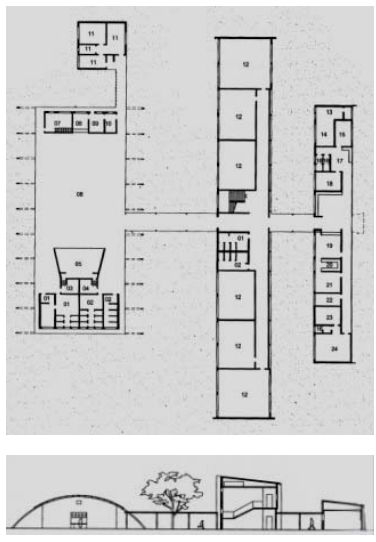

E.E. Canuto do Val (1950), de Oswaldo Correa Gonçalves. Fonte: ABREU, 2007.

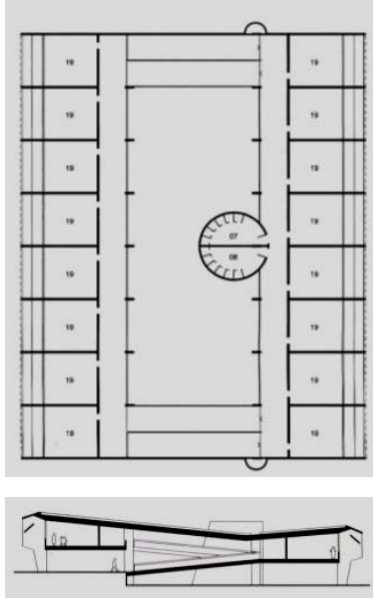

E.E. Oswaldo Samuel Massei (1962), de Fábio Penteado, FECE. Fonte: FERREIRA; MELLO. 1998b.

[156 ]
Com o Convênio Escolar, que tinha como cenário um país pós-Estado Novo, marcado por vanguardas intelectuais que buscavam afirmar suas próprias correntes, abriu-se espaço para a implementação de um novo projeto político-pedagógico. 0 convite a um modernista de vanguarda - Hélio Duarte - para liderar os trabalhos do Convênio já indicava os anseios do novo governo. Norteados pelo conceito das Escolas-Parques e desenhados por arquitetos seriamente envolvidos com a corrente modernista, os edifícios do Convênio instauraram novos padrões espaciais às escolas paulistanas. Num momento de forte experimentação, a equipe de Hélio Duarte buscou desenvolver configurações arquitetônicas mais fluidas, priorizando a relação entre 0 interno - a "Escola" - e 0 externo - 0 "Parque". Os pátios cobertos, varandas e corredores se tornaram espaços de convivência por excelência, assumindo importante papel no projeto da escola, ganhando destaque na volumetria dos edifícios por meio de estruturas de coberturas e elementos de iluminação diferenciados.

A atuação do IPESP/ FECE, iniciada no final da década de 50 , encontrou como cenário o Brasil de Juscelino Kubitschek, marcado por forte desenvolvimento econômico e estímulo à indústria nacional. Contando com a terceirização dos projetos e a contratação de arquitetos renomados, a produção de escolas neste período ensaiou procedimentos de industrialização da construção, empregando peças pré-moldadas, caixilhos industrializados e dispensando o revestimento.

Apesar da tentativa de otimização das obras e ampliação da produção, não se chegou a um desenho padronizado e tampouco a uma implantação seriada. Tal conduta só seria verificada na produção nacional com a implementação dos CIEPs no Rio de Janeiro, já na década de 80 , e depois, 


\section{A CONSTRUÇÃO PÚBLICA DE ESCOLAS}

pelos CEUs, em 2001. Apesar do anseio por uma construção industrializada, as novas técnicas empregadas nos projetos do FECE atribuíram aos edifícios caráter ousado e de difícil replicação.

Com a criação da CONESP, em 1976, há uma nítida desvalorização da política de construção de escolas. Além da redução da equipe, há um corte significativo de recursos e passa-se a trabalhar apenas com o suprimento do déficit, não havendo grandes inovações no que se refere à qualidade das propostas, tanto arquitetônicas, quanto pedagógicas. É, no entanto, um período de forte planejamento administrativo, 0 que se intensifica sob a coordenação da arquiteta Mayumi de Souza Lima.

Os primeiros relatórios de planejamento relativos especificamente à rede de equipamentos educacionais foram elaborados pela Comissão Permanente, de modo a embasar a política a ser implementada. Em geral, esses relatórios tratam de quantificar e situar a demanda no município, não se atendo a caracterizá-la. A partir daí, os equipamentos são construídos seguindo um programa padrão, atendendo ao déficit de cada localidade. Desse modo as escolas vêm sendo construídas ao longo das décadas, quase que mecanicamente, seguindo a expansão populacional, derivada tanto da construção de conjuntos habitacionais, quanto da ocupação espontânea das periferias. Nestes últimos casos, as escolas, em geral, passam a constituir a única representação do Poder Público nas regiões, funcionando como elemento estruturador daqueles bairros.

Ao falar do planejamento quantitativo das redes de equipamentos institucionais, Preteceille (1977) tece uma contundente crítica ao processo político que se instaura, acusando-o de constituir método paliativo para "camuflar" as reais necessidades da população, sob a alegação de uma demanda local, o que gera uma rede numerosa, contudo pouco qualificada.

A pretensão das matrizes de equipamentos assim elaboradas, de fornecer um conhecimento quantitativo das necessidades e de propor uma resposta adaptada, deve ser severamente criticada. E 0 processo político-administrativo de sua elaboração, que não é mais do que uma maneira restritiva, censurada, até mesmo repressiva, de levar em conta as necessidades sociais, sob a pressão das lutas reivindicatórias, permite compreender sua natureza. Hoje, as matrizes de equipamentos, jamais respeitadas, apesar de seu caráter restritivo e censurado, podem desempenhar um papel positivo apenas como referência, para assinalar a pobreza extrema do quadro de vida destinado aos trabalhadores, sendo que a evolução da política de urbanismo operacional tende até a camuflar a subestimação das necessidades, sob o pretexto do respeito à "escala humana": preconiza-se realizar somente pequenos conjuntos imobiliários, o que só faz aparecer, a nível operacional, as necessidades em equipamentos de proximidade imediata. (PRETECEILLE, 1977, p. 13) 

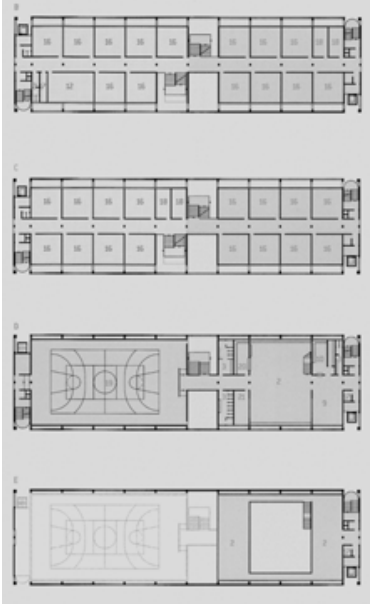

E.E. Vila Nova III e IV (2005), de Barossi \& Nakamura. Fonte: FERREIRA; MELLO, 2006b.
Numa espécie de resposta a essa crítica, Mayumi tentou incorporar aos projetos da CONESP o processo participativo. Apesar de serem poucas as experiências, a arquiteta realizou durante sua atuação na instituição algumas reformas de edifícios escolares contanto com a participação dos alunos e funcionários na definição da proposta arquitetônica e implementou ainda canteiros experimentais de pré-fabricados, numa tentativa de rever a organização dos canteiros e obras e incorporar técnicas construtivas populares às obras públicas, de modo a quebrar o domínio das grandes empreiteiras, o que nunca se concretizou.

Surgindo com uma extensão da CONESP, a FDE procurou dar continuidade à política anterior, buscando levar o planejamento ao extremo, por meio da padronização dos procedimentos e funcionalidade dos edifícios, garantindo uma qualidade mínima às escolas da rede. 0 distanciamento das atividades de projetos foi assumido definitivamente como diretriz, aprimorando-se os processos de gestão da instituição. Atualmente, a FDE tem um trabalho de excelência enquanto resposta à demanda repassada pela Secretaria de Educação, produzindo, com certa eficiência, edifícios cuidadosamente enquadrados nos padrões de qualidade da empresa. No entanto, desde sua criação em 1987, segue realizando o mesmo trabalho, com pequenas alterações dimensionais ou no programa de usos empregado, em geral, de acordo com as instruções normativas instituídas. A demanda é tratada exatamente da mesma maneira em todas as regiões, não havendo exceções em todo o Estado. A política pedagógica também segue a mesma.

No que se refere às plantas dos edifícios, dadas as restrições impostas pelos catálogos técnicos aplicados, poucas inovações podem ser verificadas. Talvez as mais constantes sejam a verticalização dos edifícios, a utilização de blocos separados e a locação da quadra poliesportiva no último piso, alterações ocasionadas pelas pequenas dimensões dos terrenos disponíveis. Antônio Claudio da Fonseca analisa a evolução das plantas escolares como um direto reflexo das transformações socioculturais da população brasileira.

E aí você vai ver que ao longo de todo 0 século XX até 0 início dos anos 50 , a variação destas tipologias - elas não são únicas, mas são muito parecidas - vai se dar pela inserção de novos programas. Então, por exemplo, o aparecimento da quadra esportiva: duas quadras. Em seguida, a quadra esportiva vai pedir uma cobertura. E aí vai ser sempre a quadra do lado feminino que recebe a cobertura $e$ a do masculino fica descoberta. Aí vai aparecer a ideia de uma cantina, que é 0 "comer fora". Isso aparece no final dos anos 40. Não se tinha o costume de se comer fora. 0 Brasil tinha um costume que só se comia fora de casa em viagem. [...] Então se levava lancheira, merenda. E aí a cantina aparece. A cantina vai entrar do lado feminino e olha que curioso: ela vai entrar aqui, na quadra, esta 


\section{A CONSTRUÇÃO PÚBLICA DE ESCOLAS}

quadra deixa de ser quadra para virar um pátio coberto e passa a ter uma quadra só. (informação verbal) $)^{50}$

Voltando à crítica tecida por Preteceille (1977), ao falar da cantina, percebese a adoção de parâmetros adotados típicos a uma classe média brasileira, 0 que está longe de representar os padrões de vida da família alvo da educação pública no país. Mesmo assim, os projetos foram homogeneizados a partir destas referências, seguindo os novos padrões de consumo de que se espera de uma sociedade burguesa.

Frente a este histórico, percebe-se que apesar das constantes atualizações das condutas produtivas e da evolução das técnicas construtivas, em termos conceituais/ pedagógicos os padrões seguiram praticamente os mesmo desde o Convênio Escolar. Nesse contexto, os CEUs aparecem como a primeira tentativa concreta de reforma educacional desde o Convênio. Norteado pelos princípios da Cidade Educadora de Paulo Freire, o programa político-pedagógico proposto para os CEUs previa uma verdadeira reformulação do ensino, considerando a integralidade da formação do indivíduo e a conquista da cidade pela escola, reconhecendo nas diversas estruturas urbanas um rico potencial pedagógico.

No entanto, ao contrário das Praças de Equipamentos - que, também influenciadas pela Cidade Educadora, propunham articular equipamentos institucionais ao redor de uma "praça", criando um centro estruturador do bairro -, os CEUs, enquanto estratégia para proporcionar um ensino integral, optaram pela multiplicidade de usos dentro do equipamento. Ora, se 0 princípio era integrar a escola à cidade e proporcionar a aproximação dos alunos com seu bairro e sua história, criava-se um paradoxo ao voltar 0 projeto para "dentro" de seus muros, criando-se uma ilha de serviços públicos em meio à malha urbana, ao invés de um elemento estruturador da mesma.

Em termos de desenho, os CEUs não trouxeram grandes inovações. 0 programa de usos foi de fato a grande novidade. Além da multidisciplinaridade, ensaiaram a incorporação de instrumentos de gestão participativa, refletida na figura do Conselho Gestor como elemento fundamental na composição do programa arquitetônico. A intenção da autogestão vem caminhando, entretanto, a passos lentos, sendo ainda fundamental a presença da Secretaria Municipal de Educação para o perfeito funcionamento do equipamento.

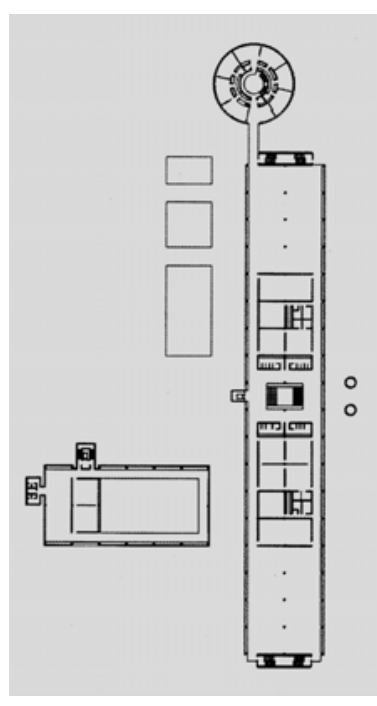

Planta padrão do pavimento térreo dos CEUs da $1^{\text {a }}$ gestão. Fonte: DORIA; PEREZ, 2003. 
Embora o projeto não tenha alcançado as ambições previstas em sua concepção, dois pontos merecem ser destacados: 1) os CEUs imprimiram novo padrão de qualidade e investimento ao equipamento educacional; 2) a política educacional retomou lugar privilegiado no campo das políticas públicas, sendo encarada como potencial estratégia de governo e como espaço propício para significativas transformações. Seguindo a crítica de Aymonino (1981), os CEUs pecariam pela homogeneização, mas, de alguma forma, viriam a incorporar em seu conceito, diferente dos programas anteriores, referências contemporâneas de tempo livre, por meio da reformulação de seu programa de usos.

[...] comprenderemos que la movilidad intrínseca a las nuevas relaciones existentes entre la vivienda y el espacio y el tipo de trabajo [...] comporta necesariamente una clase de equipamientos que podríamos definir como equipamientos de usos múltiples, es decir, "utilizables" en momentos diferentes a lo largo del día (o de otros intervalos temporales) por las mismas personas". (AYMONINO, 1981, p. 92)

Nem sempre o projeto arquitetônico acompanha os passos da política pública. Por outro lado, o projeto público nunca estará isento de uma carga político-ideológica, que pautará não só a sua localização, custo e forma, mas também o seu significado dentro do contexto urbano e seu papel dentro da estrutura social a que visa "satisfazer". 


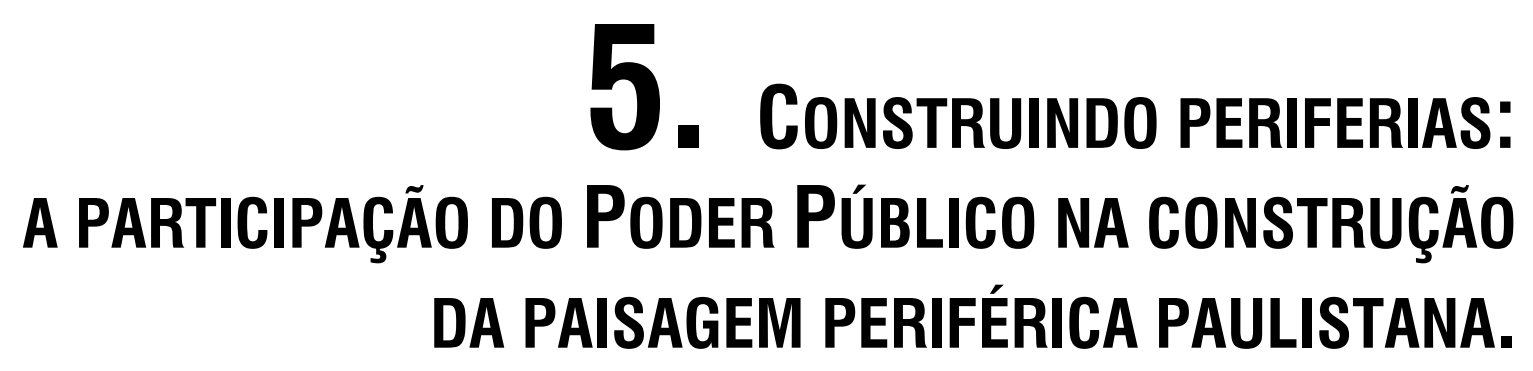


OS MEANDROS DA PRODUÇÃO PÚBLICA NA CONSTRUÇÃO DA PAISAGEM PERIFÉRICA PAULISTANA: 0 CASO DOS EQUIPAMENTOS EDUCACIONAIS

[162 ] 


\section{CONSTRUINDO PERIFERIAS}

A questão dos equipamentos coletivos assume hoje uma importância social e política que se manifesta sob múltiplas formas, dos discursos sobre a qualidade da vida aos movimentos sociais urbanos, passando pelos debates sobre a política dos Estados, à parte dos equipamentos coletivos nas despesas públicas.

(PRETECEILLE, 1977, p. 2)

A produção pública de arquitetura constitui um processo em duas vias; primeiro, por carregar sempre um projeto político-ideológico em sua essência e, segundo, por contar com um potencial significativo de transformação urbana, dada a escala das possibilidades, que têm como terreno de projeto, a cidade. Mais do que um bom projeto de escola, o que realmente impacta no meio urbano é 0 como, 0 onde e 0 porquê um equipamento educacional é implementado. Esse planejamento, mais do que uma resposta à demanda pelo ensino, parte de um plano de ação política muito mais amplo, que visa a estruturação sócio-espacial da cidade. Para Jacobs (2003), o erro está em considerar a arquitetura como ferramenta para a salvação social, devendo-se perceber a amplitude da intervenção em termos políticos.

Um bom abrigo é um bem útil em si enquanto abrigo. Quando, ao contrário, tentamos justificar um bom abrigo com o pretenso argumento de que ele fará milagres sociais e familiares, estamos enganando a nós mesmos. [...] Acontece o mesmo com as escolas. Não se pode depender das boas escolas, embora elas sejam importantes, para a recuperação de bairros ruins e a criação de bairros bons. Da mesma maneira, um bom prédio escolar não garante uma boa educação. As escolas, como os parques, têm tudo para ser elementos passageiros do bairro (assim como elementos de um plano de ação política mais amplo). (JACOBS, 2003, p. 124)

Segundo Preteceille (1977), mais do que uma questão sócio-geográfica de localização da demanda, a produção estatal de equipamentos coletivos é norteada por anseios econômicos, englobando simultaneamente aspectos de produção e de consumo. Este consumo é demandado pelas lutas de classe, buscando sempre equilibrar as desigualdades geradas pelo capital.

Para Harvey (1982), o consumo racional pode ser assegurado pela coletivização do consumo, ou seja, por demandas de uma classe, o que se dá, geralmente, através do Estado, com as demandas por saúde, educação, habitação, etc. No caso do ambiente construído, isso também pode acontecer, sobretudo no tocante à infraestrutura urbana, havendo ainda uma demanda por controle e administração coletivos. Com isso, o ambiente 
construído se torna um campo importante na disputa entre capital e trabalho, na defesa de seus interesses específicos.

Tendo em vista que o capitalismo tem sobrevivido, temos forçosamente que concluir que o capital domina 0 trabalho não só no local de trabalho, mas também no espaço de viver, através da definição da qualidade e dos padrões de vida da força de trabalho, em parte pela criação de ambientes construídos que se adaptem às exigências da acumulação e da produção de mercadorias. (HARVEY, 1982, p. 20)

Desse modo, o projeto do equipamento coletivo passa a constituir projeto de uma estrutura urbana e social muito mais ampla. Neste contexto, as periferias passam a figurar como espaços privilegiados de intervenção, dada a informalidade da ocupação e a possibilidade de estruturação, ao contrário das áreas centrais, já consolidadas e engessadas pelo mercado.

A periferia é de fato um local onde vivem os pobres, é socialmente segregada, e o preço da terra é baixo, porém, ao mesmo tempo, é um local mutante, sempre reproduzido em novas extensões de terra, enquanto velhas periferias são gradualmente incorporadas à cidade, ocupadas por novos moradores e reorganizadas pelo capital. (MAUTNER, 1999, p. 254) - grifos do autor

A entrada do Estado nas periferias já ocupadas, o que se dá, em geral, primeiro pela implementação de equipamentos, representa não só uma resposta à demanda existente, mas também a inserção da região na cidade formal, reproduzindo nas regiões de ocupação espontânea os parâmetros urbanos encontrados nas regiões centrais. Desse modo, o Estado procura afirmar seu domínio sobre o território, atribuindo-lhe status de cidade. Segundo análise de Ramoneda (1992), importante ressaltar que, por se tratar de um território virgem, essas periferias, ao contrário dos centros consolidados, podem abrigar projetos inovadores, experiências urbanas potenciais, oferecendo condições inéditas para tanto. Tal fato pode atribuir a essas áreas especial interesse.

There is a compulsory relationship: centre - periphery. Every periphery is, precisely, the surroundings of a centre. Thus it is the latter that takes on the initiative in the relationship, meaning the power. It is from the centre that the interventions are made on the periphery, and it is in the city centre's trail that the periphery is constructed. A place for expansion and growth, a place where all that which is a nuisance in the centre, ranging from factories that make noise and contaminate, to the immigrants who are only wanted to work; a place for exclusion and margination. But this periphery is also the image of the centre, a mirror of the way in which the latter is constructed. [...] A relationship of authority has never corresponded to one side alone. And the periphery has its own weapons. The centre is old whereas the periphery is new and young. The centre is a ground for restoration, the periphery can represent a space for innovation. (RAMONEDA, 1992, p. 1) 


\section{CONSTRUINDO PERIFERIAS}

A ocupação de regiões periféricas pelo Estado, mais do que atender a uma demanda populacional, gera valorização imobiliária e atrai equipamentos e serviços privados. Justamente aí está o potencial de transformação remetido aos processos de produção de equipamentos, não presente, por exemplo, na produção habitacional. A produção de habitação por si só não insere o local na rede urbana, e consequentemente o deixa fora do circuito do consumo. Por outro lado, conforme já colocado, a construção de conjuntos pode impulsionar a implementação de equipamentos, levando, desse modo, à valorização do território. Por constituir ação estratégica para as políticas públicas e por tratar da construção de bens permanentemente públicos, a produção de equipamentos institucionais conta com investimentos significativos e condições de execução privilegiadas dentro do contexto estatal, sobretudo se comparadas à produção de habitação.

No caso das escolas, entrando neste campo político, coloca-se uma primeira conclusão: os projetos para equipamentos educacionais apresentam qualidade técnico-arquitetônica não verificada em outros setores governamentais que investem na construção de edifícios, como, por exemplo, no setor habitacional. Além de um histórico de qualidade construtiva, os equipamentos educacionais vêm sustentados por um arcabouço conceitual, verificando-se ao longo da história uma recíproca relação entre esses processos construtivos/ arquitetônicos e as propostas pedagógicas.

À parte dos diferentes contextos político-administrativos - sobretudo no caso dos equipamentos educacionais, que contam com dotação orçamentária exclusiva -, o descompasso entre a produção de equipamentos e a produção de habitação está fortemente apoiado na questão da propriedade. 0 fato de a política habitacional estar integralmente calcada na propriedade privada - isto é, na venda das unidades habitacionais produzidas, em geral, pelo Poder Público - leva a uma redução máxima dos investimentos, buscando apenas uma produção massiva, que se sobrepõe ao interesse pela qualidade. No caso dos equipamentos, em se tratando de patrimônio estatal, a preocupação com o desempenho do edifício no médio e longo prazo se acentua, visando sempre a maior funcionalidade e a menor manutenção.

Aproveitando este paralelo, outro aspecto a mencionar é que, se por um lado apresenta melhor qualidade, por outro, a produção de equipamentos caminha num ritmo muito mais lento que a produção habitacional, havendo sempre uma significativa defasagem entre a construção de conjuntos habitacionais e a implementação dos serviços. 
A moradia no bairro foi parcialmente resolvida pela verticalização, ou seja, instalação de conjuntos habitacionais para 0 segmento da população de baixa renda, 0 que também vem se processando em bairros mais distantes. Mas 0 ritmo de implantação de equipamentos urbanos e de saneamento básico não acompanha o ritmo das construções verticalizadas e de outros tipos de ocupação da Cidade. (PONTUSCHKA, 2004, p. 373)

Conforme apontado por Pontuschka, a verticalização dos empreendimentos residenciais - que se apresenta como uma importante alternativa para lidar com a escassez de terrenos, problema constantemente enfrentado pela administração pública - constitui umas das causas do descompasso da produção de equipamentos frente à ocupação da cidade. A concentração de unidades habitacionais numa mesma região acentua-se, demandando equipamentos de maior porte, 0 que não só eleva os custos como dificulta a busca por terrenos.

Embora todo conjunto habitacional conte com uma área institucional, dois obstáculos se colocam à sua utilização: 1) as más condições desses terrenos, que consistem, em geral, em restos da gleba descartados pelo projeto habitacional; 2) a ocupação espontânea por habitações informais. Dessa forma, a implantação do equipamento precisa, muitas vezes, recorrer a outras locações ou, na pior das hipóteses, à desapropriação, conduta evitada ao máximo, dada a complexidade e lentidão do processo.

Uma outra causa dessa defasagem da produção está no financiamento. Como a habitação conta com investimento privado - subsidiado, mas privado - em momentos econômicos ascendentes há expansões imobiliárias significativas, impossiveis de serem acompanhadas pelas demais redes de serviços públicos, mesmo que bem planejadas.

E, tratando da expansão habitacional, a terceira causa deste descompasso, talvez a mais grave, é a expansão intensa e incessante das ocupações irregulares. Torna-se inviável acompanhar a expansão da mancha urbana, que cresce a proporções superiores ao crescimento populacional. Para a regularização dessas áreas, há uma demanda formal por equipamentos públicos, intervenção fundamental no processo de urbanização desses territórios.

Partindo para o campo técnico-construtivo, uma segunda conclusão merece ser apontada: os equipamentos educacionais contam com um histórico construtivo particular no contexto da produção pública, demonstrando saltos qualitativos significativos e atrelando projeto pedagógico à arquitetura, Dos Grupos Escolares em seu estilo neoclássico ou eclético, imprimindo à arquitetura a grandiosidade exigida pela política implementada, passando 
pelos edifícios do Convênio e do FECE, calcados na funcionalidade e erguidos sob as novas possibilidades estruturais do concreto, chegando aos elementos pré-fabricados da FDE ou às estruturas metálicas dos edifícios padronizados dos CEUs, a produção de escolas segue uma linha evolutiva que reflete, muitas vezes, as ambições artísticas e técnicas vividas pelo país.

A evolução das técnicas construtivas caminhou junto com as ambições das políticas pedagógicas, constantemente revistas, mas, sobretudo, com as demandas por vagas sempre crescentes, que levavam à busca por alternativas de otimização da produção. Embora a inserção dessas novas técnicas possa ter, em geral, elevado os custos iniciais da obra, segundo Mello ${ }^{51}$, se mantidas, foi porque comprovou-se a eficácia do investimento no médio/ longo prazo. No caso da habitação, este tipo de conduta não é admitida, dada a diretriz de reduzir os investimentos iniciais ao extremo.

Por fim, no campo simbólico, uma terceira conclusão deve ser apontada: há forte impacto desta produção na paisagem urbana periférica, evidenciando a formação de redes de equipamentos, não verificadas em outros setores. Dado 0 elevado número de escolas - geralmente o primeiro equipamento público a chegar às periferias -, o porte dos edifícios e 0 fato de contarem com programas de usos padronizados, ocasionando tipologias similares, a rede de equipamentos torna-se facilmente reconhecível em meio à paisagem dos bairros periféricos. Em uma foto aérea estas redes podem ser facilmente destacadas.

Foto aérea da região do Jardim Ipanema, área-estudo adotada por este trabalho. Fonte: Google Earth, 2010. Elaboração da autora.

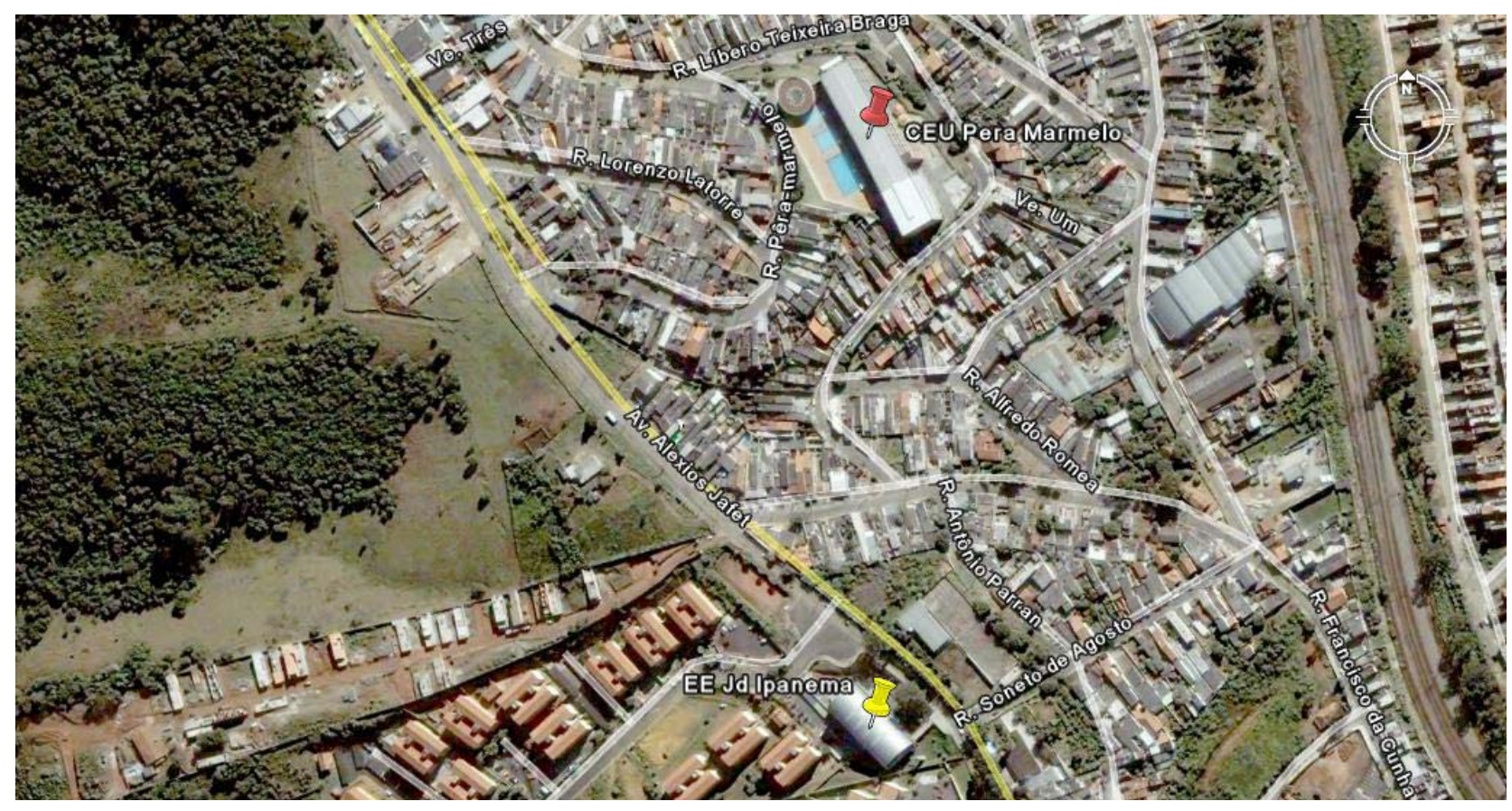



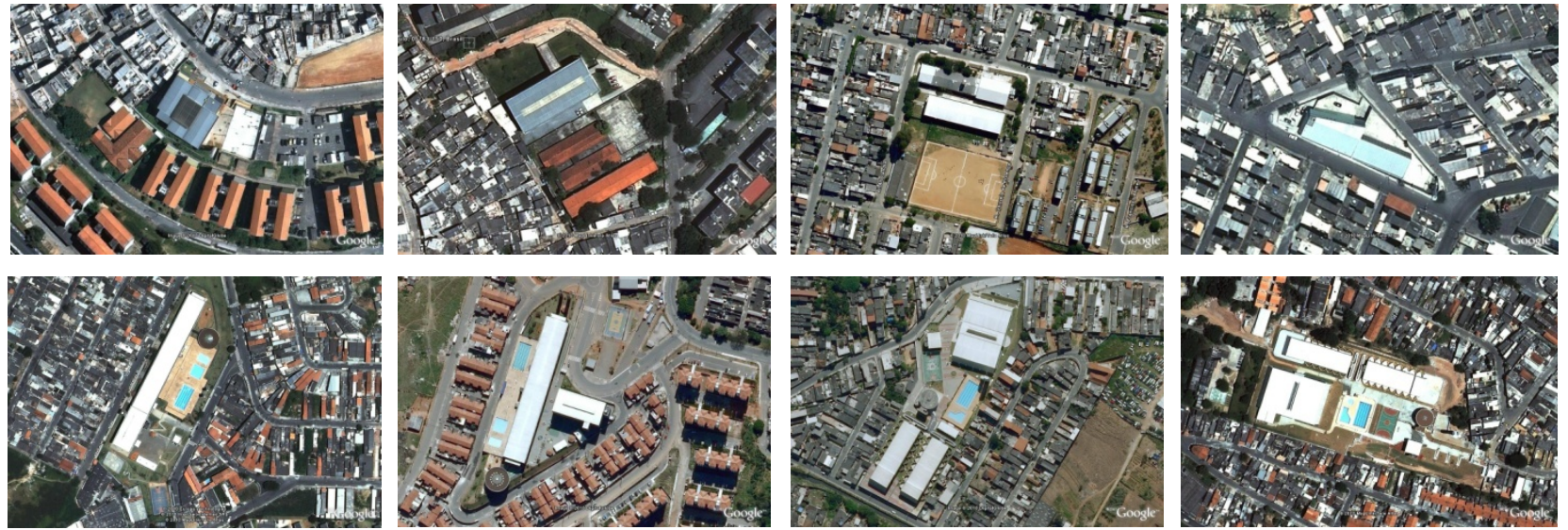

Impactos na inserção urbana dos equipamentos educacionais estudados: acima, escolas da FDE; abaixo, alguns edifícios dos CEUs. Fonte: Google Earth, 2010.
[...] los servicios públicos colectivos se encuentran organizados, en la ciudad industrial, como puntos de referencia de un sistema urbano "incompleto", contrastando, en parte (en razón de la conexión de su localización con los recorridos existentes), con la especialización funcional de la ciudad según zonas diferenciadas. (AYMONINO, 1982, p. 60)

Nas regiões centrais, a presença dos equipamentos não é tão marcada, dada a diversidade tipológica e 0 gabarito do entorno, que acaba por camuflar 0 edifício escolar. Nas periferias ocupadas pela autoconstrução e por baixos gabaritos, essas escolas não só se destacam pela tipologia, como também se convertem em marcos visuais, avistados ao longe. À parte do aspecto tipológico, fato é que os equipamentos educacionais causam forte impacto nas paisagens periféricas por se constituírem em exemplares de uma arquitetura formal, em meio a um entorno de completa informalidade.

Além de simbolizarem a presença do Poder Público em áreas periféricas, 0 que potencializa processos de estruturação urbana espontâneos, os equipamentos institucionais acabam por trazer também impactos indiretos, como, por exemplo, alterações nos padrões construtivos empregados nas residências autoconstruídas, que, em geral, passam a incorporar componentes introduzidos nos edifícios implantados.

Enquanto aspecto indireto, vale mencionar o comportamento do mercado imobiliário frente à implantação dos equipamentos nos bairros, 0 que significa não só a incorporação das regiões à cidade formal, mas sobretudo, sua valorização enquanto área urbanizada e com oferta de serviços. Além da disponibilidade do equipamento por si só, sua implantação traz, em geral, uma série de intervenções urbanas associadas, como pavimentação de vias, infraestrutura básica, iluminação, etc. No caso dos CEUs, em entrevistas aos moradores, rapidamente se pode verificar a existência de um processo de valorização imobiliária em curso, ocasionando uma alta significativa dos valores dos imóveis situados nas proximidades do equipamento. 
Compreender os processos de produção do espaço urbano consiste na melhor ferramenta para aprimorá-los. A pesquisa aqui apresentada espera ter contribuído enquanto um diagnóstico propositivo de um cenário em constante mutação, mas que, no entanto, já produziu um consistente repertório, sobre 0 qual as práticas futuras poderão de fundamentar. 
OS MEANDROS DA PRODUÇÃO PÚBLICA NA CONSTRUÇÃO DA PAISAGEM PERIFÉRICA PAULISTANA: 0 CASO DOS EQUIPAMENTOS EDUCACIONAIS 


\section{Bibliografia}


OS MEANDROS DA PRODUÇÃO PÚBLICA NA CONSTRUÇÃO DA PAISAGEM PERIFÉRICA PAULISTANA: 0 CASO DOS EQUIPAMENTOS EDUCACIONAIS 
ARANTES, P. F. Arquitetura Nova: Sérgio Ferro, Flávio Império e Rodrigo Lefèvre, de Artigas aos mutirões. São Paulo: Editora 34, 2002.

AYMONINO, C. El significado de las ciudades. Madrid: Hermann Blume Ediciones: 1981.

BENCOSTTA, M. L. A. (org.). História da educação, arquitetura e espaço escolar. São Paulo: Cortez, 2005.

BENJAMIN, W. "A Obra de Arte na Era da sua Reprodutibilidade Técnica" In: Magia e Técnica, Arte e Política. Ensaios Sobre Literatura e História da Cultura. São Paulo: Brasiliense, 1994.

BONDUKI, N. G. Origens da habitação social no Brasil. São Paulo: Estação Liberdade/ FAPESP, 1998.

BUFFA, E.; PINTO, G. de A. Arquitetura e Educação: organização do espaço e propostas pedagógicas dos grupos escolares paulistas, 1893 - 1971. São Carlos/ Brasília: EdUFSCar, INEP, 2002.

CARLOS, A. F. A.; OLIVEIRA, A. U. de (org.). Geografias de São Paulo: Representação e crise da Metrópole. São Paulo: Contexto, 2004.

CENTRO BRASILEIRO DE CONSTRUÇÕES E EQUIPAMENTOS ESCOLARES. Elaboração de catálogos de materiais e componentes para construções escolares. Rio de Janeiro: Ministério da Educação e Cultura, Secretaria Geral, Centro Brasileiro de Construções e Equipamentos Escolares, 1978.

CORREA, M. E. P. Arquitetura escolar paulista: 1890-1920. São Paulo: FDE, 1991.

DONNE, M. Teorias sobre a cidade. São Paulo: Martins Fontes, 1983.

DEBORD, G. A sociedade do espetáculo. Rio de Janeiro: Contraponto, 1997.

DÓRIA, 0.; PEREZ, M. A. Educação, CEU e Cidade: breve história da educação pública brasileira nos $\mathbf{4 5 0}$ Anos da Cidade de São Paulo. São Paulo: Secretaria Municipal de Educação da Cidade de São Paulo, 2007.

DUARTE, $H$. de Q. Escolas-classe, escola-parque: uma experiência educacional. São Paulo: FAU-USP, 1973.

FARIA, A. L. G. de; MELLO, S. A. (org.). Territórios da infância: linguagens, tempos e relações para uma pedagogia para as crianças pequenas. Araraquara, SP: Junqueira \& Marin, 2007.

FARIA, A. L. G. de. Educação pré-escolar e cultura: para uma pedagogia da educação infantil. Campinas, SP: Unicamp, 1999a.

"A contribuição dos parques infantis de Mário de Andrade para a construção de uma pedagogia da educação infantil." In: Educação e Sociedade, ano XX, n. 69, dez.l 1999b. 
FERRAZ, M. C. (org.). Lina Bo Bardi. São Paulo: Empresa das Artes/ Instituto Lina Bo e P.M. Bardi, 1993.

Vilanova Artigas. São Paulo: Fundação Vilanova Artigas/ Instituto Lina Bo e P.M. Bardi, 1994.

FERREIRA, A. F.; MELLO, M. G. de (org.). Arquitetura escolar e política educacional: os programas na atual administração do Estado. São Paulo: FDE, 1998a.

Arquitetura escolar paulista: restauro. São Paulo: Fundação para 0 Desenvolvimento da Educação - FDE, 1998b.

Arquitetura escolar paulista: anos 1950 e 1960. São Paulo: Fundação para 0 Desenvolvimento da Educação - FDE, 2006a.

Arquitetura escolar paulista: estruturas pré-fabricadas. São Paulo: FDE, 2006b.

FERRO, S. A casa popular/ Arquitetura Nova. São Paulo: GFAU, 1975.

0 canteiro e o desenho. São Paulo: Projeto Editores Associados, 1979.

FREIRE, P. Pedagogia do Oprimido. Rio de Janeiro: Paz e Terra, 1987.

Educação na Cidade. São Paulo: Editora Cortez, 1995.

Pedagogia da Autonomia. São Paulo: Paz e Terra, 1996.

FUNDO ESTADUAL DE CONSTRUÇÕES ESCOLARES - FECE. A execução do programa de construções escolares. São Paulo: Secretaria de Educação. Diretoria do Ensino, 1963.

Projetos de arquitetura escolar. São Paulo: Secretaria de Educação. Diretoria do Ensino, 1972.

GREGOTTI, V. Território da Arquitetura. São Paulo: Perspectiva, EDUSP, 1975.

HERTZBERGER, H. Lessons for Students in Architecture. Rotterdam: 010 Publishers, 2005.

Space and Learning. Lessons in Architecture 3. Rotterdam: 010 Publishers, 2008.

JACOBS, J. Morte e vida de grandes cidades. São Paulo: Martins Fontes, 2003.

KATINSKY, J. R. "A Escola Republicana em São Paulo." In: FERREIRA, A. F.; MELLO, M. G. de (org.). Arquitetura escolar: anos 1950 e 1960. São Paulo: Fundação para 0 Desenvolvimento da Educação - FDE, 2006, p. 21-39.

KOURY, A. P. Grupo Arquitetura Nova: Flávio Império, Rodrigo Lefèvre e Sérgio Ferro. São Paulo: Romano Guerra Editora: EDUSP: FAPESP, 2003.

LE CORBUSIER, J. A carta de Atenas (tradução de Rebeca Scherer). São Paulo: HUCITEC: EDUSP, 1993. 
LIMA, M. W. de S. A cidade e a criança. São Paulo: Nobel, 1989.

Espaços educativos: uso e construção. Brasília: MEC/ CEDATE, 1988.

Arquitetura e educação. São Paulo: Nobel, 1995.

MANGNANI, J. Festa no pedaço. São Paulo: Brasiliense, 1984.

MARCILIO, M. L. História da Escola em São Paulo e no Brasil. São Paulo: Imprensa Oficial do Estado, 2005.

MARICATO, E. (org.). A produção capitalista da casa (e da cidade) no Brasil industrial. São Paulo: Editora Alfa-Omega, 1979.

Brasil, cidades: alternativas para a crise urbana. Petrópolis, RJ: Vozes, 2001.

MAUTNER, Y. "A periferia como fronteira de expansão do capital" In: DÉAK, C.; SCHIFFER, S. R. (org.). $\mathbf{O}$ processo de urbanização no Brasil. São Paulo: Editora da Universidade de São Paulo, 1999.

NIEMEYER, C. A. da C. Parques infantis de São Paulo: lazer como expressão de cidadania. São Paulo: Annablume/ FAPESP, 2002.

OLIVEIRA, F. de. Crítica à razão dualista. 0 Ornitorrinco. São Paulo: Boitempo, 2003.

PONTUSCHKA, N. N. "São Paulo, a cidade educadora" In: CARLOS, A. F. A.; OLIVEIRA, A. U. de (org.). Geografias de São Paulo: Representação e crise da Metrópole. São Paulo: Contexto, 2004. Pg. $369-388$.

PRETECEILLE, E. Equipamentos coletivos e consumo social. São Paulo: Fundap, 1977.

SILVA, J. T. da. "A construção da cidadania e da escola nas décadas de 1950 e 1960". In: FERREIRA, A. F.; MELLO, M. G. de (org.). Arquitetura escolar: anos 1950 e 1960. São Paulo: Fundação para o Desenvolvimento da Educação - FDE, 2006, p. 41-57.

SOMMER, R. 0 papel do arquiteto - a conscientização do design. São Paulo: Ed. Brasiliense, 1979.

VELHO, G. A utopia urbana. Rio de Janeiro: Zahar, 1978.

WISNIK, G. "O programa escolar e a formação da 'escola paulista". In: FERREIRA, A. F.; MELLO, M. G. de (org.). Arquitetura escolar: anos 1950 e 1960. São Paulo: Fundação para o Desenvolvimento da Educação - FDE, 2006, p. 59-66.

WOLFF, S. F. S. Escolas para a República: os Primeiros Passos da Arquitetura das Escolas Públicas Paulistas. São Paulo: Editora da Universidade de São Paulo, 2010. 


\section{Dissertações e teses:}

ABREU, I. R. N. Convênio escolar: utopia construída. Dissertação de mestrado. São Paulo: FAU-USP, 2007.

ALVES, A. A. de A. Arquitetura escolar em São Paulo 1959-1962: o PAGE, o IPESP e os arquitetos modernos paulistas. Tese de doutorado. São Paulo: FAU-USP, 2008.

BARBUGIAN, E. Pré-fabricados de concreto na arquitetura escolar. Tese de doutorado. São Paulo: FAU-USP, 2005.

BUITONI, C. S. Mayumi Watanabe Souza Lima: a construção do espaço para a educação. Dissertação de mestrado. São Paulo: FAU-USP, 2009.

FERRATA, C. A. Escolas públicas em São Paulo (1960-1972). Dissertação de mestrado. São Paulo: FAU-USP, 2008.

GILIOLI, U. Arquitetura e lugar: exercícios e experiências. Tese de doutorado. São Paulo: FAU-USP, 1994.

MASCARENHAS, M. P. Os centros educacionais unificados da cidade de São Paulo. Dissertação de mestrado. São Paulo: FAU-USP, 2006.

NIEMEYER, C. A. da C. A criação de espaços públicos de lazer organizado como expressão de cidadania: 0 caso dos Parques Infantis em São Paulo (1934 - 1954). Dissertação de mestrado. São Paulo: FAU-USP, 2001.

PETRELLA, G. M. Das fronteiras do conjunto ao conjunto das fronteiras. Dissertação de mestrado. São Paulo: FAU-USP, 2009.

PIGNANELLI, P. E. B. Origens históricas e involução da arquitetura: os últimos vinte anos de projetos da Companhia de Desenvolvimento Habitacional e Urbano do Estado de São Paulo-CDHU. Dissertação de mestrado. São Paulo: FAU-USP, 2003.

RONCONI, R. L. N. Habitações construídas com gerenciamento pelos usuários, com organização da força de trabalho em regime de mutirão: o programa FUNAPS comunitário. Dissertação de Mestrado. São Carlos: EESC-USP, 1995.

SANTOS, M. Educação e arquitetura escolar. Trabalho de conclusão de curso. São Paulo: FAU-USP, 1973.

SEIXAS, A. R. A arquitetura escolar de Vilanova Artigas e Carlos Cascaldi (1959-1962). Dissertação de mestrado. São Carlos: EESC-USP, 2003.

TAKIYA, A. Edif 60 anos de arquitetura pública. Dissertação de mestrado. São Paulo: FAUUSP, 2009.

VALENTIM, F. R. Casas para o ensino: as escolas de Vilanova Artigas. Dissertação de mestrado. São Paulo: FAU-USP, 2003.

WOLFF, S. F. S. Espaço e educação: os primeiros passos da arquitetura das escolas públicas paulistas. Dissertação de mestrado. São Paulo: FAU-USP, 1992. 
Periódicos:

ANELLI, R. "Centros Educacionais Unificados: arquitetura e educação em São Paulo". In: Arquitextos, n. 55, dez/ 2004. Disponível no endereço eletrônico: http://www.vitruvius.com.br/arquitextos/arq055/arq055 02.asp.

ARTIGAS, V. “Sobre escolas...”. In: Acrópole, n.377, set.1970, p.10-13.

BALAZINA, A.; TÓFOLI, D. "Escolas de lata acabam em São Paulo; "puxadinhos" não." In: Folha de São Paulo, 29/09/2006.

BARDI, L. B. “Primeiro: escolas”. In: Habitat, n.4, 1951.

BONDUKI, N. G.; KOURY, Ana Paula; MANOEL, Sálua K. "Análise tipológica da produção de habitação econômica no Brasil (1930 - 1964)". In: Docomomo 5. Disponível em pdf no endereço eletrônico: http://www.docomomo.org.br/seminario\%205\%20pdfs/115R.pdf.

BOTELHO, I. "Os equipamentos culturais na cidade de São Paulo: um desafio para a gestão pública". In: Espaço e Debates, n.43/44, São Paulo, 2004. Disponível no endereço eletrônico: http://www.centrodametropole.org.br/pdf/espaco debates.pdf.

CHRISTIANSEN, C. J. "The desert, the center and the periphery". In: U.R. - Urbanismo Revista: Projectar la Perifèria. 1992: 9 - 10, p. 5.

DIMENSTEIN, G. "Para entender os CEUs e não ser enganado pelos marqueteiros", In: http://aprendiz.uol.com.br/content/priclespes.mmp.

DUARTE, H. “A arquitetura do Convênio Escolar”. In: Habitat, n.4, 1951, p. 4-6. 236-238

“Considerações sobre arquitetura e educação". In: Acrópole, n. 210, abr./ 1956, p.

GOMES, F. F. "Teto de "escola de lata" atinge $60^{\circ}$ C." In: Folha de São Paulo, 18/10/2005.

HARVEY, David. "O trabalho, o capital e o conflito de classes em torno do ambiente construído nas sociedades capitalistas avançadas". In: Espaço e Debates, $n^{0} 6$. São Paulo: Ed. Cortez, 1982, pp 6-35.

HOLSTON, J. "Espaços de cidadania insurgente". In: Revista do Patrimônio Histórico e Artístico Nacional, n.24, Rio de Janeiro: IPHAN, 1996, p.243-253.

LAGUILLO, M. "La belleza de la periferia". In: U.R. - Urbanismo Revista: Projectar la Perifèria. 1992: $9-10$, p. 24.

MOREIRA, C. M. "Hélio Duarte e Ernest Mange: arquitetura escolar, São Paulo anos 50". In: Resumos. São Paulo: USP, 2000.

NICOLIN, P. L. "Periferia. Metrópolis. Erranza". In: U.R. - Urbanismo Revista: Projectar la Perifèria. 1992: 9 - 10, p. 8 e 9.

PRETECEILLE, E. "Políticas urbanas, equipamentos e serviços coletivos". In: Espaço e Debates, n. 18, 1986, p. 5-18. 
RAMONEDA, J. "The periphery". In: U.R. - Urbanismo Revista: Projectar la Perifèria. 1992: $9-10$, p. 1 .

SOLÀ-MORALES, M. de. "Periphery as a project". In: U.R. - Urbanismo Revista: Projectar la Perifèria. 1992: $9-10$, p. 5.

VENTURA, A. "Notas sobre a arquitetura escolar paulista dos anos 50 até os anos 90: os programas e os partidos". In: Sinopses, n.38, out. 2002, p.21-38.

[...]. "Governo do Estado também tem escola de lata" In: Estado de São Paulo, 30/04/2002.

\section{Catálogos Técnicos:}

BRASIL, MINISTÉRIO DE EDUCAÇÃO E CULTURA - MEC. MANEQ 1: Manual de Equipamento $\mathbf{1}^{0}$ grau. [S.I.]: MEC, 1974.

COMPANHIA DE CONSTRUÇÕES ESCOLARES DO ESTADO DE SÃO PAULO - CONESP. Manual de dimensionamento modular e especificações de ambientes para construções escolares de $1^{0}$ Grau. São Paulo: CONESP, 1977.

Manual de padronização de componentes para construçóes escolares de $\mathbf{1}^{\mathbf{0}}$ Grau. São Paulo: CONESP, 1977.

Manual de diretrizes gerais para projetos de construçóes escolares de $1^{\circ} \mathrm{Grau}$. São Paulo: CONESP, 1977.

Manual de equipamentos para construções escolares de $1^{0}$ Grau. São Paulo: CONESP, 1978.

Manual de especificações de vegetação para construções escolares. São Paulo: CONESP, 1979.

Arquitetura. São Paulo: CONESP, 1986.

Edificação e seus elementos construtivos. São Paulo: CONESP, 1986.

Estrutura. São Paulo: CONESP, 1986.

Catálogo de componentes e serviços. São Paulo: CONESP, 1988.

DEPARTAMENTO DE OBRAS PÚBLICAS DO ESTADO DE SÃO PAULO. DOP e a padronização de projetos para obras públicas. São Paulo: DOP, 1974.

FUNDAÇÃO PARA O DESENVOLVIMENTO DA EDUCAÇÃO - FDE. Ambientes: especificações da edificação escolar de primeiro grau. São Paulo: FDE, 1998.

Catálogo de componentes. São Paulo: FDE, 1998.

Especificações da edificação escolar de primeiro grau: vegetação e paisagismo. 
Sítios virtuais consultados:

ARCOWEB, sobre os CEUs: Disponível em:

http://www.arcoweb.com.br/memoria/memoria68.asp. Acesso em 9 jun. 2009.

ESCRITÓRIO RUY OTHAKE: Disponível em:

http://www.ruyohtake.com.br. Acesso em 22 mar. 2010.

FUNDAÇÃO PARA O DESENVOLVIMENTO DA EDUCAÇÃO - FDE: Disponível em: http://www.fde.sp.gov.br. Acesso em 9 jun. 2009.

INSTITUTO BRASILEIRO DE GEOGRAFIA E ESTATÍSTICA - IBGE: Disponível em: http://www.ibge.gov.br. Acesso em 9 jun. 2009.

PROJETO SÃO PAULO 450 ANOS: Disponível em:

http://www.aprenda450anos.com.br/450anos/escola_cidade. Acesso em 9 jun. 2009.

SECRETARIA MUNICIPAL DE EDUCAÇÃO DE SÃO PAULO: Disponível em:

http://educacao.prefeitura.sp.gov.br. Acesso em 22 mar. 2010.

SECRETARIA MUNICIPAL DE PLANEJAMENTO DE SÃO PAULO - SEMPLA / INFOCIDADE.

Disponível em: http://sempla.prefeitura.sp.gov.br/infocidade. Acesso em 9 jun. 2009. 
OS MEANDROS DA PRODUÇÃO PÚBLICA NA CONSTRUÇÃO DA PAISAGEM PERIFÉRICA PAULISTANA: 0 CASO DOS EQUIPAMENTOS EDUCACIONAIS 


\section{Anexo_Produção de Equipamentos Educacionais em São Paulo | 2001 - 2010}


OS MEANDROS DA PRODUÇÃO PÚBLICA NA CONSTRUÇÃO DA PAISAGEM PERIFÉRICA PAULISTANA: 0 CASO DOS EQUIPAMENTOS EDUCACIONAIS

[182 ] 
A seguir, serão apresentados os projetos catalogados no âmbito desta pesquisa, conforme descrito no item 3.1 deste trabalho.

0 levantamento tomou por objeto a produção pública de equipamentos educacionais realizada no município de São Paulo na última década (2001 2010), enfatizando, dessa forma, os dois processos que marcaram 0 período: na esfera estadual, a produção da Fundação para o Desenvolvimento Educacional - FDE e, na esfera municipal, a construção dos Centros Educacionais Unificados - CEUs.

A catalogação seguirá a seguinte estrutura:

_Produção do Governo do Estado - FDE (2004 - 2009);

_Produção do Governo Municipal - CEUs (1ª Gestão | 2001 - 2004);

_Produção do Governo Municipal - CEUs (2ª Gestão | 2005 - 2009). 
OS MEANDROS DA PRODUÇÃO PÚBLICA NA CONSTRUÇÃO DA PAISAGEM PERIFÉRICA PAULISTANA: 0 CASO DOS EQUIPAMENTOS EDUCACIONAIS 


\section{ProduÇão do Governo do Estado - FDE}

2004-2009 
OS MEANDROS DA PRODUÇÃO PÚBLICA NA CONSTRUÇÃO DA PAISAGEM PERIFÉRICA PAULISTANA: 0 CASO DOS EQUIPAMENTOS EDUCACIONAIS 


\section{PRODUÇÃO DE EQUIPAMENTOS EDUCACIONAIS}

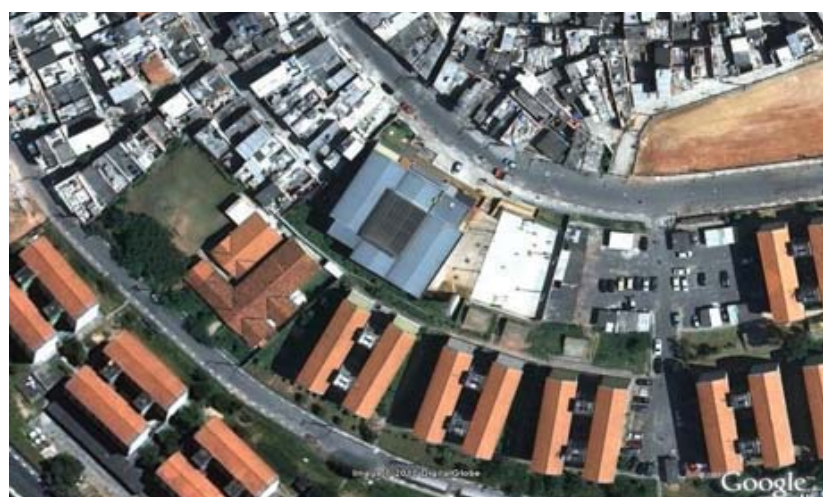

\section{E.E. PROF. MARIA GARBOSSA FRANCISCO}

R. Paulo Lamore, s/n. - Jd. São João

área construída: $2.351 \mathrm{~m}^{2}$

data projeto: 2003

data obra: 2005

tipo de obra: obra nova/ adequação

custo: $\mathrm{R} \$ 2.757 .482,32$

\section{Projeto}

Edifício com 14 salas de aula, setor administrativo, cozinha, refeitório, sanitários, recreio coberto e quadra poliesportiva descoberta.

\section{Partido arquitetônico}

Optou-se por uma volumetria compacta, de modo a liberar espaço para implantação de quadra poliesportiva. A escola se desenvolve em 3 pavimentos e um vazio central com iluminação zenital. No pavimento térreo estão dispostos os setores administrativos e de serviços e nos demais, as salas de aulas. A estrutura é pré-fabricada, em concreto aparente. Utiliza-se cores nas paredes e no piso, vinílico, de modo a quebrar a rigidez do volume.

\section{Histórico \\ A escola foi solicitada não apenas para atender à demanda escolar proveniente dos conjuntos habitacionais da CDHU já implantados, mas também para barrar a ocupação informal que vinha ocorrendo na área institucional destes conjuntos, já parcialmente ocupadas por autoconstrução.}

\section{Proveniência da demanda}

Construção de conjuntos habitacionais CDHU.

\section{Equipe de projeto}

Arquitetura: MPS Associados Ltda (Arq. Magno T. Inoue); Estrutura de concreto: Ruy Bentes Engenharia de Estruturas S/C Ltda.; Hidráulica e combate a incêndio : Eurico Freitas Marques S/C Ltda - Projetos de Instalações.; Elétrica e SPDA : Eurico Freitas Marques S/C Ltda - Projetos de Instalações; Consultoria de Solos e Fundações: Cepollina Engenheiros Consultores S/C Ltda.; Consultoria de Estrutura : Zamarion e Millen Consultores S/S Ltda.

\section{Coordenação do projeto}

FDE/ Arq. Débora Maria Casarim Arcieri

\section{Fiscalização da Obra}

FDE/ Concremat - Engenheiro Paulo Márcio Parsequian Fantato

\section{Construtora}

Tarumã Engenharia Ltda.

\section{Propriedade da terra}

Governo do Estado de São Paulo - área institucional de conjunto habitacional

\section{Financiamento}

Secretaria Estadual de Educação. 


\section{E.E. PROF. MARIA GARBOSSA FRANCISCO | sem escala}
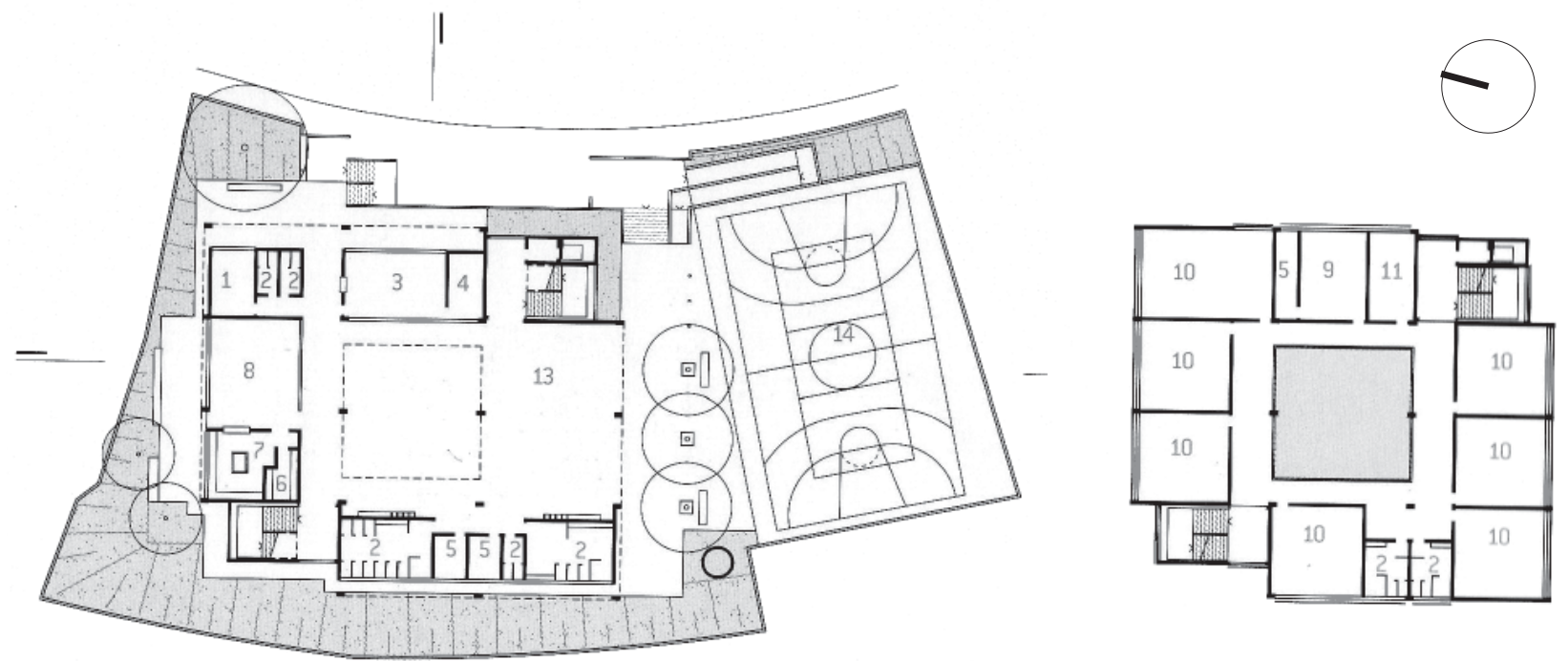

\section{PLANTA TÉRREO/ IMPLANTAÇ̃̃o}

1. diretoria 2. sanitários 3. secretaria 4. almoxarifado 5. depósito

6. despensa 7. cozinha 8. refeitório 13. pátio 14. quadra

\section{PLANTA 10 PAVIMENTO}

9. professores 10. sala de aula 11. coordenação

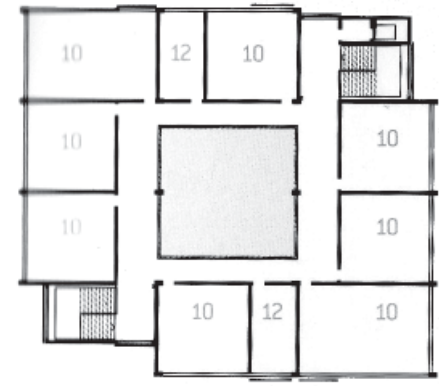

PLANTA 20 PAVIMENTO

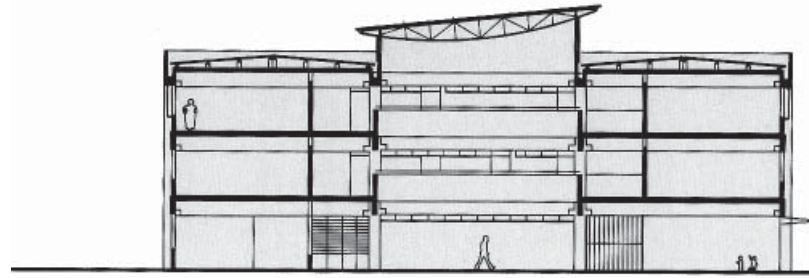

CORTE TRANSVERSAL

10. sala de aula 12. reforço

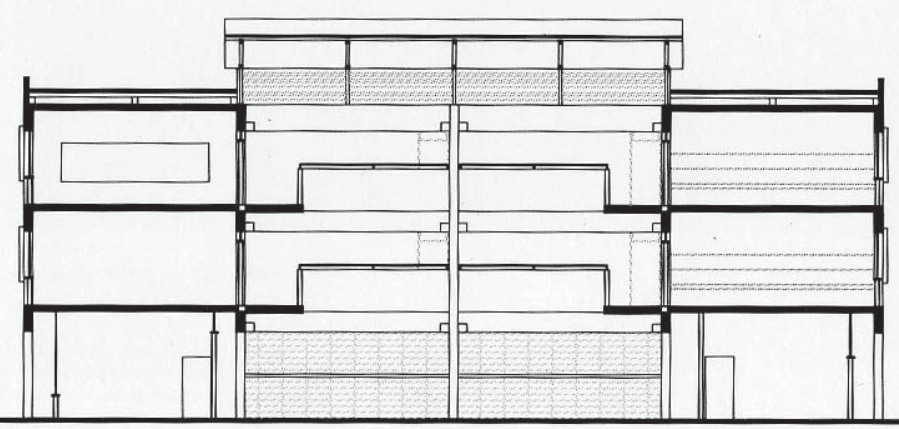




\section{PRODUÇÃO DE EQUIPAMENTOS EDUCACIONAIS}
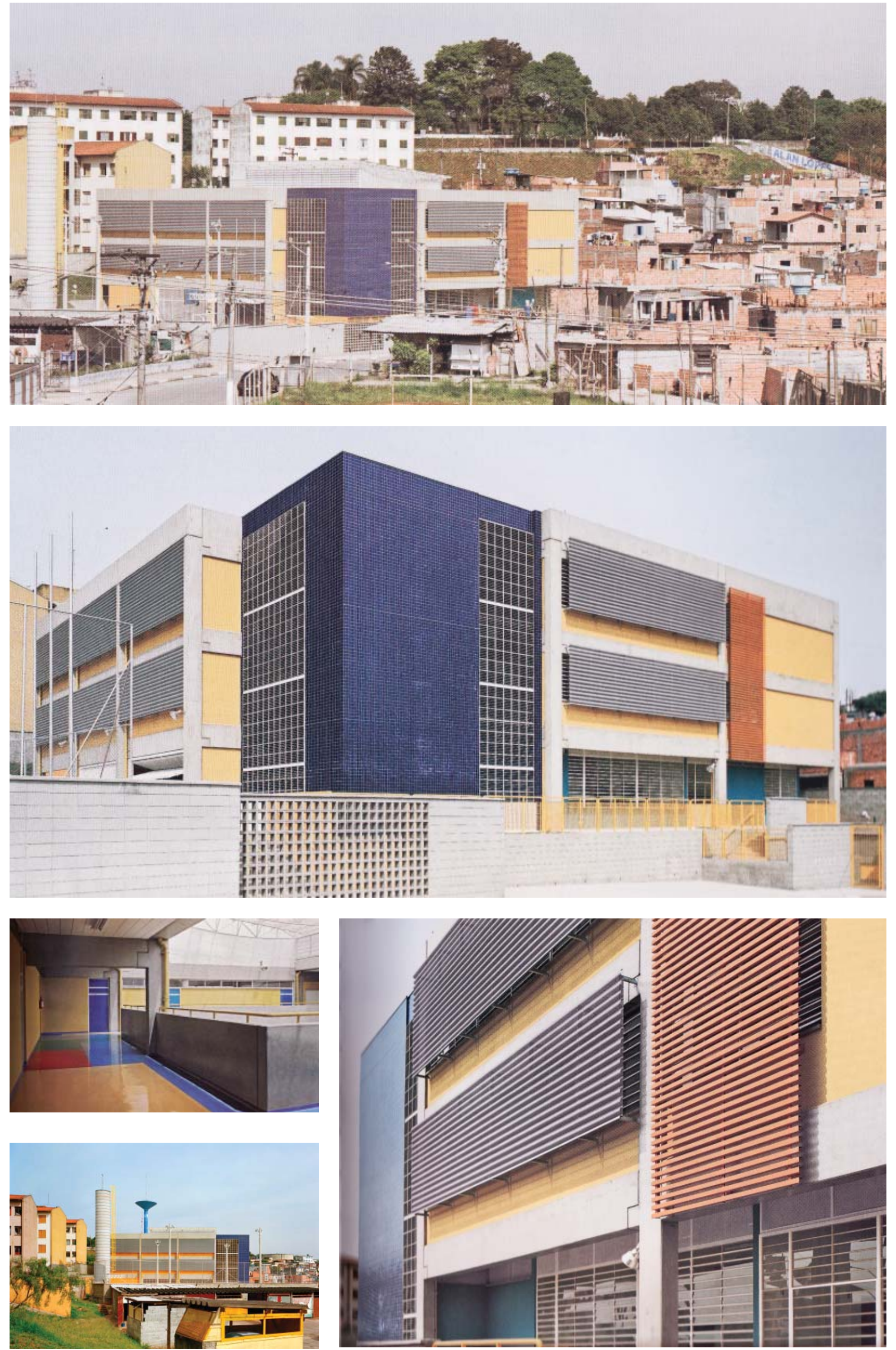


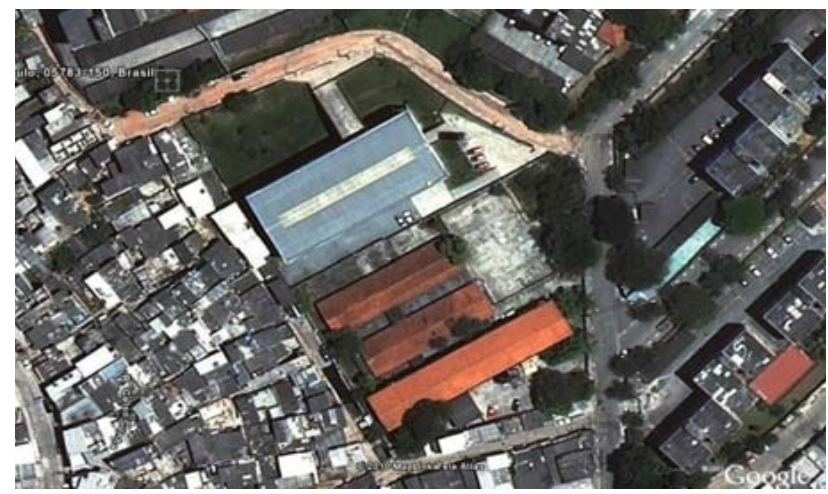

\section{E.E. FERNANDO GASPARIAN}

Rua Luster, 216 - Jd. Umuarama

área construída: $2.054 \mathrm{~m}^{2}$

data projeto: 2003

data obra: 2005

tipo de obra: obra nova

custo: $\mathrm{R} \$ 3.607 .284,63$

\section{Projeto}

Edifício com 15 salas de aula, setor administrativo, cozinha, refeitório, sanitários, grêmio, cantina, sala de uso múltiplo, informática, leitura, recreio coberto e quadra poliesportiva coberta.

\section{Partido arquitetônico}

A dificuldade deste projeto estava em vencer os taludes que separavam o platô principal das ruas do entorno (altura variável entre 3,5 e 12,5m). Em função disso, 0 edifício foi resolvido em um único volume de 4 pavimentos, disposto paralelamente aos blocos anteriores, integrado ao entorno por 2 pontes em cotas diferentes: acesso ao setor administrativo no $1^{0}$ pavimento e acesso dos alinos no último. Com isso, optou-se por uma disposição oposta à tradicionalmente utilizada em escolas, colocando-se as áreas comuns nos pavimentos superiores, evitando áreas de lazer confinadas e sombreadas no fundo do terreno. A criação do acesso superior trouxe ganhos também para o entorno, viabilizando aberturas e novas visuais a partir da via de acesso, antes cercada por muros cegos.

\section{Histórico}

A escola foi construída para atender a forte demanda da região, que vinha sobrecarregando as escolas locais. Devido à ausência de terrenos, o edifício foi implantado na área remanescente da já existente E.E. Moacyr de Castro Ferraz.

\section{Proveniência da demanda}

Crescimento populacional do bairro.

\section{Equipe de projeto}

Arquitetura : Estúdio 6 Arquitetos S/C Ltda. (Arqs. Alexandre Mirandez, César Shundi, Marcelo de Carvalho, Ricardo Bellio); Estrutura de concreto : Ruy Bentes Engenharia de Estruturas S/C Ltda.; Estrutura metálica: Oficina de Arquitetura Ltda.; Hidráulica e combate a incêndio : Eurico Freitas Marques S/C Ltda - Projetos de Instalações.; Elétrica e SPDA : Eurico Freitas Marques S/C Ltda - Projetos de Instalações; Consultoria de Solos e Fundações : Zaclis, Falconi \& Engenheiros Assoc. S/C Ltda.e Consultrix; Consultoria de Estrutura : Zamarion e Millen Consultores

\section{Coordenação do projeto}

FDE/ Arq. Débora Maria Casarim Arcieri

\section{Fiscalização da Obra}

FDE/ Concremat - Engenheiro Paulo Márcio Parsequian Fantato

\section{Construtora}

Tarumã Engenharia Ltda.

\section{Propriedade da terra}

Governo do Estado de São Paulo - área da quadra de esportes de escola já existente

\section{Financiamento}

Secretaria Estadual de Educação.

\section{Premiações}

$6^{0}$ Prêmio Jovens Arquitetos - IAB-SP 2004 - categoria: Arquitetura Projetos Prêmio "EX-AEQUO" 


\section{PRODUÇÃO DE EQUIPAMENTOS EDUCACIONAIS}

\section{E.E. FERNANDO GASPARIAN | sem escala}

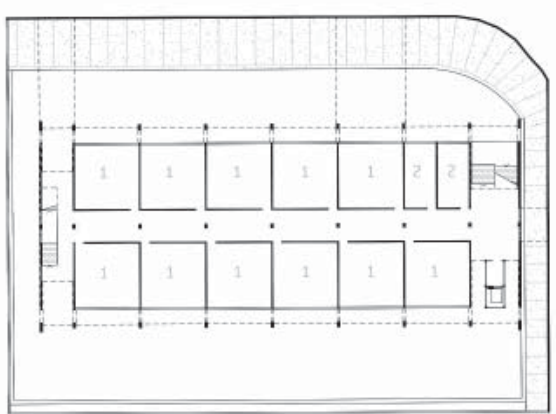

PLANTA TERREO

1. sala de aula 2. reforço

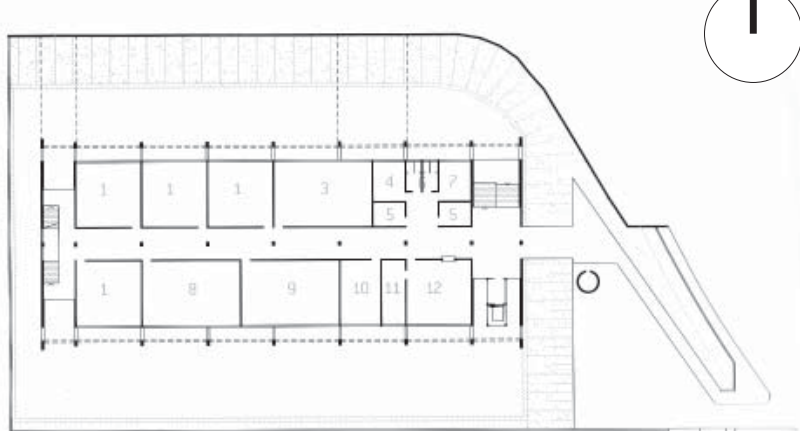

PLANTA $1^{\circ}$ PAVIMENTO

1. sala de aula 3. uso múltiplo 3. secretaria 4. coordenação 5. depósito 6. sanitário 7. diretoria 8. informática 9. leitura 10. professores 11. almoxarifado 12. secretaria

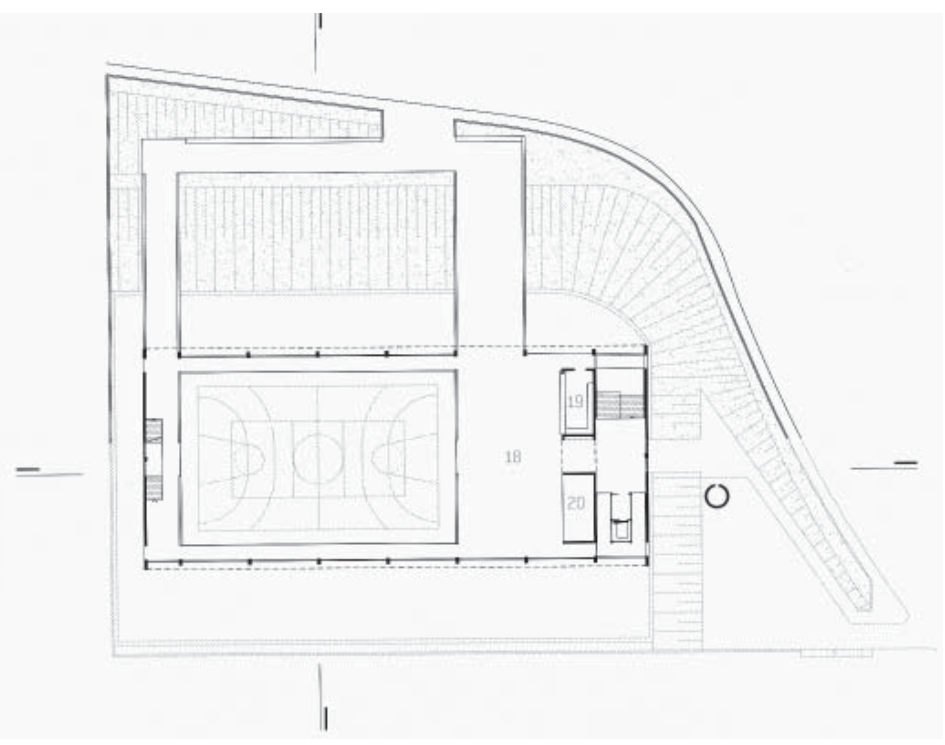

30 PAVIMENTO/ IMPLANTAÇÃO

18. recreio 19. cantina 20. grêmio

13. quadra 14. depósito 15. refeitório 16. cozinha 17. despensa

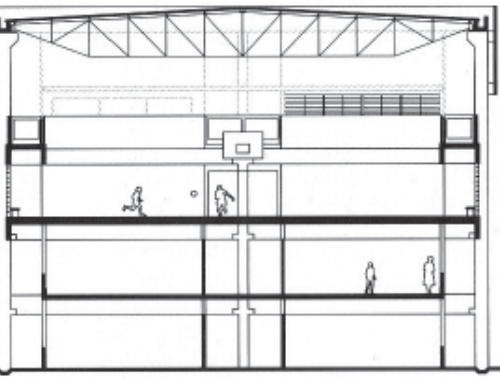



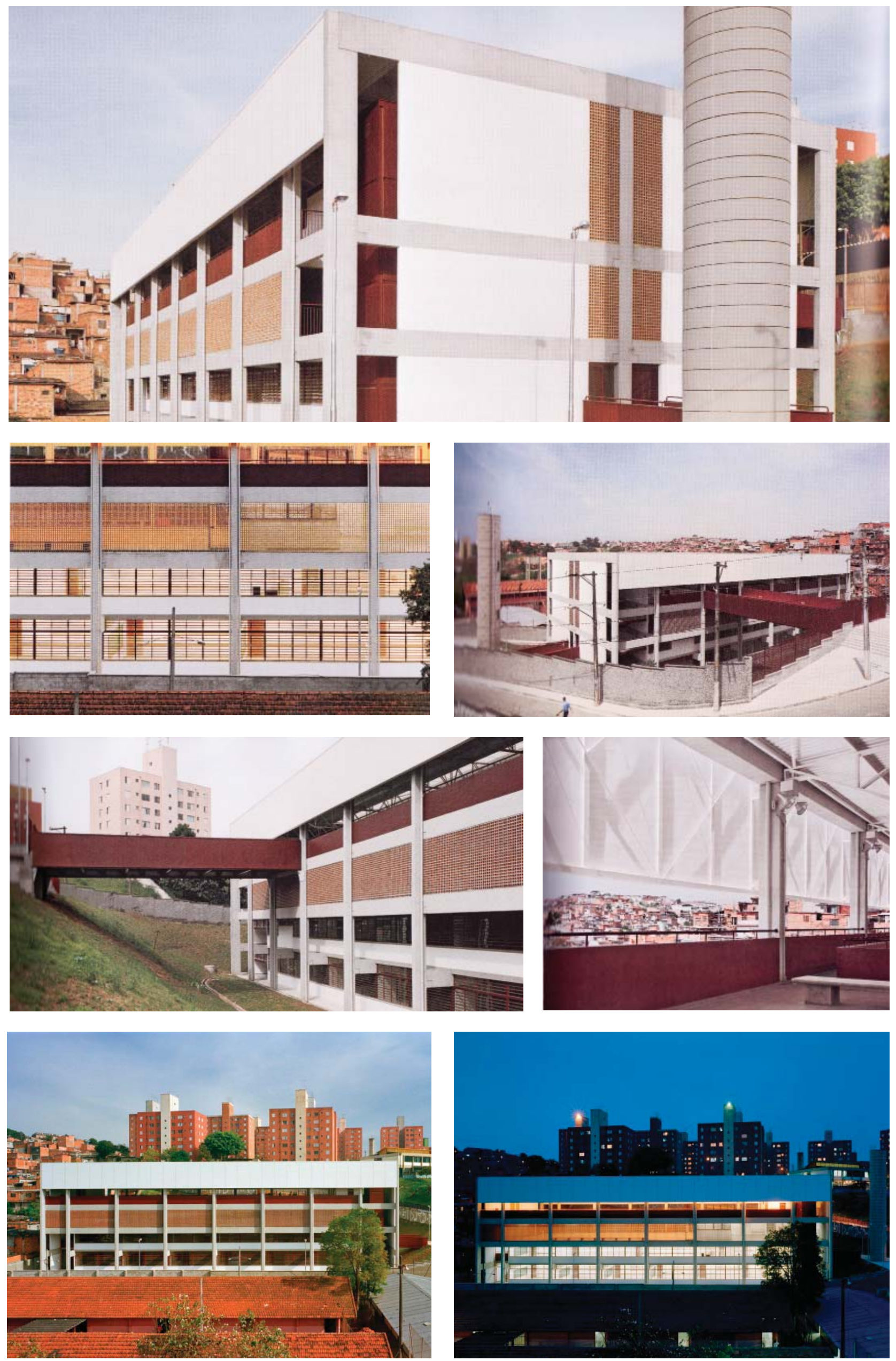


\section{PRODUÇÃO DE EQUIPAMENTOS EDUCACIONAIS}

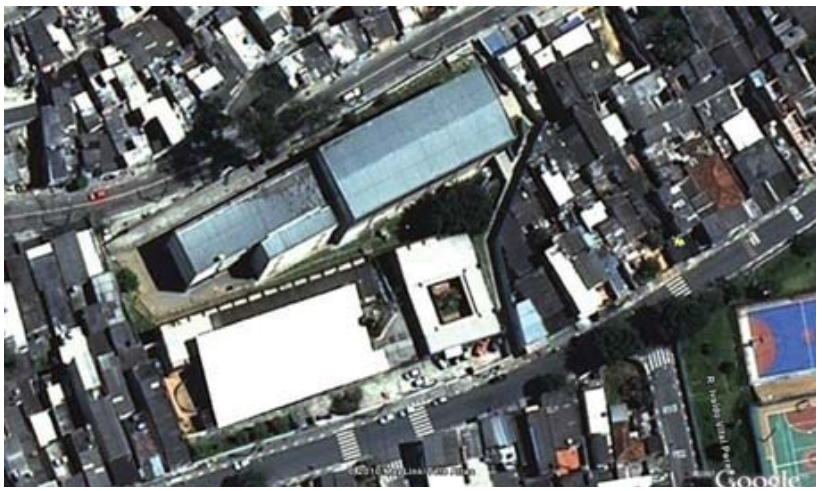

E.E. EUDORO VILLELA/ JD. PLANALTO

R. Estrada do Guavirituba, 600 - Capela do Socorro

área construída: $3.091 \mathrm{~m}^{2}$

data projeto: 2003

data obra: 2005

tipo de obra: obra nova

custo: $\mathrm{R} \$ 3.205 .877,76$

\section{Projeto}

Edifício com 12 salas de aula, setor administrativo, cozinha, refeitório, sanitários, grêmio, cantina, sala de uso múltiplo, informática, leitura, recreio coberto e quadra poliesportiva coberta.

\section{Partido arquitetônico}

Como a escola seria construída na área da quadra da escola já existente, além do programa básico, o novo edifício deveria abrigar uma segunda quadra, com acesso independente. Em vista da topografia acidentada, optou-se por utilizar os dois platôs já existentes e dois acessos em pontos opostos do terreno. No platô mais baixo, foram situados os ambientes de uso comum, com exceção das quadras, que foram instaladas no último pavimento, visando facilitar 0 acesso à escola antiga. Em função do desenho irregular do terreno, a caixa de circulação foi estruturada em uma torre isolada, que se liga a circulações generosas e abertas. No primeiro pavimento estão salas de aula, cozinha/ refeitório e 0 setor administrativo e, no último, as salas especiais e as quadras.

\section{Histórico}

A escola foi construída para atender a forte demanda da região. Por se tratar de um bairro situado em área de proteção aos mananciais, a disponibilidade de terrenos torn-se ainda mais reduzida. Com isso, a nova escola foi implantada no próprio terreno da já existente E.E. José Raul Poletto.

\section{Proveniência da demanda}

Crescimento populacional do bairro.

Equipe de projeto

Arquitetura : Nagle e Cecco Arquitetos Associados S/C Ltda. (Arqs. Angelo Cecco Junior e Edna Nagle); Estrutura de concreto : Ruy Bentes Engenharia de Estruturas S/C Ltda.; Hidráulica e combate a incêndio : Eurico Freitas Marques S/C Ltda - Projetos de Instalações.; Elétrica e SPDA : Eurico Freitas Marques S/C Ltda - Projetos de Instalações; Consultoria de Solos e Fundações : Zaclis, Falconi \& Engenheiros Assoc. S/C Ltda.; Consultoria de Estrutura : Zamarion e Millen Consultores S/S Ltda.

\section{Coordenação do projeto}

FDE/ Arq. Débora Maria Casarim Arcieri

Fiscalização da Obra

FDE/ Concremat - Engenheiro Paulo Márcio Parsequian Fantato

\section{Construtora \\ Tarumã Engenharia Ltda.}

\section{Propriedade da terra}

Governo do Estado de São Paulo - área dos fundos de escola já existente

\section{Financiamento}

Secretaria Estadual de Educação. 


\section{E.E. EUDORO VILLELA | sem escala}

\section{PLANTA TÉRREO}

1. recreio 2. grêmio 3. sanitário 4. depósito

5. cantina

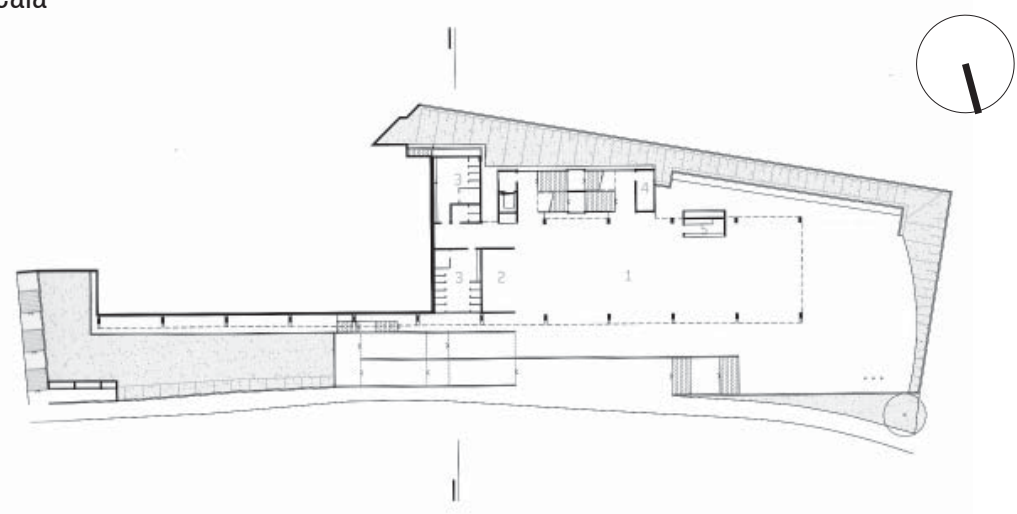

\section{PLANTA $1^{\circ}$ PAVIMENTO}

6. diretoria 7. almoxarifado 8. coordenação

9. professores 10 . sala de aula

11. secretaria 12. despensa 14. cozinha

15. refeitório

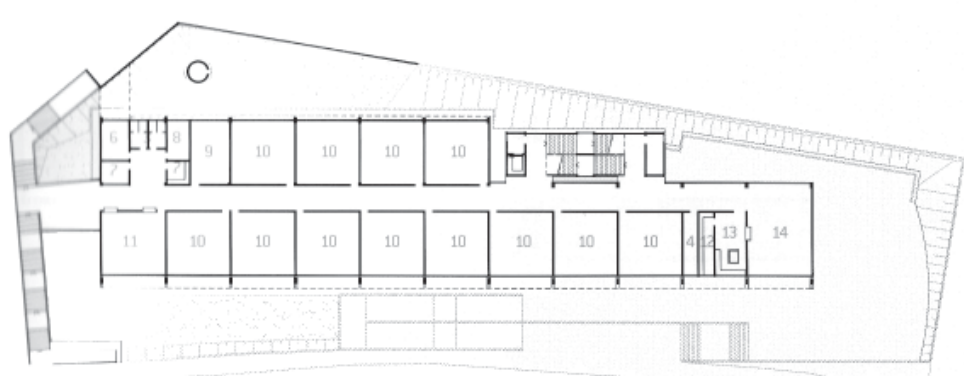

\section{PLANTA $2^{\circ}$ PAVIMENTO}

15. quadra 16. reforço 17. uso múltiplo

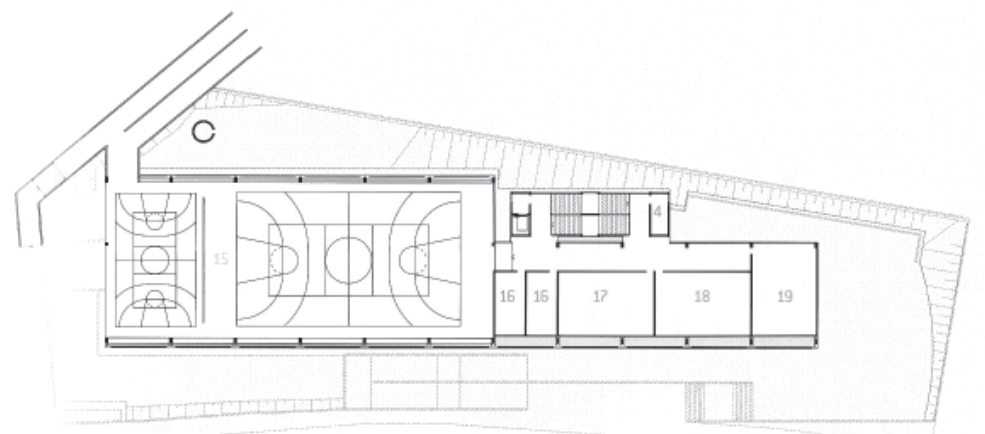

CORTE TRANSVERSAL
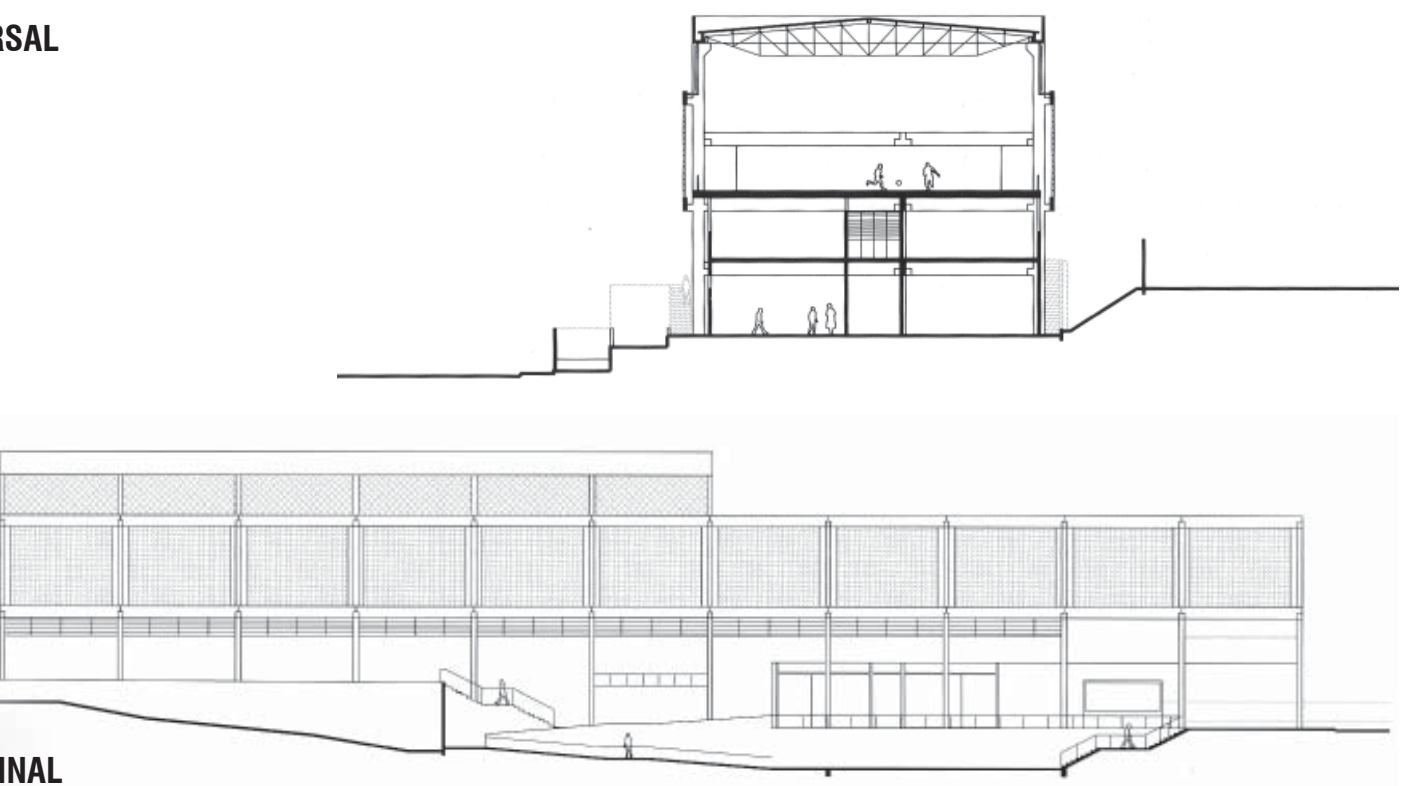


\section{PRODUÇÃO DE EQUIPAMENTOS EDUCACIONAIS}
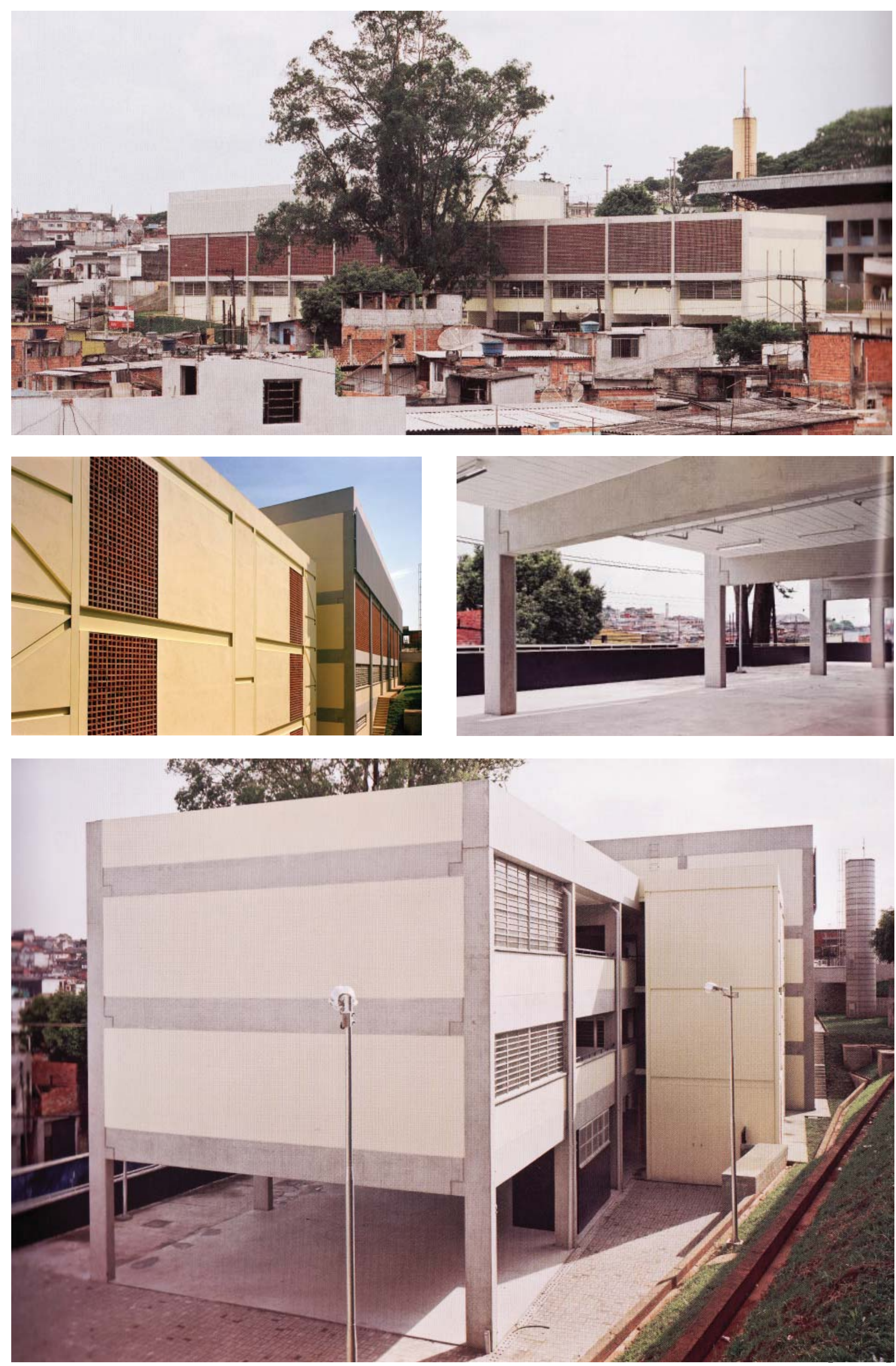


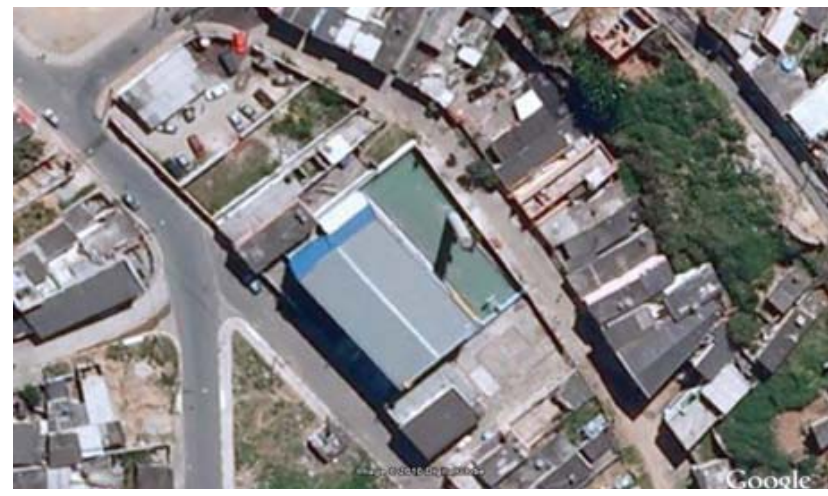

\section{E.E. JD. DOM ANGÉLICO II}

R. Alphonse Joailler, $\mathrm{s} / \mathrm{n}$ - Cidade Tiradentes

área construída: $1.616 \mathrm{~m}^{2}$

data projeto: 2004

data obra: 2005

tipo de obra: substituição de prédio

custo: $\mathrm{R} \$ 1.894 .775,60$

\section{Projeto}

Edifício com 8 salas de aula, setor administrativo, cozinha, refeitório, sanitários, grêmio, cantina, sala de uso múltiplo, informática, leitura e recreio coberto.

\section{Partido arquitetônico}

0 grande desafio deste projeto estava em abrigar o extenso programa dentro de um terreno de dimensões reduzidas, cortado ao meio por um córrego canalizado. Para garantir a permeabilidade entre 0 interno e 0 externo, optou-se pela implantação no térreo do recreio no centro do edifício, entre os dois volumes principais, garantindo uma passagem larga, que liga os pátios frontal e posterior. 0 ponto de destaque do projeto está na rampa central, com guarda-corpo curvo em planta e vista, objeto de um marcante painel artístico.

\section{Histórico}

0 edifício foi construído para substituir a escola anterior, E.E. Jd. Dom Angélico. Em função da indisponibilidade de terrenos na região, optou-se pela substituição do edifício anterior, por um maior.

\section{Proveniência da demanda}

Crescimento populacional do bairro.

\section{Equipe de projeto}

Arquitetura : Pedro Mendes da Rocha - Arquitetura (Arqs. Colaboradores Celso Maleronka, Francisco Gitahy, Felipe Noto e Maira Rios); Estrutura metálica : Kurkdjian \& Fruchtengarten Engenheiros Associados S/C Ltda.; Hidráulica e combate a incêndio : Caiuby Projetos e Serviços de Engenharia Ltda.; Elétrica e SPDA : P.D'Aprile Consultoria e Projetos;Consultoria de Solos e Fundações : Zaclis, Falconi \& Engenheiros Assoc. S/C Ltda.; Consultoria de Estrutura : Kurkdjian \& Fruchtengarten Engenheiros Associados S/C Ltda.

\section{Coordenação do projeto}

FDE/ Arq. Ana Cláudia Souza de Oliveira e Sandra Tiemi Canashiro

\section{Fiscalização da Obra}

FDE/ Engenheiro Walter Haidar

\section{Construtora}

Construtora Itajaí Ltda.

\section{Propriedade da terra}

Governo do Estado de São Paulo - área dos fundos de escola já existente

\section{Financiamento}

Secretaria Estadual de Educação.

\section{Premiações}

$1^{0}$ Concurso Internacional "El color de la arquitectura em latinoamérica" - Menção Honrosa 


\section{PRODUÇÃO DE EQUIPAMENTOS EDUCACIONAIS}

\section{E.E. JD. DOM ANGÉLICO || | sem escala}
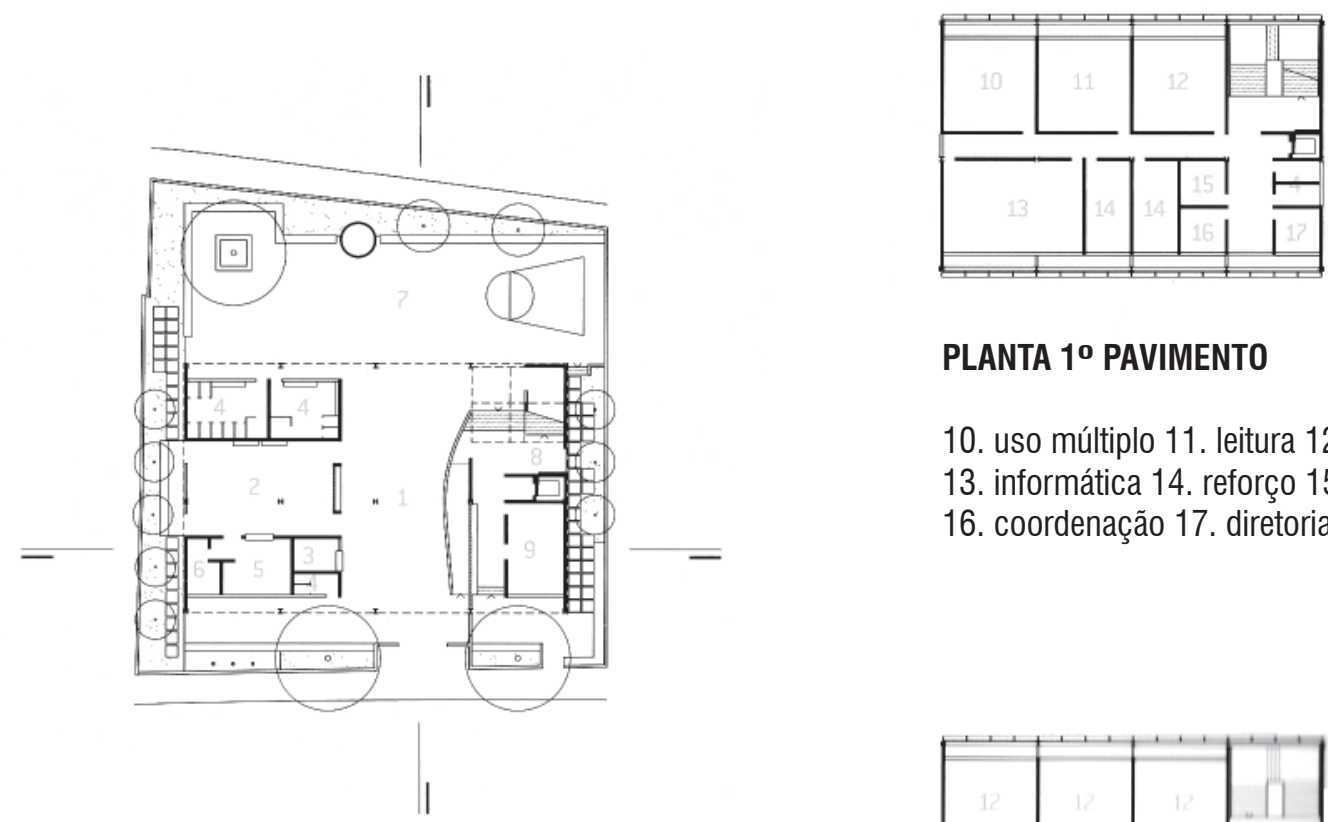

\section{PLANTA 10 PAVIMENTO}

10. uso múltiplo 11. leitura 12. sala de aula 13. informática 14. reforço 15. depósito 16. coordenação 17. diretoria

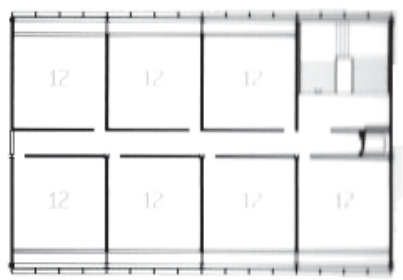

1. recreio 2. refeitório 3. cantina 4. sanitário 5. cozinha

6. despensa 7. pátio 8. grêmio 9. secretaria

\section{PLANTA $2^{\circ}$ PAVIMENTO}

12. sala de aula

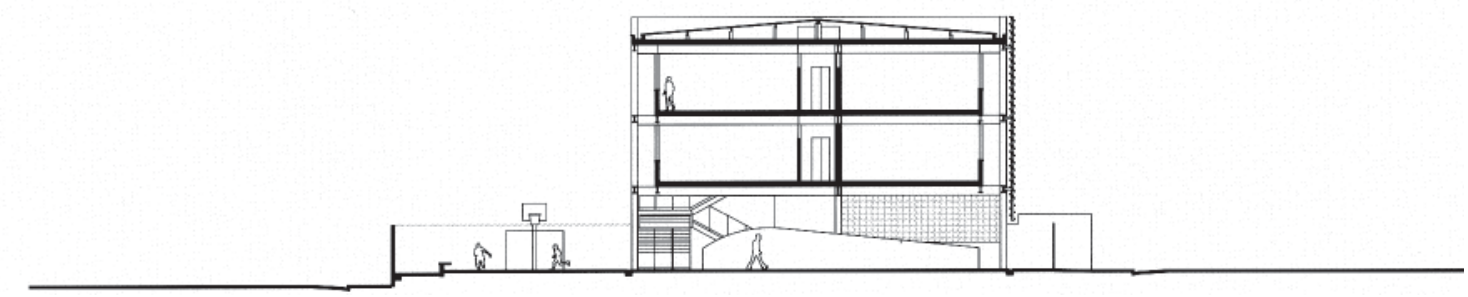

CORTE TRANSVERSAL

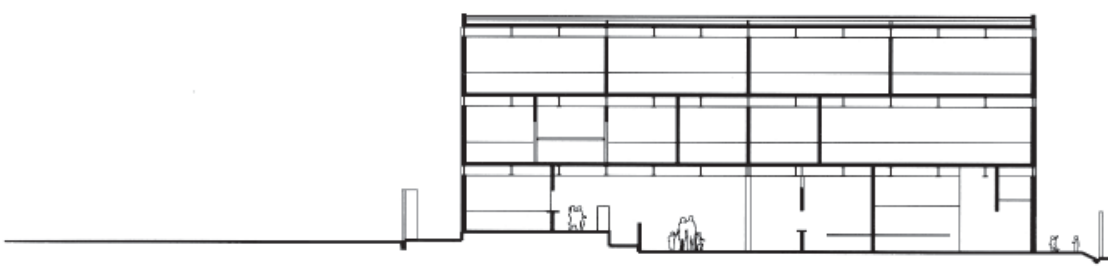



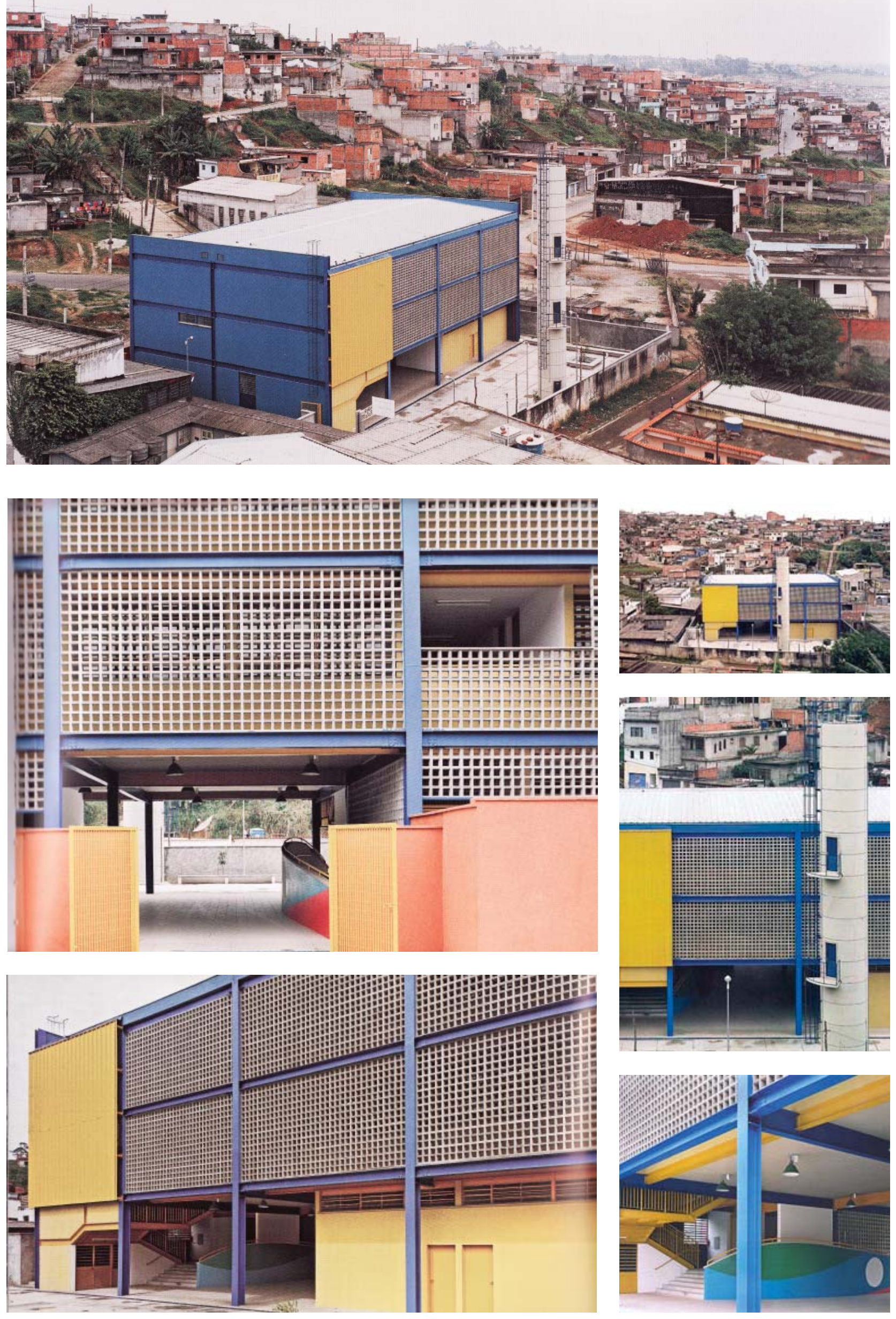


\section{PRODUÇÃO DE EQUIPAMENTOS EDUCACIONAIS}

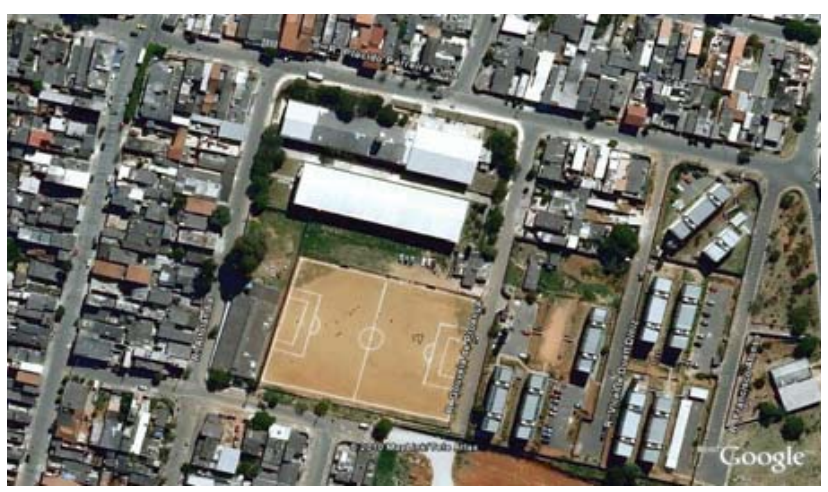

\section{E.E. DESEMBARGADOR LUIS AMBRA}

R. Altolândia, s/n - Pq. Dom João Neri

área construída: $3.399 \mathrm{~m}^{2}$

data projeto: 2003

data obra: 2006

tipo de obra: obra nova

custo: $\mathrm{R} \$ 3.438 .244,37$

\section{Projeto}

Edifício com 12 salas de aula, setor administrativo, cozinha, refeitório, sanitários, grêmio, cantina, sala de uso múltiplo, informática, leitura, recreio coberto e quadra poliesportiva coberta.

\section{Partido arquitetônico}

Programa disposto em um único bloco de 3 pavimentos, estando o térreo destinado aos usos comuns e os demais às salas de aula e salas especiais. 0 recreio coberto, com pé-direito duplo, organiza o espaço, separando o bloco pedagógico do administrativo. A quadra de esportes, embora coberta, é aberta dos lados, voltada para a via do fundo do lote, de modo a facilitar 0 acesso e reduzir custos.

\section{Histórico}

Edifício construído na área da quadra de esportes da escola anteriormente existente, E.E. Profa. Rosarita Torkomian, visando suprir a crescente demanda por vagas no bairro.

\section{Proveniência da demanda}

Crescimento populacional do bairro.

\section{Equipe de projeto}

Arquitetura: Ricoy Torres Consultoria e Projetos Ltda. (Arqs. Welinton Ricoy Torres e Fabio Kassai); Estrutura de concreto: Ruy Bentes Engenharia de Estruturas S/C Ltda.; Estrutura metálica: Oficina de Arquitetura Ltda.; Hidráulica e combate a incêndio : MBM Serviços de Engenharia S/C Ltda.; Elétrica e SPDA : MBM Serviços de Engenharia S/C Ltda.; Consultoria de Solos e Fundações : Zaclis, Falconi \& Engenheiros Assoc. S/C Ltda.; Consultoria de Estrutura : Ruy Bentes Engenharia de Estruturas S/C Ltda.

\section{Coordenação do projeto}

FDE/ Arq. Siméia de Carvalho Pinto e FDE/ Ductor - Arq. Dimas Bertolotti

\section{Fiscalização da Obra}

FDE/ Engenheiro Walter Haidar

\section{Construtora}

Construtora Massafera Ltda.

\section{Propriedade da terra}

Governo do Estado de São Paulo - área da quadra de esportes de escola já existente

\section{Financiamento}

Secretaria Estadual de Educação. 


\section{E.E. DESEMBARGADOR LUIS AMBRA | sem escala}

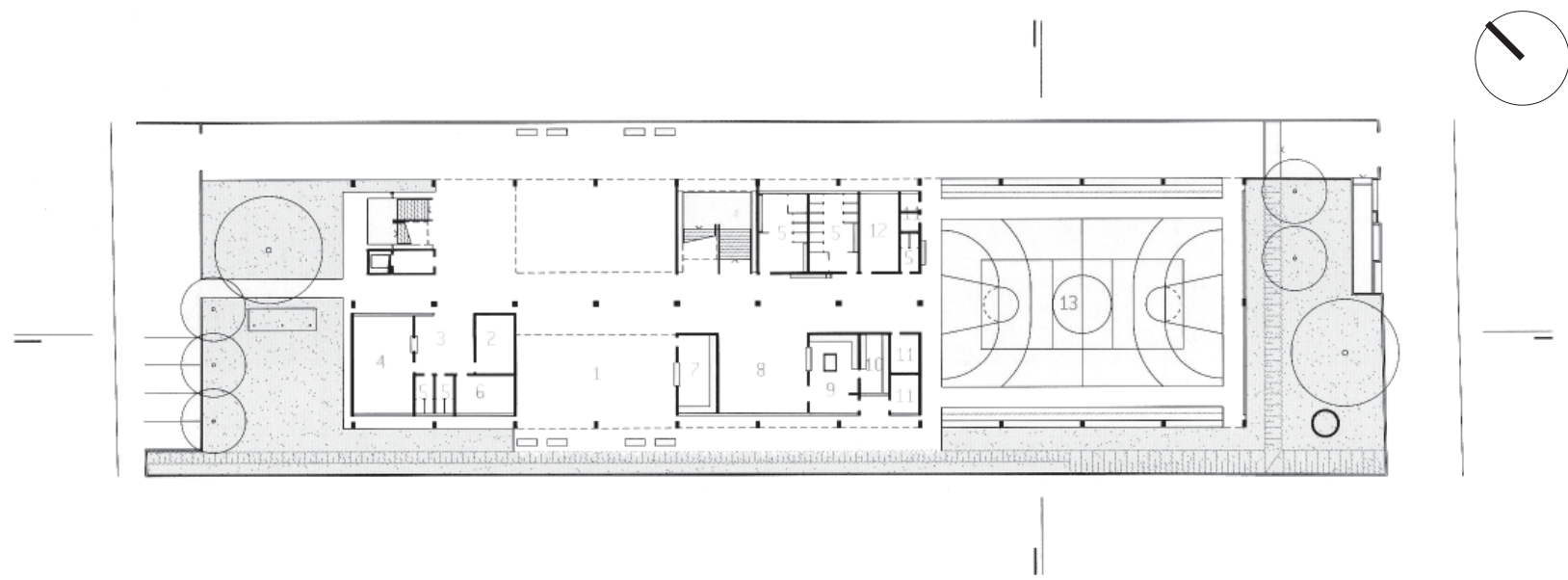

\section{PLANTA TÉRREO/ IMPLANTAÇÃO}

1. recreio 2. almoxarifado 3. hall 4. secretaria 5. sanitário 6. diretoria 7. cantina 8. refeitório 9. cozinha 10. despensa 11. depósito 12. grêmio 13. quadra

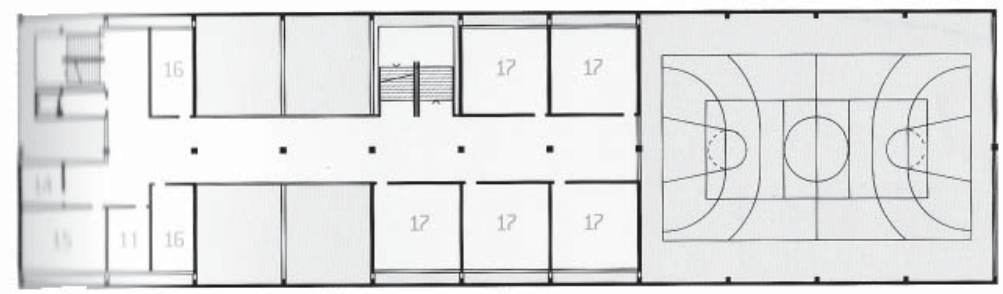

\section{PLANTA $1^{\circ}$ PAVIMENTO}

11. depósito 14. coordenação 15. professores 16. reforço 17. sala de aula

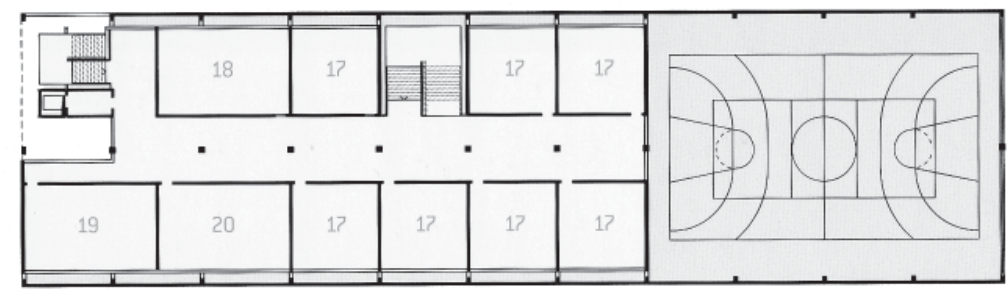

PLANTA $2^{\circ}$ PAVIMENTO

17. sala de aula 18. informática 19. uso múltiplo 20. leitura

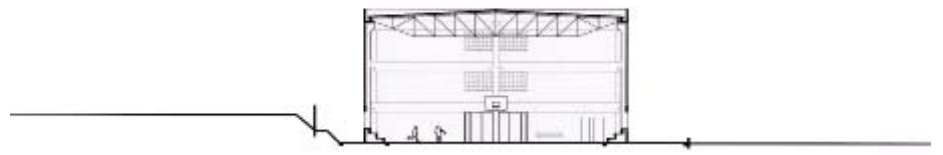

CORTE TRANSVERSAL

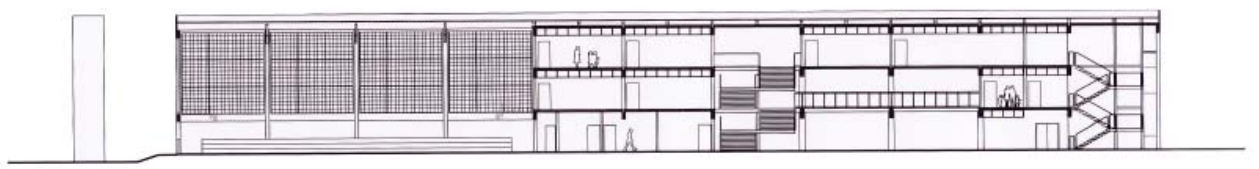




\section{PRODUÇÃO DE EQUIPAMENTOS EDUCACIONAIS}
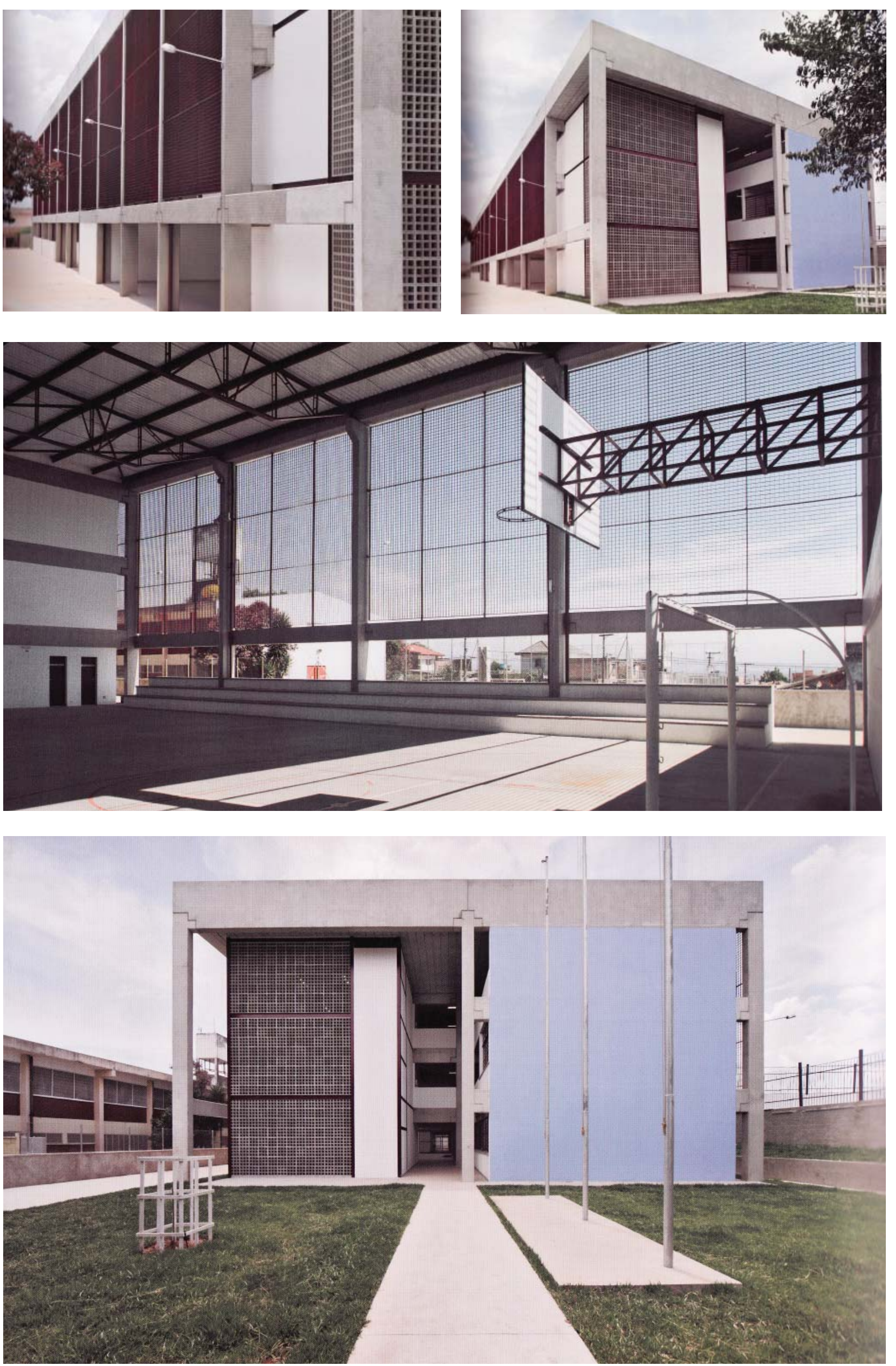


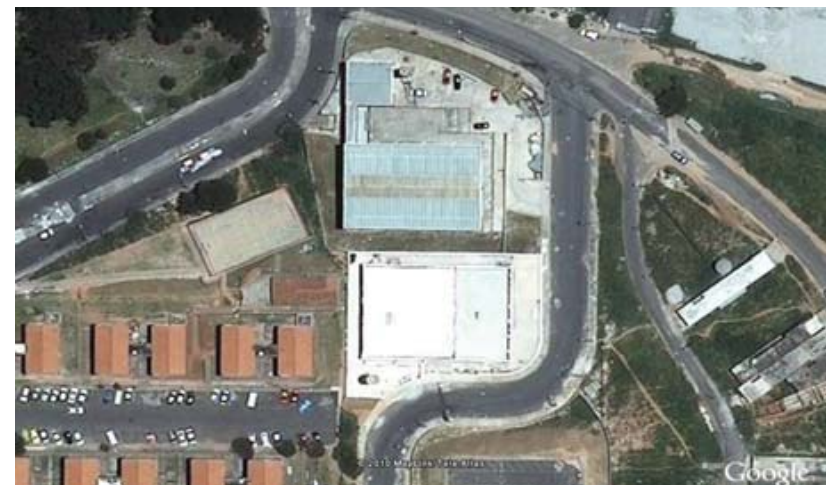

\section{E.E. BELIZE}

Estrada do Palanque/ Av. Iguatemi, s/n - Guaianazes

área construída: $3.548,62 \mathrm{~m}^{2}$

data projeto: 2003

data obra: 2006

tipo de obra: obra nova

custo: $\mathrm{R} \$ 2.971 .464,53$

\section{Projeto}

Edifício com 12 salas de aula, setor administrativo, cozinha, refeitório, sanitários, grêmio, cantina, sala de uso múltiplo, informática, leitura, recreio coberto e quadra poliesportiva coberta.

\section{Partido arquitetônico}

Optou-se por uma solução vertical, em 4 pavimentos. Os blocos pedagógico e administrativo encontram-se em cotas diferentes, respeitando os platôs naturais do terreno. 0 pavimento térreo foi destinado aos usos comuns e a circulação vertical é feita no bloco pedagógico, que se liga ao administrativo por patamares em meios níveis. Pretende-se que este edifício funcione como elemento articulador dos dois conjuntos e da futura escola de ensino infantil a ser construída.

\section{Histórico}

Trata-se de um bairro de urbanização recente, não muito adensada, composta, sobretudo, por invasões e construções irregulares. Portanto, não havia escola. Com a implantação de dois conjuntos habitacionais da CDHU, a implantação do equipamento tornou-se imprescindível. Futuramente, pretende-se articular o edifício à escola infantil a ser construída.

\section{Proveniência da demanda}

Construção de 2 conjuntos habitacionais da CDHU (2.440 unidades).

\section{Equipe de projeto}

Arquitetura : Piratininga Arquitetos Associados S/C Ltda. (Arq. José Armênio de Brito Cruz); Estrutura de concreto: Ruy Bentes Engenharia de Estruturas S/C Ltda.; Estrutura metálica: Kurkdjian \& Fruchtengarten Engenheiros Associados S/C Ltda.; Hidráulica e combate a incêndio : Sandretec Consultoria S/C Ltda.; Elétrica e SPDA : Sandretec Consultoria S/C Ltda.; Consultoria de Solos e Fundações : Cepollina Engenheiros Consultores S/C Ltda.

\section{Coordenação do projeto}

FDE/ Arq. Sergio Hiroaki Ishikawa e FDE/ Ductor - Arq.Naide Patapas Cotrim Correia

\section{Fiscalização da Obra}

FDE/ Engenheira Lucia Toshiko Futigami Cabral

\section{Construtora}

Construtora Paez de Lima Construções Comércio e Empreendimentos Ltda.

\section{Propriedade da terra}

Governo do Estado de São Paulo - área da quadra de esportes de escola já existente

\section{Financiamento}

Secretaria Estadual de Educação. 


\section{PRODUÇÃO DE EQUIPAMENTOS EDUCACIONAIS}

\section{E.E. BELIZE | sem escala}

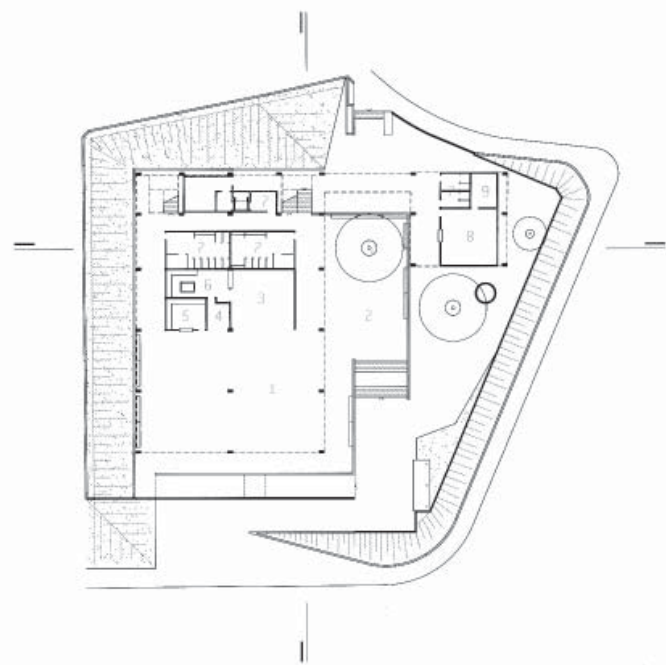

PLANTA TÉRREO/ IMPLANTAÇÃO

1. recreio 2. pátio 3. refeitório 4. despensa 5 . cantina 6 . cozinha

7. sanitário 8. secretaria 9. almoxarifado

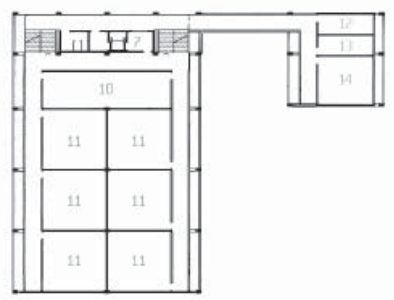

\section{PLANTA 10 PAVIMENTO}

10. informática 11. sala de aula 12. coordenação 13. diretoria 14. professores

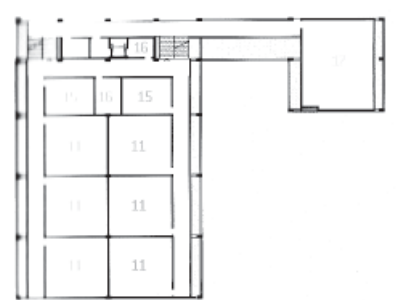

PLANTA $2^{\circ}$ PAVIMENTO

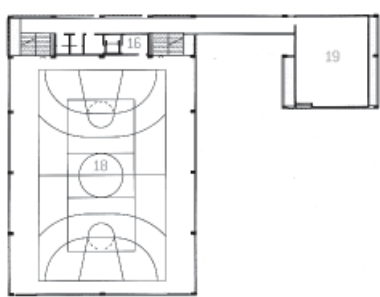

PLANTA 30 PAVIMENTO

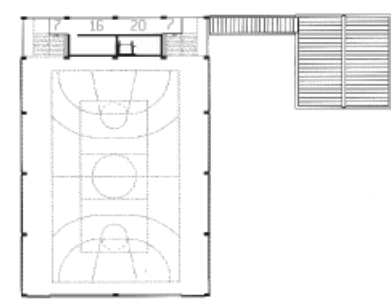

PLANTA $4^{\circ}$ PAVIMENTO

11. sala de aula 15. reforço 16. depósito 17. biblioteca

16. depósito 18. quadra 19. uso múltiplo 7. sanitário 16. depósito 20. grêmio

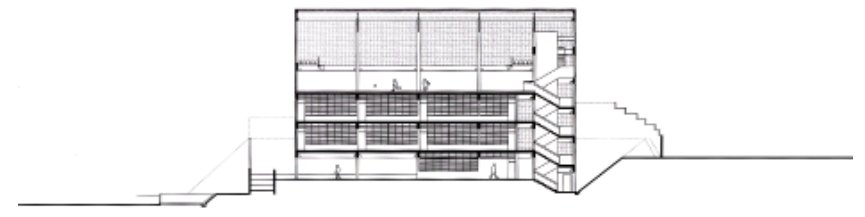

CORTE TRANSVERSAL

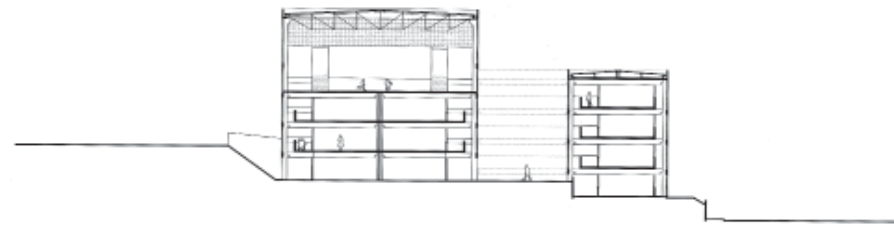



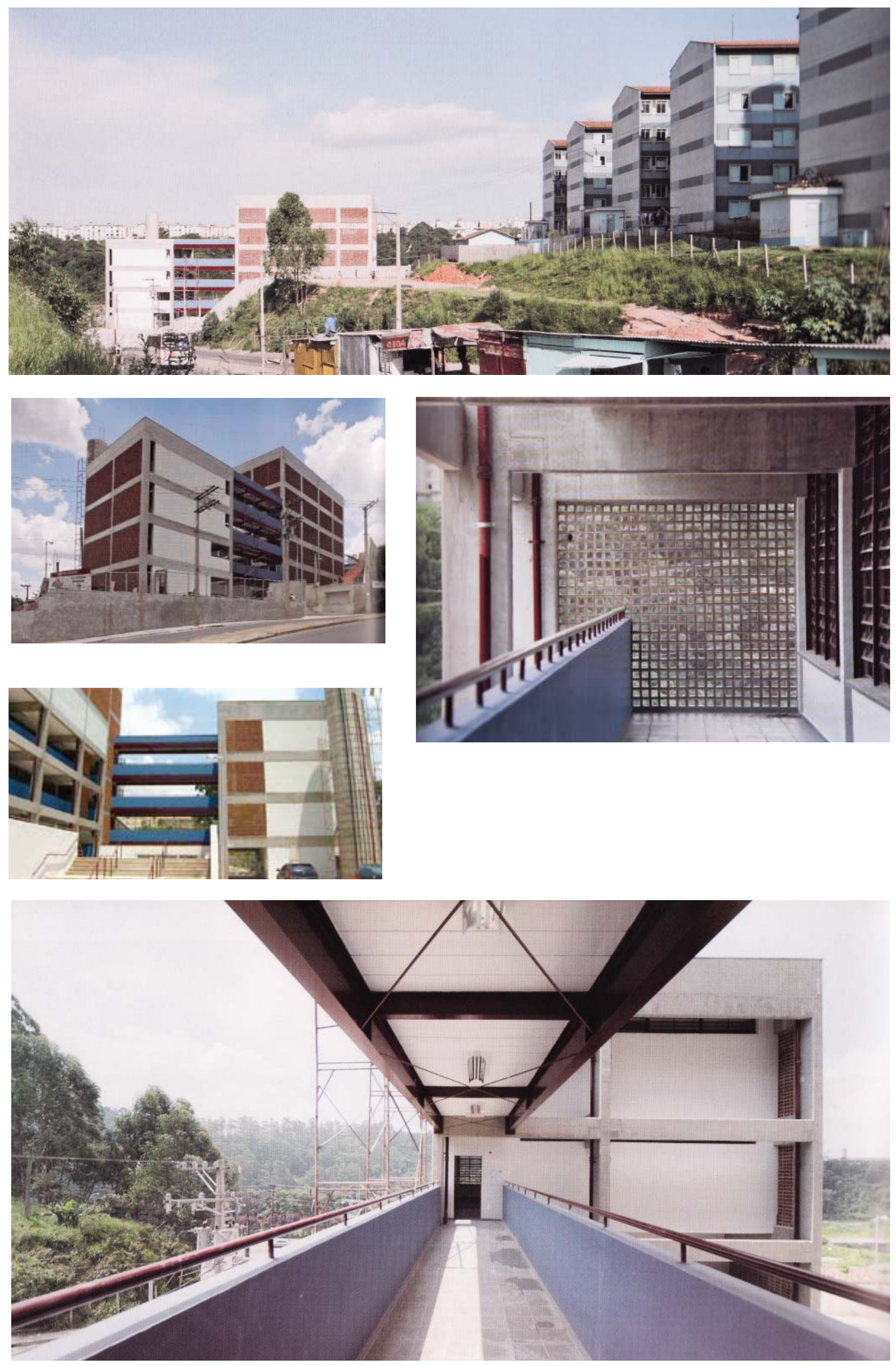


\section{PRODUÇÃO DE EQUIPAMENTOS EDUCACIONAIS}

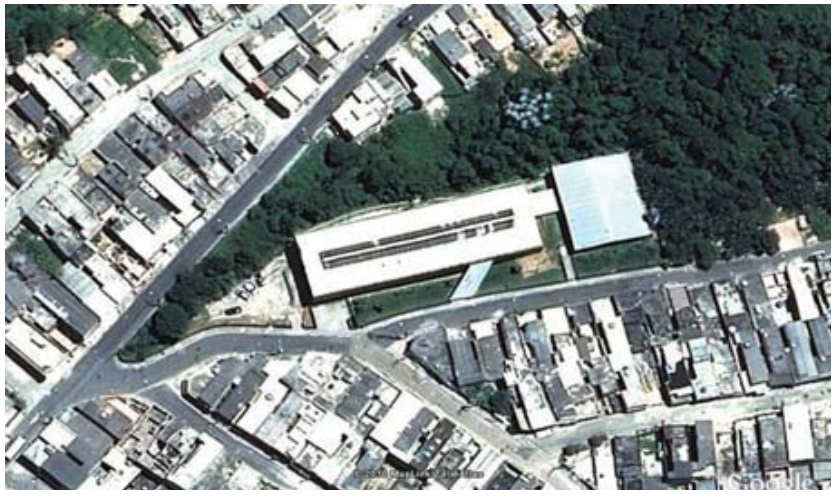

\section{E.E. RECANTO VERDE SOL}

Av. Recanto Verde Sol, Quadra I, s/n - Guaianazes

área construída: $2.730 \mathrm{~m}^{2}$

data projeto: 2004

data obra: 2005

tipo de obra: obra nova

custo: $\mathrm{R} \$$ -

Projeto

Edifício com 12 salas de aula, setor administrativo, cozinha, refeitório, sanitários, grêmio, cantina, sala de uso múltiplo, informática, leitura, recreio coberto e quadra poliesportiva coberta.

\section{Partido arquitetônico}

0 projeto partiu de diversas limitações impostas pelo terreno, tais como as dimensões reduzidas para 0 extenso programa de usos e a presença de um córrego ao fundo do lote, cuja faixa não edificada foi respeitada. Sendo assim, o edifício apresenta uma volumetria compacta, com planta simétrica, com corredores ao redor de um vão central, que distribuem a circulação. 0 recreio coberto volta-se para o fundo do terreno, com vista para a mata existente, enquanto os setores administrativos e de serviços voltam-se para a rua.

\section{Histórico}

Trata-se de um bairro situado na divisa do município de São Paulo com Ferraz de Vasconcelos, região esta de acentuado crescimento populacional recente, calcado numa malha urbana formada por ocupações irregulares e invasões. A nova escola foi projetada para substituir a antiga, construída em módulos metálicos do tipo container, voltada apenas ao ensino infantil.

\section{Proveniência da demanda}

Crescimento populacional do bairro.

\section{Equipe de projeto}

Arquitetura : Eduardo de Almeida Arquitetos Assoc. Ltda. (Arqs. Eduardo de Almeida, Felipe Noto, Maira Rios, Roberto Zocchio); Estrutura metálica: Kurkdjian \& Fruchtengarten Engenheiros Associados S/C Ltda.; Hidráulica e combate a incêndio : Caiuby Projetos e Serviços Ltda.; Elétrica e SPDA : P.D'aprile Consultoria e Projetos; Consultoria de Solos e Fundações : Zaclis, Falconi \& Engenheiros Associados S/C Ltda.; Consultoria de Estrutura : Kurkdjian \& Fruchtengarten Engenheiros Associados S/C Ltda.

\section{Coordenação do projeto}

FDE/ Arq. Sandra Tiemi Canashiro

\section{Fiscalização da Obra}

FDE/ Engenheiro Walter Haidar

\section{Construtora}

Construtora Itajaí Ltda.

\section{Propriedade da terra}

Governo do Estado de São Paulo - área da escola anteriormente existente (substituição).

\section{Financiamento}

Secretaria Estadual de Educação. 


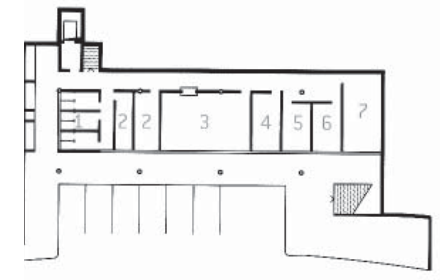

\section{PLANTA SUBSOLO}

1. sanitário 2. depósito 3. secretaria 4. almoxarifado 5. diretoria 6. coordenação 7. professores

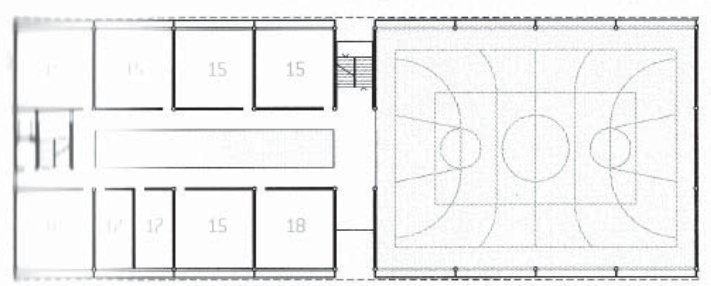

PLANTA $1^{\circ}$ PAVIMENTO

15. sala de aula 16. uso múltiplo 17. reforço 18. informática

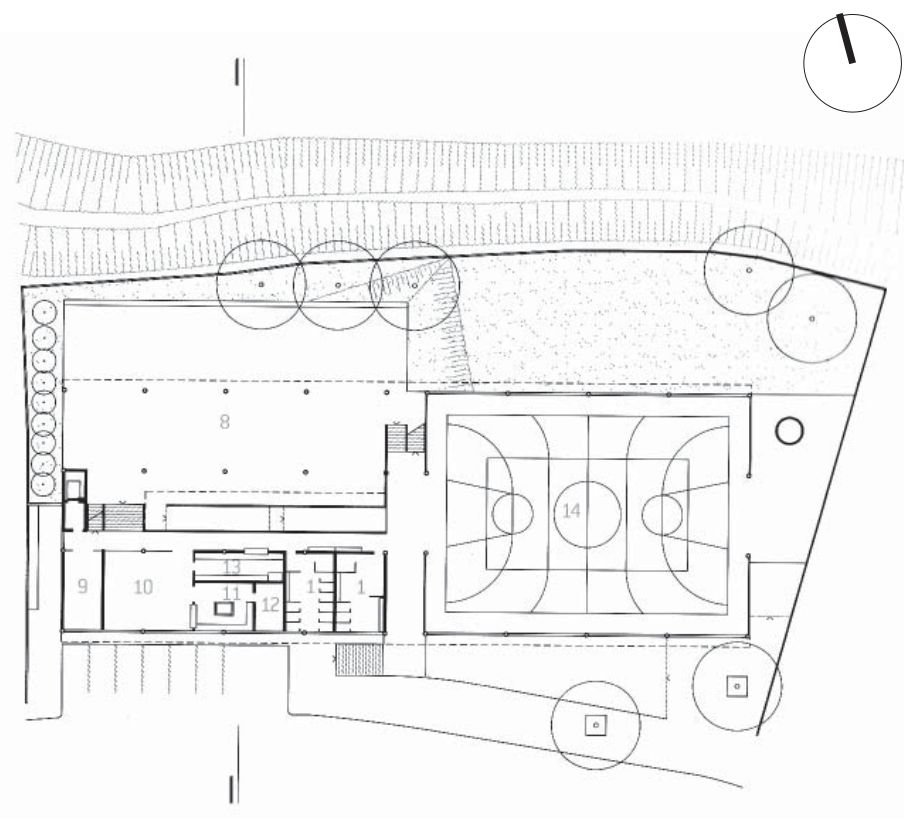

PLANTA TÉRREO/ IMPLANTAÇÃO

8. recreio 9. grêmio 10. refeitório 11. cozinha 12. despensa 13. cantina 14. quadra

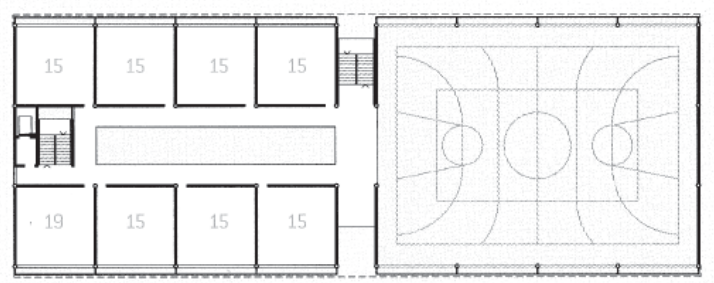

PLANTA $2^{\circ}$ PAVIMENTO

15. sala de aula 19. leitura

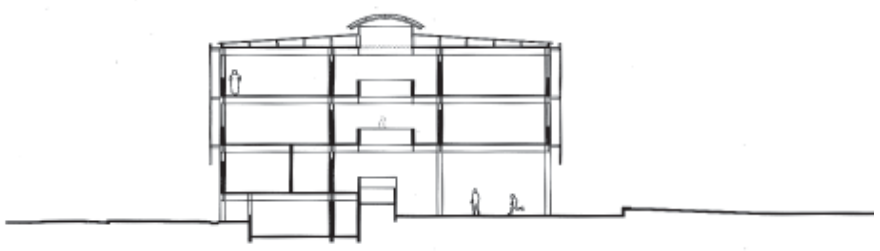

CORTE TRANSVERSAL

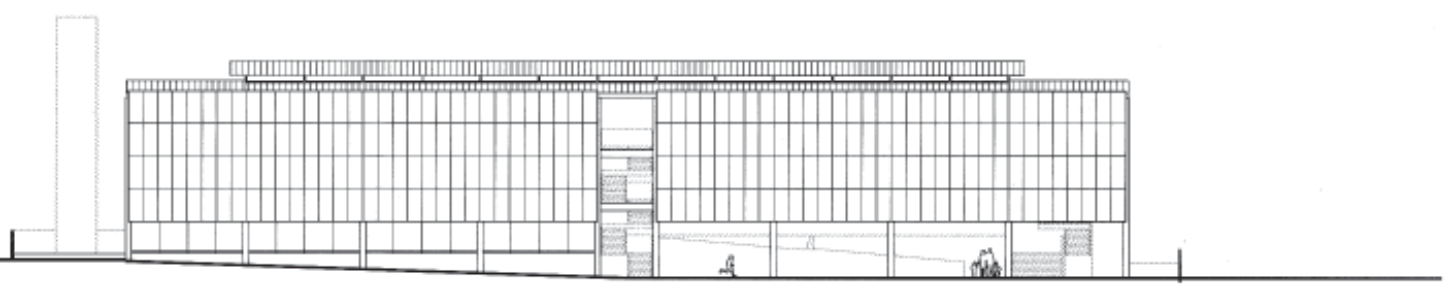




\section{PRODUÇÃO DE EQUIPAMENTOS EDUCACIONAIS}
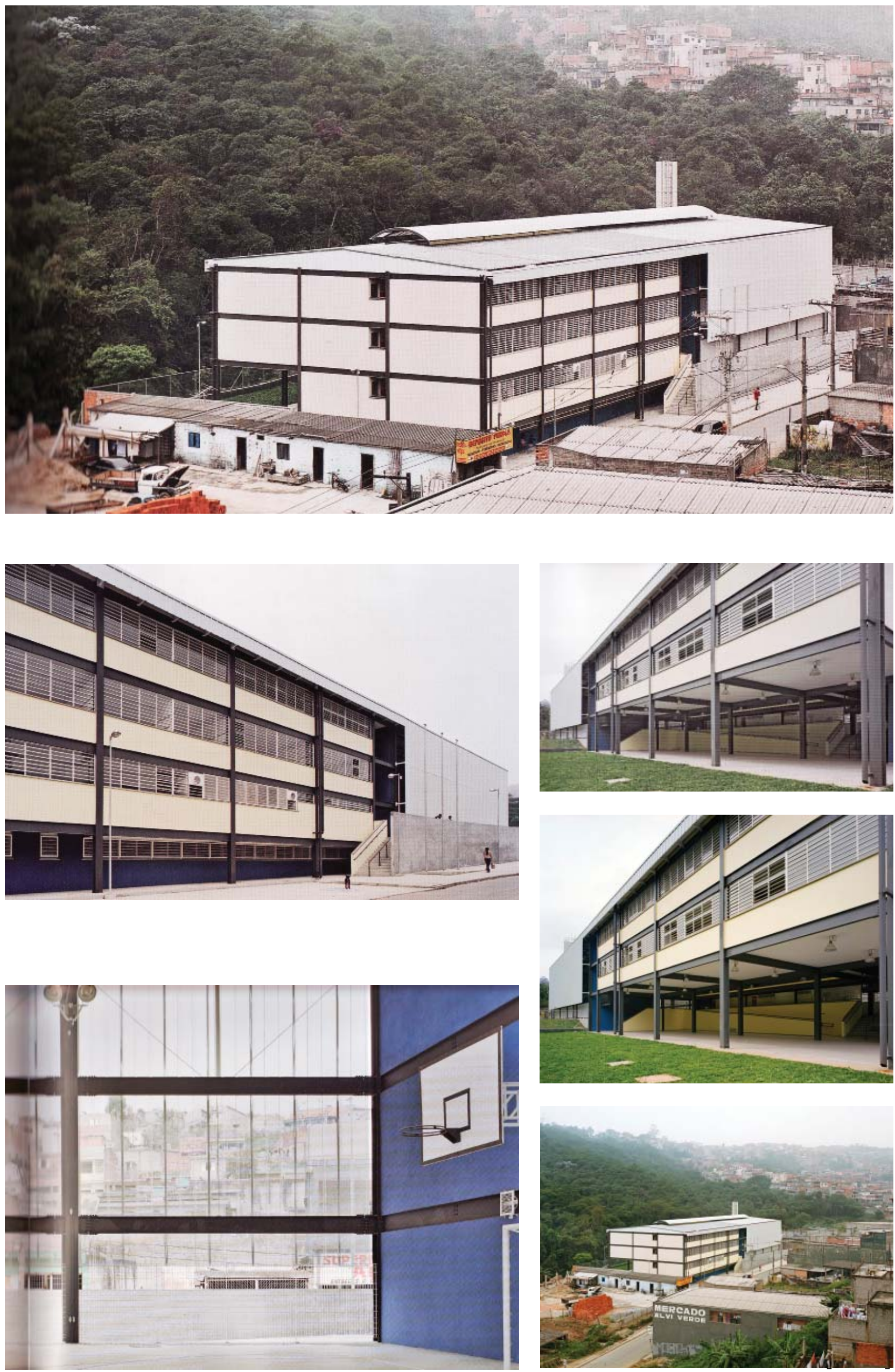


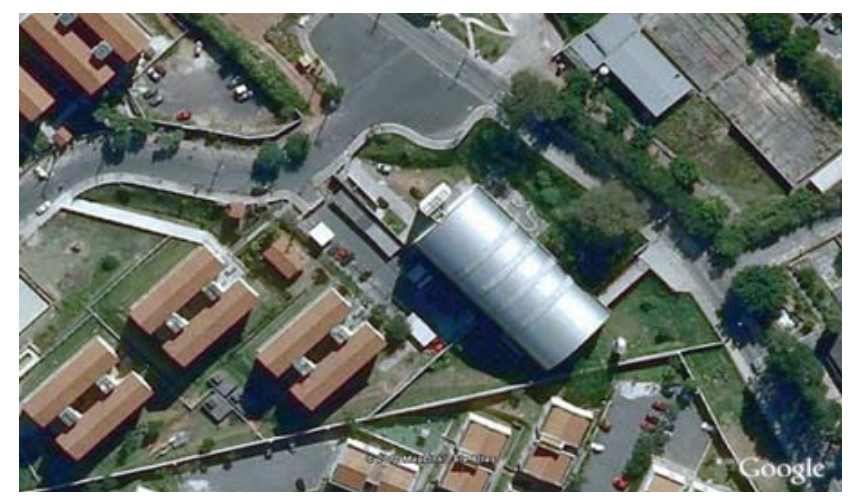

\section{E.E. MINISTRO OSCAR DIAS CORREIA}

Av. Alexios Jafet, s/n - Jaraguá

área construída: $3.953 \mathrm{~m}^{2}$

data projeto: 2003

data obra: 2006

tipo de obra: obra nova

custo: $\mathrm{R} \$ 3.589 .903,99$

\section{Projeto}

Edifício com 12 salas de aula, setor administrativo, cozinha, refeitório, sanitários, grêmio, cantina, sala de uso múltiplo, informática, leitura, recreio coberto e quadra poliesportiva coberta.

\section{Partido arquitetônico}

Situado em um pequeno platô $7 \mathrm{~m}$ abaixo da via principal, o edifício parte de uma solução compacta, com acesso em nível com a rua, por meio de uma passarela elevada. 0 programa foi disposto de modo a sugerir uma divisão vertical dos usos, optando pela localização das áreas administrativa e didática nos pavimentos mais baixos, abaixo do nível da rua, as áreas de serviço e convivência em nível com 0 acesso principal, facilitando 0 uso nos finais de semana pela comunidade e a quadra no último piso, de modo a tirar partido da estrutura. 0 edifício se ergue sobre uma estrutura pré-moldada de concreto, coroado por uma cobertura metálica em arco, que evita as altas paredes de fechamento da quadra.

\section{Histórico}

Com a construção dos conjuntos da CDHU Jaraguá C e F, houve um forte aumento da demanda por vagas. Sendo assim, a escola foi construída na área institucional de um dos conjuntos.

\section{Proveniência da demanda}

Construção dos conjuntos habitacionais Jaraguá C e F, da CDHU.

\section{Equipe de projeto}

Arquitetura : Ubyrajara Arquitetos Assoc. S/C Ltda.; Estrutura de concreto: Ruy Bentes Engenharia de Estruturas S/C Ltda.; Estrutura metálica: Kurkdjian \& Fruchtengarten Engenheiros Associados S/C Ltda.; Hidráulica e combate a incêndio : Sandretec Consultoria S/C Ltda.; Elétrica e SPDA : Sandretec Consultoria S/C Ltda.; Consultoria de Solos e Fundações : Cepollina Engenheiros Consultores S/C Ltda.; Consultoria de Estrutura: Ruy Bentes Engenharia de Estruturas S/C Ltda.

\section{Coordenação do projeto}

FDE/ Arq. Vânia Regina Pierri Oliveira e Ductor - Arq. Naide Patapas Cotrim Correa

\section{Fiscalização da Obra}

FDE/ Concremat - Engenheiro José Machado Maluf

\section{Construtora}

Construtora Paez de Lima Construções Comércio e Empreendimentos Ltda.

\section{Propriedade da terra}

Governo do Estado de São Paulo - área institucional de conjunto habitacional implantado pela CDHU.

\section{Financiamento}

Secretaria Estadual de Educação. 


\section{PRODUÇÃO DE EQUIPAMENTOS EDUCACIONAIS}

\section{E.E. MINISTRO OSCAR DIAS CORREIA | sem escala}

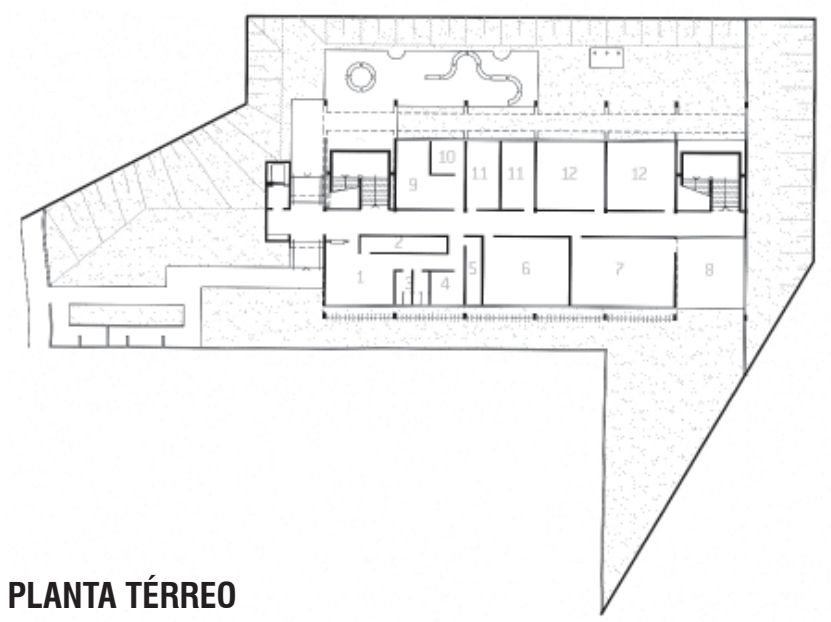

1. secretaria 2. almoxarifado 3. sanitário 4. diretoria 5. depósito 6. informática 7. leitura 8. pátio 9. professores 10. coordenação 11. reforço 12. sala de aula

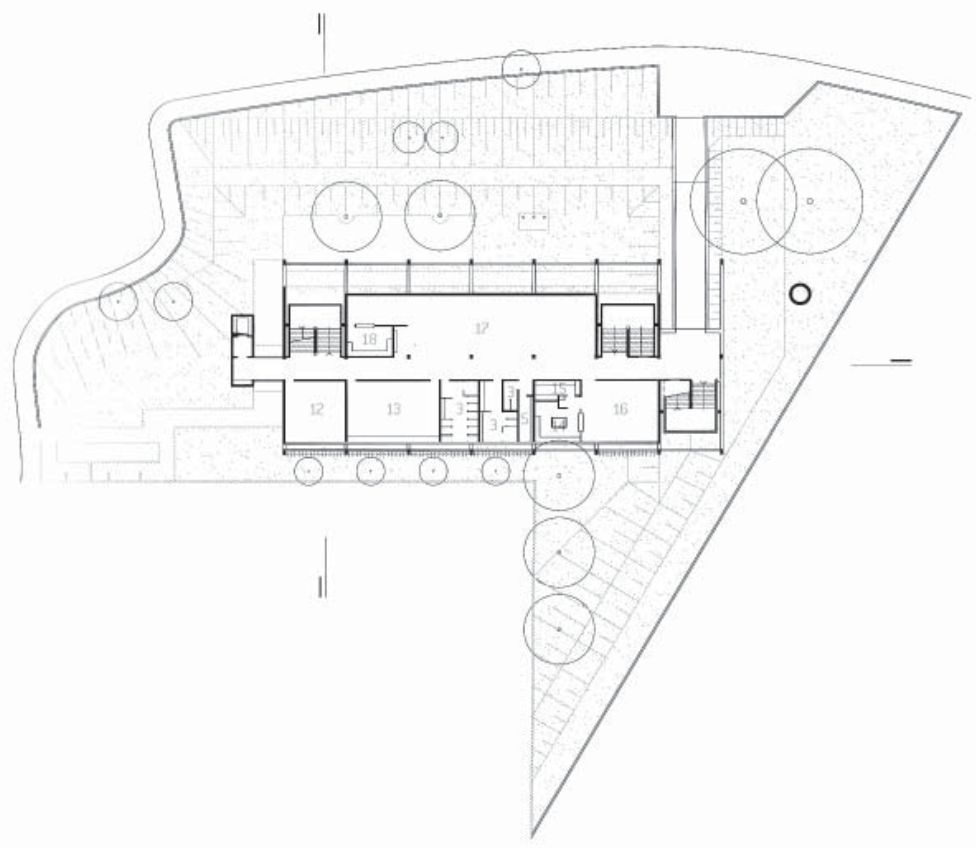

PLANTA $2^{\circ}$ PAVIMENTO/ IMPLANTAÇÃO

12. sala de aula 13. uso múltiplo 14. cozinha 15. despensa

16. refeitório 17. recreio 18. cantina

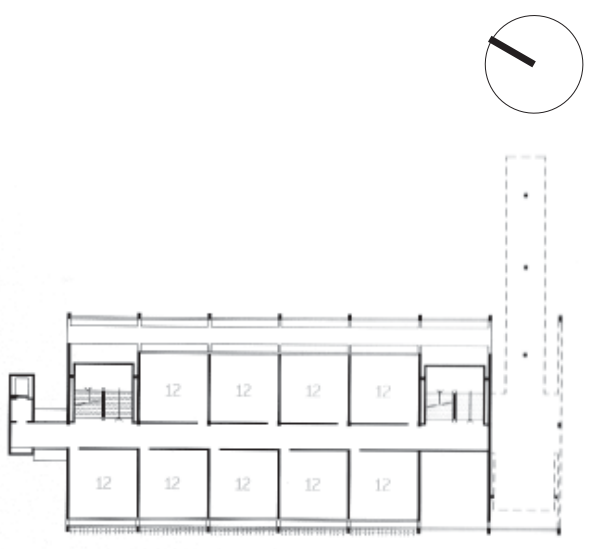

12. sala de aula

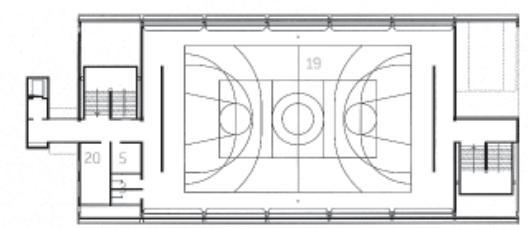

\section{PLANTA $3^{\circ}$ PAVIMENTO}

19. quadra 20. grêmio

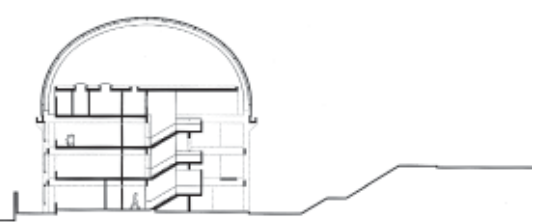

CORTE TRANSVERSAL 

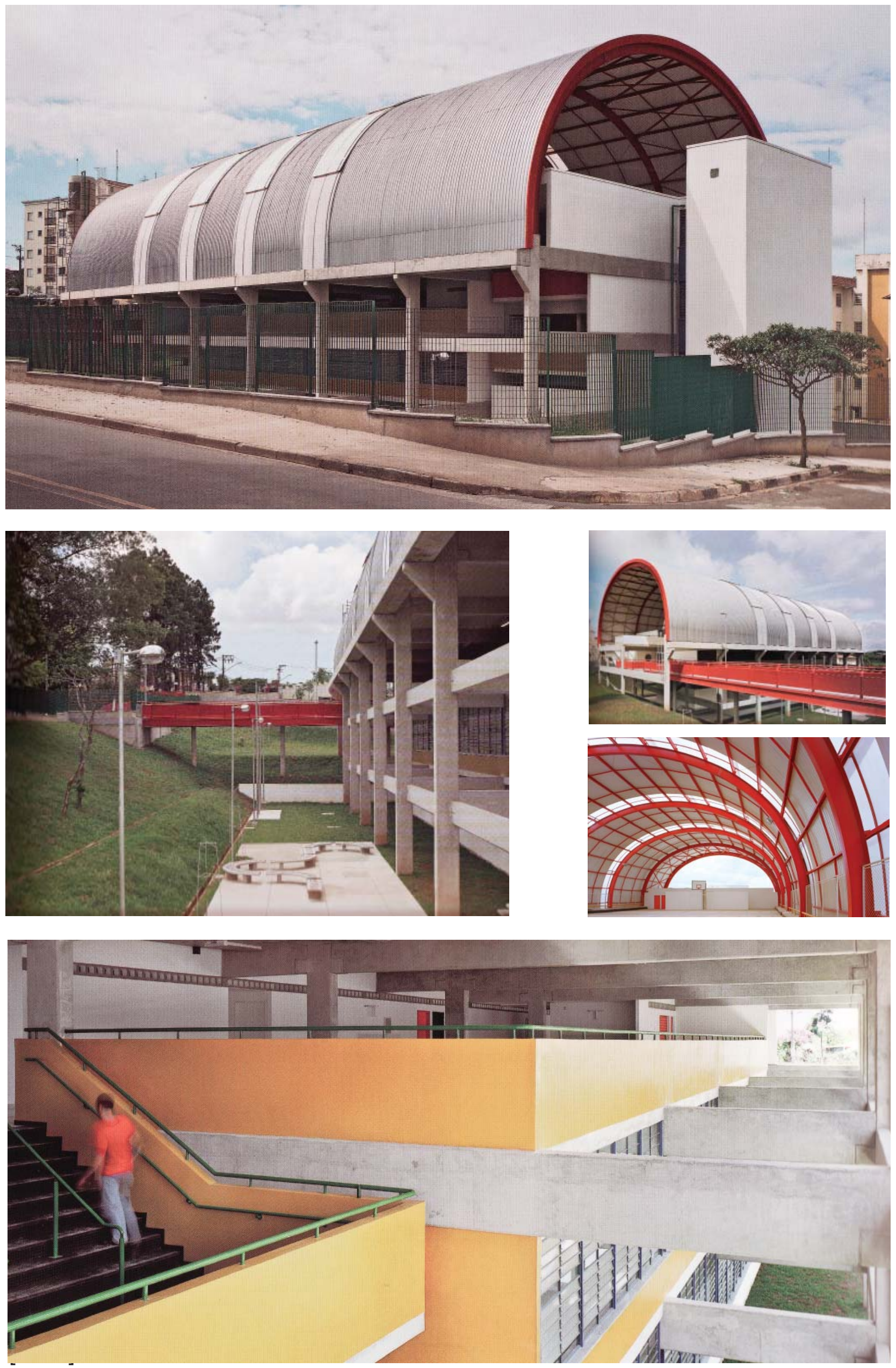


\title{
PRODUÇÃO DE EQUIPAMENTOS EDUCACIONAIS
}

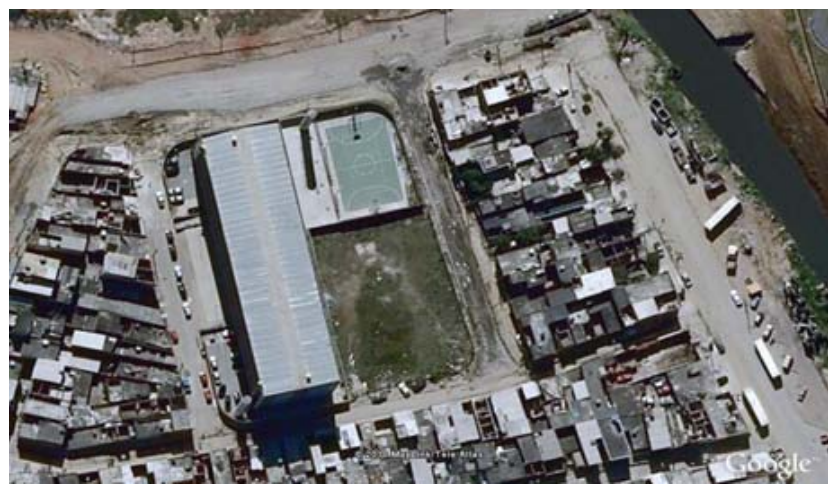

\section{E.E. HÉLIO HELENE; E.E. PROF. PAULO KOBAYASHI/ UNIÃO VILA NOVA III E IV}

Rua Dener, $\mathrm{s} / \mathrm{n}$ - União da Vila Nova

área construída: $6.841 \mathrm{~m}^{2}\left(2.482 \mathrm{~m}^{2}+4.359 \mathrm{~m}^{2}\right)$

data projeto: 2003

data obra: 2005

tipo de obra: obra nova

custo: $\mathrm{R} \$ 6.640 .259,35$ (2.999.419,43 +

Projeto

Edifício com 30 salas de aula, setor administrativo, cozinha, refeitório, sanitários, grêmio, cantina, sala de uso múltiplo, informática, leitura, recreios coberto e descoberto e quadras poliesportivas coberta e descoberta.

\section{Partido arquitetônico}

0 reduzido terreno em "L" levou à opção por um único edifício para abrigar as duas escolas. A escola que atende às crianças menores tem sua área de convivência situada no térreo, com acesso direto à rua, contando com recreio e quadra poliesportiva externos. A escola que atende ao Ensino Médio dispõe de uma grande área de convívio no terceiro piso, que abriga quadra poliesportiva, pátio e serviços. As salas de aula se distribuem nos 10 e 20 pavimentos, estando localizadas as primeiras à norte e as demais a sul, separadas pelo bloco de circulação. 0 acesso é único e se dá por uma grande praça, que permite 0 encontro de todos os pais e alunos.

\section{Histórico}

0 bairro União da Vila Nova, na Zona Leste do município, está situado em meio ao Parque Ecológico do Tietê, delimitado pelo Rio Tietê a norte, córrego do Jacu a leste e pela ferrovia a sul e oeste, o que faz dele uma ilha urbana. As escolas fazem parte da proposta de urbanização desenvolvida pela CDHU para a área, que envolvia a implantação de duas escolas estaduais e um posto de saúde.

\section{Proveniência da demanda}

Projeto de urbanização da CDHU para o bairro.

\section{Equipe de projeto}

Arquitetura : Barossi \& Nakamura Arquitetos Ltda. e Hereñu + Ferroni Arquitetos Ltda. (Arqs. Antônio Carlos Barossi, Eduardo Ferroni, Leila Mair Saleh Hussein, Milton Susumo Nakamura, Pablo Hereñu); Estrutura de concreto: SB Projetos e Consultoria Ltda.; Estrutura metálica: Oficina de Arquitetura Ltda.; Hidráulica e combate a incêndio : MBM Serviços de Engenharia S/C Ltda.; Elétrica e SPDA : MBM Serviços de Engenharia S/C Ltda.; Consultoria de Solos e Fundações : Zaclis, Falconi \& Engenheiros Associados S/C Ltda.; Consultoria de Estrutura: Ruy Bentes Engenharia de Estruturas S/C Ltda.

\section{Coordenação do projeto}

FDE/ Arq. Sandra Tiemi Canashiro e Siméia de Carvalho Pinto

\section{Fiscalização da Obra}

FDE/ Arq. Sérgio Rubens Barros

\author{
Construtora \\ Construtora Massafera Ltda.
}

\section{Propriedade da terra}

Governo do Estado de São Paulo - área institucional de conjunto habitacional implantado pela CDHU.

\section{Financiamento}

Secretaria Estadual de Educação. 


\section{E.E. HÉLIO HELENE/ E.E. PROF. PAULO KOBAYASHI | sem escala}

E.E. Hélio Helene/ E.E. União da V. Nova III E.E. Prof. Paulo Kobayshi/ E.E. União da V. Nova IV

\section{PLANTA TÉRREO/ IMPLANTAÇÃO}

1. praça de acesso 2. recreio 3. sanitário 4. secretaria 5. almoxarifado 6. diretoria 7. coordenação

8. professores 9. refeitório 10. cozinha 11. despensa

12. uso múltiplo 13. leitura 14. informática 15. quadra

\section{PLANTA $1^{\circ}$ PAVIMENTO}

16. sala de aula 17. depósito 18. reforço

\section{PLANTA $2^{\circ}$ PAVIMENTO}

16. sala de aula 18. roforço

\section{PLANTA 30 PAVIMENTO}

2. recreio 3. sanitário 9. refeitório 10. cozinha

17. depósito 19. quadra 20. cantina 21. grêmio

\section{PLANTA $4^{\circ}$ PAVIMENTO}

2. recreio 17. depósito
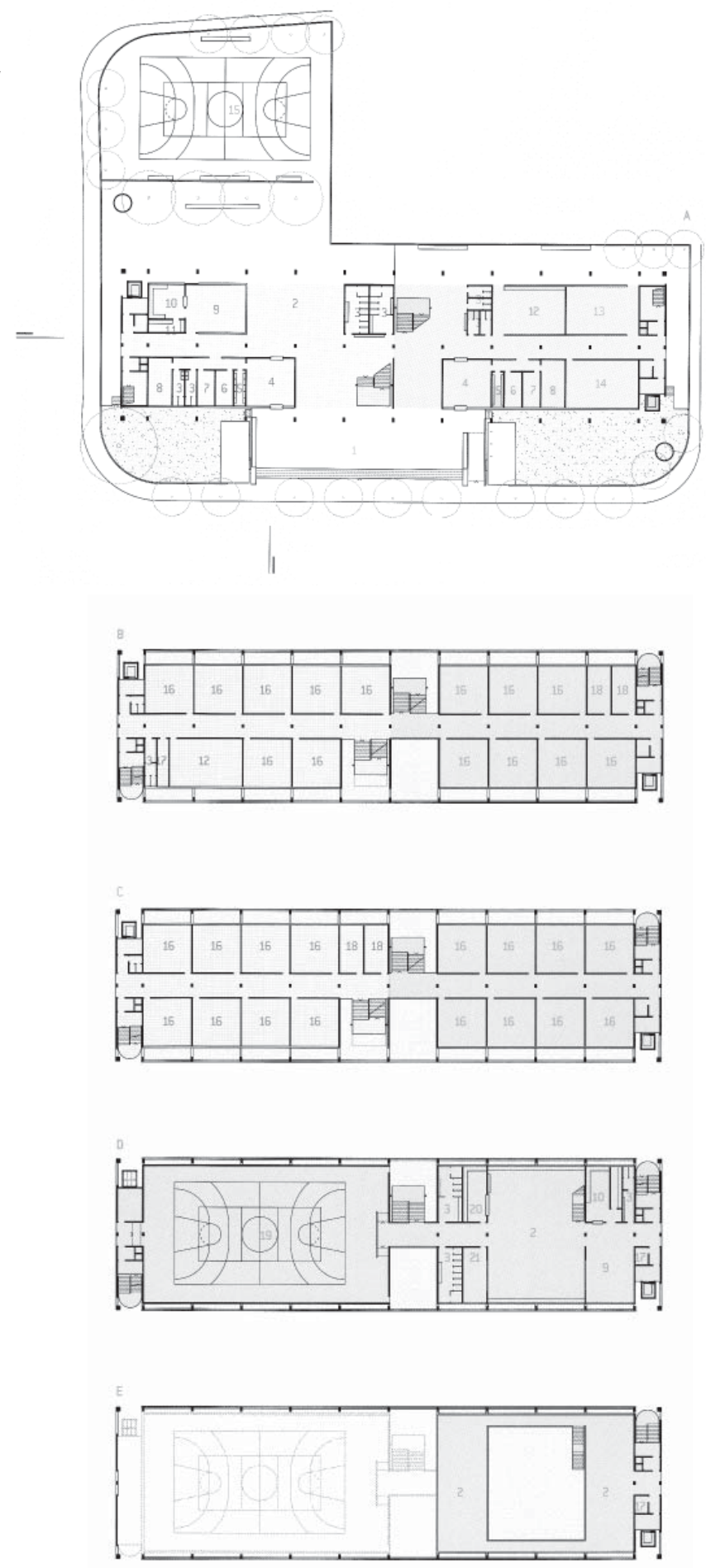


\section{PRODUÇÃO DE EQUIPAMENTOS EDUCACIONAIS}
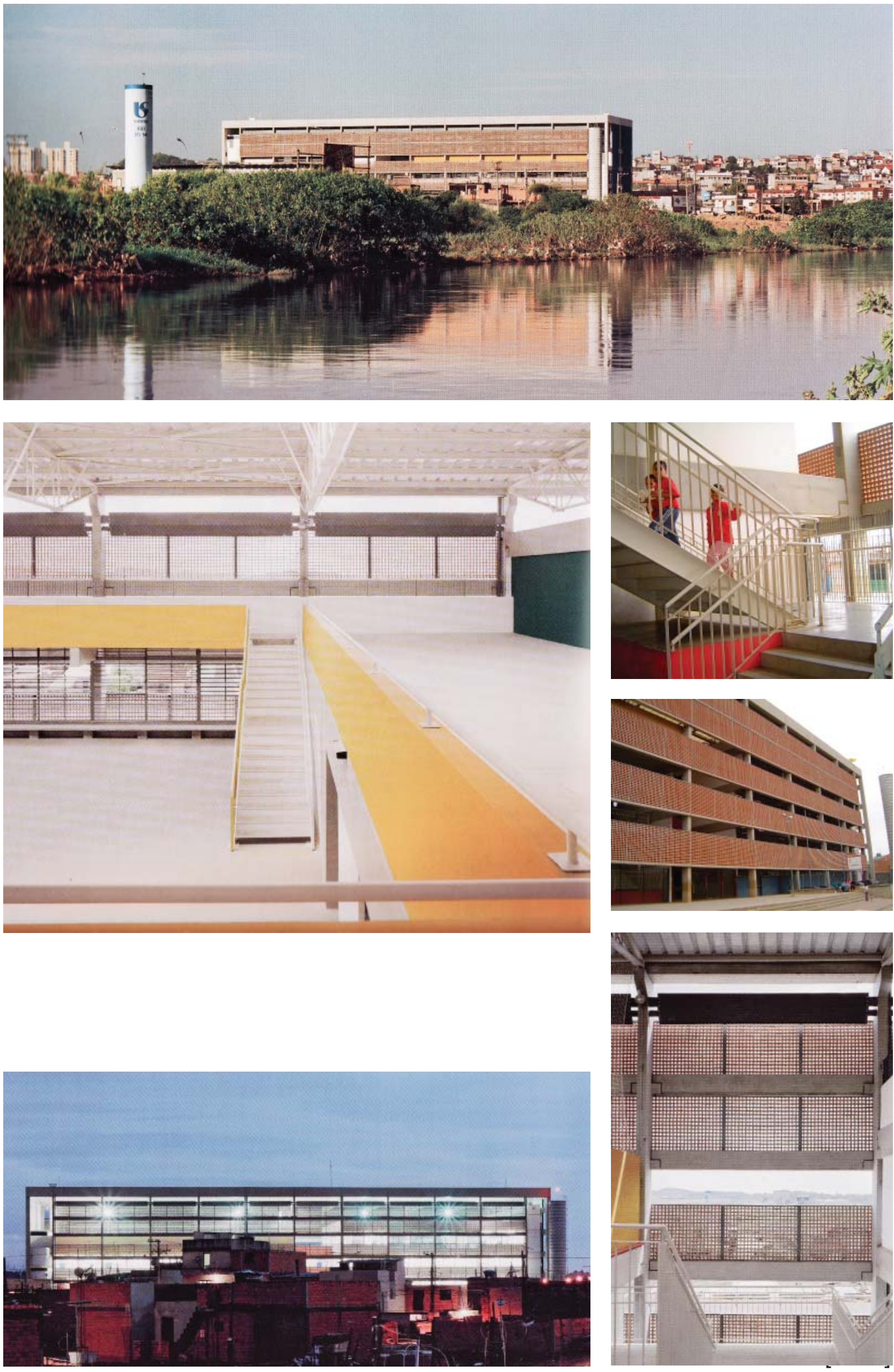


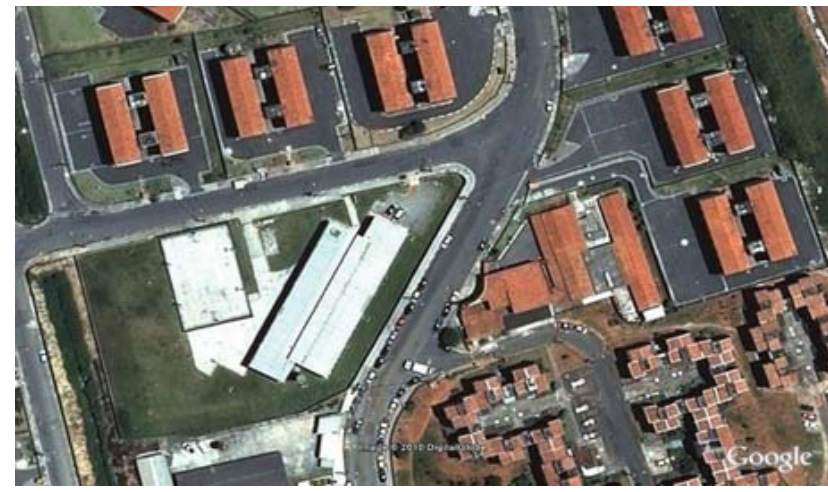

\section{E.E. FAZENDA DA JUTA VI}

Rua Lisa Noblet (Rua Dois), s/n - COHAB Itaquera B

área construída: $1.926 \mathrm{~m}^{2}$

data projeto: 2003

data obra: 2005

tipo de obra: substituição de prédio

custo: $R \$ 2.313 .116,92$

\section{Projeto}

Edifício com 12 salas de aula, setor administrativo, cozinha, refeitório, sanitários, grêmio, cantina, sala de uso múltiplo, informática, leitura, recreio coberto e quadra poliesportiva descoberta.

\section{Partido arquitetônico}

Edifício resolvido em um único bloco, com salas de aula no pavimento superior e demais usos no pavimento térreo, facilitando 0 uso pela comunidade nos finais de semana. 0 pavimento didático se organiza em dois blocos lineares de salas de aula, com corredores de circulação centrais divididos por um vão, que permite a integração entre os pavimentos e a iluminação do piso térreo, por meio do uso de elementos zenitais. A escola dispõe de ampla área externa, onde está também situada a quadra poliesportiva, descoberta.

\section{Histórico}

A escola visa atender a forte demanda de uma área cujo entorno é inteiramente ocupado pelo Conjunto Habitacional Fazenda da Juta, da CDHU, que conta com cerca de 4.000 unidades, parte delas construídas em modelo tradicional e outra em regime de mutirão. A população até então contava com duas escolas, com 17 e 16 salas, e uma terceira, que esta obra viria a substituir, implantada em caráter provisório, com 10 salas de aula, em módulos metálicos do tipo container.

\section{Proveniência da demanda}

Substituição da E.E. Fazenda da Juta V; forte demanda do conjunto CDHU Fazenda da Juta, com 4 mil unidades.

\section{Equipe de projeto}

Arquitetura : Ecoplan Arquitetura e Planejamento S/C Ltda. (Arqs. José Ricardo de Carvalho, Evelin Bermejo (colab.)); Estrutura de concreto: SB Projetos e Consultoria Ltda.; Hidráulica e combate a incêndio : Yoshizaki e Sato Engenheiros Associados; Elétrica e SPDA : Yoshizaki e Sato Engenheiros Associados; Consultoria de Solos e Fundações : Zaclis, Falconi \& Engenheiros Associados S/C Ltda.; Consultoria de Estrutura: Zamarion e Millen Consultores S/S Ltda.

\section{Coordenação do projeto}

FDE/ Arq. Sérgio Hiroaki Ishikawa e Siméia de Carvalho Pinto

\section{Fiscalização da Obra}

FDE/ Eng. Lucia Toshiko Futigami Cabral

\section{Construtora}

Construtora Massafera Ltda.

\section{Propriedade da terra}

Governo do Estado de São Paulo - área da escola anteriormente existente (substituição).

\section{Financiamento}

Secretaria Estadual de Educação. 


\section{PRODUÇÃO DE EQUIPAMENTOS EDUCACIONAIS}

\section{E.E. FAZENDA DA JUTA VI | sem escala}

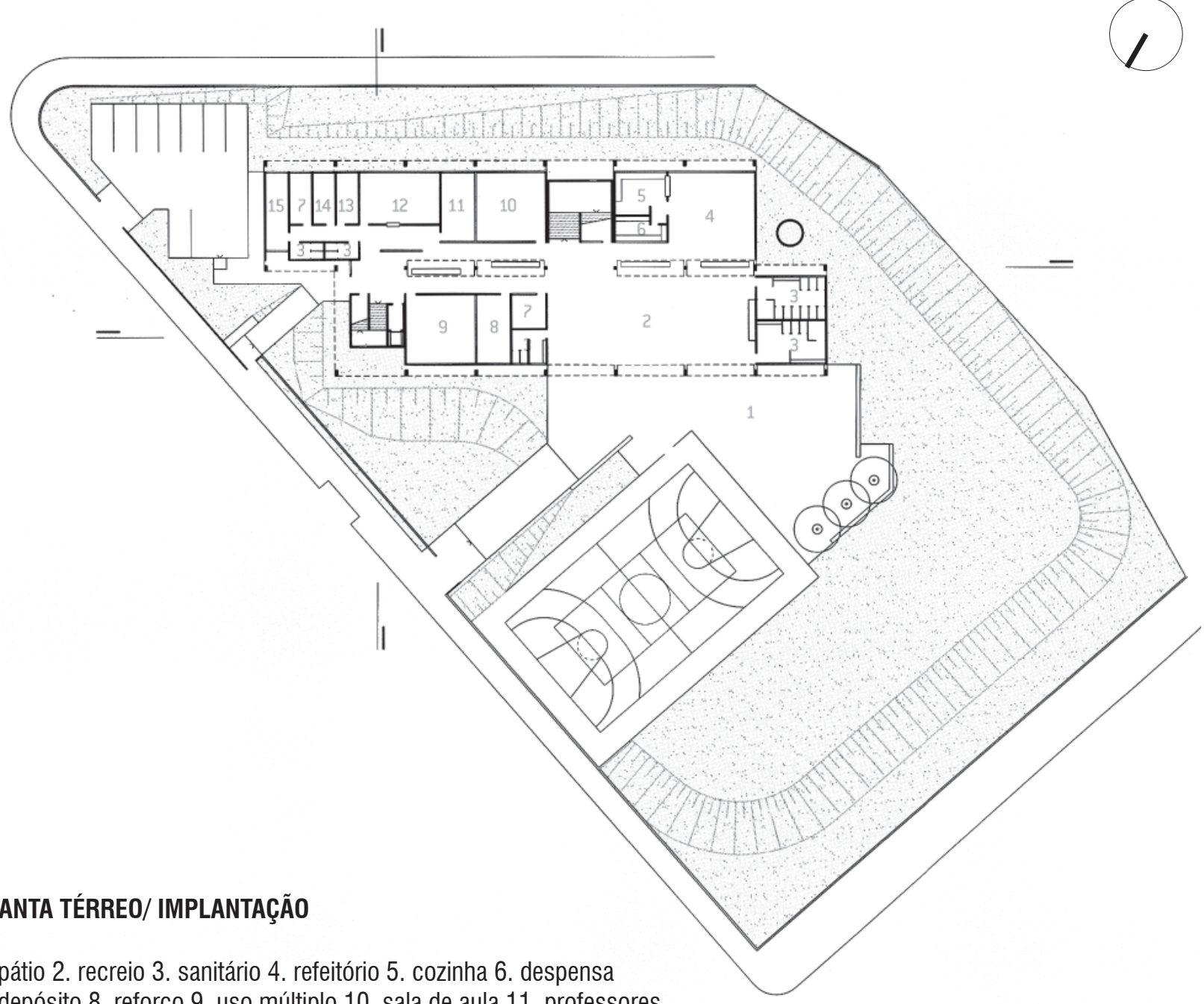

7. depósito 8. reforço 9. uso múltiplo 10. sala de aula 11. professores

12. secretaria 13. diretoria 14. coordenação 15. almoxarifado

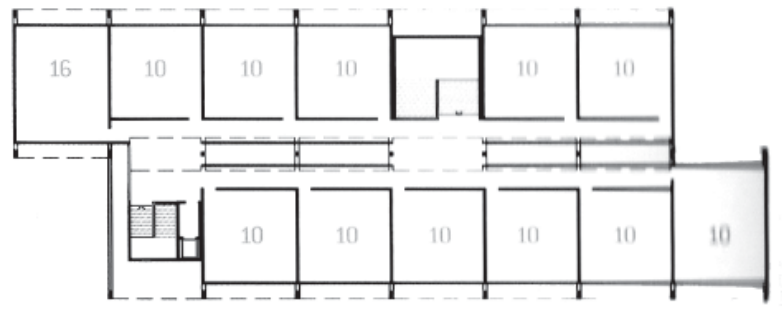

\section{PLANTA $1^{\circ}$ PAVIMENTO}

10. sala de aula 16. informática
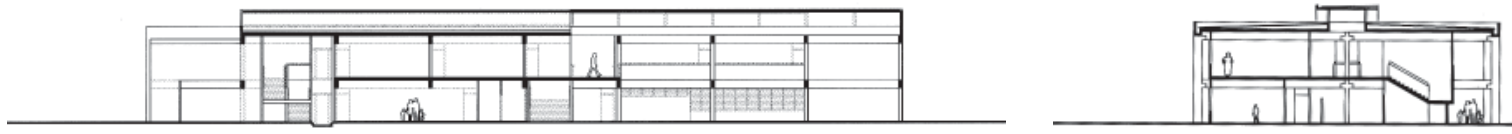

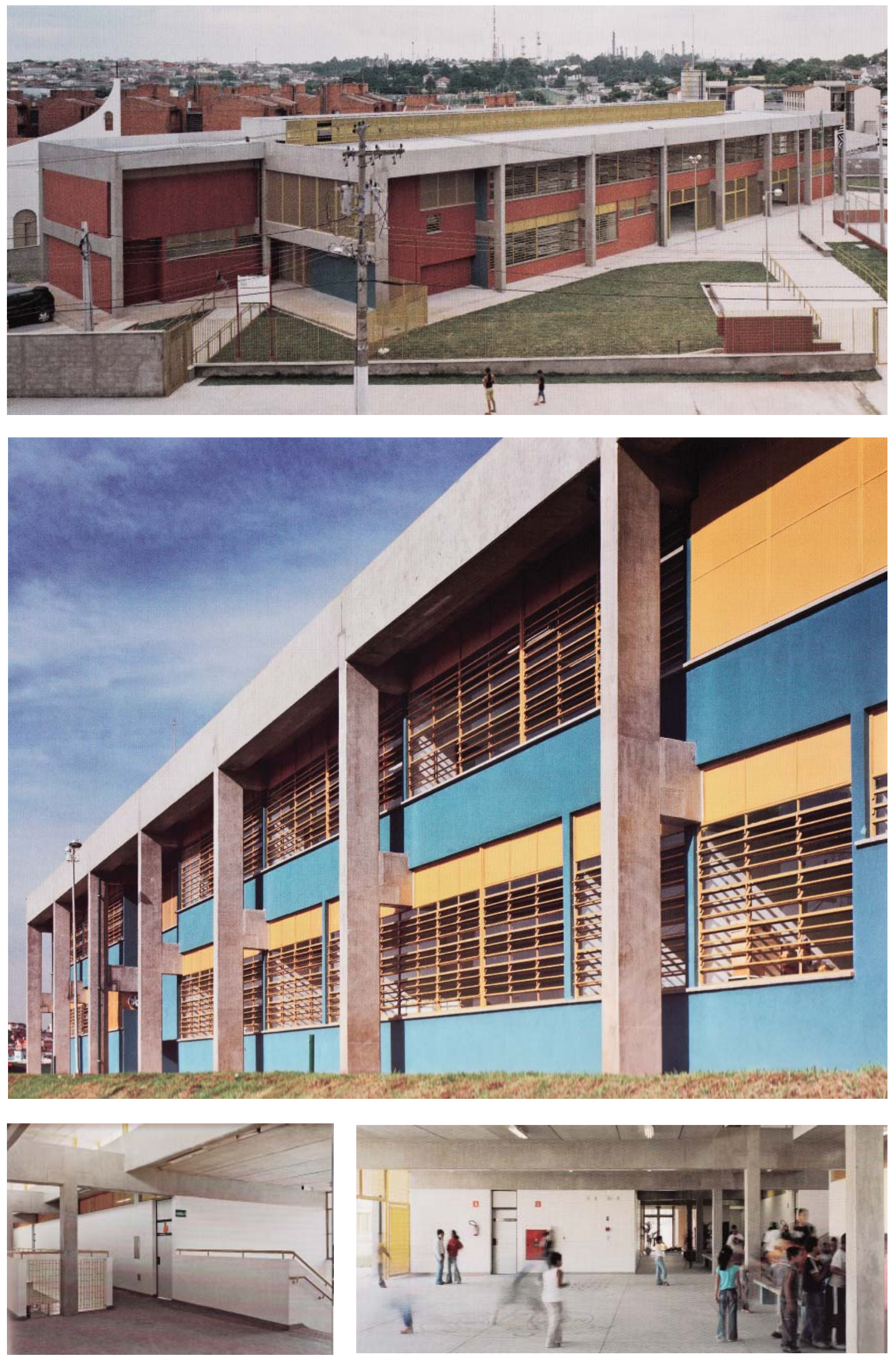


\title{
PRODUÇÃO DE EQUIPAMENTOS EDUCACIONAIS
}

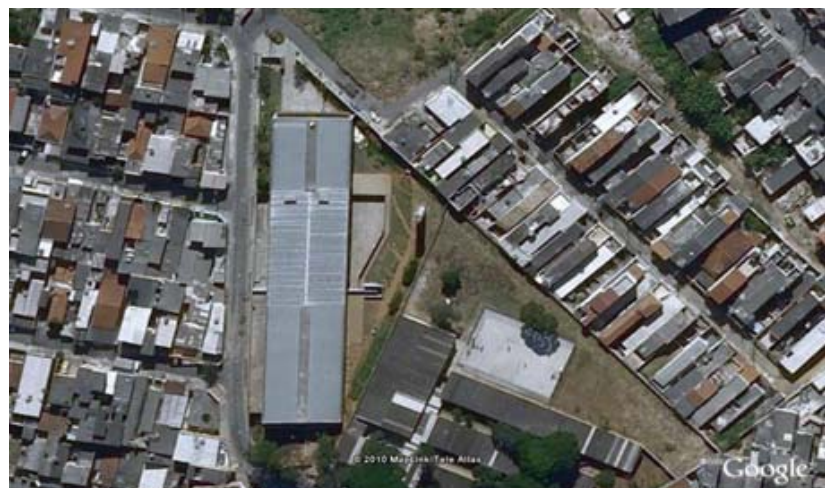

\section{E.E. DR. PEDRO DE MORAES VICTOR}

Rua Boaventura Coletti, s/n - Jd. Ataliba Leonel

área construída: $4.210 \mathrm{~m}^{2}$

data projeto: 2003

data obra: 2006

tipo de obra: obra nova

custo: $\mathrm{R} \$ 4.019 .427,09$

Projeto

Edifício com 15 salas de aula, setor administrativo, cozinha, refeitório, sanitários, grêmio, cantina, sala de uso múltiplo, informática, leitura, recreio coberto e quadra poliesportiva coberta.

\section{Partido arquitetônico}

Em função do relevo acentuado, a escola conta com 3 acessos distintos: 0 de nível mais alto marca 0 acesso dos estudantes, em nível com o pátio; 0 de nível intermediário, acessa diretamente a administração; entre os dois, um platô rebaixado, que coincide com o nível da rua, abriga a quadra poliesportiva, facilitando sua utilização nos finais de semana. As salas de aula foram disposta no 20 pavimento, com circulação junto às fachadas, formadas por passarelas metálicas atirantadas à cobertura. 010 pavimento é dedicado às áreas de convívio, salas de apoio e serviços, com acesso direto à rua e comunicação com os demais pavimentos por meio do grande vão da quadra. No pavimento térreo, ficam salas administrativas e quadra poliesportiva, que também dispõem de acesso próprio.

\section{Histórico}

A escola foi construída para atender a forte demanda da região, cujas escolas estavam sobrecarregadas. Devido à ausência de terrenos, a nova escola foi implantada na área remanescente da escola já existente.

\section{Proveniência da demanda}

Crescimento populacional do bairro.

\section{Equipe de projeto}

Arquitetura : SPBR Arquitetos Ltda. (Arqs. Angelo Bucci, Alvaro Puntoni, Maria Isabel Imbronito, Juliana Braga, Ciro Miguel, Tobias Xavier, Omar Mohamad Dalank); Estrutura de concreto : Estruturarte - Estruturas e Artes Ltda.; Estrutura metálica: Eng. Adilson Luis da Costa; Hidráulica e combate a incêndio : Eurico Freitas Marques S/C Ltda.- Projetos de Instalações; Elétrica e SPDA : Eurico Freitas Marques S/C Ltda.- Projetos de Instalações; Consultoria de Solos e Fundações : Cepollina Engenheiros Consultores S/C Ltda.; Consultoria de Estrutura : Ruy Bentes Engenharia de Estruturas S/C Ltda.; Painel artístico : Speto/ Paulo Cesar Silva

\section{Coordenação do projeto}

FDE/ Arq. Vânia Regina Pierri Oliveira

\section{Fiscalização da Obra}

FDE/ Concremat - Eng. José Machado Maluf

\author{
Construtora \\ Construtora L'Annunziata e Cia. Ltda.
}

\section{Propriedade da terra}

Governo do Estado de São Paulo - área da escola anteriormente existente (substituição).

\section{Financiamento}

Secretaria Estadual de Educação. 


\section{E.E. DR. PEDRO DE MORAES VICTOR | sem escala}

\section{PLANTA TÉRREO}

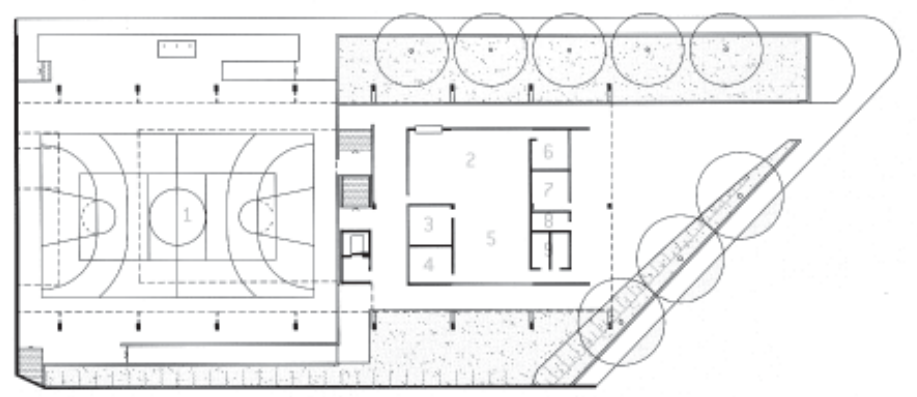

1. quadra 2. secretaria 3. diretoria 4. coordenação

5. professores 6. almoxarifado 7. depósito

8. vestiário 9. sanitário

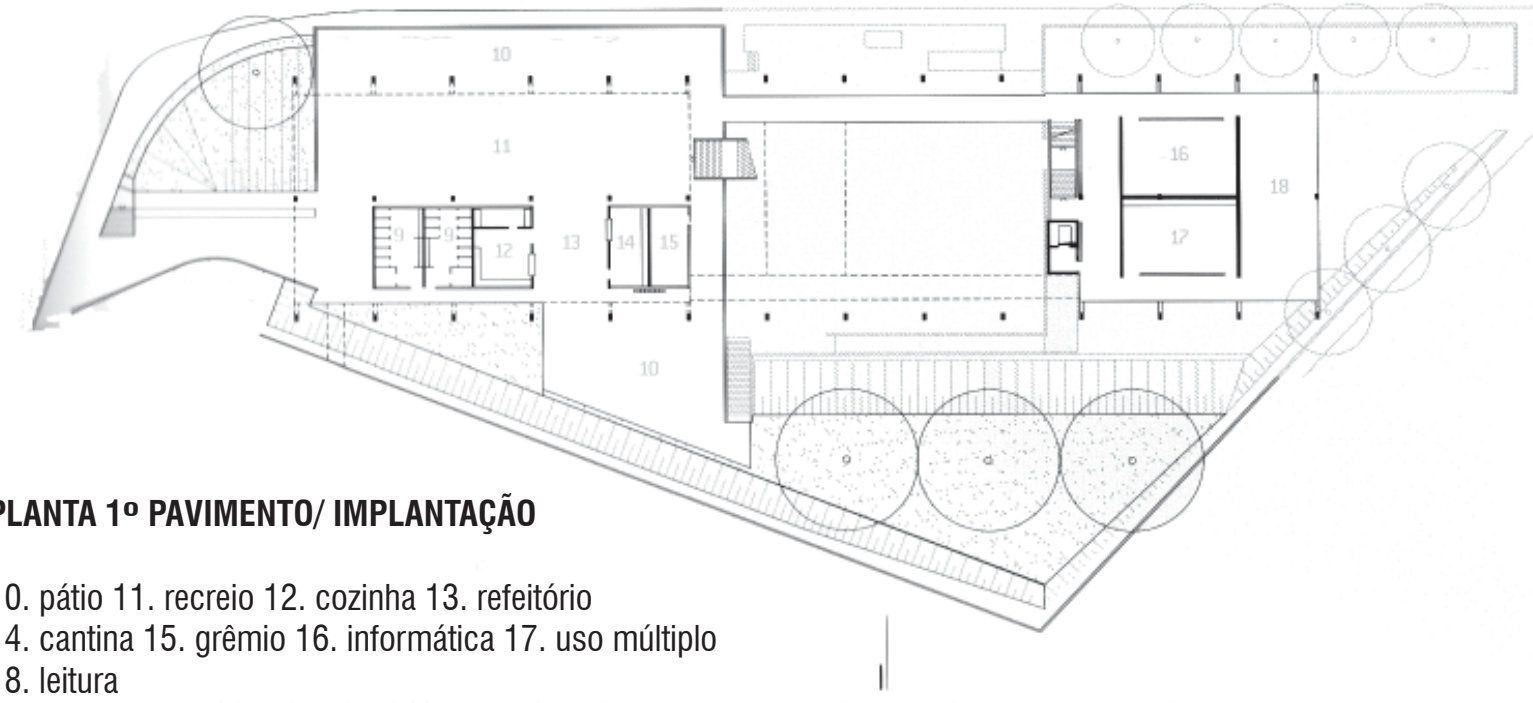

14. cantina 15. grêmio 16. informática 17. uso múltiplo

18. leitura

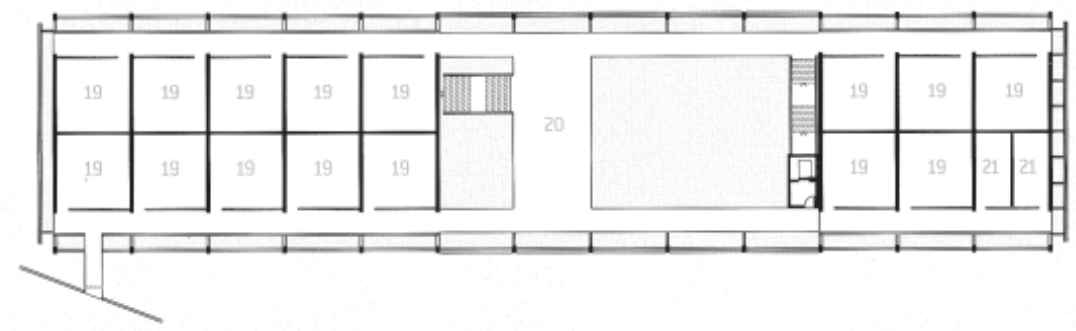

\section{PLANTA 20 PAVIMENTO}

19. sala de aula 20. praça 21. reforço

CORTE TRANSVERSAL

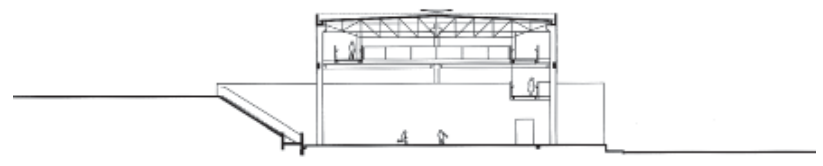

\section{VISTA LONGITUDINAL}

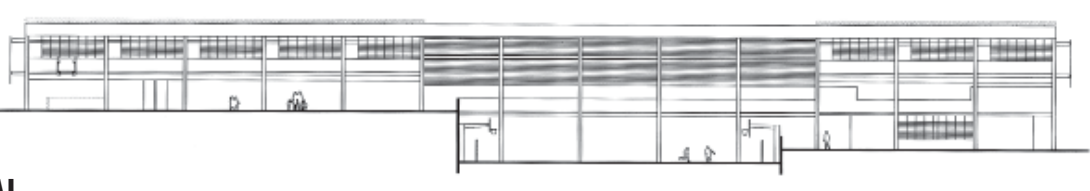




\section{PRODUÇÃO DE EQUIPAMENTOS EDUCACIONAIS}
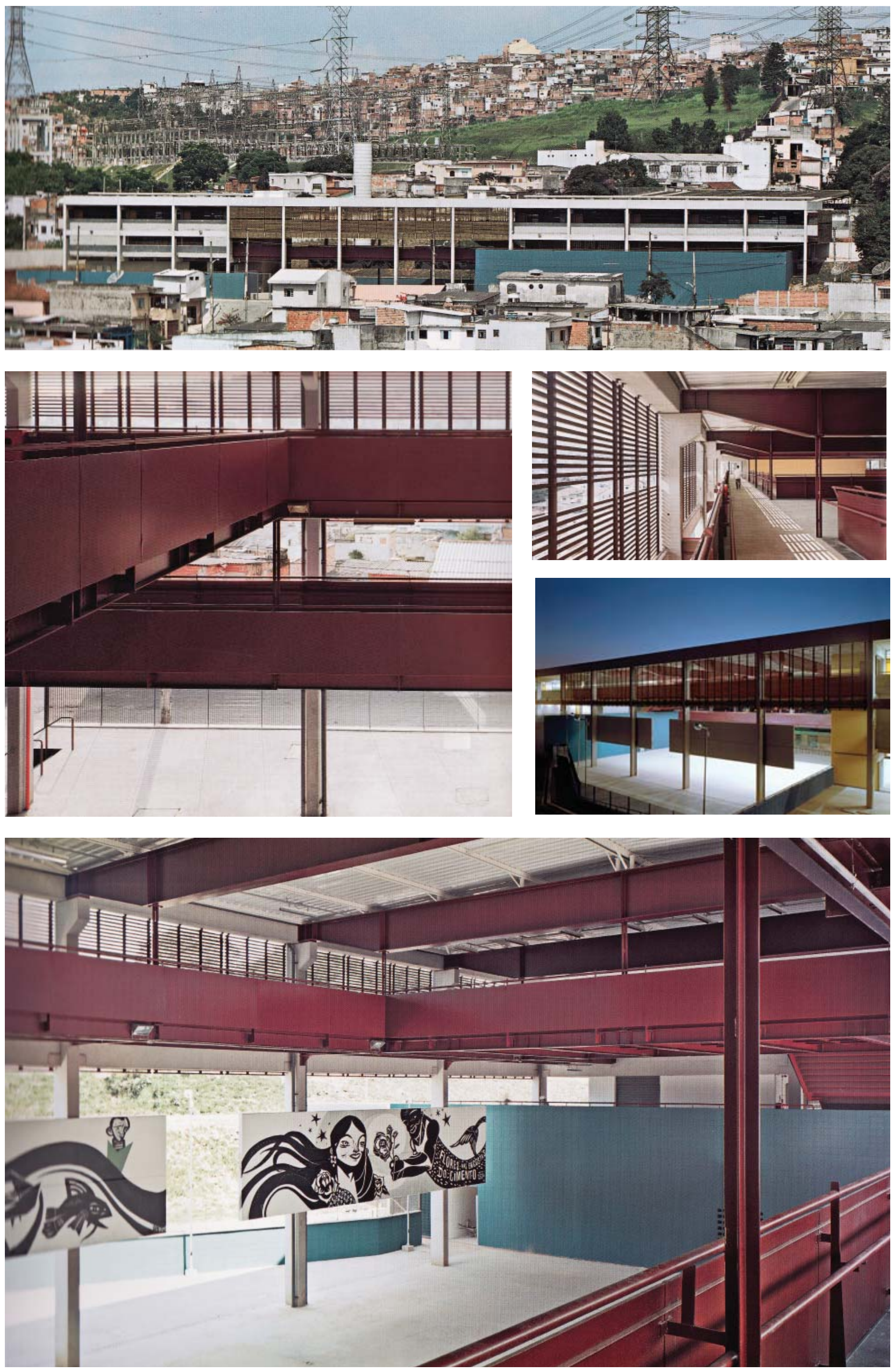


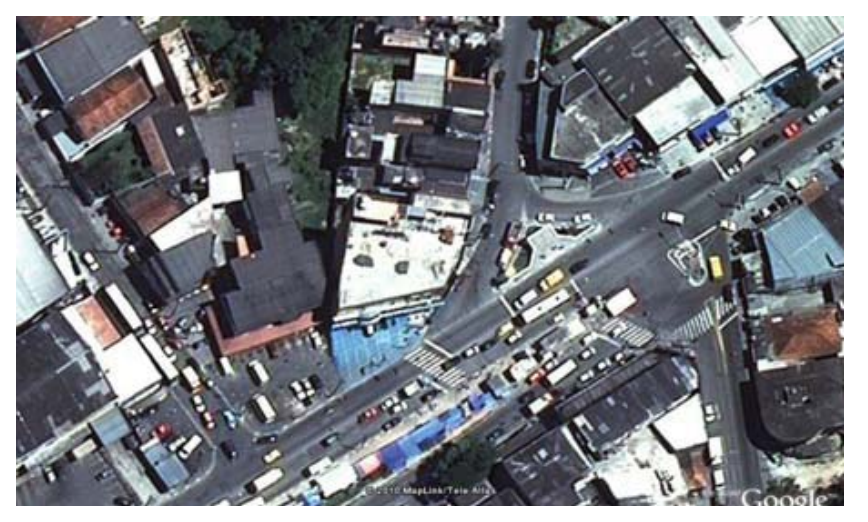

\section{E.E. PROF. MARIA JANNUZZI MASCARI}

Estrada de Itapecerica, 9950 - Pq. Fernanda

área construída: $804 \mathrm{~m}^{2}$

data obra: 2007

tipo de obra: substituição de prédio

construtora: Mello de Azevedo S/A

custo: $\mathrm{R} \$ 3.312 .689,17$
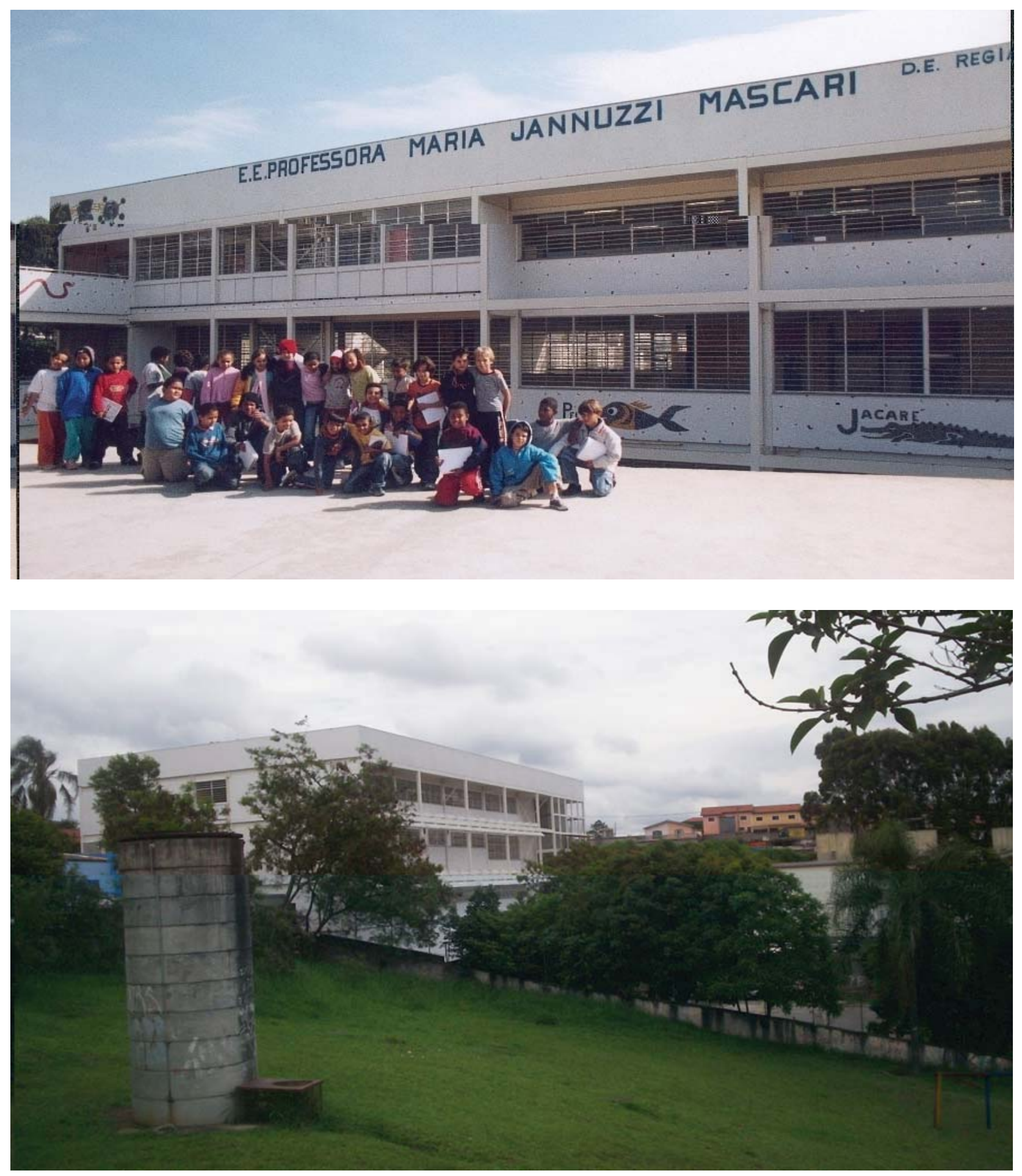


\section{PRODUÇÃO DE EQUIPAMENTOS EDUCACIONAIS}

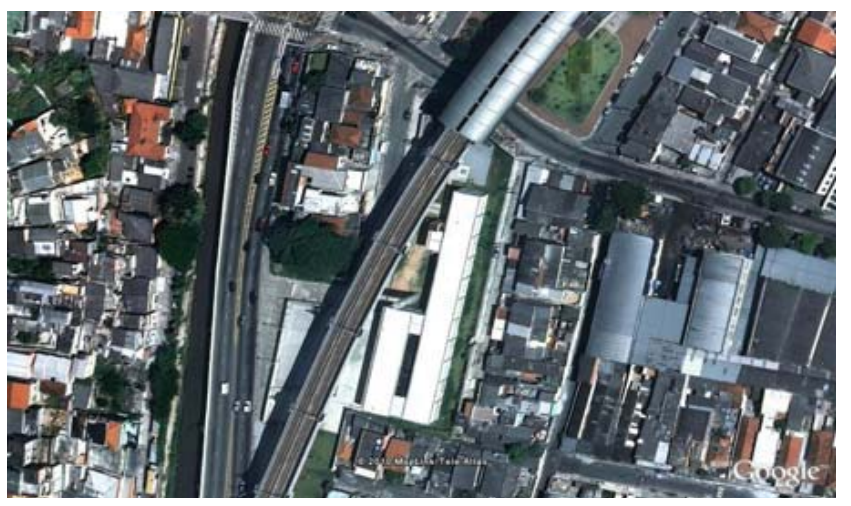

\section{E.E. REPÚBLICA DO PANAMÁ}

Rua Piemonte da Borborema, 75 - Jd. Bronzato

área construída: $2.285,44 \mathrm{~m}^{2}$

data obra: 2007

tipo de obra: obra nova

construtora: Cronacon Ltda.

custo: $\mathrm{R} \$ 3.151 .043,79$
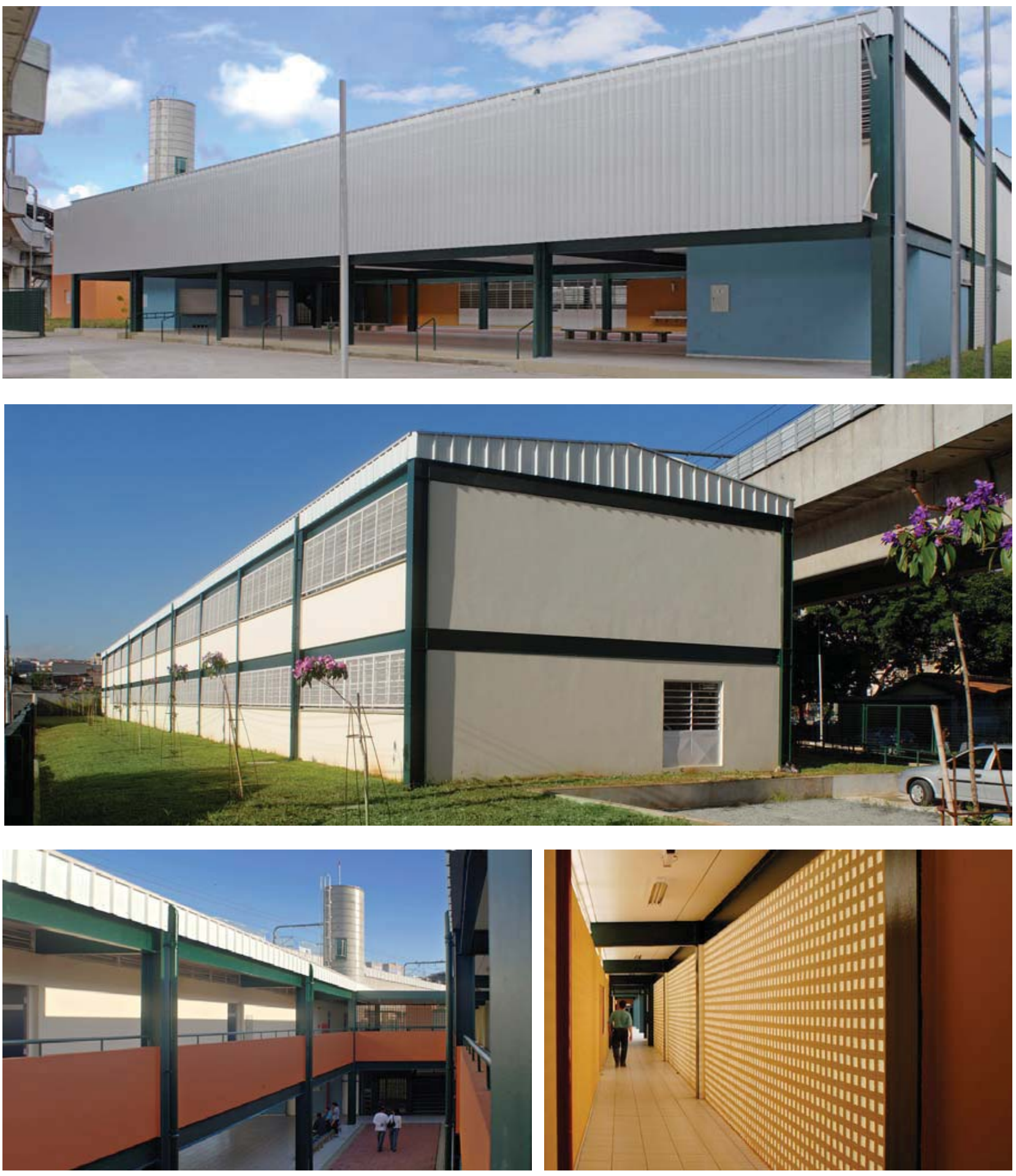


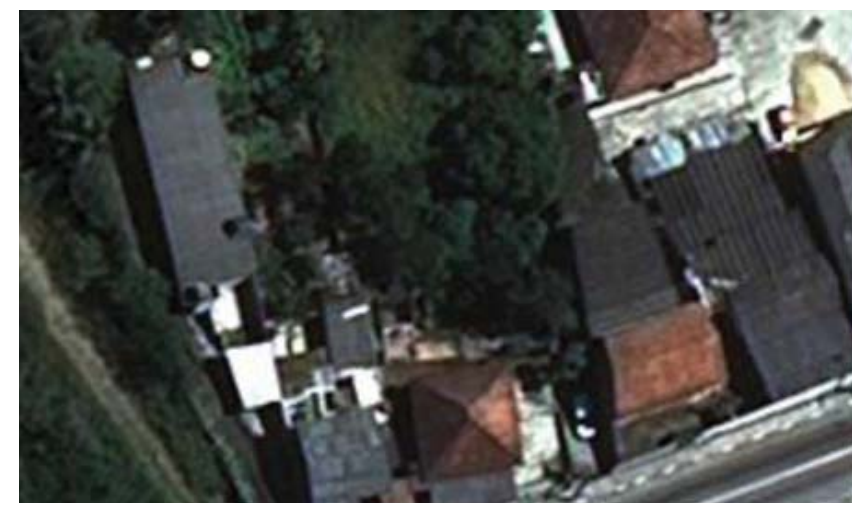

\section{E.E. JD. CAPELA IV}

Estrada da Baronesa, 100 - Embu Mirim

área construída: $1.701 \mathrm{~m}^{2}$

data obra: 2005

tipo de obra: obra nova

construtora: Decivil Construções Ltda.

custo: $\mathrm{R} \$ 1.123 .055,36$

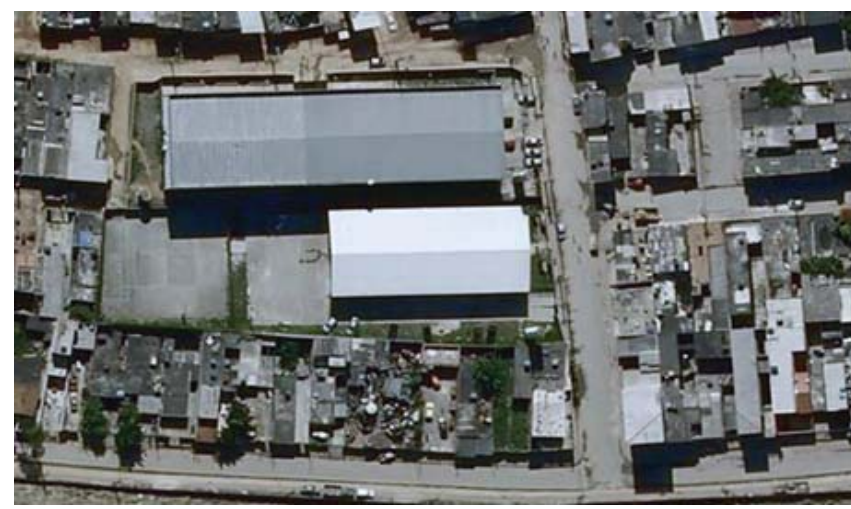

\section{E.E. JOSE DE SAN MARTIN}

Rua Delta c/ Rua Santa Catarina, 79 - Vila Jacui

área construída: $2.817 \mathrm{~m}^{2}$

data obra: 2005

tipo de obra: substituição de prédio

construtora: SANED - Engenharia e Empreendimentos

custo: $\mathrm{R} \$ 2.950 .391,68$

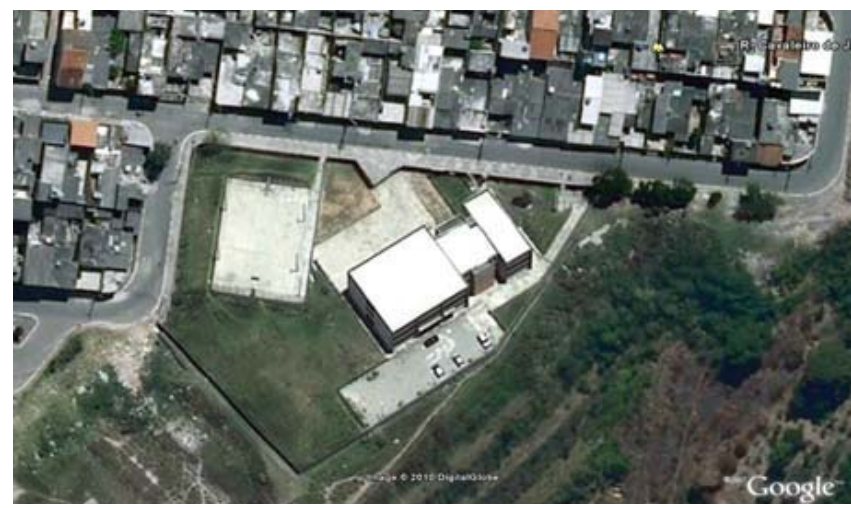

\section{E.E. ROQUE THEOPHILO}

Rua Cavaleiro de Jorge, 280 - COHAB Castro Alves

área construída: $2.114 \mathrm{~m}^{2}$

data obra: 2005

tipo de obra: obra nova

construtora: Progredior Ltda.

custo: $R \$ 1.658 .303,82$

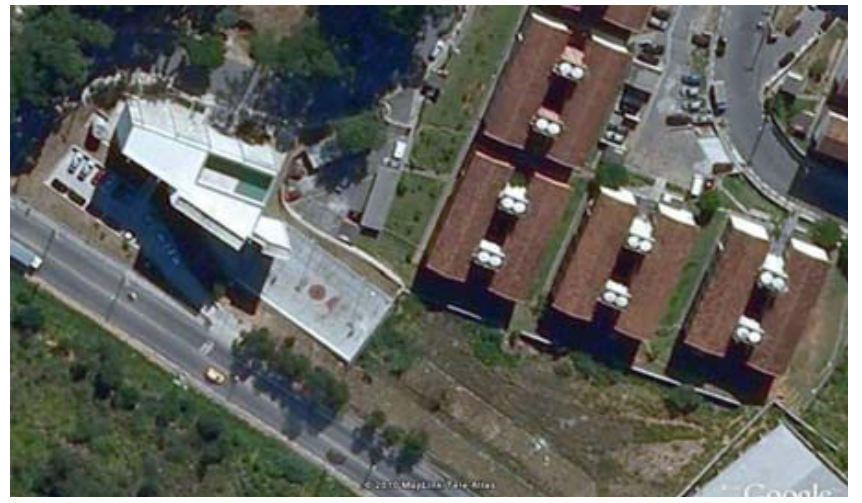

\section{E.E. PROF. MARIA HELENA G. DE ARRUDA}

Av. Dep. Cantidio Sampaio, 4380 - Jd. Brasilândia

área construída: $1.989 \mathrm{~m}^{2}$

data obra: 2005

tipo de obra: obra nova

construtora: Forplan Comercial e Construtora Ltda.

custo: $\mathrm{R} \$ 1.889 .601,86$ 


\section{PRODUÇÃO DE EQUIPAMENTOS EDUCACIONAIS}
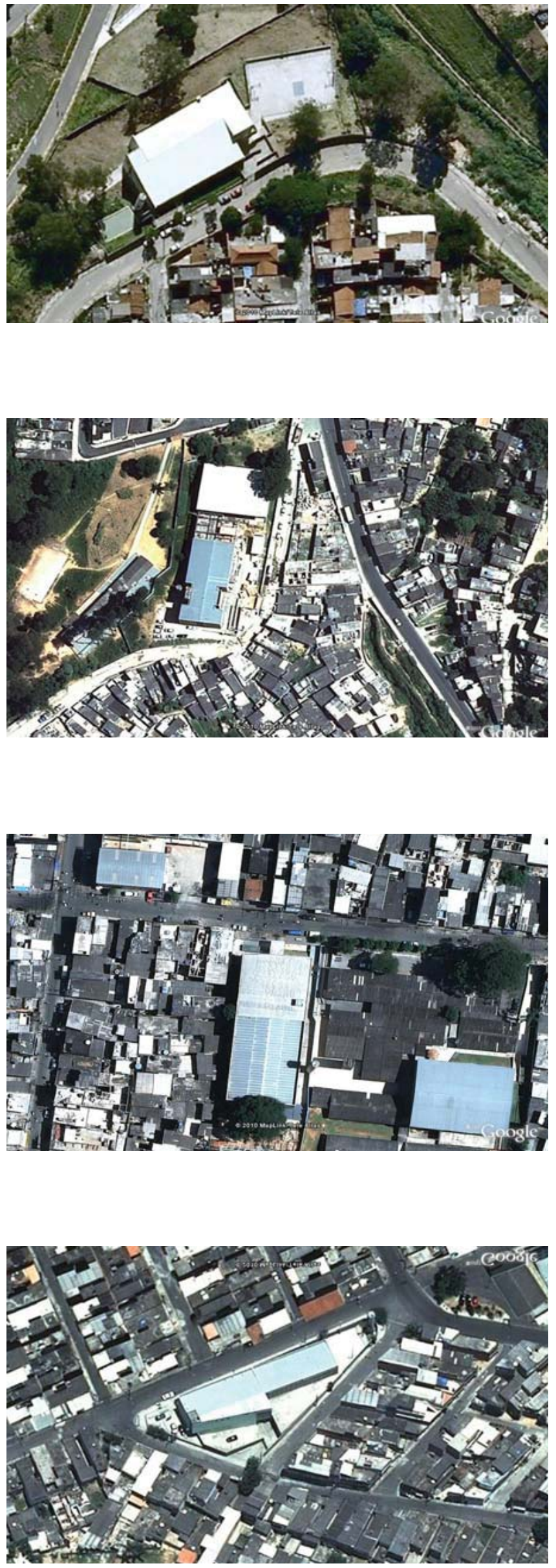

\section{E.E. PROF. NELSON GOMES CAETANO}

Rua Antônio Sergio Matos, 1910 - COHAB Nova Rural

área construída: $2.087 \mathrm{~m}^{2}$

data obra: 2006

tipo de obra: obra nova

construtora: MPC Engenharia Ltda.

custo: $\mathrm{R} \$ 2.301 .036,87$

\section{E.E. DOM AGNELO CARDEAL ROSSI}

Rua Américo Turini, s/ n - Sapato Branco

área construída: $2.701 \mathrm{~m}^{2}$

data obra: 2007

tipo de obra: obra nova

construtora: FEC Construções e Comércio Ltda.

custo: $\mathrm{R} \$ 189.438,00$

\section{E.E. GOVERNADOR MIGUEL ARRAES}

Rua Herbert Spancer, s/n - Vila Andrade

área construída: $2.825 \mathrm{~m}^{2}$

data obra: 2007

tipo de obra: obra nova

construtora: Proeng Construtora e Comércio Ltda.

custo: $\mathrm{R} \$ 3.424 .660,76$

\section{E.E. COHAB CARRÃOZINHO III}

Travessa Sinhá Moça, 53 - Iguatemi

área construída: -

data obra: 2007

tipo de obra: obra nova

construtora: Elecon Ltda.

custo: $\mathrm{R} \$ 2.076 .902,23$ 

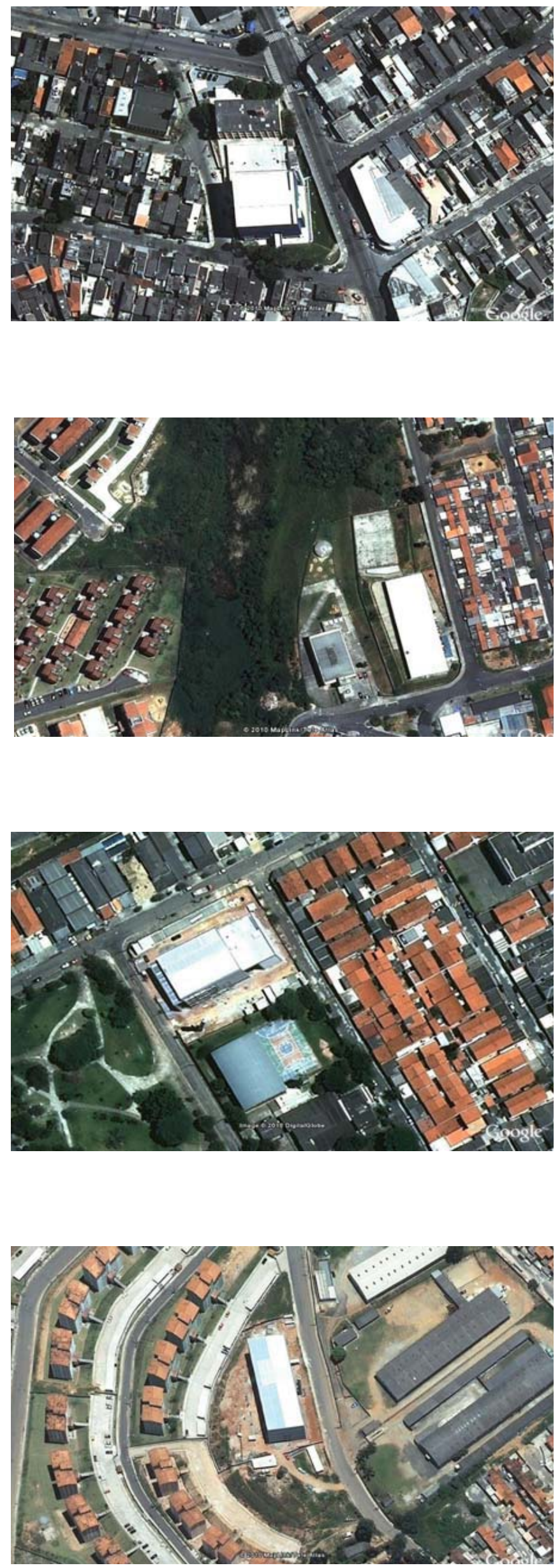

[ 224 ]

\section{E.E. PARQUE GRAJAU}

Rua Augusto Teixeira, 101 - Parque América

área construída: -

data obra: 2009

tipo de obra: obra nova

construtora: Construtora Massafera Ltda.

custo: $\mathrm{R} \$ 3.670 .598,30$

\section{E.E. FAZENDA CARMO IV \\ Rua Camutanga, s/n - José Bonifácio}

área construída: $3.819 \mathrm{~m}^{2}$

data obra: 2009

tipo de obra: obra nova

construtora: Lacon Engenharia Ltda.

custo: $R \$ 4.620 .817,16$

\section{E.E. JD. SANTA CRUZ}

Rua Prof. Sila Matos, s/n - Jardim Santa Cruz

área construída: $3.735 \mathrm{~m}^{2}$

data obra: 2009

tipo de obra: obra nova

construtora: Construtora Itajai Ltda.

custo: $R \$ 5.377 .012,35$

\section{E.E. JARDIM PEDRA BRANCA}

Estrada de São Simão, s/n - Jd. Pedra Branca

área construída: $4.136 \mathrm{~m}^{2}$

data obra: 2009

tipo de obra: obra nova

construtora: Mazza, Fregolente \& CIA.

custo: $R \$ 5.290 .271,46$ 


\section{PRODUÇÃO DE EQUIIPAMENTOS EDUCACIONAIS}

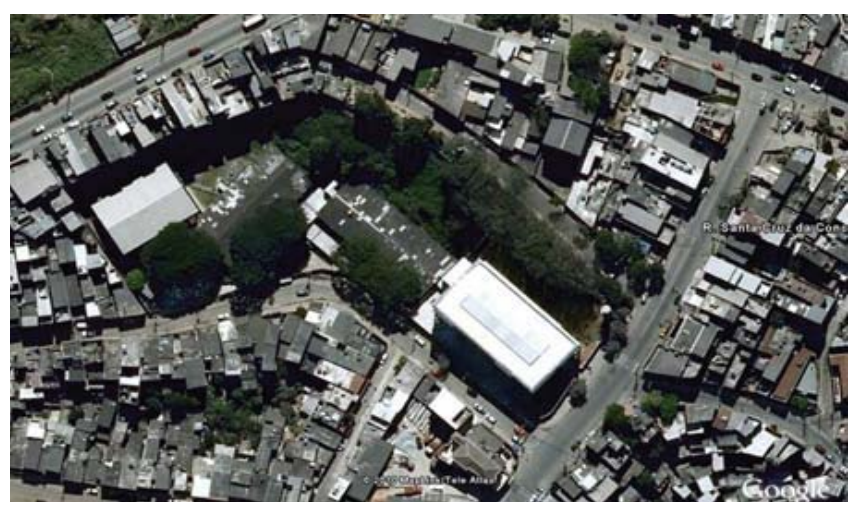

\section{E.E. VILA GUARANI}

Rua Santa Cruz da Conceição, s/n - Jd. Guarani

área construída: -

data obra: 2009

tipo de obra: obra nova

construtora: Lopes Kalil Engenharia e Comércio Ltda.

custo: $\mathrm{R} \$ 4.703 .378,92$

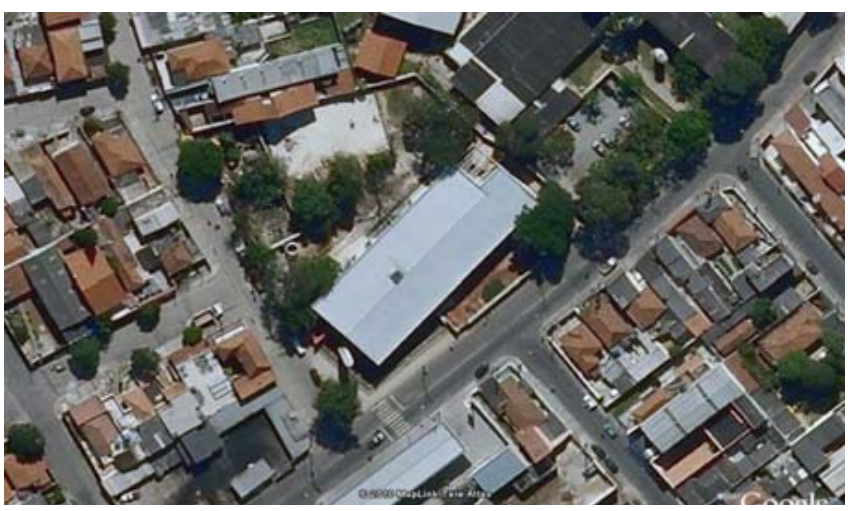

\section{E.E. CHÁCARA TRÊS MENINAS II}

Av. Dr. José Artur Nova, s/n - Chácara Três Meninas

área construída: -

data obra: 2009

tipo de obra: obra nova

construtora: Construtora Augusto Velloso S/A

custo: $\mathrm{R} \$ 2.362 .197,55$ 
OS MEANDROS DA PRODUÇ̃̃o PÚbLICA NA CONSTRUÇ̃̃o DA PAISAGEM PERIFÉrICA PAULISTANA: 0 CASO DOS EQUIPAMENTOS EDUCACIONAIS

[226] 


\section{Produção do Governo Municipal - CEUS 1a GeSTÃo | 2001 - 2004}


OS MEANDROS DA PRODUÇÃO PÚBLICA NA CONSTRUÇÃO DA PAISAGEM PERIFÉRICA PAULISTANA: 0 CASO DOS EQUIPAMENTOS EDUCACIONAIS 


\section{PRODUÇÃO DE EQUIPAMENTOS EDUCACIONAIS}

\section{TIPOLOGIA PADRÃO CEUS 1a GESTÃO | sem escala}

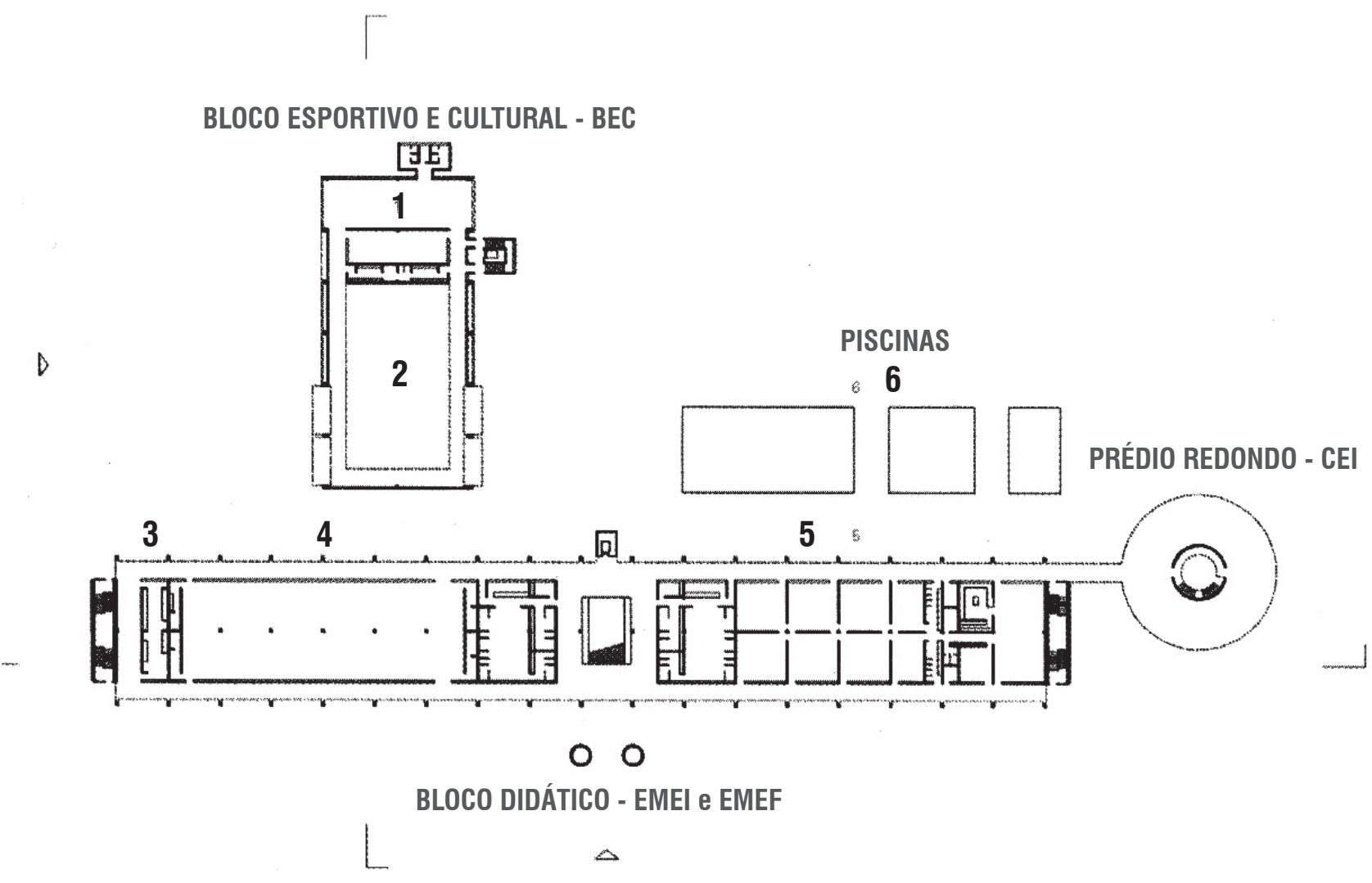

PLANTA TÉRREO

1. foyer 2. teatro 3. padaria-escola 4. biblioteca 5. berçário 6. piscinas

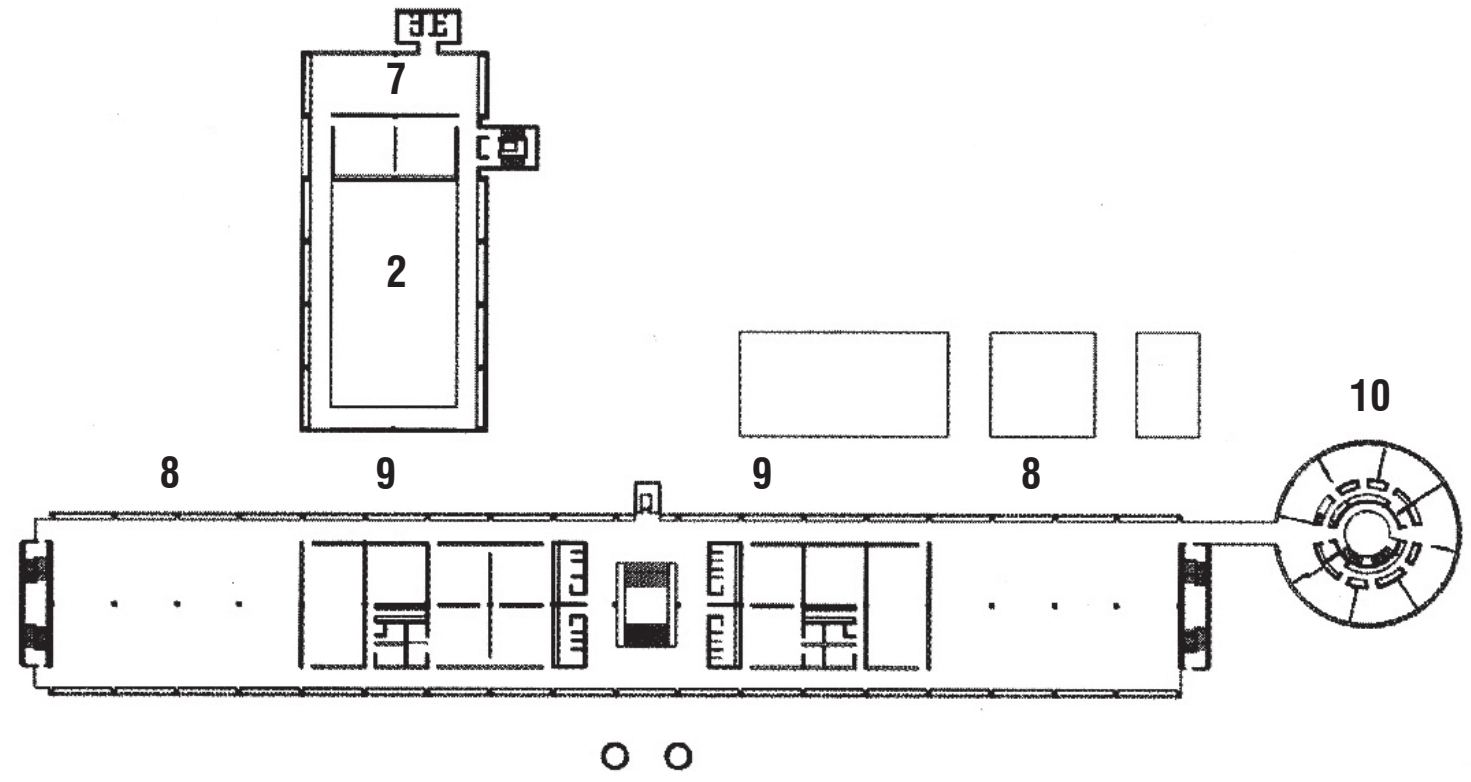




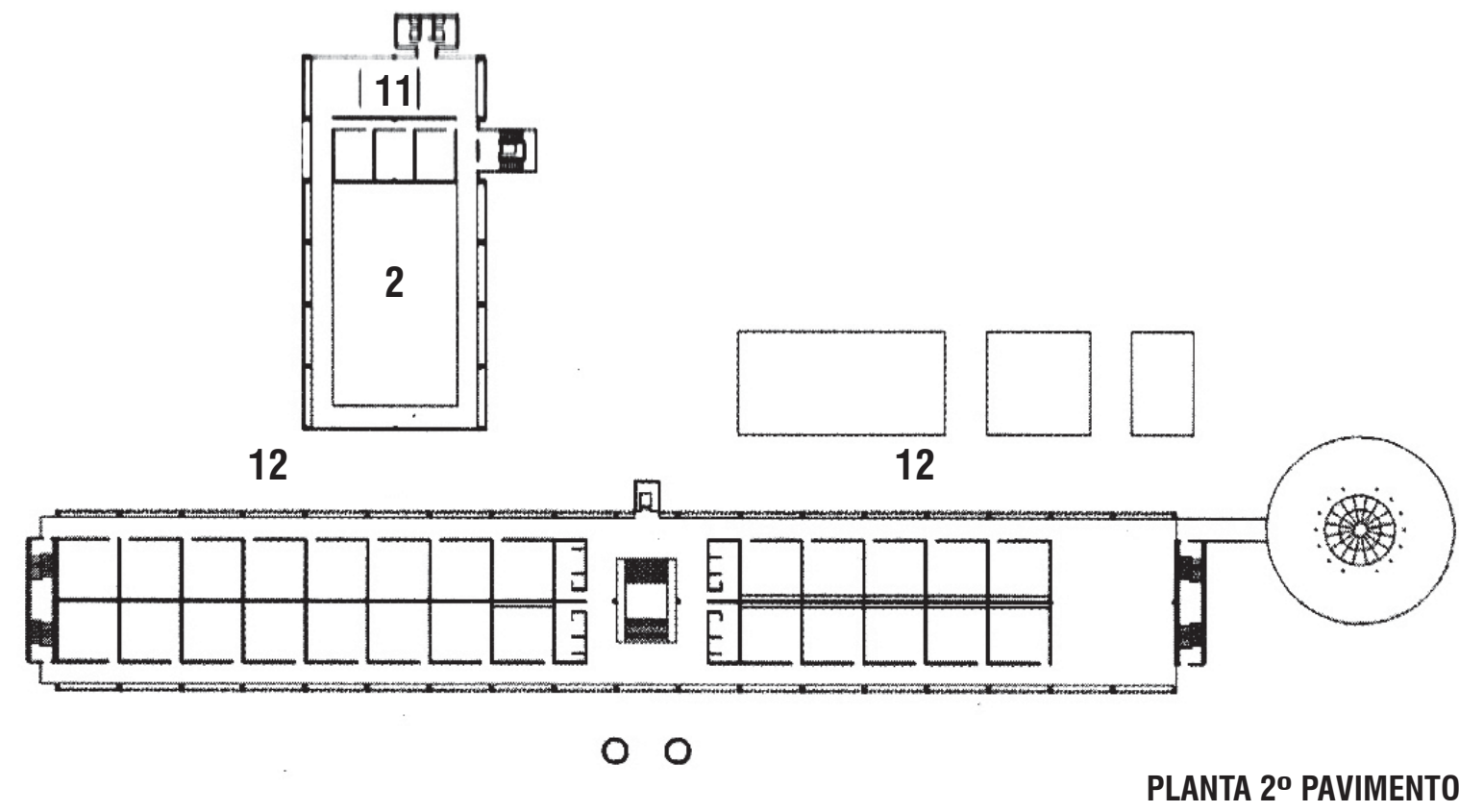

2. teatro (balcão) 11. estúdio 12. sala de aula

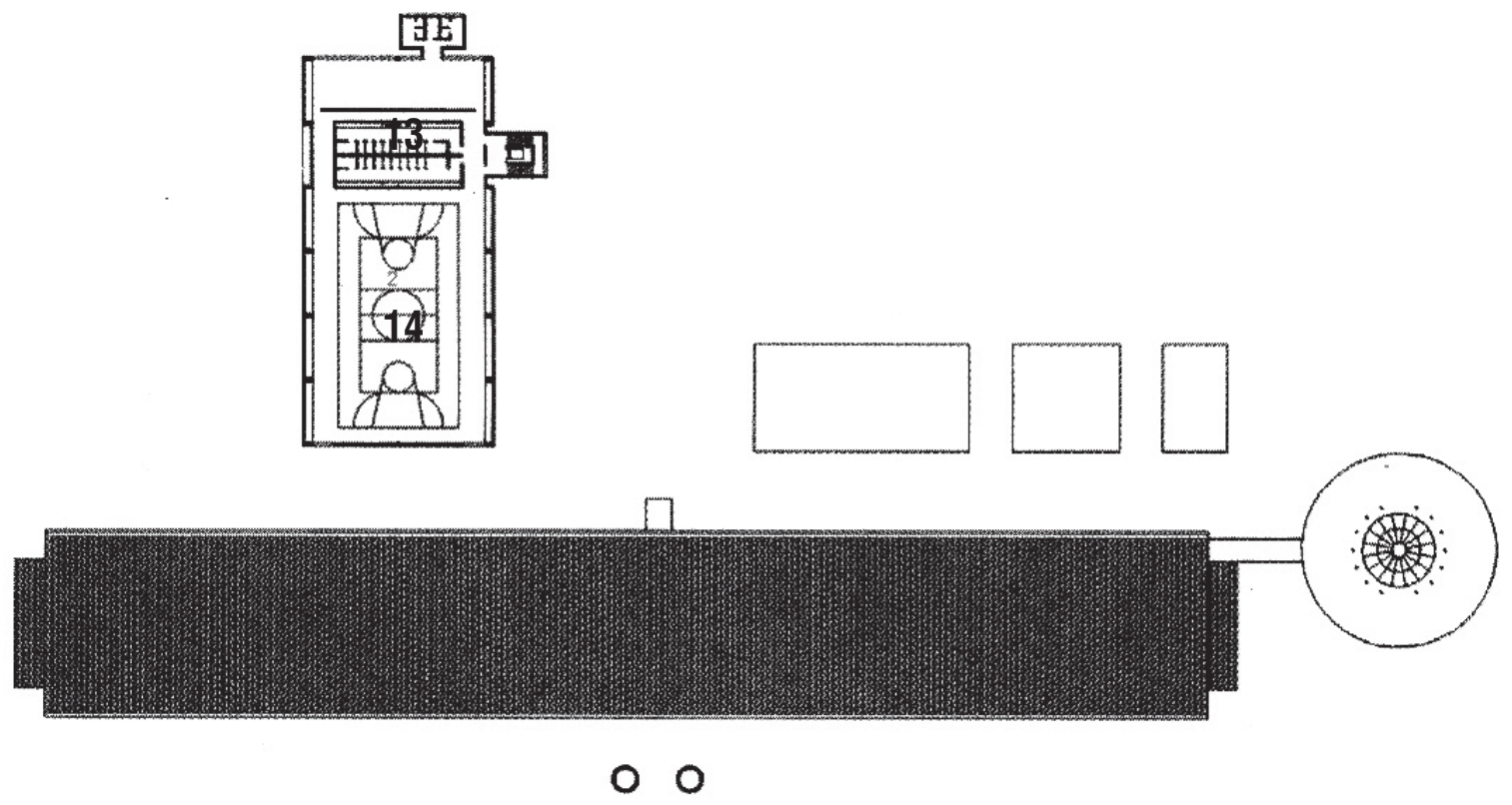

PLANTA 30 PAVIMENTO

13. conselho gestor 14. quadra esportiva

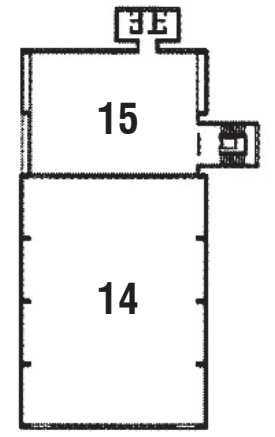




\section{PRODUÇÃO DE EQUIPAMENTOS EDUCACIONAIS}

\section{TIPOLOGIA PADRÃO - BLOCO DIDÁTICO | sem escala}

123

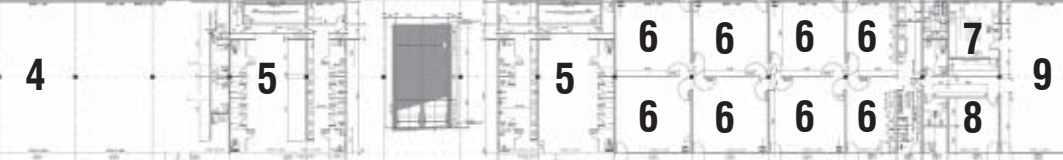

\section{PLANTA NÍVEL 0,03}

1. praça do café 2. padaria 3. telecentro 4. biblioteca 5. vestiário 6 . sala de atividade 7. cozinha 8. administração 9. refeitório

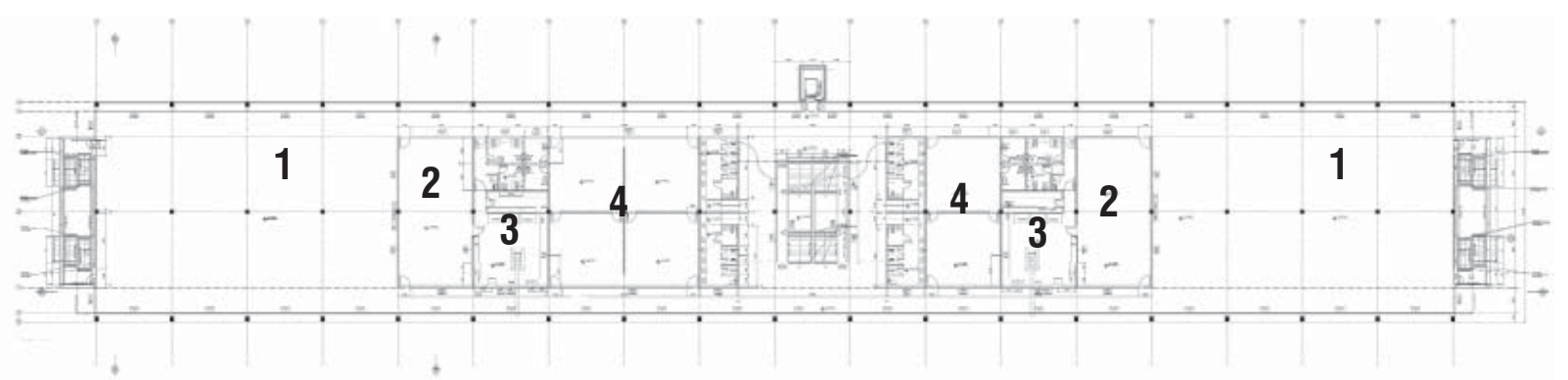

PLANTA NÍVEL 3,43

1. pátio 2. refeitório 3. cozinha 4. administração

\section{PLANTA NÍVEL 6,83}

1. sala de aula 2. anfiteatro

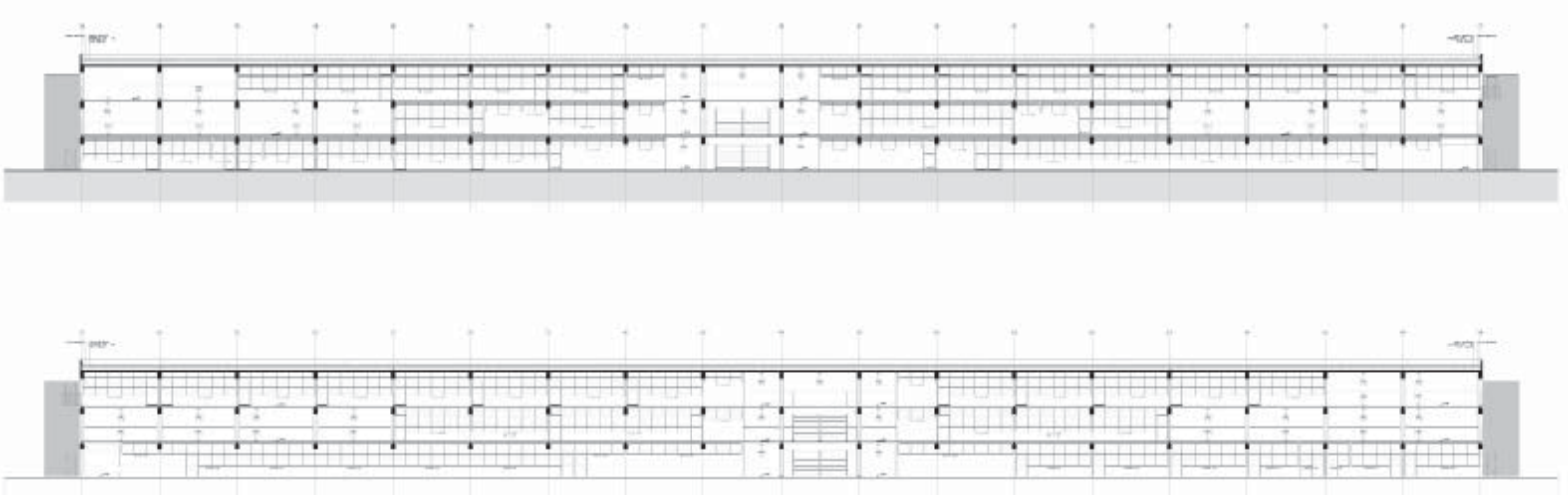


TIPOLOGIA PADRÃO - BEC | sem escala
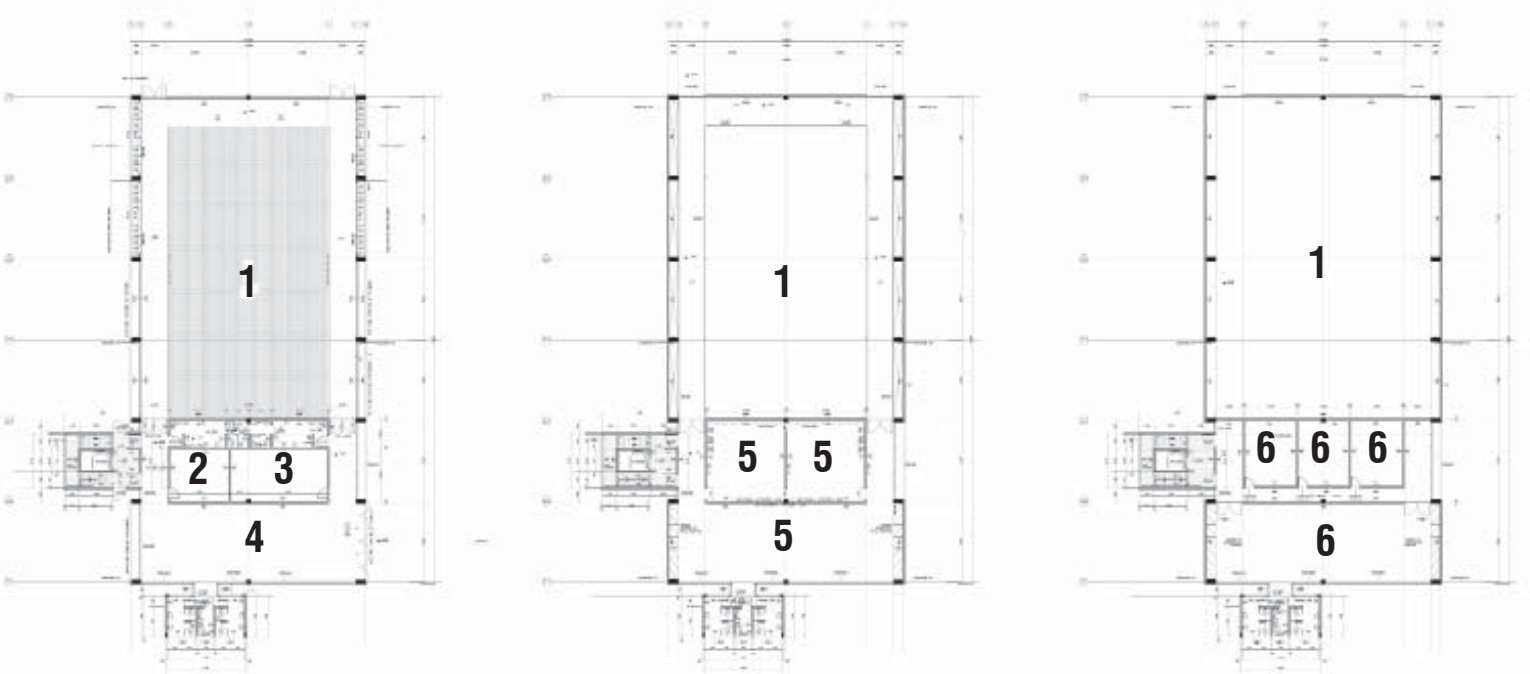

PLANTA TÉRREO | PLANTA 10 PAVIMENTO | PLANTA 20 PAVIMENTO

1. teatro 2. casa de máquinas 3 . depósito 4. foyer 5. ateliê 6 . estúdio
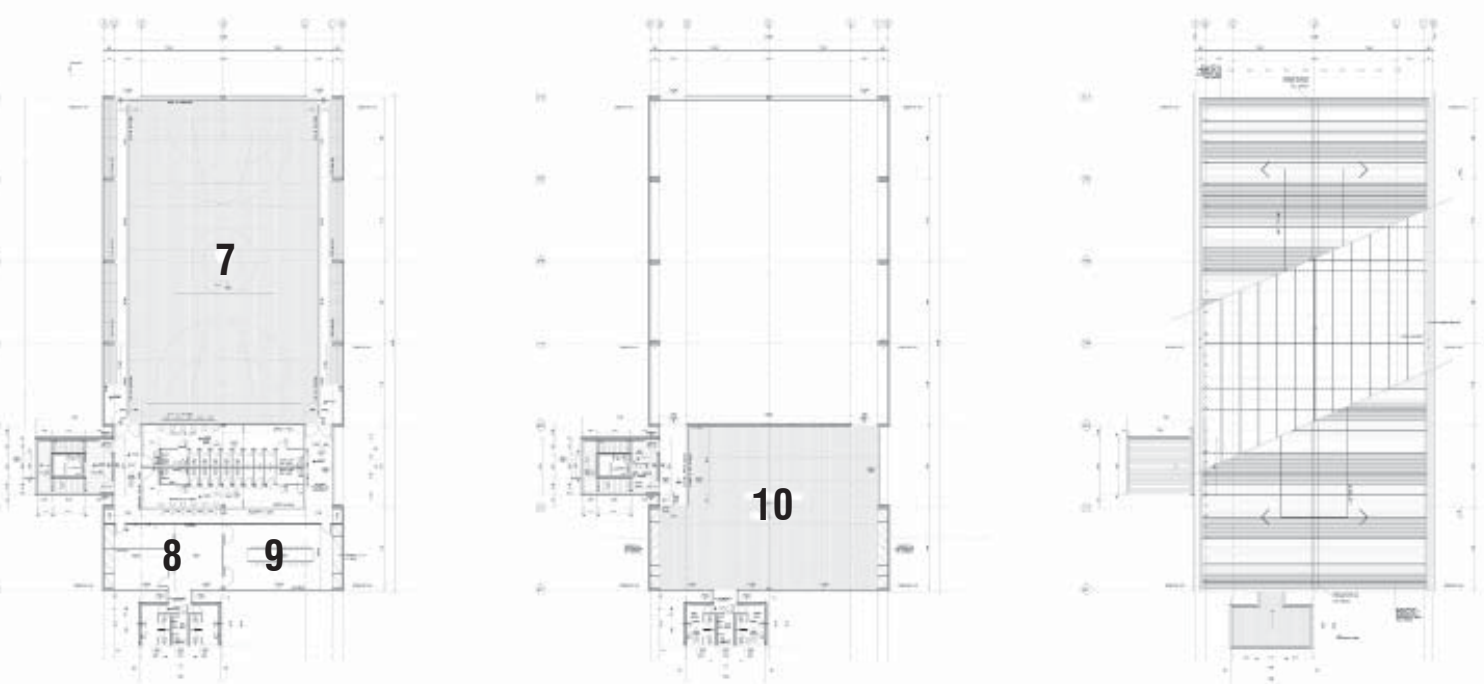

PLANTA 30 PAVIMENTO | PLANTA 40 PAVIMENTO | PLANTA COBERTURA

7. ginásio 8. administração 9. sala de reunião 10. sala de dança
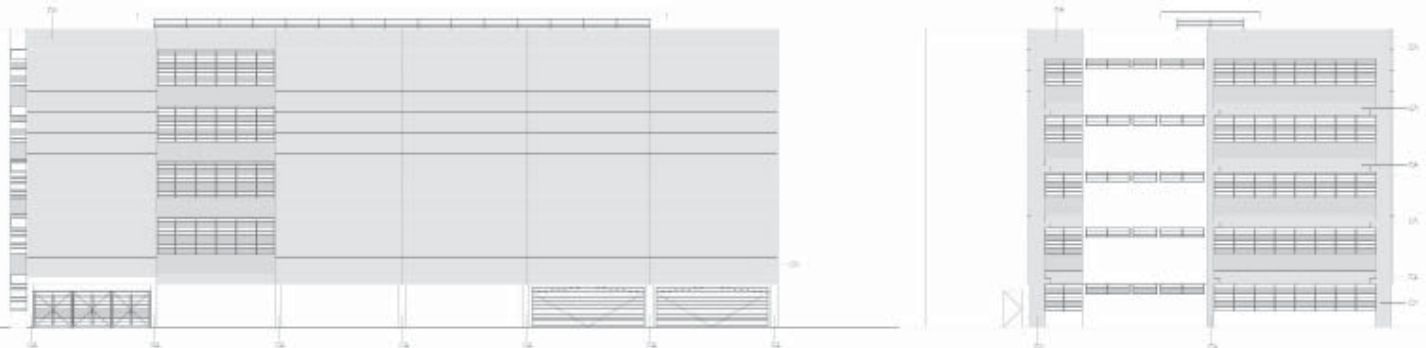


\section{PRODUÇÃO DE EQUIPAMENTOS EDUCACIONAIS}

\section{TIPOLOGIA PADRÃO - BERÇÁRIO | sem escala}

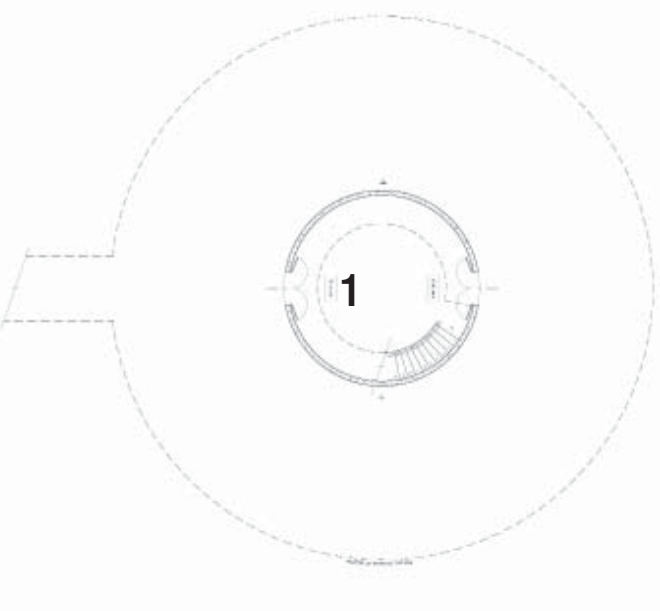

PLANTA TÉRREO

1. vazio

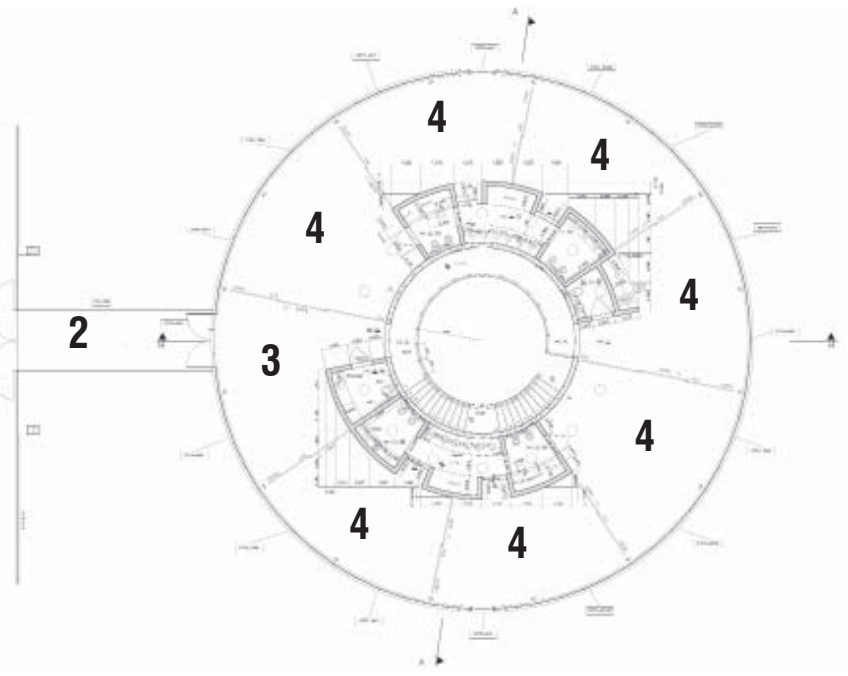

PLANTA 10 PAVIMENTO

2. solário 3. varanda 4. salas de aula
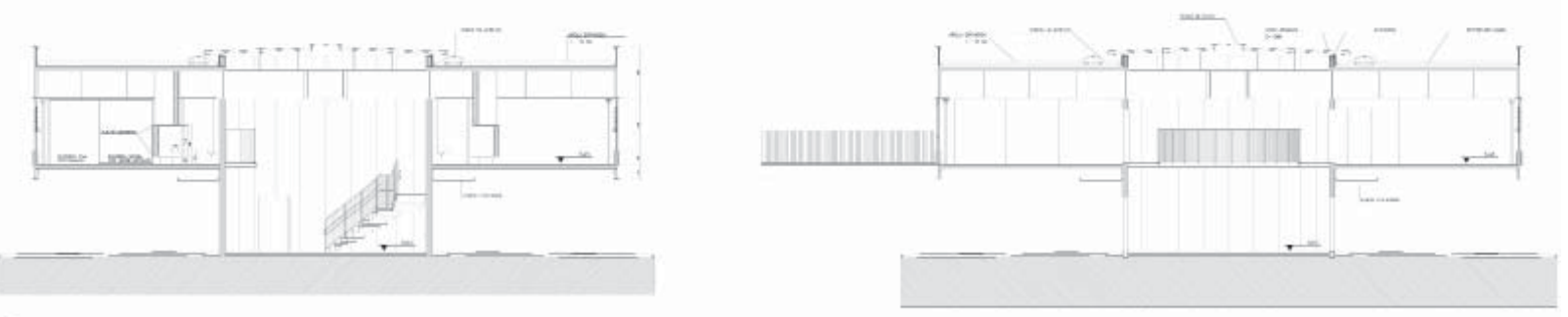

CORTES LONGITUDINAIS

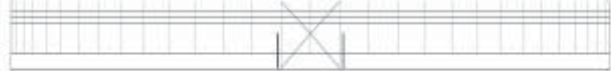

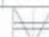




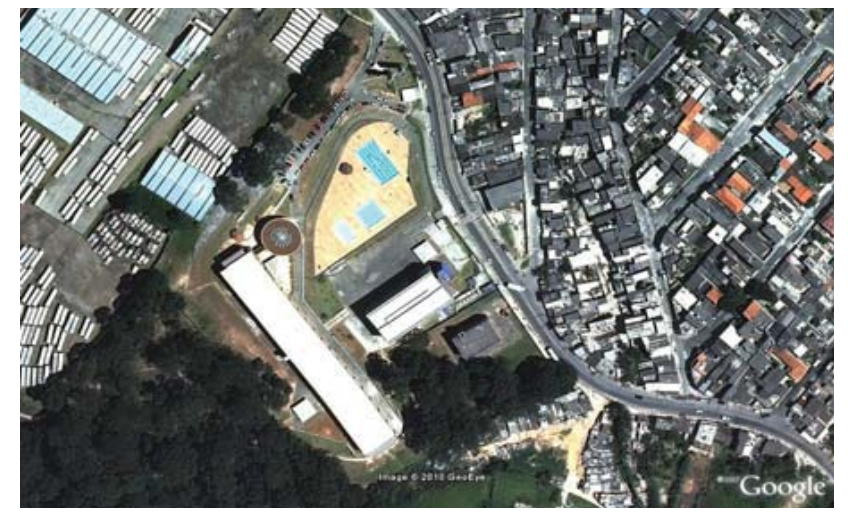

\section{CEU ALVARENGA}

Estrada do Alvarenga, 3752 - Pedreira

área do terreno: $70.000 \mathrm{~m}^{2}$

área construída: $14.077 \mathrm{~m}^{2}$

construtora: Carioca Christiani Nielsen Engenharia

data inauguração: 08/09/2003

custo: $\mathrm{R} \$ 17$ milhoes*

financiamento: Secretaria Municipal de Educação

\section{Projeto}

Edifício com programa padrão, acrescido de campo de futebol, quadra poliesportiva, bosque de Mata Atlântica preservada e estação de tratamento de esgoto.

\section{Histórico}

Este CEU encontra-se na Estrada do Alvarenga, caminho para Diadema, próximo à represa Billings e à Favela Pantanal, região muito pobre, mas com uma população bastante engajada e atuante. A implantação do equipamento nesta área configura uma resposta à luta da população local.

\section{Partido arquitetônico}

Num terreno de $70.000 \mathrm{~m}^{2}$, o maior entre todos os CEUs, esta implantação procurou incorporar ao programa um bosque de mata atlântica preservada, que funciona também como elemento pedagógico, no ensino de princípios ambientais. Situado próximo à represa Billings, numa área de grande informalidade habitacional, o equipamento conta ainda com uma estação de tratamento de esgoto, um campo de futebol e uma quadra poliesportiva.

\section{Proveniência da demanda}

Proximidade com a Favela Pantanal e outros núcleos habitacinais precários.

\section{Propriedade da terra}

Terreno particular desapropriado.
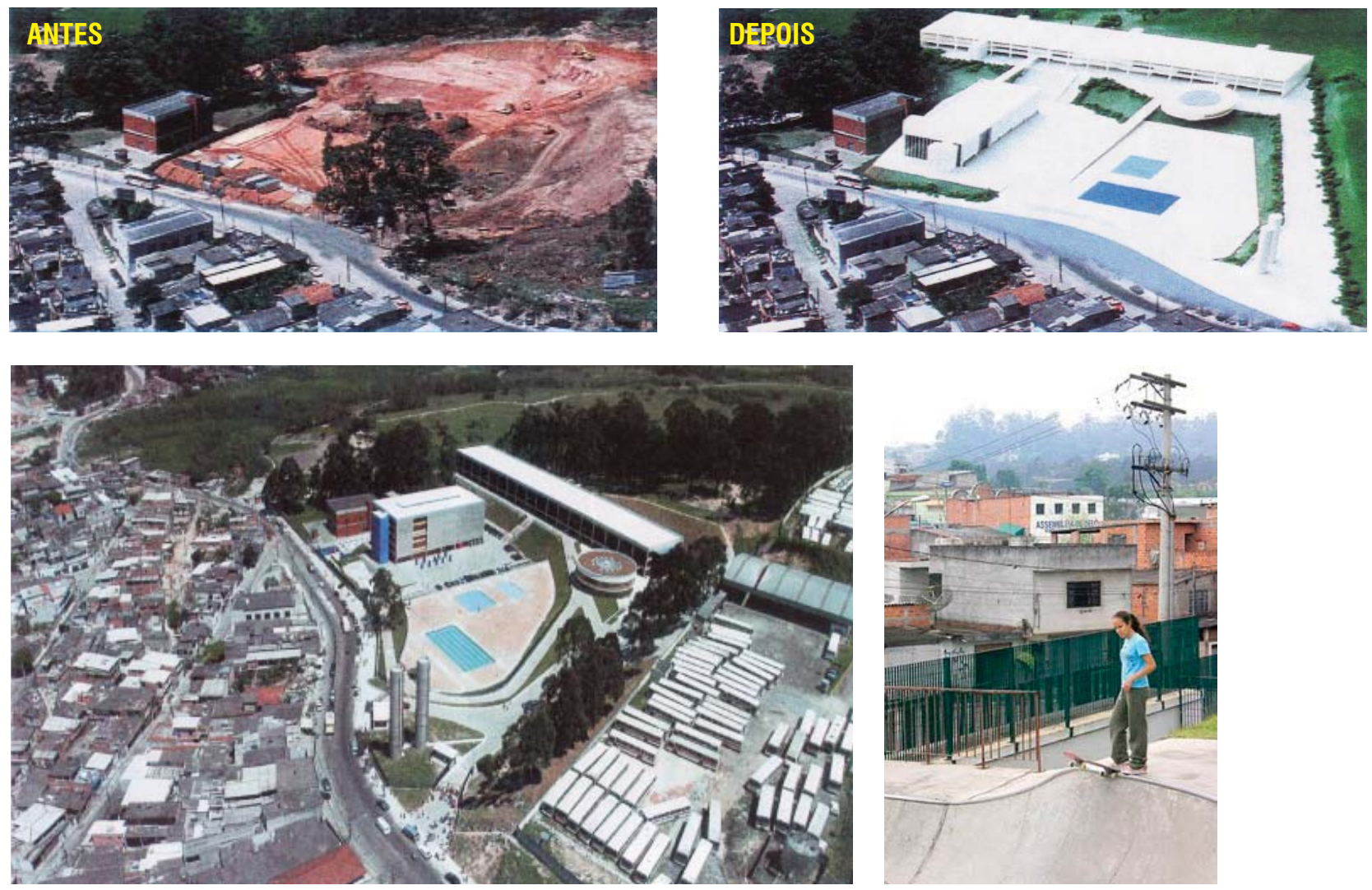


\section{PRODUÇÃO DE EQUIPAMENTOS EDUCACIONAIS}

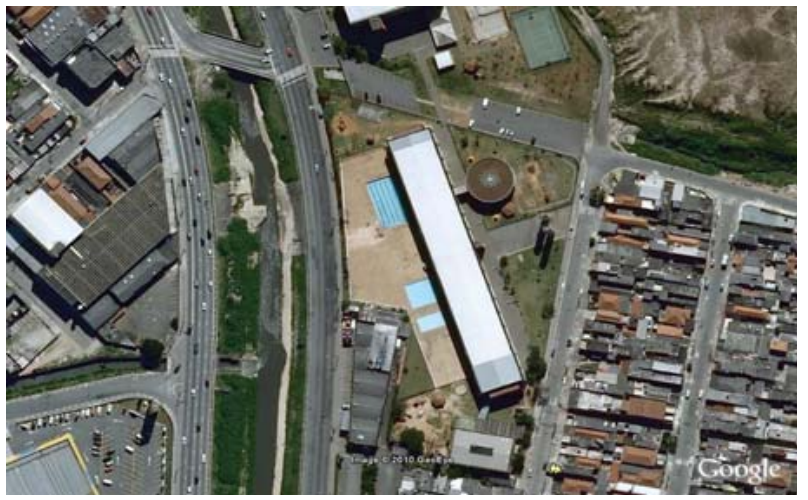

\section{CEU ARICANDUVA}

Av. Olga Fadel Abarca, s/n - Itaquera

área do terreno: $41.400 \mathrm{~m}^{2}$

área construída: $12.991 \mathrm{~m}^{2}$

construtora: Construção

data inauguração: 25/08/2003

custo: $\mathrm{R} \$ 17$ milhoes*

financiamento: Secretaria Municipal de Educação

Projeto

Edifício com programa padrão.

\section{Histórico}

0 edifício foi construído numa área já contemplada por uma Unidade Básica de Saúde, uma outra EMEl, construída nos anos 70, e pela Biblioteca Pública Milton Santos, buscando-se, assim, constituir uma verdadeira "Praça de Equipamentos".

\section{Partido arquitetônico}

Construído às margens do Rio Aricanduva, na zona leste da cidade, este CEU foi implantado de modo a formar um mesmo eixo com os demais equipamentos já existentes, constituindo uma espécie de centralidade de bairro. As piscina e o solário foram dispostos de frente para o rio, remetendo à idéia de uma praia fluvial urbana, e privilegiando a visual para o rio, cuja presença exalta as discussões a cerca da preservação dos mananciais. Desta forma, o rio aparece como elemento pedagógico e importante marco paisagístico.

\section{Proveniência da demanda}

Presença de um importante pólo comercial na região intensificou a demanda por vagas.

\section{Propriedade da terra}

Terreno público.
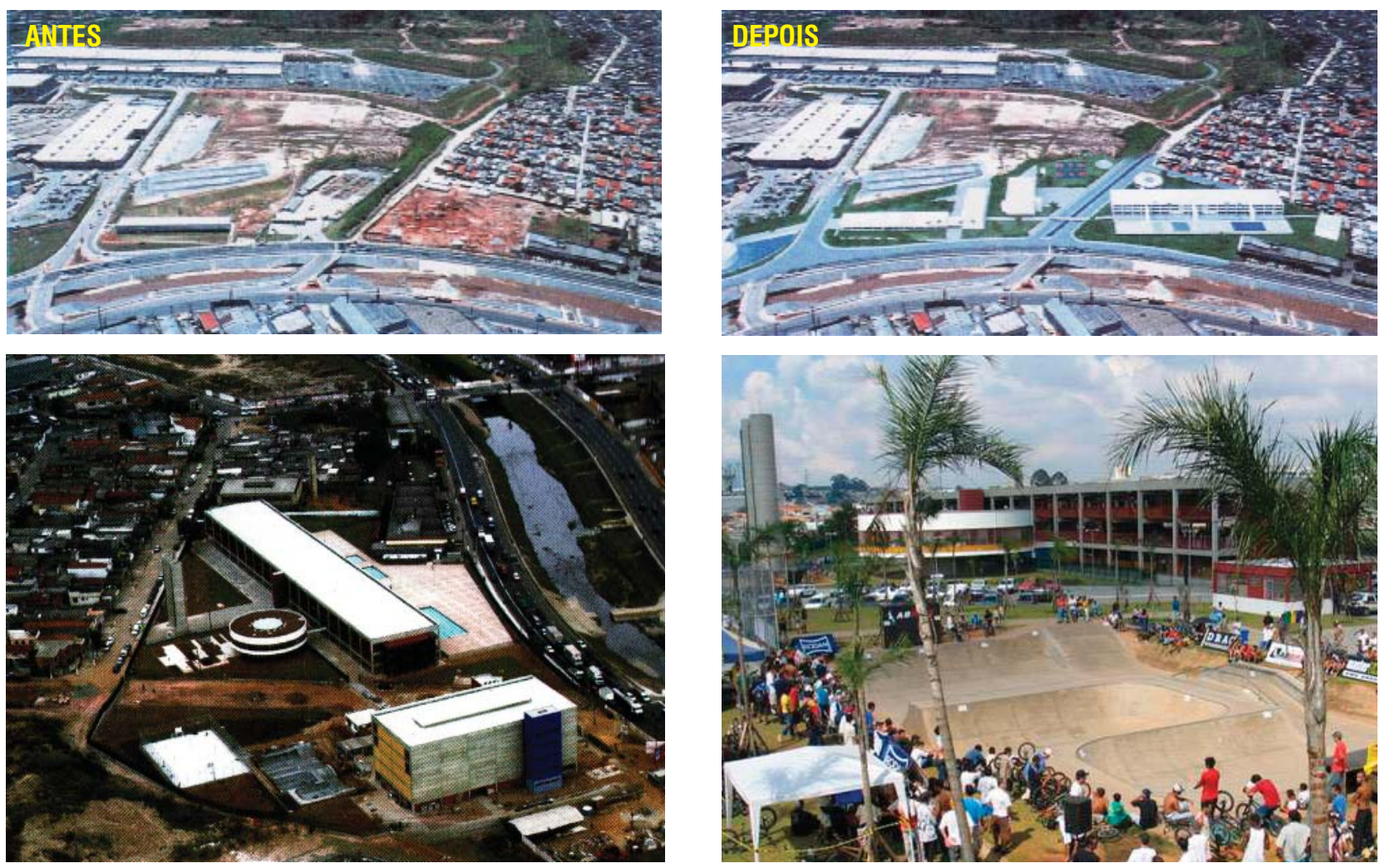


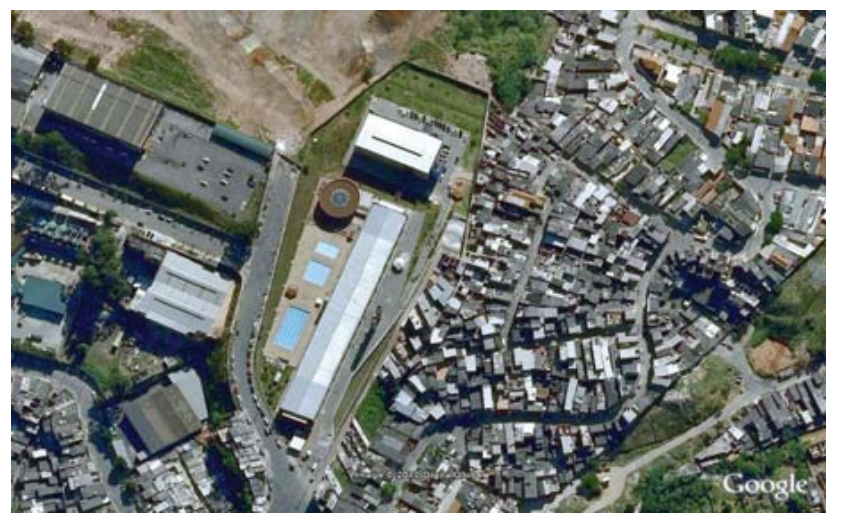

\section{CEU VILA ATLÂNTICA}

Rua Coronel José Venâncio Dias, 840 - Pirituba

área do terreno: $69.466,12 \mathrm{~m}^{2}$

área construída: $12.548 \mathrm{~m}^{2}$

construtora: Construtora OAS

data inauguração: 01/09/2003

custo: $\mathrm{R} \$ 17$ milhões*

financiamento: Secretaria Municipal de Educação

\section{Projeto}

Edifício com programa padrão.

\section{Histórico}

Erguido nas proximidades do pico do Jaraguá, numa área de moradias informais e bastante precárias, este CEU rcebeu tal nome não apenas por estar situado próximo a um loteamento vizinho chamado Vila Atlântica, mas também por estar próximo a um dos pontos de Mata Atlântica ainda conservada.

\section{Partido arquitetônico}

Por se tratar de um terreno bastante elevado, o edifício foi contemplado com uma vista, a leste, do Centro de São Paulo, e, a norte, do Pico do Jaraguá, que pode ser grandiosamente admirado a partir do prédio redondo, onde está a CEI. Já a pista de skate voltou-se para o Centro, dando a sensação ao usuário de sobrevoar a cidade. Em função dos desníveis do terreno, 0 acesso ao teatro - que está dois níveis abaixo do bloco didático - é feito por uma passarela, que funciona como um interessante mirante.

\section{Proveniência da demanda}

Área pública ocupada irregularmente.

\section{Propriedade da terra}

Terreno público.
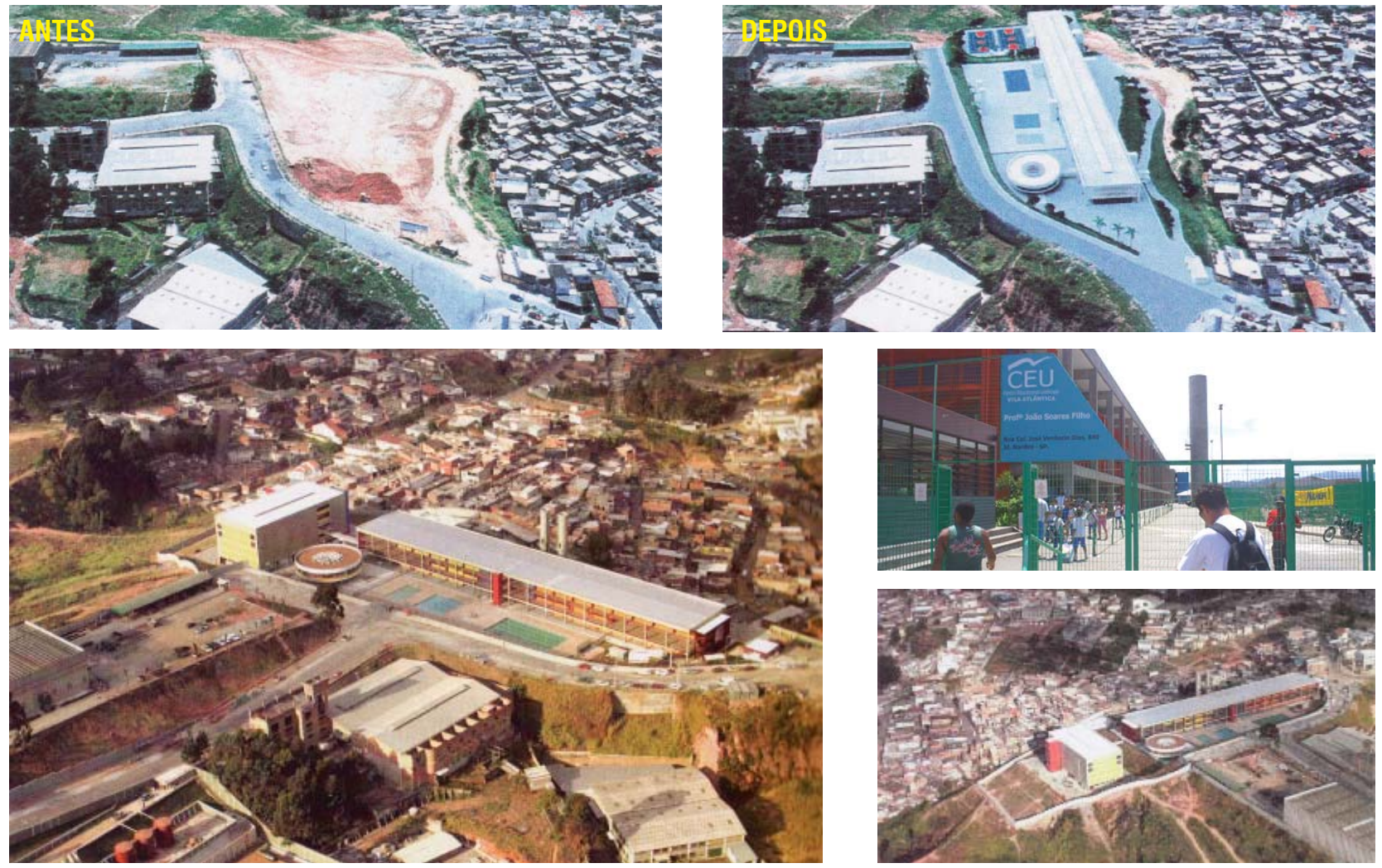


\section{PRODUÇÃO DE EQUIPAMENTOS EDUCACIONAIS}

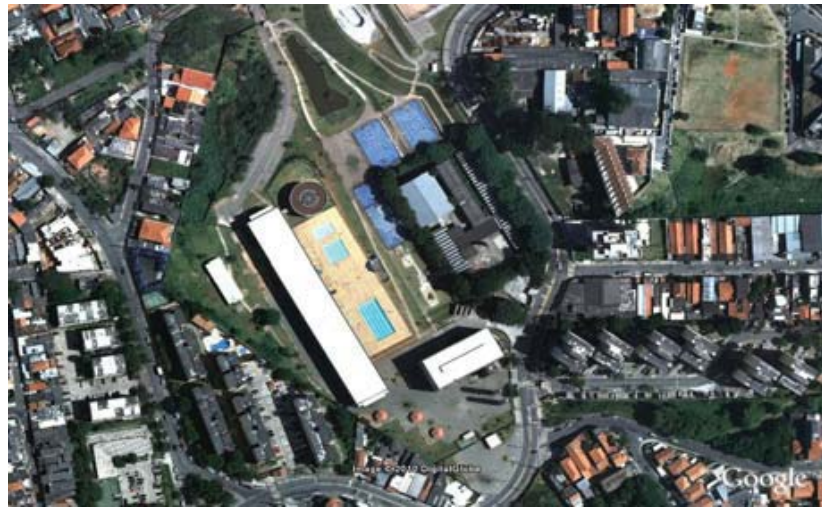

\section{CEU BUTANTÃ}

Av. Eng. Heitor Antônio Eiras Garcia, 1700 - Butantã

área do terreno: $49.810 \mathrm{~m}^{2}$

área construída: $13.310 \mathrm{~m}^{2}$

construtora: Blokos Engenharia Ltda.

data inauguração: 08/09/2003

custo: $\mathrm{R} \$ 17$ milhões*

financiamento: Secretaria Municipal de Educação

\section{Projeto}

Edifício com programa padrão, acrescido de três quadras poliesportivas abertas, um campo de futebol e lago com nascente, com carpas e tartarugas.

\section{Histórico}

Situado num terreno bem próximo à Favela do Sapé, uma região muito carente de equipamentos públicos, este CEU, embora sendo 0 segundo maior da primeira leva de equipamentos construídos, enfrentou bastante inicialmente dificuldade em atender toda a demanda acumulada, o que gerou diversos conflitos entre os usuários. 0 problema só foi resolvido com a criação de um Conselho Gestor das Quadra do CEU.

\section{Partido arquitetônico}

Erguido às margens de uma avenida importante, num terreno que antes comportava um esgoto a céu aberto, 0 equipamento procurou não só se integrar ao entorno ocupado como também funcionar com uma praça de chegada ao assentamento. Para tanto, abre-se uma grande esplanada junto à avenida, onde se localizam as torres de água e o bloco do teatro. As piscinas e 0 solário abrigam-se entre os blocos, procurando privacidade. Frente a demanda do bairro, o complexo ainda conta com três quadras abertas, um campo de futebol e um lago com carpas e tartarugas, elemento curioso numa área tão urbanizada.

\section{Proveniência da demanda}

Presença da Favela do Sapé, uma das maiores da Zona Oeste; forte demanda por equipamentos públicos em geral.

\section{Propriedade da terra}

Terreno particular desapropriado.
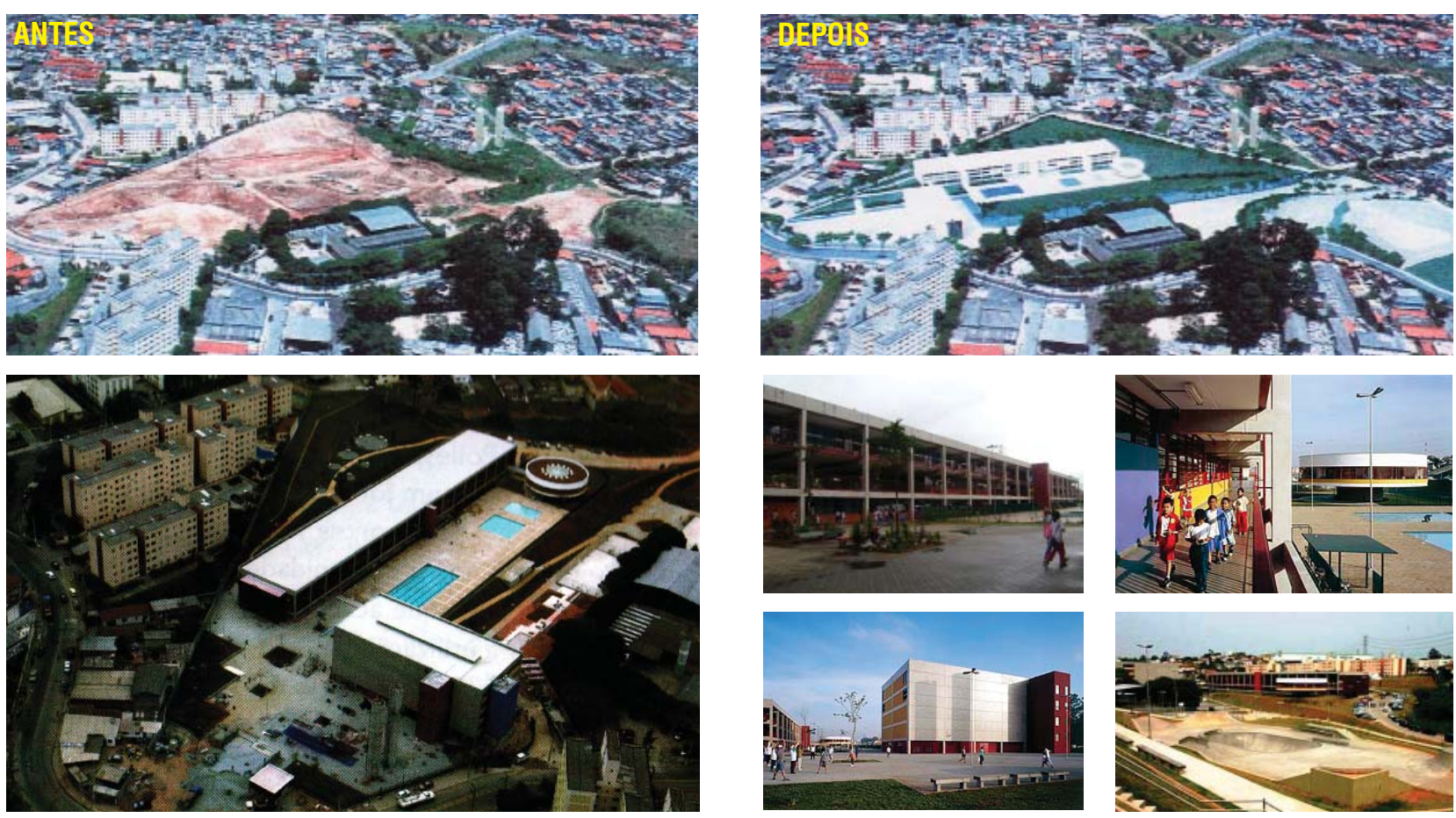


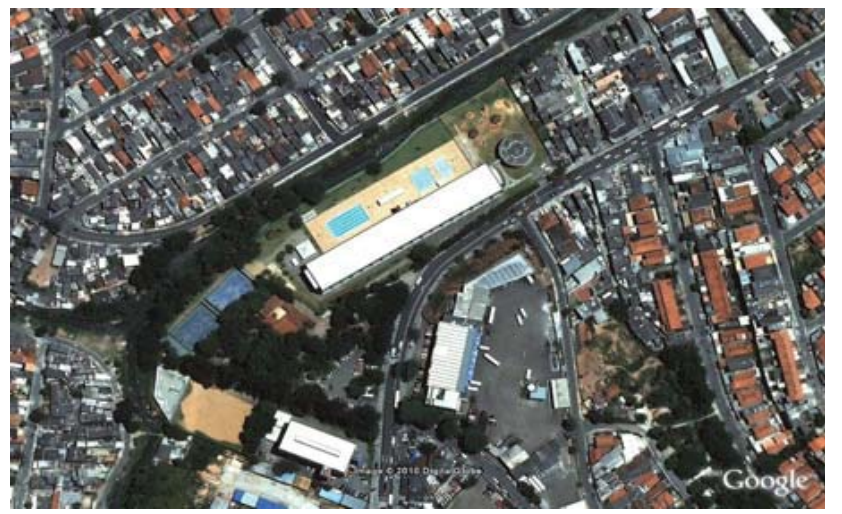

\section{CEU CAMPO LIMPO}

Av. Carlos Lacerda, 678 - Campo Limpo

área do terreno: $34.410 \mathrm{~m}^{2}$

área construída: $12.991 \mathrm{~m}^{2}$

construtora: Blokos Engenharia Ltda.

data inauguração: 01/03/2004

custo: $\mathrm{R} \$ 17$ milhões*

financiamento: Secretaria Municipal de Educação

\section{Projeto}

Edifício com programa padrão, acrescido da preservação de duas construções existentes, destinando uma delas à padaria comunitária e a outra a áreas administrativas. Lago e "bosque da leitura" construídos posteriormente.

\section{Histórico}

Este CEU foi construído na área da antiga Chácara São Pedro, um clube fechado, restrito a poucas dezenas de sócios. A implantação do clube simbolizou a abertura do clube à comunidade local e a disponibilização de uma estrutura de educação, esporte, cultura e lazer a uma região de extrema carência.

\section{Partido arquitetônico}

Tratando de um clube desativado, o projeto procurou preservar as edificações que pudessem ser adaptadas, tirando partido da infra-estrutura já disponível e resguardando parte da história do lugar. Desse modo, duas contruções foram preservadas: a da sede da chácara, que foi destinada à instalação do Conselho Gestor, área administrativa e centro comunitário, e, a antiga lanchonete, que passou a complementar a área da padaria comunitária. As piscinas foram instaladas de frente para 0 Rio Pirajuçara, remetendo, mais uma vez, ao conceito de praia fluvial urbana. Numa segunda etapa, 0 equipamento foi contemplado com um pequeno bosque, batizado como "bosque da leitura", e um lago com espécies aquáticas.

\section{Proveniência da demanda}

Déficit de vagas na região.

\section{Propriedade da terra}

Terreno particular desapropriado (antiga Chácara São Pedro).
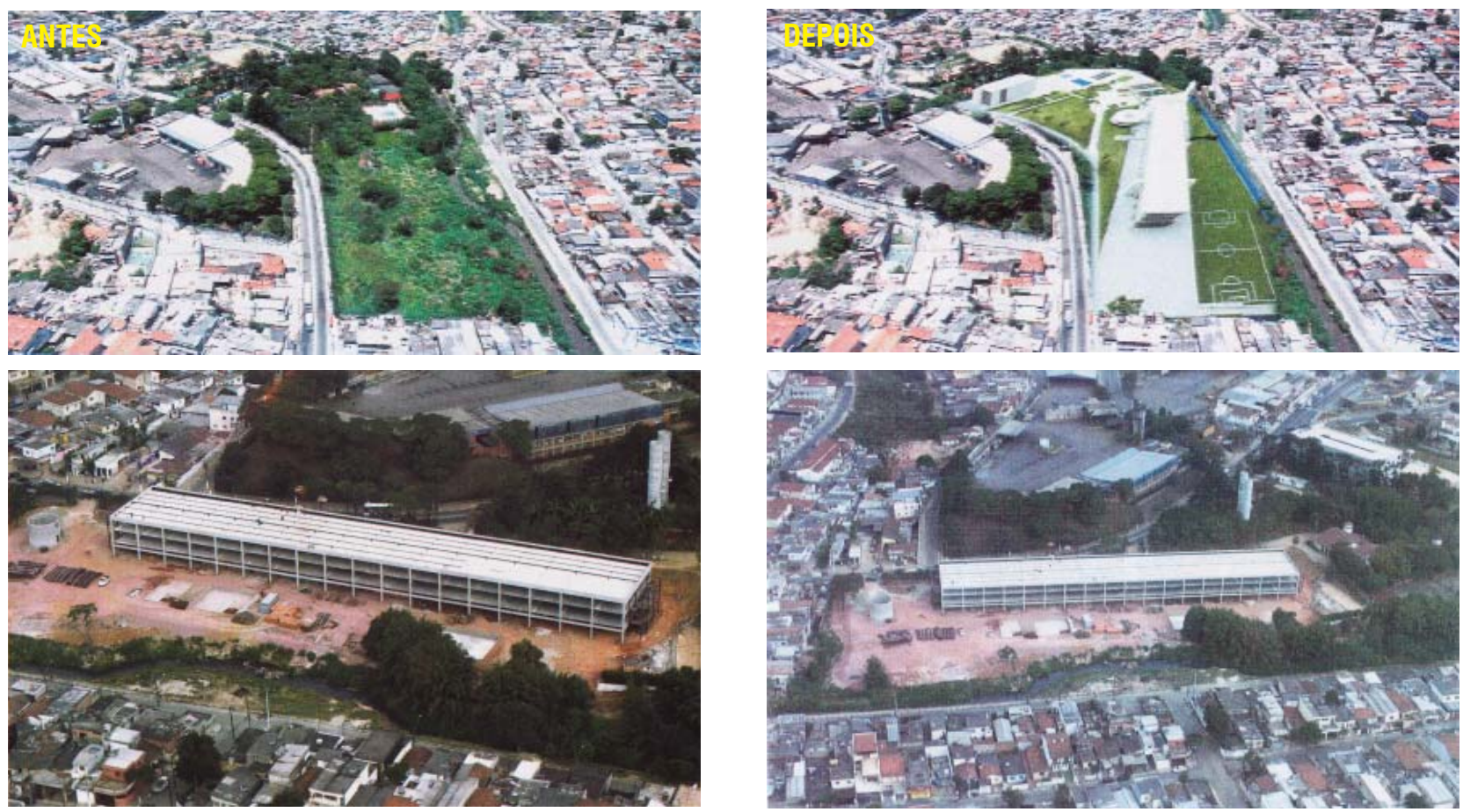


\section{PRODUÇÃO DE EQUIPAMENTOS EDUCACIONAIS}

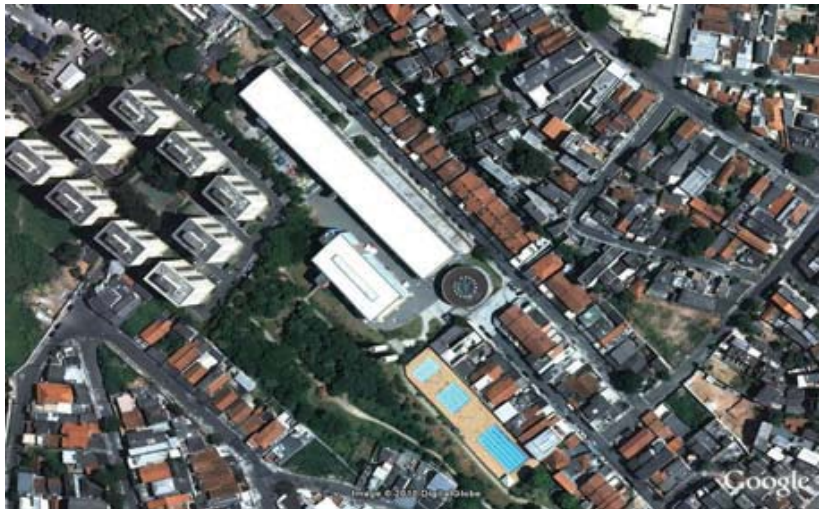

\section{CEU CASA BLANCA}

R. João Damasceno, s/n - Jd. Casa Branca

área do terreno: $25.500 \mathrm{~m}^{2}$ área construída: $13.798 \mathrm{~m}^{2}$

construtora: Blokos Engenharia Ltda.

data inauguração: 01/08/2004

custo: $\mathrm{R} \$ 17$ milhões*

financiamento: Secretaria Municipal de Educação

\section{Projeto}

Edifício com programa padrão, acrescido de um mini-bosque.

\section{Histórico}

A desapropriação deste terreno foi um processo bastante complicado, o que levou a um grande atraso na execução das obras. Iniciado anteriormente ao projeto do CEU, o processo de desapropriação da área, solicitado pela comunidade local, visava a implantação de um centro comunitário ou uma UBS, equipamentos de que o bairro não dispunha. 0 envolvimento das lideranças comunitárias neste processo foi intensificada frente a uma ameaça do Movimento de Moradias de invadir o local. Com isso, a população se aprorpriou ainda mais do território, acompanhando e participando, inclusive, de todo 0 processo posterior de construção do equipamento.

\section{Partido arquitetônico}

Localizado numa região vizinha ao bairro do Morumbi, o projeto deste CEU procurou encarar os contrastes e trazer para 0 bairro o parque, a escola, a área de lazer que apenas o bairro viznho parecia oferecer. Com isso, este equipamento, além do programa padrão, passou a contar com um pequeno bosque, com trilhas para caminhada, áreas para descanso e uma pequena vegetação nativa preservada, de modo a trazer lazer para a população e dar um respiro a uma área de ocupação tão densa e precária.

\section{Proveniência da demanda}

Ausência de creches, EMEl e demais tipos de equipamentos públicos na região.

\section{Propriedade da terra}

Terreno particular desapropriado.
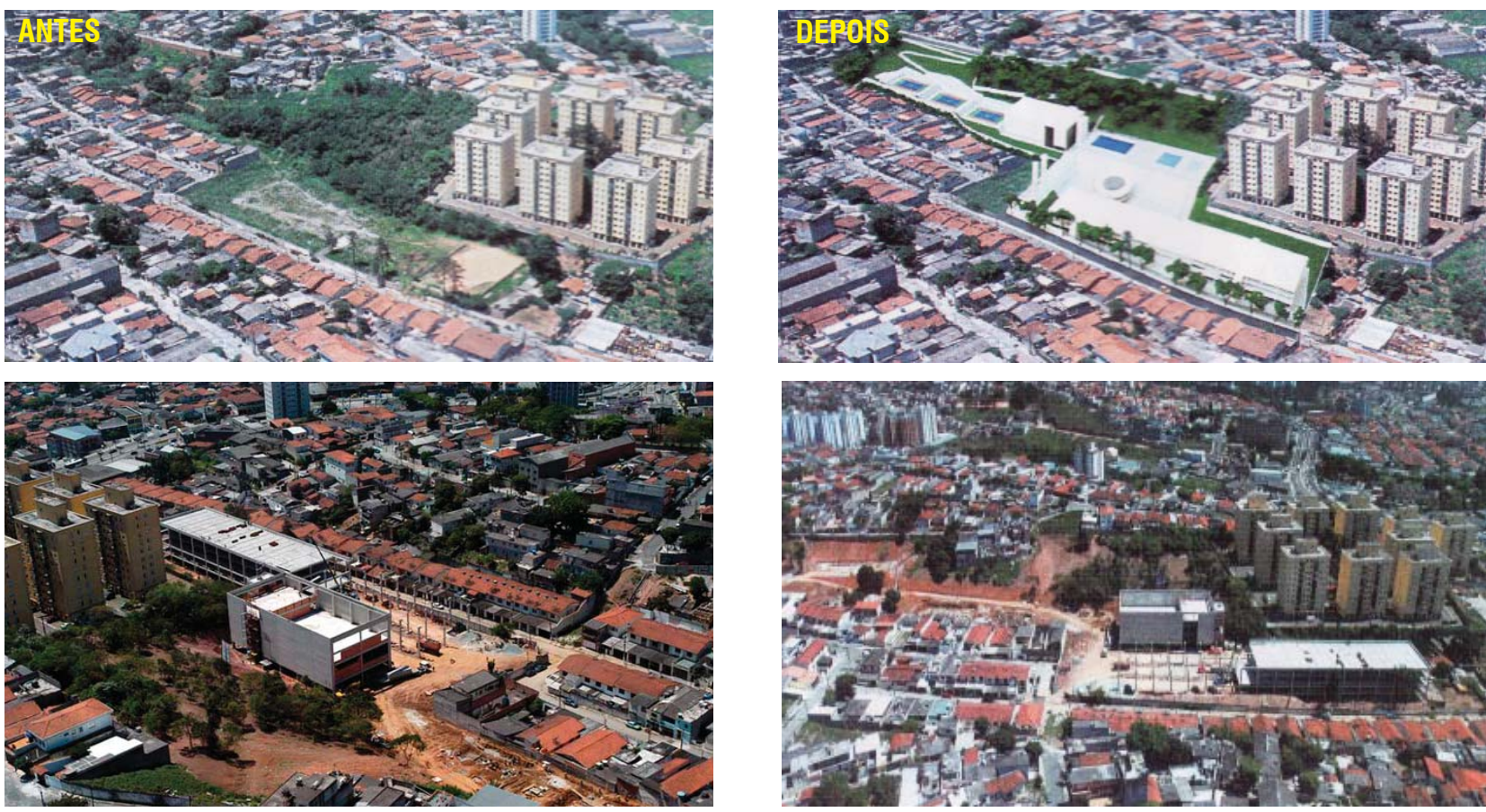


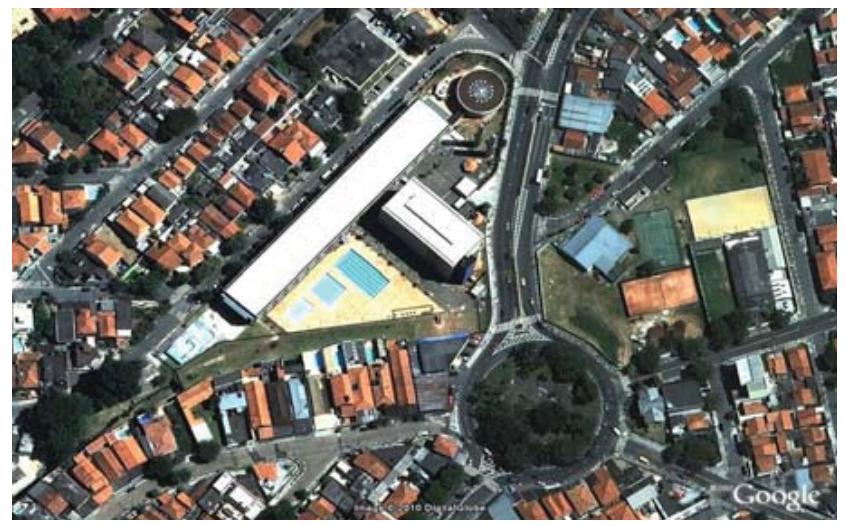

\section{CEU CIDADE DUTRA}

Avenida Interlagos, 7.350 - Interlagos

área do terreno: $11.500 \mathrm{~m}^{2}$

área construída: $13.121 \mathrm{~m}^{2}$

construtora: Carioca Christiani Nielsen Engenharia

data inauguração: 25/08/2003

custo: $\mathrm{R} \$ 17$ milhões*

financiamento: Secretaria Municipal de Educação

\section{Projeto}

Edifício com programa padrão.

\section{Histórico}

0 CEU Cidade Dutra foi construído numa região onde já havia um Clube Desportivo Municipal e uma Unidade Básica de Saúde. A opção pelo terreno deu-se, sobretudo, pela possibilidade de agragar tais equipamentos num mesmo espaço, formando a tal "Praça de Equipamentos" sugerida por Paulo Freire, onde os diferentes serviços públicos se comunicariam, interagindo e se completando.

\section{Partido arquitetônico}

Implantado num terreno triangular de dimensões reduzidas, próximo a uma rotatória da Avenida Interlagos, o edifício foi projetado como um marco na paisagem, sendo facilmente avistado para quem trafega na avenida. As torres de água, com 22,5m de altura e $3 \mathrm{~m}$ de diâmetro, foi situadas no eixo da avenida, indicando uma espécie de pórtico que leva ao CEU. 0 prédio redondo foi instalado em um dos vértices do triângulo, também às margens da avenida, constituindo uma fácil referência para quem se aproxima.

\section{Proveniência da demanda}

Ocupação densa e forte demanda por vagas.

\section{Propriedade da terra}

Terreno público.
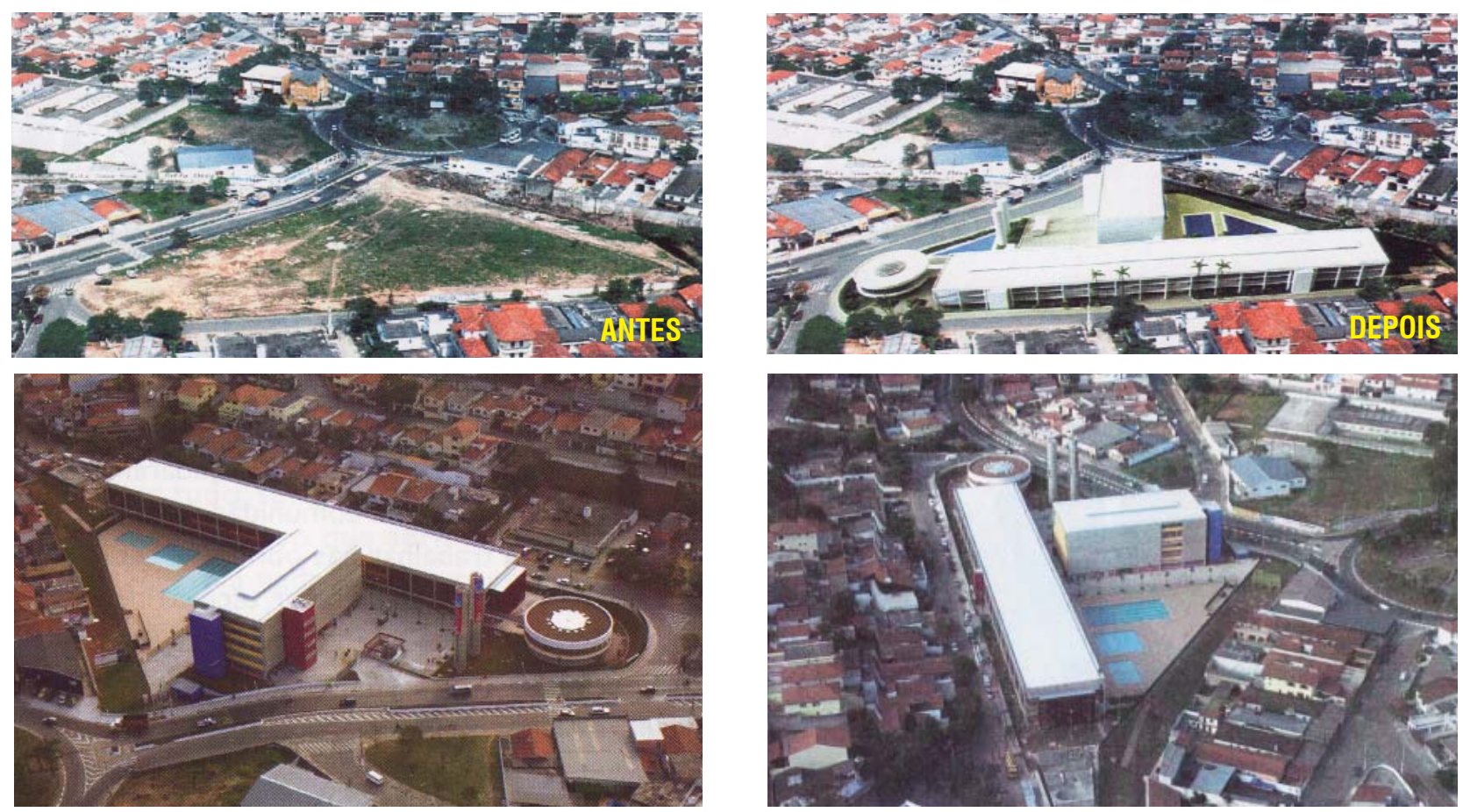


\section{PRODUÇÃO DE EQUIPAMENTOS EDUCACIONAIS}

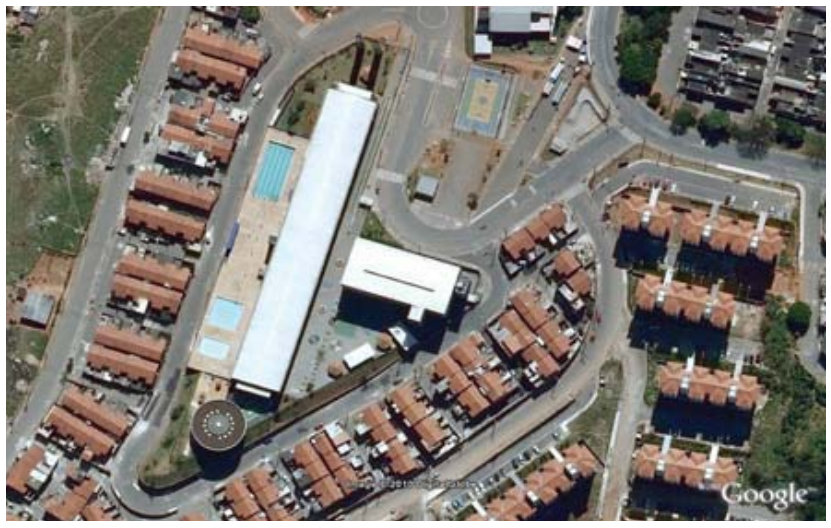

\section{CEU INÁCIO MONTEIRO}

R. Barão Barroso do Amazonas, s/n - Cidade Tiradentes

área do terreno: $12.633 \mathrm{~m}^{2}$

área construída: $13.121 \mathrm{~m}^{2}$

construtora: Construtora Varca Scatena

data inauguração: 01/09/2003

custo: $\mathrm{R} \$ 17$ milhões*

financiamento: Secretaria Municipal de Educação

Projeto

Edifício com programa padrão.

\section{Histórico}

Este CEU foi implantado numa região que abriga diversos conjuntos habitacionais da COHAB. Ao ocupar estes conjuntos, a instituição priorizou pessoas com necessidades especiais. Com isso, a forte concentração deste grupo no bairro fez com que o CEU a ser implantado preocupasse-se mais ainda com a questão, não só do ponto de vista arquitetônico, mas também ao pensar na implementação de programas diferenciados, especificamente ligados a questões de acessibilidade.

\section{Partido arquitetônico}

Este CEU foi o primeiro a ser projetado. Situado em meio a diversos conjuntos habitacionais, utiliza uma das áreas institucionais, desde o início pensada como uma "Praça de Equipamentos", que concentrasse diversos equipamentos públicos. Dada as preocupações intensificadas com as questões de acessibilidade, este complexo se desenvolve sobre um único platô, criando-se taludes e arrimos na divisa com a via mais baixa.

\section{Proveniência da demanda}

Construção pela COHAB de diversos conjuntos habitacionais no entorno.

\section{Propriedade da terra}

Terreno público.
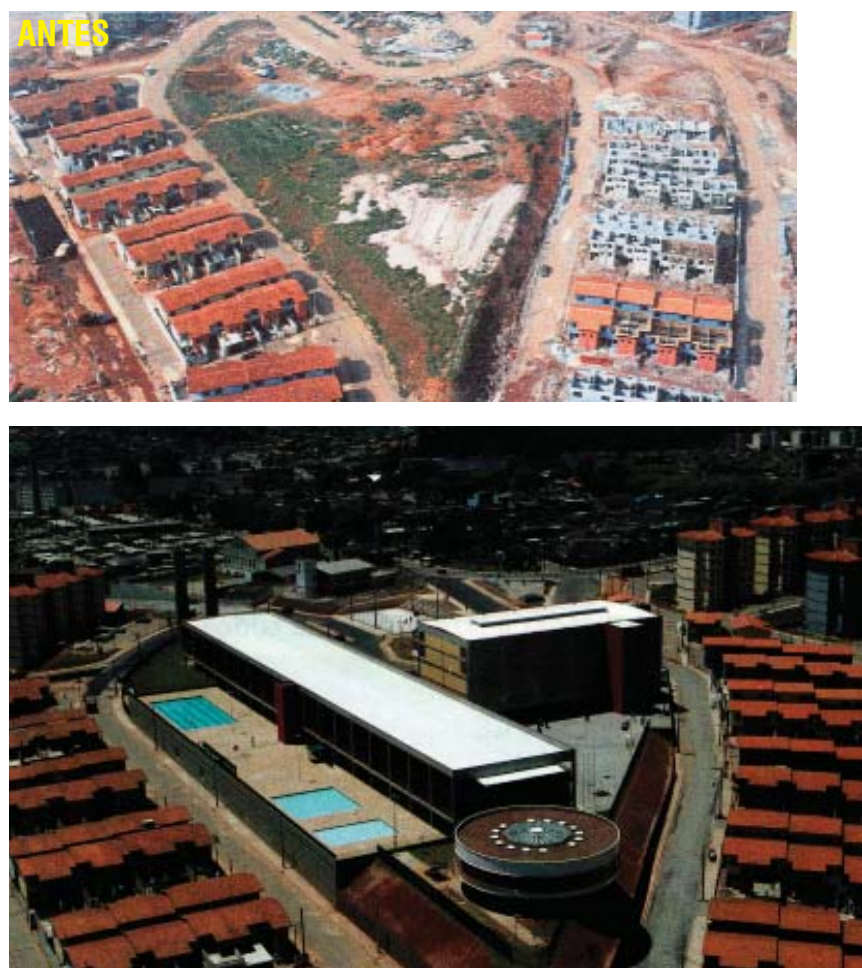
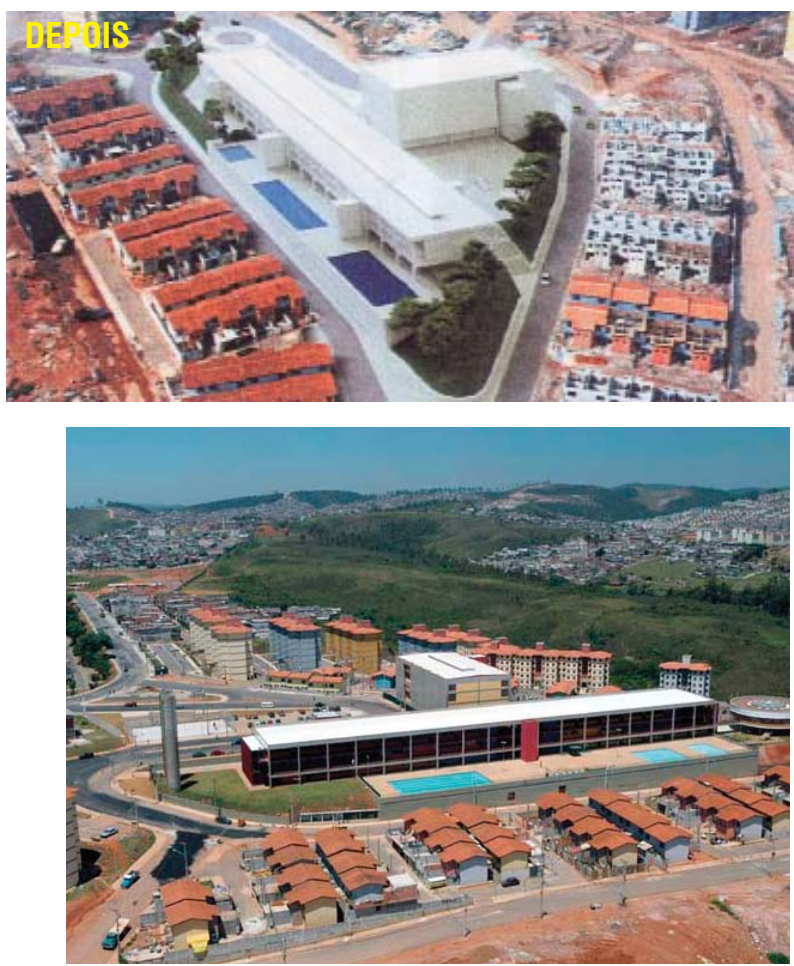

[241] 


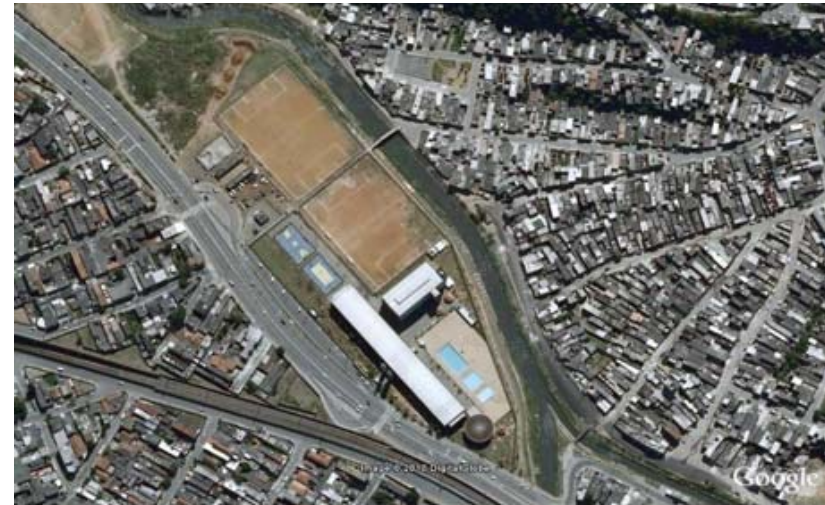

\section{CEU JAMBEIRO}

R. Flores do Jambeiro, 61 - Guaianazes

área do terreno: $59.543 \mathrm{~m}^{2}$

área construída: $12.991 \mathrm{~m}^{2}$

construtora: Construbase Engenharia

data inauguração: 04/08/2003

custo: $\mathrm{R} \$ 17$ milhões*

financiamento: Secretaria Municipal de Educação

\section{Projeto}

Edifício com programa padrão, acrescido de dois campos de futebol e três quadras poliesportivas, dada a existência de times organizados na região.

\section{Histórico}

Este foi o primeiro CEU a ser inaugurado. As constantes apresentações e discussões do projeto com a comunidade foram essenciais para que a inicial rejeição ao equipamento fosse convertida em apropriação. Por ser o primeiro, este CEU contou com um importante trabalho voluntário da comunidade, driblando os atrasos nas licitações. Parte destes voluntários foram contratados para trabalhar na obra ou mesmo, posteriormente, no próprio CEU.

\section{Partido arquitetônico}

Este CEU apresenta programa ampliado, visando suprir os anseios da comunidade. Como no terreno havia dois campos de futebol, o novo projeto se comprometeu em realocá-los, de modo a preservar os campeonatos locais. A proximidade com 0 Rio Itaquera, fez com que o solário da piscina fosse implantado de frente para ele, remetendo à idéia de uma praia fluvial urbana. As torres de águas foram situadas próximas ao saguão de entrada central, constituindo uma espécie de portal.

\section{Proveniência da demanda}

Área cercada por ocupações irregulares.

\section{Propriedade da terra}

Terreno particular desapropriado.
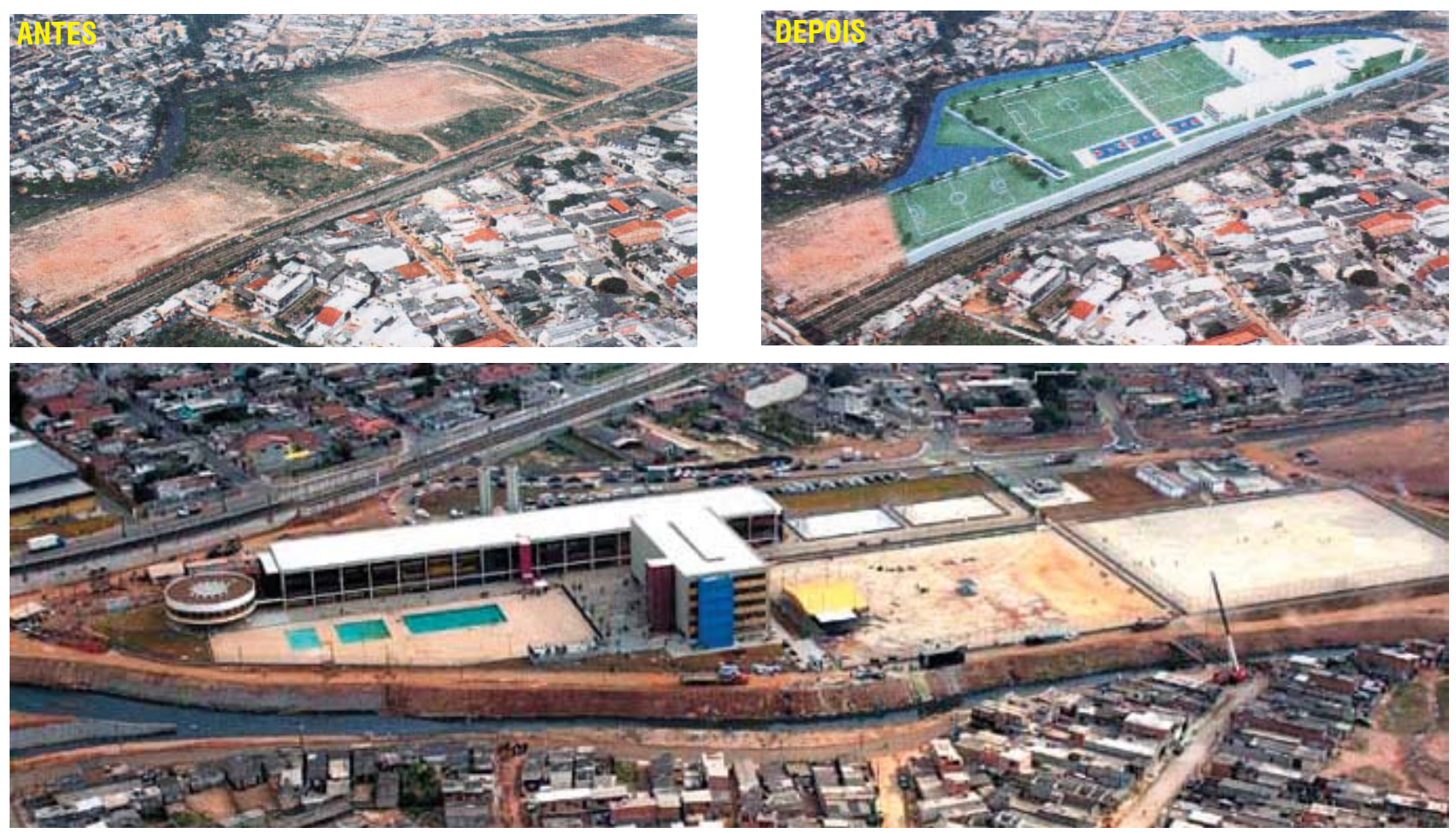


\section{PRODUÇÃO DE EQUIPAMENTOS EDUCACIONAIS}

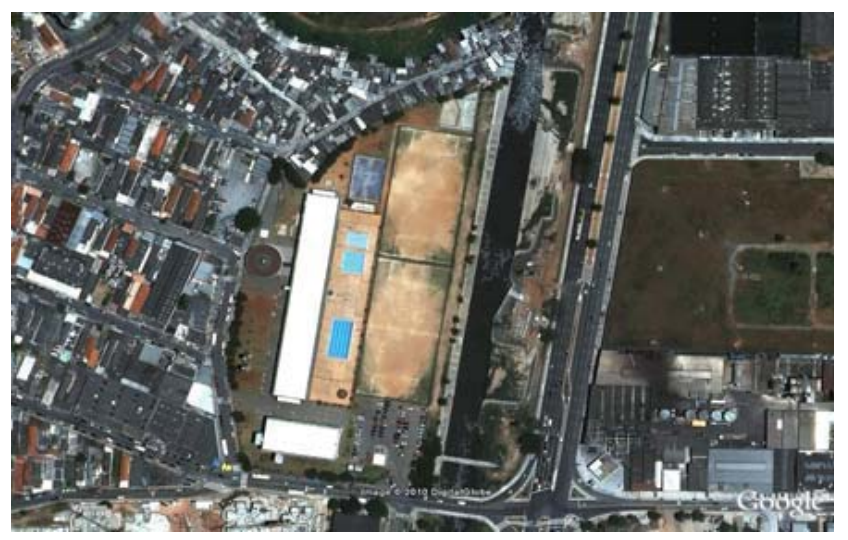

\section{CEU MENINOS}

Rua Barbinos, 111 - Ipiranga

área do terreno: $32.600 \mathrm{~m}^{2}$ área construída: $12.991 \mathrm{~m}^{2}$

construtora: Construção

data inauguração: 01/10/2003

custo: $\mathrm{R} \$ 17$ milhões*

financiamento: Secretaria Municipal de Educação

\section{Projeto}

Edifício com programa padrão, acrescido de dois campos de futebol, onde o time São Caetano já treinava a equipe de juvenil, e uma sala bilingue.

\section{Histórico}

Situado nas proximidades da Favela Heliópolis, onde há uma demanda fortíssima por vagas, este CEU foi implantado em uma das margens do Córrego dos Meninos, um dos afluentes do Rio Tamanduateí, na divisa de São Paulo com o município de São Caetano. Como anteriormente o time São Caetano treinava seus meninos do juvenil nos campos de várzea até então situados neste terreno, foi necessário que o novo projeto os incluísse ao programa.

\section{Partido arquitetônico}

A presença do Córrego dos Meninos levou mais uma vez ao conceito das praias fluviais urbanas, fazendo com que as piscinas conversassem com o leito do rio, acompanhando seu traçado. Neste caso, entretanto, elas são separadas das margens do córrego por dois campos de futebol, que já existiam no local e serviam de área de treinamento para um time juvenil profissional. Uma curiosidade específica em relação ao programa deste CEU é a existência de uma "sala bilíngue", voltada a aulas de francês, fruto da parceiria da Prefeitura com o Governo da França, o que justifica 0 apelido de "CEU Francês". Com isso, este CEU diferencia-se dos demais por oferecer cursos extra-curriculares de francês, assim como cursos de capacitacão para professores interessados em lecionar o idioma.

\section{Proveniência da demanda}

Proximidade com a Favela Heliópolis, o que gerou uma forte demanda reprimida por vagas.

\section{Propriedade da terra}

Terreno particular desapropriado.
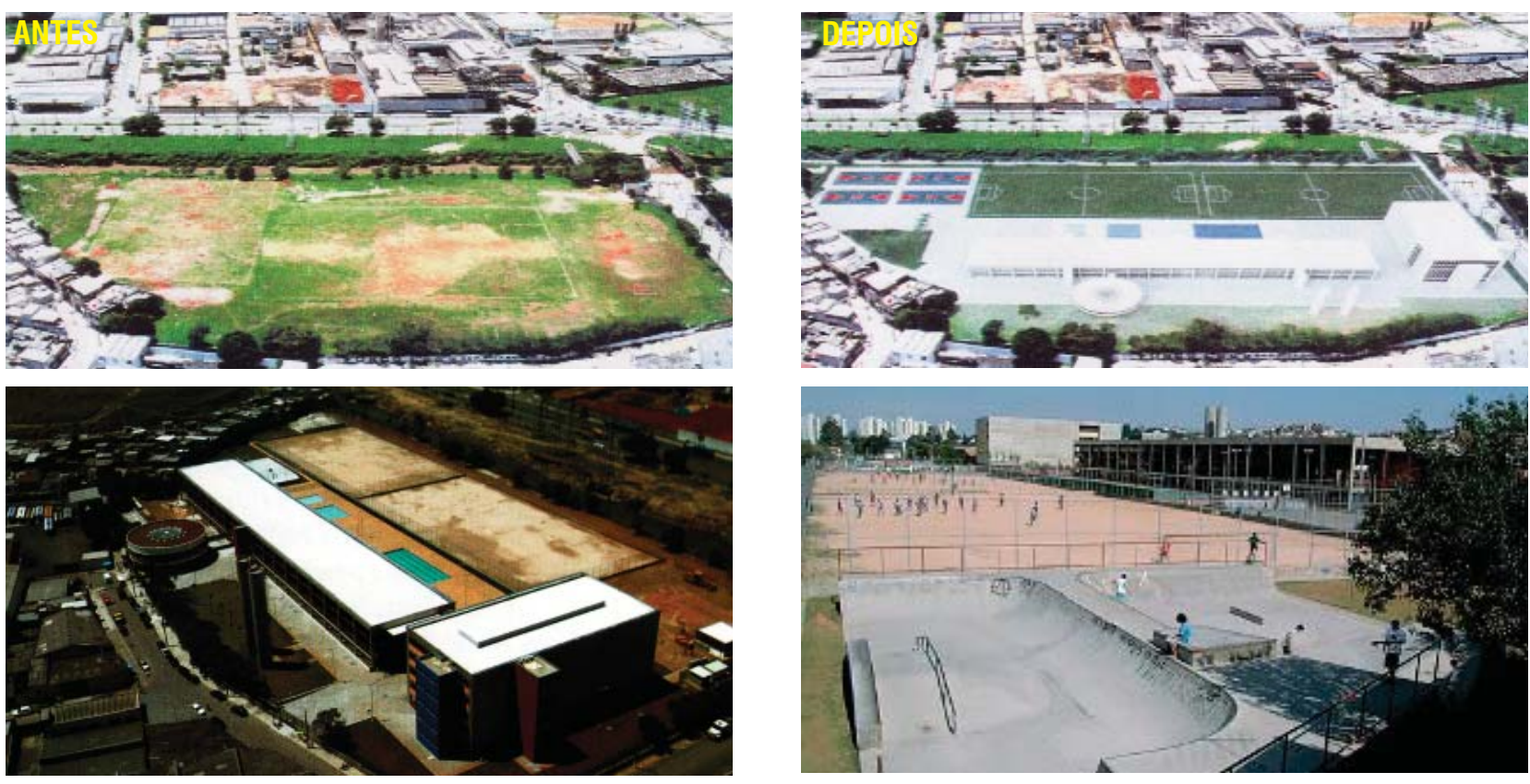


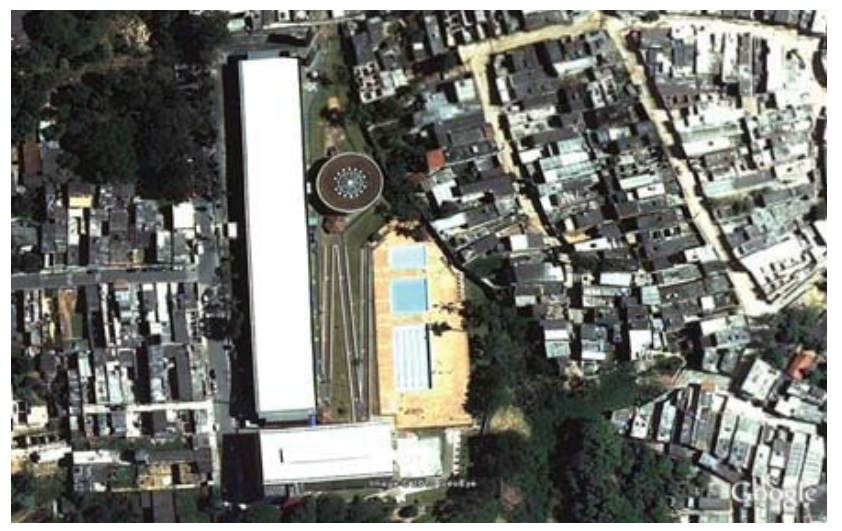

\section{CEU NAVEGANTES}

R. Maria Moassabi Barbour, s/n - Capela do Socorro

área do terreno: $14.700 \mathrm{~m}^{2}$

área construída: $12.981 \mathrm{~m}^{2}$

construtora: Carioca Christiani Nielsen Engenharia

data inauguração: 12/09/2003

custo: $\mathrm{R} \$ 17$ milhões*

financiamento: Secretaria Municipal de Educação

\section{Projeto}

Edifício com programa padrão.

\section{Histórico}

Este CEU foi construído em um antigo sítio desaprorpriado, muito arborizado, praticamente abandonado em meio a uma região muito pobre, basicamente ocupada por ocupações irregulares, parte dela classificada Favela Cantinho do Céu. A escolha do nome está no fato do terreno estar situado num dos braços da Represa Billings, numa região entre lagos, que já abrigou, no passado, muitas chácaras e clubes náuticos, com estaleiros e construções navais, que foram abandonando o local em funcão das invasões e ocupações irrequlares que se sucederam.

\section{Partido arquitetônico}

Estando 0 terreno situado nas margens da Represa Billings, a idéia era fortalecer o papel deste elemento na paisagem, ressaltando inclusive seu aspecto pedagógico, no tocante à discussão de questões ambientais. Desse modo, solário e piscinas foram dispostos de frente para a represa, constituindo figurativamente um cais. As torres de água foram também voltadas para a água, remetendo, segundo os arquitetos de EDIF, aos faróis de navegação marítima.

\section{Proveniência da demanda}

Região muito pobre na Zona Sul, onde está a favela Cantinho do Céu.

\section{Propriedade da terra}

Terreno particular desapropriado (antigo sítio).
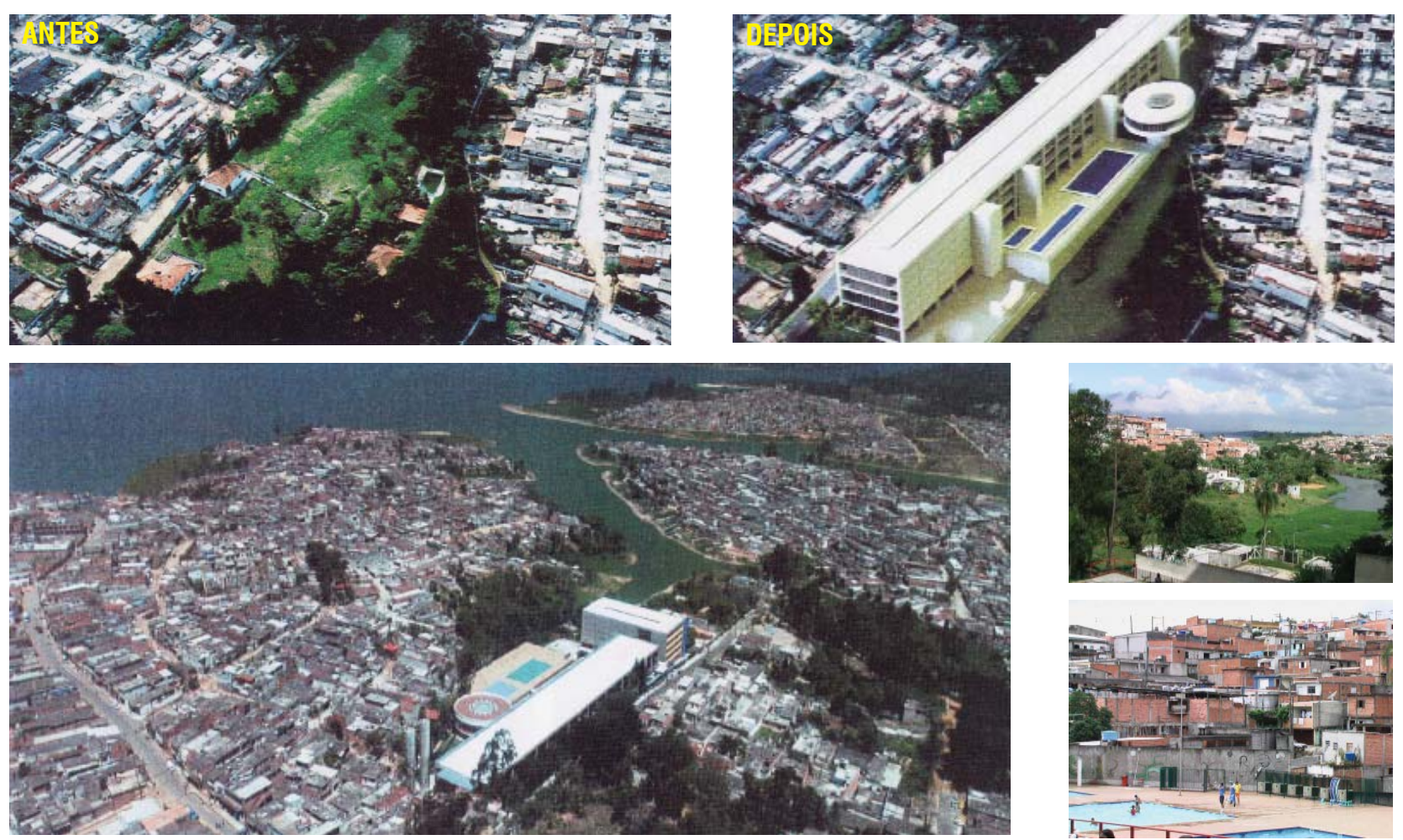


\section{PRODUÇÃO DE EQUIPAMENTOS EDUCACIONAIS}

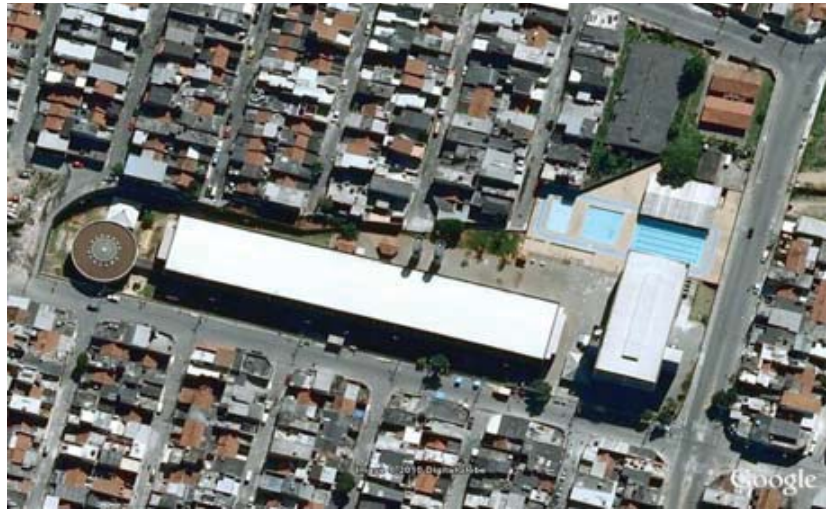

Projeto

Edifício com programa padrão, exceptuando-se a pista de skate.

\section{Histórico}

Este CEU foi construído em terreno público, próximo a um loteamento regularizado pela CDHU, onde anteriormente havia, além de um campo de futebol de várzea, um esgoto a céu aberto, que a comunidade tentava a tempos tampar. Desse modo, o uso do espaço pelo equipamento foi muito bem recebido.

\section{Partido arquitetônico}

Pelo fato do projeto remover o campo de futebol anteriormente existente, foi necessário contruir um outro campo, em terreno próximo, dada a demanda da comunidade. As piscinas foram instaladas no nível da rua, de frente para um centro comunitário local, de modo a facilitar sua preservação. 0 complexo foi estruturado em forma de "L", tendo numa das extremidades do bloco didático o teatro e, na outra, o prédio redondo. A pista de skate precisou ser removida do programa, em funcão da carência de espaco.

\section{Proveniência da demanda}

Regularização de um loteamento pela CDHU.

\section{Propriedade da terra}

Terreno público.
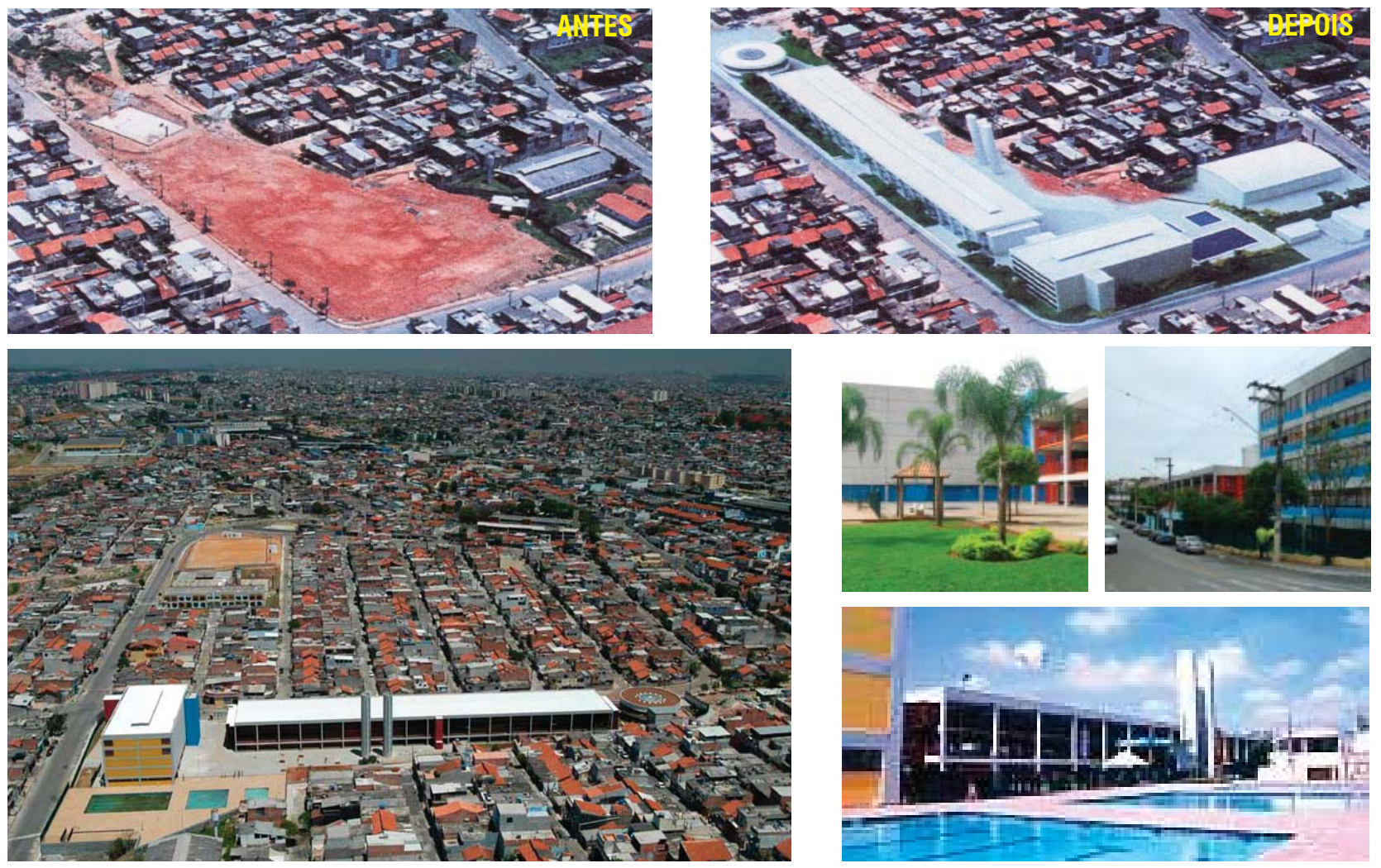


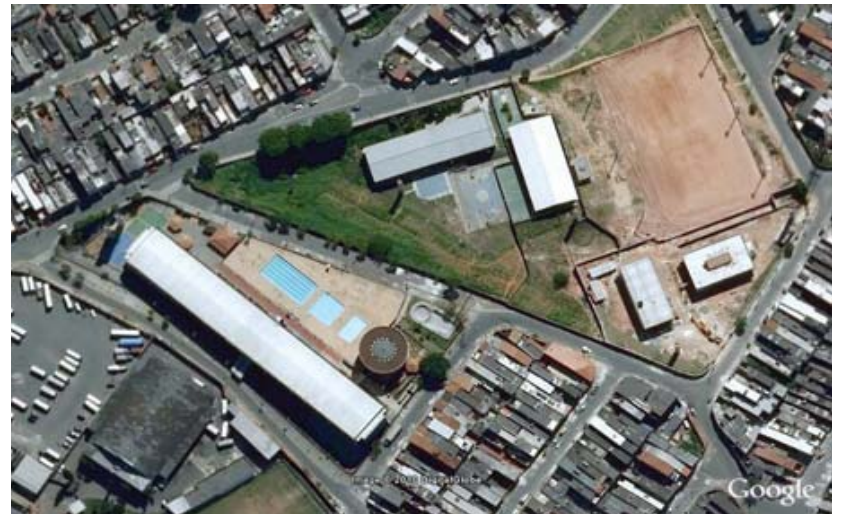

\title{
CEU PARQUE VEREDAS
}

\author{
R. Daniel Muller, s/n. - Itaim Paulista
}

área do terreno: $11.800 \mathrm{~m}^{2}$ área construída: $14.177 \mathrm{~m}^{2}$

construtora: Construbase Engenharia

data inauguração: 25/08/2003

custo: $\mathrm{R} \$ 17$ milhões*

financiamento: Secretaria Municipal de Educação

\section{Projeto}

Edifício com programa padrão, contudo adaptado às dimensões reduzidas e à alta declividade do terreno.

\section{Histórico}

No terreno onde o edifício foi construído, havia antes um centro esportivo construído em mutirão pela comunidade local e depois regularizado pela Prefeitura como Centro Desportivo Municipal. Consistia num campo de futebol cercado, com vestiários, o qual constituia a única opção de lazer do bairro. Sendo assim, a idéia de substituir o CDM por uma escola, a princípio, foi rejeitada pela comunidade, que temia ainda que o equipamento fosse posteriormente abandonado. Depois de muita negociação, foi acertado que o CEU seria construído na parte maior do terreno e o CDM seria realocado onde anteriormente havia um Centro de Assistência Integral à Criança - CAIC.

\section{Partido arquitetônico}

0 edifício foi construído num terreno pequeno, com cerca de 11 mil metros quadrados, e com grande declividade equivalente a três pavimentos. Com isso, o complexo conta com um acesso intermediário, pelo terceiro pavimento de um bloco com cinco, o que facilita a distribuição dos fluxos. Em função da escassez de área, o programa teve que ser condensado, extinguindo-se o bloco cultural/ esportivo e agregando-o ao bloco didático. Desse modo, em uma extremidade do edifício está o teatro e, na outra, o ginásio. Além disso, a biblioteca acontece em dois pavimentos, no térreo e no primeiro andar. 0 prédio da CEI tem pé-direito triplo, diferentemente dos demais, de modo a se conectar com 0 bloco didático.

\section{Proveniência da demanda}

Déficit de vagas.

\section{Propriedade da terra}

Terreno público.
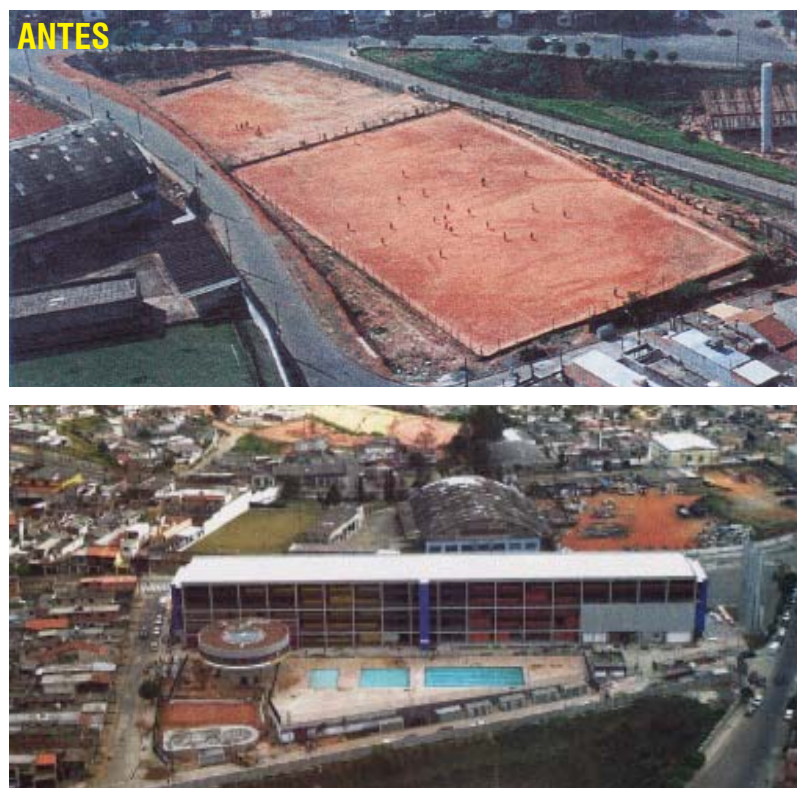

[ 246 ]
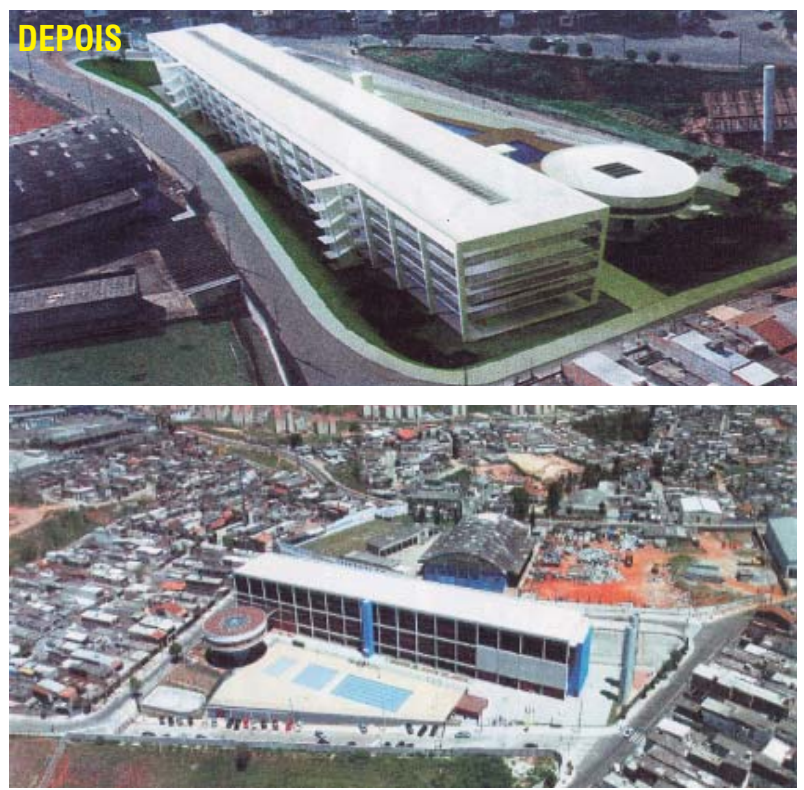


\section{PRODUÇÃO DE EQUIPAMENTOS EDUCACIONAIS}

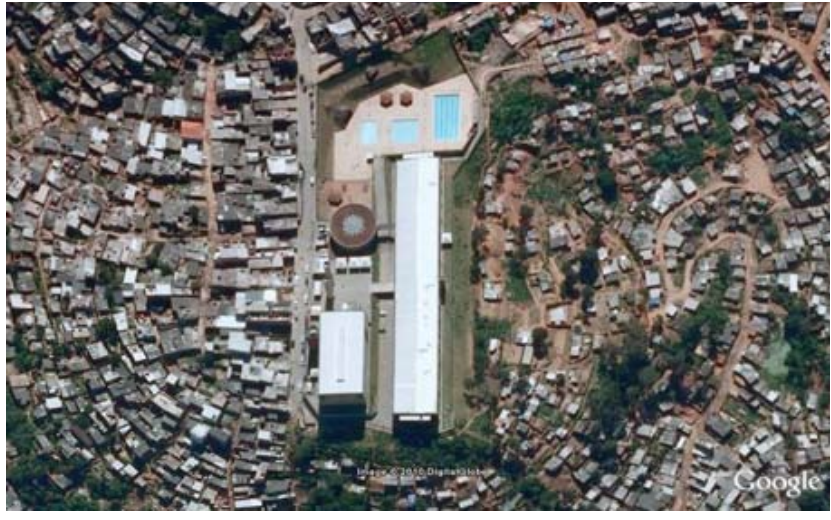

\section{CEU DA PAZ}

R. Firminópolis, s/n - Brasilândia

área do terreno: $28.400 \mathrm{~m}^{2}$ área construída: $12.992 \mathrm{~m}^{2}$

construtora: Construtora OAS

data inauguração: 08/03/2004

custo: $\mathrm{R} \$ 17$ milhões*

financiamento: Secretaria Municipal de Educação

Projeto

Edifício com programa padrão.

\section{Histórico}

Este terreno está situado no Jardim Paraná, bairro situado numa região alta da Serra da Cantareira, que começou a se formar a cerca de 10 anos. Apesar da articulação e engajamento da população local, o bairro só recebeu redes de infraestrutura básica pouco antes da construção do $\mathrm{CEU}$, que, da mesma forma, foi um dos primeiros equipamentos públicos disponíveis na reqião.

\section{Partido arquitetônico}

A implantação deste complexo procurou privilegiar a paisagem, aproveitando o desnível de 50m da terreno em relação à várzea, voltando as janelas do bloco didático para esta impressionante vista. 0 terreno que anteriormente servia como deposito de lixo, incrustado em meio a um loteamento clandestino, foi transformado numa praça, que se volta para 0 entorno de casas e é abraçado pelos edifícios. As piscinas e o solário foram implantados de frente para a mata, facilitando ainda a ensolacão nesta área.

\section{Proveniência da demanda}

Área ocupada por um loteamento clandestino, sem qualquer oferta de serviço público.

\section{Propriedade da terra}

Terreno particular desapropriado.
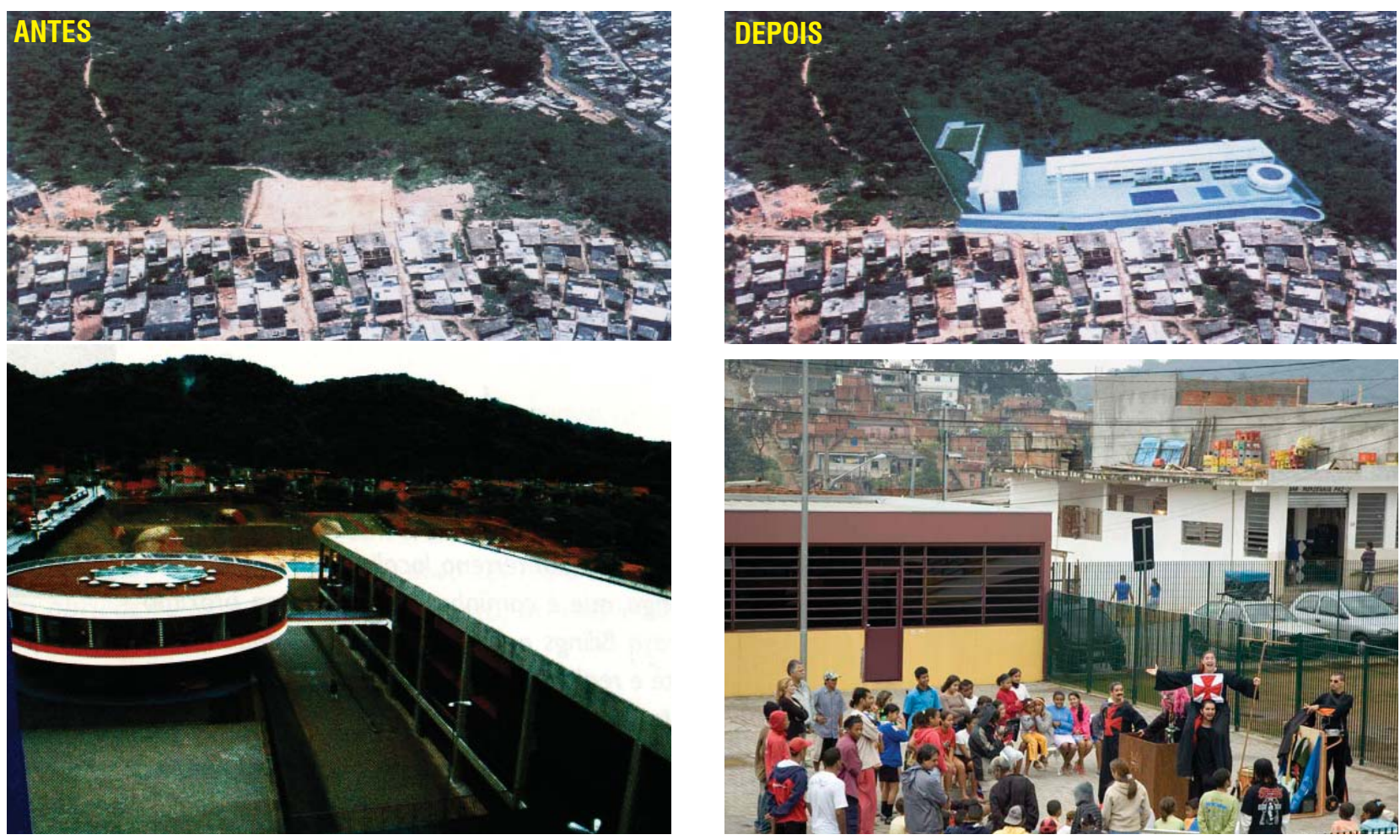


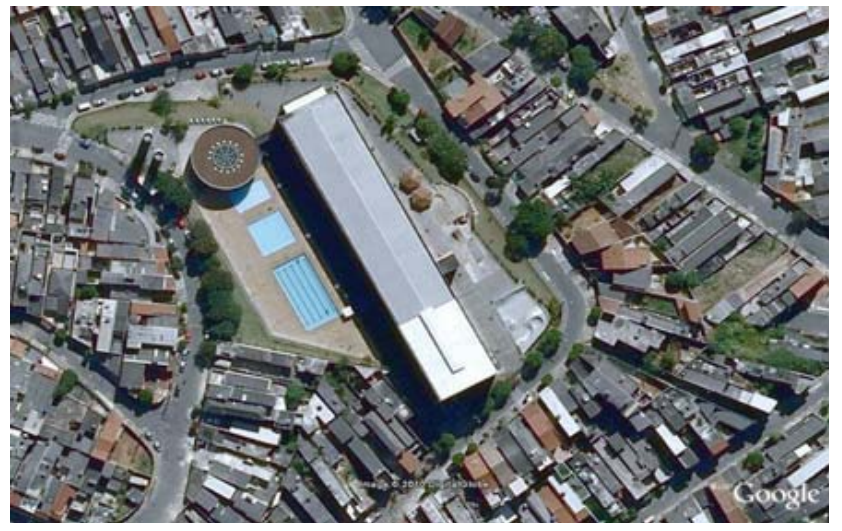

\section{CEU PERA MARMELO}

R. Pera Marmelo, 226 - Pirituba

área do terreno: $11.000 \mathrm{~m}^{2}$

área construída: $13.783 \mathrm{~m}^{2}$

construtora: Construtora OAS

data inauguração: 23/09/2003

custo: $\mathrm{R} \$ 17$ milhões*

financiamento: Secretaria Municipal de Educação

\section{Projeto}

Edifício com programa padrão.

\section{Histórico}

Construído num terreno bastante reduzido, 20 X 120m, e de forte declividade, este equipamento procurou atender a demanda de uma região próxima a grandes conjuntos da CDHU, o que intensificou a demanda por vagas.

\section{Partido arquitetônico}

Em função das dimensões reduzidas e da alta declividade do terreno, este projeto diferencia-se um pouco dos demais. Não havendo comprimento suficiente para implantar o bloco didático, e sequer para comportar os três edifícios padrão, optou-se por juntar o bloco didático e o cultural/ esportico em um único volume, mais alto, com o dobro de pavimentos que os originais. Este edifício passaria a concentrar, portanto, as escolas, o teatro, o ginásio, as salas de dança, os estúdios, a biblioteca, a padaria comunitária e o telecentro. Apenas o prédio redondo seria implantado separamente, até por constituir um interessante referência simbólica-formal dos CEUS. 0 bloco maior dispõem de acessos em dois níveis, por dois lados opostos do terreno. 0 acesso que se dá pelo nível das piscinas e da CEl é contemplado com uma ponte de liaacão com o edifício principal. oque proporciona um efeito interessante ao traseunte.

\section{Proveniência da demanda}

Construção de conjuntos da CDHU aumentou significativamente o déficit já existente.

\section{Propriedade da terra}

Terreno público, então utilizado como campo de futebol.
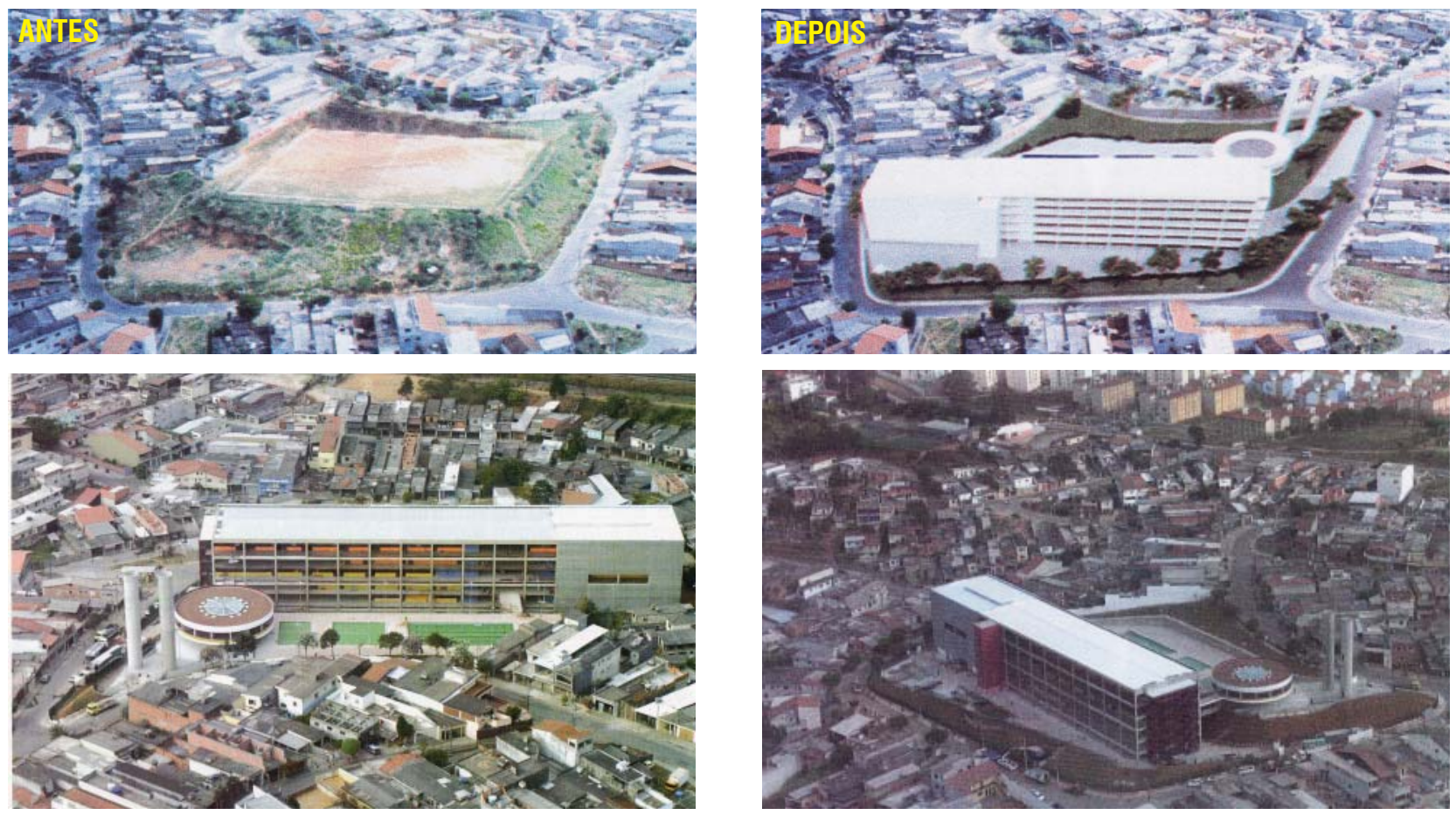


\section{PRODUÇÃO DE EQUIPAMENTOS EDUCACIONAIS}

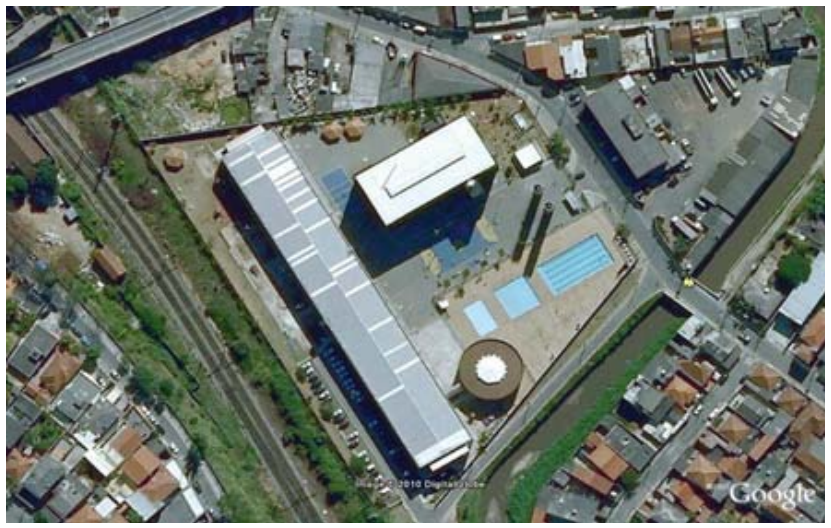

\section{CEU PERUS}

R. Bernardo José de Lorena, s/n - Perus

área do terreno: $20.870 \mathrm{~m}^{2}$

área construída: $13.091 \mathrm{~m}^{2}$

construtora: Construtora OAS

data inauguração: 25/08/2003

custo: $\mathrm{R} \$ 17$ milhões*

financiamento: Secretaria Municipal de Educação

\section{Projeto}

Edifício com programa padrão.

\section{Histórico}

A opção por um terreno delimitado por um córrego, uma ferrovia, um viaduto e uma avenida, remete, segundo EDIF, a um resgate de várias situações históricas de estruturação das cidades, que em sua maioria de ergueram, a princípio, nas proximidades dos leitos d'água e, posteriormente, das ferrovias.

\section{Partido arquitetônico}

Este projeto carrega a idéia não exatamente da "Praça de Equipamentos", mas sim da Praça da Estação de Trem. Num terreno situado às margens da ferrovia Perus-Pirapora, este CEU procura representar um pequeno centro estruturador do bairro, atrelado à malha ferroviária, remetendo ao processo de configuração urbana padrão em cidades do mundo todo, onde as estações de trem impulsionam a estruturação de centralidades urbanas, mesmo que locais.

\section{Proveniência da demanda}

Demanda local em função da alta densidade populacional.

\section{Propriedade da terra}

Terreno particular desapropriado.
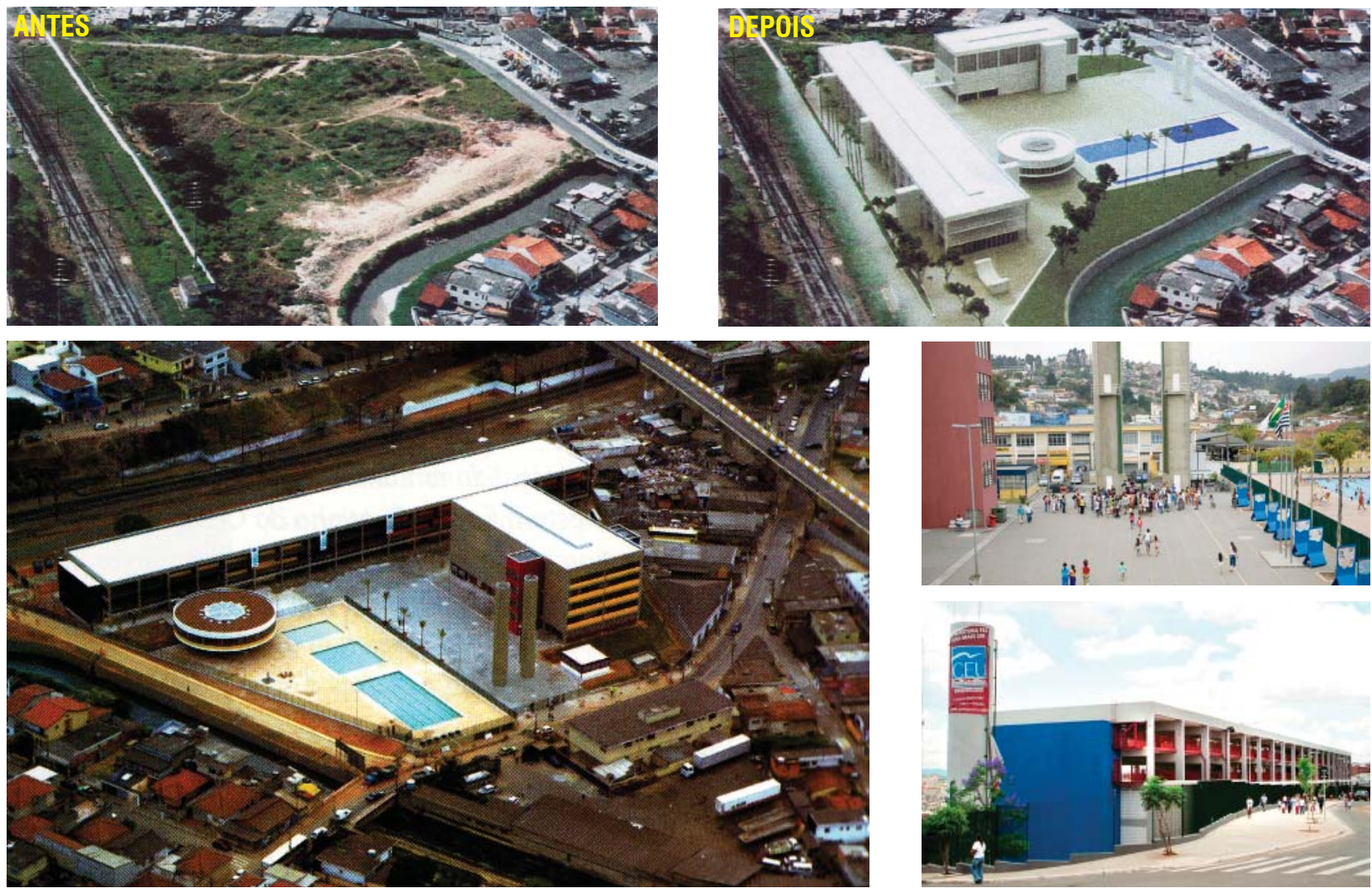


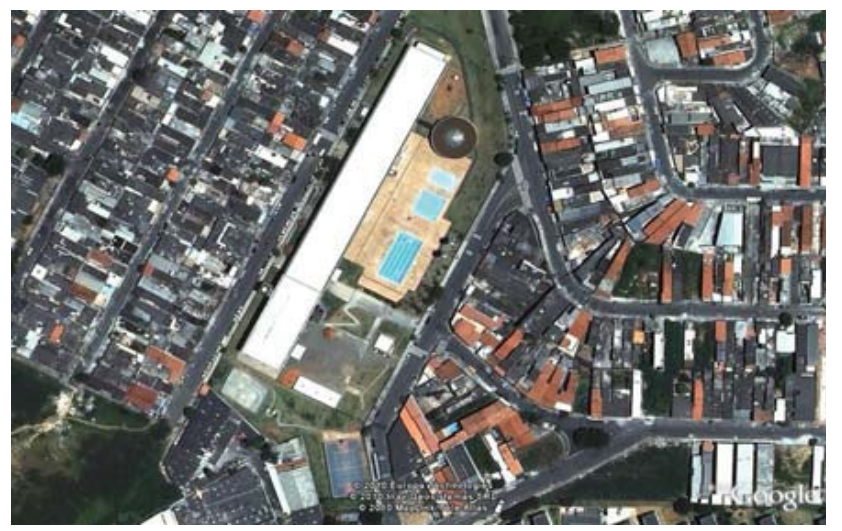

\section{CEU ROSA DA CHINA}

R. Rosa da China, 113 - Vila Prudente

área do terreno: $20.000 \mathrm{~m}^{2}$

área construída: $13.121 \mathrm{~m}^{2}$

construtora: Construção

data inauguração: 10/08/2003

custo: $\mathrm{R} \$ 17$ milhões*

financiamento: Secretaria Municipal de Educação

\section{Projeto}

Edifício com programa padrão, acrescido de quadra poliesportiva e espaço coberto de $800 \mathrm{~m}^{2}$ para exposições, fruto da adaptacão dos edifícios à alta declividade do terrreno.

\section{Histórico}

0 terreno escolhido, por ser cortado por um córrego, era sempre descartado para qualquer tipo de ocupação, o que fazia dele uma área insegura e bastante degradada. A implantação do CEU, além de garantir uso ao terreno, consequentemente, torná-Io-ia mais seguro. A região, que respeitava o toque de recolher, passou a ser beneficiada com atividades noturna, imprimindo-se um novo ritmo ao bairro.

\section{Partido arquitetônico}

Situado na encosta da Avenida Sapopemba, num dos pontos mais altos da cidade, onde está situada, inclusive, a torre de comunicação entre o Aeroporto Internacional de Cumbica e o Aeroporto de Congonhas, este CEU representa um significativo marco na paisagem. Buscou-se, ao máximo, integrar o equipamento às vias do entorno, amenizando as situações de insegurança urbana. 0 teatro, por exemplo, dá para uma rua sem saída, que pode ser utilizada para apresentações de teatro de rua. A declividade do terreno permitiu que fosse construído ainda, no bloco do teatro, que está anexado ao bloco didático, um espaço coberto para exposições de $800 \mathrm{~m}^{2}$. 0 conjunto agrega ainda uma quadra nnliesnnrtiva

\section{Proveniência da demanda}

Carência de equipamentos públicos na região; altos índices de violência.

\section{Propriedade da terra}

Terreno público.
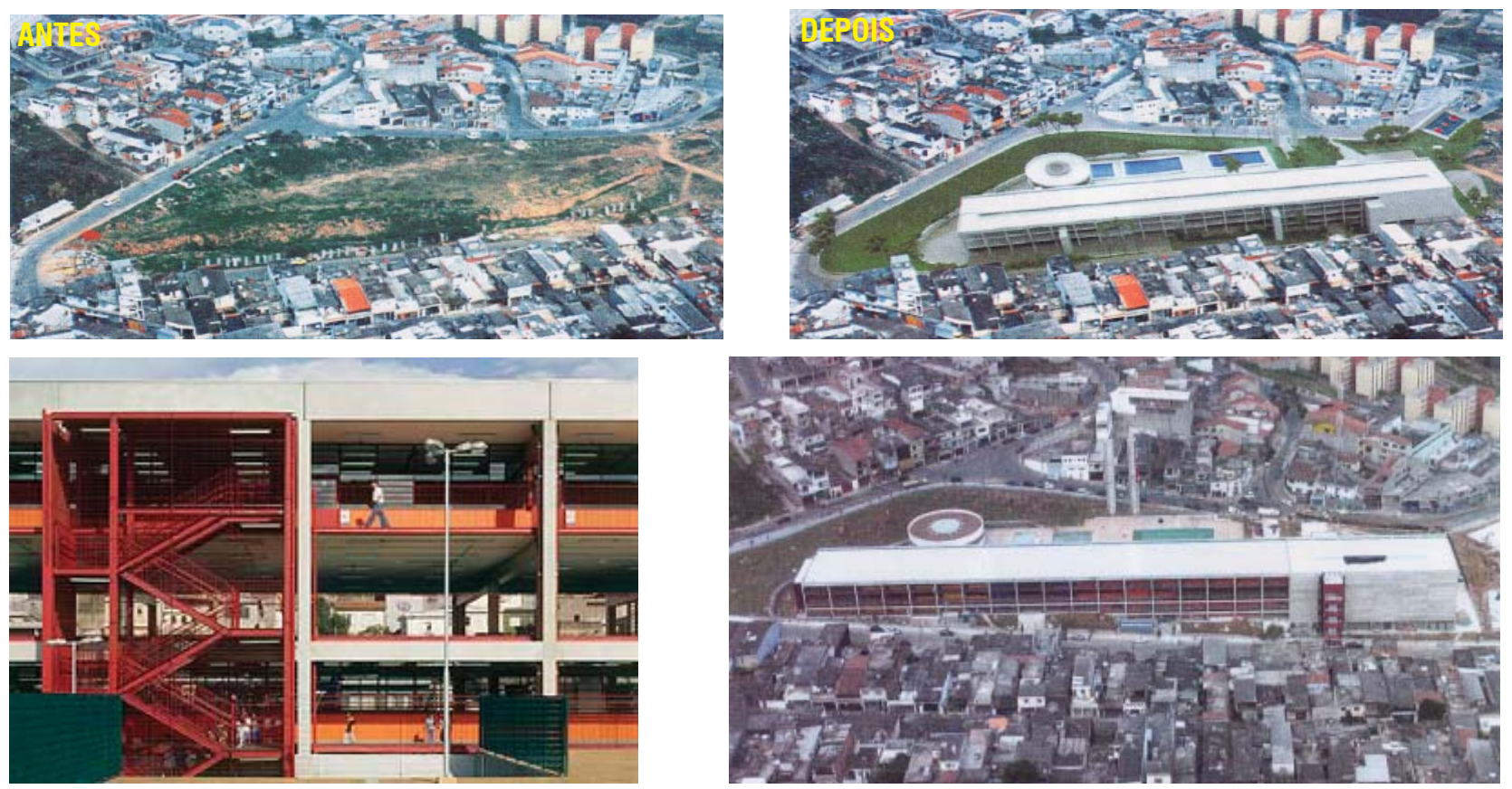


\title{
PRODUÇÃO DE EQUIPAMENTOS EDUCACIONAIS
}

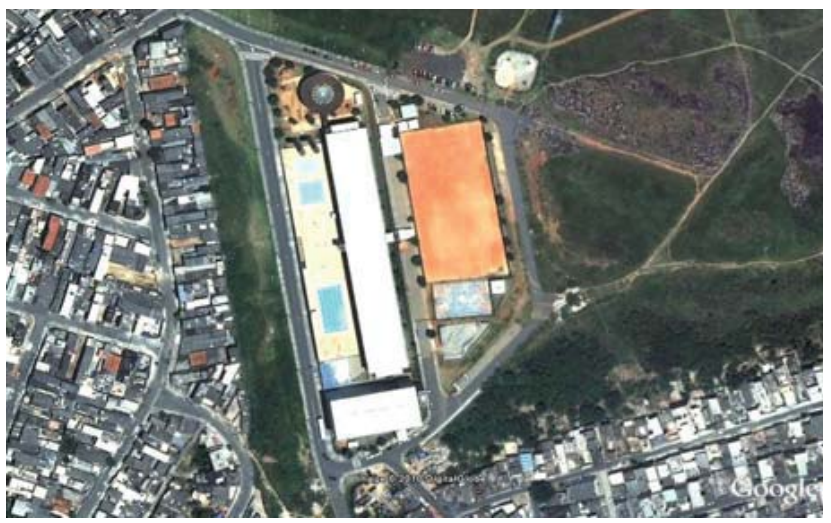

\author{
CEU SÃO MATEUS \\ R. Curumatim, 201 - São Mateus
}

área do terreno: $20.000 \mathrm{~m}^{2}$

área construída: $12.196 \mathrm{~m}^{2}$

construtora: Construtora Varca Scatena

data inauguração: 09/09/2003

custo: $\mathrm{R} \$ 17$ milhões*

financiamento: Secretaria Municipal de Educação

\section{Projeto}

Edifício com programa padrão, acrescido de campo de futebol, dada a demanda da região.

\section{Histórico}

0 edifício foi construído em uma região próxima a uma ocupação irregular bastante desordenada, onde a implantação de equipamentos sociais havia sido prejudicada e mesmo inviabilizada pela escassez de espaço. Construídas na gestão anterior, uma EMEI, uma EMEF e uma creche compartilhavam um pequeno terreno, dispondo apenas de uma única quadra como área externa das três escolas.

\section{Partido arquitetônico}

Inicialmente concebido para ser construído em uma área desapropriada de 11 mil metros quadrados, este CEU acabou exigindo a desapropriação de um segundo terreno anexo, para abrigar o campo de futebol, conforme demanda da população local. A comunidade, desde 0 início, solicitava a presença de um campo, dada a consolidade cultura esportiva da região.

\section{Proveniência da demanda}

Déficit de vagas significativo, com listas de esperas e transporte de 1.500 alunos para outros bairros.

\section{Propriedade da terra}

Desapropriação de dois terrenos: um para o CEU e posteriormente outro para o campo de futebol.
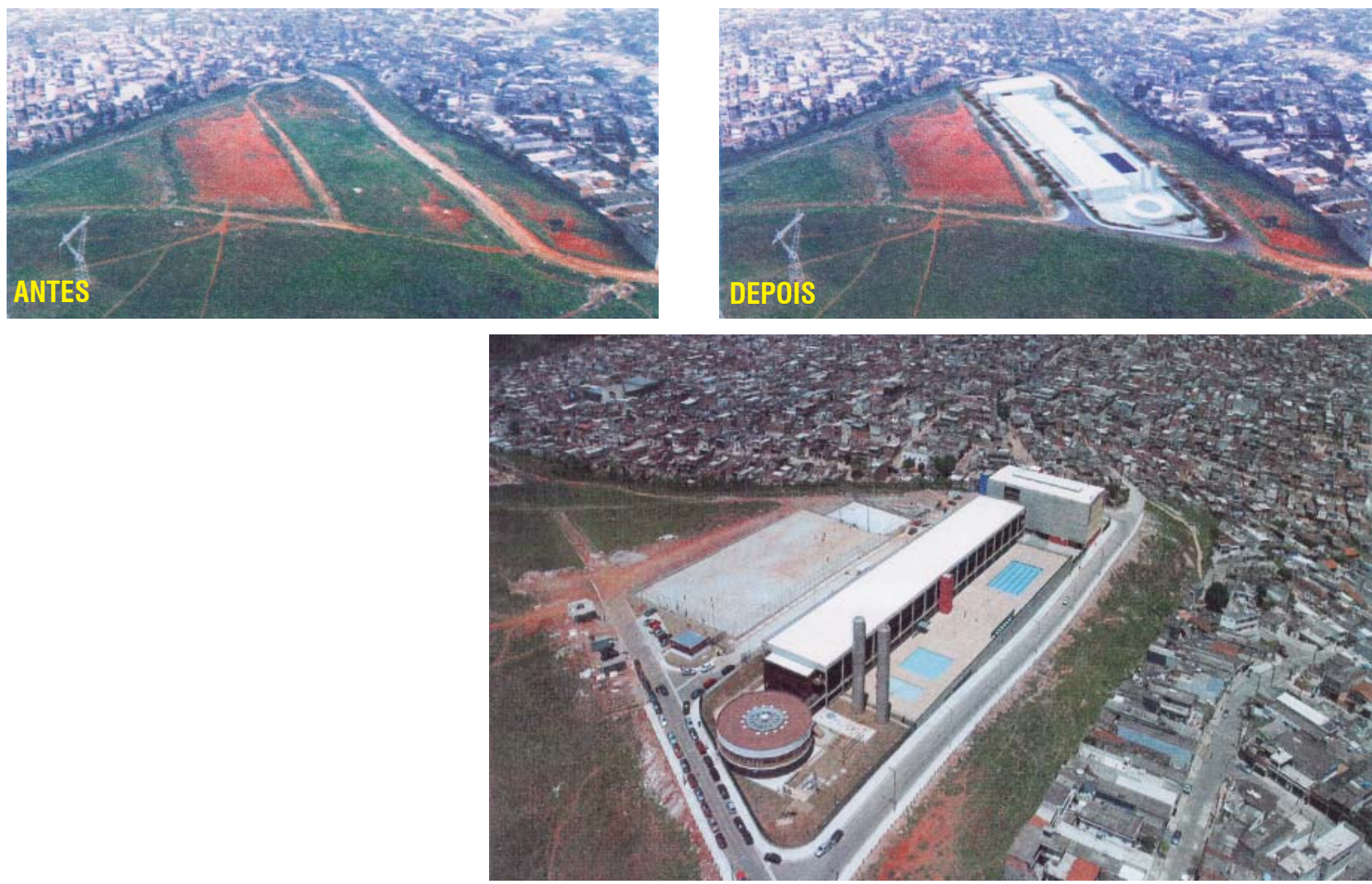


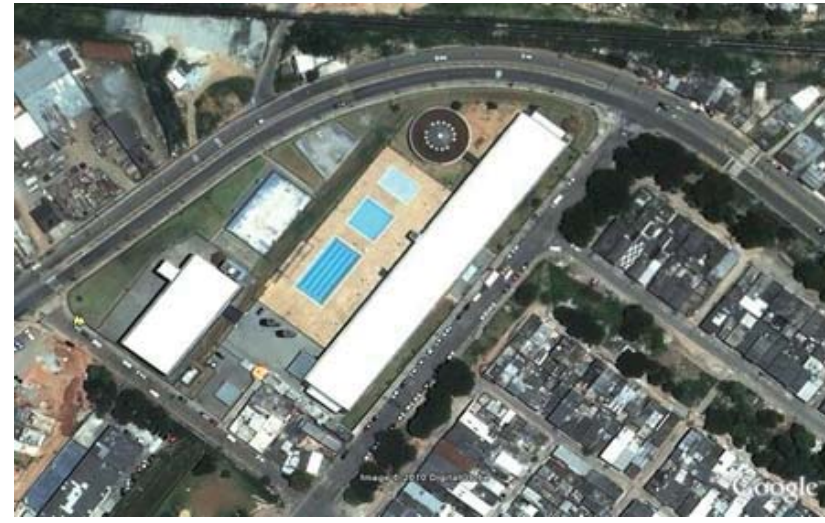

\section{CEU SÃO RAFAEL}

R. Cinira Polônia, 100 - São Rafael

área do terreno: $16.500 \mathrm{~m}^{2}$ área construída: $12.196 \mathrm{~m}^{2}$

construtora: Construtora Varca Scatena

data inauguração: 08/03/2004

custo: $\mathrm{R} \$ 17$ milhões*

financiamento: Secretaria Municipal de Educação

\section{Projeto}

Edifício com programa padrão.

\section{Histórico}

Este CEU teve sua construção atrasada em função de uma constatação de contaminação do solo do terreno a ser utilizado. Com isso, foi necessário se buscar uma nova área. Depois de muita negociação, chegou-se a um terreno público na mesma região, contudo ocupado por uma igreja, um centro de atendimento a menores em Liberdade Assistida e ainda 18 casas contruídas irregularmente, que encontravam-se dentro de uma cessão de uso da COHAB. A solução foi a reconstrução da igreja e do centro de atendimento em outras áreas e a remoção de 4 das 18 casas, cujas famílias foram indenizadas e transferiram-se para outros imóveis nas redondezas.

\section{Partido arquitetônico}

0 equipamento foi construído num terreno triangular, buscando-se, ao máximo, a manutenção das residências existentes. 0 bloco do teatro e o prédio redondo foram construídos de frente para a Avenida Sapopemba, configurando uma fácil referência na paisagem.

\section{Proveniência da demanda}

Demanda local.

\section{Propriedade da terra}

Terreno particular desapropriado.

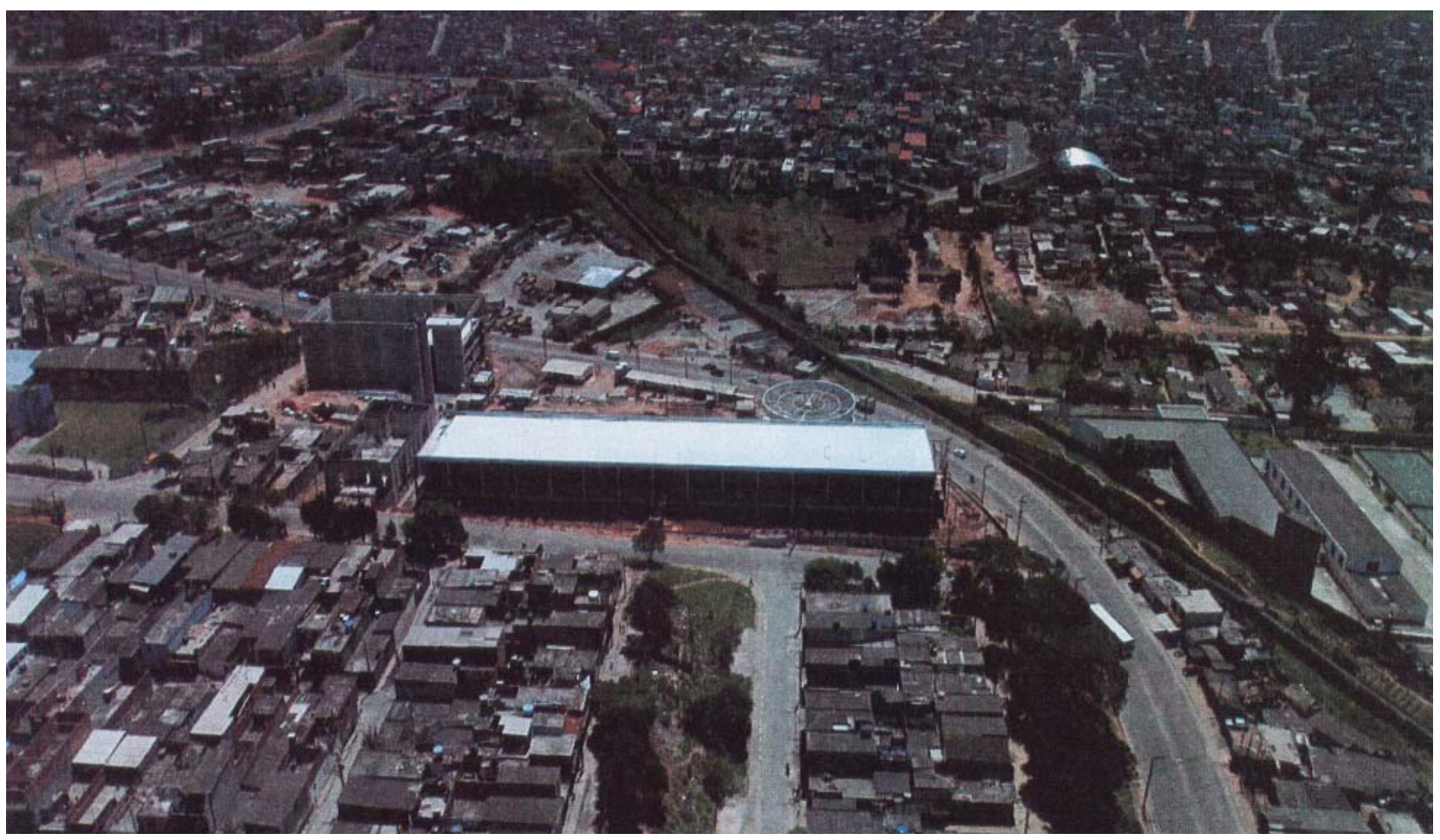




\section{PRODUÇÃO DE EQUIPAMENTOS EDUCACIONAIS}

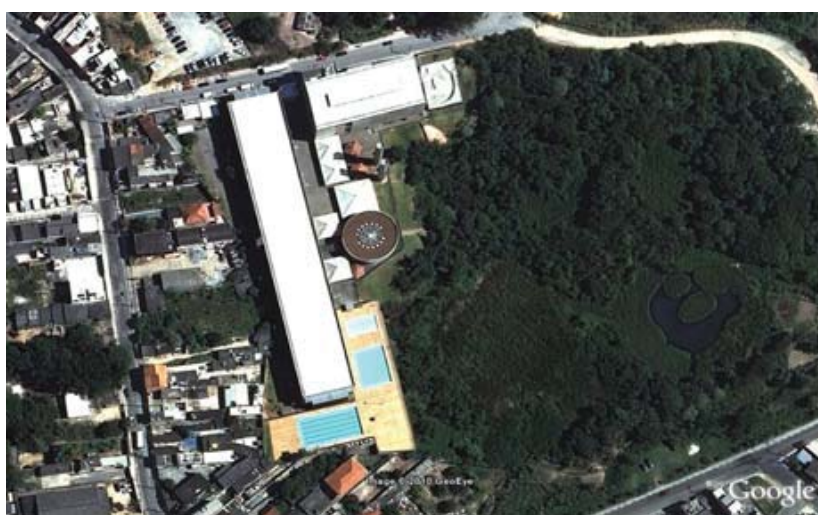

\section{CEU TRÊS LAGOS}

Estrada do Barro Branco, s/n. - Capela do Socorro

área do terreno: $47.990 \mathrm{~m}^{2}$

área construída: $13.401 \mathrm{~m}^{2}$

construtora: Carioca Christiani Nielsen Engenharia

data inauguração: 01/10/2003

custo: $R \$ 17$ milhões*

financiamento: Secretaria Municipal de Educação

\section{Projeto}

Edifício com programa padrão, acrescido de um bosque anexo e, como o próprio nome diz, três lagos naturais.

\section{Histórico}

Este foi um dos últimos CEUs da primeira leva a ficar pronto, em função de uma extensa conversa com a comunidade para acertar o programa do edifício. Situado num terreno com 3 lagos naturais, este CEU deveria, inicialmente, dispor de piscinas situadas junto aos lagos. Entretanto, pelo fato dos lagos receberrem todo 0 esgoto do bairro, o solo estava contaminado, não podendo abrigar as piscina. A decisão em suprimir estas do programa não foi aceita pela população, que se manteve firme até que fosse encontrada uma solução arquitetônica para sua implantacão.

\section{Partido arquitetônico}

Situado em terreno próximo à Represa Billings, este CEU foi encarado como uma equipamento um pouco diferenciado, mais atrelado à questão ambiental. Com área de quase 50.000 metros quadrados, a gleba conta com 3 lagos naturais e um bosque anexo. Estas condições naturais levaram à configuração de um parque associado ao $\mathrm{CEU}$, que também funciona como instrumento pedagógico. Além disso, no porão do teatro foi construída uma estação de tratamento de esgoto, que trata todo 0 esgoto gerado no CEU, assumindo importante caráter educacional. Os lagos, atualmente poluídos, vem sendo tratados, visando sua futura desinfecção. Do ponto de vista arquitetônico, as piscinas tiveram que ser repensadas, dada a contaminacão do terreno. sendo construídas acima do nível do solo. suspensas sobre pilares.

\section{Proveniência da demanda}

Demanda local.

\section{Propriedade da terra}

Terreno particular desapropriado.
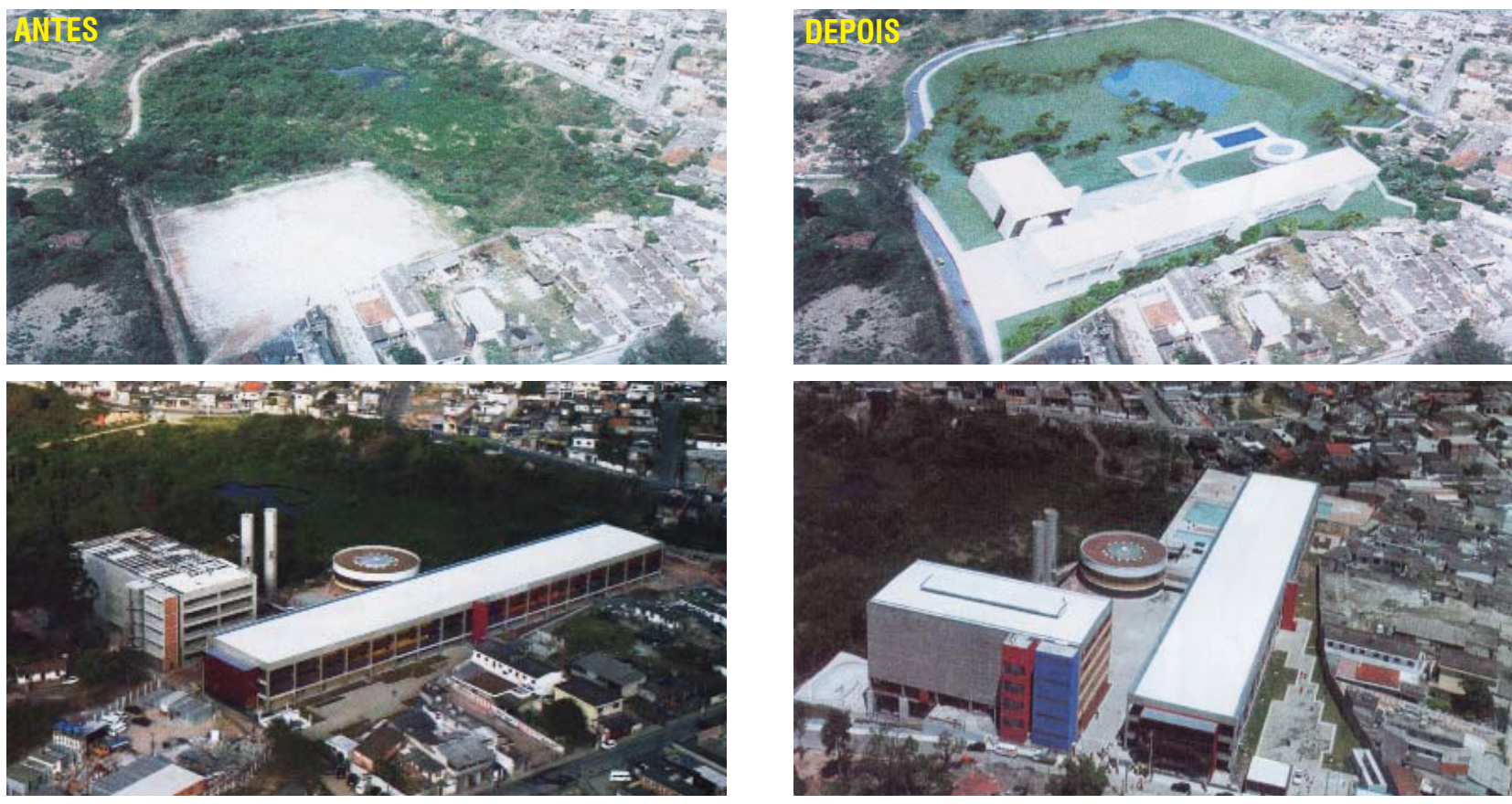


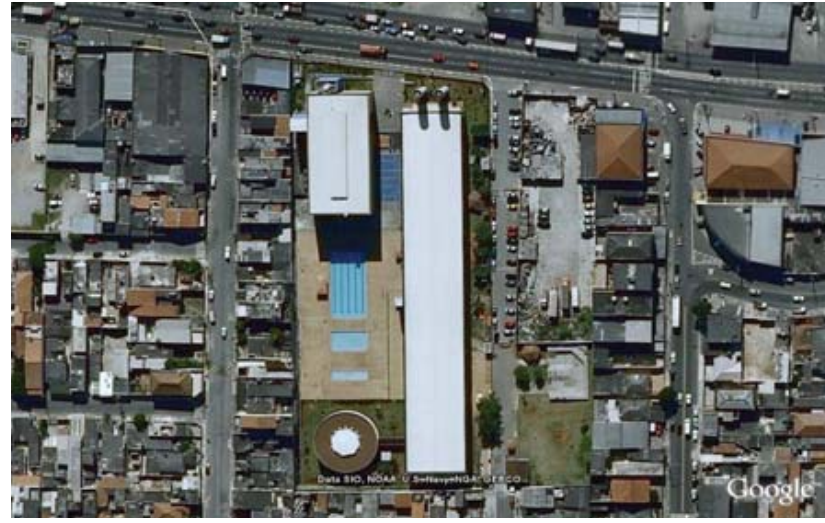

\section{CEU VILA CURUÇÁ}

Av. Marechal Tito, 3.450 - Itaim Paulista

área do terreno: $10.600 \mathrm{~m}^{2}$

área construída: $13.121 \mathrm{~m}^{2}$

construtora: Construbase Engenharia.

data inauguração: $31 / 08 / 2003$

custo: $\mathrm{R} \$ 17$ milhões*

financiamento: Secretaria Municipal de Educação

\section{Projeto}

Edifício com programa padrão, exceptuando-se a pista de skate.

\section{Histórico}

Situado numa das principais avenidas da Zona Leste, a Marechal Tito, este CEU, diferente da maioria, está realmente incrustado na malha urbana consolidada, dividindo quadra com um casario antigo e conversando com um entorno bastante denso.

\section{Partido arquitetônico}

0 edifício foi implantado transversalmente à avenida, com as torres de água formando os pórticos de entrada, 0 que facilita sua identificação para quem cruza a via de alta velocidade. 0 teatro e 0 terraço da padaria comunitária estão também voltados para esta face, de modo a convidar a comunidade a entrar. As piscinas e o solário acontecem no meio da quadra, circundados pelo bloco didático, o teatro, o prédio redondo e o casario existente, configurando uma espécie de pátio central, ou ainda, uma "piazza" italiana, cujos limites dão uma sensação de acolhimento ao espaço de convivência comunitária. Desse modo, preserva-se ainda a vista das casas do entorno desobstruídas, voltando-as para este balneário interno.

\section{Proveniência da demanda}

Área bastante densa e de fácil acesso, às margens da Av. Marechal Tito, uma das principais avenidas da Zona Leste.

\section{Propriedade da terra}

Terreno particular desapropriado.
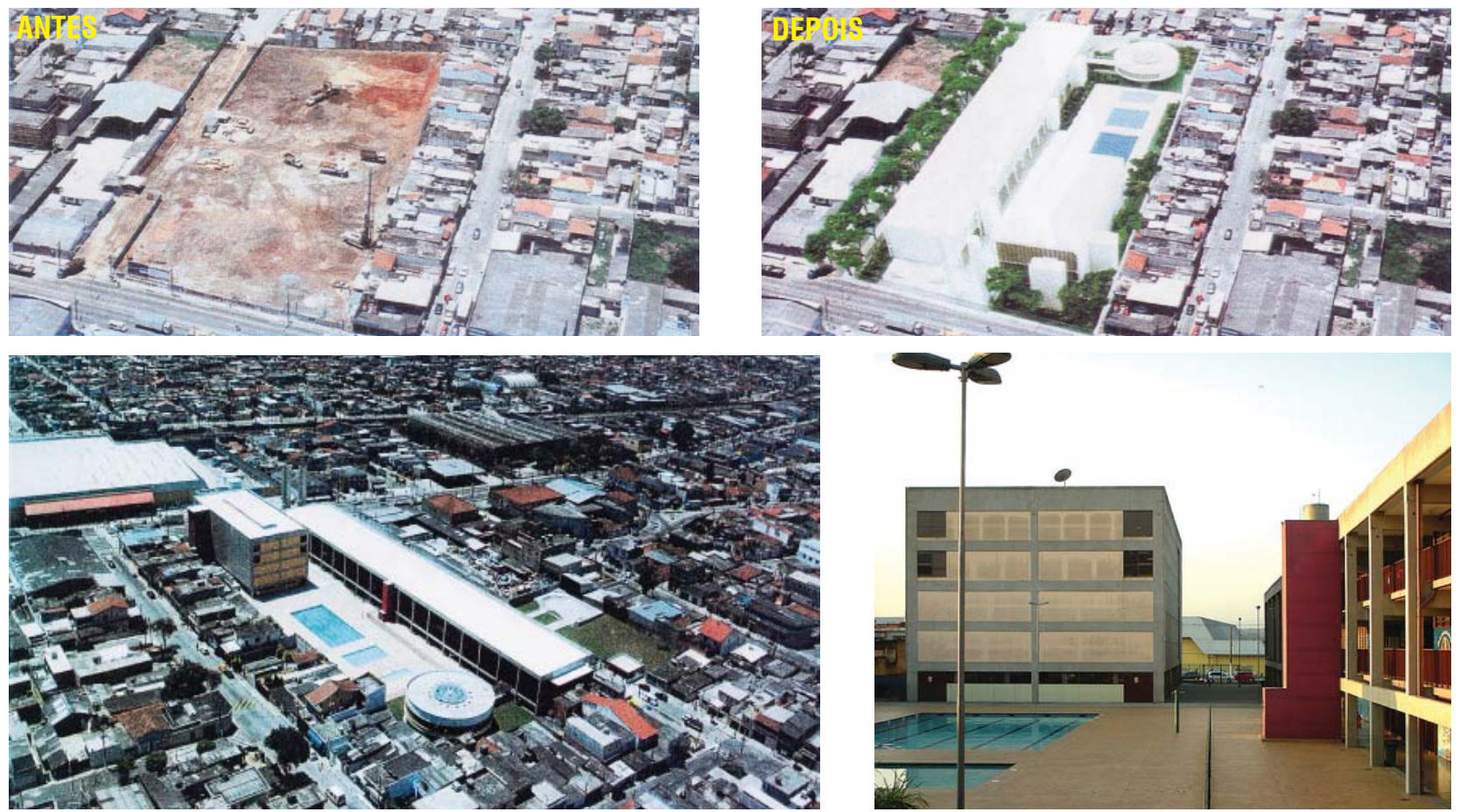


\section{Produção do Governo Municipal - CEUS}

2a GESTÃo | 2005- 2009 
OS MEANDROS DA PRODUÇ̃̃o PÚbLICA NA CONSTRUÇ̃̃o DA PAISAGEM PERIFÉrICA PAULISTANA: 0 CASO DOS EQUIPAMENTOS EDUCACIONAIS

[256] 


\section{PRODUÇÃO DE EQUIPAMENTOS EDUCACIONAIS}

TIPOLOGIA PADRÃO CEUS 2a GESTÃO - BLOCO DIDÁTICO | sem escala

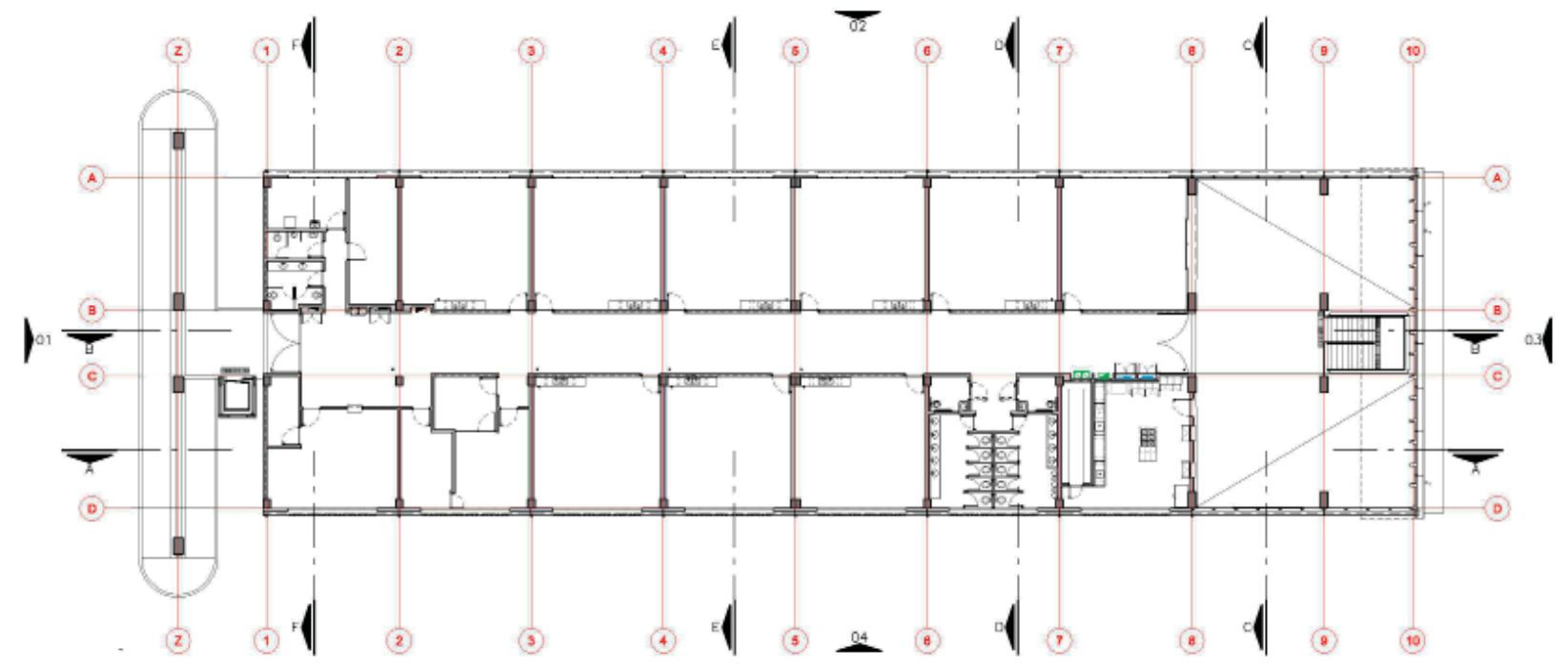

PLANTA SUPERIOR

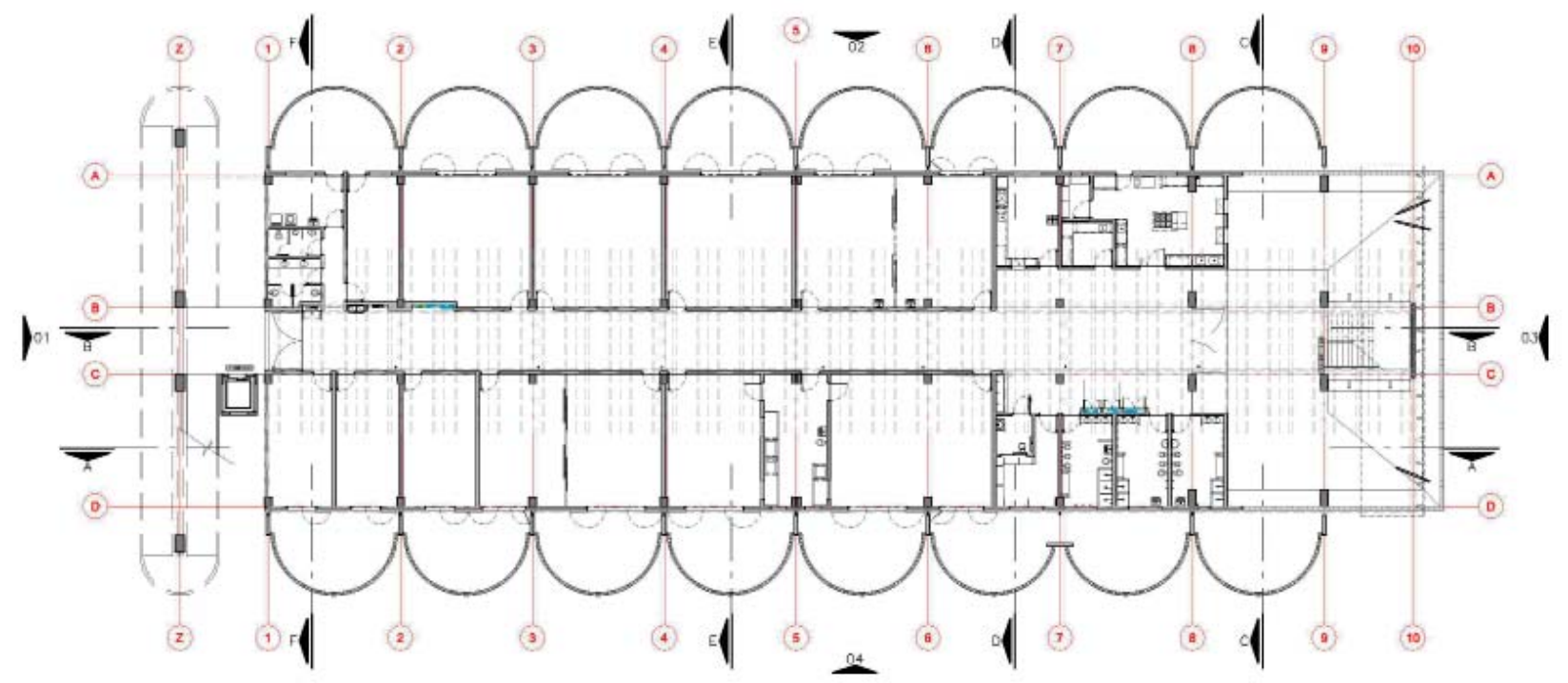

PLANTA TÉRREO
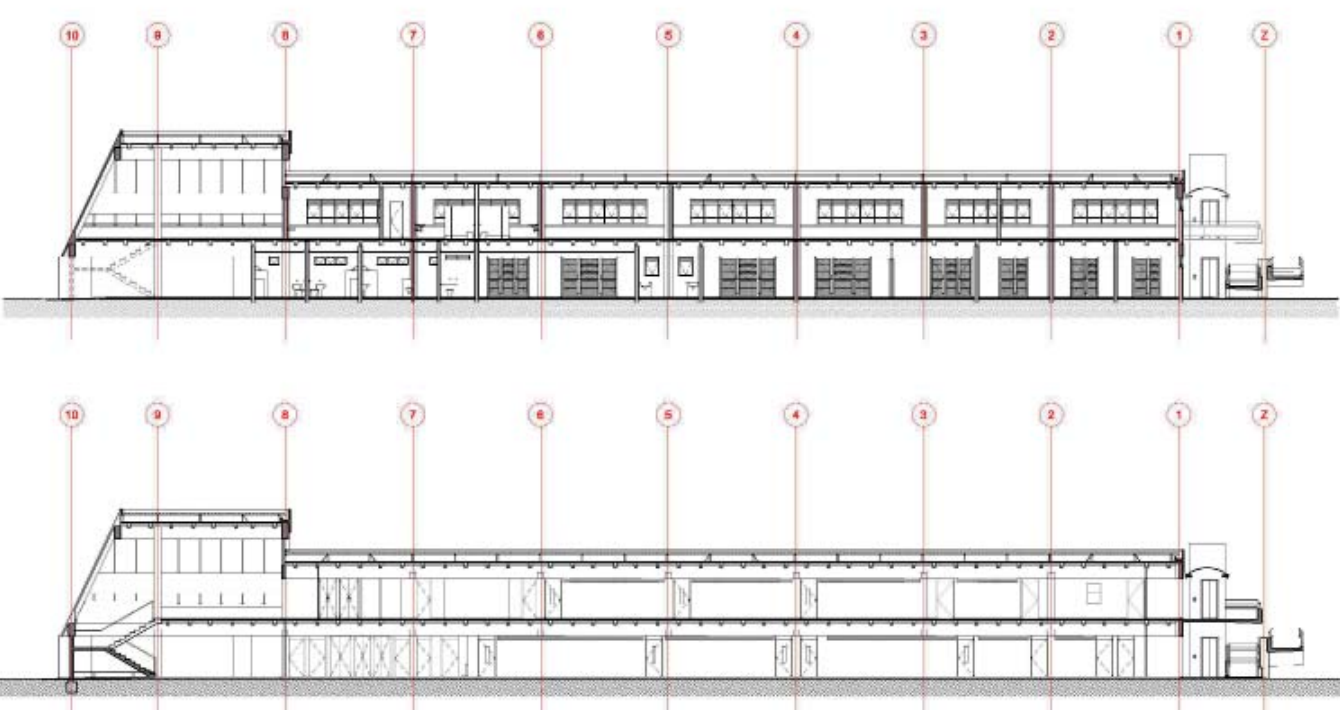


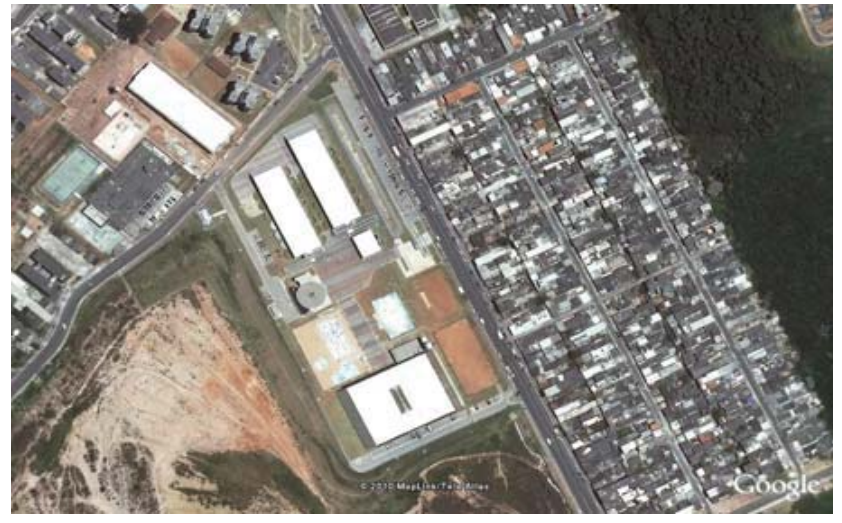

CEU ÁGUA AZUL

Av. dos Metalúrgicos, 1300 - COHAB Cid. Tiradentes

área do terreno: $35.000 \mathrm{~m}^{2}$

área construída: $12.000 \mathrm{~m}^{2}$

construtora: -

data inauguração: 20/10/2007

custo: $\mathrm{R} \$ 27,3$ milhões

financiamento: Secretaria Municipal de Educação

\section{Projeto}

Programa padrão com teatro com 400 lugares, acrescido de um mini-campo de futebol (com dimensões de $25 \times 50$ metros), uma quadra de grama específica para voleibol e um telecentro para 20 computadores. Atende 2600 alunos.

\section{Proveniência da demanda}

Área de forte adensamento recente.

\section{Propriedade da terra}

Terreno público.
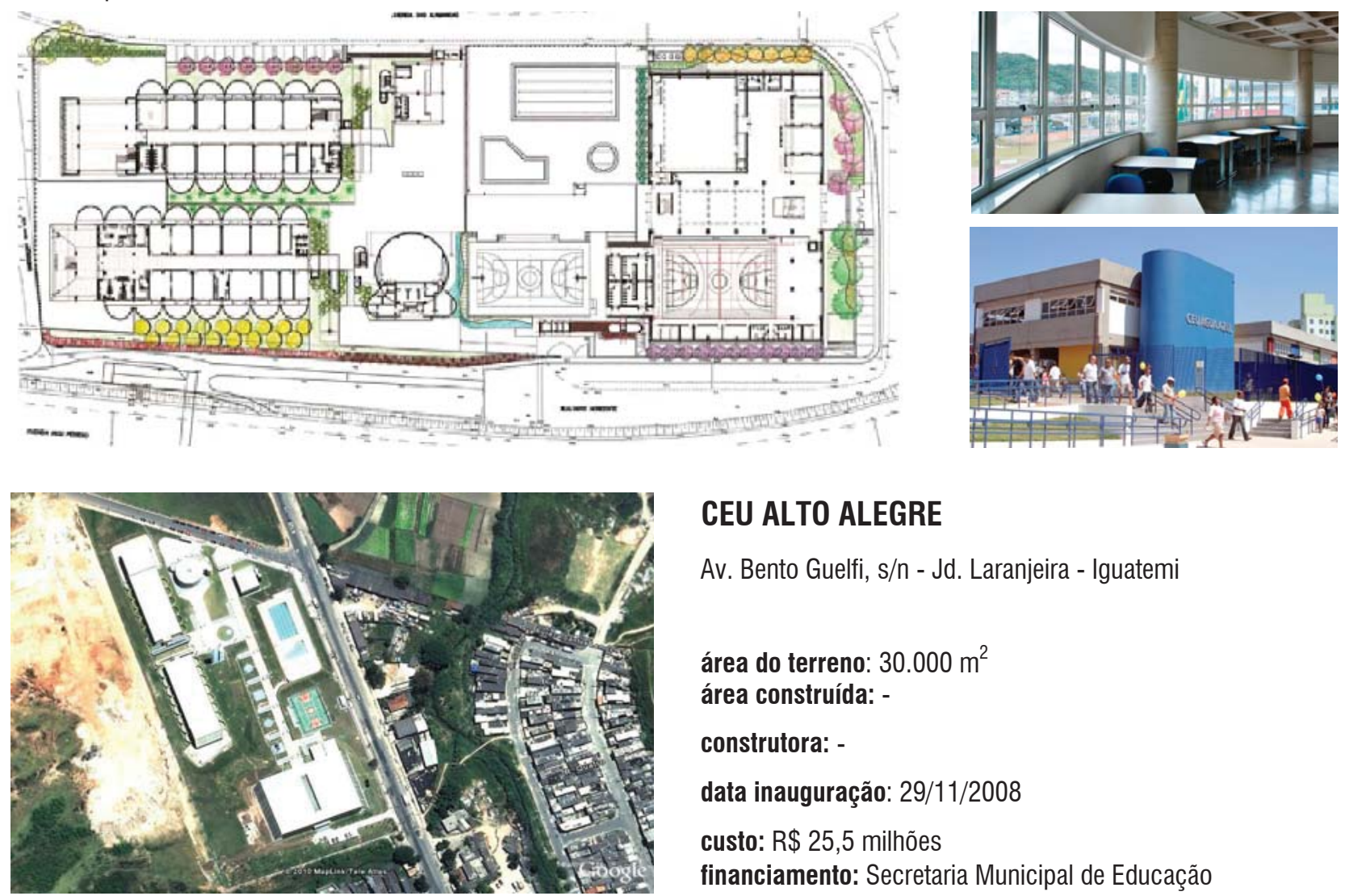

\section{CEU ALTO ALEGRE}

Av. Bento Guelfi, $s / n$ - Jd. Laranjeira - Iguatemi

área do terreno: $30.000 \mathrm{~m}^{2}$

área construída: -

construtora: -

data inauguração: 29/11/2008

custo: $R \$ 25,5$ milhões

financiamento: Secretaria Municipal de Educação

\section{Projeto}

Programa padrão com teatro com 184 lugares e um telecentro para 20 computadores. Atende 2700 alunos.

\section{Proveniência da demanda}

Necessidade de absorver os alunos que antes estudavam na EMEF Prefeito Wladmir de Toledo Piza, eliminando $03 .{ }^{\circ}$ turno na unidade.

\section{Propriedade da terra}

Terreno público. 


\section{PRODUÇÃO DE EQUIPAMENTOS EDUCACIONAIS}

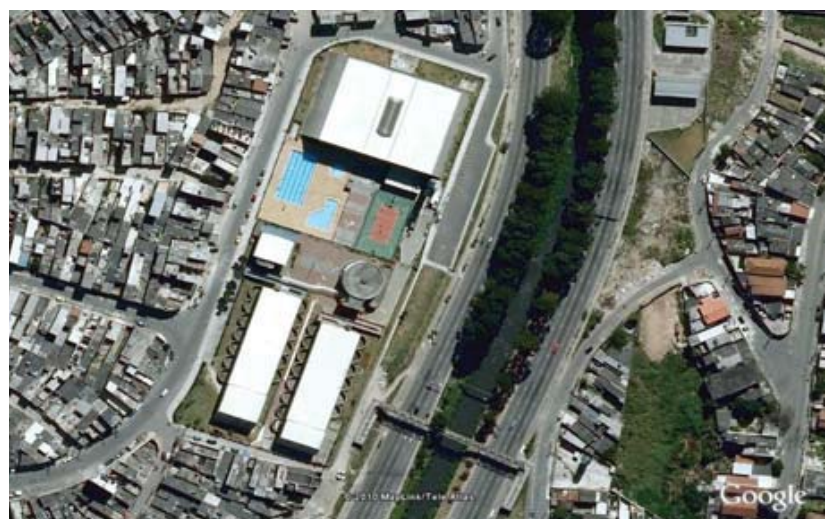

CEU AZUL DA COR DO MAR

Rua Ernesto de Souza Cruz, 2171 - Cidade A. E. de

Carvalho

área do terreno: $69.466,12 \mathrm{~m}^{2}$

área construída: $12.548 \mathrm{~m}^{2}$

construtora: -

data inauguração: 27/10/2007

custo: $\mathrm{R} \$ 26,4$ milhões

financiamento: Secretaria Municipal de Educação

\section{Projeto}

Programa padrão com teatro com 402 lugares, mais telecentro com 20 computadores instalados. Atende 2600 alunos.

\section{Histórico}

No início das obras de construção do CEU Azul da Cor do Mar, a Escola Municipal de Educação Fundamental (EMEF) Jardim Vila Nova (escola de lata) estava em funcionamento e as crianças foram transferidas para o galpão de um supermercado. 0 Departamento de Edificações (EDIF) priorizou a construção da EMEF neste CEU, e, em setembro de 2006, os alunos retomaram as aulas na nova unidade.

\section{Proveniência da demanda}

Substituição de duas "escolas de lata" que funcionavam no terreno e necessidade de eliminação do terceiro turno nas EMEFs Ayres Martins Torres e Professor Antônio Duarte de Almeida.

\section{Propriedade da terra}

Terreno público de $11.000 \mathrm{~m}^{2}$ mais área desapropriada.

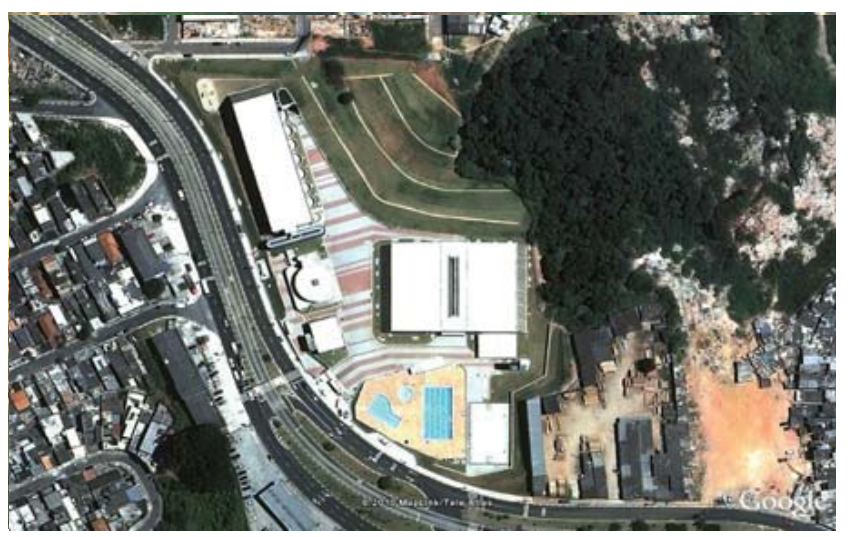

\section{CEU CAMINHO DO MAR}

Rua Engenheiro Armando de Arruda Pereira, 5.241 Jabaquara

área do terreno: $25.538,32 \mathrm{~m}^{2}$

área construída: $10.957 \mathrm{~m}^{2}$

construtora: Simioni \& Viesti

data inauguração: 12/10/2008

custo: $\mathrm{R} \$ 26,7$ milhões

financiamento: Secretaria Municipal de Educação

\section{Projeto}

Programa padrão com teatro com 184 lugares, mais telecentro com 20 computadores instalados. Atende 2069 alunos.

\section{Histórico}

No início das obras de construção do CEU Azul da Cor do Mar, a Escola Municipal de Educação Fundamental (EMEF) Jardim Vila Nova (escola de lata) estava em funcionamento e as crianças foram transferidas para o galpão de um supermercado. 0 Departamento de Edificações (EDIF) priorizou a construção da EMEF neste CEU, e, em setembro de 2006, os alunos retomaram as aulas na nova unidade.

\section{Proveniência da demanda}

Demanda por equipamentos públicos.

\section{Propriedade da terra}

Terreno particular desapropriado. 

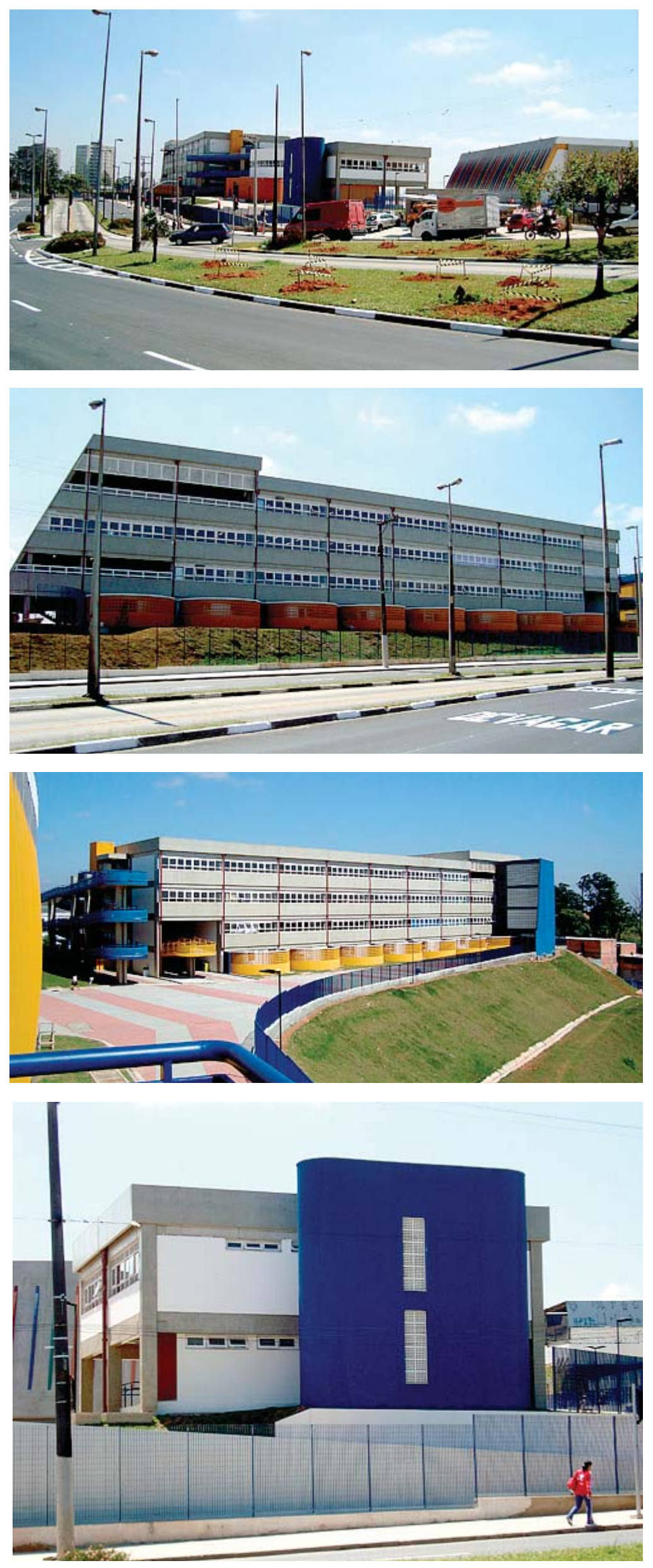

[ 260 ]
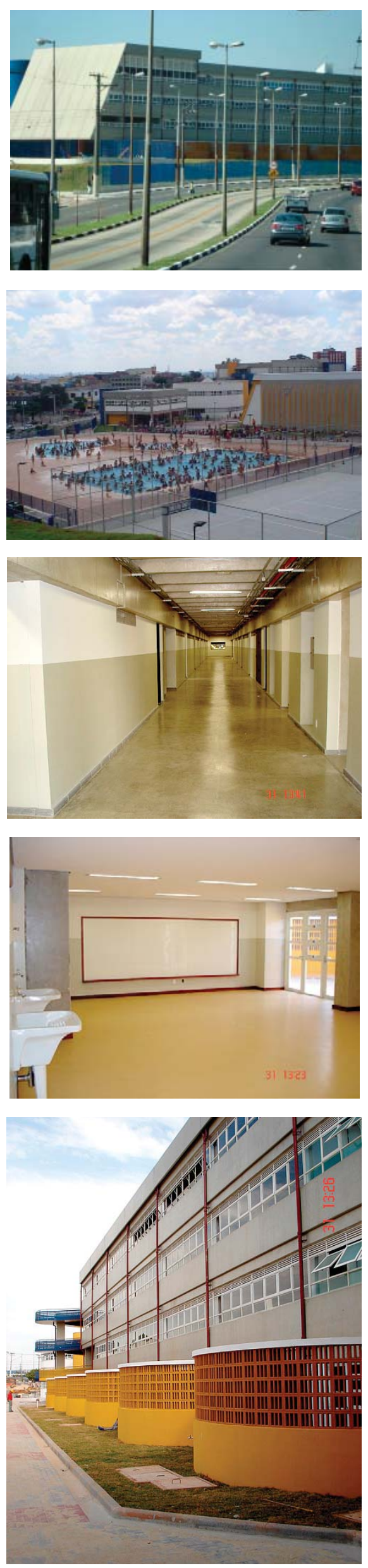


\section{PRODUÇÃO DE EQUIPAMENTOS EDUCACIONAIS}

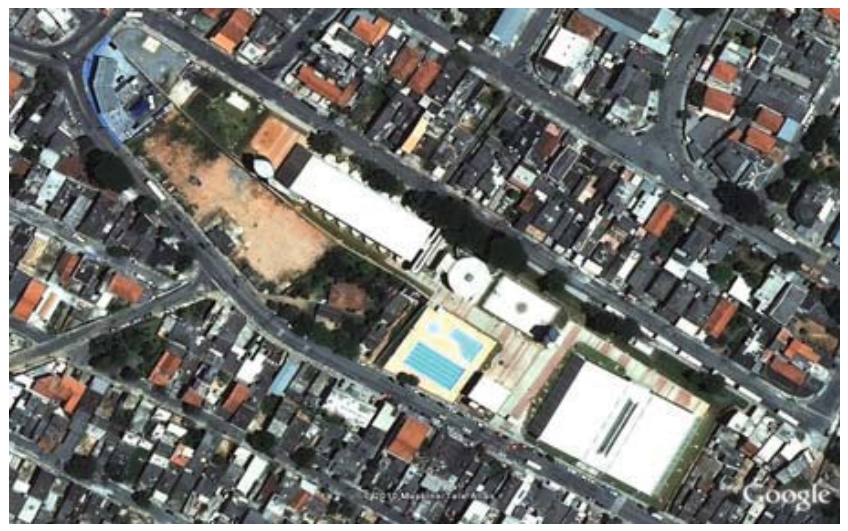

\section{CEU CANTOS DO AMANHECER}

Av. Cantos do Amanhecer, s/n $/ n^{0}$ Jardim Eledy

área do terreno: $14.595 \mathrm{~m}^{2}$

área construída: $11.205 \mathrm{~m}^{2}$

construtora: Camargo Corrêa

data inauguração: 22/06/2008

custo: $\mathrm{R} \$ 28,8$ milhões

financiamento: Secretaria Municipal de Educação

\section{Projeto}

Programa padrão com teatro com 200 lugares, mais telecentro com 20 computadores instalados. Atende 1.600 alunos.

\section{Histórico}

0 CEU Cantos do Amanhecer iniciou as aulas em fevereiro de 2008 atendendo a mais de 1.600 alunos, eliminando $03^{\circ}$ turno da EMEF Professor Levy de Azevedo Sodré.

\section{Proveniência da demanda}

Sobrecarga de demanda da EMEF Professor Levy de Azevedo Sodré.

\section{Propriedade da terra}

Terreno particular desapropriado.
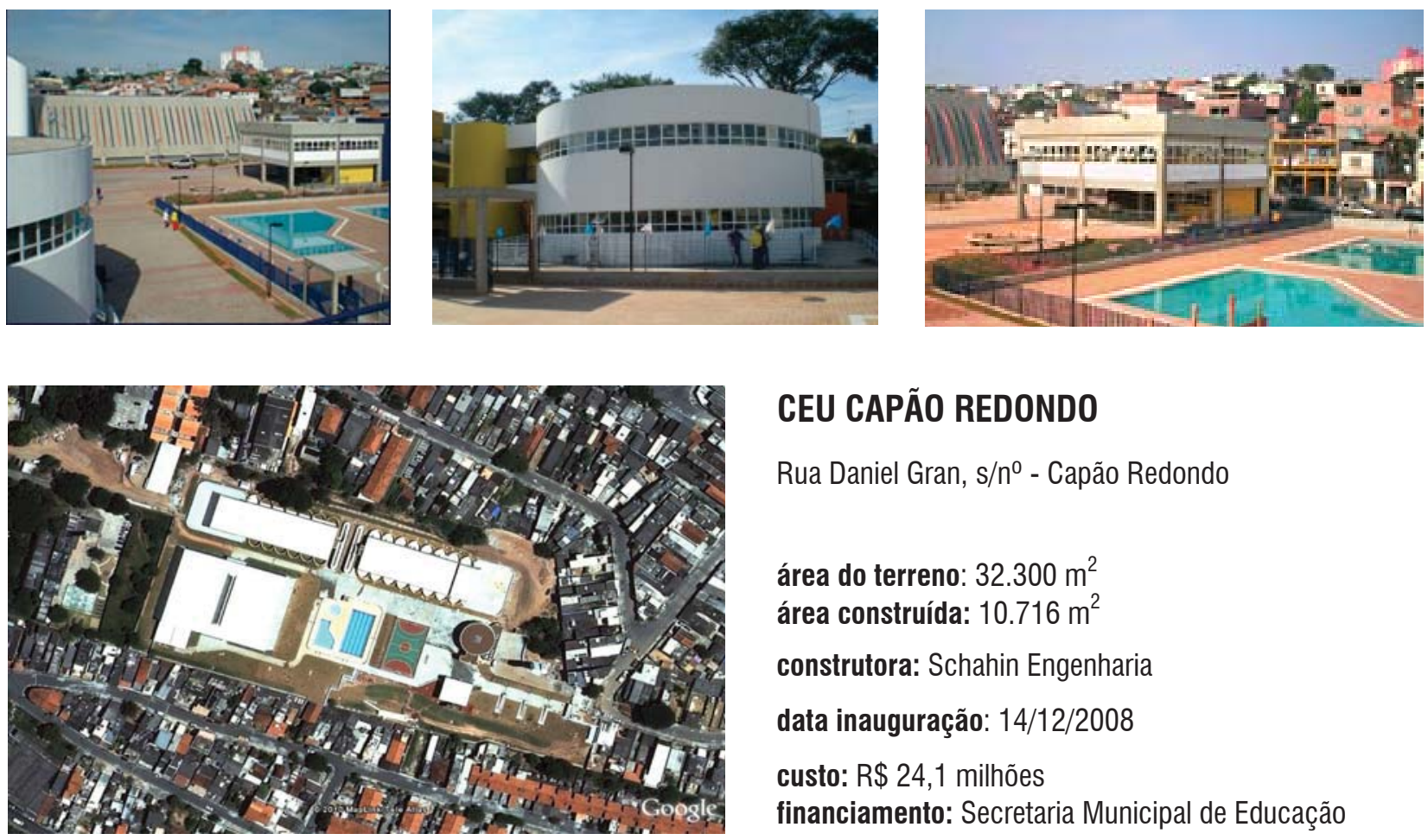

\section{CEU CAPÃO REDONDO}

Rua Daniel Gran, s/no - Capão Redondo

área do terreno: $32.300 \mathrm{~m}^{2}$ área construída: $10.716 \mathrm{~m}^{2}$

construtora: Schahin Engenharia

data inauguração: 14/12/2008

custo: $R \$ 24,1$ milhões

financiamento: Secretaria Municipal de Educação

\section{Projeto}

Programa padrão com teatro em semi-arena com 180 lugares, mais telecentro com 20 computadores instalados. Atende 2.600 alunos.

\section{Partido arquitetônico}

Possui cinco blocos: dois didáticos, um esportivo e cultural, um administrativo e um onde estão instalados o refeitório, a biblioteca e 0 telecentro.

\section{Propriedade da terra}

Terreno particular desapropriado. 

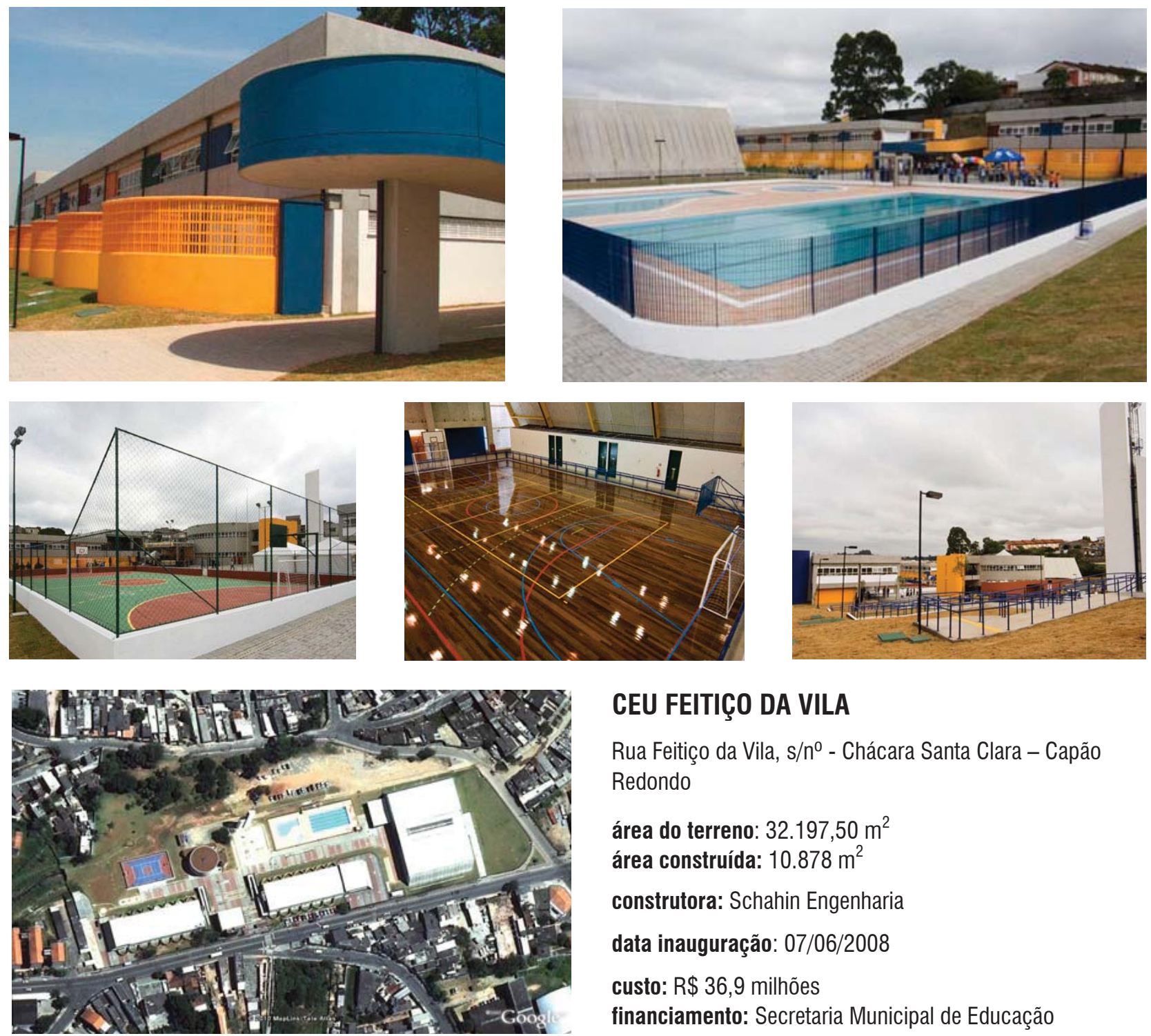

\section{CEU FEITIÇO DA VILA}

Rua Feitiço da Vila, s/nº - Chácara Santa Clara - Capão Redondo

área do terreno: $32.197,50 \mathrm{~m}^{2}$ área construída: $10.878 \mathrm{~m}^{2}$

construtora: Schahin Engenharia

data inauguração: 07/06/2008

custo: $\mathrm{R} \$ 36,9$ milhões

financiamento: Secretaria Municipal de Educação

\section{Projeto}

Além do programa padrão, este CEU terá o "Parque Feitiço da Vila", onde será executado um viveiro-escola, que deve conter salas de aula teórica e prática, banheiros, copa, depósito de ferramentas, área de cultivo de plantas para interior, mandala com plantas medicinais, horta, sementeira, área educacional ambiental interativa e área para compostagem (para preparação de adubo), dentre outras estruturas. Atende 2.100 alunos.

\section{Histórico}

Para a viabilização das obras foi necessário realizar a canalização de um córrego que passa pela área do CEU, e paralelamente a essa canalização, construir uma rede dupla de coletor de esgoto. Ao lado do terreno do CEU será implantado ainda mais um parque, o "Parque Linear Moenda Velha/Feitiço da Vila", com área de 27.759,96 m², que será interligado ao parque "Feitiço da Vila". 0 córrego existente foi contemplado pelo "Programa Córrego Limpo" da Operação Natureza, cujas ações visam incorporar o córrego à paisagem do parque linear, onde haverá áreas de playground, de piquenique e, ao redor, um passeio com áreas de descanso. Os dois parques serão construídos com o objetivo de compensar as árvores que foram removidas durante a construção do CEU e integram o programa 100 Parques para São Paulo.

\section{Partido arquitetônico}

A área total do terreno onde se encontram o CEU e o "Parque Feitiço da Vila" é de 32.197,50 m², dos quais 10.365,00 m² serão destinados para a construção do viveiro-escola.

\section{Propriedade da terra}

Terreno particular desapropriado. 


\section{PRODUÇÃO DE EQUIPAMENTOS EDUCACIONAIS}

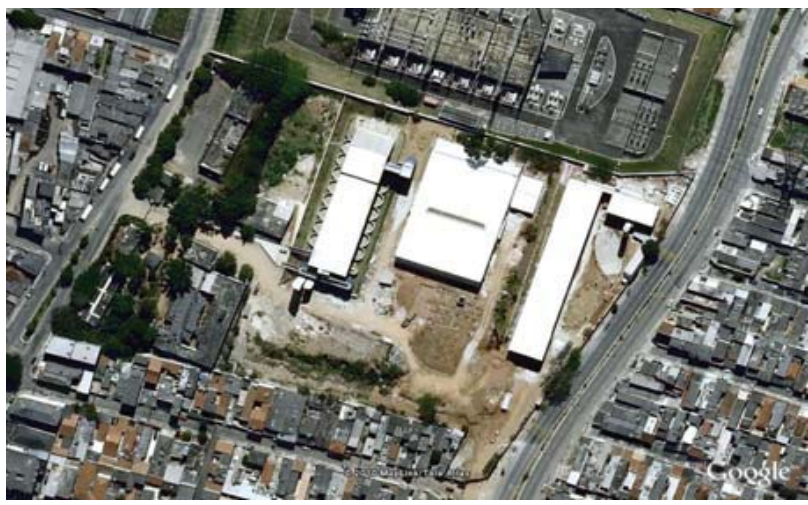

\section{CEU FORMOSA}

R. Manoel Ferreira Pires, no 560 - Pq. Santo Antonio Vila Formosa

área do terreno: $18.000 \mathrm{~m}^{2}$ área construída: $10.957 \mathrm{~m}^{2}$

construtora: -

data inauguração: em construção (início das aulas em custo: $\mathrm{R} \$ 22,6$ milhões

financiamento: Secretaria Municipal de Educação

\section{Projeto}

Programa padrão com teatro com 184 lugares, mais telecentro com 20 computadores instalados. Atende 2.600 alunos.

\section{Histórico}

As obras começaram em outubro de 2008, em função do Termo de Compensação Ambiental autorizando o projeto de utilização desta área densamente arborizada ter sido publicado no Diário Oficial de São Paulo apenas em setembro do mesmo ano.

\section{Partido arquitetônico}

Diferentemente das outras unidades, o Bloco Didático do CEU Formosa será localizado em um único prédio, com quatro pavimentos.

\section{Propriedade da terra}

Terreno particular desapropriado.

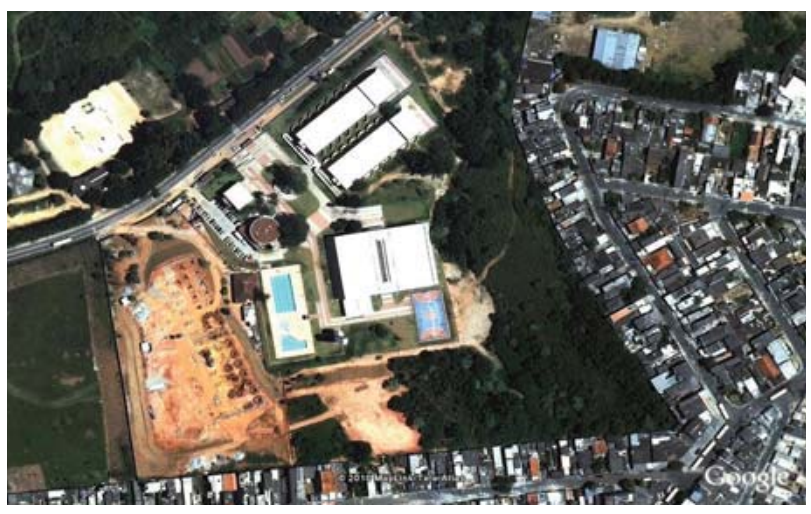

\section{CEU GUARAPIRANGA}

Estrada da Baronesa, 1.120 - Jardim Ângela

área do terreno: $76.560,21 \mathrm{~m}^{2}$

área construída: $10.716 \mathrm{~m}^{2}$

construtora: Schahin Engenharia

data inauguração: 24/05/2008

custo: $R$ \$ 24,7 milhões

financiamento: Secretaria Municipal de Educação

\section{Projeto}

Programa padrão com anfiteatro com 188 lugares, mais telecentro com 20 computadores instalados. Atende 2.600 alunos.

\section{Partido arquitetônico}

Dada a demanda da região e a área elevada do terreno, este CEU deverá dividir espaço com uma escola técnica de ensino médio, mantida por um acordo entre os governos municipal e estadual. Do terreno total disponível, o CEU ocupa $36 \mathrm{mil} \mathrm{m}^{2}$ e os demais 40.560,21 m² serão destinados à escola técnica. Desta forma, o partido arquitetônico buscou integrar os dois equipamentos, remetendo à idéia origem do programa, que eram as Praças de Equipamentos.

\section{Propriedade da terra}

Terreno particular desapropriado.
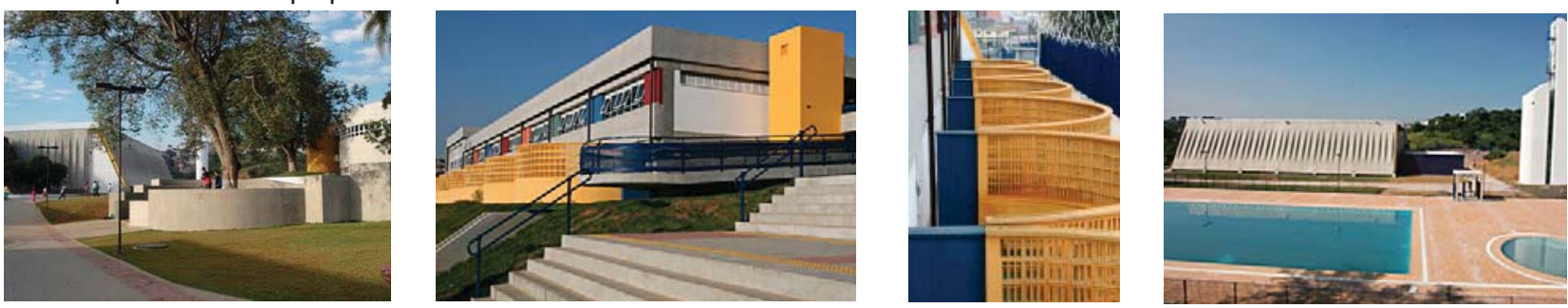


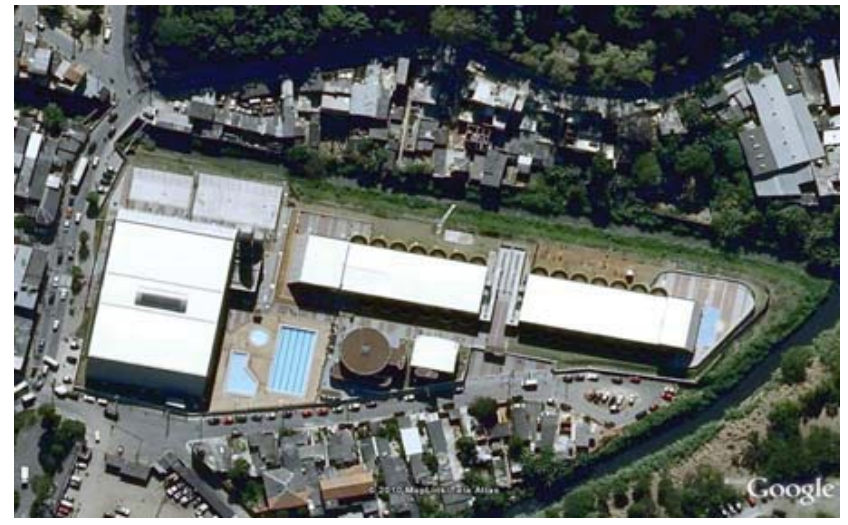

\section{CEU JAÇANÃ}

Rua Antonio Cezar Neto, 105 - Jardim Guapira

área do terreno: $12.000 \mathrm{~m}^{2}$

área construída: $14.517 \mathrm{~m}^{2}$

construtora: -

data inauguração: 06/10/2007

custo: $\mathrm{R} \$ 28,3$ milhões

financiamento: Secretaria Municipal de Educação

\section{Projeto}

Programa padrão mais quadra de vôlei e telecentro com 20 computadores instalados. Atende 2.000 alunos.

\section{Proveniência da demanda}

Sobrecarga de demanda das escolas municipais da região, que estavam funcionando em regime de 3 turnos.

\section{Propriedade da terra}

Terreno particular desapropriado.
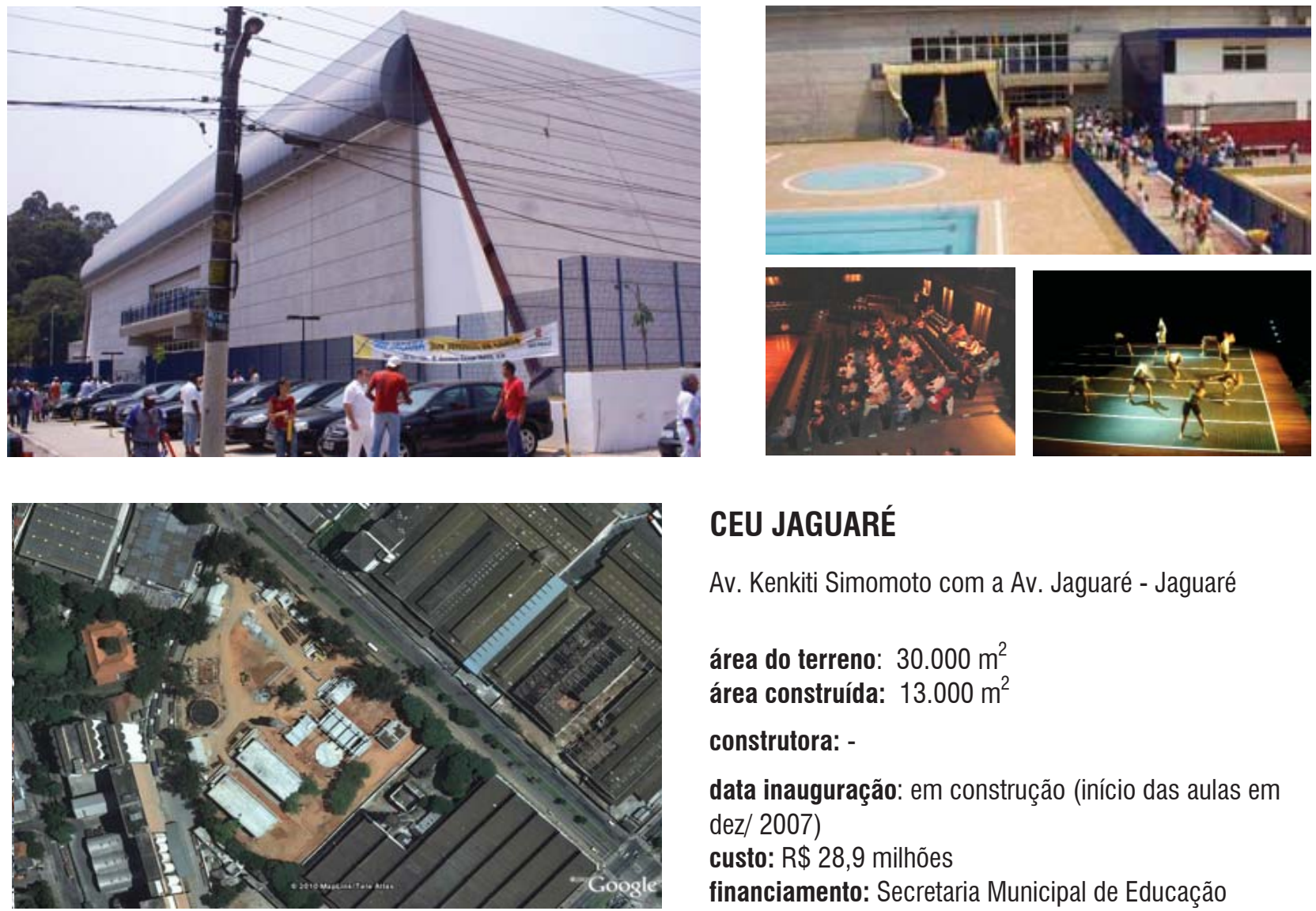

\section{CEU JAGUARÉ}

Av. Kenkiti Simomoto com a Av. Jaguaré - Jaguaré

área do terreno: $30.000 \mathrm{~m}^{2}$

área construída: $13.000 \mathrm{~m}^{2}$

construtora: -

data inauguração: em construção (início das aulas em dez/ 2007)

custo: $\mathrm{R} \$ 28,9$ milhões

financiamento: Secretaria Municipal de Educação

\section{Projeto}

Programa padrão mais telecentro com 20 computadores instalados. Atende 2.000 alunos.

\section{Proveniência da demanda}

Eliminação do terceiro turno nas escolas municipais locais.

\section{Propriedade da terra}

Terreno particular desapropriado. 


\section{PRODUÇÃO DE EQUIPAMENTOS EDUCACIONAIS}

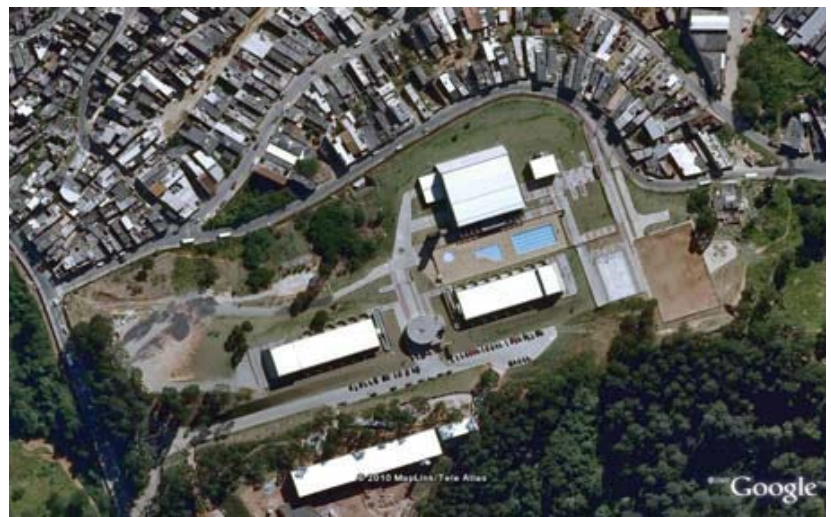

CEU JARDIM PAULISTANO

R. Aparecida do Taboado, s/no - Jd. Paulistano Brasilândia

área do terreno: $56.465,63 \mathrm{~m}^{2}$

área construída: $9.301,45 \mathrm{~m}^{2}$

construtora:

data inauguração: 15/06/2008

custo: $\mathrm{R} \$ 28,4$ milhões

financiamento: Secretaria Municipal de Educação

\section{Projeto}

Programa padrão mais campo de futebol, quadra descoberta, telecentro com 20 computadores e um planetário instalados. Atende 2.600 alunos.

\section{Proveniência da demanda}

Eliminação do terceiro turno nas escolas municipais locais.

\section{Propriedade da terra}

Terreno particular desapropriado.
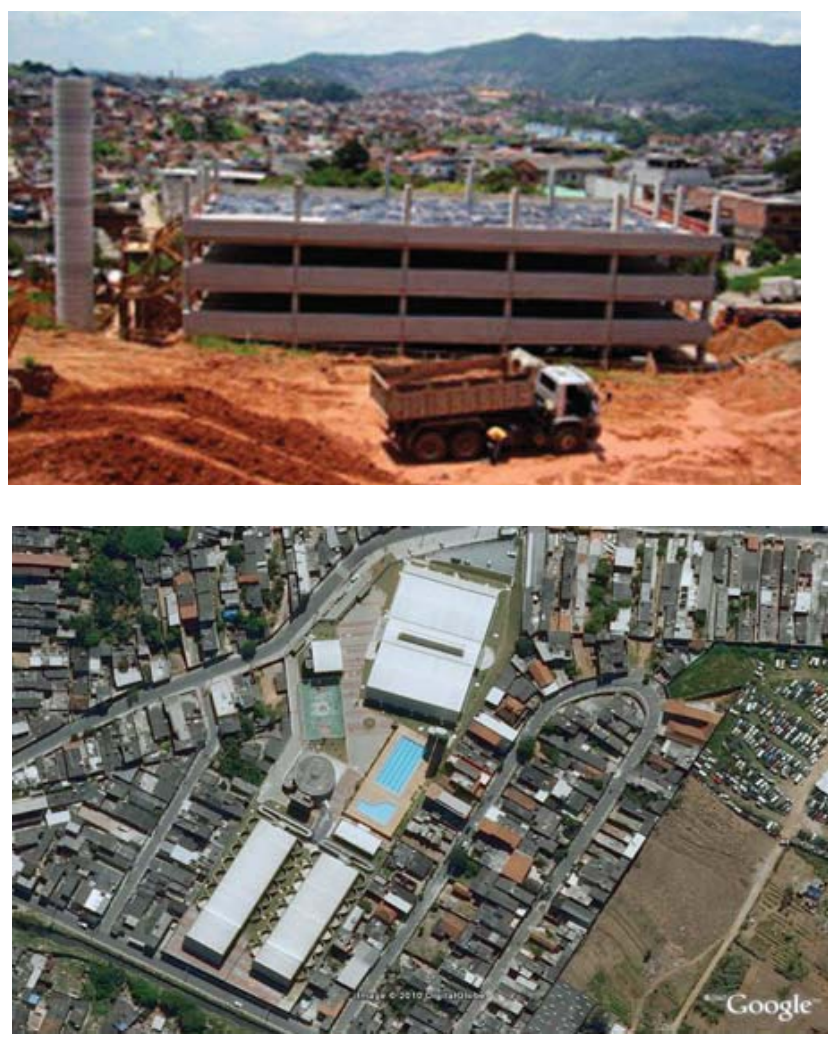

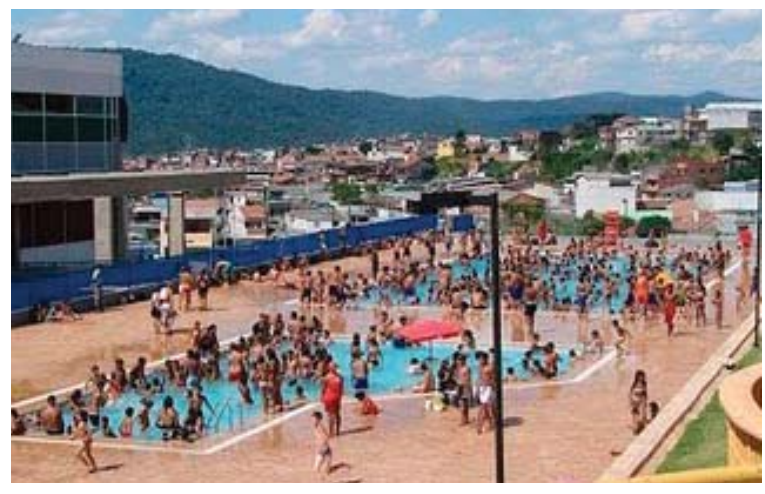

\section{CEU LAJEADO}

Rua Manuel da Mota Coutinho, 293 - Lajeado

\author{
área do terreno: $11.800 \mathrm{~m}^{2}$ \\ área construída: $11.205 \mathrm{~m}^{2}$ \\ construtora: Passarelli \\ data inauguração: 17/05/2008 \\ custo: $\mathrm{R} \$ 25,4$ milhões \\ financiamento: Secretaria Municipal de Educação
}

\section{Projeto}

Programa padrão com teatro com 400 lugares, mais telecentro com 20 computadores instalados. Atende 2.600 alunos.

\section{Partido arquitetônico}

0 CEU Lajeado possui um Bloco Didático, composto por dois prédios - um com uma CEl (Centro de Educação Infantil) e uma EMEI (Escola Municipal de Educação Infantil) e o outro com uma EMEF (Escola Municipal de Educação Fundamental) , um Bloco Esportivo e Cultural (BEC), um bloco para administração e um bloco para refeitório principal, biblioteca e telecentro.

\section{Propriedade da terra}

Programa padrão com teatro com 400 lugares, mais telecentro com 20 computadores instalados. Atende x alunos. 


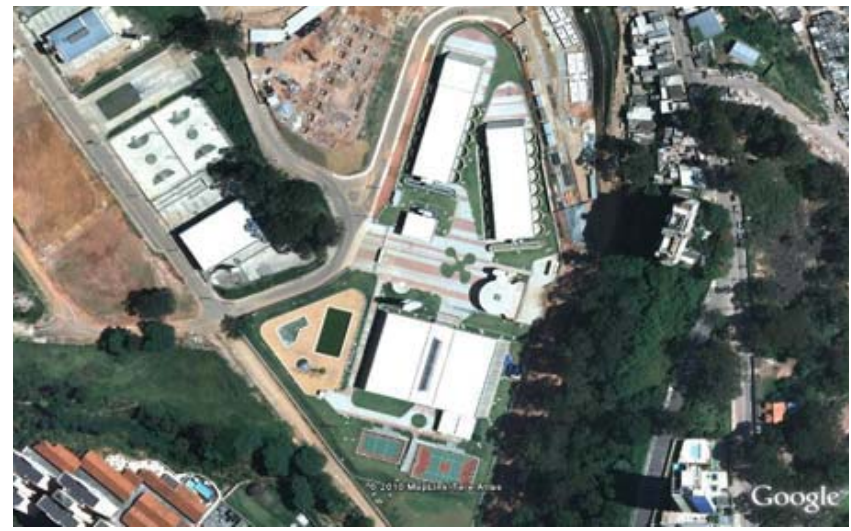

\section{CEU PARAISÓPOLIS}

Rua Doutor José Augusto Souza e Silva, s/nº - Jd.

área do terreno: $25.4000 \mathrm{~m}^{2}$

área construída: $10.154,49 \mathrm{~m}^{2}$

construtora: Kallas Engenharia e Empreendimentos

data inauguração: 13/12/2008

custo: $\mathrm{R} \$ 27$ milhões

financiamento: Secretaria Municipal de Educação

\section{Projeto}

Programa padrão mais telecentro com 20 computadores. Atende 2.800 alunos.

\section{Proveniência da demanda}

Bairro com 80 mil habitantes, onde se situa a maior favela de São Paulo.

\section{Propriedade da terra}

Terreno particular desapropriado.
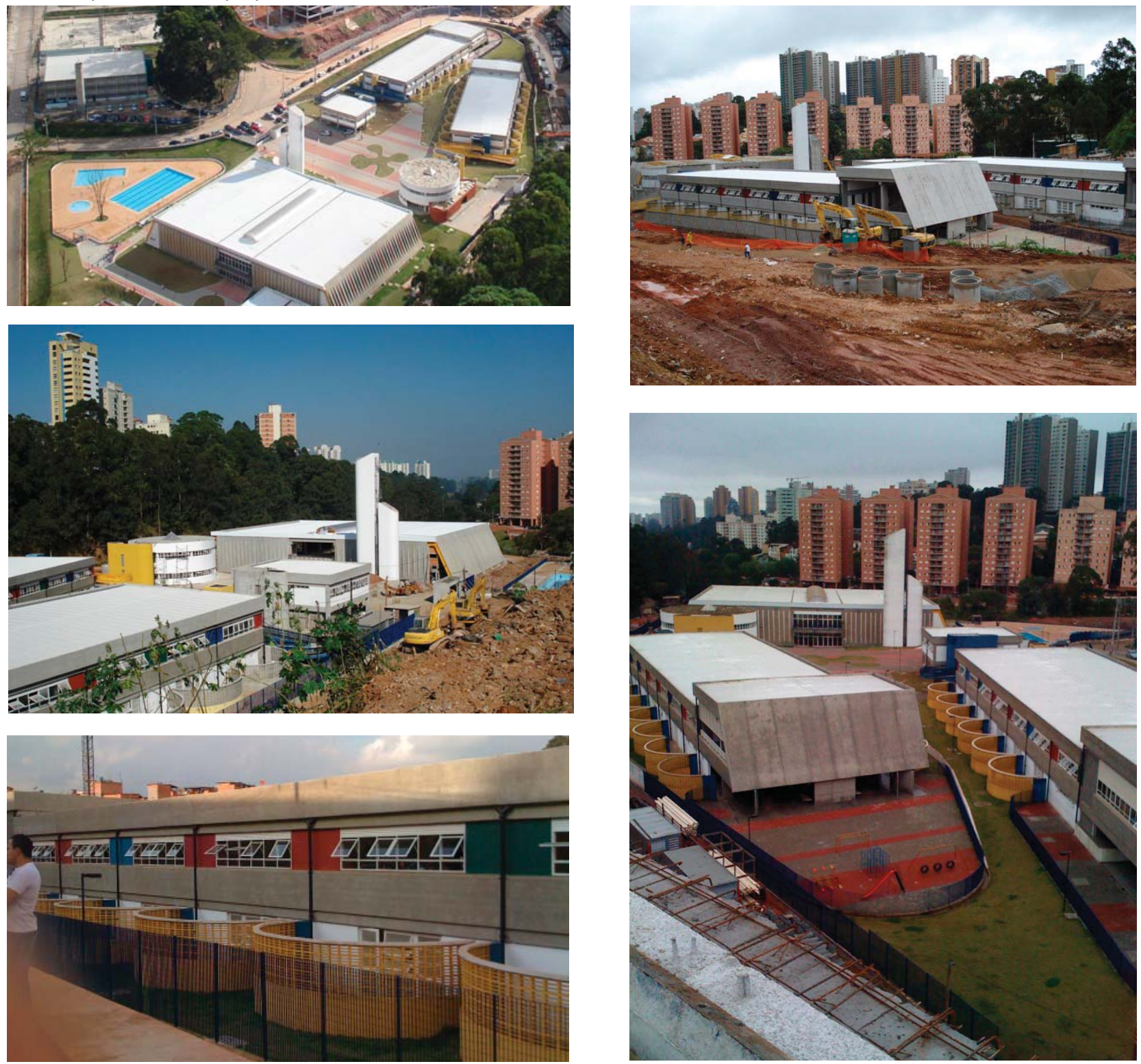


\section{PRODUÇÃO DE EQUIPAMENTOS EDUCACIONAIS}

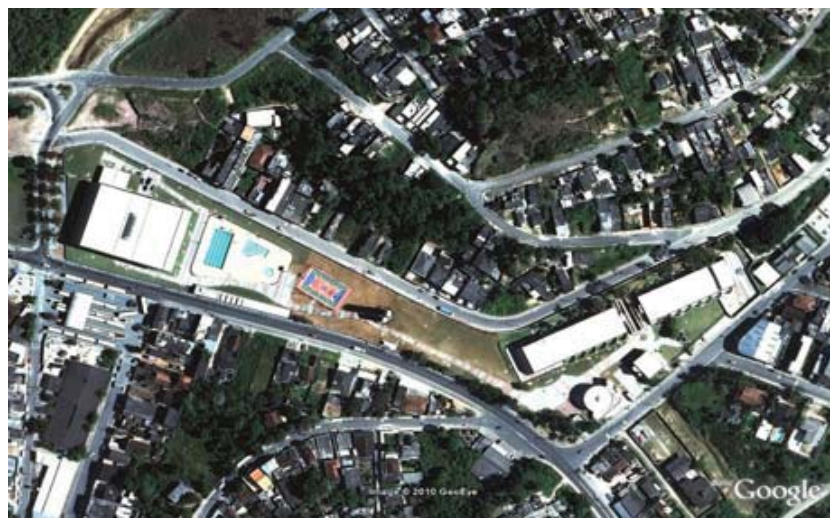

\section{CEU PARELHEIROS}

Rua José Pedro de Borba, 20 - Jardim Novo Parelheiros

área do terreno: $19.500 \mathrm{~m}^{2}$

área construída: -

construtora: Contrubase Engenharia/ Engeform

data inauguração: 06/12/2008

custo: $\mathrm{R} \$ 27,5$ milhões

financiamento: Secretaria Municipal de Educação

Projeto

Programa padrão mais quadra descoberta e um planenário com capacidade para 196 pessoas. Atende 2.100 alunos.

Proveniência da demanda

Necessidade de eliminar o terceiro turno na Emef Manoel Vieira de Queiroz Filho e na Emef Plínio Marcos.

Propriedade da terra

Terreno particular desapropriado.
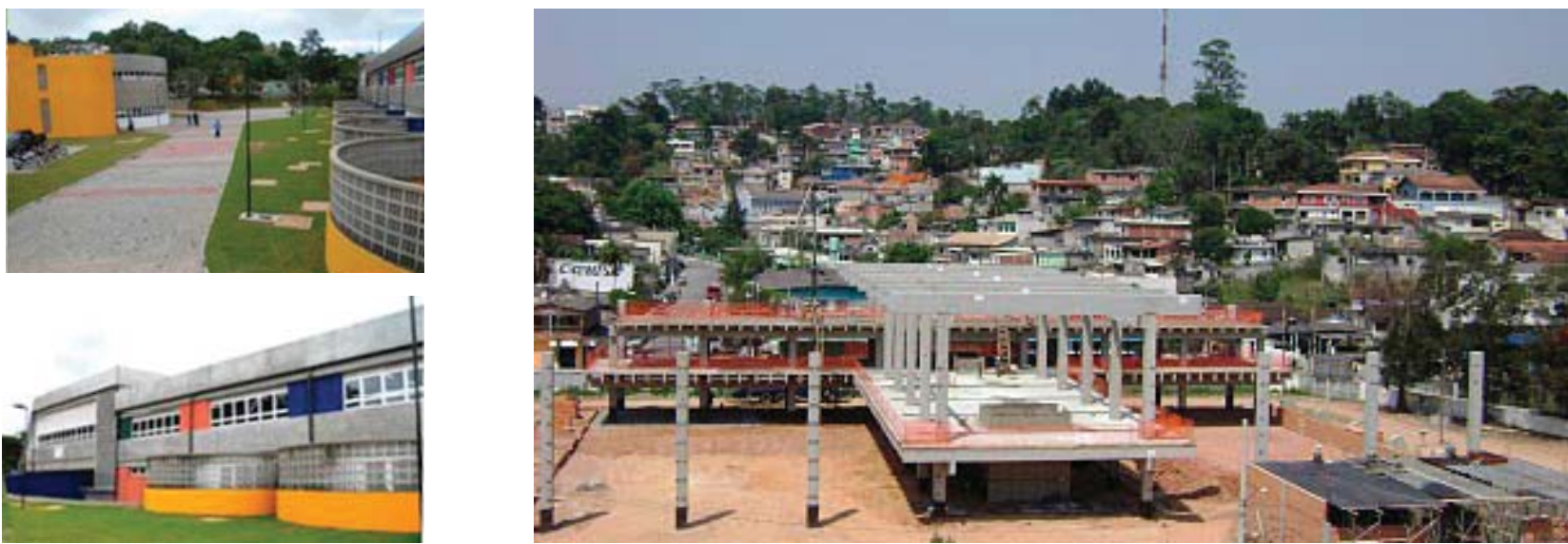

\section{CEU PQ. ANHANGUERA (JD. BRITHÂNIA)}

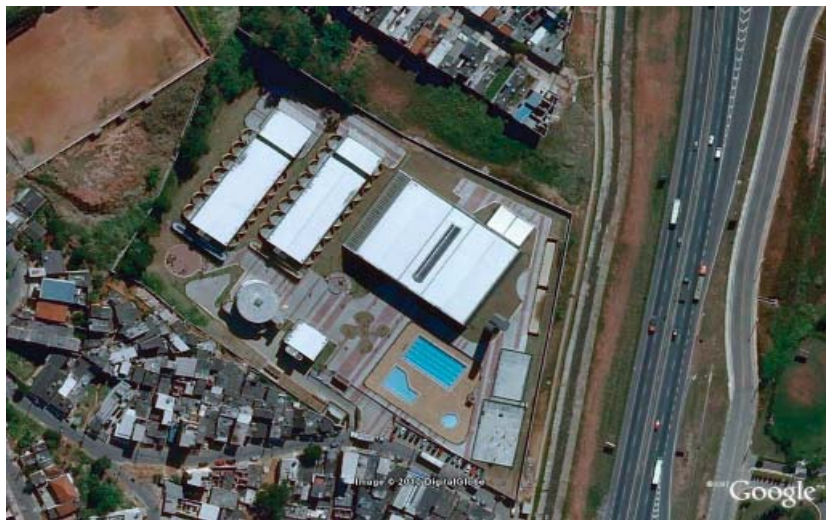

R. Pedro José de Lima, s/nº - Jardim Anhanguera

área do terreno: $23.662,30 \mathrm{~m}^{2}$

área construída: $10.145,31 \mathrm{~m}^{2}$

construtora: -

data inauguração: 20/12/2008

custo: $\mathrm{R} \$ 27,2$ milhões

financiamento: Secretaria Municipal de Educação

\section{Projeto}

Programa padrão com teatro com 188 lugares, mais uma quadra de vôlei e duas canchas de bocha. Atende 2.800 alunos.

\section{Proveniência da demanda}

Demanda local por equipamentos públicos.

Propriedade da terra

Terreno particular desapropriado. 


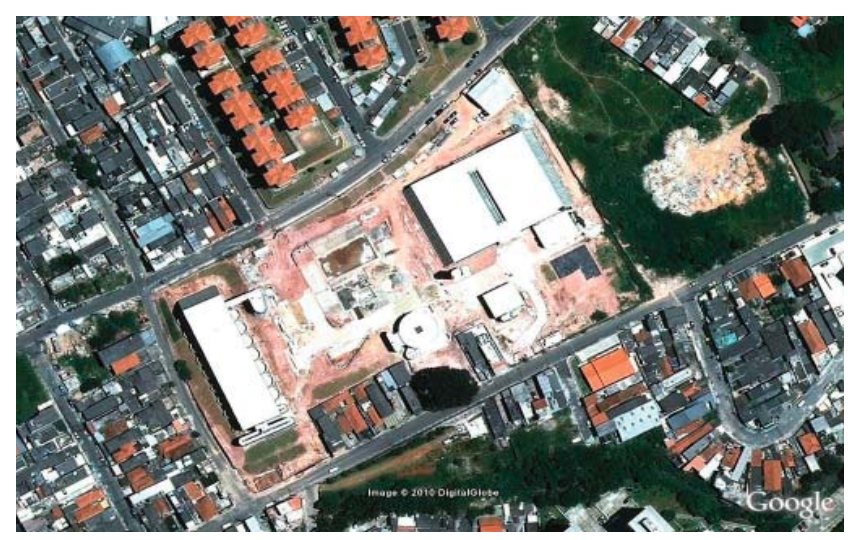

\section{CEU PARQUE BRISTOL}

R. Prof. Arthur Primavesi com Rua Roudão Eufrázio Leal . Pq. Bristol

área do terreno: $22.919 \mathrm{~m}^{2}$ área construída: $10.957,26 \mathrm{~m}^{2}$

construtora: Simioni \& Viesti

data inauguração: 21/03/2009

custo: $\mathrm{R} \$ 26$ milhões

financiamento: Secretaria Municipal de Educação

\section{Projeto}

Programa padrão com anfiteatro para 184 lugares, mais uma quadra descoberta e telecentro com 20 computadores instalados. Atende 1.600 alunos.

\section{Partido arquitetônico}

0 CEI, a EMEl e a EMEF estão distribuídos em um único prédio de três pavimentos.

\section{Proveniência da demanda}

Demanda local por equipamentos públicos.

\section{Propriedade da terra}

Terreno particular desapropriado.
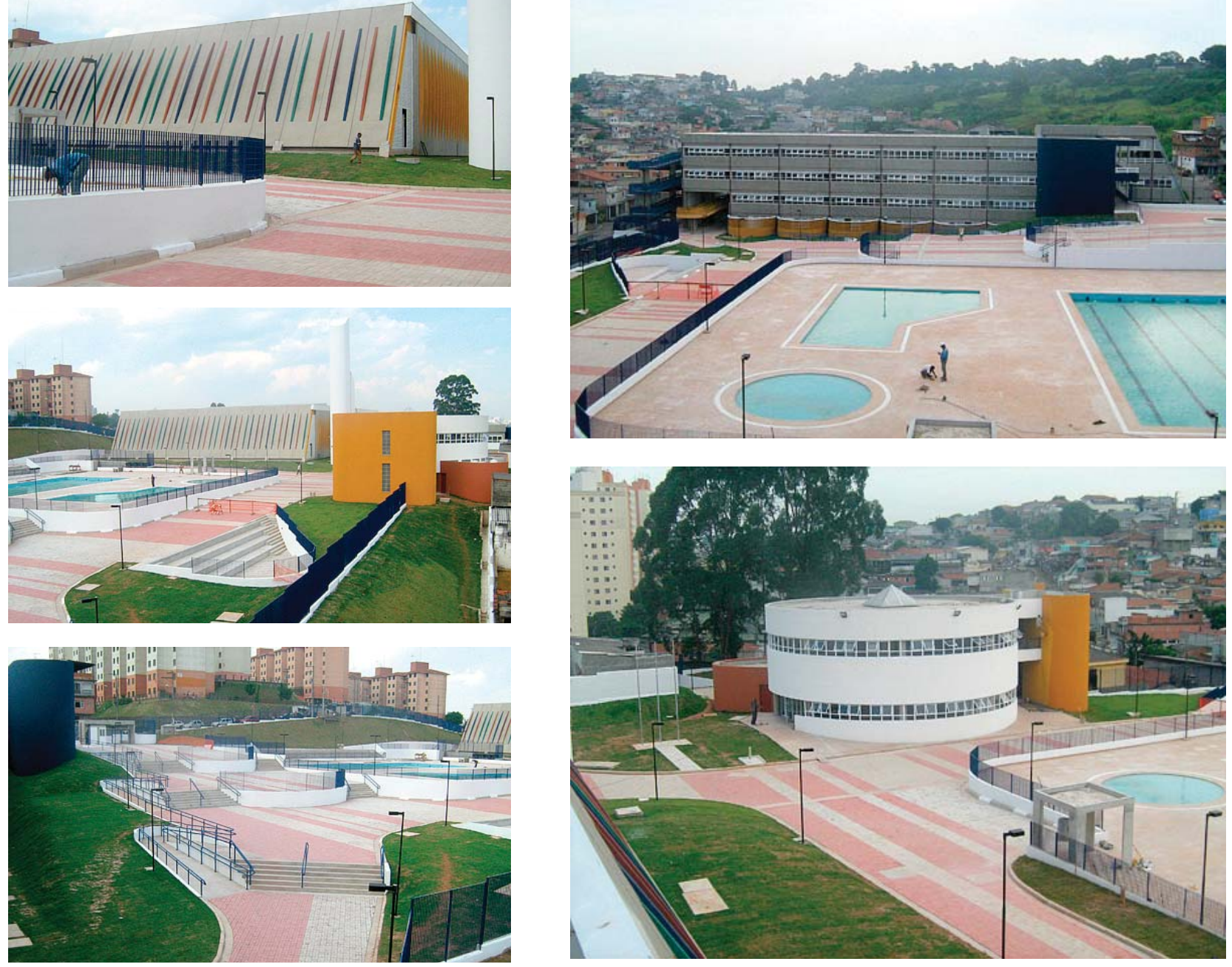


\section{PRODUÇÃO DE EQUIPAMENTOS EDUCACIONAIS}

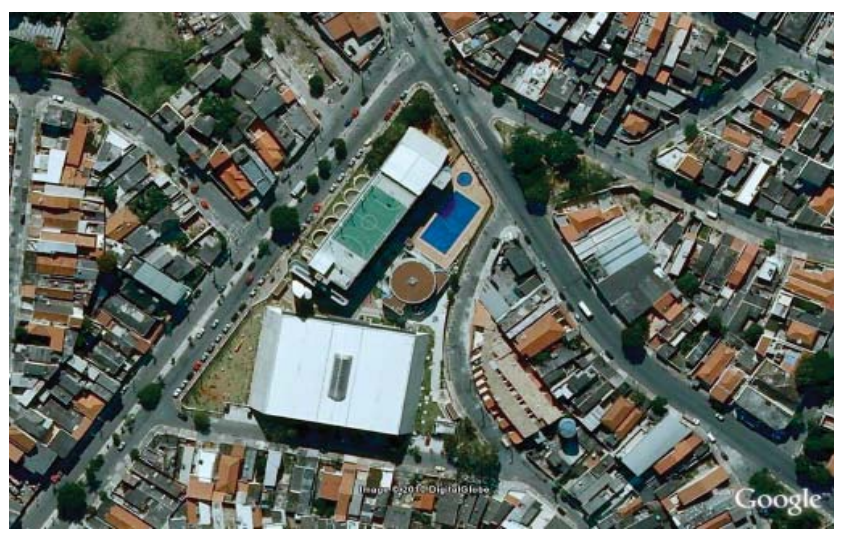

CEU QUINTA DO SOL

Avenida Luiz Imparato, 564 - Cangaíba

área do terreno: $9.972 \mathrm{~m}^{2}$

área construída: $11.205 \mathrm{~m}^{2}$

construtora: Via Engenharia S.A.

data inauguração: 19/04/2008

custo: $R \$ 25,2$ milhões

financiamento: Secretaria Municipal de Educação

Projeto

Programa padrão com teatro com 400 lugares, mais telecentro com 20 computadores instalados. Atende 2.600 alunos.

\section{Partido arquitetônico}

Para construir $11.205 \mathrm{~m}^{2}$ em um terreno de $9.972 \mathrm{~m}^{2}$, a primeira solução foi alterar o projeto original. 0 bloco didático, originalmente previsto em dois prédios, foi concentrado em um único edifício com cinco pavimentos. Duas rampas de acesso separam a entrada dos alunos de ensinos diferentes. No primeiro pavimento está instalado 0 CEI - Centro de Educação Infantil; no segundo pavimento a EMEI - Escola Municipal de Educação Infantil; e no terceiro e quarto pavimentos a EMEF - Escola Municipal de Educação Fundamental; no quinto pavimento ou cobertura está a quadra poliesportiva, protegida por redes e grades laterais.

\section{Proveniência da demanda}

Demanda por equipamentos públicos de cultura, esporte, lazer e educação para atender a grande quantidade de crianças, adolescentes e jovens que moram no bairro e ausência de vagas em creches da região, chegando a, em uma delas, mais de 1.000 (mil) crianças aguardarem por uma vaga.

\section{Propriedade da terra}

Terreno público.

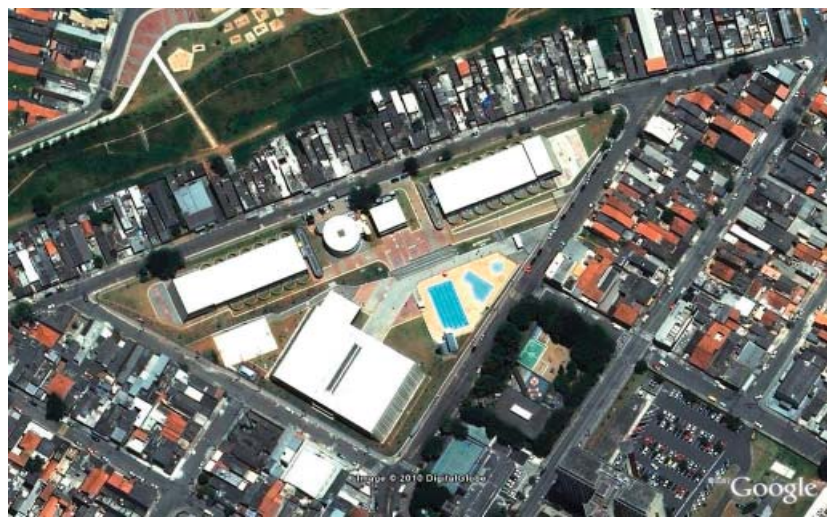

\section{CEU SAPOPEMBA}

Rua Manuel Quirino de Mattos, s/n $n^{0}$ Jardim Sapopemba

área do terreno: $21.091 \mathrm{~m}^{2}$ área construída: $10.076 \mathrm{~m}^{2}$

construtora: -

data inauguração: 28/06/2008

custo: $R \$ 25,2$ milhões

financiamento: Secretaria Municipal de Educação

Projeto

Programa padrão com teatro com 200 lugares, mais telecentro com 20 computadores instalados. Atende 2.626 alunos.

\section{Proveniência da demanda}

0 CEU Sapopemba permitiu que a Secretaria Municipal de Educação eliminasse $03^{\circ}$ turno da Escola Municipal de Educação Infantil (EMEI) Vicente de Carvalho e da Escola Municipal de Educação Fundamental (EMEF) Olival Costa.

\section{Propriedade da terra}

Terreno público. 

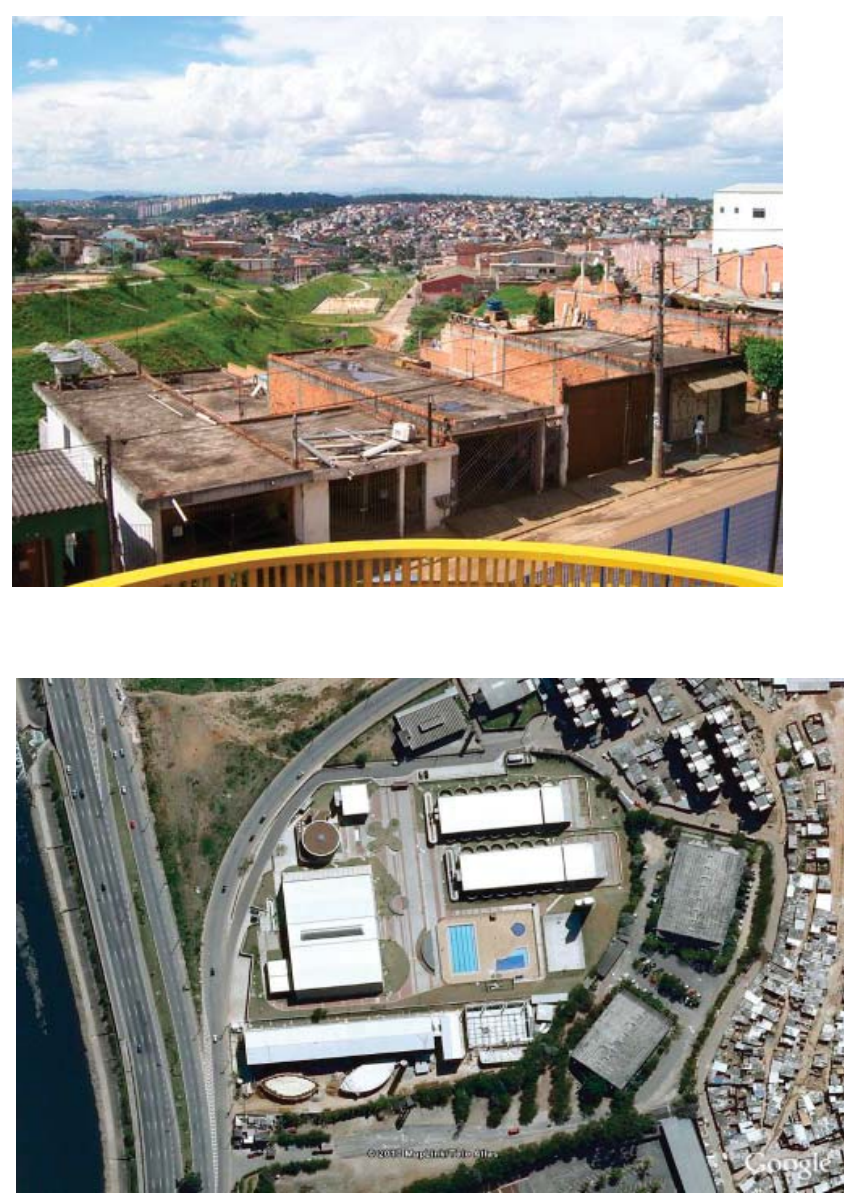

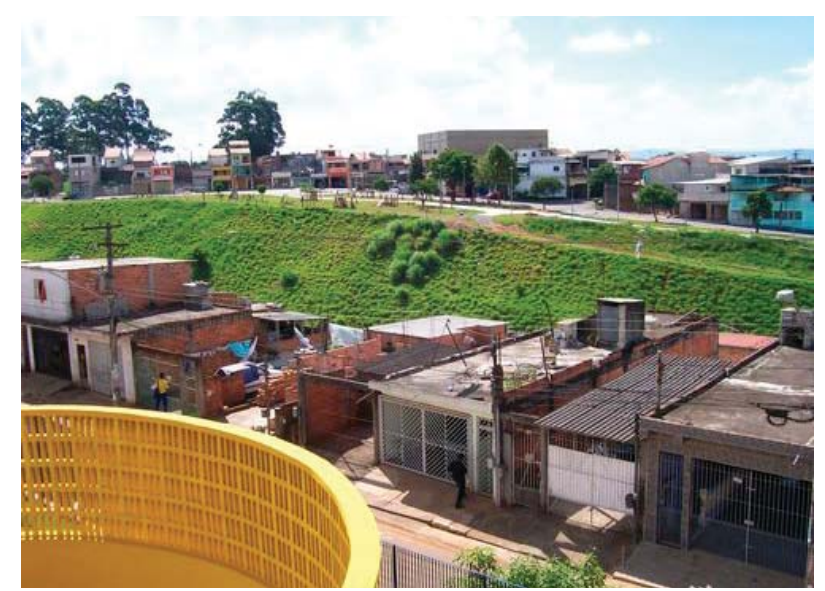

\section{CEU TIQUATIRA}

Av. Condessa Elizabeth Robiano com a Rua Kampala, 270 - Penha

área do terreno: $18.000 \mathrm{~m}^{2}$ área construída: -

construtora: Via Engenharia S.A.

data inauguração: 15/11/2008

custo: $\mathrm{R} \$ 26,9$ milhões

financiamento: Secretaria Municipal de Educação

\section{Projeto}

Programa padrão com teatro com 188 lugares, mais telecentro com 20 computadores instalados. Atende 2.000 alunos.

\section{Histórico}

0 terreno onde foi implantado o CEU Tiquatira possuia, no total, uma área de $30.000 \mathrm{~m}^{2}$, dos quais $18.000 \mathrm{~m}^{2}$ foram destinados ao CEU e os $12.000 \mathrm{~m}^{2}$ restantes foram passados para o Governo do Estado, por convênio, para a construção de uma ETEC - Escola Técnica. A idéia é que os equipamentos estejam articulados.

\section{Partido arquitetônico}

0 Bloco Didático é formado por um Centro de Educação Infantil (CEI) e uma Escola Municipal de Educação Infantil (EMEI) em um prédio, e uma Escola Municipal de Educação Fundamental (EMEF) em outro.

\section{Proveniência da demanda}

0 novo CEU foi construir para suprimir o terceiro turno na EMEF Edgar Cavalheiro.

\section{Propriedade da terra}

Terreno particular desapropriado.
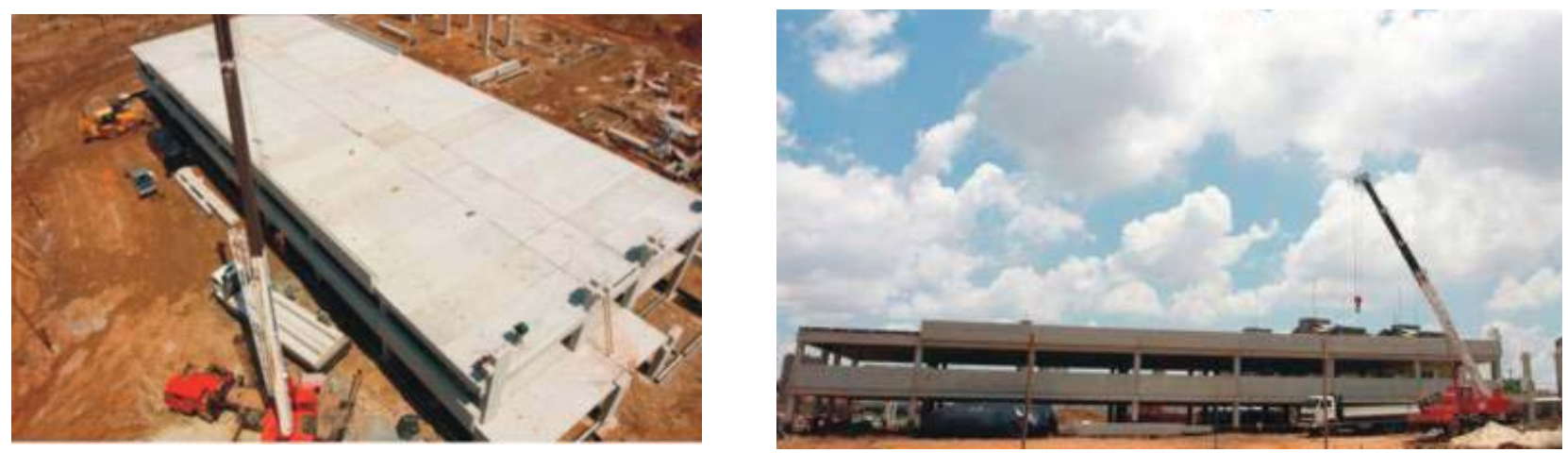


\section{PRODUÇÃO DE EQUIPAMENTOS EDUCACIONAIS}

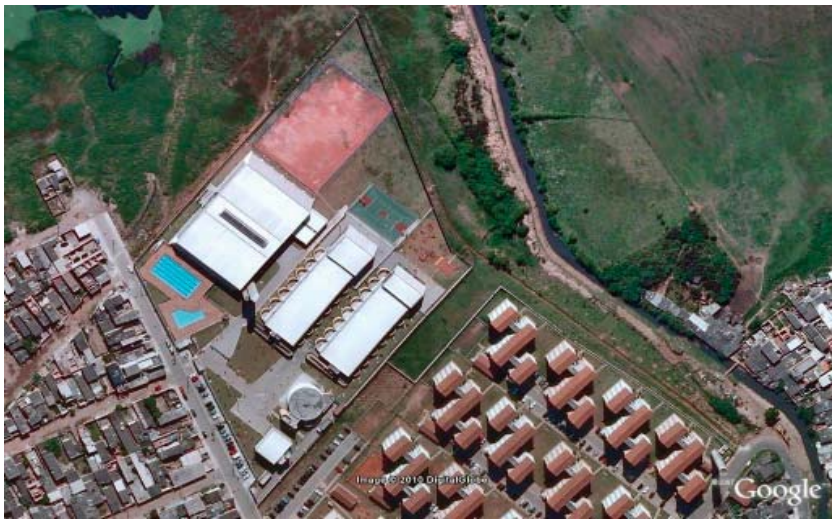

\section{CEU TRÊS PONTES}

Rua Capachós, s/nº - Jardim Célia

área do terreno: $21.000 \mathrm{~m}^{2}$

área construída: $11.205 \mathrm{~m}^{2}$

construtora: Passarelli

data inauguração: 31/08/2008

custo: $\mathrm{R} \$ 28,4$ milhões

financiamento: Secretaria Municipal de Educação

\section{Projeto}

Programa padrão com anfiteatro com 200 lugares, mais telecentro com 20 computadores instalados. Atende 1.600 alunos.

\section{Partido arquitetônico}

O Bloco Didático é distribuído em dois prédios, com refeitórios em cada um, articulados pela área de lazer externa.

\section{Proveniência da demanda}

Déficit de vagas na região.

\section{Propriedade da terra}

Terreno particular desapropriado.

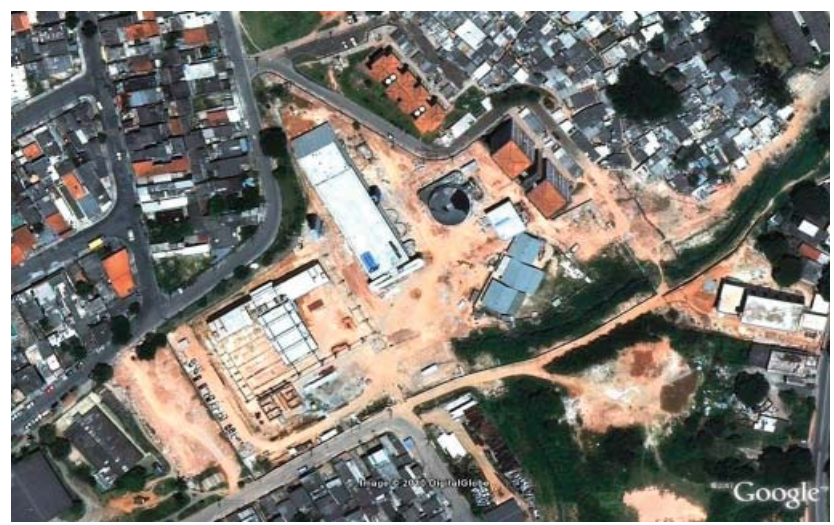

\section{CEU UIRAPURU}

R. Frei Claude Alberville, s/no, com R. Nazir Miguel - Jd. João XXIII

área do terreno: $20.000 \mathrm{~m}^{2}$ área construída: $12.000 \mathrm{~m}^{2}$

construtora: Camargo Corrêa

data inauguração: em construção (início das aulas em custo: $\mathrm{R} \$ 22,5$ milhões

financiamento: Secretaria Municipal de Educação

\section{Projeto}

Programa padrão com teatro com 200 lugares, mais pista de skate, cancha de bocha, telecentro com 20 computadores instalados e consultórios médicos (odontológico, médico e psicológico). Atende 2.600 alunos.

\section{Proveniência da demanda}

Demanda por equipamentos públicos na região.

\section{Propriedade da terra}

Terreno particular desapropriado.
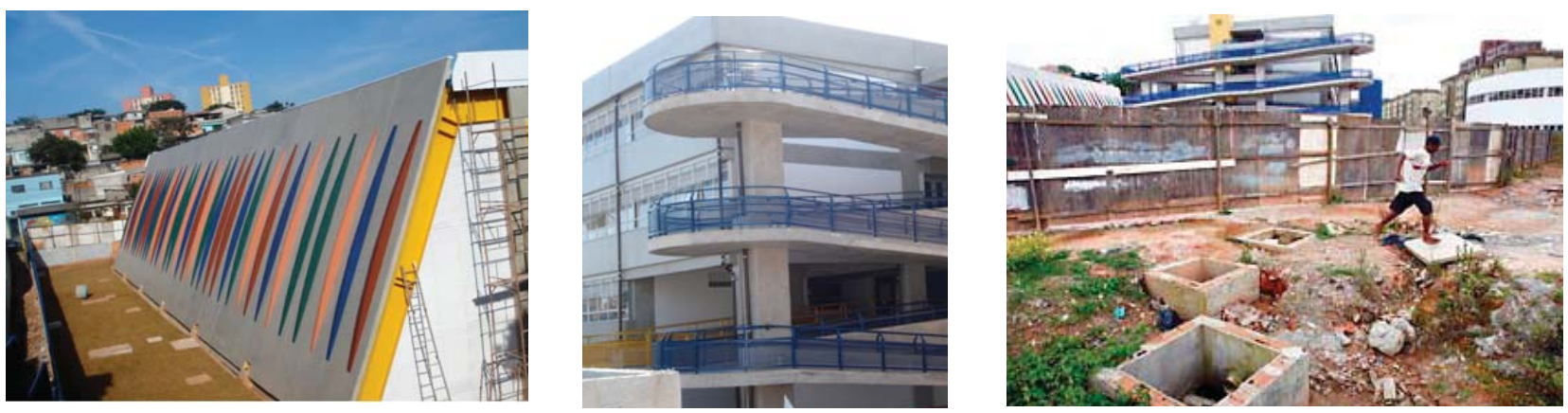


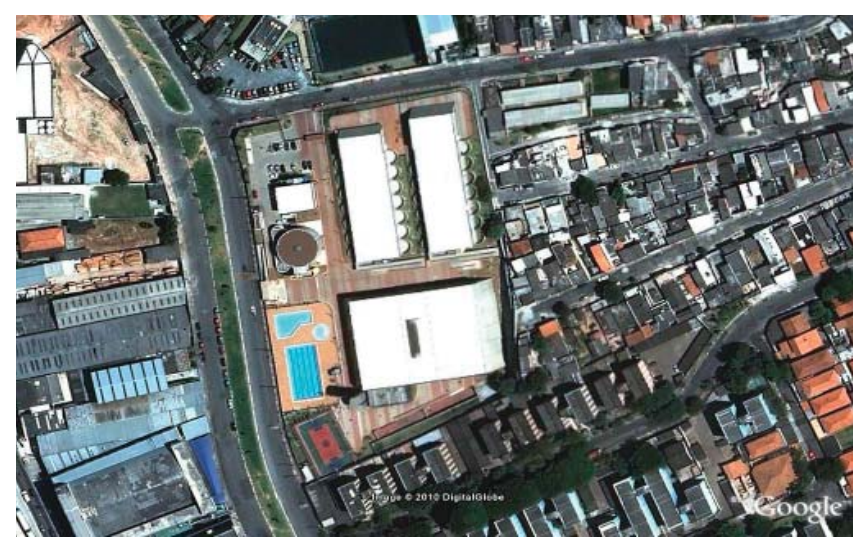

\section{CEU VILA RUBI}

R. Domingos Tarroso, 101 - Vila Rubi - Grajaú

área do terreno: $17.598 \mathrm{~m}^{2}$

área construída: $12.000 \mathrm{~m}^{2}$

construtora: Construbase Engenharia/ Engeform

data inauguração: 29/09/2007

custo: $\mathrm{R} \$ 25,5$ milhões

financiamento: Secretaria Municipal de Educação

\section{Projeto}

Programa padrão com teatro com 200 lugares, mais telecentro com 20 computadores instalados. Atende 2.600 alunos.

\section{Proveniência da demanda}

Demanda por equipamentos públicos na região.

\section{Propriedade da terra}

Terreno público.

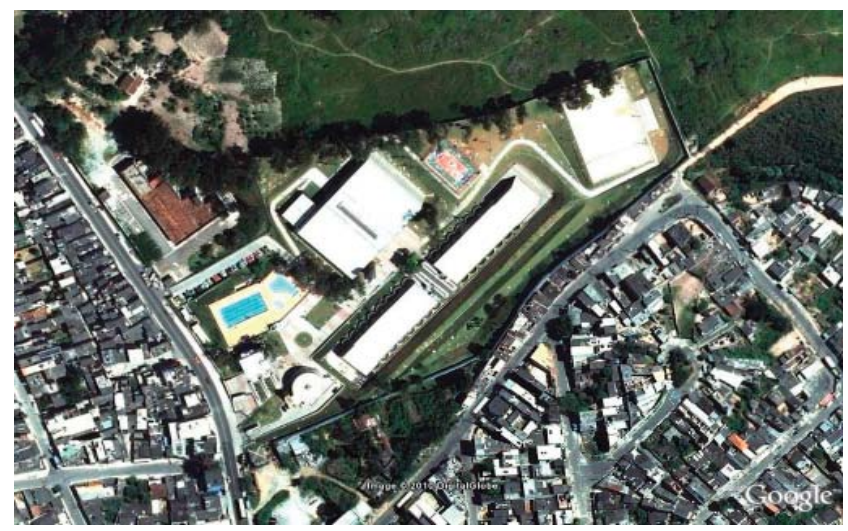

\section{CEU VILA DO SOL}

Av. dos Funcionários Públicos, 369 - Vila do Sol - Jd. Ângela

área do terreno: $32.300 \mathrm{~m}^{2}$

área construída: $11.205 \mathrm{~m}^{2}$

construtora: Construbase Engenharia/ Engeform

data inauguração: 31/05/2008

custo: $\mathrm{R} \$ 28,4$ milhões

financiamento: Secretaria Municipal de Educação

\section{Projeto}

Programa padrão com anfiteatro com 188 lugares e um campo de futebol (de terra e areia). Atende 2.600 alunos.

\section{Partido arquitetônico}

0 Bloco Didático é composto por dois prédios - um com uma CEI (Centro de Educação Infantil) e uma EMEI (Escola Municipal de Educação Infantil) e o outro com uma EMEF (Escola Municipal de Educação Fundamental). 0 Bloco Esportivo e Cultural (BEC), cujos equipamentos de lazer serão oferecidos à comunidade local nos fins de semana, ou conforme for determinado pela coordenação de educação, possui acesso independente.

\section{Proveniência da demanda}

Déficit de vagas na região.

\section{Propriedade da terra}

Terreno particular desapropriado.
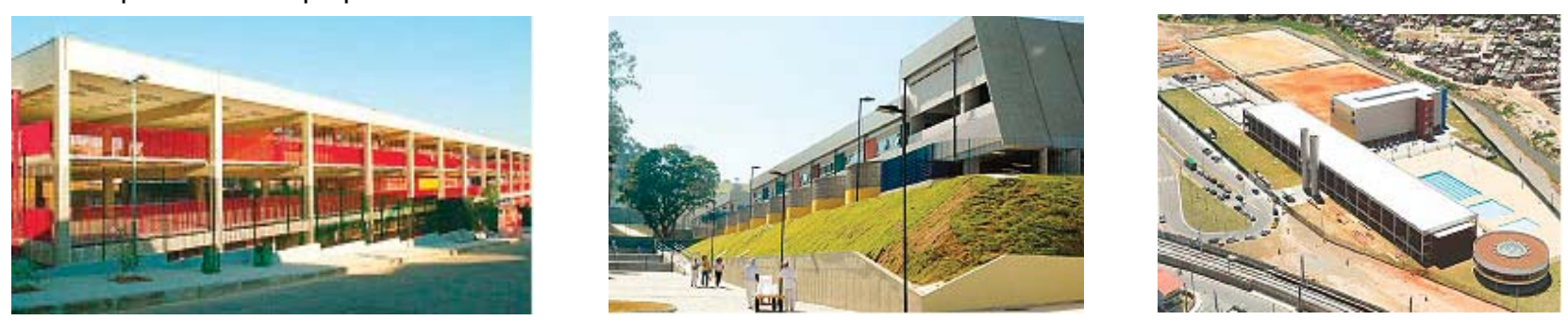


\section{PRODUÇÃO DE EQUIPAMENTOS EDUCACIONAIS}

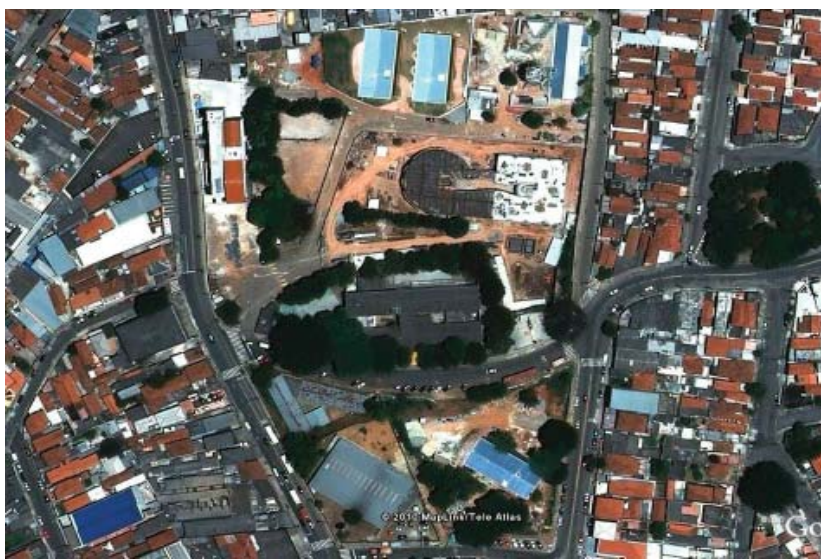

\section{CENTRO DE CONVIVÊNCIA EDUCATIVO E CULTURAL DE HELIÓPOLIS}

R. Cavalheiro Frontini com Estrada das Lágrimas - Lgo. São João Clímaco

área do terreno: $35.994 \mathrm{~m}^{2}$

área construída: $6.219 \mathrm{~m}^{2}$ (CEls + Centro Cultural)

data inauguração: em construção (as duas creches entraram em funcionamento em 22/11/2007)

custo: $\mathrm{R} \$ 6,5$ milhões

\section{Projeto}

0 projeto, doado pelo arquiteto Ruy Ohtake, engloba na primeira fase a construção/ reforma de três CEls, com $789 \mathrm{~m}^{2}$ cada, contendo dois pavimentos, 5 salas de atividades, 2 berçários e uma sala multiuso - totalizando 8 salas - e a reforma do Centro Cultural onde serão implantados, em uma área de $1.485 \mathrm{~m}^{2}$, cinema, salas de exposições, reuniões, palestras, foto e de vídeo, TV comunitária e cursos profissionalizantes. Na segunda etapa, com projeto também de autoria do arquiteto, serão executadas as obras de urbanização, que estão em fase de licitação. Mais tarde, o terreno deve receber ainda um auditório, salas para ensino de música, dança, balé e teatro, frutos de uma parceria da Prefeitura com o Instituto Baccarelli.

\section{Histórico}

A cessão de um velho galpão da Prefeitura para uma entidade local, a UNAS, permitiria a instalação do novo centro cultural, iniciando o projeto do complexo em 2007. Pouco mais tarde, a Cohab cederia, em comodato, o terreno de 3 mil $^{2}$ para a construção da nova sede do Instituto Baccarelli, obra em andamento.

\section{Partido arquitetônico}

0 projeto resume-se à integração de diversos equipamentos por meio da construção de uma grande praça e um centro cultural. Uma área que onde já estavam sendo construídas três creches municipais - Centros de Educação Infantil (CEls) Heliopólis I, II e III - e a Escola Técnica Paula Souza, do Governo do Estado, foi articulada a uma praça contígua onde já estavam instaladas duas escolas municipais - a EMEI Antônio Francisco Lisboa e a EMEF Presidente Campos Salles. 0 Centro Cultural integra arquitetonicamente o conjunto. A Rua Cavalheiro Frontini será integrada à área do projeto, não sendo permitido o tráfego de veículos, buscando promover encontros dos pedestres.

\section{Proveniência da demanda}

Maior favela de São Paulo, com significativa carência de equipamentos institucionais.

Equipe de projeto

Escritório Ruy Othake - arquitetura.

\section{Coordenação do projeto}

SIURB - Prefeitura de São Paulo.

\section{Fiscalização da Obra}

SIURB - Prefeitura de São Paulo.

\section{Construtora}

\section{Propriedade da terra}

Prefeitura de São Paulo - COHAB.

\section{Financiamento}

Prefeitura da Cidade de São Paulo (EDIF/ SIURB e SME), Governo do Estado e iniciativa privada. 


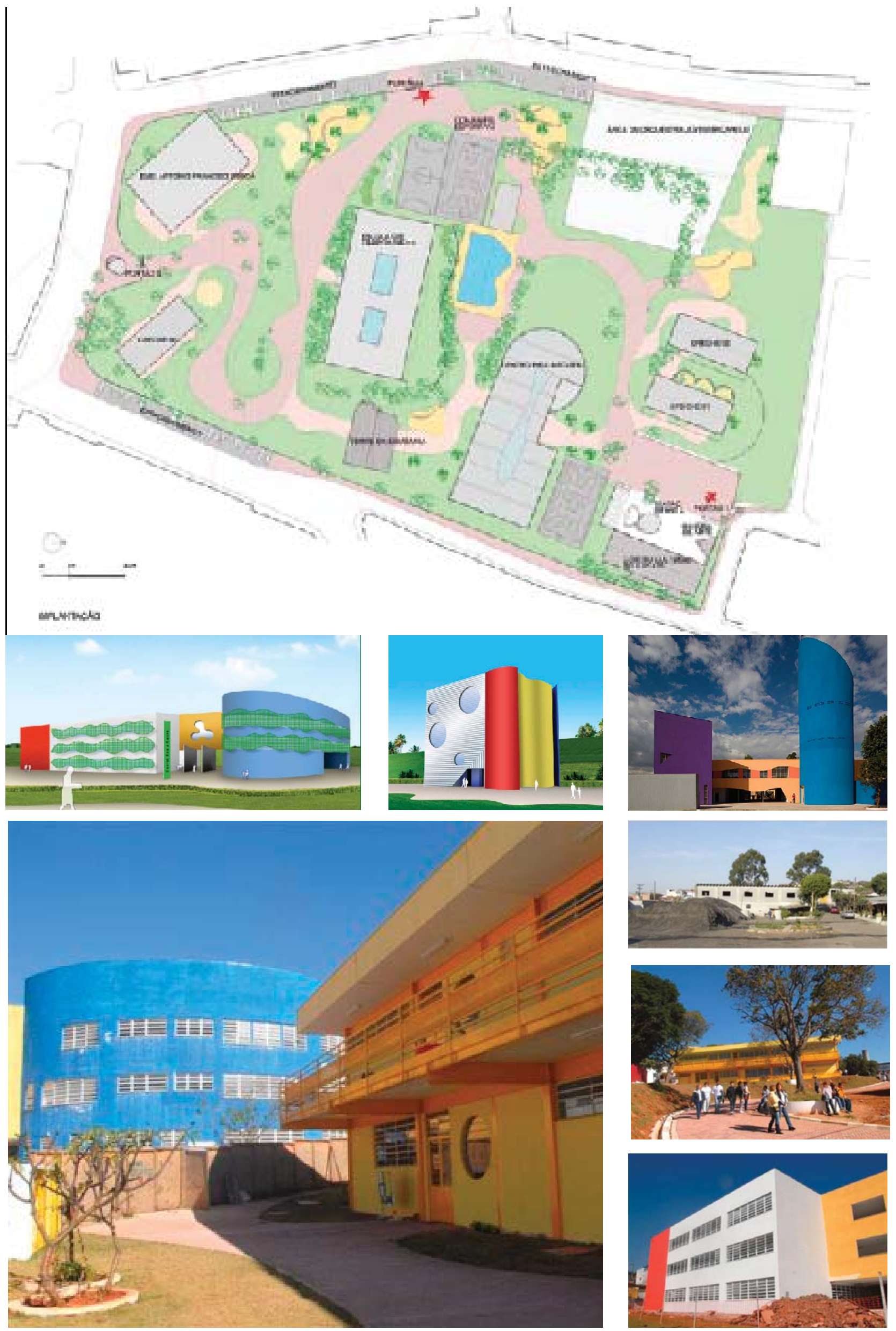

